\title{
EXTENSIONES CORPORALES EN EL CONTEXTO DEL BODY ART REVOLUCIÓN DEL DESEO
}

UNIVERSIDAD POLITÉCNICA DE VALENCIA DEPARTAMENTO DE PINTURA

Tesis Doctoral presentada por: Agustín Albero Teijeiro Dirigida por: Dr. D. David Pérez Rodrigo

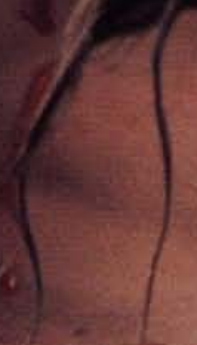





\title{
EXTENSIONES CORPORALES EN EL CONTEXTO DEL BODY ART REVOLUCIÓN DEL DESEO
}

\author{
UNIVERSIDAD POLITÉCNICA DE VALENCIA \\ DEPARTAMENTO DE PINTURA
}

Tesis Doctoral presentada por: Agustín Albero Teijeiro Dirigida por: Dr. D. David Pérez Rodrigo

VALENCIA, 2010 

A mis padres 



\section{ÍNDICE}

INTRODUCCIÓN.

OBJETIVOS, METODOLOGÍA Y CONTENIDOS …....................... 9

1. CONCEPTOS PREVIOS ............................................................ 25

1.1. Cuerpo, máquina corporal y corporeidad ................................ 29

1.2. Natural versus artificial ....................................................... 38

2. CUERPO MECANIZADO Y/O PROSTÉTICO EN LAS

VANGUARDIAS ARTÍSTICAS DEL SIGLO XX ….......................... 47

2.1. La representación estética y el maquinismo ............................. 51

2.2. Arte de acción. Paradigma del cuerpo mecanizado.................... 64

2.2.1. Balli meccanichi futuristas .................................... 65

2.2.2. La URSS biomekhanica ......................................... 73

2.2.3. El teatro de la Bauhaus ................................................ 83

3. ANTECEDENTES Y PERIFERIAS DEL BODY ART ….............. 95

3.1. Aproximación al contexto sociocultural ................................... 101

3.2. Los años 1950-1960 ......................................................... 112

3.2.1. Happenings y Fluxus ................................................ 114

3.2.2. Man-made. Yves Klein, Piero Manzoni y Joseph

Beuys ..................................................................... 129

3.2.3. El Accionismo vienés ........................................... 146

4. PLANTEAMIENTOS TEÓRICOS DEL BODY ART …................ 167

4.1. La escena estadounidense. El Body Work de Avalanch........... 172

4.2. Europa y $L$ 'art corporel de François Pluchart ......................... 185

4.2.1. Manifeste de l'art corporel ........................................ 186

4.2.2. Deuxième manifeste .................................................. 188

4.2.3. Troisième manifeste ................................................. $\quad 190$

5. LA EXTENSIÓN CORPORAL Y SU VINCULACIÓN CON LA PRÁCTICA ARTÍSTICA _.......................................................... 195

5.1. Frankenstein y la disfunción eréctil ...................................... 201

5.2. Con su permiso, Sr. McLuhan ............................................. 208 
6. VESTIDOS MAQUILLAJES Y PURPURINAS.

DESMONTANDO LA MASCULINIDAD ....................................... 221

6.1. Umbrales de una «extensión corporal» ................................... 227

6.1.1. «Je suis lesbien». El caso de Pierre Molinier .............. 227

6.1.2. La mirada de Diane Arbus ....................................... 237

6.2. Transformer.

La serie fotográfica como proceso performativo ............................ 241

6.3. Empieza el espectáculo.

Cross-Dressing en la cultura popular ........................................... 269

7. LA LÓGICA DE LOS COMPLEMENTOS.

SEMIÓTICA DEL PADRE ….................................................... 289

7.1. Trazando el sujeto. Ficciones del yo ..................................... 294

7.2. El poder de los objetos. El signo como extensión ................... 312

7.3. Cuerpo-objeto en el espacio público ...................................... 331

7.4. El control de los atuendos ................................................... 341

7.5. Père-versiones ..................................................................... 351

8. EL CUERPO PROSTÉTICO ..................................................... 363

8.1. Extensiones sensoriales.

De la antropofagia a Rebecca Horn .............................................. 366

8.2. El cuerpo obsoleto.

La «ciberestética» y el teatro de operaciones ................................. 390

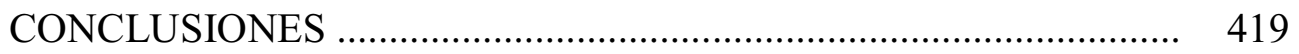

RESÚMENES

- Resumen de la Tesis ............................................................. 427

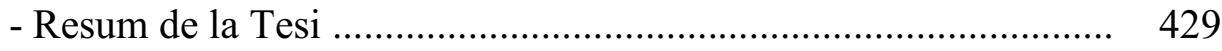

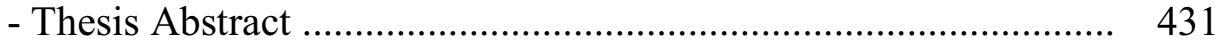

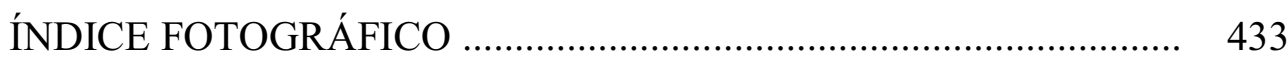

BIBLIOGRAFÍA _.................................................................... 437 


\section{AGRADECIMIENTOS}

Un laberinto es un espacio construido por un conjunto de calles intencionadamente ordenadas para confundir a toda persona que ose introducirse en él. Apenas recuerdo el día que cometí la imprudencia de atravesar su portezuela sin ser verdaderamente consciente de que en este lugar no hay Ariadnas que valgan. Supongo que no tengo más remedio que aceptar que, ahora, este es mi lugar, mi morada, mi hogar y lo único que me queda es aprender a sobrevivir en su interior sorteando a todos los Teseos que traten de privarme de los encantos de su paisaje. Afortunadamente llevo conmigo un candil, una llama que se mantiene encendida gracias a un combustible inagotable: el ejemplo de todas las personas que han compartido y comparten, de una forma u otra, esta odisea. Nada habría sido posible sin vuestra colaboración y apoyo.

Especialmente quiero agradecer a mi tutor de tesis, el Dr. D. David Pérez Rodrigo, Profesor Titular del Departamento de Pintura de la Facultad de Bellas Artes, su dirección, apoyo incondicional y dedicación. Mil gracias David por tus lecciones de supervivencia, tu inagotable paciencia y por las horas invertidas en hacerme entender que podía conseguirlo, yo no siempre lo creí. 
Deseo, sinceramente, dar las gracias a todos los profesores y profesoras que han construido los andamios del presente proyecto, especialmente al Dr. D. Juan Vicente Aliaga Espert, por hacerme consciente de mi enorme ignorancia, y al Dr. D. Miguel Molina Alarcón, por enseñarme a ver el mundo con el entusiasmo de un niño.

Al personal de lo que se ha convertido en mi segunda casa - la biblioteca del IVAM-, especialmente a Eloísa, María Victoria y Félix, por haber soportado durante tantos años mi estancia allí con todo lo que ello conlleva.

A mis padres que, pese a darme por imposible, me han enseñado a ser yo mismo; a Begoña, mi hermana, por darme fuerzas en los momentos más difíciles; a Empar, por estar a mi lado independientemente de lo despeluchado que pudiera estar, tanto por dentro como por fuera; a Carol, Tama y Pablo, vosotros también habéis sufrido de alguna manera toda esta aventura; y a Over the Range, un proyecto cada vez más grande que me permite desahogarme cuando más lo necesito.

Pero sobre todo, este trabajo está dedicado a mi abuela, una de las personas más sabias que he conocido en mi vida y, que en su juventud centenaria, mantiene una mente lúcida y activa. 


\section{INTRODUCCIÓN. OBJETIVOS, METODOLOGÍA Y CONTENIDOS}

En febrero de 2004 presentamos el trabajo de investigación Cuerpo y artificio mecánico en las vanguardias artísticas del siglo $X X$, un estudio que se centraba en las representaciones del cuerpo en relación a un contexto social y cultural en el que tanto personas como máquinas eran concebidas en términos similares.

Tomando aquel compendio como punto de partida, hemos seguido investigando sobre la utilización de una tecnología que, aplicada a nuestra vulnerable fisicidad, adquiere la función de analizar, cuestionar y/o distorsionar los límites impuestos por la norma y el estereotipo. Debido a ello, queremos detenernos en el presente trabajo con especial atención en los años situados en torno a Mayo del 68, una fecha clave en la que vuelven a repetirse las fórmulas esenciales que tuvieron lugar a principios del pasado siglo y de cuyas representaciones artísticas se nutre el concepto de Body Art.

No cabe duda de que la Revolución Industrial ha sido uno de los acontecimientos más trascendentales de nuestra historia. El ser humano dejó de ser el principal productor directo y fue relevado de sus funciones por la 
máquina, la verdadera encargada de transformar la fuerza humana en economía y utilizar al individuo como mero colaborador de ésta. El cuerpo quedó así a merced de las nuevas tecnologías de control que, aunque es cierto que fueron planteadas en los siglos XVII y XVIII, se instauraron en todos los ámbitos de la vida cotidiana a lo largo del siglo XIX para preservar y regular la existencia del cuerpo, su salud, sexualidad, subsistencia, acomodo, educación, etcétera. Fue así como la prosperidad y la productividad de los cuerpos se convirtieron en el núcleo del poder.

Tales hechos llevaron implícitas nuevas relaciones entre la sociedad y un incipiente maquinismo. Este último transformó la apariencia y los modos de existir, modificó las relaciones con la naturaleza y modeló profundamente a un nuevo ser humano, un individuo que quedó adherido para siempre a un proceso tecnológico, un destino biológico «extendido» $\mathrm{y}$ «expandido»-y, por esta condición, implícita y paradójicamente amputado - por artilugios que alteraban su relación con el mundo.

Fue así como la sociedad del siglo XX, frente a la necesidad de tomar posición en torno a un estado de acontecimientos tan complejo, trató de buscar un símbolo ordenador para hacer frente al caos que imperaba a principios del siglo pasado. Este símbolo lo encontramos en la máquina, el elemento de confrontación ante la naturaleza, un elemento que se convierte en el idóneo símbolo de lo moderno y de ruptura con el pasado.

Como es lógico, el arte no quedó indemne a toda esta metamorfosis. La máquina, la industria y la nueva era devinieron epicentro de sus representaciones, especialmente a principios de siglo $\mathrm{XX}$, lo que supuso, una transformación radical de los parámetros conceptuales tradicionales del arte. El término vanguardia - una apropiación directa del vocabulario bélico que englobó los diferentes movimientos que conformaron el arte hasta la Segunda Guerra Mundial- daba buena fe de sus intenciones: ataque y transformación de la institución burguesa. La Europa más crítica estuvo caracterizada por un verdadero intento de despedazar el discurso político de 
la alta cultura a través de la fusión con la cultura popular, creando, de esta manera, una ecuación fundamental: arte $=$ vida.

Espacios públicos, teatros, pero especialmente bares y cafés fueron escenario de peculiares representaciones en las que el cuerpo y su relación con las más recientes «extensiones» tecnológicas se materializaron de una manera magistral. Gracias a este tipo de actuaciones, los ismos rompieron con sus límites formales y técnicos — centrados exclusivamente en la pintura, la escultura y la arquitectura - para introducir nuevos sistemas de representación. Fue la manera más directa de reflexionar acerca de las repercusiones que la técnica infligía en el cuerpo y el verdadero papel de la tecnología en la sociedad contemporánea.

A pesar de que la mayor parte de los textos sobre la obra de los movimientos de vanguardia tratados en el presente estudio - Bauhaus, Futurismo y Constructivismo- continúan concentrándose en los trabajos tangibles realizados en su correspondiente período, la mayor parte de las veces intentaron resolver las cuestiones que más les preocupaban a través de la performance, mediante la acción física del cuerpo del o de la artista en relación a su dependencia con la máquina.

Sin embargo, aquella libertad y entusiasmo que caracterizaron globalmente a las vanguardias artísticas se vieron truncadas por la Segunda Guerra Mundial. La tragedia puso en evidencia a aquellos movimientos culturales que adoptaron la máquina como panacea de la humanidad. Se cumplieron los peores augurios de los dadaístas y expresionistas: millones de muertos, ciudades enteras destrozadas, imágenes absolutamente desoladoras y una confianza en el ser humano hecha añicos. Es comprensible que el cuerpo y sus representaciones fueran soterrados. Aquel momento caracterizado por el desequilibrio social fue determinante para reestructurar una sociedad anulada bajo unos valores profundamente conservadores. 
Diez años después de una terrible guerra, ciertos sectores intelectuales sintieron que no podían seguir aceptando un contenido desideologizado en el terreno artístico y cultural. Aquel estado de ánimo políticamente consciente alentó las manifestaciones y gestos recuperando el más puro estilo dadaísta como medio para atacar los valores establecidos. A finales de la década de los años 1950, tanto en Estados Unidos como en Europa se reemprendió la acción corporal en las propuestas artísticas como el lenguaje más apropiado para atacar a la reaccionaria ideología burguesa.

Así pues, tal y como hemos comentado al principio de esta introducción, llegamos al año 1968, instante que marcó prematuramente el comienzo de la década de los setenta. Gracias a la conciencia social que despertaron todas las reflexiones sobre el totalitarismo que afectaba a la época, el cuerpo recuperó su categoría y se convirtió en el medio de expresión más directo. La performance — término que no se inauguró como tal hasta la década de 1970 - se transformó en el lenguaje más adecuado para materializar los nuevos valores estéticos y, además, se convirtió en la práctica correspondiente a muchas de las teorías más reivindicativas. De este modo comenzó a consolidarse un concepto de arte sociológico que defendía la integración del cuerpo en el proceso creativo, estas demostraciones que se centraban en el cuerpo del artista como material llegó a conocerse como Body Art.

En la década de los setenta podemos volver a hablar de somacentrismo. Sin embargo -y es aquí donde Extensiones corporales en el contexto del Body Art. Revolución del deseo cobra su sentido-, algunos y algunas artistas, insatisfechos con una exploración del cuerpo de raigambre materialista, adoptaron elementos configuradores de la corporeidad tales como vestidos, complementos y objetos de diversa naturaleza. Si centramos nuestra atención en este aspecto, descubrimos que aquel interés que los y las artistas de vanguardia habían mostrado por la tecnología quedaba transformado de manera espectacular en una tecnología de naturaleza muy distinta que, a pesar de sus aparentes diferencias, cumplía 
las mismas funciones que la máquina había adquirido a principios de siglo $\mathrm{XX}$ : la de «extensión corporal», componentes que añadidos o complementados al cuerpo cobraban la función de analizar, transgredir y/o ampliar las limitaciones somáticas.

Pero todo tiene su declive, aquel entusiasmo revolucionario comenzó a serenarse a mediados de la década de 1970. En esta ocasión no fue necesaria una guerra para paliar la ideología radical, tanto una aguda crisis económica como una actitud cargada de resignación y desengaño comenzaron a esbozar el final de este período. No nos olvidemos de la popularización de la era digital, que también tuvo mucho que ver en la reversión de la idea del cuerpo y, con ello, el error de volver a entender la nueva realidad desde dos concepciones antagónicas cayendo en los dualismos que han definido históricamente la sociedad occidental, verbigracia, el cuerpo como lugar de negación y sacrificio, despojo retorcido, sangre y suplicio, y la mente, metáfora de nuestra fisicidad pensada como máquina.

Sin embargo, aquella «revolución del deseo» que caracterizó el pensamiento más provocador del Body Art fue decisivamente erradicada por una tragedia clave: la pandemia del SIDA. Recordemos que en 1982 fue acuñado el término, una categoría mayor de enfermedades de transmisión sexual, una dolencia padecida por aquellos y aquellas como resultado — tal y como se encargaron de estigmatizar la institución médica y los representantes del orden moral- de unas prácticas sexuales desenfrenadas y promiscuas. Un año más tarde los mass media se esmeraron en sembrar el pánico y la histeria y, con ello, el cuerpo - un cuerpo vulnerable y en extremo peligro de contaminación - desapareció mayoritariamente de las prácticas artísticas.

Dicho esto, Extensiones corporales en el contexto del Body Art. Revolución del deseo no es un estudio pormenorizado de todos los y las artistas que han utilizado su cuerpo como elemento fundamental en las 
representaciones artísticas en la década de 1970. Nuestra investigación se centra en aquellos autores y autoras que han utilizado su propia fisicidad complementada con diferentes añadidos con la finalidad primordial de analizar una humanidad en la que el artificio deviene natural dentro de una sociedad absolutamente desnaturalizada.

Dicho esto, el principal objetivo de nuestra investigación consiste en examinar un período concreto cuyas similitudes con las vanguardias son evidentes. Asimismo, trataremos de buscar respuesta a toda una serie de cuestiones: ¿Por qué tras más de tres décadas se repitieron los conceptos claves que caracterizaron la utilización del cuerpo en las representaciones artísticas? ¿Cuáles fueron sus principales transformaciones? ¿Para qué sirvieron todo este tipo de manifestaciones? ¿Por qué esta actitud reivindicativa duró poco más de diez años? ¿Por qué razones la historia del arte no ha prestado especial importancia a la performance $\mathrm{y}$, mucho menos, a su relación con la tecnología hasta que ha sido verdaderamente inexcusable?

Siendo conscientes de nuestras limitaciones, la metodología utilizada tiene su punto de partida en los estudios de género, en las reflexiones feministas y postfeministas y en la queer theory, todas ellas teorías imprescindibles para el conocimiento de un cuerpo que no existe en sí mismo, sino que interactúa con un entorno sociocultural. Es evidente que más de medio siglo atiborrados y atiborradas con textos, exposiciones, ensayos y/o manifiestos en torno a la importancia - o no- del cuerpo no han sido suficientes para romper con toda una serie de normas y estereotipos contingentes que construyen el funcionamiento de una sociedad que no tiene la menor intención de diluir las desigualdades.

Sin caer en el fundamentalismo histórico-cronológico, consideramos esta aproximación necesaria para contextualizar unos hechos artísticos y sociales claves, cuya finalidad principal es la de aportar al lector o lectora una visión contextualizadora indispensable para poder comprender el 
lenguaje del arte corporal. No obstante, Extensiones corporales en el contexto del Body Art. Revolución del deseo no se ciñe a un discurso estrictamente histórico —ni lo pretende-, nuestro estudio circunscribe ciertas obras y artistas en tres apartados interrelacionados entre sí por unas doctrinas muy comunes y por la utilización de una serie de complementos que, en su relación con la acción corporal, ayudaron a reflexionar, denunciar y subvertir los límites sociales impuestos.

Aunque es innegable que cada vez resulta más sencillo acceder a bibliografía especializada en nuestro idioma, todavía falta mucho camino que recorrer si se desea llegar al nivel de las editoriales anglosajonas o francófonas. Para el desarrollo de la presente Tesis, hemos utilizado numerosos escritos, sin embargo, debemos destacar una serie de catálogos y ensayos cuya documentación ha sido imprescindible: L'art au corps. Le corps exposé de Man Ray à nous jours recopila varios textos ofrecidos por diferentes autores y autoras aportando una completísima información sobre el Body Art; The Artist's Body cataloga una multitud de trabajos artísticos relacionados con el cuerpo bajo unas determinadas directrices (cabe diferenciar la edición inglesa de la española, esta última publicada unos años más tarde y terriblemente amputada de unos magníficos anexos en los que se recogen fragmentos de textos esenciales en la historia del lenguaje corporal en el arte). En el territorio nacional, destacamos el excelente trabajo de Juan Vicente Aliaga Orden fálico. Androcentrismo y violencia de género en las prácticas artísticas del siglo $X X$, una esencial visión tratada desde el punto de vista de las teorías queer; y, por último, siendo conscientes del hecho de que no podemos enumerar toda la bibliografía esencial, tenemos el deber de mencionar a Juan Antonio Ramírez, una de las referencias más importantes en el arte de nuestro país que recientemente nos ha dejado huérfanos, a él le debemos, entre otros muchos trabajos, Corpus Solus. Para un mapa del cuerpo en el arte contemporáneo, una compilación de reflexiones muy personales sobre diversos y diversas artistas narradas con una familiaridad y sencillez ejemplares. 
La estructura de Extensiones corporales en el contexto del Body Art. Revolución del deseo se bifurca en dos partes claramente diferenciadas. La primera se ciñe a una contextualización teórico-histórica que condensa la utilización del cuerpo en la representación artística hasta la década de 1960, esta sección nos aporta los conceptos claves del trabajo — en este apartado se encuentran englobados los cinco primeros capítulos. La segunda sección - formada por los puntos seis, siete y ocho- profundiza en las diferentes «extensiones corporales» que fueron utilizadas en obras que pertenecieron o surgieron a partir del Body Art y de su entorno y/o contexto.

En el capítulo 1 de la Tesis - “Conceptos previos"- analizaremos el cuerpo como un producto socio-cultural, un cuerpo que deja de entenderse como mera entidad material a causa de su interacción constante con el mundo exterior. Debido a ello, el ser humano es inherente a la tecnología, es decir, a toda una serie de herramientas que han «extendido» las posibilidades físicas del individuo. Deviene necesario, por tanto, explicar no sólo las diferencias entre cuerpo como entidad material y entidad semántica, sino también sus «procesos de incorporación». Asimismo, resulta de enorme interés contextualizar el concepto de máquina corporal como emblema de una entidad física formada por la fusión entre tecnología y ser humano. Por último, también analizaremos los términos natural y artificial, dos conceptos que despliegan una ambigüedad de significados encarecidamente difusa.

En "La utilización del cuerpo mecanizado y/o prostético en las vanguardias artísticas del siglo XX" - capítulo 2- realizaremos una revisión histórica que se inicia a principios del siglo pasado. La Revolución Industrial exportó la utilización de la máquina a todos los ámbitos de la vida cotidiana transformándose en el elemento central de las representaciones que caracterizaron a las vanguardias artísticas. Sin embargo, nos centraremos únicamente en aquellos movimientos que utilizaron el cuerpo físico del o de la artista como soporte o lenguaje expresivo, es por ello por lo que omitiremos la aparición de otros movimientos que, aunque también 
reflexionaron sobre la irrupción de la máquina y de la tecnología, lo hicieron desde técnicas arraigadas a la tradición como son la pintura y la escultura, verbigracia el Cubismo o el Expresionismo. Tomando como caso el Surrealismo y el Dadaísmo cabe apuntar que el arte de acción formó parte de sus celebérrimas veladas, una de tantas características dada su condición literaria y teatral. No obstante, la relación directa entre cuerpo y máquina adquiere especial relevancia en tres movimientos clave: el Futurismo, el Constructivismo y la escuela de la Bauhaus.

La Segunda Guerra Mundial acabó con toda representación del cuerpo en el terreno artístico. El estereotipo de artista de postguerra se había personificado en un protagonista hipermasculino, aislado y nihilista, un personaje capaz de expresar exhaustivamente el existencialismo que imperó en aquel período. Empero, los valores del Expresionismo abstracto en Estados Unidos y del Informalismo y/o Tachismo en Europa y Japón empezaron a entrar en crisis en los albores de la década de 1960. Hastiados de aquella ocultación y de una sociedad sumergida en los valores más reaccionarios, una serie de autores y autoras comenzaron a reflexionar sobre la importancia de nuestra entidad física en la sociedad. Así, en "Antecedentes y periferias del Body Art" - punto 3-, realizaremos un exiguo recorrido histórico por aquellos y aquellas artistas que fueron pioneros en re-utilizar el cuerpo como herramienta de representación después de años de letargo.

Iniciamos, pues, este trayecto con el surgimiento del happening, de la acción en el espacio, un gesto agresivo que tomó forma ante una situación social intolerable y cuya principal intención coligió en activar al público a través de una indudable extensión de los estímulos. Con ello, se hace inexcusable revisar el trabajo del norteamericano Allan Kaprow, un aventajado alumno de Cage que acuñó, en 1959, el término happening. En el caso de Europa - más consecuente en activar la conciencia del espectador o espectadora - revisaremos la importancia de Wolf Vostell y de Jean-Jaques Lebel. 
En esta misma línea surgieron varios autores y autoras que se unieron a estas manifestaciones, verbigracia los y las integrantes de Fluxus, un complejo movimiento que, pese a estar adscrito al arte de acción, estuvo más ligado a la música que a las artes plásticas. En el mismo marco de desmaterialización de la obra de arte, tres autores fueron clave en utilizar su propia entidad física como objeto artístico, lo que denominamos man-made: el primer artista que abordaremos será Yves Klein, quien entendía el cuerpo como receptor de energía espiritual; seguidamente, revisaremos la labor del italiano Piero Manzoni, en cuya obra se hace patente la somatización del ready-made, es decir, la objetualización de lo corporal como obra de arte; y, finalmente, nos adentraremos en el complejo e inclasificable trabajo de Joseph Beuys, ocupado esencialmente por múltiples acciones corporales.

Para terminar, el Accionismo vienés ocupará el último subcapítulo que dedicaremos a los principales antecedentes que definieron —en el año 1970 - el Body Art. A pesar de que las prácticas corporales de los componentes del grupo austriaco son radicalmente diferentes, Hermann Nitsch, Günter Brus, Otto Mühl y Rudolf Schwarzkogler trabajaron bajo una fuerza y un objetivo común: reaccionar contra una sociedad cegada por los valores tradicionales y burgueses.

Visto esto, se hace necesario sentar las bases teóricas y formales del emergente Body Art. Para ello nos centraremos en dos subcapítulos que integrarán el punto 4 - "Planteamientos teóricos del Body Art"- y, que pese a su distancia, convergen en similares propósitos. Por una parte, comenzaremos con la escena estadounidense, formada en torno a la revista Avalanch de Bear y Sharp. Tanto el cine underground, como la entrada en el sistema universitario de la educación artística o la concentración en el SoHo de un hiperactivo sector intelectual, fueron factores determinantes en la gestación de un concepto: Body Work. Con ello, en 1968 germina el proyecto Avalanch, una publicación cardinal en cuyo primer número se divulgó un artículo bajo el título Body Works y en el que se trataron actividades donde el o la artista utilizaba su propio cuerpo como material 
escultórico. Respecto a la escena europea, François Pluchart, desde su revista arTitudes fundada tres años más tarde, sentó las bases de un «arte corporal sociológico-crítico» gracias a tres manifiestos.

En el capítulo 5 estableceremos las pautas que explican el concepto de «extensión corporal». Para ello, partiremos de un libro de culto titulado Les machines célibataires de Michel Carrouges en el que el autor catalogaba ciertas máquinas fantásticas descritas en la literatura del siglo XIX y las analizaba en relación al Grand verre de Duchamp. Tras ello, iniciaremos una ligera reflexión sobre cómo nos hemos convertido en verdaderos cyborgs, nadie puede negar hoy día que la tecnología es inherente al ser humano.

Seguidamente, el concepto «extensión» de McLuhan será el responsable de definir el término «tecnología» como suplemento prostético de una o varias funciones naturales. Asimismo, Baudrillard nos hablará del mito del robot e introducirá el gadget y Donna Haraway, en coherencia con el postestructuralismo, introducirá el concepto «tecno-biopolítica», noción por la cual somos organismos cibernéticos, es decir, seres de realidad social conformada por una construcción política. Para cerrar este capítulo, gracias a Beatriz Preciado introduciremos el concepto «farmacopornografía», un régimen postindustrial, global y mediático que toma como referencia, por una parte, los procesos de gobierno biomolecular (fármaco-) y, por otra, las construcciones semiótico-técnicas de la subjetividad sexual (-porno). Con todo ello, definiremos «extensiones corporales» como aquellos componentes que, añadidos o complementados al cuerpo humano, adquieren la función de analizar, transgredir y/o ampliar uno o varios miembros pertenecientes a éste. Esta definición será la encargada de enlazar las representaciones artísticas de las vanguardias de principios de siglo XX con el arte más actual.

El orden burgués profundamente decoroso que caracterizó los años de posguerra fue contundentemente rechazado por los sectores más críticos 
de la sociedad. La nueva década se convirtió en hito del replanteamiento del ego o, mejor aún, de una recodificación del género. En el capítulo 6, "Vestidos, maquillajes y purpurinas. Desmontando la masculinidad" revisaremos aquellos y aquellas artistas que analizaron el campo semántico de lo masculino cuestionando las actitudes hegemónicas que entienden la potencia, la fuerza y el control como sinónimos de unos valores inherentes. La indumentaria $\mathrm{y} / \mathrm{o}$ el maquillaje se transformaron en «extensiones corporales» propias de un proceso de auto-representación adquiriendo la capacidad de construir nuestra subjetividad.

Con ello, comenzaremos este punto con el trabajo de dos autores difíciles de clasificar que devinieron emblema de una actitud enfrentada a la moral dominante, ya que ambos fueron pioneros de una nueva generación sensibilizada con la liberación homosexual y la cultura andrógina. Por una parte, nos adentraremos en el trabajo de Pierre Molinier, un artista francés que inmortalizó fotográficamente el uso de diversas «extensiones corporales» con el propósito de romper todo límite que la sociedad biempensante fuera capaz de establecer; por otra parte, el caso de Diane Arbus es bien diferente, su obra artística se centró exclusivamente en retratar los sectores más afrentados de la sociedad.

A partir de 1968, una serie de autores - principalmente masculinos - iniciaron un trabajo artístico de profundo carácter narcisista que vislumbraba la ambivalencia entre el ser y el parecer. Dicha actitud quedó recopilada en 1974 en una exposición que, bajo el título de Transformer: Aspekte der Travestie, analizó el travestismo desde múltiples puntos de vista. Tomando dicha muestra como referente obligatorio, nos aproximaremos al trabajo de Urs Lüthi, verdaderas acciones próximas al cross-dressing donde la realidad y la ficción del yo se fusionan en imágenes fotográficas, una transformación tanto física, como psíquica y, por tanto, social; Jürgen Klauke creó imágenes de sí mismo generando una evidente ambigüedad sexual ayudado de accesorios que imitaban los genitales tanto masculinos como femeninos. En cambio, Katharina Sieverding se empeñó 
en encontrar similitudes entre ambos sexos mientras que Michel Journiac entendía la vestimenta como una trampa social, utilizando el travestismo a modo de extensión semántica del cuerpo social. En el territorio nacional encontraremos un hueco para Carlos Pazos, un artista catalán que apostó por la ambigüedad al crear un personaje mutante y transformista llevando el desdoblamiento a una creación irónica e irreverente. Andy Warhol aportará su grano de arena a esta fascinación por los poderes metamorfoseantes al igual que Lucas Samaras, quien seguirá capturando instantes de una vida teatralizada. Bajo los mismos parámetros que Diane Arbus, Nan Goldin sugerirá un álbum de drag queens y transexuales.

Retomando el recorrido que estableció Transformer: Aspekte der Travestie nos adentraremos en un tercer subcapítulo donde la música y el cine cobrarán un papel primordial en el camino en el que los cuerpos se extienden hasta diluir las fronteras del género. Con ello, estableceremos dos tipos de actitudes dentro del rock de la década de 1970, por un lado, los artistas más satíricos que ridiculizaron la imagen tradicional del estatus masculino - es el caso principalmente de Frank Zappa, New York Dolls, Alice Cooper, Lou Reed o Patti Smith; y, por otro lado, aquellos en los que el glamour adquirió un carácter preferentemente estético - Marc Bolan y David Bowie - junto a estos surgieron otros muchos más artistas que imitaron los mismos patrones aunque, más que por motivos ideológicos, con la finalidad de alcanzar el éxito. En el terreno del celuloide, el polémico y extravagante Kenneth Anger se erigió como referente obligatorio del cine underground influyendo en directores tan dispares como John Waters, Warhol/Morrisey o Fassbinder entre otros. Travestis y transexuales protagonizaron un considerable número de proyecciones - a menudo en clave de humor - con la intención última de desenmascarar las contradicciones de la sociedad y liberando comportamientos y actitudes ocultas.

En "La lógica de los complementos. Semiótica del padre" - capítulo 7- abordaremos aquellas obras que trataron de analizar las 
imposiciones sociales a través de objetos con una carga simbólica concreta. Asuntos como la opresión social, la dominación de la mirada masculina, el fanatismo radical, la autoría de la obra de arte o el valor económico y la contribución del trabajo artístico, se materializaron en diferentes «extensiones corporales».

Así pues, teniendo en cuenta que el cuerpo humano es un generador de ficciones, un productor de símbolos y un modelo susceptible de mímesis, comenzaremos el primer subapartado analizando el disfraz como camuflaje mental e integración en un entorno ajeno. A través de diversas series fotográficas —entendidas éstas como acciones corporales debidamente documentadas - Cindy Sherman demostrará que el yo conforma una serie discontinua de imitaciones y falsedades. En las directrices del arte de acción, Joan Jonas también investigó sobre la construcción de identidades, la performance permitió a la artista estadounidense explorar la imposición mediática de la representación, la identidad y el sexo.

A continuación, el objeto se constituirá como dictadura simbólica de connotaciones profundamente estandarizadas. Así, Hannah Wilke exploró su cuerpo a través de signos especialmente relacionados con particularidades atribuidas a la feminidad y a la masculinidad. Continuaremos con Martha Rosler, preocupada por el fetichismo que domina todos los registros de la existencia y seguiremos con el trabajo de Lynda Benglis, quien utilizó diversos objetos con la intención de responder al potencial misógino inherente en las prácticas artísticas.

El espacio público será el siguiente protagonista, un lugar que deviene entorno objetualizador donde se establecen las relaciones de poder, intereses y diferencias. Las protagonistas de este apartado serán Adrian Piper y Valie Export, ambas interesadas en llevar a la calle su trabajo ante un público inconsciente de ello. Las performances de Piper trataban de cuestionar y trastornar la actitud colectiva general en relación con la diferencia, cuanto más fuerte era la obra, mayor se hacía el impacto y la 
reacción del público. Como oposición al agresivo clima de machismo autoritario y obstinado del Accionismo vienés Valie Export estableció tensas, radicales y agresivas relaciones de dominio entre los dos sexos, teniendo como tema nuclear la resistencia femenina a la dominación del hombre sobre la mujer.

En el cuarto subapartado trabajaremos el atuendo como tecnología en el sentido foucaultiano del término. Revisaremos cómo la cultura patriarcal ha aplicado la tecnología al cuerpo femenino para satisfacer las fantasías masculinas. Los inicios de la obra creativa de Jana Sterbak reflejarán la complejidad de nuestra relación con la cultura, la autora se introduce en una especie de exploración de la subjetividad situada en la interfaz entre nuestro cuerpo y nuestras extensiones. La importancia de sus primeros trabajos nos obligará a tener en cuenta la evolución de una obra que, aunque se aleje del período central de nuestra Tesis, reúne las características principales de este trabajo y nos abre las puertas hacia un nuevo somacentrismo surgido en la década de 1990. Recordaremos también una acción de Louise Bougeois en la que, sin abandonar el tema central de su trabajo, vistió una extensión muy particular.

Para cerrar el capítulo 7, incurriremos en aquellos complementos que, desde una fetichización del imaginario infantil y adolescente, son capaces de poner en tela de juicio los valores patriarcales de la sociedad occidental. Paul McCarthy será el protagonista principal de este apartado analizando todo aquello que la cultura de masas se niega a reconocer, el autor se apropia de mitos modernos dotándolos de un nuevo contenido verdaderamente sarcástico. La posterior relación profesional de McCarthy con Mike Kelley nos llevará a investigar los inicios de este último, un interesante autor que inició su trabajo con unas acciones caracterizadas por una actitud verdaderamente Neo-dadá

Por último, en el capítulo 8 - "El cuerpo prostético"— nos centraremos en aquellos autores y autoras obstinados en rebasar las fronteras 
existentes entre el exterior y el interior del cuerpo a través de la experimentación con ellos y ellas mismos. A través de la hibridación entre lo corpóreo y lo tecnológico, reafirmaron no sólo la existencia de una identidad variable e inédita, sino también una nueva estética de carácter político absolutamente anticonformista e ilimitada respecto a las acepciones categóricas más convencionales, todo ello creado por voluntad propia y con buenas dosis de dolor y masoquismo. Empezaremos esta sección con dos autoras cuyo trabajo tiene muchos aspectos en común tanto estéticos como semánticos. La brasileña Lygia Clark trabajó la dimensión sensorial mediante unas particulares prótesis que nos hacen reflexionar sobre las posibilidades comunicativas entre el ser humano. La obra de Rebecca Horn conforma un exhaustivo estudio sobre el cuerpo entendido como fragmento, prótesis y/o prolongación.

Bajo la sentencia «el cuerpo está obsoleto» tanto Orlan como Stelarc exploran la corporeidad a través de las normas en las que se recrea la cultura occidental. Ambos han adoptado espectaculares riesgos promoviendo el escándalo como una trampa para la moral, hecho que ha provocado una infinidad de respuestas desde diferentes estratos de la sociedad.

Nuestro trabajo finaliza con una serie de reflexiones y cuestiones en torno a la simbiosis cuerpo-tecnología, una realidad presente cargada de innumerables codificaciones somatopolíticas de la que trataremos de tomar conciencia en este intenso recorrido artístico. Parafraseando a Pilar Pedraza, el arte no sólo sirve para el goce sino para no perderse. 


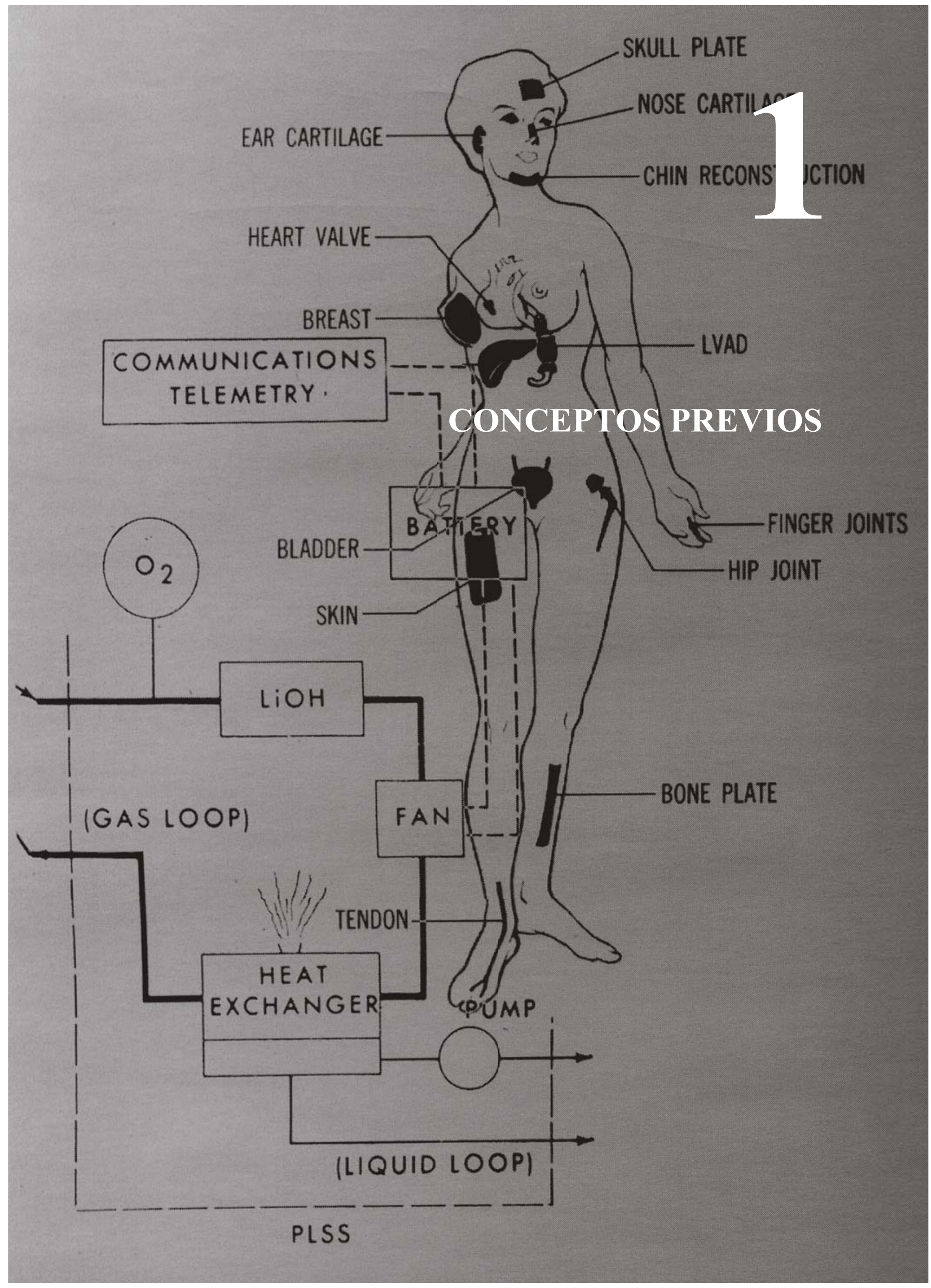



7 ntre las múltiples acepciones que otorga el Diccionario de la Lengua de la Real Academia Española al término «cuerpo», nos encontramos con dos definiciones susceptibles de tener en cuenta: «aquello que tiene una extensión limitada, perceptible por los sentidos»; y una segunda, «conjunto de sistemas orgánicos que constituyen un ser vivo».

La primera definición —aunque más propia de la geometría - nos plantea ciertas cuestiones de interés. Que el cuerpo sea un volumen que ocupa un espacio es evidente, puesto que éste queda restringido a unos límites determinados. No obstante, esa condición inherente al ser humano ha sido, desde la prehistoria, la fuerza generadora de creación tecnológica específica, es decir, una fuerza dirigida a la puesta en marcha de mecanismos cuya principal función ha radicado en ampliar la acción del individuo, en «extender» sus posibilidades, unas veces por necesidades biológicas - armas para cazar, herramientas para cultivar, medicinas- y otras para facilitar o desarrollar ciertas labores y aspectos culturales y cultuales —nos referimos, por ejemplo, a artilugios para comer, vestidos, 
refugios o drogas. Asimismo, el desarrollo tecnológico ha llevado al cuerpo a límites insospechados $\mathrm{y}$, a menudo, no perceptibles a través de los sentidos, verbigracia, las substancias de diseño utilizadas por atletas capaces de franquear cualquier control de dopaje o, incluso, el mismo espacio que ocupamos, plagado de millones de ondas inapreciables a nuestra vista, oído, tacto u olfato.

La segunda definición que nos aporta el diccionario remarca una serie de contradicciones a considerar, ¿cuáles son los sistemas orgánicos - supuestamente naturales - que constituyen al ser vivo?, ¿la carencia de alguno de estos sistemas o la complementación con otros inorgánicos $-\mathrm{y}$ por tanto artificiales - constituyen también un cuerpo, conformarán un individuo?

A lo largo de todo el siglo XX diversos estudios han abordado una interesante reflexión sobre el cuerpo y cómo éste se ha visto absolutamente invadido por elementos externos e internos que, si durante la época de las vanguardias artísticas quedaban complementados por la reciente incursión de la máquina en la vida cotidiana, con posterioridad, cerraban un siglo convirtiendo al ser humano en un verdadero cyborg, un sujeto provisto de un sinfín de añadidos destinados a subvertir, ampliar y/o corregir las limitaciones de nuestra vulnerable corporalidad. Este presupuesto de pinceladas cientifistas y exacerbado positivismo, insinúa que el cuerpo alcanzará su máximo potencial tanto físico como mental a través de toda una parafernalia tecnológica.

Teniendo en cuenta lo señalado, es conveniente incidir en dos puntos claves que, utilizados extensamente en el siguiente estudio, nos ayudarán a matizar más adelante ciertos conceptos. Nos referimos, por un lado, a las nociones de «cuerpo y corporeidad»y, por otro, a la contraposición «natural versus artificial». 


\subsection{Cuerpo, máquina corporal y corporeidad}

Revisando siquiera sea livianamente las infinitas interpretaciones que ha sufrido el cuerpo a lo largo de la historia, podríamos llegar a la conclusión de que éste es un palmario producto socio-cultural del cual se desprenden diferentes visiones e imágenes que el sujeto dispondrá - dependiendo en todo caso de su propia situación concreta - sobre su entorno. Esto nos lleva a la importancia de distinguir dos términos claramente diferenciados: cuerpo y corporeidad. No deberíamos hablar, por tanto, sólo de cuerpos — body - en tanto que entidades materiales, sino también de corporeidades y procesos de incorporación tales como los propiciados desde la cultura - embodiment. ${ }^{1}$

Las representaciones sociales - afirma Cortés - inscriben sobre el cuerpo un discurso concreto relacionado con el simbolismo general de la sociedad. Las imágenes y los saberes que le conciernen dependen completamente de un estado social, de una visión del mundo y, dentro de ella, de una definición de la persona. ${ }^{2}$

El cuerpo, por tanto, deviene construcción simbólica, no una realidad en sí misma y, a partir de su interpretación, alcanza el carácter de mediador entre el mundo exterior y el propio sujeto. Podríamos decir que el ser humano tiene una experiencia corporal del espacio y del tiempo en el que habita. El cuerpo es el medio por el cual nos producimos como seres sociales dentro de un espacio social construido igualmente por nosotros y nosotras. ${ }^{3}$ Nuestro físico, nuestro peinado $y$, por supuesto, nuestra vestimenta - inherente a la corporeidad en nuestra sociedad - marcarán las pautas para poder $-\mathrm{O}$ no- pertenecer al grupo. No es difícil encontrar en

\footnotetext{
1 Nuestro embodiment (o corporeidad) requiere necesariamente nuestra identificación social.

${ }^{2}$ G. CORTÉS, José Miguel, El cuerpo mutilado. La angustia de muerte en el arte, Valencia, Generalitat Valenciana, 1996, p. 20.

3 JONES, Amelia, "Survey", en WARR, Tracey (ed.), The Artist's Body, London, Phaidon, 2000 , p. 19.
} 
cualquier revista dominical alguna reflexión — si bien de manera un tanto superficial - acerca de la presión a la que estamos sometidos y sometidas por el mero hecho de pertenecer a una sociedad donde los estereotipos — monstruosamente definidos - devienen irreales y donde se piensan imprescindibles para alcanzar el éxito. Como consecuencia de este tipo de dependencias podemos observar - ya desde el siglo XX- graves patologías como la anorexia, sufrida por un cada vez mayor número de personas. ${ }^{4}$ Junto a ello, se ha de destacar que paulatinamente, nos hemos transformado en una especie de cyborg, de máquina humana: somos el producto de una serie de tecnologías que nos construyen.

Por tanto, nuestra corporeidad, tal y como pone de relieve Juan Antonio Ramírez en su trabajo Corpus Solus, ${ }^{5}$ se transforma en un constante «campo de batalla»: ${ }^{6}$ es el terreno inestable donde los mecanismos de poder constantemente sitúan nuevas técnicas y estrategias, y donde se da una tenaz tensión entre mecanismos de poder y técnicas de resistencia. Hablamos del cuerpo como si fuera una circunstancia contigua a nuestro yo más íntimo. Somos el resultado de una carnalidad que nos constituye, pero en la que no

\footnotetext{
${ }^{4}$ No deberíamos pasar por alto la vigorexia. Al contrario que la anorexia, el afectado o afectada se obsesiona por aumentar el volumen muscular de su cuerpo. Erróneamente se ha tendido a encasillar por géneros ambas enfermedades, sin embargo, aunque socialmente la mujer tienda a la anorexia y el hombre a la vigorexia, cada vez son más los casos en que ocurre lo contrario.

${ }^{5}$ RAMÍREZ, Juan Antonio, Corpus Solus. Para un mapa del cuerpo humano en el arte contemporáneo, Madrid, Siruela, 2003.

${ }^{6}$ Recordemos el sugestivo cartel pseudopublicitario de Barbara Kruger Your Body is a Battleground, todavía hoy vigente. El 9 de abril de 1989 hizo aparición en Washington para convocar una manifestación. El motivo era organizar una protesta ante el posible uso por pate del gobierno de Bush padre de un caso presentado ante el tribunal supremo que pudiera suponer la limitación o supresión del derecho al aborto. En la imagen un rostro femenino, de belleza convencional, mira de frente al espectador o espectadora. Un eje vertical divide ese rostro en dos mitades simétricas: positivo fotográfico a la izquierda y negativo a la derecha. El artificio inversor de la técnica empleada le sirve a la autora como metáfora para expresar los contrastes y contradicciones del cuerpo. Nuestro cuerpo es un ámbito conflictivo difícil de delimitar, un lugar de convergencia o disputa de complejas pulsiones morales, biológicas y políticas. La batalla social, la lucha de géneros y de clases, se desarrolla en nuestro cuerpo, aunque no siempre de manera consciente.
} 
queremos diluirnos. Esta dualidad ha configurado - no sin importantes desavenencias - al ser humano desde Platón, el gnosticismo o la tradición judeo-cristiana. La carne nos atrae hacia el abismo y el pecado, de ahí que debamos disciplinarla, sacar de raíz su propensión libidinosa. El cuerpo se convierte en lugar de negación y sacrificio, despojo retorcido, sangre y suplicio. Sin embargo, la mente deviene metáfora del cuerpo pensado como máquina. El mecanismo establece un nuevo paradigma que posibilita la imaginación de los primeros autómatas, pero también de la concepción del individuo inmerso en la revolución industrial, de la misma manera que el organicismo preludia el ser humano biotecnológico y ambos las propuestas tecnológicas del universo cibernético. ${ }^{7}$

Durante los años 1960-1970, se vivió un resurgir natural, el cuerpo se reivindicó como lugar del hedonismo, el erotismo, la psicodelia, el movimiento hippie, el feminismo, la apertura de las relaciones personales o la ecología, asistiendo a un gozo y explayación de la carne. Aquella nueva conciencia sobre el cuerpo germina, entre otros motivos, como reacción a toda una biotecnología de control-poder ¿No es demasiada casualidad que el SIDA surgiese inmediatamente como reacción al "peligro" de aquel intento de liberación? ${ }^{8}$

7 RODRÍGUEZ MAGDA, Rosa María, "Introducción”, en Debats, n ${ }^{\circ}$ 79, Valencia, Institució Alfons el Magnànim, Invierno 2002/03, pp. 4-5. El presente número de la revista es de gran interés por estar dedicado íntegramente al tema de «El cuerpo».

${ }^{8}$ Para un desarrollo sobre la pandemia en la sociedad véase: SONTAG, Susan, El sida y sus metáforas, Barcelona, Muchnik Editores, 1989. Aunque el tema de la enfermedad no esté directamente relacionado con nuestra investigación, es interesante tenerlo en cuenta como ejemplo de «uso del cuerpo». Sontag realiza un brillante manifiesto donde reflexiona sobre la utilización que se hace de la enfermedad como figura o metáfora. El SIDA ha corrido, prácticamente, la misma suerte que la sífilis, la peste o la tuberculosis, es decir, ha sido concebido como un castigo, en este caso a la promiscuidad sexual de los años sesenta y setenta, una caza de brujas para la homosexualidad (entre otros grupos de "riesgo"). Considerar una enfermedad como un castigo es la más arcaica idea que se tiene de la causa de ésta. De este modo, las fobias, prejuicios y miedos han tejido una red de complicadas metáforas que dificultan su comprensión. Uno de los primeros estudios publicados en el contexto nacional fue: LLAMAS, Ricardo (comp.), Construyendo sidentidades. Estudios desde el corazón de un pandemia, Madrid, Siglo XXI, 1995. Esta compilación de textos 
Tras aquel breve paréntesis, el cuerpo parece que ha vuelto a asumir aquella separación esquizoide con la mente. Surge así la inteligencia artificial que se despliega como una promesa en la que la corporalidad parece un lastre arcaico susceptible de ser modelado para camuflar su vulnerabilidad. El cuerpo se convierte ahora -más que nunca- en circunstancia dispuesta a ser modificada por los dictados de la voluntad o el diseño. La ingeniería genética se pretende horizonte superador de la imperfección física, de la enfermedad o de la muerte misma. A partir de este tipo de ingeniería se pueden reconstruir tejidos y órganos, promover la eugenesia, imaginar la clonación de prototipos perfectos. El sexo, antaño entendido como natural e inamovible, se percibe no como un destino biológico, sino como un espacio abierto, modificable y manipulable: los tratamientos hormonales o la cirugía así lo posibilitan. Desde un aspecto terapéutico o estético, las prótesis, los implantes, la nanotecnología, transforman a los individuos en un híbrido de máquina y fisiología, en cuerpos absolutamente extendidos, en verdaderos cyborgs. ${ }^{9}$ El ciberespacio nos habla de una zona real que existe sólo en el interior de los ordenadores, esa velocidad de la fibra óptica encaja mal con nuestras lentas traslaciones físicas. Quizás sea por ello que desde hace siglos la ciencia ficción ha creado un imaginario colectivo, que ahora es compartido como horizonte de referentes por toda una generación. ${ }^{10}$

Respecto al arte, es más que evidente que el cuerpo humano se encuentra como punto de referencia del discurso artístico a lo largo de la historia. Gran cantidad de artistas han dibujado, esculpido y pintado lo

constituye una reflexión abierta y desprejuiciada sobre los fenómenos sociales y políticos de la enfermedad. Mientras la opinión dominante circunscribía la problemática del SIDA a una cuestión individual o propia de grupos de riesgo, Llamas fue capaz de abrir múltiples campos de debate. Véase también: ALIAGA, Juan Vicente y G. CORTÉS, José Miguel, De amor y rabia. Acerca del arte y el sida, Valencia, Universidad Politécnica de Valencia, 1993.

9 HARAWAY, Donna J., "Manifiesto para cyborgs: ciencia, tecnología y feminismo socialista a finales del siglo XX", en HARAWAY, Donna J., Ciencia, cyborgs y mujeres. La reivindicación de la naturaleza, Madrid, Cátedra, 1995, pp. 251-311.

${ }^{10}$ RODRÍGUEZ MAGDA, Rosa María, op. cit., pp. 4-5. 
humano. Sin embargo, esa presencia del cuerpo y su percepción por parte de éstos y éstas ha sido modificada según las necesidades de cada época. En el transcurso de los últimos cien años se han interrogado cómo el cuerpo ha sido representado y concebido, y cómo la idea del «yo» físico y psíquico en tanto que forma estable y predeterminada ha ido erosionándose de manera gradual gracias a los avances del siglo XX en el terreno del psicoanálisis, la filosofía, la antropología, la medicina y la ciencia. Numerosos y numerosas artistas han estudiado la temporalidad, como contingencia e inestabilidad del cuerpo y han explorado la noción de lo que Judith Butler denomina performativity $^{11}$ más allá de los límites culturales. ${ }^{12}$ El cuerpo se convierte en un kit dispuesto al bricolaje, algo que sólo tras su transformación se adecua a lo que realmente deseamos ser. Dentro del arte conceptual, el Body Art consigue de manera plástica y radical evidenciar todas esas transformaciones.

Todo ello hace que hayamos alcanzado la mínima expresión —cuando no anulación - materialista de nuestro interior, llegando, incluso, a sentirnos asiduamente extraños a nuestra propia corporalidad. Hemos sido reducidos a un simple volumen, aislado de su entorno, concebido como un elemento que debe «funcionar», como una forma que no se debe detener. Un volumen al que se restringe la experiencia sensorial: tan sólo la palabra como vehículo de la razón y la vista, como elemento crucial de un mundo lleno de pantallas e imágenes, tienen necesidad de existir, llegándose a convertir en símbolos del mundo moderno. Los demás sentidos han pasado

\footnotetext{
${ }^{11}$ En el catálogo de la exposición Zona F, Ana Martínez-Collado y Ana Navarrete definen — si bien de forma muy resumida - el término «performatividad» de Judith Butler como aquellos actos conscientes de ejercicio de la diferencia. MARTÍNEZ-COLLADO, Ana y NAVARRETE, Ana, "Cyberfeminismo: dos escenarios", en el catálogo de la exposición, Zona F, Castelló, Espai d'Art Contemporani de Castelló, 2000, pp. 53-71. Recordemos, sin embargo, que tras unos cuantos años de espera, se han traducido al español dos de los trabajos más importantes de la autora norteamericana esenciales para entender su complejo pensamiento: BUTLER, Judith, El género en disputa: el feminismo y la subversión de la identidad, Barcelona, Paidós, 2001 y BUTLER, Judith, Cuerpos que importan: sobre los límites materiales y discursivos del sexo, Barcelona, Paidós, 2003.

${ }^{12}$ WARR, Tracey, "Preface", en WARR, Tracey (ed.), op. cit., pp. 10-15.
} 
a convertirse en el submundo de una realidad olvidada en el ser humano que es su cuerpo.

Es curioso cómo desde nuestra infancia se nos reprimen los sentidos: un bebé tiende a coger todo lo que está a su alcance y llevárselo a la boca debido a que el desarrollo del tacto y del gusto es mucho mayor que el de la vista. El cuerpo se ha transformado en un objeto manipulable y extensible, en un mecano susceptible de todo tipo de arreglos y composiciones, adaptable a todo el conjunto de reglamentaciones sociales. Uno de los términos fundamentales que servirán para enlazar la inherente relación entre el cuerpo y la máquina será el de flesh-machine que introduce Amelia Jones, concepto que define la relación racional del cuerpo con el capitalismo desarrollado o pancapitalismo. ${ }^{13}$

En la contemporaneidad - tal y como José Miguel G. Cortés apunta en su trabajo El cuerpo mutilado- podemos señalar dos métodos, aparentemente dispares, que marcan la visión general de la sociedad sobre el cuerpo. En un primer momento, éste se percibe como la «parte maldita» de la condición humana, parte que la ciencia y la técnica se encargan de remodelar y arreglar para, de alguna manera, liberar a la persona de su relación con la carne. En un segundo momento, el mejoramiento de la apariencia, la búsqueda de la salud, de la seducción y de la juventud, hacen del cuerpo un objeto privilegiado. A estos cuerpos artificiales que revelan de alguna forma un claro reduccionismo, es necesario añadir unos cuerpos parciales, nacidos de sistemas, de discursos y prácticas diversas. De este modo, observamos que podemos elegir entre: ver el cadáver (como el médico); ver la parte animal, los instintos y apetitos de la carne (el sacerdote); ver el robot (el economista político); ver el maniquí o el striptease (los mercaderes de la belleza y el placer); etcétera. Cada una de estas opciones se oculta detrás de una serie de «extensiones» sociales que actúan

${ }^{13}$ JONES, Amelia, op. cit., p. 21. 
como ideal: la salud, la resurrección, la productividad, la sexualidad liberada. $^{14}$

Pero, ¿en qué situación o momento histórico comienza a tener especial relevancia la consideración del cuerpo como soporte susceptible de ser modificado? Se podría decir que desde el siglo XVII la humanidad se ha interesado progresivamente en el desarrollo de artilugios que imitaran actividades propias de las personas, ya fuera con fines laborales o como mero divertimento. Las nuevas ideas sobre el cuerpo están vinculadas de manera directa con el nacimiento del capitalismo moderno y contribuyeron a la gran transformación social del individualismo. El individuo moderno es, por encima de todo, un ser humano móvil y «extensible». Este proceso histórico es el que nos lleva a hablar del concepto de «hombre máquina» introducido por Julien Offray de La Mettrie, mito moderno por el cual se reduce el ser humano a su superficie, a la parte observable de su comportamiento físico, dado que la dimensión simbólica e inconsciente es ocultada. Al negar u olvidar el carácter simbólico del cuerpo la persona se ve reducida a un conjunto de mecanismos, de funciones sustituibles, de piezas intercambiables con el objetivo de una mejora en su funcionamientorendimiento. ${ }^{15}$

Por otra parte, es evidente que si el cuerpo se convierte en una máquina escaparía éste de la precariedad de su existencia: la muerte ya no tendría lugar y sus piezas se irían sustituyendo, adaptándolas o modificándolas según las necesidades. Nos enfrentamos, pues, a un ser nuevo (autómata, androide, cyborg), construido con diferentes piezas: el mito de Frankenstein a la orden del día. ${ }^{16}$ En cualquier publicación mass

\footnotetext{
${ }_{14}^{14}$ G. CORTÉS, José Miguel, op. cit., p. 40.

${ }^{15}$ Véase LA METTRIE, Julien Offray de, El hombre máquina. El arte de gozar, Madrid, Valdemar, 2000.

${ }^{16}$ La novela sobre Frankenstein es el primer ejemplo, en la literatura popular, donde se plantea con inquietud la cuestión de los límites del ser humano y el uso del cuerpo como un material biológico disponible para su utilización y recomposición. Véase SHELLEY, Mary W., Frankenstein o el moderno Prometeo, Madrid, Siruela, 2000.
} 
media podemos encontrar infinidad de artículos e imágenes - ya sean científicos, de divulgación médica o mera información dominical- donde se pone de manifiesto la utilización de prótesis fabricadas por especialistas. Estas extensiones no solucionan — todavía - los problemas funcionales que conlleva cada órgano, pero sí pueden sustituir todas las articulaciones, los tejidos blandos y fabricar huesos. Conocido es el caso del sudafricano Oscar Pistorius, un atleta con dos prótesis que sustituyen sus piernas y que, no hace mucho tiempo, colocó a la Asociación Internacional de Federaciones de Atletismo (IAAF) ante una incómoda encrucijada. La voluntad del velocista de competir en los pasados Juegos Olímpicos choca con la norma que introdujo la IAAF prohibiendo el uso de «ayudas técnicas» a todos los atletas. $^{17}$

No es difícil observar que el cuerpo se ha «extendido», ha sobrepasado sus propias fronteras y se ha convertido en un caos, en un amasijo de agujeros y órganos-mecanismos sexuales. La transgresión de los límites de la representación del cuerpo —esa invasión de miembros mutilados, sexos monstruosos, mecanismos corpóreos, formas imposiblespodría ser entendida como una proyección de las más diversas fantasías sadomasoquistas. Pero ¿cómo se originan y desarrollan las múltiples representaciones del cuerpo extendido?, ¿qué simboliza éste en la sociedad?, ¿cómo han evolucionado - $\mathrm{O}$ no- sus múltiples connotaciones en relación a su situación histórica?, ¿cuáles han sido los motivos por los que estas extensiones han sido siempre altamente sexualizadas?

En Occidente, la representación del cuerpo, ya fuera de raíz clásica o, incluso, anterior, se resumía, esencialmente, en la escenificación del corpus divino y emblemático de la perfección —Dios crea al hombre ${ }^{18}$ a su

\footnotetext{
${ }^{17}$ Www.elpais.com/articulo/reportajes/hombre/bala/piernas/elpepudep/20070513elpdmgrep $4 /$ Tes

${ }^{18}$ El vocablo «hombre» será utilizado a lo largo del texto como referencia a definiciones propias de un determinado lenguaje social. Trataremos de evitar dicho término como generalización de ambos sexos. Cuando sea mencionado se dará por supuesto que determinará unas connotaciones de dominación masculina en detrimento de la igualdad de
} 
imagen y semejanza-, o en la de su expresión contraria, la fealdad, interpretada como símbolo de su condena. Desacralizando y entronizando la gradual secularización de los valores, el siglo XIX contribuyó a establecer la noción del cuerpo como materia aventurada, una materia en la que perderse y que, desde entonces, se requisa para diversos fines demostrativos. Goya dota de valor al cuerpo que sufre, a la monstruosidad, a las figuras de la humillación. Courbet, por su parte, centra su atención en el cuerpo real o trabajador. A su vez, Manet lo hace en el cuerpo como figura aburrida. Van Gogh, sin embargo, fija su atención en el cuerpo arrojado fuera del mundo. El siglo XX perpetúa esta línea y la intensifica con constancia. El hecho de «experimentar» el cuerpo conduce al artista a modificar la relación entablada con la imagen que, para algunos y algunas, llega a convertirse en una superficie inútil. ${ }^{19}$

El citado Paul Ardenne vincula este entusiasmo a «extraer» el cuerpo de la imagen - muy propio desde el siglo XX - con los efectos traumáticos de la crisis histórica del humanismo que impulsa la modernidad; una crisis que lleva al extremo sus acentos más fuertes en filosofías pesimistas, en la defensa del absurdo y, por supuesto, en la implacable tesis de «la muerte del hombre» que Foucault sostendrá ya en Las palabras y las cosas, y que constituye un violento cuestionamiento del principio de la positividad humana. $^{20}$

Sin embargo, la visión de Beatriz Preciado deconstruye de alguna forma las teorías postestructuralistas en su trabajo Manifiesto contra-sexual. Para la autora el cuerpo es entendido como espacio de construcción tecnobio-política, como lugar de opresión, pero también $-\mathrm{y}$ en esto es en lo que

género. En muchos casos no tendremos más remedio que utilizar el género masculino debido a que los movimientos artísticos a lo largo de la historia, a pesar de su planteamiento de ruptura con los valores tradicionales, se muestran verdaderamente conservadores ante la mujer.

19 ARDENNE, Paul, "Figurar lo humano en el siglo XX", en Debats, op. cit., p. 22.

20 FOUCAULT, Michel, Las palabras y las cosas. Una arqueología de las ciencias humanas, Madrid, Siglo XXI, 1997. 
difiere de las teorías foucaultianas - como centro de resistencia. La «contrasexualidad» de Preciado no es la creación de una nueva naturaleza, sino más bien el fin de la Naturaleza como orden que legitima la sujeción de unos cuerpos a otros. La «contra-sexualidad» de la autora no habla de un mundo por venir; al contrario, lee las huellas de aquello que ya es el fin del cuerpo, tal y como éste ha sido definido por la modernidad. ${ }^{21}$

Para concluir, deberíamos reiterar que el tratamiento del cuerpo propio de nuestra era se revela en un estado de concordancia con los principales accidentes simbólicos registrados por la historia: en primer lugar, un abandono paulatino del corpus de esencia divina; por otra parte, el crecimiento del materialismo, que amplía su vía de expansión a las teorías del «hombre-máquina», constituidas en el fundamento de una relación más técnica que ética con el cuerpo; y, por último, una crisis profunda e irreversible del humanismo, acelerada dramáticamente por las tragedias de la Segunda Guerra Mundial. La representación artística del cuerpo constituirá, rigurosamente, un calco de esta evolución. ${ }^{22}$ Muchas de las fantasías de Frankenstein dependen del horror de un ser humano sintético enloquecido por su carencia de «alma». ¿No es ésta una forma simbólica de expresar el hecho de que mucha gente se ha vuelto tan mecanizada, que siente un débil resentimiento por estar privada de su estatus humano?

\subsection{Natural versus artificial}

Como acabamos de ver, tanto el cuerpo como la corporeidad son susceptibles de modificación. Esta aserción que a priori no plantea problema alguno, nos lleva a cuestionarnos el segundo conjunto de conceptos que debemos analizar: nos referimos a los términos «natural» y «artificial». En este sentido, un cuerpo, que suponemos en un principio ente

21 PRECIADO, Beatriz, Manifiesto contra-sexual. Prácticas subversivas de identidad sexual, Madrid, Opera Prima, 2002, pp. 12-18.

${ }^{22}$ ARDENNE, Paul, op. cit., p. 23. 
biológico y por tanto natural, quizás no lo sea tanto en cuanto observamos que su corporeidad no es más que un diseño socio-cultural, en términos de Preciado, un soporte «tecno-bio-político».

El tropo «naturaleza» frente a su supuesto antónimo «artificio» ha sido y es - sin duda el debate está a la orden del día posiblemente como consecuencia de las catástrofes medioambientales - uno de los temas centrales del pensamiento occidental. Y como tal, parece tarea ardua evitar esa lucha de contrarios, es decir, socavar los binomios o, mejor aún, los antagonismos entre ambos términos, base de un pensamiento moralista y de raigambre platónico-cristiana. La teoría postestructuralista fue capaz de poner en evidencia que los sistemas simbólicos en Occidente estuvieron basados en estas oposiciones binarias generándose el significado por exclusión, es decir, el primer término de cada dualismo quedaba siempre subordinado al segundo. Por ello, de lo que se trata es de desarticular esas jerarquías que afianzan unos criterios de verdad en detrimento de los contrarios.

Sin entrar en discusiones en torno a lo ecológico y/o lo artístico, Jesús Mosterín aporta una de las reflexiones más interesantes para este trabajo en relación a los términos «natural»y «artificial». Éste rompe con el binomio tradicional y hace una excepción trazando la frontera entre nature y nurture. Para el autor, el primer término es aquello cuya información es transmitida genéticamente, mientras que el segundo - semejante al concepto «cultural» al que nos referimos- no se transmite mediante los genes, sino por aprendizaje social. La similitud con los términos body y embodiment, definidos anteriormente, es evidente. Mientras que «cuerpo» designaba la entidad material, «corporeidad» se refería a los procesos de incorporación cultural. Sin embargo, aquí es donde se nos plantean las primeras contradicciones: un ser natural — como en un principio lo es el ser humano- ¿puede hacer algo que no sea natural?, pero, ¿qué es un ser natural?, ¿a qué correspondería un ser artificial?, ¿podría éste hacer algo 
que no fuera artificial? $^{23}$ Cuestiones a priori evidentes, comienzan a plantear serias dudas. Asimismo, Elliot Sober afirma que el concepto de «naturaleza» padece la misma ambigüedad que el concepto «normalidad», ya que «normal» puede significar tanto usual como deseable. ${ }^{24}$

Sin abandonar el término nurture que implicaba el aprendizaje social, sería interesante revisar el trabajo de Félix Guattari. El autor niega rotundamente en su trabajo Las tres ecologías que la naturaleza pueda separarse de la cultura y apologiza por un pensamiento «transversal» de las «interacciones entre ecosistema, mecanosfera y Universo de referencia sociales e individuales», en otras palabras y como indica el título del ensayo, una interacción entre «las tres ecologías» a las que el autor se refiere: la ecología del medio ambiente, la de las relaciones sociales y una última de la subjetividad humana. ${ }^{25}$ Las conexiones de la humanidad - denuncia Guattari- con estos tres factores tienden a deteriorarse paulatinamente hasta llegar a la pérdida absoluta de la subjetividad.

En Meditación de la técnica, de Ortega y Gasset, se señala que el ser humano no es tanto el fruto de la adaptación a un medio natural, sino más bien - y crecientemente - el producto de la adaptación del medio natural a él. A diferencia de los demás animales, el ser humano no satisface sus necesidades adaptándose a la naturaleza, sino que introduce entre él y el mundo natural esa mediación, esa supranaturaleza que hoy solemos llamar «tecnosfera». Mediante la técnica el ser humano va conformando el mundo natural para adaptarlo a sus necesidades y apetitos. ${ }^{26}$

Ortega y Gasset nos responde aquí a varias cuestiones planteadas con anterioridad: el mundo natural se define constantemente, conforma

\footnotetext{
${ }^{23}$ MOSTERÍN, Jesús, Ciencia viva. Reflexiones sobre la aventura intelectual de nuestro tiempo, Madrid, Espasa-Calpe, 2001, pp. 262-265.

${ }^{24}$ SOBER, Elliot, El comportamiento altruista: evolución y psicología, Madrid, Siglo XXI, 2000, p. 53.

${ }^{25}$ GUATTARI, Félix, Las tres ecologías, Valencia, Pre-Textos, 1996, p. 34.

${ }^{26}$ Véase ORTEGA Y GASSET, José, Meditación de la técnica, Madrid, Alianza, 2002.
} 
aquello que podríamos denominar en términos foucaultianos como biopoder, un espacio altamente tecnificado que determina la normalidad, y por tanto lo natural.

El ideal de crear o recrear una naturaleza sintética —incluyendo la propia naturaleza biológica del ser humano - se lleva hasta sus últimas consecuencias. De forma metafórica, Jorge Riechmann describe la Revolución Industrial como un proceso mediante el cual las sociedades se alejan del sol para hundirse en el subsuelo. En las sociedades industriales hasta hoy conocidas encontramos una economía del subsuelo movida por combustibles fósiles. La humanidad, en tanto que especie esencialmente definida por una animalidad de artefacto y artificio, obra sobre la naturaleza entera artificiándola. ${ }^{27}$ Así pues, la tecnociencia moderna se podría resumir en dos proposiciones generalizadas:

- Todo puede hacerse, todo es técnicamente factible, lo hoy imposible será mañana posible gracias a un progreso técnico sin fin que en lo fundamental no conoce límites.

- Aquello que puede hacerse (teóricamente) está justificado (moralmente) hacerlo.

A modo de información cabría prestar atención al citado Guattari, quien reflexiona sobre el concepto de ecología en el período posterior a la revolución tecnológica en el texto anteriormente mencionado.

Por su parte, en su trabajo La crisis de las vanguardias y la cultura moderna, Eduardo Subirats hace hincapié en el concepto de ecología dentro del período posterior a la revolución tecnológica. Hoy día — según el autor - la máquina ocupa para el individuo moderno el mismo lugar semántico que la naturaleza tuvo para el hombre del siglo XVIII. En última instancia, es cierto que la tecnología es la mediadora de todos nuestros

\footnotetext{
27 Véase RIECHMANN, Jorge, Un mundo vulnerable. Ensayos sobre ecología, ética y tecnociencia, Madrid, Catarata, 2000.
} 
procesos vitales, desde el nacimiento hasta la muerte, y que nuestra confrontación con los fenómenos de la razón instrumental comprende todas aquellas actividades y facultades que en una cultura pre-industrial dirigen la confrontación del hombre con la naturaleza. ${ }^{28}$

Posiblemente uno de los impulsos más primarios del ser humano sea el de crear objetos, es decir, cosas materiales constituidas a partir de la manipulación directa de cualquier sustancia presente a nuestro alrededor que conduzca a la formación de algo distinto de lo que existía con anterioridad. ${ }^{29}$ Vivimos en un mundo donde la importancia asumida por los objetos que nos rodean ha relevado, prácticamente, a la naturaleza. Es, por tanto, inherente a nuestra sociedad y nuestra cultura ese universo objetual y artificial que nos rodea y del cual ya no podemos desvincularnos. La relación persona-objeto a lo largo de la historia nos proporciona información reveladora acerca de las condiciones socioculturales de una determinada zona geográfica.

El término tecnología activa pone en funcionamiento una serie de oposiciones binarias: natural/artificial, órgano/máquina, primitivo/moderno. En las mismas, el «instrumento» juega un papel de mediación entre los términos de la oposición. Tanto en las narraciones positivistas del desarrollo tecnológico —en las que el hombre se representa como la razón soberana que doma, domestica y domina la naturaleza bruta- como en las narraciones apocalípticas o antitecnológicas, se comparte un mismo presupuesto metafísico: la oposición entre el cuerpo vivo (como naturaleza) y la extensión inanimada (como tecnología). ${ }^{30}$

En el marco de la gestión tayloriana y racional del trabajo - tanto en la industria en tiempos de paz, como en la industria de destrucción masiva de la guerra-, el cuerpo masculino constituía ya en sí mismo la prótesis orgánica al servicio de un mecanismo más amplio. Se concebía como un

28 SUBIRATS, Eduardo, La crisis de las vanguardias y la cultura moderna, Madrid, Ediciones Libertarias, 1985, p. 72.

${ }^{29}$ DORFLES, Gillo, Naturaleza y artificio, Barcelona, Lumen, 1972, p. 55.

${ }^{30}$ PRECIADO, Beatriz, op. cit., p. 118. 
aparato mecánico que podía reconstruirse artificialmente con la ayuda de miembros prostéticos: «brazos trabajadores» o «piernas pedaleantes» por medio de los que el trabajador podía incorporarse a la máquina industrial. En palabras de Anders: «nuestro mundo actual en su conjunto se transforma en una máquina, está en camino de convertirse en una máquina». ${ }^{31}$

Quizás a través del elemento «prótesis» podamos entender claramente la confusión de ambas oposiciones: el estatuto borderline de la prótesis expresa la imposibilidad de trazar límites nítidos entre lo «natural» y lo «artificial», entre el «cuerpo» y la «máquina». La prótesis muestra que la relación cuerpo-máquina no puede comprenderse simplemente como un ensamblaje de partes anodinas y articuladas conjuntamente que cumplen una labor específica. En lo que concierne a la modificación de las actividades vivas del cuerpo orgánico, la prótesis sobrepasa el orden mecánico. Tal y como afirma Beatriz Preciado: «la prótesis alucinatoria ya es un cyborg». ${ }^{32}$

En Comprender los medios de comunicación: las extensiones del ser humano, Marshall McLuhan anticipó que las tecnologías del siglo XX se caracterizarían por actuar como suplementos prostéticos de una función natural. La prótesis, pensada como una sustitución artificial en caso de mutilación, una copia mecánica de un órgano vivo, ha transformado la estructura de la sensibilidad humana en algo que el nuevo siglo ha bautizado con el nombre de «post-humano». La prótesis no reemplaza solamente a un órgano ausente, es también la modificación y el desarrollo de un órgano vivo con la ayuda de un suplemento tecnológico, es la «extensión corporal». Como extensión del oído, el teléfono permite a dos interlocutores distantes intercambiar una comunicación. La televisión es una extensión del ojo y del oído que permite a un número indefinido de espectadores compartir una experiencia al mismo tiempo comunitaria y desencarnada. En otros términos, cada «órgano tecnológico» reinventa una «nueva condición

\footnotetext{
${ }^{31}$ ANDERS, Günther, Nosotros, los hijos de Eichmann. Carta abierta a Klaus Eichmann, Barcelona, Paidós, 2001, p. 52.

${ }^{32}$ PRECIADO, Beatriz, op. cit., p. 132.
} 
natural» para la que somos discapacitados y discapacitadas. O mejor aún, cada nueva tecnología reinventa nuestra naturaleza como discapacitada con respecto a una nueva actividad que requiere ser suplida tecnológicamente. Toda tecnología es una extensión que requiere nuevas relaciones con nuestro cuerpo. ${ }^{33}$

La diferencia entre «bio» $\mathrm{y}$ «tecno» no es una diferencia entre lo orgánico y lo inorgánico. No se trata aquí de evaluar el paso de lo biológico a lo sintético, sino de señalar la aparición de un nuevo tipo de corporalidad. Las nuevas técnicas de producción del cuerpo no son fieles a una taxonomía clásica según la cual a cada órgano y a cada tejido corresponde una única función y un único emplazamiento. Lejos de respetar una totalidad formal o material del cuerpo, la biotecnología y las técnicas prostéticas combinan modos de representación que provienen del cine y de la arquitectura, como el montaje o el modelado en 3D.

En definitiva, y a modo de reflexión, cabría reiterar que la sociedad occidental continúa encorsetada y, en el acertado término de Caroline A. Jones, introducida en un doble atolladero. Doble a causa de un pensamiento dualista heredado de una tradición que propicia discursos antagonistas. Posiblemente hayan sido los postestructuralistas, junto con algunas corrientes teóricas feministas, los encargados de poner en tela de juicio ciertos conceptos socialmente opuestos que han sido los encargados de generar numerosas desigualdades. De este modo, deberíamos re-pensar significados de pares opuestos como público/privado, hombre/mujer $\mathrm{y}$, por supuesto, natural/artificial entre otros muchos. ${ }^{34}$ Nuestro cuerpo deviene plataforma tecnoviva, resultado de una implosión irreversible entre sujeto y objeto, entre lo natural y lo artificial. De ahí que la noción misma de «vida» resulte arcaica para identificar los actores de esta nueva tecnoecología. Por

${ }^{33}$ McLUHAN, Marshall, Comprender los medios de comunicación: las extensiones del ser humano, Barcelona, Paidós, 2009, pp. 67-73.

${ }^{34}$ A. JONES, Caroline, "The Sex of the Machine: Mechanomorphic Art, New Women, and Francis Picabia's Neurasthenic Cure", en A. JONES, Caroline y GALISON, Peter (eds.), Picturing Science Producing Art, New York, Routledge, 1998, pp. 145-150. 
este motivo Donna Haraway adopta la noción de «tecnobiopoder», derivada de la foucaultiana «biopoder», puesto que lo que entra en juego no es el poder sobre la vida, es decir, el poder de gestionar y maximizar lo vital, como quería Foucault, sino el poder y el control sobre un todo tecnovivo conectado.

Hoy en día es imposible establecer dónde terminan «los cuerpos naturales»y dónde comienzan las «tecnologías artificiales»; los ciberimplantes, las hormonas, los transplantes de órganos, la gestión del sistema inmunológico humano en el VIH, la World Wide Web, etcétera, no son sino algunos ejemplos entre otros. Dentro del contexto de nuestra investigación nos centraremos en el concepto «extensión corporal» como el mejor ejemplo explicativo sobre los límites de lo «natural»y lo «artificial». «Vivimos en la hipermodernidad punk, ya no se trata de revelar la verdad oculta de la naturaleza, sino que es necesario explicitar los procesos culturales, políticos, técnicos a través de los cuales el cuerpo como artefacto adquiere estatuto natural»». ${ }^{35}$

${ }^{35}$ PRECIADO, Beatriz, op. cit., p. 33. 



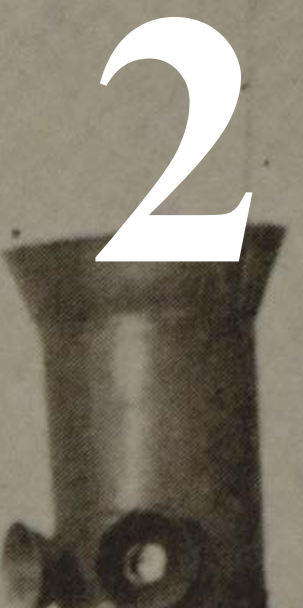

CUERPO MECANIZADO YO PROSTÉTTCO EN LAS VANGUARDIAS ARIÉSTICAS DELSIGLO XX 



\begin{abstract}
A lo largo del primer capítulo hemos analizado el cuerpo como un $\triangle$ producto socio-cultural, un cuerpo que deja de entenderse como 1 mera entidad material ya que éste interacciona incesantemente con el mundo exterior. Asimismo, hemos comprobado que el ser humano es inherente a la tecnología, es decir, a toda una serie de herramientas que, dependiendo de su instante histórico, han sido y son utilizadas para romper los límites que nuestra propia fisicidad nos impone.
\end{abstract}

Aunque nuestro estudio se centre en un período de tiempo acotado, es ineludible realizar una revisión de las principales vanguardias históricas del siglo XX, movimientos pioneros que, con un gran acierto, reflexionaron sobre el cuerpo humano como modelo y referente creativo. Tal y como hemos visto en las páginas precedentes, ya desde el siglo XIX comenzaron a popularizarse componentes técnicos acoplados y/o complementados al cuerpo. Estos están presentes en las representaciones artísticas, aunque si bien, es cierto que no se materializaron de la misma forma a lo largo de toda la pasada centuria. No obstante, encontramos un común denominador en el arte contemporáneo: la necesidad de integración del arte en la vida. Bajo 
este propósito, las vanguardias artísticas del siglo $\mathrm{XX}$ atacaron a la institución burguesa tratando de resquebrajar el discurso político de la alta cultura mediante la fusión con la cultura del maquinismo.

En este sentido y, como veremos en nuestra investigación, el Body Art afrontará - aunque probablemente jamás llegue a la actitud visceral de principios de siglo XX - la provocación de la «extensión corporal» desde dos puntos de vista prácticamente enfrentados. Por un lado, una posición negativa y crítica hacia el peligro de la pérdida de subjetividad que conllevan las estrategias tecnobiopolíticas $\mathrm{y}$, por otro, una postura positivista y de carácter cientifista que observa cómo la humanidad transgrede los límites impuestos por la naturaleza. Esta oposición debemos entenderla como herencia directa de la conciencia social que tuvo lugar durante los ismos, en los que - como planteamos en nuestro previo trabajo de investigación Cuerpo y artificio mecánico en las vanguardias artísticas del siglo $X X$ - movimientos como el futurismo, el constructivismo o la escuela de la Bauhaus ensalzaron la máquina hasta una categoría absolutamente deificada.

De alguna manera, la Segunda Guerra Mundial cumplió sus expectativas, aunque eso sí, en el sentido más destructivo. Esta tragedia histórica fue - negativamente hablando - la encargada de mostrar cómo aquella poderosa tecnificación redentora y deificada iba a impulsar al ser humano hacia territorios inhóspitos, así como a facilitar ciertas funciones laborales y sociales. Las terribles pesadillas y visiones críticas propias de las representaciones expresionistas y dadaístas se transformaron rápidamente en una realidad tangible.

No obstante, debemos tener siempre presente el ejemplo discursivo de Donna Haraway y darnos cuenta de que, una vez más, caemos en el ancestral orden de oposiciones binarias. Debemos ser conscientes de dos tipos de engaños narrativos propios de una cultura de tradición reaccionaria cuando tratamos de predecir el futuro de la humanidad y su entorno. El 
primero, una tentación mesiánico-redentora: alguien va a venir a salvarnos, una fuerza única, religiosa o técnica, un saber único posee todas las respuestas para transformar la condición de la humanidad. El segundo, la tentación apocalíptica: no hay nada que hacer, la desaparición de la especie es inminente.

Desde esta perspectiva, deberíamos aprender a dudar de nuestros miedos y certezas sobre los desastres, así como de nuestros sueños de progreso. Ya es hora de que aprendamos a vivir sin los rígidos discursos de la historia de la salvación.

\subsection{La representación estética y el maquinismo}

Con anterioridad a establecer el cuerpo como parte fundamental de la representación artística en relación a su entorno sociocultural, es conveniente contextualizar los ideales de la vanguardia para comprender el proceso al que se ve sometido el individuo en relación a los avances técnicos. De hecho, la reciprocidad entre arte y artificio no es un invento del siglo $\mathrm{XX}$.

La historia del arte está repleta de las máquinas más diversas: estatuas animadas de la antigüedad griega de las cuales se temía que abandonaran su pedestal, máquinas de guerra e instrumentos para volar de Leonardo da Vinci, los autómatas de Vaucanson tan elogiados por Diderot, etcétera. El hecho de estar ligados a la naturaleza y a nuestro cuerpo nos obliga a trascender los límites que ella impone. De este modo, la ciencia, la magia o el arte mismo son actividades creativas cuyas estrategias están destinadas a subvertir nuestra precariedad. Quizás sea por ello que el imaginario del ser humano siempre se ha dedicado a construir objetos más o menos imaginarios con un único fin: funcionar. 
La Revolución Industrial dio lugar a un nuevo escenario en todos los ámbitos —económico, social, político e ideológico- de cuyos resultados, como es lógico, surgieron unas inexploradas relaciones entre el arte y la técnica. Las primeras representaciones de la máquina constituyen formas de arte de carácter escasamente museable no reconocidas por la academia. Sus manifestaciones fueron producidas mediante sistemas de estampación como el grabado y/o a través de actividades artesanales. No obstante, en el siglo XIX, las máquinas se prodigaron en el arte como una de las consecuencias de la irrupción de la Revolución Industrial, fenómeno que transformó radicalmente la apariencia del mundo existente. ${ }^{1}$

La invención de la máquina de vapor en 1765 y el posterior taylorismo desembocaron en una aprehensión del cuerpo tomado como instrumento de trabajo al servicio de la máquina. La industrialización de la actividad humana, en el transcurso del siglo XIX, invirtió los términos de la metáfora mecánica: la máquina se convierte en sujeto y en organismo. Los obreros pasan a ser simples «extensiones» conscientes de que se ajustan a los órganos inconscientes del mecanismo. El trabajo, por tanto, urge como resultado de este ensamblaje entre miembros naturales y mecánicos. ${ }^{2}$ No obstante, no fue hasta las vanguardias artísticas cuando la iconología del cuerpo se relacionó con los artificios generados en la Revolución Industrial.

A comienzos del siglo XX las palabras «dinamismo», «maquinismo» o «modernidad» se escuchaban sin cesar en todas las esferas culturales. Las vanguardias en Europa atacaron y transformaron la institución burguesa del arte. De este modo, trataron de romper el discurso político de la alta cultura a través de la fusión con la cultura popular e integrar de esta manera el arte en la vida. ${ }^{3}$ Sin embargo, la pregunta es inmediata, ¿lo consiguió?

\footnotetext{
${ }^{1}$ PAZ, Marga, "Máquinas fuera de servicio", en el catálogo de la exposición Máquinas, Las Palmas de Gran Canaria, Centro Atlántico de Arte Moderno, 2000, p. 16.

${ }^{2}$ FRUDE, Neil, The Intimate Machine, London, Century Publishing, 1983, pp. 58 y ss.

${ }^{3}$ PICÓ, Josep (comp.), Modernidad y postmodernidad, Madrid, Alianza, 2002, p. 10.
} 
Es evidente que la vanguardia logró atacar directamente el comportamiento burgués, y lo hizo tomando como punto de referencia la cultura popular y las características propias de lo vulgar, y esta fue una de las victorias más importantes del movimiento de la modernidad. Pero ¿acaso la negación de la sociedad burguesa implica la aceptación de lo opuesto, de lo popular? Es necesario aclarar que a partir de la modernidad la vida queda de alguna forma - y cada vez más - integrada en el arte, pero no a la inversa —quizás sean los medios audiovisuales los que más se hayan acercado a este propósito, aproximar el arte a la vida, eso sí, sin entrar en el debate de hasta qué punto es beneficioso. La cuestión que marca la controversia entre modernidad y postmodernidad es, al respecto, fundamental: ¿es la modernidad un proyecto incompleto, tal y como defiende Habermas, o su crisis tan radical se debe simplemente a que no ha podido sobrevivir a su promesa? ${ }^{4}$

Entre los escritos de Léger podemos encontrar una afirmación que resume de manera brillante el espíritu y el pensamiento de la modernidad: «Lo bello está en todas partes, en el orden de vuestras cacerolas, sobre la blanca pared de vuestra cocina, con más fuerza quizás que en vuestro salón estilo siglo XVIII o en los museos oficiales»». ${ }^{5}$

La nueva civilización que se constituía se manifestó ante todo por impulsos que, aceptados, rechazados o contrarrestados, implicaban movimientos opuestos. La sociedad del siglo XX, frente a la necesidad de tomar posición en torno a un estado novedoso y tan complejo, trató de buscar un símbolo ordenador que se pudiera desprender del caos que imperaba a principios de siglo. Ese símbolo se materializó en la máquina, el elemento de confrontación con la naturaleza, un símbolo idóneo de lo moderno que actuó como elemento de ruptura con el pasado. El maquinismo transformó la apariencia y los modos de existir, al igual que modificó las relaciones con la naturaleza modelando profundamente a un nuevo ser

\footnotetext{
${ }^{4}$ PICÓ, Josep (comp.), op.cit., p. 10.

${ }^{5}$ LÉGER, Fernand, Funciones de la pintura, Barcelona, Paidós, 1990, p. 48.
} 
humano. Los y las artistas, probablemente más que nadie, se hallaron ante un confuso dilema: la máquina, por una parte, urgía como signo inmediato de su tiempo, pero a su vez, como instrumento uniformizador de seres.

El valor cultural universal de la máquina fue, por tanto, inherente a la aparición de las vanguardias artísticas. Fueron éstas quienes descubrieron que la esencia de la modernidad radicaba en la nueva dinámica urbana unida a la mecanización del trabajo y la vida cotidiana, donde cuerpo y máquina eran concebidos en los mismos términos. Los comportamientos y los objetos que se creaban estaban sometidos a una determinada lógica mecánica, igual que los efectos perceptivos que provocaban, los cuales se convirtieron entonces, para un gran número de artistas de esta época, como una especie de reserva de nuevos temas a representar y analizar. Su valor fue proyectado hacia lo sublime o, incluso, hacia el terreno de lo religioso y mitológico: el maquinismo se convirtió de hecho en principio de salvación y de esperanza.

El arte y la arquitectura de las vanguardias cumplieron en general la tarea de elevar la máquina a principio absoluto de constitución de la cultura, así como a postulado elemental de la nueva forma artística y valor último de la civilización. No sería incoherente afirmar que en ciertos casos la máquina llegó a desempeñar una función cultural similar a la del genio en el Renacimiento o, en otros términos, al papel que el Romanticismo había atribuido a la naturaleza. La idealización artística de la máquina en los pioneros de la vanguardia llegó al extremo de otorgarle las características de sujeto histórico, de demiurgo, de mesías.

Los y las artistas plásticos más renovadores se convirtieron intencionalmente en uno de los agentes históricos más importantes de esta transformación y la máquina $-\mathrm{y}$, en especial, su presencia inmediata, sus exigencias y sus normas de funcionamiento- se hace sensible en todos los terrenos. En los textos doctrinales de la vanguardia se constituía un nuevo mito, concebido no ya como una curiosidad pintoresca, sino como objeto sobre el que se proyectaban tanto la angustia como el deseo. Al igual que la 
naturaleza y los objetos de ésta para los románticos, la máquina se convirtió en una especie de divinidad, en objeto lúdico o, más interesante incluso, en el doble del cuerpo humano. De este modo, se hizo necesario seducirla, domarla y dominarla. ${ }^{6}$

Según Le Bot, se puede fechar con bastante precisión el momento en que el objeto técnico y el medio urbano mecanizado aparecen en la iconografía del arte contemporáneo formando un repertorio privilegiado de nuevos temas y de símbolos. Fue durante los años 1911-1912, en el mismo momento en que la crítica empezó a emplear el término «vanguardia» para aludir a un conjunto de producciones artísticas aparentemente muy dispares. La nueva noción ya adquiere claras connotaciones respecto al maquinismo, su estrecha relación con la guerra proclamaba una batalla contra los valores tradicionales reflejados en el arte decimonónico imperante en el museo. La reaparición del término en los polémicos manifiestos artísticos se establece en Francia con las crónicas que Guillaume Apollinaire consagra a la pintura desde 1902 y sobre todo en sus Meditations esthétiques publicadas en 1913. Igualmente, se consolida — al mismo tiempo - como una de las palabras clave para la Unión Soviética y para los manifiestos futuristas. El empleo de la voz «vanguardia» muestra que tanto artistas como críticos han tomado conciencia - con un desfase temporal de la teoría sobre la práctica, de ahí que la firma del manifiesto se consolida como ingrediente previo del nuevo arte- del carácter radical de la crisis generalizada de los valores figurativos, introducida por la pintura impresionista. ${ }^{7}$

Contra el humanismo, contra la intemporalidad de sus referencias y contra la autoridad de la naturaleza deducimos que las doctrinas de la vanguardia son generalmente partidarias de la máquina y, sobre todo, de la ciudad, símbolos de todos los artificios y de su incesante renovación.

\footnotetext{
${ }^{6}$ LE BOT, Marc, Pintura y maquinismo, Madrid, Cátedra, 1979, p. 148.

${ }^{7}$ LE BOT, Marc, op. cit., p. 148.
} 
No obstante, la politización de la actividad artística no tendrá un carácter sistemático y no aparecerá en un primerísimo plano en las preocupaciones de los artistas, salvo en los casos de Italia y la Unión Soviética. Estos dos ejemplos son representativos por su radicalismo y también porque se sitúan —ideológicamente hablando- en los dos extremos opuestos. Las tomas de posición política propias de las otras doctrinas artísticas que surgen dentro de la cultura occidental durante el mismo período de tiempo se pueden reducir a estos dos modelos. No es una casualidad: Italia, apenas acaba de realizar su unidad nacional en 1870.

Es altamente paradójico que en el Constructivismo, dentro de una cultura comunista, el lenguaje de la modernización recurriera a patrones capitalistas de eficacia en la producción industrial. Los líderes de la Revolución Rusa eran defensores entusiastas de los modelos de racionalización de la industria de los Estados Unidos como medio de modernizar una economía atrasada. Henry Ford y Frederick W. Taylor fueron tomados como ejemplos de modernización. Pero la Unión Soviética vivió una primera fase muy característica de su revolución, la que coincide con los años en los que Lenin detentó el poder (1917-24).

El enfoque optimista del régimen soviético tenía como punto de partida la tesis de Karl Marx sobre la neutralidad ética de la tecnología - aunque sí es cierto que en ocasiones y refiriéndose al capitalismo lanzó duras críticas contra la máquina. Esta perspectiva coincide con las necesidades prácticas del proceso revolucionario de construcción de la sociedad socialista. A la vanguardia soviética le urgía modernizar y hacer progresar la sociedad, para ellos el individuo no era un servidor de la máquina, sino que ésta lo era del trabajador y de la trabajadora. Gracias a ella, el individuo se libera de la servidumbre del trabajo físico que le convertía en un animal y en unas simples manos, en un cuerpo esclavo del estado de necesidad. La máquina libera: la fábrica está a la cabeza de la revolución y ayuda a la mecanización del campo. 
Tanto en el caso de Italia como en el de la Unión Soviética, los diversos componentes de la actividad social se juzgan con frecuencia en función de criterios políticos. Durante los años veinte tuvieron lugar una serie de acontecimientos cruciales para el entendimiento de la época de las vanguardias. En primer lugar, el desarrollismo soviético mediante la gran industrialización de la URSS. A su vez, también tuvo lugar el proyecto wilsoniano, la burocratización de la sociedad con el protagonismo de la clase media y el ascenso al poder de los fascismos. ${ }^{8}$ No es demasiada casualidad que fueran los futuristas y los constructivistas los que vieron en la máquina la salvación, la superación del pasado y el abandono definitivo de la herencia decadente del romanticismo. A esta concepción responde un esplendor viril de la máquina en acción, como en el Ballet mécanique (1924) de Léger, en el ballet también mecánico con que da comienzo el film Metrópolis (1926) de Fritz Lang, en el Ballo meccanico futurista (1922) de Bragaglia, en la secuencia del laboratorio de L'Inhumaine (1923) de L'Herbier y Léger, o en las acrobacias de los obreros titánicos de Eisenstein entre las ruedas y los mecanismos de la fábrica zarista en La huelga (1924), claramente influida por la estética de la FEKS y en general por el excentricismo.

En un primer momento, y a nivel descriptivo, el análisis que realizan los artistas versará sobre el inventario del nuevo material simbólico de las imágenes mecanomorfas. Los textos mismos de los futuristas, de Fernand Léger, de Robert Delaunay o de Francis Picabia, se complacen en enumerar los nuevos objetos figurativos que estos pintores introducían en el universo imaginario de la pintura: trenes, torres, tranvías, automóviles, aviones, estaciones, edificios, iluminación eléctrica, carteles publicitarios; es decir, los objetos que entraban en juego en la animación de las ciudades modernas y que las marcaban con el sello del maquinismo. De este modo, en las vanguardias se pone de relieve la creación de un nuevo individuo masculino, mecanizado y socialmente productivo, de ahí que la máquina adquiera una

\footnotetext{
${ }^{8}$ LE BOT, Marc, op. cit., p. 148.
} 
significación desconocida. Convertida en objeto de culto de la nueva religión del siglo, la máquina produjo iconos que inspiraron una infinidad de pinturas mecanomórficas, dibujos, arquitectura, escultura, música, cine, literatura, etcétera. ${ }^{9}$

Sin embargo, al igual que la ambigüedad que se respira en el seno de la sociedad, en el arte de principios del siglo XX el nuevo mito tendrá, tal y como hemos podido apreciar, aspectos optimistas o pesimistas. El desarrollo del arte moderno ofrece dos orientaciones muy distintas: numerosos $\mathrm{y}$ numerosas artistas o escuelas han creído ver en el modernismo la obligación de adherirse a la máquina, considerándola en sus propias fuerzas o en las consecuencias de su funcionamiento. El carácter contestatario de esta nueva mitología tiene como fines proclamados la exaltación de las fuerzas productoras de la industria en el Futurismo, donde velocidad e intensidad constituyen un patrimonio que quedará paradigmatizado en esa Aeropittura en la que el avión, proyectado al espacio por sus motores, se convertía en un tema de inspiración principal. ${ }^{10}$ A su vez, la representación de la actividad social común y popular instaurada por Léger trasponía a otro plano una obsesión del mismo origen. Por otra parte, la uniformización mediante elementos cambiables que responden a normas racionales simples halló su contrapartida en las iniciativas del grupo holandés De Stijl, tanto en el terreno arquitectónico o decorativo como en el pictórico. Por último, la exaltación de la revolución socialista, unida a la revolución industrial, fue puesta de relieve por los soviéticos. Todos ellos son ejemplos que, ante una común apología, presentan elementos diferenciadores que definen y configuran particularmente cada planteamiento artístico.

La vanguardia creyó descubrir en la lógica funcional de la máquina una nueva forma de «belleza», deducida de la racionalidad propia de la fabricación en serie industrial y de las leyes de la mecánica aplicada: lo que

\footnotetext{
${ }^{9}$ LE BOT, Marc, op. cit., p. 176.

10 Véase PRAMPOLINI, Enrico, "La Aeropintura, valores espirituales de la plástica futurista", en SAN MARTÍN, Francisco Javier, La mirada nerviosa. Manifiestos y textos futuristas, Donostia, Arteleku, 1992, pp. 309-319.
} 
Marinetti denominó en su manifiesto futurista de 1914 Esplendor geométrico y mecánico y sensibilidad numérica; ${ }^{11}$ y Fernand Léger «el nuevo estado visual impuesto por los nuevos modos de producción, condición de "advenimiento de la mecánica"». Partiendo de ello, se puede afirmar que en todas las doctrinas de la vanguardia se encuentra un conjunto de tesis comunes que marcan un cambio absoluto de actitud con respecto a lo que fue el pensamiento del siglo XIX, en cuanto al modo de existencia de la máquina en la sociedad contemporánea y en cuanto a la concepción de la modernidad. $^{12}$

La nueva temática mecanizada se generalizó rápida y casi simultáneamente en toda Europa. En Italia fueron los pintores futuristas; en Francia, Robert Delaunay, Marcel Duchamp, Francis Picabia y el ya nombrado Fernand Léger; en Rusia, la vanguardia denominada primero cubo-futurista. Asimismo, esta temática apareció en Alemania de forma menos sistemática y menos caracterizada en algunas producciones de Die Brücke, como las representadas por Kirchner y Pechstein (por ejemplo con el tema de la ciudad). En Holanda, los artistas De Stijl referían explícitamente al universo mecánico sus disposiciones de formas geométricas. En los Estados Unidos de América, la máquina se convirtió en el modelo concreto que determina directamente las composiciones de la mayor parte de los pintores que se reagruparon, de manera informal, alrededor de la Photo-Secession Gallery de Stieglitz. ${ }^{13}$ Poco más tarde,

\footnotetext{
${ }^{11}$ MARINETTI, Filippo Tommaso, "El esplendor geométrico y mecánico y la sensibilidad numérica", en SAN MARTÍN, Francisco Javier, op. cit., pp. 143-158.

${ }^{12}$ LE BOT, Marc, op. cit., p. 148.

13 Todos estos artistas americanos se comprometieron con la pintura de vanguardia a imitación de los pintores europeos que habían estado representados en la famosa exposición del Armory Show (1913). En particular sufrían la influencia directa de Marcel Duchamp y, más aún, de Francis Picabia, quienes se instalaron en Nueva York en 1915 a causa de la Primera Guerra Mundial; lo que impide que se considere, en esta fecha, su producción como original. Podemos citar, entre otros y otras artistas a: Mardsen Hartley, Morton Schamberg, Charles Demuth, Charles Scheeler, Louis Lozowick, Joseph Stella, Georgia O'Keeffe, Gleen O. Coleman, Man Ray, etcétera.
} 
Dadá se implantó en estos mismos lugares, excepto en Rusia, y volvió a tomar por su cuenta esta representación de la imagen. ${ }^{14}$

Para Mendelsohn, Le Corbusier, Oud, y también para Malévich y Schlemmer, la máquina rebasó la dimensión de una pura racionalización de la vida o de la expansión de la racionalidad tecnológica por medio del arte. Léger en pintura, Oud o Hilbenheimer en su concepción del urbanismo y Le Corbusier en su nueva idea de arquitectura, convirtieron la máquina en un objetivo y en un valor por sí misma en torno al cual se articulaba el conjunto de las cuestiones formales, plásticas, compositivas, constructivas y organizativas del diseño. ${ }^{15}$ La máquina se convirtió en valor último y en un factor social y económico dotado de una racionalidad en sí misma emancipadora.

Los manifiestos neo-plasticistas expusieron unívocamente la estética racionalista, al igual que el principio formal y cultural de la máquina como contrapunto a la realidad trágica que atravesaba Europa. La pureza de los colores primarios, los ángulos rectos, la obsesión de horizontales y verticales, así como sus correlatos teóricos (la postulación del arte como representación de un orden absoluto y de una armonía acabada, la invocación de un mundo cultural integralmente racionalizado) respondían a una exigencia social, ética en un sentido profundo, de signo transformador y liberador. ${ }^{16}$

Sin embargo, tal y como hemos apuntado anteriormente, las reacciones de los y las artistas frente a este fenómeno no fueron unánimes, sino que las respuestas abarcaron desde el entusiasmo de los primeros momentos (Purismo, Bauhaus, Constructivismo, Futurismo) hasta la actividad satírica (Dadá), pasando posteriormente por una ansiedad paranoica (Surrealismo). Pero es un hecho que sólo con la intervención de

\footnotetext{
${ }^{14}$ LE BOT, Marc, op. cit., p. 171.

${ }^{15}$ SUBIRATS, Eduardo, La crisis de las vanguardias y la cultura moderna, Madrid, Ediciones Libertarias, 1985, p. 48.

${ }^{16}$ SUBIRATS, Eduardo, op. cit., p. 54.
} 
las vanguardias, y más concretamente, de corrientes artísticas como el Cubismo, el Futurismo, la Neue Sachlichtkeit, el Neoplasticismo o la Bauhaus, la máquina se convierte en un símbolo cultural universal y en un principio espiritual de signo trascendente en la realidad social e histórica. Debido a ello, se puede señalar que el proceso de desarrollo del arte moderno, así como el desarrollo general de la cultura han sufrido fundamentalmente los avatares del maquinismo como principio espiritual y factor constituyente de la cultura. ${ }^{17}$

El maquinismo en cuanto fenómeno científico-técnico y civilizador, ha adquirido el carácter universal de un principio de homogeneización y organización social, pero no ha presidido la constitución de una armonía acabada. Parece que múltiples esfuerzos, también completamente modernos y que corresponden a la misma vanguardia que los anteriores, acreditan una actitud antagonista. Incluso se podría decir que la indiferencia casi general a ser comprendido y seguido que afecta a los y las artistas más innovadores, y el hermetismo provocativo de ciertas tendencias son motivados, en las profundidades inconscientes, por el deseo de romper con esa nivelación general. Posiblemente sea éste uno de los factores que opone la peor amenaza al esfuerzo emprendido por nuestro tiempo para librarse de las convicciones ciegas del pasado, puesto que lo libera, con igual docilidad, a consignas, a esnobismos o a convenciones también limitadas y pasivas, tras una brillante pátina de audacia.

La vanguardia expresionista centroeuropea sentía verdadero pavor y odio hacia la máquina, sospechaba de la ciencia y suponía que en el robot o el muñeco permanecían latencias siniestras relacionadas con la tensión entre el creador y la criatura. Estos movimientos herederos directos del simbolismo - como lo es en buena parte el Expresionismo - han figurado con ellos el conflicto del creador y la criatura. El contrapunto que lo distingue de los demás movimientos de vanguardia es que no han puesto el acento especialmente en lo femenino. Los kolossoi animados del

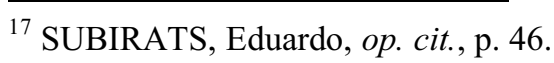


Expresionismo son seres masculinos: el Golem, Cesare, Nosferatu. Paradójicamente, sin dejar de temer a la madre, teme más al padre —al padre de las guerras, de las tiranías, de la burocracia.

En el caso de Dadá, el nihilismo dará al mito de la máquina un valor también negativo y pesimista, con la denuncia de lo absurdo de un sistema cuyos poderes destructores ha manifestado la guerra. El movimiento, con su planteamiento radical del realismo y su rechazo de la representación engañosa de la naturaleza, convierte su representación en juego, irrisión y geometría, es decir, en maquinaria imposible. Mejor dicho, prescinde de ésta en cuanto saco de huesos - «Dadá, él, no huele a nada, no es nada, nada, nada», escribe Picabia en el Manifiesto Caníbal Dadá. ${ }^{18}$ Pero esas disfunciones en sus máquinas son algo más que un mero divertimento ¿acaso no hay relación con el amor y con el cuerpo de la mujer?

La crisis de 1929 otorga la razón a quienes habían desconfiado de las virtudes del progreso y de las máquinas. Éstas pasaron a ser juzgadas como una amenaza para la persona, que había acabado por convertirse en su rehén, en su víctima e, incluso, en parte de ella. Quizás fue uno de los principales motivos por los que a partir de la década de 1930, los portadores de la modernidad ya no se veían ante la necesidad de crear un estilo como innovación revolucionaria de una forma capaz, por sí misma, de transformar los valores de la sociedad industrial. Más bien se trataba de crear un lenguaje que fuera lo suficientemente homogéneo, consistente y congruente con las exigencias de la construcción industrializada como para convertirse en un paradigma generalizable. El fracaso de los movimientos revolucionarios en el entorno inmediato de los pioneros de las vanguardias, así como el ascenso del totalitarismo fascista y estalinista a sus espaldas, habían puesto fin a sus esperanzas. Probablemente, en la actualidad, la obviedad de la destrucción ecológica, el progreso de técnicas manipulativas y de control, y el creciente desarrollo de las tecnologías militares confronten la conciencia postmoderna con un radical nihilismo.

${ }^{18}$ PICABIA, Francis, Escritos en prosa 1907-1953, Valencia, IVAM, 2003, p. 117. 
La máquina, la industria, la nueva era, pero esencialmente el cuerpo artificial se verá personificado de manera magistral en las innumerables representaciones-performances que comenzaron a tener una importante repercusión dentro de los movimientos de vanguardia. Gracias a este tipo de actuaciones, los ismos romperán con sus límites formales y técnicos - centrados exclusivamente en la pintura, la escultura y la arquitecturapara introducir nuevos sistemas de representación. Las investigaciones realizadas en danza y teatro - que hoy, sin duda, encasillaríamos claramente como performances - nos obligan a afrontar las primeras vanguardias desde un punto de vista distinto al que nos ofrece la Historia del Arte.

El «hombre nuevo» con el que soñaban los constructivistas rusos, alemanes y húngaros después de la catástrofe social que representó la Primera Guerra Mundial, debía constituirse según el modelo de aquel hombre-máquina procedente del concepto mecanicista y materialista de $\mathrm{La}$ Mettrie. ${ }^{19}$ Ello tuvo importantes consecuencias para el concepto que los y las artistas tenían de sí mismos. Según la teoría constructivista, el artista moderno debía verse a sí mismo o a sí misma casi como un ingeniero, y debía tomar como referencia de su práctica la ciencia y la técnica. El talento artístico y la capacidad formal ya no debían ponerse al servicio de la producción de pinturas y esculturas elitistas para ser contempladas por una

\footnotetext{
${ }^{19}$ En su trabajo L'Homme machine Julien Offray de La Mettrie consideraba - a mediados del siglo XVIII - que tanto el hombre como los seres vivos debían ser considerados como máquinas. El médico francés desarrolló el concepto mecanicista del ser humano, no sólo de su cuerpo, sino también de su alma. A partir de sus estudios de ciencia natural y de anatomía, se sintió con autoridad para defender la tesis - especialmente osada para una época dominada por el pensamiento cristiano - de que el cuerpo humano era una máquina que funciona mediante un mecanismo metabólico. La Mettrie subvirtió la autonomía del espíritu y de la consciencia, y puso en entredicho la existencia divina. Esta reducción materialista del alma humana le permitió comparar explícitamente la máquina del cuerpo con la máquina del tiempo (el mecanismo de un reloj). Es la máquina misma la que programa la vida del cuerpo. Los seres humanos dejan de ser personajes en un teatro divino, para ser sistemas mecánicos autodeterminados. LA METTRIE, Julien Offray de, El hombre máquina. El arte de gozar, Madrid, Valdemar, 2000.
} 
clase privilegiada, sino que debían dedicarse a la producción de objetos «igualitarios»y «útiles» para las masas. ${ }^{20}$

\subsection{Arte de acción. Paradigma del cuerpo mecanizado}

Tras este recorrido socio-cultural a través de la máquina hemos visto que cualquier aspecto originario de la Revolución Industrial era susceptible de ser expresado — máquina, industria, mano de obra, producción, etcétera. Pero, ¿acaso la pintura, la arquitectura o la escultura, es decir, los modos tradicionales de representación, fueron los más apropiados para representar la nueva era?

Los ismos serán los encargados de poner en evidencia los límites formales y técnicos que ofrecía la tradición artística e investigar nuevos sistemas de representación. Ballet, teatro, performances, actividades de pura experimentación a principios de siglo XX, quizás fueron los lenguajes artísticos donde más se evidenció la relación directa entre el cuerpo humano y la máquina. Debido a ello es incomprensible concebir el Body Art sin tener en cuenta el acontecimiento formal, técnico, ideológico e histórico que supuso la vanguardia artística. A continuación trataremos de dar una visión generalizada de la importancia del arte de acción durante la era del maquinismo. Una era en la que el término utopía se transformará en una de las palabras clave, inherente al proyecto de principios de siglo XX.

La utopía responde al deseo de trascender toda condición, aunque no debemos olvidar que a ella queda adscrita una arraigada tradición judeocristiana. Sin embargo, aquella radicalidad y espíritu revolucionario quizás no lo fue tanto dado que se descuidaron numerosas condiciones sociales. En este sentido, lejos de asumir el compromiso de igualdad, las vanguardias

${ }^{20}$ MOLDERING, Herbert, "Años de luz. El fotograma en la estética de László MoholyNagy”, en el catálogo de la exposición László Moholy-Nagy. Fotogramas 1922-1943, Barcelona, Fundació Antoni Tàpies, 1997, p. 13. 
artísticas, herederas directas de la época de la ciencia y los inventos, de la gran industrialización, de la electricidad y la fotografía, del realismo y el naturalismo, del nacimiento del feminismo, del socialismo y del psicoanálisis, no abandonan el carácter misógino del siglo XIX, de ahí que se mostraran bastante reaccionarias en lo que respecta a la consideración de la mujer, salvo en el caso de creadores fuertemente impregnados de ideologías progresistas y comprometidos con una práctica revolucionaria.

\subsubsection{Balli meccanichi futuristas}

Un autor o autora no puede nunca producir su obra sino en relación con una determinada ideología moral y política. Pero la de los futuristas —en 1909- presenta ya, de antemano, el interés de aparecer enseguida como antihumana. ${ }^{21}$ Los futuristas invierten el orden de los valores. Toman esencialmente en consideración la existencia y las cualidades propias del sistema industrial de producción, más exactamente la lógica interna de su tecnología y los efectos específicos de ésta en la actividad social en general. Consideran, pues, que el dinamismo y la potencia de las técnicas maquinistas poseen una realidad autónoma y determinante. ${ }^{22}$

\footnotetext{
${ }^{21}$ El Futurismo italiano se gesta en Milán cuando en los primeros años del siglo XX la ciudad sufre una transformación radical que la convierte en un importante centro industrial. Son múltiples los ejemplos en la poesía, en los manifiestos y en la pintura y arquitectura futuristas en los que la invocación de la máquina, la velocidad, la industria o la guerra alcanzan la ambivalente y simultánea expresión de la exaltación sublime y de la visión dramática y desgarrada. Para una documentación global del movimiento futurista véase el catálogo de la exposición Futurismo \& Futurismi, Venezia, Palazzo Grassi, 1986.

${ }^{22}$ El primer manifiesto futurista señala ya todos los nuevos aspectos de la vida urbana, en la edad del maquinismo, que modifican la sensibilidad artística: los manifiestos posteriores volverán a tomar incansablemente estos temas enriqueciéndolos, pero sin que cambie su interpretación. La ciudad es la agitación de las grandes muchedumbres y los nuevos medios de locomoción; es el ruido, es el brillo de las luces eléctricas. Cualquier fenómeno queda reducido a las nociones de fuerza o de poder, de velocidad y de dinamismo, de choques rítmicos multisensoriales. El Manifeste du Futurisme —el primero de los manifiestos- se
} 
A su regreso a Italia, Marinetti ${ }^{23}$ empezó a trabajar en la dirección de su obra Poupées électriques (traducida al italiano como La donna è mobile) presentada el 15 de enero de 1909 en el Teatro Regio de Turín. La obra fue prologada - al más puro estilo de Alfred Jarry - por una enérgica introducción - en su mayor parte coincidente con el manifiesto que se publicará un mes más tarde - que consolidaba a Marinetti no sólo como una curiosidad en el mundo del arte italiano, sino también a la «declamación», como una nueva forma de teatro que iba a convertirse en una marca de fábrica de los jóvenes futuristas en los años siguientes. Marinetti llega a afirmar: «Es preciso introducir en el teatro la sensación de dominio de la Máquina». ${ }^{24}$

Gracias a la experimentación de Russolo, la música de ruidos se incorporó a las performances, en su mayor parte como música de fondo. Pero así como el manifiesto El arte de los ruidos había propuesto medios para mecanizar la música, el de Declamación dinámica y sinóptica

publica el 20 de febrero de 1909 en Le Figaro de París, éste contiene ya los temas esenciales cuyas publicaciones posteriores desarrollarán: el futurismo se define como esencialmente nacionalista, anticlerical y belicista. Las mismas circunstancias históricas pueden también dar cuenta de que el futurismo fue racista y partidario de un Estado fuerte pretendidamente tecnócrata y funcionando eventualmente sin parlamento. El contexto político conduciría a calificar anacrónicamente esta concepción dictatorial y fascista. El segundo manifiesto (1911) proclama que de todos modos «la palabra ITALIA debe triunfar sobre la palabra LIBERTAD». Van paralelas a estas ideas diversas directrices: la apología de la violencia y el gusto por el peligro; el desprecio de la mujer; el puritanismo; el elogio de la guerra como única moral, como única higiene social, como único motor del progreso; la exaltación del genio individual y/o italiano destinado a imponer su ley al mundo y a dominarlo políticamente; y, por último, la necesidad proclamada de industrializar y de modernizar la producción económica — la necesidad de valorar la vida urbana mecanizada. Véase SAN MARTÍN, Francisco Javier, op. cit., pp. 13-48.

${ }^{23}$ El enunciado cronológico muestra que Marinetti es la principal cabeza política del movimiento. Él es el que postula, desde el principio del juego y con insistencia, que la revolución política y la institución de una estética considerada como revolucionaria en relación con la tradición figurativa están necesariamente unidas. Véase LAMBIASE, Sergio y NAZZARO (comp.), Battista, Marinetti entre los futuristas, México D. F., Fondo de Cultura Económica, 1986.

${ }^{24}$ SAN MARTÍN, Francisco Javier, op. cit., p. 108. 
bosquejaba reglas para las acciones del cuerpo basadas en los movimientos de staccato de las máquinas. "Gesticulad geométricamente -había aconsejado el manifiesto-, de una manera topológica como de delineante, creando sintéticamente cubos, conos, espirales y elipses». ${ }^{25}$

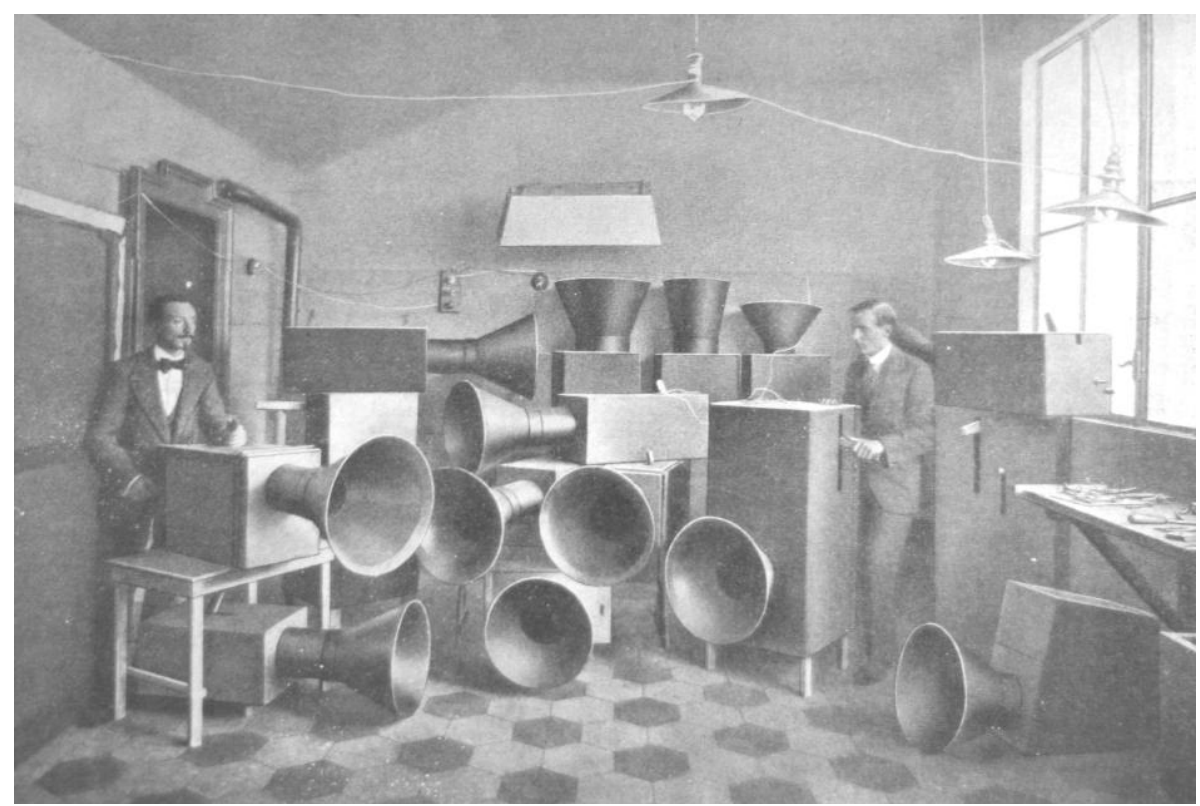

1. Russolo y su asistente Piatti en el Laboratorio degli intonarumori en Milán (1913)

La Macchina tipografica (Prensa) de Giacomo Balla de 1914 llevó a cabo todas las instrucciones en una representación realizada para Diáguilev. Doce personas, cada una parte integrante de una máquina, actuaban delante de un telón de fondo pintado con la única palabra «Tipografia». De pie, uno detrás de otro, seis intérpretes, con los brazos extendidos, simulaban cada

25 «En la antigüedad sólo había silencio» - explica Russolo- con la invención de la máquina en el siglo XIX, «nació el ruido». De este modo, «el ruido había llegado al dominio supremo sobre la sensibilidad de los hombres». Para el citado compositor, la evolución de la música fue paralela a la «multiplicación de las máquinas», lo que proporcionó una competición de ruidos. El trabajo de Russolo aspiraba a combinar el ruido de los tranvías, las explosiones de los motores, los trenes y las multitudes vociferantes. Se produjeron una infinidad de instrumentos especiales que, mediante procedimientos mecánicos, simulaban todos esos efectos. 
uno un pistón, mientras que los otros seis creaban una especie de rueda movida por los pistones. Las performances se ensayaban para asegurar la precisión mecánica. Un participante, el arquitecto Virgilio Marchi, describió cómo Balla había dispuesto a los intérpretes en dibujos geométricos y ordenó a cada persona representar el «alma» de las piezas individuales de una prensa rotativa. A cada intérprete se le asignó un sonido onomatopéyico para acompañar su movimiento específico. ${ }^{26}$

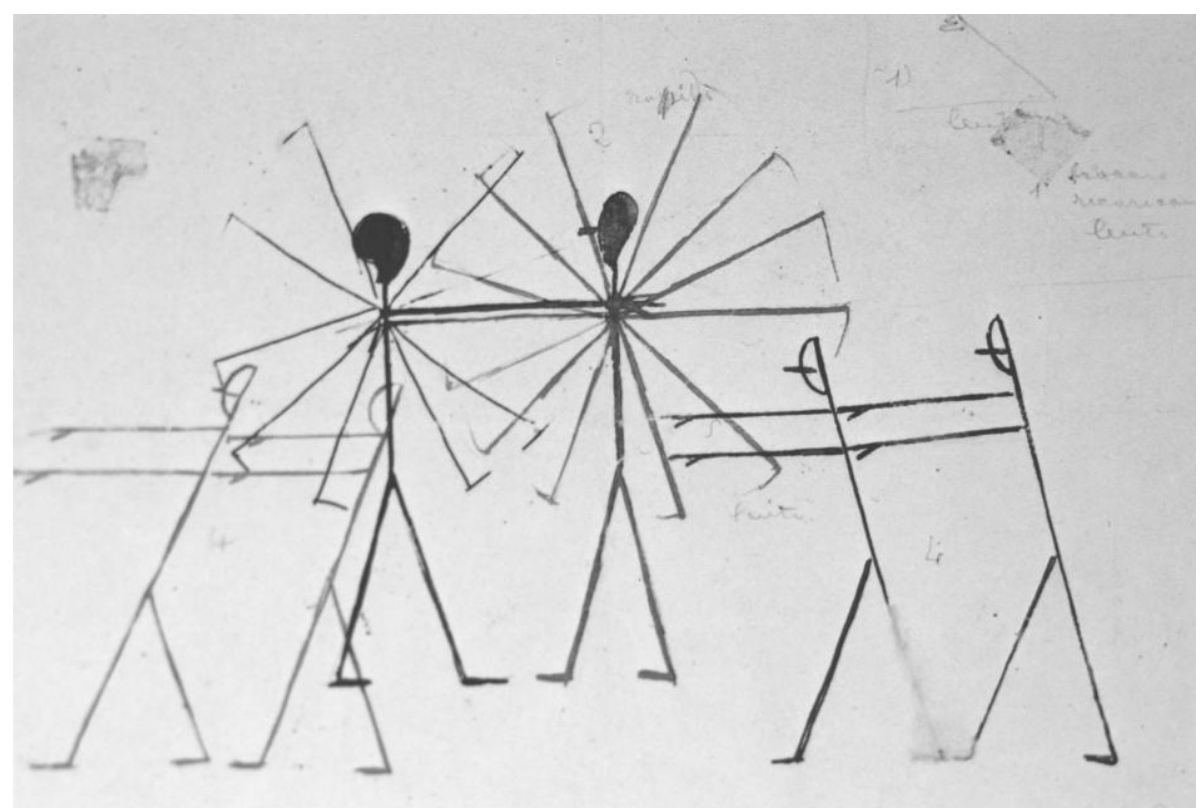

2. Giacomo Balla - Proyecto de coreografía Tipografia (1914)

Esta mecanización del intérprete imitaba ideas similares del director y teórico teatral británico Edward Gordon Craig, cuya prestigiosa revista The Mask — que había reimpreso el Manifiesto del teatro de variedades en 1914- se publicaba en Florencia. Enrico Prampolini, en sus manifiestos sobre Escenografía futurista y Atmósfera escénica futurista —ambos de 1915 - exigía - como Craig lo había hecho en 1908 - la abolición del intérprete. Craig había sugerido que el intérprete fuera reemplazado por un

${ }^{26}$ GOLDBERG, Roselee, Performance Art, Barcelona, Destino, 1996, pp. 21-22. 
Ubermarionette, pero de hecho nunca llevó a cabo esta teoría en una representación. Los futuristas, en efecto, construyeron esas criaturas inhumanas y «representaron» con ellas. $^{27}$

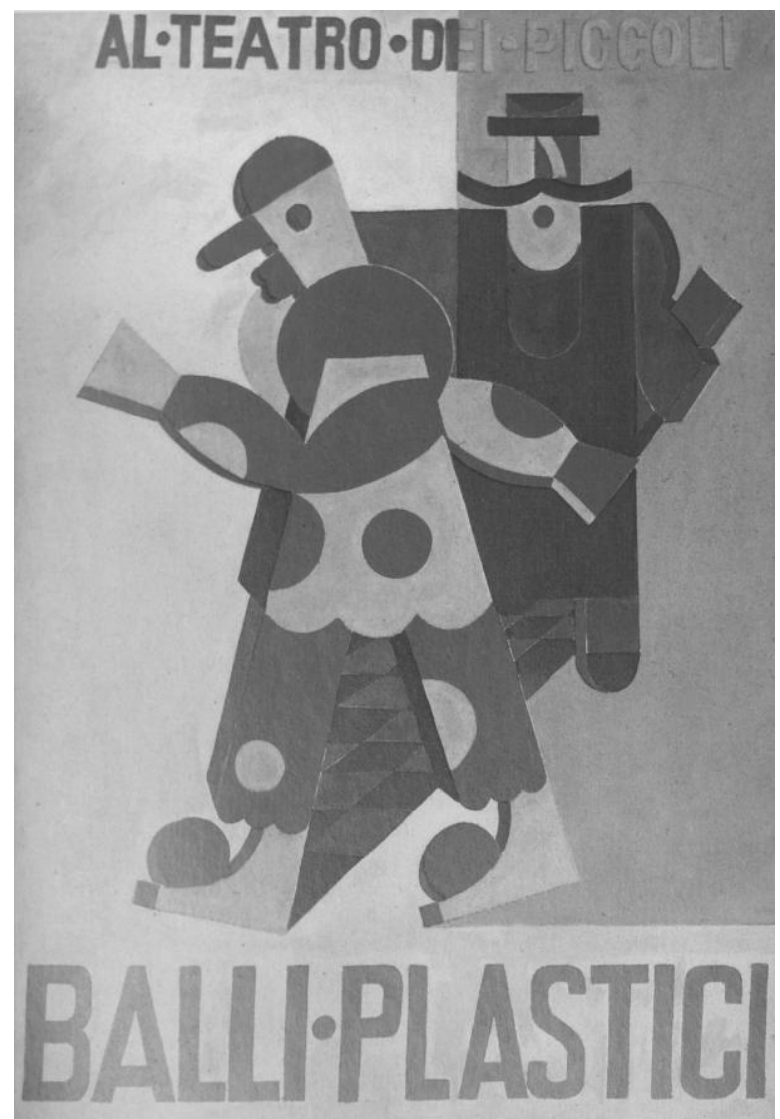

3. Fortunato Depero - Balli Plastici (1918)

Gilbert Clavel y Fortunato Depero presentaron en 1918 un programa de cinco performances breves en el Teatro dei Piccoli, en el Palazzo Odelaschi de Roma. Balli Plastici fue concebida para marionetas de tamaño más pequeño que el natural. Una figura, el buen salvaje de Depero, era más alta que una persona; su característica especial era un pequeño escenario que caía desde el vientre del salvaje y revelaba diminutos «salvajes» bailando su

${ }^{27}$ GOLDBERG, Roselee, op. cit, p. 22. 
propia rutina de marionetas. Una de las secuencias incluía una «lluvia de cigarrillos» $\mathrm{y}$, otra, una «danza de sombras» — sombras dinámicas construidas: juegos de luces. Representada dieciocho veces, Danzas plásticas fue un gran éxito en el repertorio futurista.

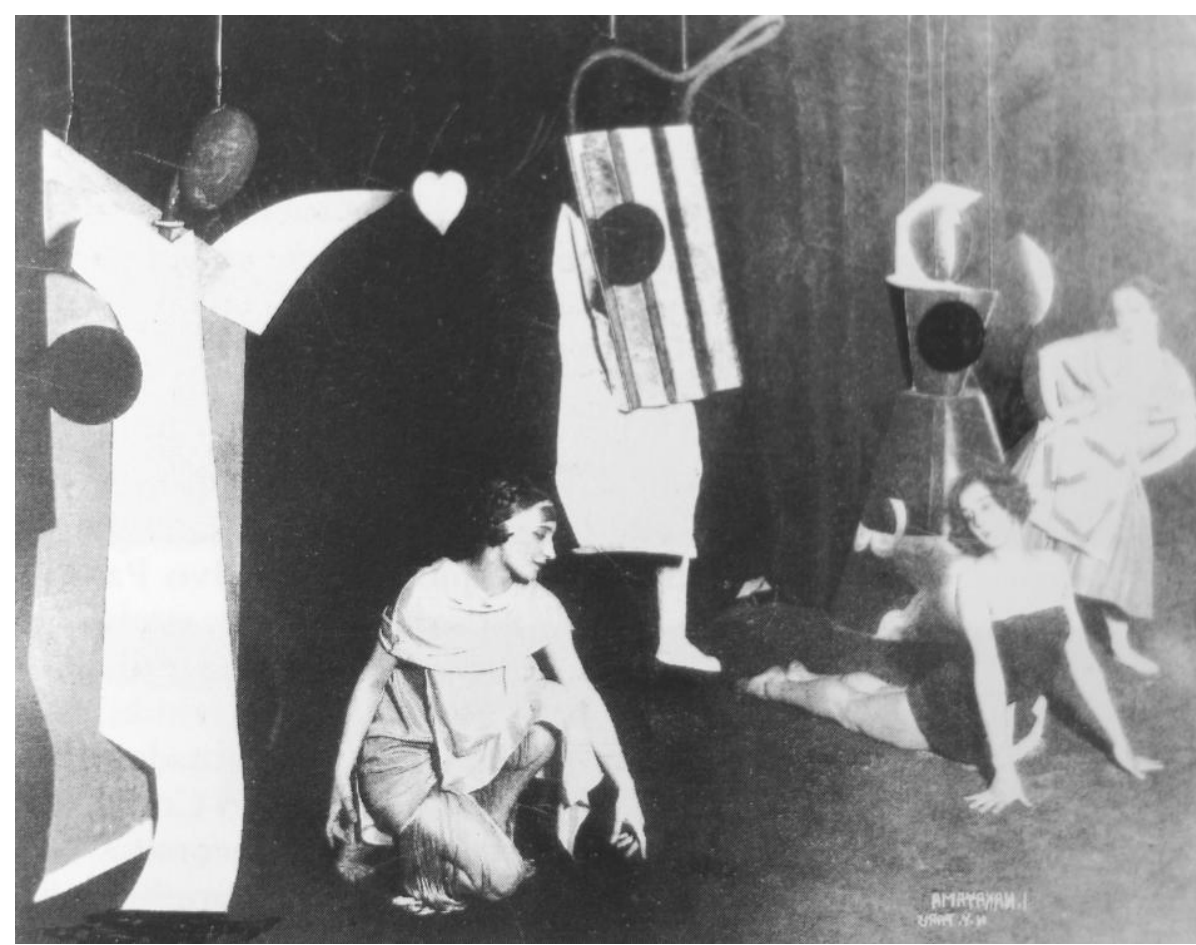

4. Enrico Prampolini y Franco Casavola - Il mercanti di cuori (1927)

El mercader de corazones de Prampolini y Casavola, representada en 1927, combinaba títeres y figuras humanas. Los títeres de tamaño natural estaban suspendidos del cielo raso. Más abstractas en cuanto al diseño y menos movibles que las marionetas tradicionales, estas figurillas actuaban junto con los actores vivos.

Un motivo esencial para estos títeres mecánicos y decorados movibles fue el compromiso de los futuristas en integrar figuras y decorados dentro de un entorno continuo. En 1919 Ivo Pannaggi había diseñado trajes mecánicos para los Balli meccanichi, mezclando figurillas en el escenario 
futurista pintado; mientras que Balla, en una performance de 1917 basada en los Fuegos artificiales de Stravinski, había experimentado con la coreografía del propio escenario. Presentado como parte del programa de los ballets rusos de Diáguilev en el Teatro Costanzi de Roma, los únicos intérpretes en la obra eran los decorados movibles y las luces. El decorado era una versión tridimensional ampliada de una de las pinturas de Balla y el propio artista dirigía el «ballet de luces» desde un tablero de mandos de iluminación. No sólo el escenario, sino también el patio de butacas, eran alternativamente iluminados y oscurecidos en esta performance sin actores. En total, la representación duraba justo cinco minutos $\mathrm{y}$, durante este tiempo, según las notas de Balla, el público había presenciado no menos de cuarenta y nueve escenarios diferentes. ${ }^{28}$

Para aquellos «ballets de intérpretes vivos», Marinetti esbozó instrucciones adicionales sobre «cómo moverse» en su manifiesto sobre Danza futurista de 1917. Allí, de manera atípica, reconoció las admirables cualidades de determinados bailarines contemporáneos, por ejemplo Nijinski - «con quien la geometría pura de la danza, libre de la imitación y sin estímulo sexual, aparece por primera vez»-, Isadora Duncan y Loie Fuller. Pero, advertía, uno debe ir más allá de las «posibilidades musculares» y aspirar en la danza a «ese cuerpo multiplicado ideal del motor con el que tanto tiempo hemos soñado». Marinetti explicó con mucho detalle cómo iba a hacerse. Propuso una danza de la metralla que incluía instrucciones: «con los pies marcar el boom-boom de los proyectiles que proceden de la boca del cañón». A su vez, para la danza de la aviadora recomendaba que la bailarina «simulara con sacudidas y zigzagues de su cuerpo los sucesivos esfuerzos de un avión tratando de despegar»». ${ }^{29}$

Pero cualquiera que fuera la naturaleza de la «metalización de la danza futurista», las figuras seguían siendo sólo un componente de la performance en su conjunto. De manera obsesiva, los numerosos

\footnotetext{
${ }^{28}$ GOLDBERG, Roselee, op. cit, p. 24.

${ }^{29}$ GOLDBERG, Roselee, op. cit., p. 24.
} 
manifiestos sobre escenografía, pantomima, danza o teatro, insistían en combinar actor y escenografía en un espacio especialmente diseñado. Sonido, escena y gesto, había escrito Prampolini en su manifiesto de Pantomima futurista, «deben crear un sincronismo psicológico en el alma del espectador». Este sincronismo - explicó- respondía a leyes de simultaneidad que ya reglamentaban «la sensibilidad futurista mundial». ${ }^{30}$

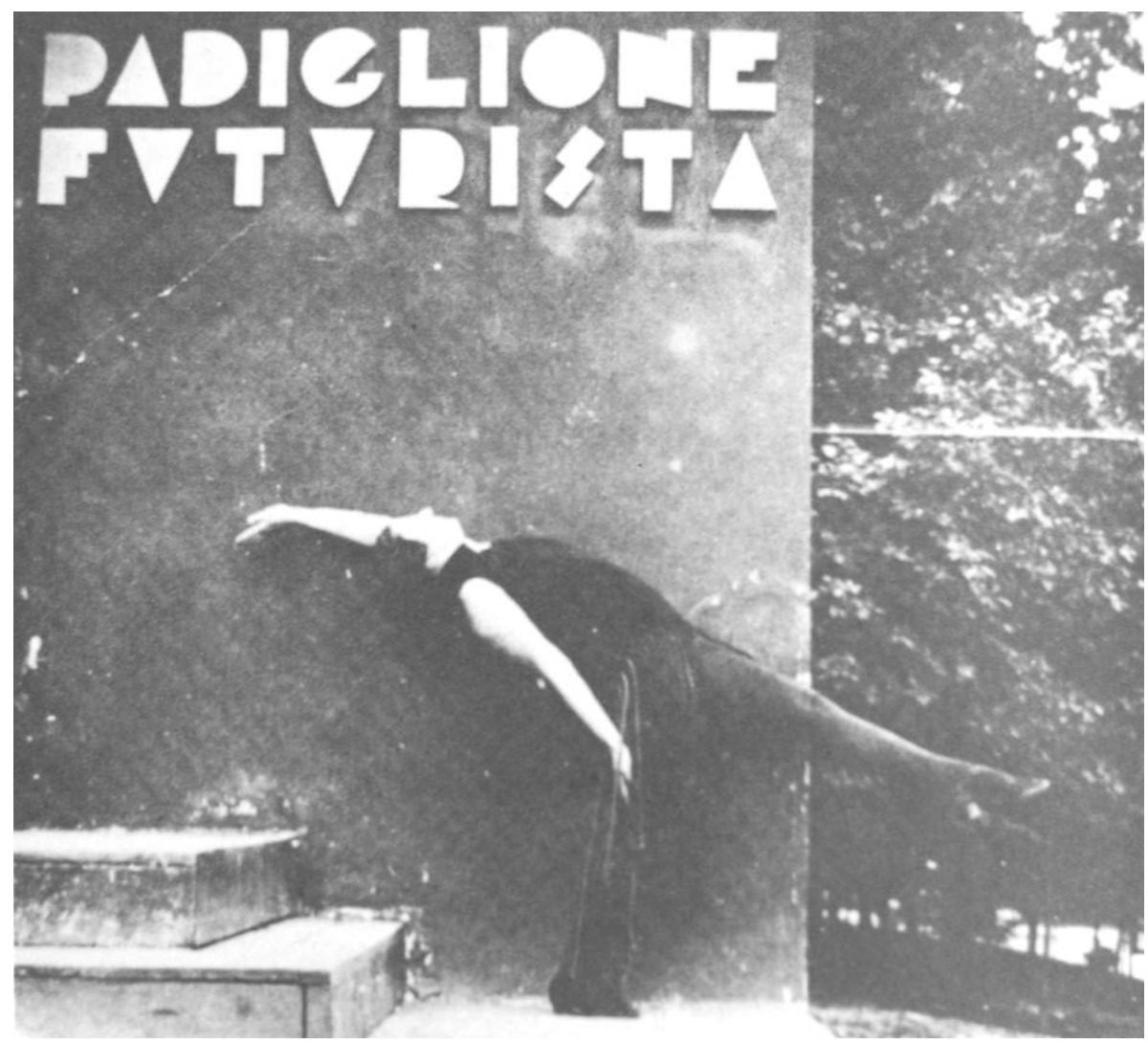

5. Enrico Prampolini - Actuación de la bailarina Zdenka Podhaska (1928)

Fue de este modo como los futuristas dejaron de lado las tradicionales representaciones artísticas y atacaron todos los productos posibles del arte, aplicando su genio a las innovaciones tecnológicas de la

${ }^{30}$ GOLDBERG, Roselee, op. cit., pp. 24-30. 
época. Quizás, en el caso italiano, el cuerpo fue el que se convirtió en una «extensión» de la máquina, complemento de un orden revolucionario que trató de romper las directrices de la naturaleza.

\subsubsection{La URSS biomekhanica}

Para muchos y muchas artistas de izquierdas de los años 20 , ya no era la vanguardia parisiense el único punto de referencia significativo: el Constructivismo y la Rusia revolucionaria se habían convertido en el nuevo símbolo de la cultura avanzada. El Constructivismo ruso planteó una nueva relación entre artista, obra y sociedad; dicho movimiento se fundamenta, básicamente, en una aproximación al trabajo desde una concepción de su potencial considerando a los y las participantes como cuerpos activos en el proceso de transformación social y político. ${ }^{31}$

Para entender el movimiento soviético es necesario tener muy en cuenta que las representaciones artísticas que se habían realizado hasta el momento, no cabían en la nueva sociedad. En su lugar, la «producción

\footnotetext{
${ }^{31}$ El Constructivismo surgió primero - a principios de los años 20- como una práctica artística y a la vez como un término para designar a ésta en el mundo artístico. El término lo encontramos impreso por primera vez en el catálogo de la exposición titulada $K$. $K$. Medunnetskii, V. A. Stenberg, G. A. Stenberg, celebrada en el Kafe Poetov (Café de los poetas) de Moscú en enero de 1922. El material exhibido comprendía estructuras espaciales hechas de materiales reales con una acentuación industrial muy fuerte, la naturaleza de estas construcciones era explicada en la declaración de los tres artistas impresa en el catálogo. Se afirmaba inequívocamente que todos y todas las artistas debían entrar en la fábrica, donde se hace el cuerpo real de la vida. Se refirieron al constructivismo como el más alto trampolín para dar el salto a la cultura humana universal y lo yuxtapusieron al arte y a la estética. El término constructivismo enlaza con el concepto de fusión de arte y vida por medio de la producción masiva y de la industria. No es objetivo de nuestro trabajo describir las diferentes y complejas corrientes dentro de la vanguardia soviética, para una información más completa sobre el tema véase: LODDER, Christina, El constructivismo ruso, Madrid, Alianza, 1988; FER, Briony, "El lenguaje constructivo", en FER, Briony, Realismo, racionalismo, surrealismo. El arte de entreguerras (1914-1945), Madrid, Akal, 1999; NASH, J. M., El cubismo, el futurismo y el constructivismo, Barcelona, Labor, 1983; CONIO, Gérard, Le constructivisme russe, Laussane, l'Age d'Homme, 1987.
} 
intelectual» serviría a la nueva colectividad comunista fusionando la experiencia formal adquirida en la realización de construcciones abstractas con la ideología del marxismo y las coacciones de la producción industrial. $^{32}$

En octubre de 1913, el futurismo ruso dejó las calles y las «películas caseras» para trasladarse al Luna Park de San Petersburgo. Maiakovski, y su amigo y poeta futurista Alexei Kruchenij, se encontraban planeando una ópera, Victoria sobre el sol. La mayor parte de los personajes, incluso aquellos que representaban a Maiakovski, eran Maiakovski: el hombre sin cabeza, el hombre con una oreja, el hombre con un ojo y una pierna, el hombre con dos besos, el hombre con un largo rostro estirado. Luego estaban las mujeres: la mujer con un desgarrón, la mujer con un desgarrón muy grande y la mujer enorme, cuyo velo arrancaba Maiakovski. Bajo el velo estaba una muñeca de seis metros, que era alzada y sacada. Victoria sobre el sol era, en esencia, un libreto que narraba cómo una banda de «futurocampesinos» se proponía conquistar el Sol. ${ }^{33}$

Kasimir Malévich diseñó el escenario y trajes para la ópera. El escenario decorado era cubista y no objetivo, los telones de fondo constituían un sugerente soporte pictórico atiborrado de formas cónicas y espirales muy similares a las que se habían pintado previamente en el telón. Los trajes estaban confeccionados con cartón y parecían armaduras pintadas al más puro estilo cubista. Los y las intérpretes llevaban cabezas de cartón piedra más grandes que el tamaño natural y actuaban en una estrecha franja de escenario con gestos análogos a los de un títere. El escenario estaba construido por grandes planchas: triángulos, círculos, piezas de maquinaria. Las máscaras de los actores y las actrices recordaban a las —en aquel momento- modernas máscaras antigás. Los trajes transformaban la

\footnotetext{
32 Por construcciones abstractas entiéndase cualquier creación «constructiva», ya sea pintura, escultura, teatro, bordado, etcétera.

${ }^{33}$ GOLDBERG, Roselee, op. cit., p. 34.
} 
anatomía humana, y los actores eran movidos, sostenidos y dirigidos por el ritmo dictado por el artista y director. ${ }^{34}$

La carencia de sentido y de realismo del libreto había sugerido a Malévich las figuras como títeres y los decorados geométricos. A su vez, las figurillas determinaban la naturaleza de los movimientos y, por tanto, el estilo total de la representación. En performances posteriores las figuras aparecían desarrollando los ideales de velocidad y mecanización de las pinturas rayonistas y futuristas. Cuchillas de luces rompían visualmente las figuras, privándolas por turno de manos, piernas y torso, e incluso las sometían a la disolución total. Los efectos de estos cuerpos meramente geométricos y de representación espacial abstracta fueron considerables en la obra posterior de Malévich. ${ }^{35}$

Sin embargo, un artista iba a convertirse en el catalizador de tal variedad de obsesiones. Nikolai Foregger había llegado en 1916 a Moscú desde su ciudad natal, Kiev, tras un breve aprendizaje en el Teatro Kamerni antes de su cierre en febrero de 1917. Llegó justo a tiempo para presenciar el entusiasmo de la prensa, despertado por los jóvenes rayonistas, constructivistas y activistas del arte. Fascinado por las interminables discusiones sostenidas en las exposiciones y por la mecanización y abstracción del arte y el teatro, extendió estas ideas para incluir la danza. En busca de medios físicos con los que reflejar los diseños estilizados de la vanguardia pre-revolucionaria, examinó los gestos de la actuación y los movimientos de la danza. Después de sólo un año en Moscú fue a Petrogrado, donde montó un taller en su estudio para llevar a cabo sus montajes. $^{36}$

Foregger sostenía que el circo era el «gemelo siamés» del teatro, citando a la Inglaterra isabelina y a la España del siglo XVII como combinaciones de teatro-circo perfectas. Al insistir en un nuevo sistema de

${ }^{34}$ GOLDBERG, Roselee, op. cit., p. 36.

${ }^{35}$ GOLDBERG, Roselee, op. cit., p. 37.

${ }^{36}$ GOLDBERG, Roselee, op. cit., p. 38. 
danza y de formación física — «nosotros vemos el cuerpo del bailarín como una máquina y los músculos de la volición como el maquinista»- el tafiatrenage no difería de otras teorías del cuerpo como las propuestas por la biomekhanica de Meyerhold o la eucenética de Laban. La biomekhanica era un sistema de formación de actores basado en dieciséis études o ejercicios que ayudaban al actor a desarrollar las habilidades necesarias para el movimiento escénico, por ejemplo moviéndose en un cuadrado, un círculo o un triángulo. Por otra parte, Foregger veía el tafiatrenage no sólo como una formación de pre-performance, sino como una forma de arte en sí mismo. ${ }^{37}$

Las Danzas mecánicas de Foregger se representaron por primera vez en febrero de 1923. Una de las danzas imitaba una transmisión: dos hombres estaban de pie a unos tres metros de distancia el uno del otro y varias mujeres, cada una bien agarrada a los tobillos de la otra, se movían como una cadena alrededor de ellos. Otra danza representaba una sierra: dos hombres asían las manos y pies de una mujer, balanceándola en movimientos curvos. Los efectos sonoros, que incluían la ruptura de cristales y el golpeteo de diferentes objetos de metal entre bastidores, los proporcionaba una animada orquesta de ruidos. Las Danzas mecánicas fueron recibidas con gran entusiasmo, pero enseguida se convirtieron en blanco de duras críticas procedentes de varios obreros que escribieron a la revista del gremio teatral amenazando con denunciar a la compañía de Foregger por sus representaciones «antisoviéticas»y «pornográficas». El crítico ruso Cherepnin las llamó «norteamericanismo mitad mítico, mitad legendario», pues el arte mecánico de Foregger parecía extraño a las sensibilidades rusas y aparecía como una mera curiosidad. Fue acusado de acercarse demasiado al music-hall y al espectáculo, así como de alejarse de las significaciones sociales y políticas exigidas a las representaciones de la época. $^{38}$

\footnotetext{
${ }^{37}$ GOLDBERG, Roselee, op. cit., p. 39.

${ }^{38}$ GOLDBERG, Roselee, op. cit., pp. 39-40.
} 
En tanto que Foregger estaba desarrollando una forma de arte puramente mecánico, que era más apreciado por su inspiración estética que por la ética, otros artistas, dramaturgos y actores eran partidarios de la máquina de propaganda, pues ésta hacía inmediatas y comprensibles las nuevas políticas y los nuevos estilos de la vida de Revolución.

En 1919, antes de estar al corriente de los constructivistas, el director teatral Vsevolod Meyerhold ${ }^{39}$ había escrito: «Hacemos bien en invitar a los cubistas a trabajar con nosotros, porque necesitamos escenarios que se parezcan a aquellos en los cuales estaremos interpretando mañana. Queremos que nuestro escenario sea un tubo de hierro, [...] erigiremos un trapecio y pondremos a nuestros acróbatas a trabajar en él, para hacer que sus cuerpos expresen la esencia misma de nuestro teatro revolucionario y nos recuerde que estamos disfrutando la lucha en que nos encontramos comprometidos». ${ }^{40}$

El estilo que Meyerhold comienza a desarrollar en la URSS hacia 1920 tenía su raíz en el Futurismo maiakovskiano y en los movimientos constructivista y productivista que un grupo de pintores y escultores formularon. Meyerhold reunió a los constructivistas para decorar piezas de teatro en las que el juego de los actores y actrices se definió como biomekhanica - el juego corporal de estos actores obedecía a una rítmica análoga a la de las cadencias de la producción industrial—, de hecho la vanguardia rusa consideraba al constructivismo y al «biomecanismo» como la cara y la cruz de una misma realidad a la vez material y espiritual.

La biomekhanica estaba directamente influenciada por el ritmo de gestos mecanizados y diseminados que el taylorismo y la organización científica de la sociedad habían regulado para los movimientos del

\footnotetext{
${ }^{39}$ En referencia a la traducción de los nombres, especialmente en las denominaciones soviéticas, hemos creído conveniente escoger la traducción más sencilla al idioma español, un claro ejemplo es el nombre de Meyerhold, donde podemos encontrarlo citado también como Meierkhol'd.

${ }^{40}$ GOLDBERG, Roselee, op. cit., pp. 44-46.
} 
trabajador que la nueva producción en masa exigía y que la industrialización se encargó de extender rápidamente por todas partes. El sistema de biomekhanica de Meyerhold estaba encaminado a eliminar de la técnica representativa los movimientos, gestos y expresiones superficiales o improductivos, inaugurando así una especie de taylorismo teatral. Como medio de vincular el teatro con el proletariado, el autor descartaba el realismo psicológico y el papel de las emociones individuales, reduciendo la interpretación a un proceso impersonal, científico y mecánico. El teatro tenía que presentar el ideal proletario, bien organizado y cualificado. El concepto de biomekhanica estaba influido por la acrobacia circense, las convenciones de la commedia dell'arte y el teatro chino y japonés. Como estos, cultivaba la economía e intensidad de los gestos estilizados.

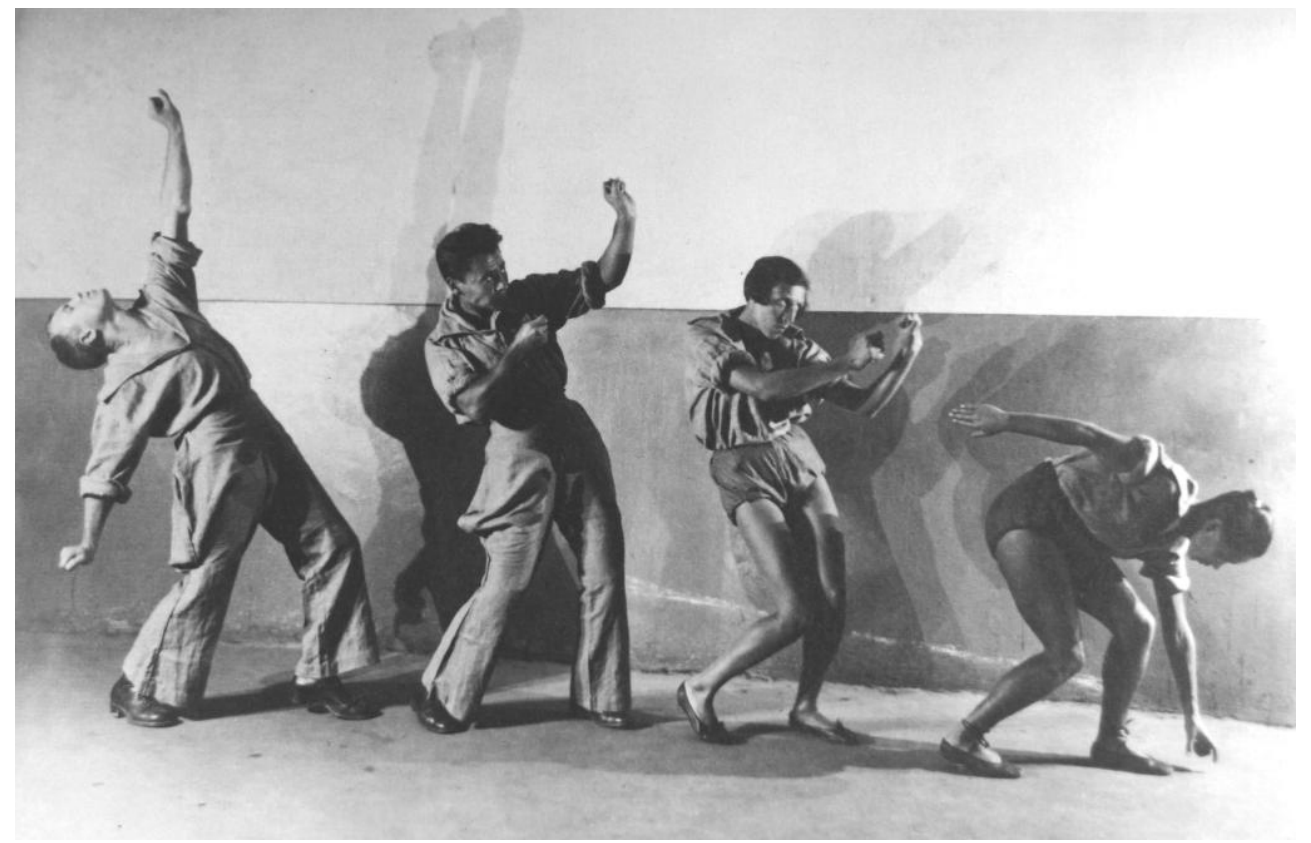

6. Vsevolod Meyerhold - Biomekhanica (1913) 
La producción de Meyerhold El cornudo magnífico ${ }^{41}$ (1922), que contó con la escenografía de Liubov Popova, fue una de las experiencias más interesantes realizadas con esta técnica, que tuvo gran repercusión en el teatro europeo de vanguardia. ${ }^{42}$

Meyerhold percibió claramente que el Constructivismo mostraba el camino a la militancia contra la tradición estética del teatro, permitiéndole realizar su sueño de representaciones extrateatrales alejadas del auditorio y desarrolladas en cualquier lugar: el mercado, la fundición de una fábrica metalúrgica, la cubierta de un acorazado. Comentó el proyecto con varios miembros del grupo, en particular Popova. Cuando a comienzos de 1922 Meyerhold sugirió una performance basada en las teorías espaciales de Popova, ella se negó de manera terminante: el grupo constructivista en conjunto se mostró poco dispuesto a participar en la representación. Una decisión demasiado precipitada habría significado arriesgarse a desacreditar las nuevas ideas. Meyerhold, no obstante, estaba convencido de que la obra de los constructivistas era ideal para su nueva representación, El cornudo magnífico, una adaptación de la obra del dramaturgo Crommelynck. Disimuladamente, se dirigió a cada artista por separado y les pidió que representaran estudios preparatorios, sólo para una eventual contingencia. Cada intérprete trabajó en secreto, sin saber que los demás estaban

\footnotetext{
${ }^{41}$ Fernand Crommelynch, dramaturgo franco-belga nacido en 1885, escribió el ya citado Le cocu magnifique en 1920. En su teatro se alterna lo real y lo onírico, lo racional con lo irracional, en escenas contrastadas y hábilmente construidas. La anécdota de Le cocu magnifique nos muestra la historia de Bruno, poeta y escritor que vive en un molino con su mujer, Stella, de la que está ferozmente celoso. Para descubrir al supuesto amante, decide meter en la cama de Stella a todos los hombres del pueblo con la esperanza de que ella se traicione en el momento psicológico oportuno y le descubra quién es. Respecto al título de la obra hemos creído conveniente traducir directamente del título original francés $L e$ cocu magnifique, sin embargo, podemos encontrar en algunas fuentes bibliográficas diversas variantes como El magnifico cornudo o El cornudo magnánimo. Véase CROMMELYNCH, Fernand, Le cocu magnifique, Paris, Labor, 2006.

${ }^{42}$ MEYERHOLD, Textos teóricos, Madrid, Alberto Corazón, 1972, p. 10.
} 
diseñando modelos para el espectáculo: la representación, el 15 de abril de 1922, fue, por tanto, un esfuerzo conjunto con Popova como coordinadora. ${ }^{43}$

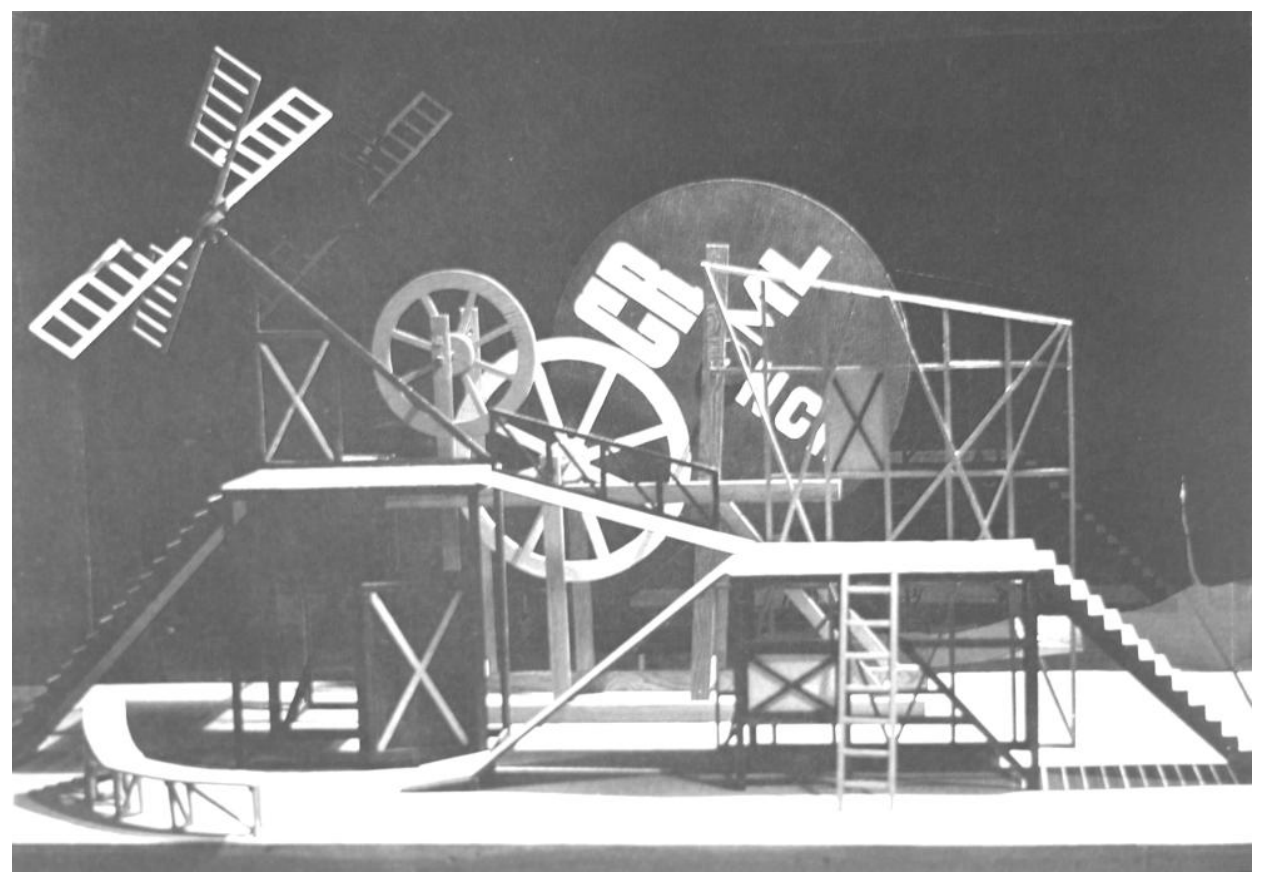

7. Liubov Popova - Maqueta para la escenografía de El cornudo magnífico (1921-22)

Meyerhold encontró en los constructivistas los escenógrafos que había estado anhelando. El decorado de El cornudo magnifico consistía en marcos de paneles teatrales convencionales, plataformas a diferentes alturas unidas por peldaños, rampas y pasarelas, aspas de molinos de viento, dos ruedas y un disco grande que llevaba las letras CR-ML-NCK (que remitían a Crommelynck, ya que eran las consonantes del apellido del autor) en blanco. Las ruedas y las aspas giraban a diferentes velocidades y con particular intensidad en momentos determinados de la obra, ello otorgaba un dinamismo propio al dispositivo escénico. El vestuario tradicional fue sustituido por ropa de producción (prozodezhda), unos característicos monos holgados que, pese a resultar una cómoda vestimenta, requerían por

${ }^{43}$ GOLDBERG, Roselee, op. cit., pp. 44-45. 
parte de actores y actrices de habilidades acrobáticas para que el decorado «funcionara». ${ }^{44}$ De esta manera, la representación se convirtió en el foro ideal para el sistema de biomekhanica de Meyerhold, desarrollado recientemente. Puesto que había estudiado el taylorismo, un método de trabajo eficaz entonces muy popular en Estados Unidos, exigió un «taylorismo del teatro [que] hará posible representar en una hora lo que en la actualidad requiere cuatro». ${ }^{45}$

La importancia de El cornudo magnífico se debe a que esta representación es la primera muestra del trabajo de Meyerhold en lo concerniente a la formación de intérpretes. El juego de los actores y actrices fue llevado a la excentricidad de la acción física, primer escalón «biomecánico». Mezcla de circo, equilibrismo, danza colectiva, Meyerhold quiso mostrar las bases de su lenguaje escénico y conectar el trabajo artístico con los rituales automáticos de la producción. El jazz sirvió como banda sonora y fue la primera vez que se escuchó en la URSS, Iliinski ${ }^{46}$ interpretó el personaje de Bruno, Babanova el de Stella y Zaichikov el de Estrugo, creando un acompañamiento pantomímico de extraordinaria precisión. ${ }^{47}$ La comedia psicológica de Crommelynck quedó convertida de este modo en una sucesión de ritmos, minuciosos saltos, arriesgadas posiciones en la máquina escenográfica, medidas cabriolas y giros, en definitiva, en un ejercicio mecanizado profundamente antipsicológico.

El éxito de El cornudo magnífico consolidó a los constructivistas como los líderes de la escenografía. Esta obra fue la culminación de un intercambio entre las artes, pues en esta representación el y la artista no sólo respondían a las necesidades teóricas de un director innovador, sino que de

\footnotetext{
${ }^{44}$ LODDER, Christina, "Constructivism and Productivism in the 1920s", en el catálogo de la exposición Art Into Life. Russian Constructivism 1914-1932, Washington, Henry Art Gallery, 1990, p. 105.

${ }^{45}$ GOLDBERG, Roselee, op. cit., p. 45.

${ }^{46}$ Iliinski fue uno de los grandes actores formados junto a Meyerhold.

${ }^{47}$ MEYERHOLD, op. cit., pp. 59-66.
} 
hecho transformaba la naturaleza de la actuación y la propia intención de la obra mediante la invención de esas complejas «máquinas actuantes». ${ }^{48}$

En octubre de 1923 se formó de manera oficial el grupo Blusa Azul. Se trataba de un grupo abiertamente político, que empleó técnicas vanguardistas además de populares $\mathrm{y}$ que se hallaba dirigido específicamente a un público de masas. La biomekhanica de Meyerhold también influyó mucho en el estilo global de las performances del grupo. Fascinados por la nueva sociedad industrial que Estados Unidos ejemplificaba, Grigori Kozinsev y Leonid Trauberg pasaron de la escenografía teatral a la acción cinematográfica, creando en 1922 la Fábrica del Actor Excéntrico (FEKS), de tendencia futurista. Los recursos mecánicos empleados en el grupo, con su habilidad para montar «representaciones industriales» a gran escala promovió esos aspectos más típicos de la vida estadounidense: alta tecnología y «baja cultura». ${ }^{49}$

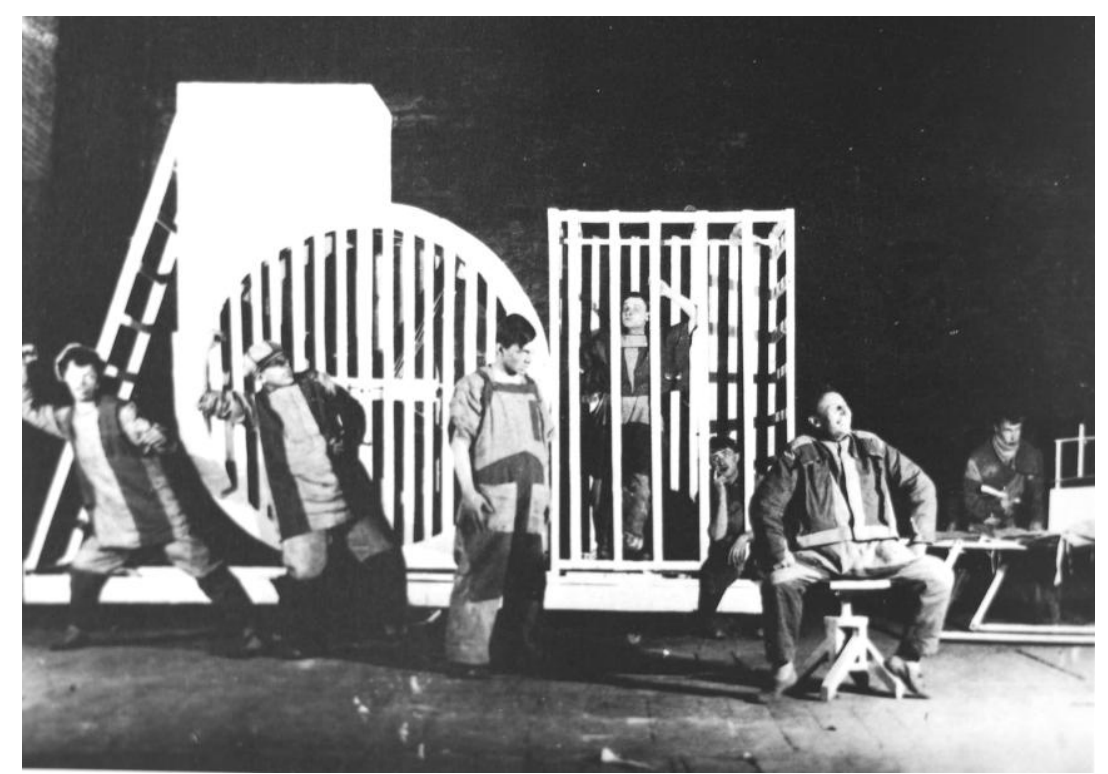

8. Varvara Stepanova - Tercer acto de La muerte de Tarelkin (1922)

${ }^{48}$ GOLDBERG, Roselee, op. cit., pp. 44-46.

49 FERNÁNDEZ CUENCA, Carlos, La obra de S. M. Einsenstein, Madrid, Filmoteca Nacional de España, 1965, p. 15. 
Especialmente notable fue la representación de la obra de SukhovoKobylin La muerte de Tarelkin, producida por Meyerhold en noviembre de 1922, para la cual Stepanova diseñó una serie de muebles plegables construidos en madera y pintados en blanco. ${ }^{50}$

Una vez más, las representaciones de performances rusas llevaron a cabo algunos de los principios establecidos en los manifiestos futuristas de casi una década antes, puesto que Fortunato Depero había pedido un teatro en el cual «todo cambia - desaparece- reaparece, se multiplica y se rompe, se pulveriza y se trastorna, tiembla y se transforma en una máquina cósmica que es vida». ${ }^{51}$

\subsubsection{El teatro de la Bauhaus}

La escuela de la Bauhaus fue uno de los movimientos - junto con el Futurismo y el Constructivismo - que planteaban el cuerpo como un engranaje más de la cadena industrializadora. Aun cuando en general se considera a la Bauhaus como célula germinal del diseño moderno, comprendiendo con ello su importancia histórica para el siglo $\mathrm{XX}$, no hay que pasar por alto el hecho de que sus fuentes sociales e intelectuales se adentran en el siglo XIX. Estas fuentes se hallan en el intento de reconstrucción de la unidad de las esferas artística y cultural-productiva rota por la industrialización, hecho que lleva tanto a integrar arte y vida, como a evitar la descomposición de los géneros artísticos, utilizando, por ello, el arte mismo como instrumento para una regeneración cultural y social.

El escenario de la Bauhaus estableció firmemente su importancia en la historia de la performance, ésta habría sido un medio para extender el principio de una «obra de arte total», lo que dará por resultado representaciones con coreografías y diseños muy cuidados. De este modo, la

${ }^{50}$ LODDER, Christina, op. cit., p. 105.

${ }^{51}$ GOLDBERG, Roselee, op. cit., pp. 46-48. 
danza y el teatro, debido a su directo contacto con el público, entrarán a formar parte en su programa como dos asignaturas más de la escuela. ${ }^{52}$

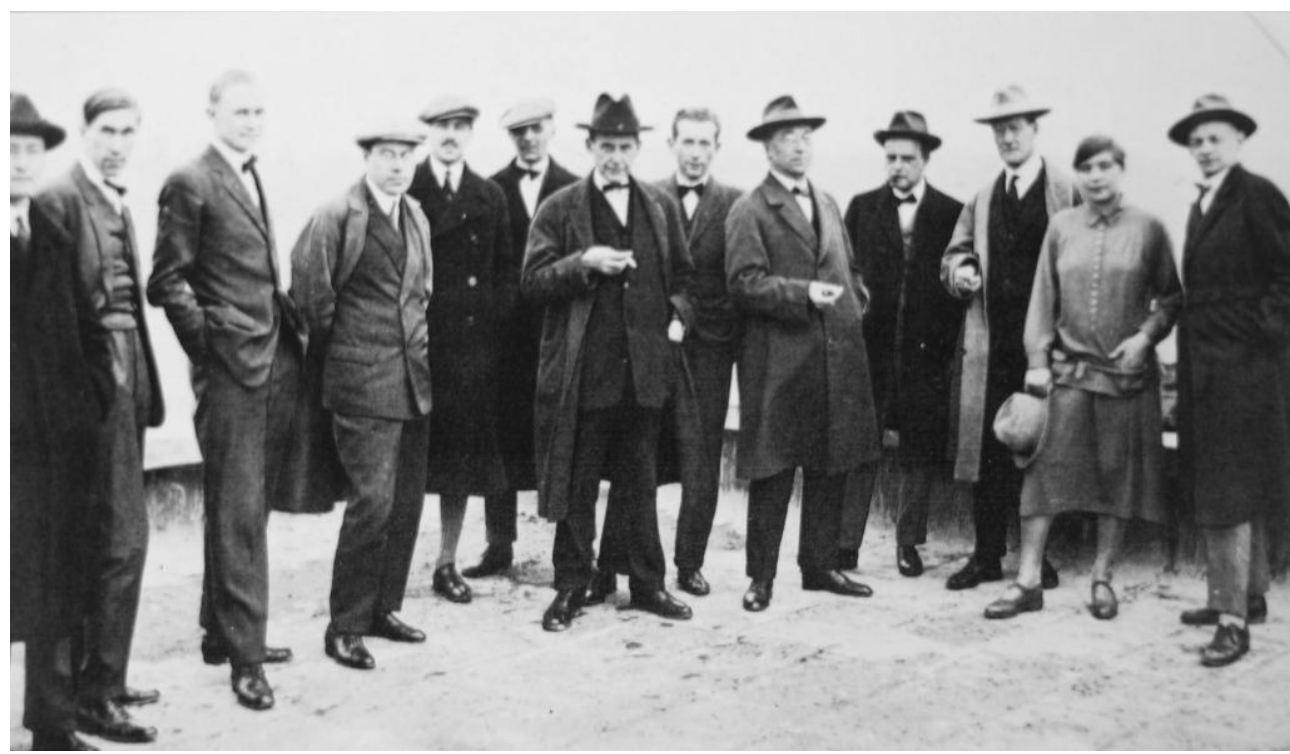

\section{Componentes de la Bauhaus}

Entre los partícipes más destacados se sitúa Oskar Schlemmer. Para aproximarnos a su figura hay que afrontar un amplio abanico de proposiciones de naturaleza muy diversa que van desde las relaciones entre arte y sociedad, hasta los vínculos entre las diversas artes. La figura de Schlemmer nos sitúa ante uno de los representantes más genuinos de las aspiraciones artísticas a la «obra de arte total» de nuestro tiempo. ${ }^{53}$ Aunque pintor de formación, se interesó enseguida por el teatro, y antes de la Primera Guerra Mundial trabajó en varias producciones de vanguardia. Entró a formar parte en la Bauhaus en 1920, prácticamente en la segunda etapa de la escuela. ${ }^{54} \mathrm{Su}$ único tema era la figura humana que trataba de

\footnotetext{
${ }^{52}$ WICK, Rainer, Pedagogía de la Bauhaus, Madrid, Alianza, 1986, p. 19.

${ }^{53}$ PAZ, Marga, "Sis facetes de l'obra d'Oskar Schlemmer", en el catálogo de la exposición Oskar Schlemmer, Barcelona, Fundació "la Caixa”, 1996, p. 41.

54 Recordemos que el período de existencia de la Bauhaus estuvo determinado estrictamente por la Constitución de Weimar promulgada en 1919 y por el triunfo del nacionalsocialismo dentro de toda Alemania en 1933 y su afán por erradicar cualquier
} 
manera severa y disciplinada y concebida en los términos de un lenguaje estrictamente geométrico. Sus figuras parecen muñecos y/o la estatuaria de alguna sociedad alejada del mundo clásico, por lo que en un principio se encargó del taller de pintura mural. ${ }^{55}$

\author{
Debido a que en otoño de 1923 Schreyer $^{56}$ abandonó la dirección del \\ taller de teatro por algunos conflictos ideológicos entre estudiantes y \\ profesores, Oskar Schlemmer pasó a dirigir el teatro de la Bauhaus, un
}

rastro de lo que llamaban «decadente»y «bolchevique». Tanto Frank Whitford, como Rainer Wick - aunque con notables discrepancias - establecen tres fases diferenciadas que resumen brevemente la historia de los catorce años que duró la utopía. No obstante, nosotros creemos que es más adecuado dividirla en cuatro partes: la primera de ellas, su fundación y su empeño en reformar la enseñanza del arte y en crear un nuevo tipo de sociedad, aunque algunos problemas internos y una crisis económica generalizada impiden un desarrollo normalizado de la misma. En la segunda etapa, comprendida entre 1923 y 1925, las nociones románticas son reemplazadas por nuevas ideas racionalistas, casi científicas, provenientes del constructivismo del húngaro Moholy-Nagy y de las ideas del arquitecto holandés Theo van Doesburg, todo esto coincidiendo con un estabilización económica y un vertiginoso desarrollo de la industria nacional (Alemania se convirtió en el país más industrializado de Europa). La tercera etapa se saldó con el triunfo del nacionalsocialismo en Weimar y con la retirada de la ayuda económica. Se produce así el abandono de Weimar para establecerse en Dessau. En esta etapa la escuela adapta las enseñanzas a las demandas de la industria. La última fase dataría desde 1929 hasta su cierre por los nazis y se caracterizaría por la inestabilidad. En 1929 su director Gropius presenta la dimisión y es sustituido por Hans Meyer, un marxista declarado que entendía el arte únicamente desde el punto de vista del beneficio social. Un año después, por divergencias políticas, es sustituido por Mies van der Rohe. En 1932 la escuela tuvo que trasladarse a Berlín, de nuevo por el triunfo del nacionalsocialismo, hasta que en 1933 los nazis se hicieron con el poder estatal, lo que supuso el fin de la Bauhaus. La mayoría de los artistas y arquitectos abandonaron Alemania llevando consigo sus ideas a los países donde buscaron refugio, especialmente Estados Unidos. Véase WHITFORD, Frank, La Bauhaus, Barcelona, Destino, 1991, pp. 9-12 y WICK, Rainer, op. cit., pp. 31-51.

${ }^{55}$ Dentro de la política de la Bauhaus el funcionamiento de la escuela era similar al de una fábrica para que el alumnado fuera capaz de desenvolverse en la vida real. El artista era un artesano y se formaba por medio de talleres: los más importantes fueron el taller de cerámica y el de tejido, llegando a tener producción en el exterior. Véase WORTMANN, Sigfried, Women's Work. Textile Art from the Bauhaus, San Francisco, Chronicle Books, 1993.

${ }^{56}$ Schreyer e Itten fueron dos de los profesores más polémicos en la Bauhaus. Sus métodos de enseñanza, cargados de misticismo y de extravagancia, no fueron bien vistos ni por la dirección de la escuela ni por parte del alumnado. 
trabajo que respondía más que ningún otro a sus gustos y conocimientos. ${ }^{57}$ Pero ¿qué importancia podía tener la escenografía y su producción en una escuela dedicada fundamentalmente a la artesanía y al diseño?

La respuesta es sencilla: el teatro era quizás el arte más público de todos. Se trata de una actividad en la que se combinan diversos medios, y en esto ofrece un paralelismo con la arquitectura. Una actuación en el escenario, como una construcción, requiere la estrecha cooperación de una cantidad de artistas y artesanos trabajando en equipo. Schlemmer deseaba una renovación total del medio, y pensaba que eso se conseguía mejor a través de un tipo de representación ritual que subrayara su alejamiento del mundo real, pero que destacara, por medio del vestuario y el movimiento estilizado, la relación entre una y otra figura humana y el espacio que las rodeaba. Oskar Schlemmer llevó a cabo la creación de un teatro mecánico en la Bauhaus poniendo en práctica la exitosa biomekhanica. Ésta consistía en una corriente que quería que toda la vida del planeta y de la especie humana se rigiera por los principios de la mecánica, entendida en el sentido más amplio, es decir, incluyendo las leyes de la física y la química. «Hombre y máquina» fue tanto una consideración dentro del análisis de la Bauhaus del arte y la tecnología como lo había sido para los intérpretes constructivistas rusos y futuristas italianos. Los trajes del taller de teatro estaban diseñados para metamorfosear la figura humana en un objeto mecánico. $^{58}$

El teatro de Schlemmer era una especie de teatro de guiñol y estaba relacionado con las teorías de uno de sus autores favoritos, Heinrich von Kleist, cuyo ensayo Sobre el teatro de marionetas $(1798)^{59}$ utiliza al personaje idealizado e inanimado movido mediante hilos como una metáfora del perfecto e inocente ser humano. Aún así, el autor estaba

${ }^{57}$ HOCHMAN, Helaine S., La Bauhaus. Crisol de la modernidad, Barcelona, Paidós, 2002, p. 54.

${ }_{58}$ WHITFORD, Frank, op. cit., p. 85.

${ }^{59}$ KLEIST, Heinrich von, Sobre el teatro de marionetas y otros ensayos de arte y filosofia, Madrid, Hiperión, 1989. 
demasiado convencido de los riesgos de tomar la máquina como modelo para cualquier cosa: «Yo no puedo desear lo que la industria ya puede hacer mejor, ni lo que los ingenieros pueden hacer mejor. Lo que queda es lo metafísico: ¡el arte!». ${ }^{60}$

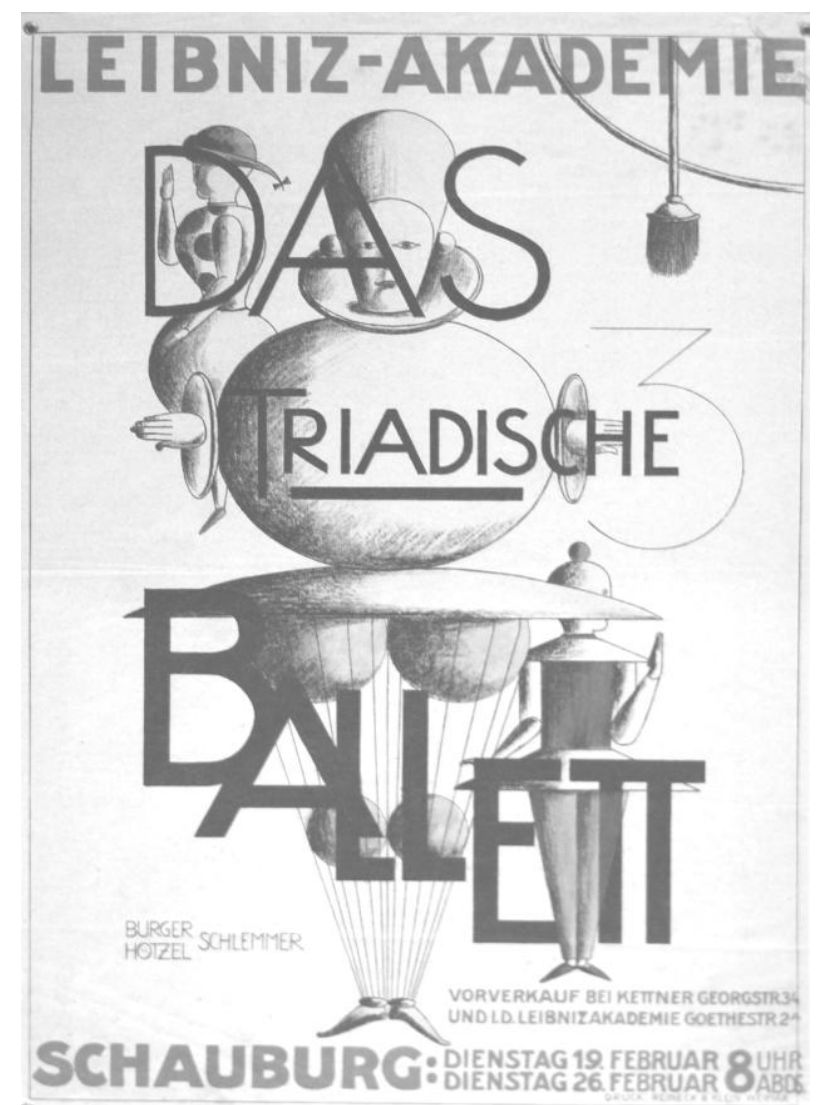

10. Oskar Schlemmer - Das Triadische Ballett (1924)

La más celebrada de sus producciones fue el Ballet triádico, estrenada en el teatro de Stuttgart ${ }^{61}$ en septiembre de 1922. El profesor utilizó tres actores — dos hombres y una mujer — vestidos con unos curiosos

${ }^{60}$ GONZÁLEZ, Ángel, "Caligari a la Bauhaus", en el catálogo de la exposición Oskar Schlemmer, op. cit., p. 18.

${ }^{61}$ Oskar Schlemmer compartió al principio sus enseñanzas en la Bauhaus con el trabajo de diseñador en el teatro de Stuttgart. WHITFORD, Frank, op. cit., p. 86. 
trajes que recordaban a muñecos infantiles. Con una rutina elaboradamente coreografiada, estos personajes exploraban de manera conjunta varios intercambios de danzas, a dos y a tres, destacándose sobre un fondo cuyos colores subrayaban la naturaleza artificial de todo el espectáculo. Oskar Schlemmer lo denominó «triádico» (de tríada) debido a los tres bailarines y a las tres partes de la composición arquitectónico-sinfónica y a su fusión de danza, trajes y música. Acompañado por una partitura de Hindemith para pianola - el instrumento mecánico que correspondía al estilo de danza estereotípica-, la música proporcionaba un paralelo a los trajes y a los contornos matemáticos y mecánicos del cuerpo. Además, las cualidades (como de muñeco) de los bailarines se correspondían con las referencias a una caja de música, lo que constituía una unidad de concepto y estilo. ${ }^{62}$ Las obras que representó más adelante en la Bauhaus constituyen un desarrollo de este ballet.

En agosto de 1923 Schlemmer aprovechó la oportunidad de la Semana de la Bauhaus para presentar su propio programa con una serie de performances y demostraciones. Los miembros del muy cambiado taller de teatro representaron El gabinete de figuras I, obra que había sido realizada antes en una fiesta de la escuela. Schlemmer describió la representación como mitad galería de tiro al blanco y mitad metaphysicum abstractum, utilizando técnicas de cabaret para parodiar la fe en el progreso tan dominante en esos tiempos. En definitiva, una mezcolanza de sentido y sin sentido. Schlemmer atribuyó su dirección a Caligari (en referencia al film $E l$ gabinete del Dr. Caligari de 1919), Estados Unidos y él mismo. El Cuerpo de violín, el Ajedrezado, el Elemental, el Ciudadano de clase superior, el Cuestionable, Miss Rosy Red y el Turco eran representados en figuras enteras, medias figuras y cuartos de figuras. Movidas por manos invisibles, las figuras caminan, están de pie, flotan, ruedan o jaranean durante un cuarto de hora. Según Schlemmer, la representación fue una confusión babélica, llena de método, un popurrí para el ojo en cuanto a forma, estilo y color.

${ }^{62}$ GOLDBERG, Roselee, op. cit., p. 111. 


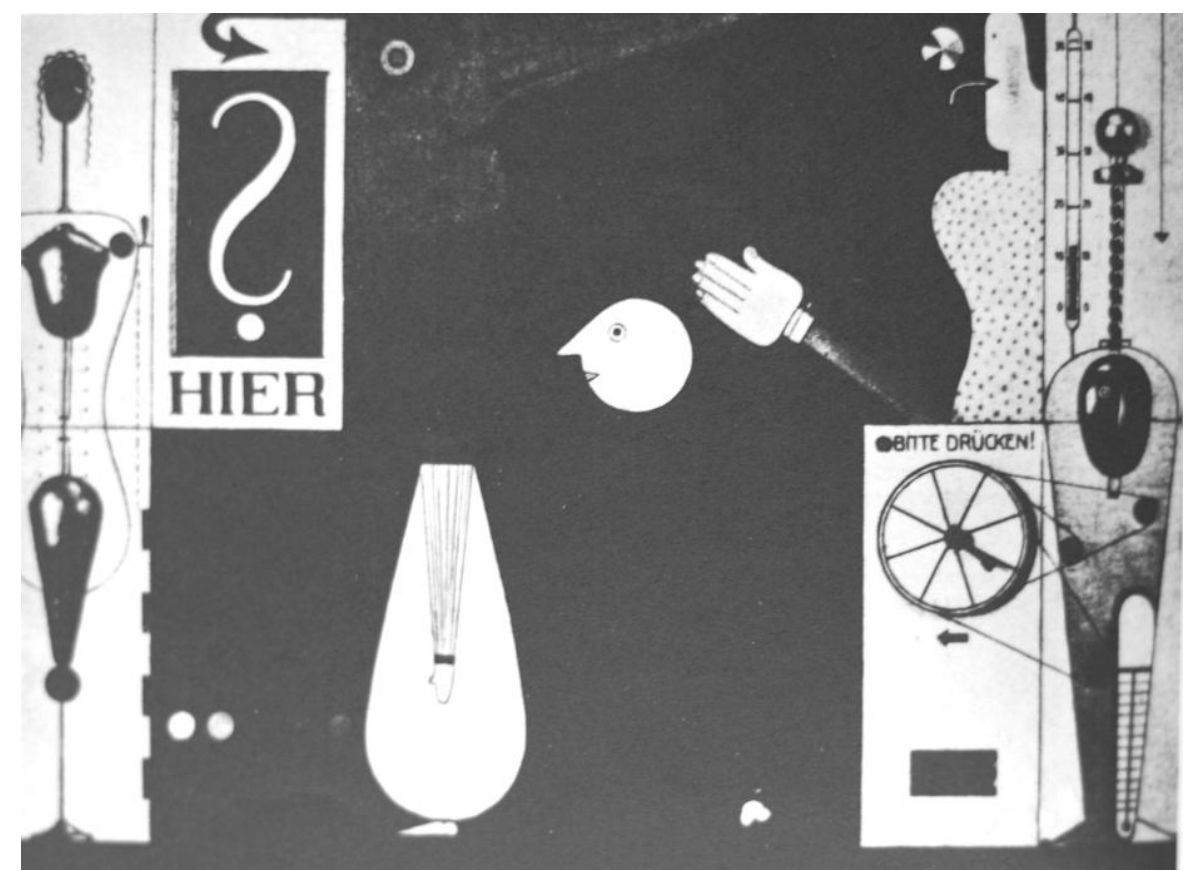

11. Oskar Schlemmer - Boceto para la producción del escenario de Gabinete de figuras I (1922-23)

El gabinete de figuras II fue una variación de la primera, con figuras metálicas sobre alambres que se movían deprisa desde el fondo al primer término y de nuevo hacia atrás. La performance fue un gran éxito precisamente porque sus recursos mecánicos y el diseño pictórico en conjunto reflejaban las sensibilidades tanto del arte como de la tecnología de la Bauhaus. ${ }^{63}$

En la pieza titulada Danza de gestos, representada en 1927, Schlemmer ideó una demostración de danza para ilustrar sus teorías sobre la performance. Primero preparó un sistema de notación que describía gráficamente los caminos lineales de marcha y los movimientos progresivos de los bailarines. Siguiendo estas direcciones, tres figuras, vestidas con los colores primarios, realizaban complicados gestos geométricos y acciones

${ }^{63}$ MICHAUD, Eric, "Llei comuna, homes nous. El teatre d'Oskar Schlemmer", en el catálogo de la exposición Oskar Schlemmer, op. cit., pp. 32-38. 
cotidianas banales que eran siempre «un medio hacia una forma abstracta de aislamiento». ${ }^{64}$ Esta demostración fue intencionalmente didáctica y al mismo tiempo revelaba la transición metódica de Schlemmer de un medio a otro. De modo que la representación de una acción implicaba estas diferentes etapas: palabras o signos impresos abstractos, demostraciones e imágenes físicas en forma de pinturas, que se convertían en un medio para la representación de capas de espacio real y cambios de tiempo. Debido a ello, la notación, además de la pintura, implicaba para Schlemmer la teoría del espacio, mientras que la performance en el espacio real proporcionaba la «práctica» para complementar esa teoría.

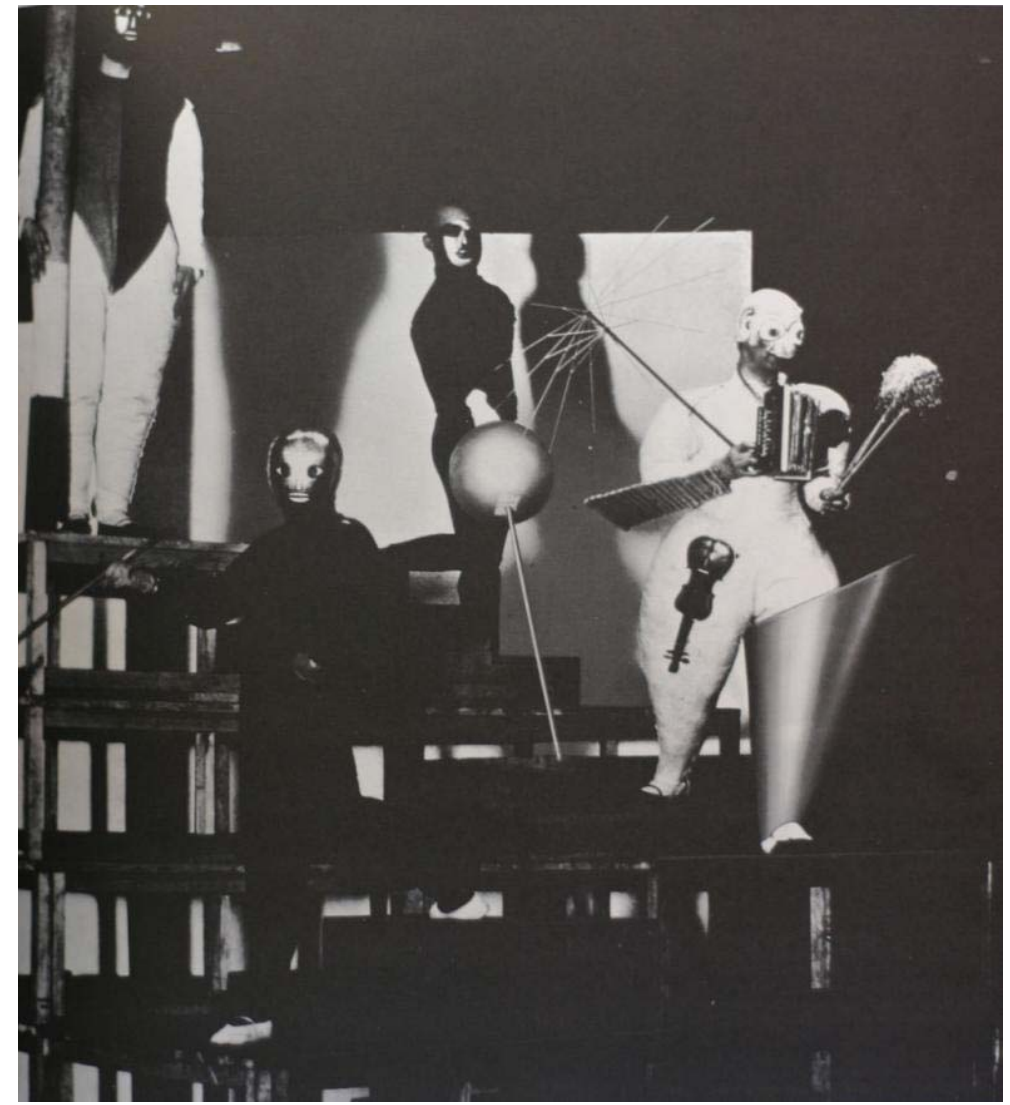

12. Oskar Schlemmer - Escena de Treppenwitz (1926-27)

${ }^{64}$ GOLDBERG, Roselee, op. cit., p. 103. 
Treppenwitz (1926-27) rayaba en el absurdo. Se trataba de una pantomima en una escalera que incluía personajes como el «payaso musical». Éste se encontraba vestido con un traje blanco acolchado con un gran objeto en forma de embudo que transformaba de manera total su pierna izquierda, y un violín que colgaba de su pierna derecha, llevando un acordeón, una coctelera de papel y un paraguas sólo con el varillaje. El «payaso musical» estaba obligado a interpretar sus propios gestos como de títere manteniéndose unido por medio de imperdibles. ${ }^{65}$

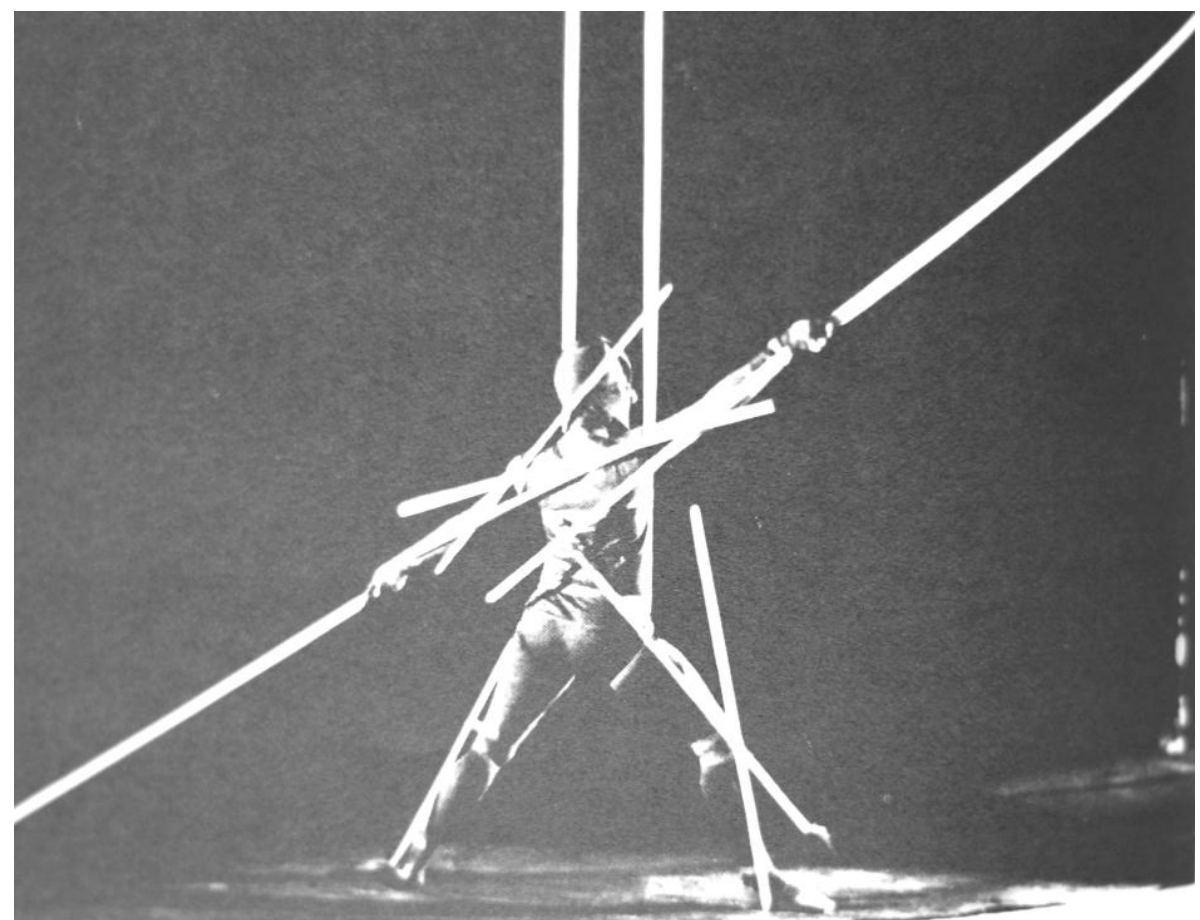

13. Oskar Schlemmer - Danza de tablillas (1927)

En la Danza de tablillas (1927), interpretada por Manda von Kreibig, las acciones de levantar y doblar los miembros del cuerpo sólo podían verse en los movimientos de las tablillas largas y delgadas que se proyectaban desde el cuerpo del bailarín. En Danza de cristales (1929),

${ }^{65}$ GOLDBERG, Roselee, op. cit., pp. 107-108. 
ejecutada por Carla Grosch con una falda en forma de aro de varillas de cristal, la cabeza cubierta con un globo de cristal y llevando esferas de vidrio, restringían de igual modo los movimientos de la bailarina. Los trajes abarcaban desde «figuras blandas» rellenas de plumón a cuerpos cubiertos de aros concéntricos, y en cada paso las propias constricciones de los elaborados atavíos transformaban de manera total los movimientos de la danza tradicional. ${ }^{66}$

Otra famosa danza de la Bauhaus, presentada en febrero, en la fiesta de Carnaval de 1929, fue el Festival metálico, llevada a cabo también por el taller de teatro. Toda la escuela estaba decorada con colores y sustancias metálicas, y a aquellas personas que habían recibido las invitaciones impresas en elegantes tarjetas de color metálico, un tobogán las esperaba en la entrada a la escuela. De allí pasaban al vestíbulo para ser recibidas en la sala principal de la fiesta con campanas tintineantes y con un estridente toque de trompeta ejecutado por una banda del pueblo compuesta por cuatro instrumentos. ${ }^{67}$

Schlemmer, de este modo, recalcaba la cualidad de «objeto» de los bailarines y cada performance lograba su deseado efecto mecánico, no distinto al de los títeres. «¿No podrían los bailarines ser títeres reales, movidos por cuerdas, o mejor aún, autopropulsados por medio de un mecanismo preciso, casi libre de la intervención humana, a lo sumo dirigidos por control remoto?». ${ }^{68}$ Acogidas tan favorables llevaron a la compañía a representar el Ballet triádico en el Congreso de Danza Internacional en 1932. Pero ésta fue también su última representación. La desintegración de la Bauhaus después de los nueve años de permanencia de Gropius allí; las exigencias de un director muy diferente, Hannes Meyer, que estaba en contra de los aspectos formales y personales del trabajo de

${ }^{66}$ MICHAUD, Eric, op. cit., p. 37.

${ }^{67}$ WHITFORD, Frank, op. cit., p. 164.

${ }^{68}$ WHITFORD, Frank, op. cit., p. 164. 
danza de Schlemmer; la censura impuesta por el nuevo gobierno prusiano: todo esto convirtió en efímero el sueño de Schlemmer. ${ }^{69}$

En 1923 los títeres y las figuras manejadas mecánicamente, las máscaras y los trajes geométricos, habían llegado a ser una característica central de muchas performances de la Bauhaus. Kurt Schmidt diseñó un Ballet mecánico, en el cual figuras movibles abstractas, identificadas por las letras A, B, C, D, E, eran llevadas por invisibles bailarines, lo que creaba una sensación de autómatas de baile. Igualmente, la representación de Hombre + Máquina (1924) de Schmidt, subraya los aspectos geométricos y mecánicos del movimiento, y su Die Abenteuer des kleinen Buckligen (Las aventuras del pequeño jorobado, 1924) condujeron a la formación de un teatro de marionetas flexibles, bajo la dirección de Ilse Fehling. Xanti Schawinsky añadió títeres de animales a su representación de Circo (1924), vestido con un leotardo negro. Schawinsky invisiblemente hacía el papel de domador de leones para el león de cartón de Von Fritsch: se trataba de teatro visual, una realización de pintura y construcciones en movimiento, con ideas en color, forma y espacio y en interacción dramática.

También tuvieron especial importancia los escenarios de la Bauhaus, entre los que podríamos destacar El escenario mecánico de 1925 de Joost Schmidt, pensado para uso de la propia Bauhaus. A su vez, El teatro esférico de Andreas Weininger se diseñó para alojar «obras mecánicas». Los espectadores y espectadoras, alrededor de la pared interior de la esfera, se sentirían, según Weininger, en una nueva relación con el espacio y en una nueva conexión física, óptica y acústica con la acción de la performance. Por otra parte, el escenario de Heinz Loew estaba diseñado para llevar a la

${ }^{69}$ Lamentablemente la información asequible respecto a la interesantísima trayectoria de Oskar Shlemmer es bastante parca. Existen numerosos textos del mismo Schlemmer que no han sido traducidos ni al inglés ni al francés, ni siquiera pensamos ya en español. Sin embargo, hemos podido encontrar dos interesantes catálogos que - aunque a modo de documentación visual - pueden ser interesantes para una ampliación de la obra e ideas de un revolucionario artista que nunca ha sido valorado suficientemente por los historiadores: Oskar Schlemmer. Der Folkwangzyklus Malerei Um 1930, Stuttgart, Staatsgalerie, 1993 y Oskar Schlemmer. Tanz Theater Bühne, Hannover, Sprengel Museum, 1995. 
parte delantera el aparato técnico que en el teatro tradicional permanece oculto a la vista del público. Esto dio por resultado que las actividades entre bastidores se convirtieran en el aspecto más interesante del teatro. Loew propuso que la tarea del futuro teatro debía «desarrollar un personal técnico tan importante como los actores, cuyo trabajo sería sacar ese aparato a la vista, abiertamente y como un fin en sí mismo». ${ }^{70}$

${ }^{70}$ GOLDBERG, Roselee, op. cit., p. 114. 


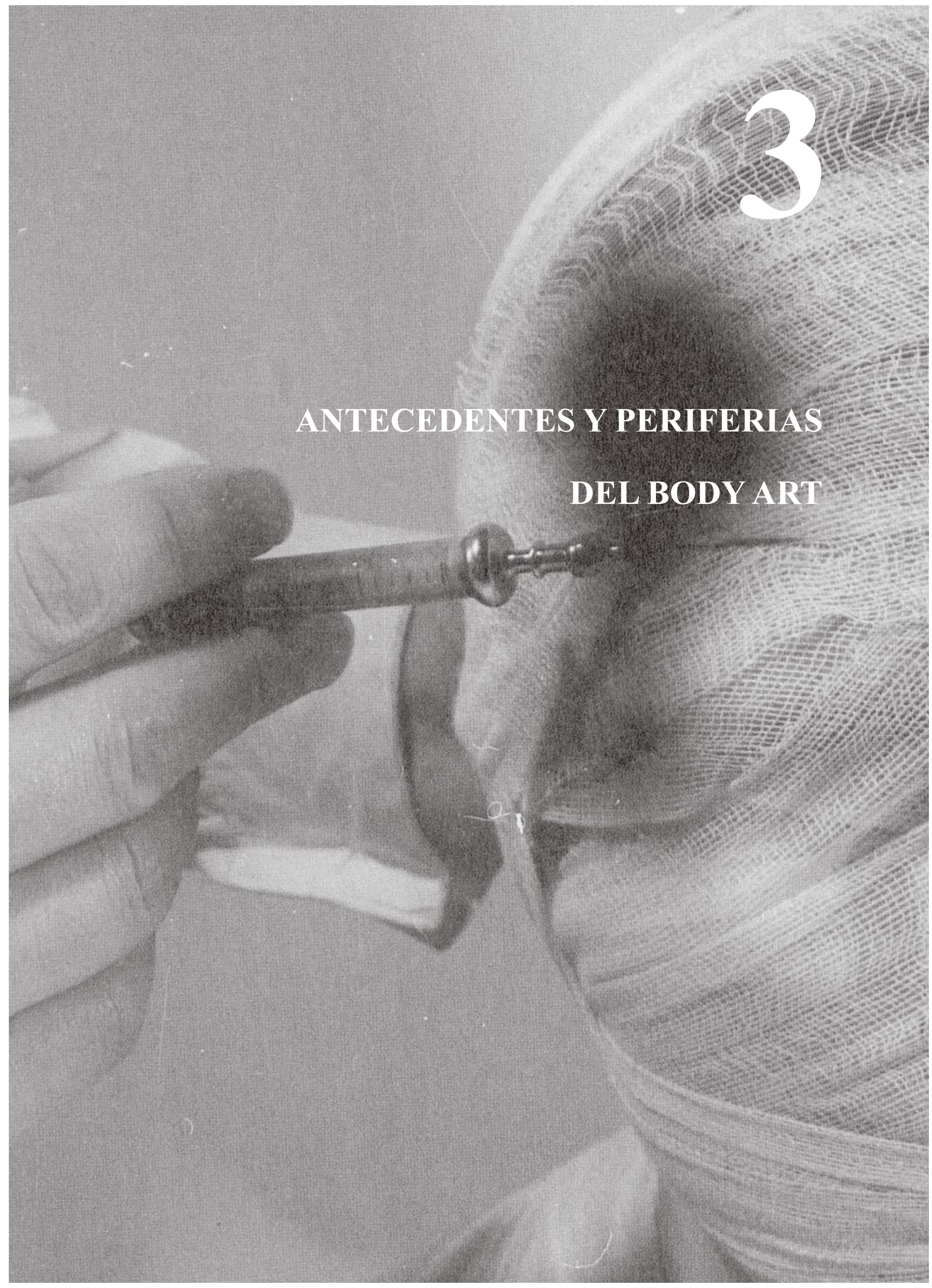



$\mathrm{C}$ omo hemos visto en el anterior capítulo, las vanguardias artísticas propiciaron diferentes sistemas de representación que pudieran reflejar de manera conveniente las nuevas relaciones entre el ser humano y su contexto socio-cultural. Así pues, el cuerpo se convirtió en una herramienta más de trabajo y creación repleto de un inimaginable potencial, lo que supuso dejar en un segundo plano las técnicas artísticas más tradicionales. Se hace, por tanto, necesario no abandonar en ningún momento las reflexiones formales, técnicas, ideológicas e históricas que significaron las vanguardias para comprender el génesis del Body Art.

Pero, ¿por qué motivos el cuerpo pierde protagonismo tras la Segunda Guerra Mundial? ¿Por qué es silenciado éste por las pudibundas clarividencias de algunos influyentes teóricos y críticos que lo neutralizan mediante la marginalización y la mitologización? O, planteando la cuestión desde otra perspectiva, ¿por qué hasta la resaca de Mayo de 1968, momento en que el crítico François Pluchart propaga desde las páginas de Combat el concepto de arte sociológico y defiende la oficiosidad de lo corpóreo como lugar y medio de expresión artística, no se produce esta recuperación? 
Como se esgrime de las páginas precedentes, el estallido de carácter revolucionario que definió la ideología general de las vanguardias artísticas del siglo XX estuvo caracterizado fundamentalmente por la ruptura con el orden burgués. Su manera de llevarla a cabo podríamos estructurarla en tres ítems:

- La quiebra con toda representación artística tradicional, así como con su función y lugar expositivo. Por este motivo y salvo raras excepciones, la pintura, la escultura $\mathrm{y}$, de alguna manera, la arquitectura quedan relegadas a técnicas prácticamente obsoletas para los nuevos movimientos. Sus militantes desean acabar con todo emblema y resquicio burgués — como lo es el museo y todo lo que éste simboliza - inclinándose por la investigación y fusión de lenguajes para conformar una nueva forma de expresión más coherente y deliberada con la actualidad.

- La importancia de reflexionar sobre el momento histórico llevará a los y las artistas a tomar la máquina como elemento y referente obligado en las representaciónes propias de cada movimiento.

- Dado que el arte no debe permanecer enajenado de la vida, sino que le corresponde un valor primordial, ambos están vinculados. El cuerpo humano, como emblema de una nueva ideología, se fusiona con la máquina.

La Segunda Guerra Mundial desautorizará todas las esperanzas que la mayoría de artistas de principios de siglo XX depositaron en la máquina. Aquel cuerpo que, gracias a su comunión con el artificio mecánico, se había convertido en emblema irreductible, quedó reducido a un amasijo de carne, a figuras que volvieron a recordar aquellas grotescas deformidades que Otto Dix representó en su obra. Europa se convirtió en un mausoleo de imágenes que no sólo mostraban miembros amputados y destrozados, sino que además 
describían las devastadoras heridas con las que, sorprendentemente, hombres y mujeres se las arreglaban para sobrevivir. ¿Acaso no es razón más que suficiente para que se detuviera repentinamente toda euforia por el cuerpo y por los avances técnicos? ${ }^{1}$

Países asolados, ciudades en ruinas, más de sesenta millones de personas muertas y toda la confianza en el ser humano despedazada. Estas fueron algunas de las funestas consecuencias de la guerra. Al término de la misma, la prioridad incondicional era la reconstrucción del tejido económico, la recuperación de las estructuras básicas y el proceso de cura de las heridas tanto físicas como psicológicas. Valeriano Bozal utiliza el término «estupor» para tratar de designar la dificultad para expresar a través del lenguaje los pensamientos y sentimientos de aquellas personas que pudieron salvarse de la hecatombe -Adorno llamó la atención sobre la imposibilidad de escribir poesía después de Auschwitz. ${ }^{2}$ No es de extrañar que la amnesia se transformara en un arma analgésica de doble filo capaz de adormecer a una sociedad profundamente traumatizada e incapaz de reaccionar ante la gravedad de los hechos. ¿No podría ser éste un momento propicio para reorganizar una Europa según los valores más conservadores y moralistas?

Pero el ovido no supone la pérdida de memoria, con el paso del tiempo los hechos se imponen y el presente mira directamente al pasado. ${ }^{3}$ Por ello, tras unos años de letargo, los sectores más inconformistas de la sociedad occidental iniciaron un camino revolucionario ante todas las injusticias que se habían y estaban cometiendo contra los derechos

\footnotetext{
1 Aunque se centre en las consecuencias de la Primera Guerra Mundial es interesante revisar el catálogo editado con motivo de la exposición Ernst Jünger: Guerra, técnica y fotografía, Valencia, Universitat de València, 2002. Es indiscutible que los y las artistas de principios de siglo XX no quedaron indiferentes ante una catástrofe de tal envergadura. Posiblemente, aquellas experiencias fueran el detonante de la actitud profundamente escéptica y crítica ante la edad mecánica que caracterizó en cierta manera a los movimientos de vanguardia, verbigracia, Dadaísmo y Expresionismo.

${ }^{2}$ BOZAL, Valeriano, El tiempo del estupor, Madrid, Siruela, 2004, p. 13.

${ }^{3}$ BOZAL, Valeriano, op. cit., p. 14.
} 
humanos. Mayo del 68 fue la fecha de estallido mediático, momento en el cual la disconformidad ante el establishment se popularizó. En este sentido, aquella utilización del cuerpo, propia de las vanguardias artísticas, se empezó a propalar tímidamente hacia los años 1950 gracias a una serie de artistas. La visualización de éste como soporte creativo constituyó una empresa vincualada a un período muy determinado que reaccionó virulentamente contra la represión a la que el modernismo de carácter formalista había sometido lo corporal.

Si el cuerpo, vehículo idóneo en la representación del sincretismo arte-vida, se unía a la máquina a principios del siglo XX constituyendo una necesaria reflexión de su contexto sociocultural, aseveramos que determinadas obras del Body Art utilizarán otro tipo de tecnologías, en este caso más afines a su contextualización sociocultural. Así pues, las «extensiones corporales» — concepto en el que englobamos todo elemento como vestidos, accesorios y prótesis, que complementan al cuerpo para cumplir funciones determinadas y/o extender sus limitaciones - serán las encargadas de —en conjunción con éste- analizar las estrategias «tecnobiopolíticas» ${ }^{4}$ y reivindicar la subjetividad del individuo. Ante aquel sistema de homogeneización y control social, el arte fue el encargado de poner en tela de juicio los valores establecidos.

A pesar de ello, el público y la crítica han tendido a considerar el arte corporal como algo perturbador, de ahí que haya sido tildado no sólo de psicótico y/o exhibicionista, sino también de aberrante dentro de la propia Historia del Arte. Sin embargo, tal y como veremos, el estudio artístico con el cuerpo permite cuestionar tanto el mito del «artista como genio individual» mediante el carácter absolutamente efímero del producto, como el determinismo propio de los estamentos, supuestamente, más respetables de la sociedad.

${ }^{4}$ Sobre el concepto «tecnobiopolítico» véase el apartado 5.2. 
En el presente capítulo realizaremos, primeramente, un fugaz recorrido histórico previo necesario para contextualizar el Body Art y entender, así, sus premisas y pretensiones. Asimismo, revisaremos una serie de artistas que consideramos pioneros y pioneras en la utilización del cuerpo como elemento artístico. Es evidente que gracias al arte corporal se re-inicia un interesante e inexcusable camino de reflexión entre el individuo y su relación con el entorno social y cultural.

\subsection{Aproximación al contexto sociocultural}

Como es lógico, tras el trauma de la Segunda Guerra Mundial, se trazaron las prioridades de un nuevo orden mundial. Pronto se desencadenaría el enfrentamiento indirecto entre Estados Unidos y la Unión Soviética en la Guerra Fría, los derechos sociales y civiles quedaron por tanto, relegados a un plano alejado de las principales decisiones políticas. Las ya escasas políticas de igualdad previas al conflicto cayeron en el olvido tras el neoconservadurismo ideológico y religioso que se implantó al terminar la guerra. La meta principal era la superación de la crisis, argumento que sirvió de filtro y de contención de muchos conflictos por motivos de desigualdad y violencia de género, totalmente invisibilizados durante décadas. ${ }^{5}$

Las necesidades productivas, aceleradas mediante el fordismo y el taylorismo aplicado en las empresas y en las fábricas, tuvieron también como efecto que se aplastaran o amortiguaran los movimientos sociales reivindicativos. Después de 1945 los veteranos regresaron del frente y necesitaban una reinserción laboral. Muchas mujeres que se habían incorporado al ámbito laboral y que habían sido el sostén y el pilar de la economía familiar tuvieron que renunciar a esos puestos de trabajo y

\footnotetext{
5 ALIAGA, Juan Vicente, Orden fálico. Androcentrismo y violencia de género en las prácticas artísticas actuales del siglo XX, Madrid, Akal, 2007, p. 193.
} 
regresar al hogar. Cabe indicar también que el orden establecido se vio reforzado a través de un conjunto de dispositivos y mecanismos: prensa, publicidad, radio, cine, escuela, iglesia, familia, etcétera. ${ }^{6}$

Tras la guerra se produjo en Occidente una lánguida sumersión en la amnesia, una especie de proceso hipnótico o narcotizante en el que las luchas sociales pasaron a un término contingente, en donde la historia, analizada desde una perspectiva crítica, no se discutía, adormeciendo la necesidad de mantener una memoria viva del Holocausto y de las disputas de poder que emergieron tras el conflicto bélico. De hecho, tuvo que transcurrir cierto lapso de tiempo hasta que la engañosa cicatrización de las heridas estallara, saliendo a relucir las tensiones políticas e ideológicas existentes. $^{7}$

Sin embargo, durante la segunda mitad del siglo $\mathrm{XX}$, se produjo un dilatado movimiento social de reivindicación de la igualdad de los derechos cívicos que comenzó a perturbar sustancialmente a los países de Occidente o situados en su área de influencia. Las tensiones políticas de la Guerra Fría y los bloques ideológicos instaurados tras la Segunda Guerra Mundial trajeron consigo una concienciación sobre las grandes diferencias existentes con anterioridad entre colectivos humanos que habían venido sufriendo distintos tipos de discriminaciones.

Los países del área democrática no podían soportar, por una parte, la latente confrontación exterior que exigía una creciente inversión de recursos económicos en la industria bélica; y por otra, la crispación interior que brotaba de injusticias cotidianas como resultado de prejuicios ideológicos, segregaciones culturales e intereses económicos fuertemente asentados en amplios sectores de la sociedad. Como consecuencia, durante las décadas de los años 1950 y 1960 numerosos movimientos de liberación social, paralelos a los movimientos de liberación colonial, emergieron como resultado del

\footnotetext{
${ }^{6}$ ALIAGA, Juan Vicente, op. cit., p. 194.

${ }^{7}$ ALIAGA, Juan Vicente, op. cit., p. 201.
} 
desmoronamiento de los regímenes imperialistas decimonónicos ante la soberbia necesidad de los países europeos de hacerse fuertes internamente ante el nuevo y peligroso enemigo exterior: el comunismo.

Pero, ¿cuál fue el papel que desempeñó el arte en el período de transición comprendido entre el final de la Segunda Guerra Mundial, la reordenación de los bloques políticos y el estallido del arte del cuerpo de mediados de los sesenta y setenta? El arte se vio sometido a unas fuertes presiones de un mundo que parecía no poder ser dicho. ${ }^{8}$ Probablemente fuera ello la causa de que gran parte de los relatos y narraciones que se escribieron sobre las representaciones artísticas de los años cincuenta en Occidente quedaran centrados en la abstracción en sus distintas modalidades. Una abstracción absolutamente despolitizada en la que se hacía hincapié en la negación del referente exterior, quedando por tanto proscritos los síntomas o señales de la realidad social. Una negación que podría interpretarse como la decisión de apartar la historia.

Se avecinaba un cambio de conciencia sobre el ser humano, cuyo sufrimiento, evidenciado por el existencialismo que había calado profundamente en el individuo y el artista, se había expresado de forma hegemónica mediante el Expresionismo abstracto en Estados Unidos y el Informalismo y/o el Tachismo en Europa y Japón. Jackson Pollock en Norteamérica, Georges Mathieu en Europa o el grupo Gutai en Japón son los ejemplos cumbre de ese existencialismo en acción que convierte la superficie de la tela en un campo de gestos de carácter heroico, basados en el juego de acción-destrucción. ${ }^{9}$

El patrón de artista occidental de los años cincuenta, aislado, casi excluido del proceso histórico, política y socialmente nihilista, el tipo de

\footnotetext{
${ }^{8}$ BOZAL, Valeriano, op. cit., p. 13.

${ }^{9}$ SCHIMMEL, Paul, "Leap into the void: performance and the object", en el catálogo de la exposición Out of Actions: Between Performance and the Object 1949-1979, Los Angeles, The Museum of Contemporary Art, 1998, p. 18.
} 
artista hipermasculino que cuadra bien con aquel informalismo gestual, empezó a entrar en crisis a principios de los años 1960. Este lento proceso tuvo uno de sus principales paradigmas en la gran explosión cultural de la primavera parisina de 1968 - lo que conocemos como el Mayo francés. El arte traspasó las barreras de la contestación individual ante el hecho social y las personas de la cultura tomaron conciencia de que su obra debía dejar de ser intimista y hermética para convertirse en instrumento crítico, en arma arrojadiza contra la sociedad, un arma perturbadora, espontánea y en lucha por la libertad. ${ }^{10}$

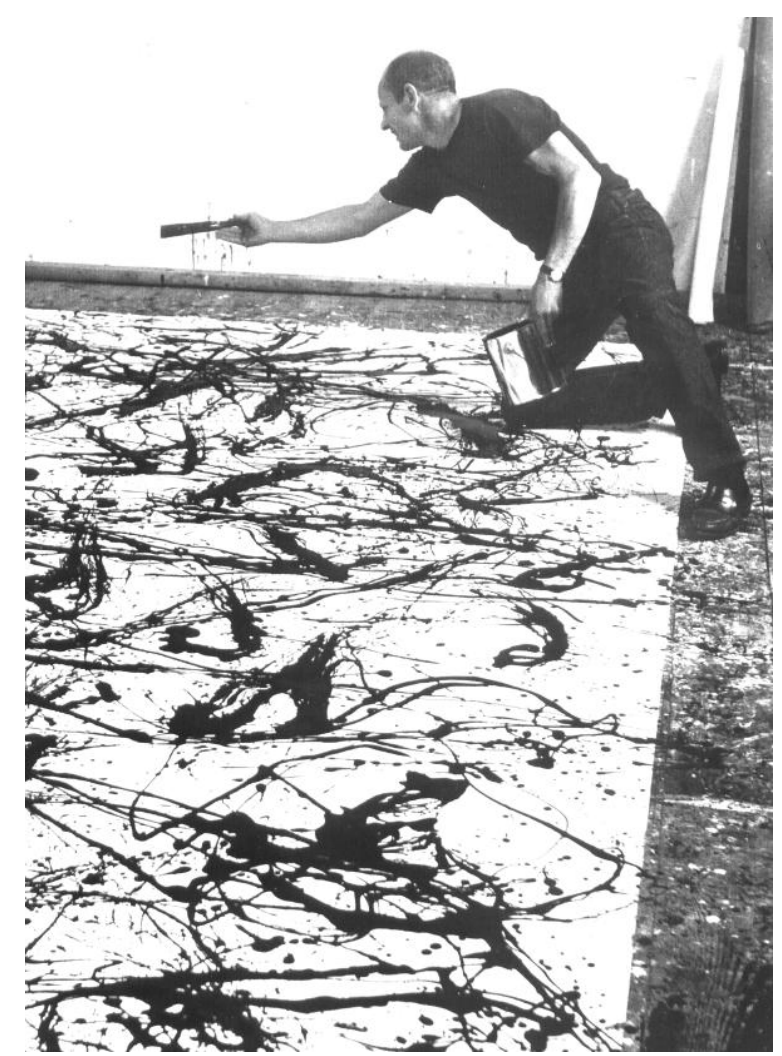

14. Jackson Pollock pintando en su estudio (1950)

\footnotetext{
${ }^{10}$ PARCERISAS, Pilar, "Cuerpo y revolución", en el catálogo de la exposición Accionismo vienés. Günter Brus, Otto Muehl, Hermann Nitsch, Rudolf Schwarzkogler, Sevilla, Centro Andaluz de Arte Contemporáneo, 2008, p. 7.
} 
Fueron momentos donde se experimentaba un doble proceso: por un lado, en Estados Unidos se vivía el fin del período del Expresionismo abstracto y, por otro, el auge del Pop Art, un nuevo arte que no sólo encarnaba la celebración figurativa y la opulencia consumista, sino que también estaba íntimamente ligado al nacimiento de nuevos movimientos sociales. Mientras el Expresionismo abstracto podríamos entenderlo como un arte duro, no literario y serio, realizado por artistas muy masculinos, el arte Pop se caracterizaba por un carácter más intelectual y ambiguo. ${ }^{11}$

A pesar de que el arranque de este fenómeno reside en París, a finales de aquella década se sumaron al mismo numerosas ciudades europeas. El objetivo del movimiento no sólo consistía en transformar la apariencia de la sociedad, sino la esencia del mundo en un intento — desde el punto de vista artístico - de conjugar al unísono el arte y la vanguardia con la izquierda revolucionaria. Tanto en París como en Milán, Berlín o Ámsterdam, entre otras capitales, se empezó a luchar para alcanzar verdaderamente los utópicos conceptos de igualdad y libertad. Tal batalla, resultado de la nueva dirección adoptada por grupos situados fuera del ámbito de los partidos comunistas tradicionales europeos en la segunda mitad de los años 1960, supuso una ideologización militante de las universidades, una afirmación de los movimientos contestatarios neomarxistas y progresistas que, refugiándose bajo los ensayos de autores como Horkheimer, Adorno o Marcuse, emprendieron una «revolución cultural» que no ocultaba sus relaciones con la movilización ideológica de las masas y la revolución cultural proletaria, aunque efectuando una relectura crítica de la misma.

Guy Debord publicaba en 1967 La société du spectacle donde describía los efectos totalizadores del capitalismo avanzado y su espejismo de libertad y satisfacción superpuesto al empobrecimiento de la vida

\footnotetext{
${ }^{11}$ GUASCH, Anna Maria, El arte último del siglo XX. Del posminimalismo a lo
} multicultural, Madrid, Alianza, 2002, p. 117. 
cotidiana. $^{12}$ Al mismo tiempo, Michel Foucault trabajaba en su antihumanismo teórico pidiendo nuevas formas de reflexión y apuntando en su crítica al ámbito institucional: la fábrica, la cárcel, la escuela, el hospital. Todas ellas estructuras que simbolizaban el autoritarismo combatido por el segmento juvenil contestatario. ${ }^{13}$

En París, las corrientes rebeldes lograron que estudiantes y artistas se implicaran en las inquietudes revolucionarias opuestas a la política de derechas del general De Gaulle y apostaron por trastocar las relaciones entre el arte y las fuerzas productivas, eliminando el concepto de individualidad en el proceso de creación artística y apostando por un trabajo colectivo que se concretó en la creación de los ateliers populaires. Todos aquellos movimientos liberadores tuvieron como objetivo final la modificación de las leyes que hacían posible la discriminación, la desigualdad y la injusticia entre personas iguales. Ahora bien, para que esta meta fuera obtenida resultaba preciso que antes la sociedad se hiciera consciente de la anomalía en la que estaba sumergida. En esta labor de concienciación colectiva, a medio camino entre la militancia y el mero desparpajo ante los convencionalismos, el arte desempeñó un papel decisivo. ${ }^{14}$

El crítico e historiador del arte Jean-François Chevrier establece dos vertientes diferenciadas respecto a Mayo del 68: la vertiente cultural y la política. Desde el punto de vista cultural, fue un movimiento antiautoritario que tendía a liquidar algunos vestigios del pensamiento patriarcal - hoy en día no queda ninguna idea de Mayo del 68 que resulte subversiva, todas han sido engullidas y recicladas. En la dimensión política - la perspectiva de una revolución - constituyó una verdadera crisis del sistema global.

${ }^{12}$ DEBORD, Guy, La sociedad del espectáculo, Valencia, Pre-Textos, 2005.

13 ALIAGA, Juan Vicente; DE CORRAL, María y G. CORTÉS, José Miguel, "La reinvención de la experiencia. ¿Hay espacio para lo pequeño en un mundo global?", en el catálogo de la exposición Micropolíticas. Arte y cotidianidad 2001 - 1968, Castelló, EACC, 2003, p. 29.

${ }_{14}$ GONZÁLEZ DE DURANDA, Javier, "La ofrenda del cuerpo", en el catálogo de la exposición Hannah Wilke. Exchange Values, Vitoria-Gasteiz, Centro Museo Vasco de Arte Contemporáneo, 2007, p. 6. 
Aunque entonces no se hablaba ni de globalización ni de mundialización, la integración mundial del capitalismo ya estaba muy avanzada. Esta perspectiva revolucionaria no tuvo éxito y el aspecto cultural, limitado a las cuestiones de autoridad, enseñanza, transmisión, etcétera, fue el que acabó imponiéndose. $^{15}$

A todo esto, debemos añadir ciertos acontecimientos políticos de la época que perturbaron inexorablemente el entorno sociocultural tanto de Europa como de Estados Unidos. La Guerra de Vietnam desacreditaba por completo la política imperialista llevada a cabo, removiendo los fantasmas del colonialismo. El conflicto duró desde 1965 hasta 1975 y fue cuestionado en sí mismo desde planteamientos vinculados al feminismo y las minorías sexuales, que aceleraron el llamado «síndrome de Vietnam».

El estado de ánimo podría reducirse a irritación e ira contra los valores y estructuras predominantes. Mientras estudiantes y obreros vociferaban eslóganes y se atrincheraban en las calles en protesta contra el establishment, numerosos y numerosas artistas se aproximaron a la institución artística con igual repulsa. Ponían en cuestión las premisas del arte aceptadas e intentaban redefinir su significado y función. Se encargaron de expresar estas nuevas direcciones en extensos manifiestos con la finalidad de no dejar esa responsabilidad al arraigado mediador, el crítico de arte. La galería y el museo fueron arremetidas como instituciones de mero mercantilismo, si bien, es cierto que pronto observaremos como aquellas manifestaciones, paradójicamente, fueron sutilmente absorbidas por la llamada institución arte.

El objeto artístico se transformó en mercancía íntegramente superflua dentro de aquella estética y la noción de «arte conceptual» se formuló como «un arte del cual el material son los conceptos». ${ }^{16}$ Los gestos vivos se utilizaron constantemente como un arma contra las convenciones

\footnotetext{
15 ALIAGA, Juan Vicente y G. CORTÉS, José Miguel, "Conversación con Jean-François Chevrier”, en el catálogo de la exposición Micropolíticas..., op. cit., p. 325.

${ }^{16}$ GOLDBERG, Roselee, Performance Art, Barcelona, Destino, 1996, pp. 152-154.
} 
del arte establecido. La indiferencia al objeto de arte estaba unida al hecho de que era visto como simple instrumento en el mercado artístico. Si la función del objeto de arte era ser un componente económico, el arte conceptual no podía adquirir ese uso. Aunque las necesidades económicas hacían de ello un sueño efímero, la performance - en este contexto- se convirtió en la extensión de una idea: era visible pero intangible, no dejaba rastro y por tanto, no podía ser ni comprada ni vendida. Se consideraba que reducía el elemento de alienación entre espectador o espectadora e intérprete puesto que ambos experimentaban el trabajo de manera simultánea.

La performance de los últimos años de la década de 1960 y la de 1970 reflejó el rechazo de los materiales tradicionales - lienzo, pincel o cincel - con intérpretes comenzando a trabajar con sus propios cuerpos como material creativo, del mismo modo que Yves Klein y Piero Manzoni habían hecho —utilizando, especialmente, cuerpos de mujeres - algunos años antes. El arte conceptual implicaba la experiencia del tiempo, del espacio y de la materia antes que una mera representación objetual, consecuencia que llevó a que el cuerpo se convirtiera en el medio de expresión más inmediato.

La juventud de la década de 1970 dejó de interesarse —o al menos en la medida en que lo hacían sus hermanos mayores - por la expansión de la mente, lo que se buscaba era la plena utilización del cuerpo, su liberación y su expansión. La fisicidad del autor o autora fue, por tanto, el medio idóneo para materializar los conceptos del arte $\mathrm{y}$, como tal, fue la práctica correspondiente de muchas teorías. Las ideas sobre el espacio podían interpretarse tan bien en el entorno real como en el formato bidimensional convencional del lienzo pintado, el tiempo podía sugerirse en la duración de la performance o con la ayuda de los primeros monitores de vídeo. Las sensibilidades atribuidas a la escultura - textura, volumen, etcéterallegaban a ser incluso más tangibles en la presentación en vivo. 
La transformación de conceptos en obras vivas dio como resultado muchas acciones que, a menudo, parecían completamente abstractas para quien presenciaba la obra, puesto que raras veces suponían una tentativa de generar una impresión visual global o de suministrar claves interpretativas a través de los objetos o de la narración. El espectador o espectadora podía, por asociación, aprehender una nueva percepción de la experiencia particular que el o la intérprete mostraba. Mientras que algunos y algunas artistas utilizaban sus propios cuerpos como material artístico, otros y otras se colocaron contra paredes, en rincones, o en campo abierto, haciendo formas de escultura humana en el espacio.

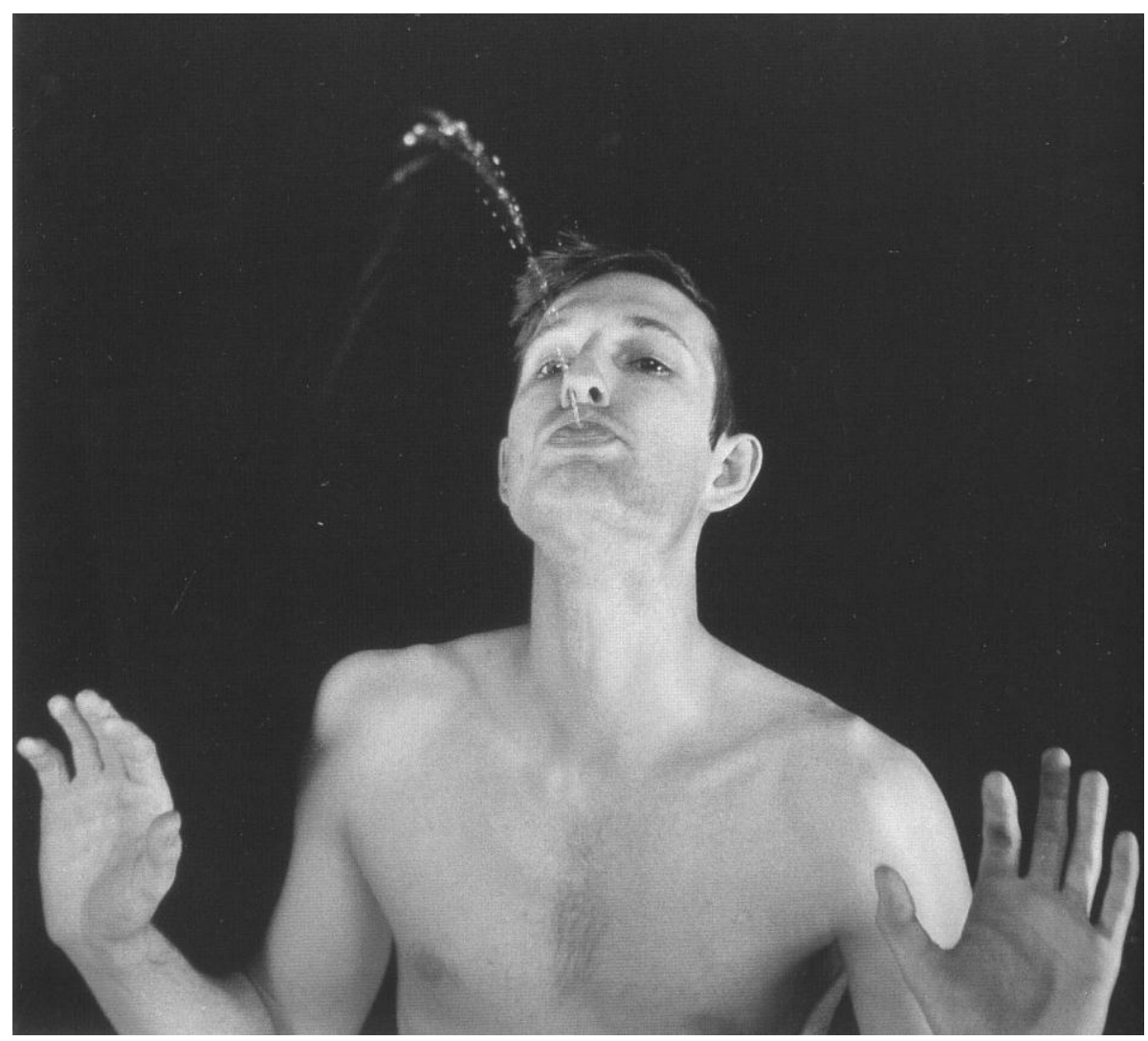

15. Bruce Nauman - Self Portrait as a Fountain (1966-67/1970) 
En esta primera sucesión de trabajos, la misma fisicidad del o de la performer era sujeto y objeto de la representación creativa. Asimismo, se revela sin ambigüedad la precavida ocupación del espacio, sea éste el puramente físico o el definido por unos roles políticos y sociológicos, roles que tenían más que ver con la autoconfiguración del «yo» consigo mismo. Este interés condujo directamente a un amplio grupo de obra a ser llamado faliblemente como «autobiográfica», dado que su contenido utilizaba aspectos de la historia personal del o de la intérprete.

Sin embargo - y a nuestro entender - insatisfechos e insatisfechas con la exploración un tanto materialista u objetual del cuerpo, surgen $a$ posteriori una serie de autores y autoras que comienzan a trabajar con «extensiones corporales», una nueva manera de reflexionar con cierta proximidad —conceptualmente hablando - a los planteamientos de las vanguardias artísticas del siglo XX, momento en el cual el cuerpo se adhería a objetos externos a modo de meditación sobre el individuo dentro de un complejo sistema organizativo.

Los cuatro años de arte conceptual iniciados a partir de 1968, tuvieron un enorme efecto en la aún joven generación que estaba surgiendo de las escuelas de arte donde enseñaban artistas relacionados con esta tendencia. En 1972 las cuestiones fundamentales planteadas habían sido absorbidas hasta cierto punto en la obra nueva. El entusiasmo por el cambio social y la emancipación había sido apaciguado considerablemente. Ni las manifestaciones estudiantiles, ni las canciones de Joan Baez consiguieron detener la Guerra de Vietnam. Las crisis monetaria y energética sutilmente alteraron tanto los estilos de vida como las preocupaciones. La institución de la galería, en otro tiempo rechazada por su explotación de artistas, fue vuelta a incluir como una salida conveniente. La performance reflejó estas nuevas actitudes convirtiéndose, repentinamente, en elegante, llamativa y entretenida. 
Desde una perspectiva internacional, en 1973 y 1975 todo se aplacó considerablemente y 1978 marcó el final, el punto de inflexión que daba cabida a los últimos sobresaltos. En 1980 la reacción ya estaba perfectamente establecida. Se iniciaba entonces la era del thatcherreaganismo.

Partiendo de este contexto, se ha de señalar que en los años en los que centramos la presente investigación existe un concepto básico que debemos considerar: el de la llamada «desmaterialización del arte», término clave en la ideología del Body Art. Cabe indicar que Lawrence Weiner fue uno de sus responsables más directos; si bien, es cierto que mucho se tendría que forzar la realidad para que el arte pudiera existir sin materia y/o sin objetos.

Frente a la idea de un valor absoluto, o un valor de cambio, Weiner propone que el arte se identifique por un valor de uso. Este uso puede no ser literal, pero sí puede ser simbólico, con tal de que un significado traspase la barrera de la inmediatez para convertirse en metáfora y que ésta pueda ser utilizada como tal. "Asumo, cuando hablo de "nuestra sociedad", un conjunto de valores morales, de comportamientos y de creencias básicas que son comunes, que se sustentan en tradiciones del pasado o que están en sintonía los unos con los otros. La comprensión del arte que hayamos podido construir durante este fin de siglo, forma parte de esa identidad escondida que algunos se empeñan en colocar en el reino de lo protegido, de lo inmaculado, que no debe tocar "lo real" porque es patrimonio exclusivo del espíritu, emplazado en alguna región superior. De hecho, ninguna otra región que aquella en la que nos encontremos en cualquier momento tiene necesidad de existir». ${ }^{17}$

En una declaración realizada para el primer número de la revista de arte conceptual Art-Language (1969) Lawrence Weiner enuncia, al mismo

\footnotetext{
${ }^{17}$ MARÍ, Bertomeu, "Visto en los labios de quien lee", en el catálogo de la exposición Lawrence Weiner. In the Stream, Valencia, IVAM-Centre Julio González, 1995, p. 32.
} 
tiempo, su revuelta contra la Historia del Arte y la manera en la que él se desvincula de ésta. La locución expresa palmariamente el espíritu revolucionario de la época: «C'est en quelque sorte le résidu merdique de l'histoire de l'art qui m'a obligé à faire des peintures et des sculptures. Mais aujourd'hui, je sens que je n'ai plus aucun contact avec l'histoire de l'art, je n'en ressens aucunement le besoin». ${ }^{18}$

\subsection{Los años 1950-1960}

Como hemos comentado anteriormente, a partir de los años 1950, los sectores más inconformistas de la cultura occidental comienzan a plantar cara a una sociedad que, a causa de las consecuencias de la Segunda Guerra Mundial, había quedado aletargada y conformada por los valores más reaccionarios y moralistas. Éste será el detonante principal por el cual el cuerpo físico del artista será sujeto y objeto de la representación creativa. Él mismo deviene soporte metafórico de la inscripción a la que permanecemos sometidos y sometidas a una compleja maquinaria que actúa imprimiéndonos violentamente un texto de temor, conducta y obediencia; en suma, una cruel caligrafía — de la misma manera que la máquina protagonista del cuento de Franz Kafka La colonia penitenciaria graba con una aguja en la sangrante piel sobre el cuerpo del soldado: «Obedeceré a mis superiores». ${ }^{19}$

\footnotetext{
${ }^{18}$ Cit. en L'art au corps. Le corps exposé de Man Ray à nos jours, Marseille, Galeries Contemporaines des Musées de Marseille, 1996, p. 46.

${ }^{19}$ La acción del relato de Kafka transcurre en una colonia penitenciaria europea situada - atendiendo a algunos detalles del texto- en un lugar de Oriente, alejado de Europa. En aquel lugar se practica un procedimiento judicial y una ejecución muy característica. Independientemente del delito cometido, el acusado es sometido a un castigo extrañamente mecanizado. Una punición que experimenta el reo directamente sobre su propio cuerpo desnudo y durante doce horas ininterrumpidas. La tortura consiste en la inscripción, cada vez más profunda, de la falta cometida mediante la refinada técnica de una impresionante máquina. El oficial, juez y verdugo al mismo tiempo en la colonia y orgulloso de su trabajo, es el encargado de mostrar la torturante máquina a un viajero, invitado a presenciar el
} 
Caos frente a orden, maquinismo y automatismo expandido en el espacio, objeto artístico realizado a partir de procesos. Se estaba quebrando la pintura en todo el mundo. Alemania pronto estuvo más dispuesta a reemprender su vida con una rápida reconstrucción y con la recuperación de sus vanguardias. Este hecho permitió recuperar la confianza en el arte y la sociedad mediante nuevas actitudes que cristalizaron en corrientes como Fluxus, en figuras individuales como Joseph Beuys y/o en certámenes como la Documenta.

Se pusieron en cuestión las premisas del arte aceptadas y se trató de redefinir su significado y función. Sin embargo, el entusiasmo por la autonomía y el cambio social reflejado a menudo en la radicalidad de las acciones, no supondrá la desaparición del generalizado carácter androcentrista de muchos autores, un aspecto que, como veremos a continuación, adquiere un común denominador. ¿Por qué detrás de un discurso desprejuiciado y cargado de reivindicación social se disimulan imágenes tremendamente reaccionarias y/o atiborradas de estereotipos? ¿Acaso no existen otras vías en las que las representaciones sean más coherentes con los ideales de ruptura propios de aquellos años?

Contestar a estas cuestiones supone que nos enfrentemos a una serie de reflexiones que no podemos obviar dentro de este contexto. De este modo, los siguientes subapartados debemos entenderlos como una escueta y

sadismo moralista de la justicia que impera en la colonia. Tras sentirse éste impresionado por la máquina olvidando por un momento su funesta finalidad, el viajero pone en duda los valores fanáticos del oficial mediante la negación a la injusta y cachazante máquina. El apologista decide suicidarse para redimir su sentimiento de culpabilidad liberando al condenado y de esta forma mostrar su reacción contra el nuevo régimen que había dejado su eficaz sistema de mantener el orden en la preterición. Cuando el oficial se acomoda en el lecho de la máquina, un extraño silencio susurra en su funcionamiento, ésta se estropea esputando una multitud de ruedecillas dentadas y aniquilando en pocos minutos al oficial ante la perpleja mirada de los tres espectadores, el viajero, el reo liberado y un soldado. El viajero huye tras leer la inscripción que contenía el nicho del antiguo comandante (inventor del artilugio punitivo) situado en una casa de té de la colonia penitenciaria. KAFKA, Franz, "En la colonia penitenciaria", La metamorfosis y otros relatos, Madrid, Cátedra, 1997, pp. 191-220. 
tangencial aproximación a los inicios de la utilización del cuerpo como sujeto y/o objeto en la representación artística en la década de 1950 y principios de la de 1960. Ciertamente, resumir en pocas líneas un trabajo tan complejo como lo es el de autores de la trascendencia de Joseph Beuys resulta ridículo.

Dicho esto, entendemos los siguientes apartados como meras referencias ineludibles — casi como citas a pie de página - que están dirigidas tan sólo a contextualizar el objeto de nuestro estudio. No obstante, cabe indicar que el lector o lectora dispone de una amplia bibliografía para introducirse en cada uno de los autores y autoras que mencionaremos a continuación.

\subsubsection{Happening y Fluxus}

«The performance should make clear to the listener that the hearing of the piece is his own action - that the music, so to speak, is his, rather than the composer's».

John Cage

El happening surge como gesto agresivo de los y las artistas ante la situación social que caracterizó la década de 1960. Las relaciones entre el arte y la vida, sus fronteras fluidas, se limitaban a potenciar la reciprocidad entre el man-made y el ready-made. La evolución de los environments - apropiación creativa de las dimensiones físicas reales del espacio circundante - desemboca en la acción en el espacio, es decir los happenings, indudablemente integrados en una tradición de acontecimientos que recurre a los procesos compositivos del collage. En cierto modo el happening responde a una forma privilegiada de neodadaísmo, dado que se 
asienta sobre una acción que es proclamada acontecimiento artístico y que se apropia directamente de la vida. A mediados de la década de 1960, Michael Kirby habla de una forma de teatro específicamente compuesta, en la que se organizan diversos elementos no lógicos en una estructura compartimentada, en particular, una forma de actuar no prevista por adelantado, una definición tremendamente parcial y reductora. ${ }^{20}$

Para Jean-Jaques Lebel, era un medio de expresión plástica de naturaleza no exclusivamente pictórica - también cinematográfica, poética, teatral, musical, política, erótica - capaz de introducir al testigo directamente en el suceso. ${ }^{21}$ Así pues, todo acontecimiento percibido y vivido por muchas personas como una superación de lo real y de lo imaginario, de lo psíquico y de lo social, podría ser calificado de happening.

Tal y como afirma Mercedes Vostell, en el happening el o la artista realiza la obra con el público, por ello el espectador deviene al mismo tiempo realizador. Hasta entonces, el público se situaba ante un cuadro, una obra de teatro, un concierto; la obra estaba ya terminada, podía gustar o no, se podía criticar o admirar. En el happening, sin embargo, la obra se va a realizar en común acuerdo entre el o la artista junto al público/participante. El happening es único, no se ensaya ni se repite como una obra de teatro. En algunas de estas acciones se reparten indicaciones, pero cada persona hace lo que quiere, cuando quiere y si quiere. Cada participante es responsable de sus acciones y cada cual se impone sus límites. ${ }^{22}$

Es innegable la influencia de los escritos de Antonin Artaud y del «teatro de la crueldad», cuya base se inspira en impresionar y sorprender a los espectadores y espectadoras mediante situaciones impactantes e

\footnotetext{
${ }^{20}$ KIRBY, Michael, Happenings, New York, P. Dutton, 1966, p. 21.

${ }^{21}$ Cit. en MARCHÁN FIZ, Simón, Del arte objetual al arte de concepto, Madrid, Akal, 1994, p. 195.

22 GUARDADO OLIVENZA VOSTELL, Mercedes, "Vostell, los happenings y yo", en AGÚNDEZ GARCÍA, José Antonio, 10 happenings de Vostell, Mérida, Editora General de Extremadura, 1999, p. 21.
} 
inesperadas de crueldad absurda. Pero a diferencia de la acción teatral, en el happening no se escenifica. El mismo es un collage de materiales en el que se introduce el movimiento de la acción humana. El happening, por tanto, se ofrece como una extensión de los estímulos que no fijan el curso de una vivencia, sino que provocan una intensificación de la atención y de la capacidad consciente de la experiencia, suscitando irritación y provocación de las costumbres convencionales. Más que provocar, la intención era activar al público a reencontrarse con las acciones cotidianas de manera distinta, a verlas en un contenido y contexto diferentes.

El estímulo provenía del trabajo musical de John Cage, que desde hacía algún tiempo utilizaba tanto el azar como los sonidos no artísticos. Allan Kaprow (Atlantic City, 1927 - Encinitas, 2006) — quien había sido alumno de Cage en The New School de Nueva York - tomó buena nota de ello, así como de la jerga de los jazzmen afroamericanos de la década de 1940, quienes preguntaban: «What's happening, man?». En 1959 conceptualizó el happening al redactar Assemblage, Environments \& Happenings, y el mismo año, en la Reuben Gallery de Nueva York, realizó la obra titulada 18 happenings in 6 parts. ${ }^{23}$ Instructions era el título de un folleto distribuido previamente a los espectadores y espectadoras que definía el desarrollo del happening y el papel de cada uno de los y las participantes. El autor creó, de este modo, un ambiente interactivo que el público manipulaba a su antojo. Se trataba de elementos combinados procedentes de diferentes dominios creativos: esculturas, música, proyecciones, danza, etcétera. A Kaprow le preocupaba la creación de un espectáculo que conjugase los elementos más diversos con la intensidad de la acción, pero su obra constituía la voluntad de elaborar una práctica liberada del pensamiento

\footnotetext{
${ }^{23}$ BLISTÈNE, Bernard, "What's happening, man? Conversación de Bernard Blistène con Jean-Jacques Lebel", en el catálogo de la exposición Un teatro sin teatro, Barcelona, MACBA, 2007, p. 36.
} 
discursivo con vistas a recuperar, mediante una acción catártica, una experiencia estética y ética profundamente original. ${ }^{24}$

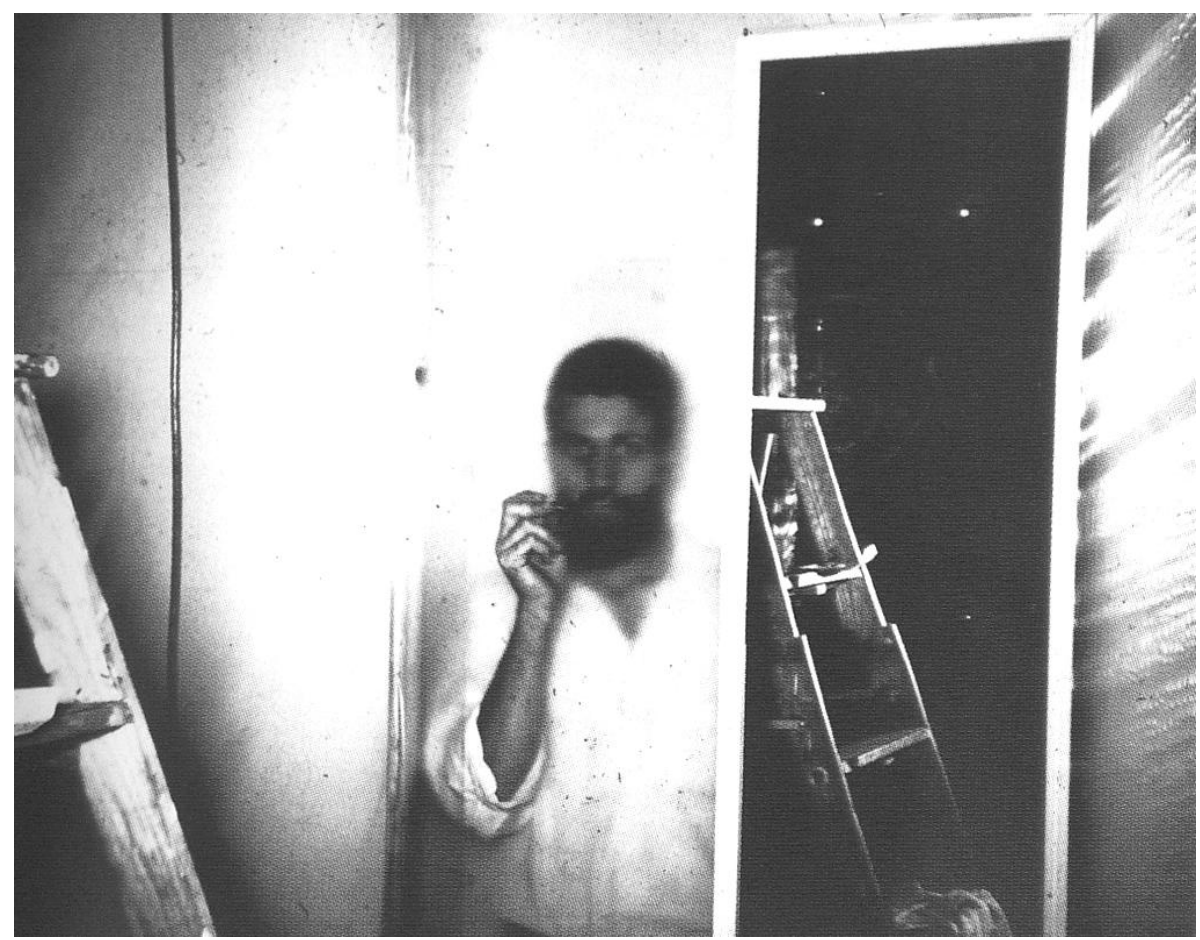

16. Allan Kaprow - 18 Happenings in 6 parts (1959)

Carolee Schneemann (New York, 1939) fue una de las pocas mujeres que, ya en la década de 1960, se implicaron activamente en la concepción del happening —o, como ella lo denominaba, Kinetic Theater, una interesante combinación que se situaba dentro del terreno de la danza, la música y la coreografía - y fue, incluso, la primera artista en incorporar su propio cuerpo desnudo en su trabajo, un cuerpo reivindicado como erótico, sexual, deseado y deseante.

Desde estas premisas, en Eye Body: 36 Transformative Actions (1963) Scheneemann construyó un environment mediante unos grandes

${ }^{24}$ MARCHÁN FIZ, Simón, op. cit., pp. 194-195. 
paneles, varios espejos rotos, cristales y algunos objetos a los que les había añadido motores. Sobre esta obra la propia autora afirmaba: «I wanted my actual body to be combined with the work as an integral material [...] Covered in paint, grease, chalk, ropes, plastic, I establish my body as visual territory. Not only am I an image-maker, but I explore the image values of flesh as material I choose to work with».

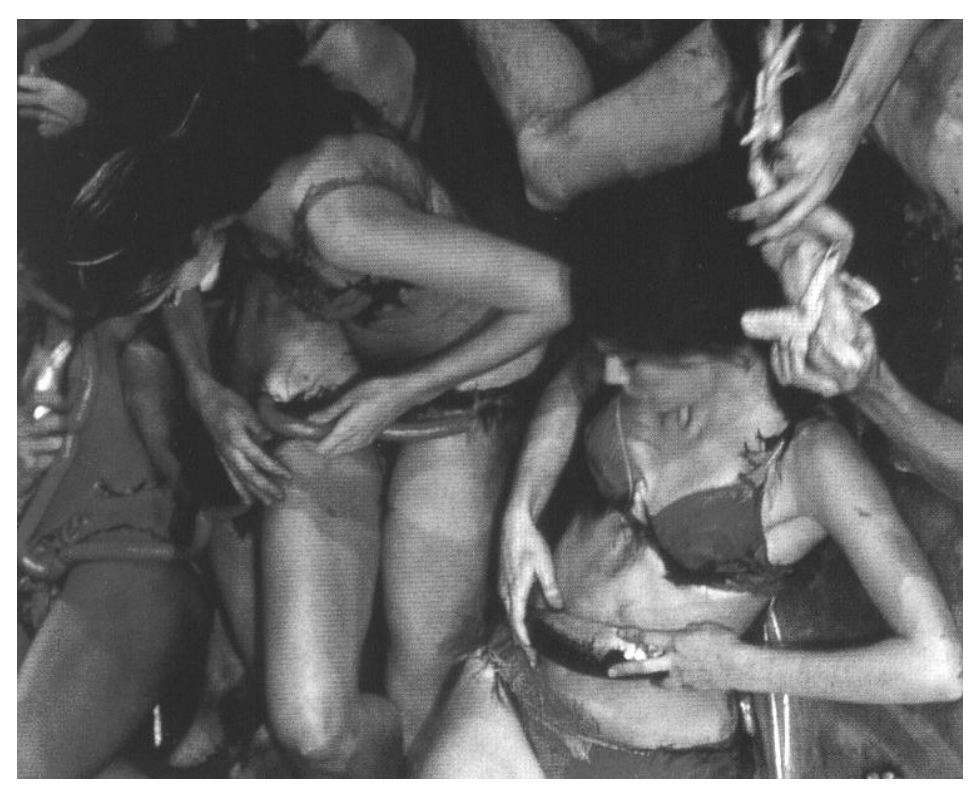

17. Carolee Schneemann - Meat Joy (1964)

El siguiente año, Schneemann se centró en denunciar los tabúes de la sensualidad humana. Ella describió uno de sus más célebres trabajos, Meat Joy (1964) — presentado en un festival de cine de mujeres en Chicago-, como una exuberante celebración sensorial de la carne. ${ }^{25}$ Para llegar a tal propósito introdujo en una coreografía materiales abyectos. Los y las participantes se frotaban desnudos, rodaban y bailaban en pilas repletas de trozos de papel mientras, gradualmente, eran añadidas otros elementos tales como pintura, pescados crudos, pollos y variadas salsas, resultando de ello

25 COTTINGHAM, Laura, "Are you esperienced? Le féminisme, l'art, et le corps politique”, en el catálogo de la exposición L’art au corps..., op. cit., p. 337. 
un erótico ritual de retorcidas masas, sensual y repelente al mismo tiempo. A través de toda una ceremonia para los sentidos, Meat Joy fue un experimento cuya finalidad se centraba en condenar los límites sociales impuestos a la sensualidad llegando a establecer relaciones desconocidas e impredecibles. $^{26}$

Schneemann fue muy consciente de los tabúes asociados al desnudo femenino, por esta razón, eligió exponerlo directamente como sujeto y objeto transgresor de las normas de género. De este modo, su obra se ha convertido en pancarta para otras mujeres en su lucha para reclamar sus cuerpos y sus identidades.

Por el contrario, la tendencia europea no sólo ansiaba documentar una situación, sino también influir en las personas. La legitimación de la agitación no era puramente artística, sino una representación social de su objetivo. Se tendía a una elaboración de patrones de comportamientos y modelos de acción socialmente relevantes, una búsqueda dirigida con más ahínco a la transformación de la conciencia del individuo y al derecho a una vida psíquica. El happening europeo sentía la necesidad de una instrumentalización transformadora de la realidad y de la reivindicación de la vida psíquica ahogada por las condiciones históricas. Toda posible transformación se filtra a través del redescubrimiento de la propia subjetividad.

En Europa las acciones realizadas no se limitaron a provocar neutralmente la activación de la conciencia perceptiva y creadora. Los y las artistas se preocuparon por instaurar una autoactividad que hiciera visible el contexto sociopolítico en sus determinantes y en sus posibilidades de cambio. Para ello introdujeron motivos que remitían a determinados acontecimientos. Los dos protagonistas principales de este comportamiento

\footnotetext{
${ }^{26}$ JONES, Leslie C., "Transgresive Feminity: Art and Gender in the Sixties and Seventies", en el catálogo de la exposición Abject Art. Repulsion and Desire in America Art, New York, Whitney Museum of American Art, 1993, pp. 50-51.
} 
fueron Wolf Vostell y Jean-Jaques Label, responsable este último de traer el happening a Europa. ${ }^{27}$

Wolf Vostell (Leverkusen, 1932 - Berlín, 1998) acuñó el término dé-coll/age que diferenció de la yuxtaposición creativa de elementos propia del collage tradicional mediante la traducción literal de la palabra francesa de la que derivaba: despegar, desprender, y destruir/morir. ${ }^{28} \mathrm{Su}$ experimentación le lleva a los décollage/happenings, con los que hacía alusión a motivos relacionados con fenómenos o acontecimientos sociales, presentes o pasados: accidentes de aviación o de automóviles, elementos de la publicidad, etcétera. El autor reconocía en todo momento la influencia ejercida sobre él por el dadaísmo de Colonia -Max Ernst, Richard Huelsenbeck, Kurt Schwitters o el teatro de la Bauhaus. El happening era para el autor un «proceso de aprendizaje», en el cual el artista era considerado como una «instancia moral». ${ }^{29}$

El trabajo de Vostell tiende a un desvelamiento crítico y consciente de las condiciones sociales - absurdas en ocasiones - que oprimen al ser humano. En sus acciones provocativas se destruían materiales hasta reducirlos a lo inservible, y su intención consistía en llevar a cabo dicha destrucción a la vida cotidiana. Desde los primeros años de la década de 1960, Vostell estuvo interesado en producir - mediante el shock provocado al público espectador - nuevos modos de comportamiento que hicieran reflexionar al público.

\footnotetext{
${ }^{27}$ FLECK, Robert, "Art as Rhizome”, en el catálogo de la exposición Jean-Jaques Lebel. Bilder, Skulpturen, Installationen, Wien, Museum Moderner Kunst Stiftung Ludwig Wien, 1998, p. 27.

${ }^{28}$ En 1954, en París, Vostell encontró por azar el concepto dé-coll/age leyendo un artículo en Le Figaro sobre un accidente de avión. El autor descubrió en su diccionario francésalemán el sentido ambiguo de esta palabra que reunía al mismo tiempo el término collage. GIROUD, Michel, "L’Épopée transmedia d'un utopien", en el catálogo de la exposición Wolf Vostell, Nîmes, Carré d'Art - Musée d'Art Contemporain de Nîmes, 2008, p. 13.

${ }^{29}$ MARCHÁN FIZ, Simón, op. cit., p. 200.
} 


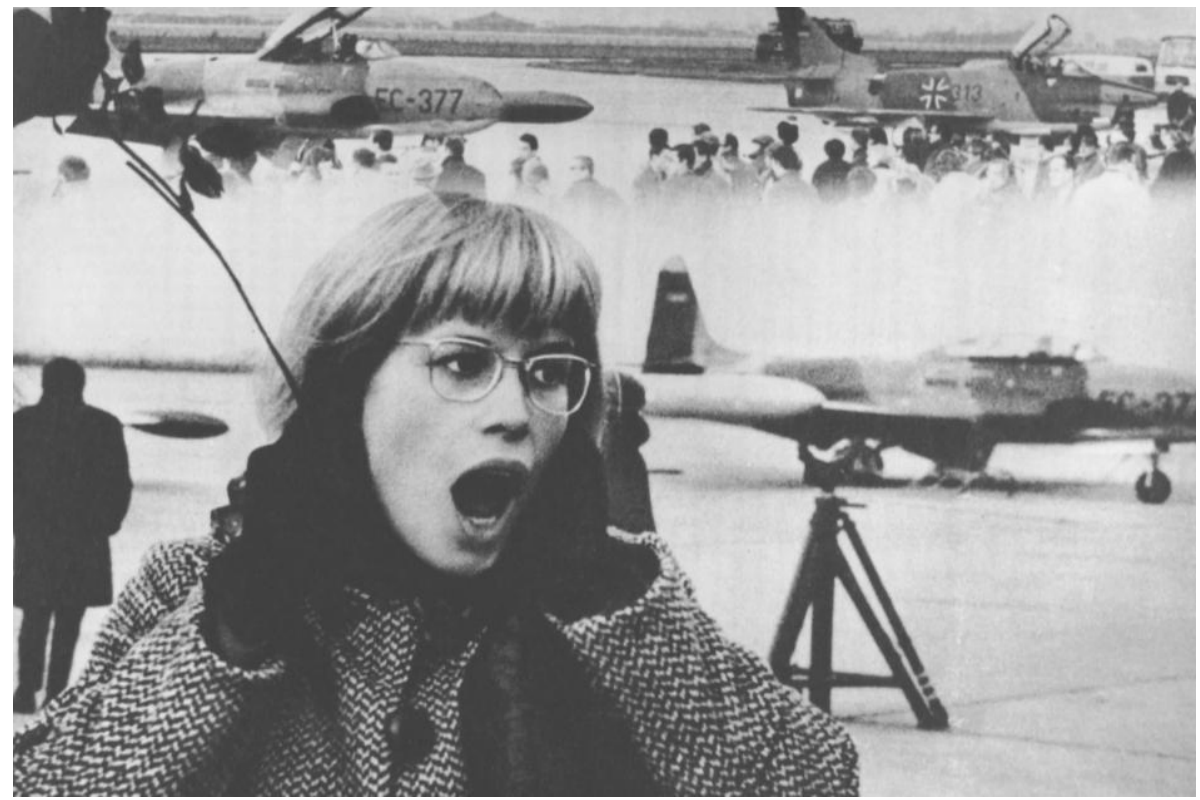

18. Wolf Vostell - Im UIm, um Ulm und Um UIm Herum (1964)

Así, por ejemplo, en Im Ulm, um Ulm und Um Ulm Herum (1964), unas trescientas personas fueron trasladas de un lugar de acción a otro emitiendo durante los trayectos las grabaciones de distintos textos publicitarios. Entre los lugares que se visitaron llama la atención un aeropuerto militar donde se asistió a un ensordecedor concierto de motores de tres cazarreactores, un lavado automático de coches donde un automóvil chocaba repetidamente contra trozos de carne, o un garaje subterráneo donde una serie de mujeres con cochecitos de niño paseaban ataviadas con máscaras de gas. El happening de Ulm es una recopilación y a la vez una conexión de las ideas anteriormente descubiertas por Vostell: confrontar lugar y contenido, declarar el sonido como música, establecer la analogía entre el arte y la vida, recuperar el contenido artístico como contenido sociológico o, conjugar el azar, la casualidad y el juego, entre otros elementos. $^{30}$

${ }^{30}$ AGÚNDEZ GARCÍA, José Antonio, op. cit., pp. 185-218. 


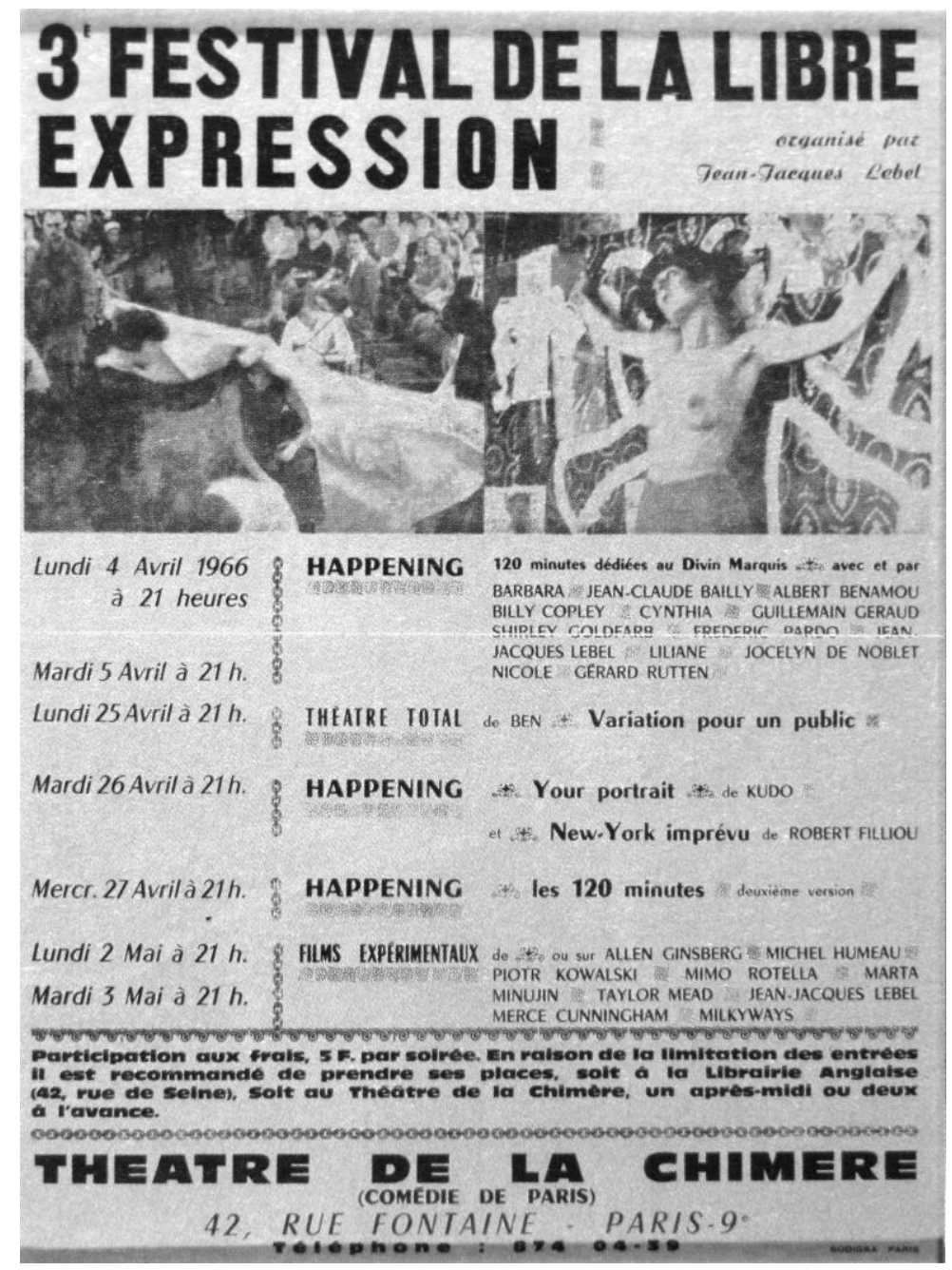

19. Cartel anunciador del III Festival de la libre expression (1966)

Por su parte, el imaginario de Jean-Jaques Lebel (París, 1936) estaba basado en redefiniciones del erotismo y su relación con la libertad del deseo, un pre-requisito para la libertad de la humanidad. Todos estos aspectos particulares de la formación intelectual de Lebel — debemos tener en cuenta que fue un poeta-pintor- se hicieron patentes en un festival que organizó el 
propio Lebel entre los años 1964 y 1967 -Festivals de la libre expression-, una verdadera conjunción de disciplinas. ${ }^{31}$

En 1966 Jean-Jaques Lebel presentó Cent vingt minutes au Divin Marquis, una obra performativa que concluyó tortuosamente tras la llegada de la policía. Respondiendo a la censura de la cual había sido objeto los libros de Sade que trataba de publicar Jean-Jaques Pauvert y de la presión eclesiástica contra la película de Rivette, Lebel, pionero del happening en Francia, organizó un espectáculo de considerables consecuencias. Más de mil personas acudieron al Théâtre de la Chimère de la rue Fontaine de París. En la oscuridad del teatro, el público se topó con unos pedazos de reses colgados con ganchos de carnicería que todavía derramaban gotas de sangre. Shirley Goldfarb, una expatriada americana que había trabajado con Warhol y gozaba de una magnífica voz de soprano, cantó a cappella los fragmentos más obscenos de Les 120 Journées de Sodome ou l'école du libertinage, mientras que otra participante, con el culo por fuera del piso principal y ataviada con una máscara del general De Gaulle, orinaba sobre el público situado debajo. ${ }^{32}$ Sin embargo, el momento de mayor intensidad se produjo con el striptease del transexual Cynthia. ${ }^{33}$ La curiosidad desbordante del público mostraba la ignorancia supina ante la realidad trans, que apenas empezaba a ser visible en un espacio social marcadamente machista y heterosexista como el francés. La posibilidad de vivir la experiencia

\footnotetext{
${ }^{31}$ Jean-Jaques Lebel creció entre artistas dadaístas y surrealistas. Además de heredar el surrealismo directamente de André Breton — quien jugó un papel primordial en su adolescencia-, su padre, Robert Lebel, fue el primer biógrafo de Marcel Duchamp. STILES, Kristine, "Uncorrupted Joy: International Art Actions", en el catálogo de la exposición Out of Actions..., op. cit., pp. 252-253. Véase también el catálogo Jean-Jaques Lebel. Bilder, Skulpturen, Installationen, op. cit.

${ }^{32}$ BLISTÈNE, Bernard, op. cit., p. 39.

${ }^{33}$ Como cuenta Lebel, Cynthia era una transexual muy seductora que trabajaba como bailarina desnuda en La Nouvelle Ève (cuyo dueño obligaba a ocultar sus genitales con esparadrapos) y, los fines de semana, como prostituta. Todo el mundo creía que era una mujer. Sólo soñaba con exhibirse tal como era en su totalidad, incluidos los genitales, y volver un día a su pueblo, en Serbia, a desvestirse completamente a la salida de misa y proclamar a todos los personajes importantes: ¡Aquí estoy! ¡He vuelto! Véase BLISTÈNE, Bernard, op. cit., p. 39.
} 
corporal en la que cohabitan órganos sexuales supuestamente incompatibles para el orden fálico normativo y la clase médica, fue una de las enseñanzas que destiló este happening, de tono mucho más transgresor que los que abundan en las formulaciones de Allan Kaprow. ${ }^{34}$

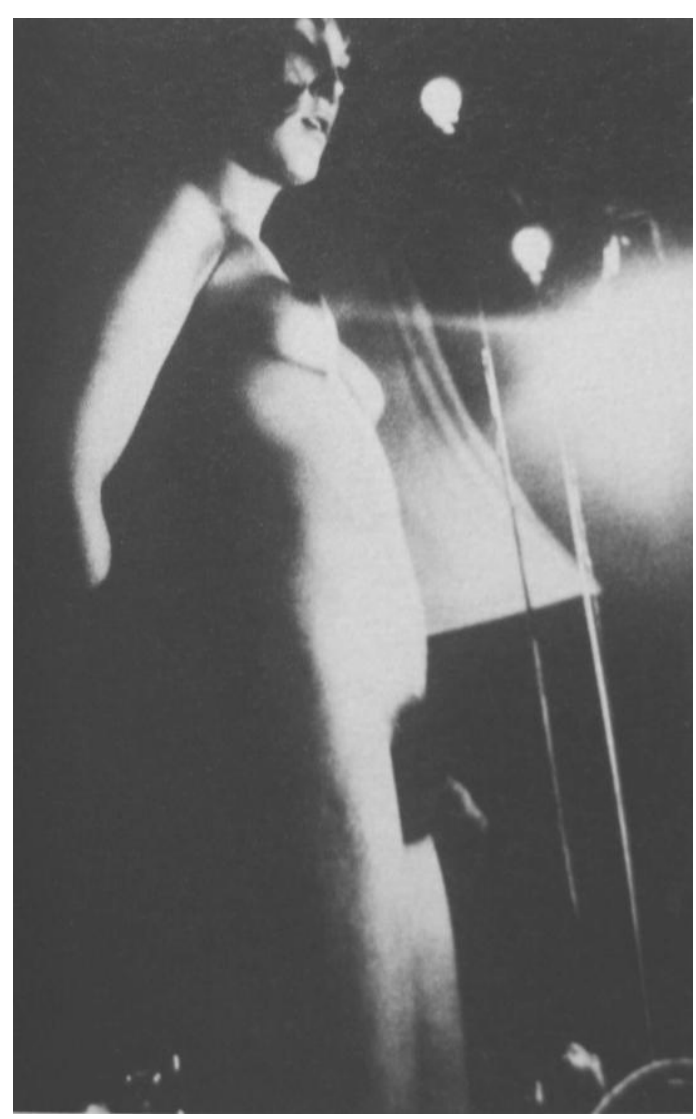

20. Jean-Jaques Lebel - Cent vingt minutes au Divin Marquis (1966)

Junto a ello, el happening ha representado otro de los intentos de romper con la mercantilización del producto artístico aislado, es decir, con el privilegio indiscriminado de especular con el valor de cambio. Su estructura abierta e indeterminada denuncia su inadecuación al marco

${ }^{34}$ ALIAGA, Juan Vicente, Orden fálico..., op. cit., p. 211. 
clásico de las instituciones. No obstante, su pretensión de potenciar el arte como acción consciente mantiene escasa relación social con el individuo. En este sentido, ha constituido con frecuencia un ámbito muy restringido al propio campo del arte, y ello a pesar de sus propuestas de integración artevida. Las acciones no sólo han estado aisladas estructuralmente entre sí, sino que lo han estado también de la realidad, al quedar reducidas al dominio reconocido del arte. Con todo, una de las afirmaciones más reiteradas desde este ámbito ha sido la integración y fusión del arte con la vida, apostando por la fluidez de sus fronteras e, incluso, por la desaparición de sus diferencias. El happening acentúa por ello la propuesta vitalista heredada de diversas vanguardias (Dadaísmo, Futurismo, Constructivismo y Surrealismo).

En paralelo, podemos considerar a Fluxus como un movimiento adscrito al arte de acción, aunque es cierto que, desde sus orígenes, ha estado más ligado a la música que a las artes plásticas. Su nombre insinuaba la fluidez entre los diversos medios que caracteriza la actividad artística de la época. La imprecisión comenzaba por el propio término, acuñado por Georges Maciunas (Kaunas, 1931 - Boston, 1978) en 1961 como título de una revista que tenía que publicar obras de artistas, escritores y músicos experimentales, aunque pronto fue adoptado para abarcar un amplio abanico de actividades. En los primeros manifiestos, Maciunas partía de la definición que daba el diccionario a la palabra latina flux: «Acción de fluir: movimiento o paso incesante, como el de un fluido; sucesión continua de cambios». 35

Sin embargo, según afirma Jean-Jaques Lebel, el grupo apareció en junio de $1962,{ }^{36}$ es decir, cuatro o cinco años después de los primeros happenings, posteriormente a que Maciunas participara en la velada

${ }^{35}$ F. SMITH, Owen, "Fluxus: una breu història i altres ficcions", en el catálogo de la exposición En l'esperit de Fluxus, Barcelona, Fundació Antoni Tàpies - Walker Art Center, 1994, p. 16.

${ }^{36}$ En algunas publicaciones, aunque se hable de proto-Fluxus, se puede encontrar como año de inicio 1958. 
organizada en la Galería Parnass de Rolf Jährling titulada Después de John Cage. Allí leyó su manifiesto Neo-Dada in Music, Theater, Poetry, Art, antes de participar, por invitación de Nam June Paik, en la reunión NeoDada in der Musik y organizar, en septiembre, el festival Fluxus de Wiesbaden. ${ }^{37}$

La historia de Fluxus es compleja y su estética y filosofía difíciles de definir, ya que los y las artistas del grupo ni siquiera se consideraban como tales. Tampoco se veían a sí mismos o a sí mismas como creadores de un estilo específico, sino como partidarios de una actitud alternativa respecto al arte, la cultura y la vida. ${ }^{38}$ Para incrementar la ambigüedad de sus trabajos y objetivos, Fluxus experimentó un proceso evolutivo y de cambio continuo. René Block define «Fluxus as state of mind, as a mental attitude». ${ }^{39}$

Con la intención de retomar aquel espíritu Dadá, Fluxus, tanto en París como en Nueva York, Japón y Alemania, intentó combinar diferentes medios de expresión. Dentro de su contexto interdisciplinar supuso un alivio ante la presión consumista del mercado del arte, proponiendo actividades performativas de índole lúdica, provisional y efímera. Fluxus se concentra sobre todo en la vivencia de un acontecimiento que discurre de un modo improvisado, recurriendo a acciones muy simples cargadas de un humor agudo y descaradamente literales: en Word Event, de George Brecht, la palabra Exit estaba fijada dentro del espacio de la performance; en Counting Songs, de Emmett Williams, se contaba al público de diversas maneras; y en

\footnotetext{
${ }^{37}$ Maciunas, enfermizamente envidioso de Kaprow, intentó falsear la cronología para negar la importancia fundadora y la anterioridad de los happenings. BLISTÈNE, Bernard, op. cit., p. 38 .

${ }_{38}$ PICAZO, Glòria, "La performance: de las primeras acciones a los multimedia de los ochenta", en PICAZO, Glòria (coord.), Estudios sobre performance, Sevilla, Centro Andaluz de Teatro, 1993, pp. 17-18.

${ }^{39}$ BLOCK, René y BERGER, Tobias, "What Is Fluxus", en el catálogo de la exposición What's Fluxus? What's Not! Why., Brasilia - Rio de Janeiro, Centro Cultural Banco do Brasil, 2002, p. 38.
} 
2 inches, de Robert Watts, se desplegaba una cinta de punta a punta del escenario que después era cortada. ${ }^{40}$

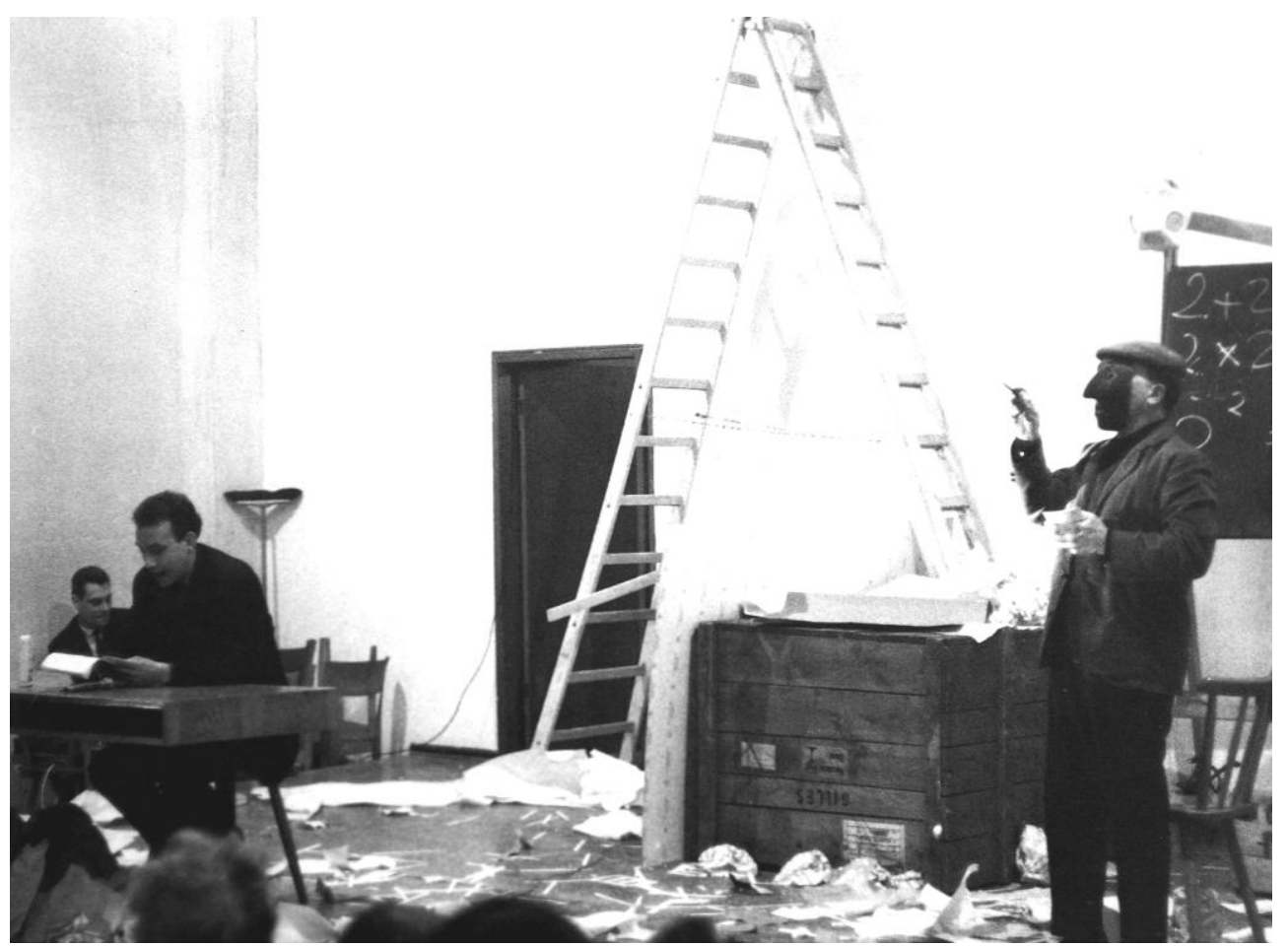

21. Emmet Williams - Counting Songs (1963)

De diversos actos y declaraciones de Maciunas se pueden extraer algunos de los objetivos del grupo, los cuales no son estéticos sino sociales, implicando la eliminación de las Bellas Artes para utilizar sus características como fines sociales constructivos. Fluxus era una forma de antiarte que se alzaba contra la práctica profesional del arte y contra la separación artificial entre productor y espectador, es decir, entre arte y vida. Se posicionaba en contra del objeto artístico tradicional como mercancía falta de función y contra el arte como artículo comercial. La supresión del aura, en una línea duchampiana, se llevaba a cabo mediante la transformación de todo lo no

${ }^{40}$ F. SMITH, Owen, op. cit., p. 28. 
artístico en artístico, a través del cultivo del antiarte: un estornudo, un chaparrón, el canto de un pájaro. ${ }^{41}$

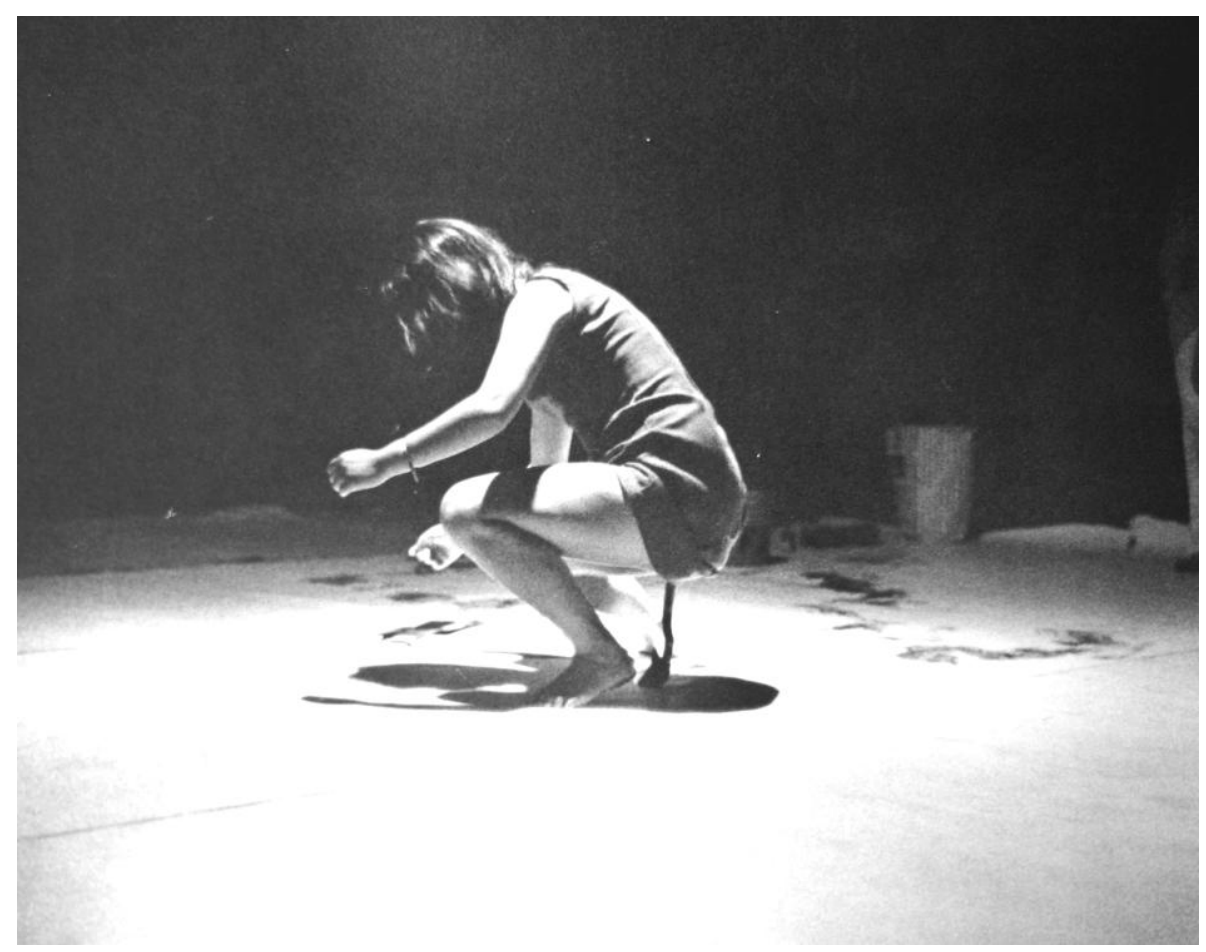

22. Shigeko Kubota - Vagina Painting (1965)

En los casos más radicales como el de Henry Flynt, Fluxus culminó en un nihilismo plástico que rechazó toda actividad artística y creativa. En este gesto de negación total del objeto artístico fue más allá de cualquier otra propuesta posterior, incluidas las conceptuales. Paralelamente, se plantearon diversas cuestiones vinculadas al género y a la sexualidad, a menudo tan olvidadas en las artes visuales. Estas cuestiones surgieron de las experiencias personales y sociales directas de los y las artistas pero, al mismo tiempo, reflejaban el incipiente movimiento feminista, la revolución sexual de los años sesenta y la mayoría de movimientos a favor de los derechos civiles. En las performances de las mujeres japonesas vinculadas a

${ }^{41}$ MARCHÁN FIZ, Simón, op. cit., p. 207. 
Fluxus, a menudo aparecen fuertes elementos protofeministas y, en el caso de Yoko Ono, entrelazados frecuentemente con comentarios sobre raza y clase. A pesar de que los artistas Fluxus no siempre aceptaban plenamente estos contenidos en el contexto de sus acciones - Shigeko Kubota recuerda que sus colegas odiaban Vagina Painting (1965)—, nadie podía negar su existencia. $^{42}$

Fluxus nos desafía a contemplar con nuestros propios ojos la Historia del Arte del siglo XX, sobre todo por lo que respecta a las raíces de la innovación artística. Examinar sus pretensiones obliga a replantearse cuestiones perennes sobre la naturaleza de la búsqueda artística, la relación entre arte y sociedad y el papel de la innovación dentro de la evolución del ser humano.

\subsubsection{Man-made. Yves Klein, Piero Manzoni y Joseph Beuys}

La breve aproximación que realizaremos a continuación corresponde a los primeros autores en presentar y utilizar el man-made, es decir, el cuerpo como obra de arte. Su trabajo, grosso modo, se encuentra a medio camino entre la tradición informalista y una clara re-introducción del cuerpo en sus representaciones artísticas. En las siguientes páginas veremos como el cuerpo alcanzará un evidente auge gracias a su uso en las performances de la década de 1970 .

El francés Yves Klein (Niza, 1928 - París, 1962) utilizó el cuerpo como receptor de energía espiritual al igual que — según el artista — lo eran también el vacío y otro tipo de materiales y objetos, especialmente aquellos que pintaba con su bautizado International Klein Blue (IKB), un intenso azul ultramar.

${ }^{42}$ STILES, Kristine, "Entre l'aigua i la pedra", en el catálogo de la exposición En l'esperit de Fluxus, op. cit., p. 77. 
De la misma manera que su amigo Daniel Spoerri (Galați, 1930), quien fue bailarín y daba clases de danza antes de dedicar sus energías a la creación plástica, Klein era un experto yudoca que acabó aplicando sus saberes a la creación plástica. No era tanto el componente marcial del yudo lo que cautivó al autor, sino más bien el dominio de las relaciones energéticas en el espacio y la explotación simultánea de lo físico y lo mental. Klein realizó una conexión directa entre sus monocromos y sus pinturas con el cuerpo y el yudo. Estas representaciones artísticas manifiestan el concepto inherente al arte marcial según el cual el cuerpo es un centro de energía física, sensorial y espiritual y su poder reside en la liberación disciplinada de su energía al exterior. Asimismo, existe en su obra cierta evocación de las tenues huellas del cuerpo que dejan los yudocas en la estera del tatami después de haber sido derribados. Klein había sido muy sensible a este tipo de imágenes desde el comienzo mismo de su afición al yudo y, justo después de haber dejado de enseñar y practicar, las convirtió en el centro de su trabajo. ${ }^{43}$

$\mathrm{Su}$ obsesión por la esencia inmaterial del arte y por el vacío - en ocasiones puso en venta «zonas de vacío» y porciones de «sensibilidad inmaterial» a cambio de un mínimo de veinte gramos de oro- forjada sin duda en las teorías de Gaston Bachelard, ${ }^{44}$ tuvo su manifestación más espectacular en la acción Le peintre de l'espace se jette dans le vide! u Obssesion de la lévitation (1960), en la que el cuerpo del artista, saltando desde lo alto de un muro de la calle Gentil Bernard se convertía en una escultura del espacio-nada, entendido éste como zona de sensibilidad pictórica inmaterial. ${ }^{45}$ No registraba la verdad, aunque podría haberlo sido,

\footnotetext{
${ }^{43}$ ARNALDO, Javier, Yves Klein, Madrid, Nerea, 2000, p. 9.

44 Pierre Restany dedica un libro en el cual se evidencia la relación de Klein con el inclasificable Bachelard. RESTANY, Pierre, Yves Klein. Fire at the Heart of the Void, North Haven, Journal of Contemporary Art, 1992.

${ }^{45}$ No son pocas las voces que especulan acerca de la influencia que aquel "salto al vacío" tuvo en otros y otras artistas. Tanto la muerte de Schwarzkogler como la de Ana Mendieta han girado - y giran hoy día - en torno a la poética y morbosa idea del suicidio como última acción.
} 
el autor había realizado asombrosos saltos desde alturas de hasta siete metros.

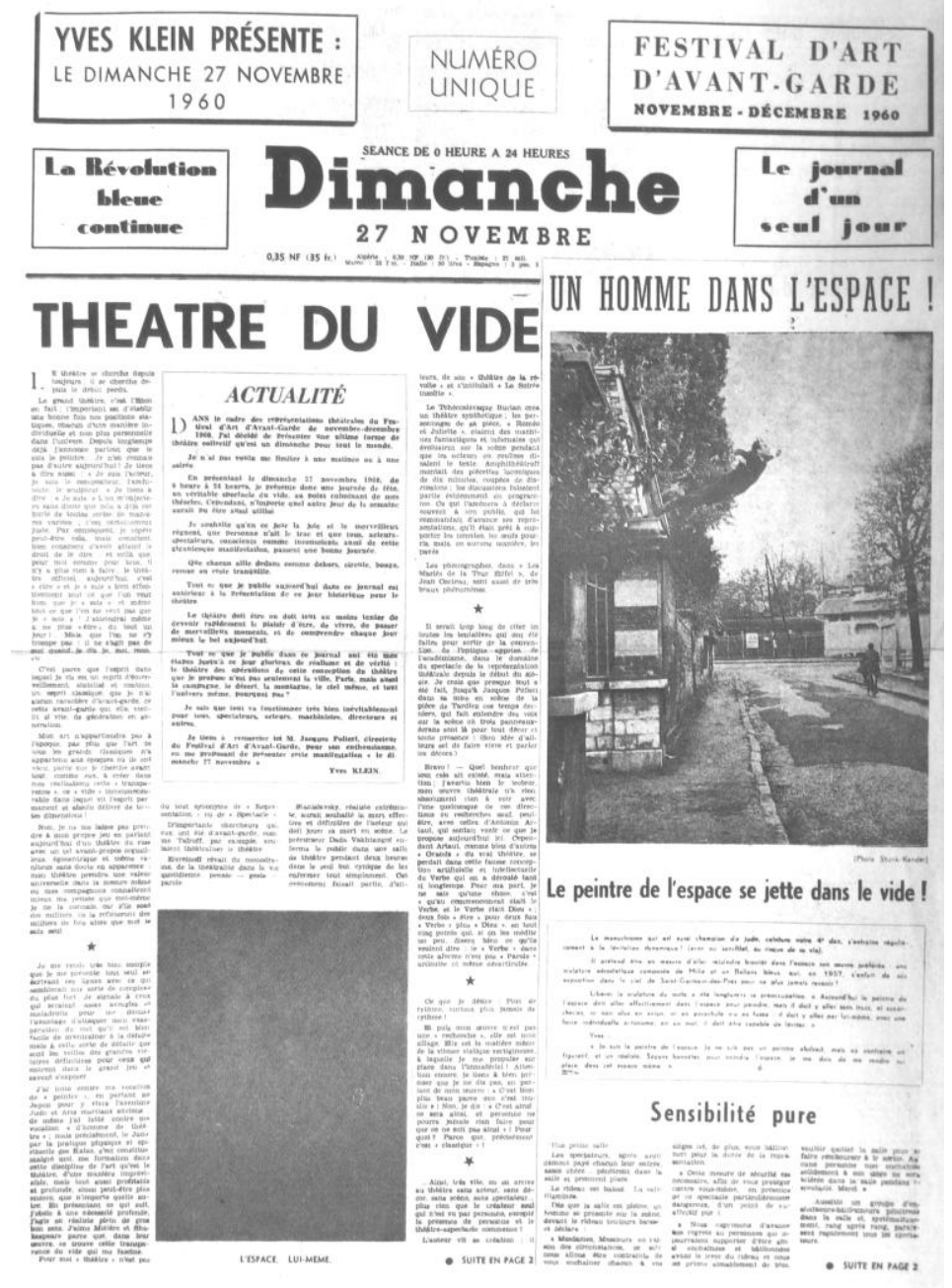

23. Yves Klein - Dimanche, le journal d'un seul jour (1960)

La ilustración correspondía a un documento visual que aparecía en el único número del periódico Dimanche, el «periódico de un sólo día», publicado por él mismo el 27 de noviembre de 1960 en el marco de las 
representaciones teatrales del Festival d'Art d'Avant-Garde. ${ }^{46}$ El formato coincidía con el de la edición dominical de France-Soir, conocido popularmente como Journal du Dimanche, aunque éste no tenía más que cuatro páginas. Indudablemente, la imagen tuvo un gran impacto entre los accionistas vieneses que trabajaban arriesgadamente con el cuerpo, y en buena parte de la obra performativa corporal de los años setenta, en especial de Gina Pane y Chris Burden. ${ }^{47}$

Yves Klein acababa de finalizar su gran encargo para Gelsenkirchen, ${ }^{48}$ su estudio estaba vacío, y sentía la necesidad de iniciar un nuevo tipo de trabajo. Había desarrollado el hábito de tener modelos desnudas en su espacio de trabajo debido a que sentía que creaban un clima sensual que estabilizaba sus monocromos. ${ }^{49}$ Este peculiar entendimiento del cuerpo le llevó a las «antropometrías» (pinturas corporales), término acuñado por Pierre Restany (París, 1930-2003), que consistían en la realización de pinturas con pinceles vivientes sirviéndose del cuerpo de mujeres desnudas embadurnadas de color para hacer el cuadro.

La modelo actuaba directamente sobre el soporte, imprimiendo con limpieza la huella del pecho, el abdomen y los muslos frente a frente con el papel o bien extendiendo el color con todo el cuerpo, moviéndose o revolcándose sobre la superficie situada sobre el suelo.

\footnotetext{
${ }^{46}$ «En présentant le dimanche 27 novembre 1960, de 0 heure à 24 heures, je présente donc une journée de fête, un véritable spectacle du vide, au point culminant de mes théories. Cependant, n'importe quel autre jour de la semaine aurait pu être aussi utilisé». KLEIN, Yves, Le dépassement de la problématique de l'art et autres écrits, Paris, École Nationale Supérieure des Beaux-Arts, 2003, pp. 174-175.

${ }^{47}$ ARNALDO, Javier, op. cit., p. 56.

${ }^{48}$ El consistorio de Gelsenkirchen encargó a Werner Ruhnau un teatro de ópera en el centro de la ciudad, éste colaboró — en lo que respectaba a la decoración artística del edificiocon jóvenes artistas cuyas innovaciones le interesaban especialmente. Su aprecio por la obra de Klein desembocó en un proyecto de trabajo en común. Es interesante revisar las reflexiones personales del artista sobre esta labor en KLEIN, Yves, op. cit., pp. 71-78.

${ }^{49}$ STICH, Sidra, "Pinturas antropométricas", en el catálogo de la exposición Yves Klein, Madrid, Museo Nacional Centro de Arte Reina Sofía, 1995, p. 171.
} 


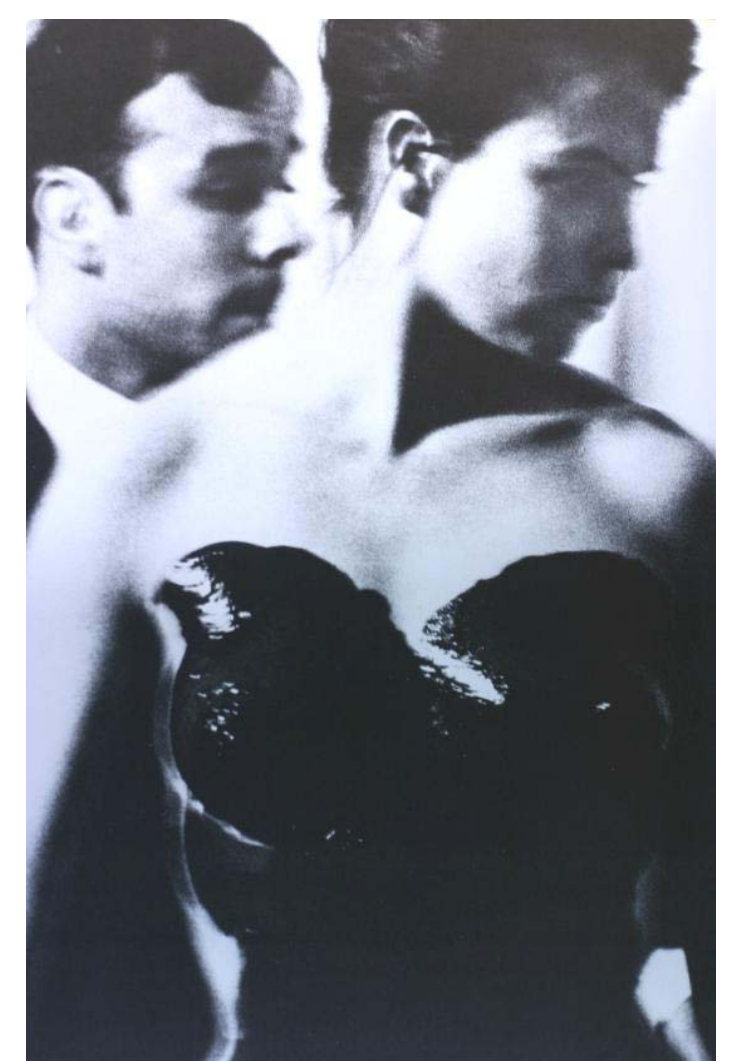

24. Yves Klein - Anthropometry of the Blue Epoch (1960)

Los inicios de estas prácticas se remontan al encuentro fortuito con un libro de brujería que advertía de los mágicos poderes de la sangre menstrual. Klein —eligiendo el momento apropiado del mes- pagó los servicios de una prostituta de Montmartre con el fin de ejecutar las «antropometrías» con su propia sangre. La joven, ya embadurnada con su flujo menstrual, se negó a realizarla en el momento de comenzar la impresión. Después de todo, el pánico a la desgracia era lógico ya que a la obra fue atribuida - según el pensamiento mágico que indicaba en las páginas del manual - una perturbación cósmica a causa de la transgresión de lo prohibido. Tras el abandono de su primera femme-pinceau, Klein decidió realizar sus impresiones con su modelo habitual mediante sangre de vaca, sin embargo, a cierta distancia de allí, el autor se enteró de que una 
joven japonesa se tiró de lo alto de un tejado sobre una tela blanca con el fin de dejar su huella. Temiendo que sus sangrantes «antropometrías» tuvieran alguna relación y con el fin de eximir toda culpa, Klein destruyó con ayuda del fuego estos trabajos en el curso de una ceremonia nocturna de la que Pierre Restany fue testigo. ${ }^{50}$

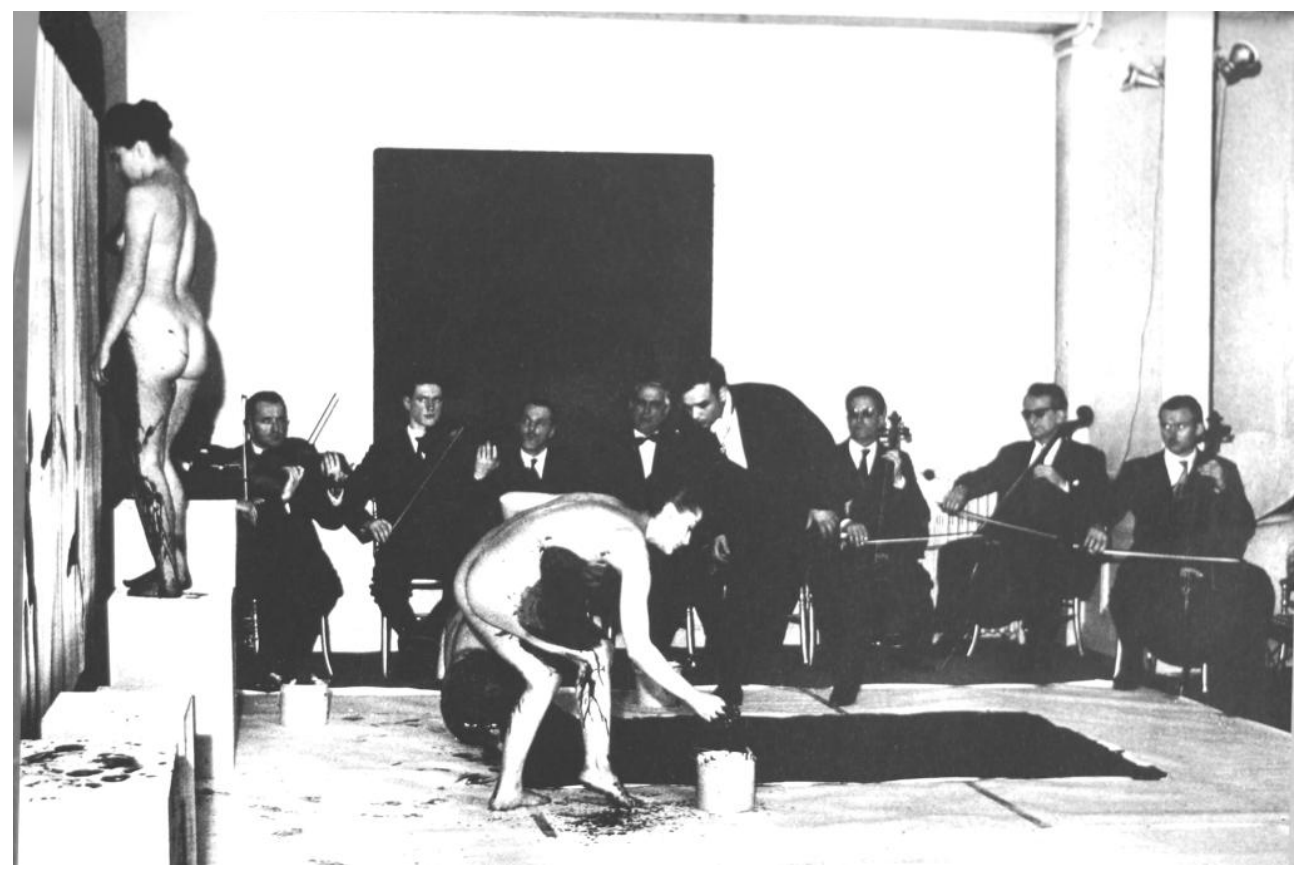

25. Yves Klein - Anthropometry of the Blue Epoch (1960)

El 9 de marzo de 1960, en la Galerie Internationale d'Art Contemporain de París, el artista, enfundado en un esmoquin, con corbata blanca y la Cruz de Malta de la Hermandad de San Sebastián dirigió, erguido e inmaculado, la Symphonie Monotone que él mismo había compuesto y que constaba de un ciclo de veinte minutos con una sola nota musical y veinte minutos de silencio — claramente influenciado por John Cage. Sólo se invitó a unos cien asistentes, entre ellos algunos artistas y críticos, pero en su mayoría, dueños de galerías, una élite social que se

50 PABST, Angelica, "Dans les règles de l'art", en el catálogo de la exposición Fémininmasculin. Le sexe de l'art, Paris, Centre Georges Pompidou, 1996, p. 355. 
reunía habitualmente en presentaciones culturales. Hojas de papel en blanco cubrían el suelo del escenario y una larga sábana colgaba de la pared del fondo, mientras tanto, la sinfonía contrastaba con la presencia de tres modelos desnudas y cubiertas también de IKB que refregaban su cuerpo, a modo de pincel humano, sobre grandes tiras de papel dispuestas en el suelo y en la pared frontal. ${ }^{51}$

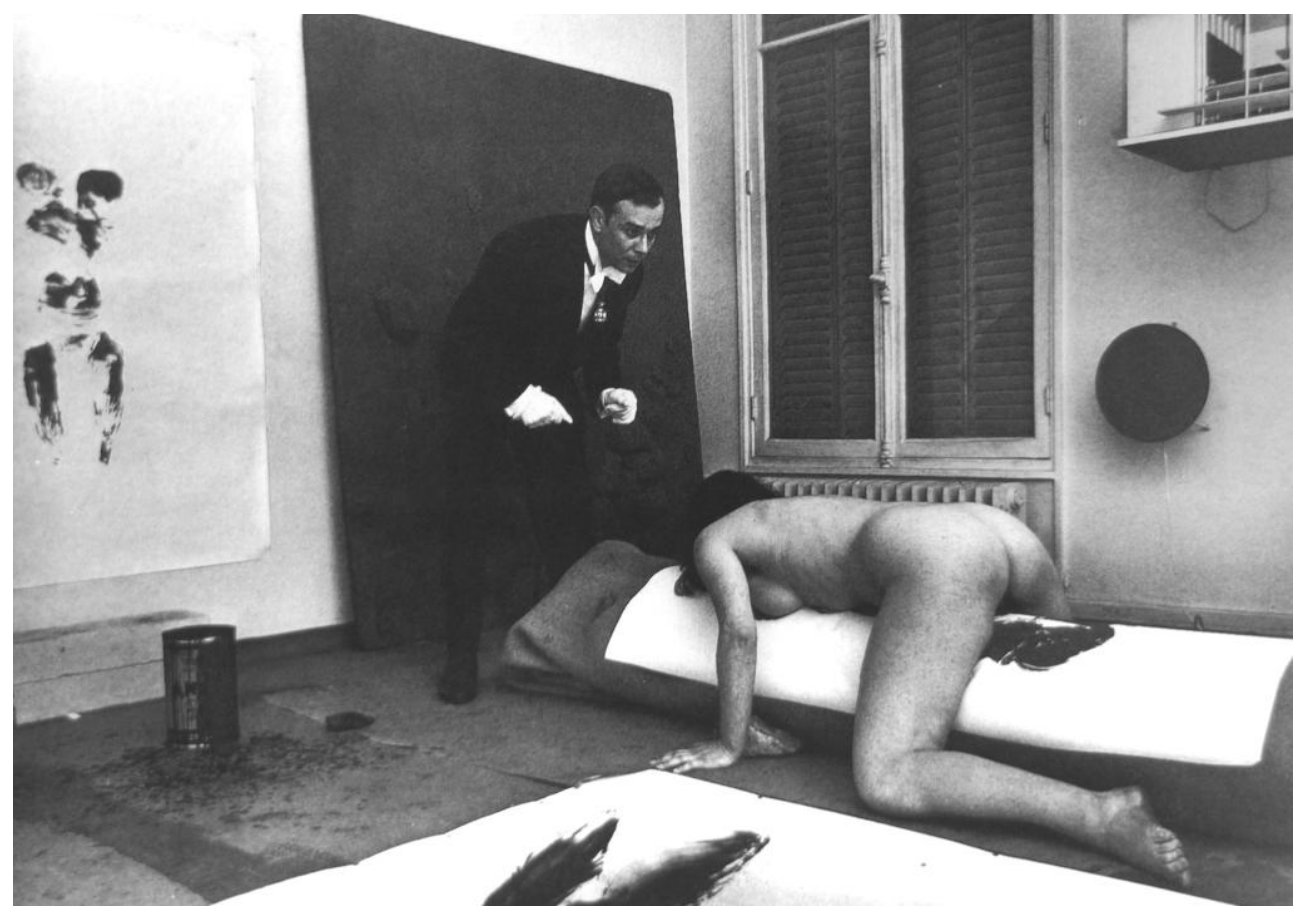

26. Yves Klein - Anthropometry of the Blue Epoch (1960)

El trabajo de Klein con las antropometrías no concluyó con aquella acción única en la Galerie Internationale d'Art Contemporain. Mediante el mismo procedimiento realizó muchas otras obras en su taller, aunque introdujo algunas variantes, como la de colocar el soporte sobre un apoyo cilíndrico — no en la pared - sobre el que se situaba la modelo a horcajadas, de modo que, al abrazarlo, pudiera dejar la huella del torso y de los muslos, con las piernas más abiertas de lo que es posible hacerlo con el cuerpo

${ }^{51}$ STICH, Sidra, op. cit., pp. 173-174. 
erguido. Son éstas las pinturas donde más explícitas resultan las connotaciones sexuales de la obra. También realizó impresiones polícromas utilizando pintura azul, rosa, roja, negra y dorada sobre tejido arrugado, éstas fueron designadas como suaires. ${ }^{52}$

Una de las impresiones con diferentes valores semánticos a las 149 antropometrías registradas por Klein, es el cuadro Hiroshima (1961), una pintura de casi tres metros de largo en la que aparecen varias siluetas de cuerpos enteros en negativo, en posiciones muy variadas, captadas como instantes de movimientos. La referencia a Japón en el título es una alusión a la tragedia de la Segunda Guerra Mundial y, más en concreto, a la impresionante piedra hallada en Hiroshima que contiene la imagen de un hombre cuya silueta abrasada fue grabada sobre su superficie por la deflagración atómica. Klein observó esta piedra cuando estuvo en Japón en 1953 , sintiéndose profundamente conmovido por ella. ${ }^{53}$

Cabría preguntarse por qué eligió a unas mujeres desnudas a las que remuneró para disponer de ellas como instrumento de creación. Gran parte de las respuestas de la crítica omiten este tipo de componentes. En este sentido, no hay que olvidar el hecho de que, por infrecuente que fuera, en un país todavía católico como Francia, predominaba una mentalidad social que hacía comprensible y aceptable que algunas mujeres se desnudasen en público y alquilasen sus servicios, fuesen o no prostitutas; en cambio, un hombre siempre iba a actuar como cliente y nunca como modelo. En ningún momento se planteó la posibilidad de que los peleles de la acción propuesta por Klein fueran varones o que él mismo se embadurnase de pintura.

Tal y como plantea Juan Vicente Aliaga, nos encontramos ante una propuesta a medio camino entre el énfasis dejado por la marca viril en la pintura informal, compulsiva y enérgica de Pollock y la reintroducción de la

${ }^{52}$ MORINEAU, Camille, "De l'imprégnation à l'empreinte, de l'artiste au modèle, de la couleur à son incarnation", en el catálogo de la exposición Yves Klein. Corps, couleur, immatériel, Paris, Centre Pompidou, 2006, pp. 120-129.

${ }^{53}$ STICH, Sidra, op. cit., p. 179. 
corporalidad en el espacio de la producción artística que llegaría a su auge, con un propósito cuestionador del machismo, en la performance feminista de la década de $1970 .{ }^{54}$ Klein prosigue con la inagotable tradición representativa del arquetipo de la femme-peinture según cierta visión masculinista cargada de misoginia: amenazadora, agresiva, peligrosa y al mismo tiempo seductora y fecunda. Recordemos las coléricas salpicaduras de las Women de Willem De Kooning, las telas rasgadas de Lucio Fontana o, retrocediendo unos años, las Demoiselles d'Avignon de Picasso.

Junto a Yves Klein, uno de los primeros artistas plásticos en presentar y utilizar el man-made - el cuerpo como obra de arte- fue el italiano Piero Manzoni (Soncino, 1934 - Milán, 1963). Al igual que en toda Europa, entre finales de 1950 y principios de 1960, se vivía en Italia momentos de agitación. El boom económico, la inmigración, un incontrolable éxodo rural y la congestión de las áreas metropolitanas, entre otros factores, acarrearon ciertas agitaciones sociales, abriendo una brecha en la ideología norteamericana del life-style. Los nuevos mass media, la explosión de la TV, el cine en color o, con posterioridad, el vídeo desencadenaron una extensión sensorial, activando y envolviendo todos nuestros sentidos y reconduciendo un cuerpo que se escindía poco a poco de la mente. Es más que probable que fueran el nihilismo y la aniquilación del sujeto las palabras clave de la época. Esto se revela, por ejemplo, en la literatura beat americana, la cual mezcla éxtasis y anarquía, misticismo y revuelta. ${ }^{55}$ Éstas son las básicas asunciones en las que Piero Manzoni fue injertado, celebrando el final de los grandes valores de la vieja cultura.

Así como Klein había considerado la pintura como una prisión de la cual los monocromos lo liberarían, Manzoni veía la pintura como una zona de libertad en la cual buscaba nuestras imágenes más primarias. Sus representaciones, totalmente blancas — Ácromos - pretendían generar una

\footnotetext{
${ }^{54}$ ALIAGA, Juan Vicente, op. cit., p. 200.

55 Entre las principales obras literarias de la Beat Generation figuran Aullido de Allen Ginsberg (1956), En el camino de Jack Kerouac (1957) o Almuerzo desnudo de William S. Burroughs (1959).
} 
superficie nívea más allá de todas las formas de fenómeno pictórico y/o de cualquier intervención extraña sobre el valor de la superficie. 1959 es el año en el que Manzoni abandona definitivamente el Gruppo Nucleare - período al cual pertenecen sus primeros trabajos, basados en imágenes elementales y primarias cargadas de cierto misticismo- y rompe las relaciones teóricas y artísticas con Castellani y Agnetti, quienes representaban en aquel momento el purismo extremo de la búsqueda de lo que denominaban concretismo visual. Manzoni se embarca en una línea de búsqueda hacia la producción de trabajos conceptuales que le identifican como uno de los precursores de los movimientos contemporáneos. En abril de 1959, ya planea firmar cuerpos de personas vivas proporcionándoles un certificado de autenticidad. Estos proyectos acompañan la idea de encerrar cadáveres en paralelepípedos de plástico transparente. ${ }^{56}$

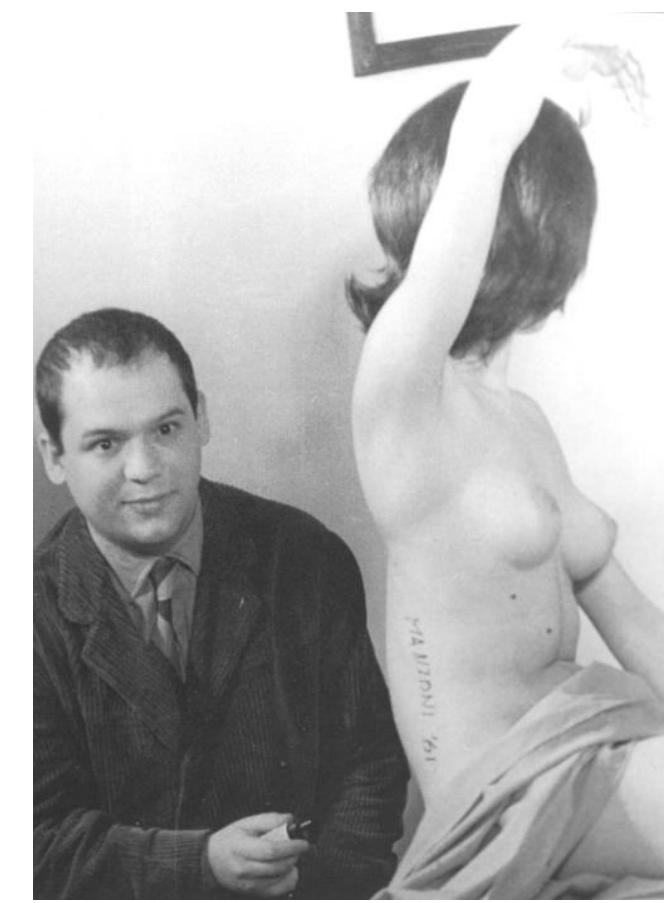

27. Piero Manzoni - Escultura viviente (1961)

56 CELANT, Germano, "Piero Manzoni, un artista del presente", en el catálogo de la exposición Piero Manzoni, Madrid, Fundación “la Caixa”, 1991, p. 16. 
Piero Manzoni convirtió el cuerpo del artista en una especie de factoría ready-made. A su vez, realizó Esculturas vivientes (1961) en las que cualquier individuo podía convertirse en obra de arte sólo con que su cuerpo fuese firmado por el artista. Una firma roja le confería el carácter o el certificado de autenticidad de obra de arte total hasta su muerte; una firma amarilla únicamente confería naturaleza de obra de arte a la parte del cuerpo firmada; verde implicaba condiciones al gesto escultórico del cuerpo según las cuales éste era arte sólo en determinadas posiciones y/o actividades; finalmente púrpura, que adquiría las mismas licencias que el color rojo, pero indicaba que el servicio había sido remunerado. ${ }^{57}$

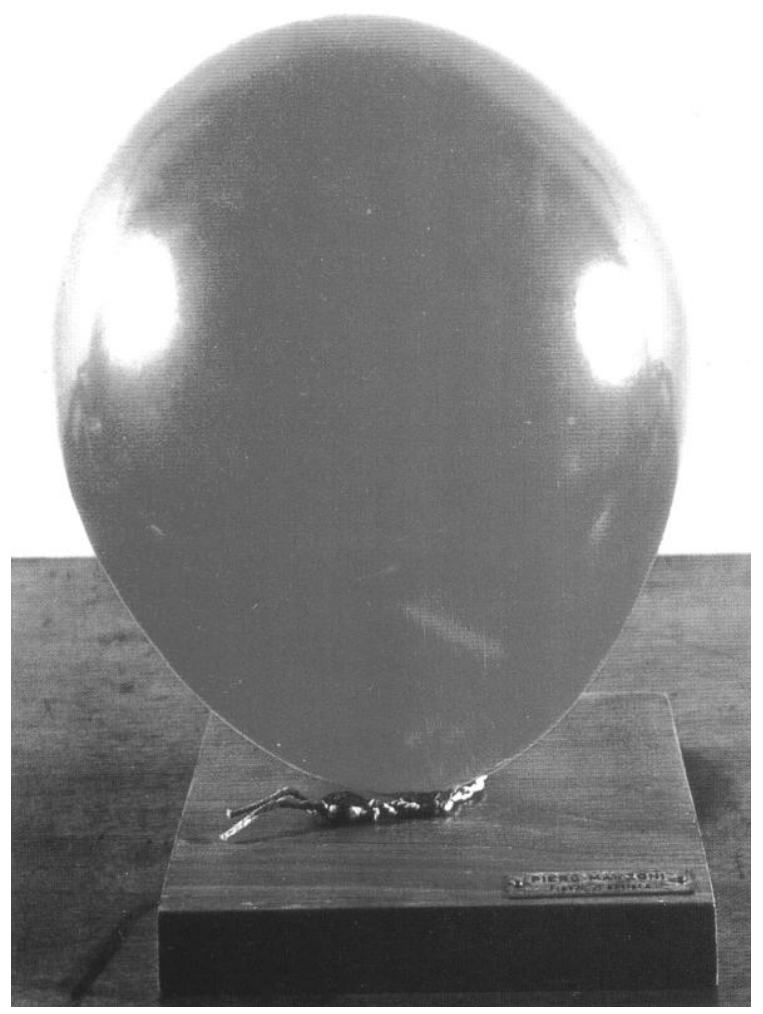

28. Piero Manzoni - Fiato d'artista (1960)

57 CELANT, Germano, "Piero Manzoni: The Body Infinite", en el catálogo de la exposición Piero Manzoni, Londres, Serpentine Gallery - Charta, 1998, p. 32. 
Pero el mundo - al igual que cualquier individuo - también podía ser declarado obra de arte. En Base del mundo (1961) colocaba, metafóricamente, el mundo sobre un pedestal. La producción material del artista fue igualmente importante en la ecuación arte-vida. Primero hizo cuarenta y cinco Corpi d'aria (1959-60): globos llenos de aire y vendidos por treinta mil liras. Los globos no inflados eran empaquetados en cajitas de lápices junto con un pequeño trípode que serviría de pie de exposición para estos cuando se inflaran. Al igual que Escultura viva, eran valorados de manera diversa: el comprador que lo deseara podía adquirir un globo inflado por el propio previo pago de doscientas liras el litro. Sólo en este caso, la obra era re-titulada como Fiato d'artista. ${ }^{58}$

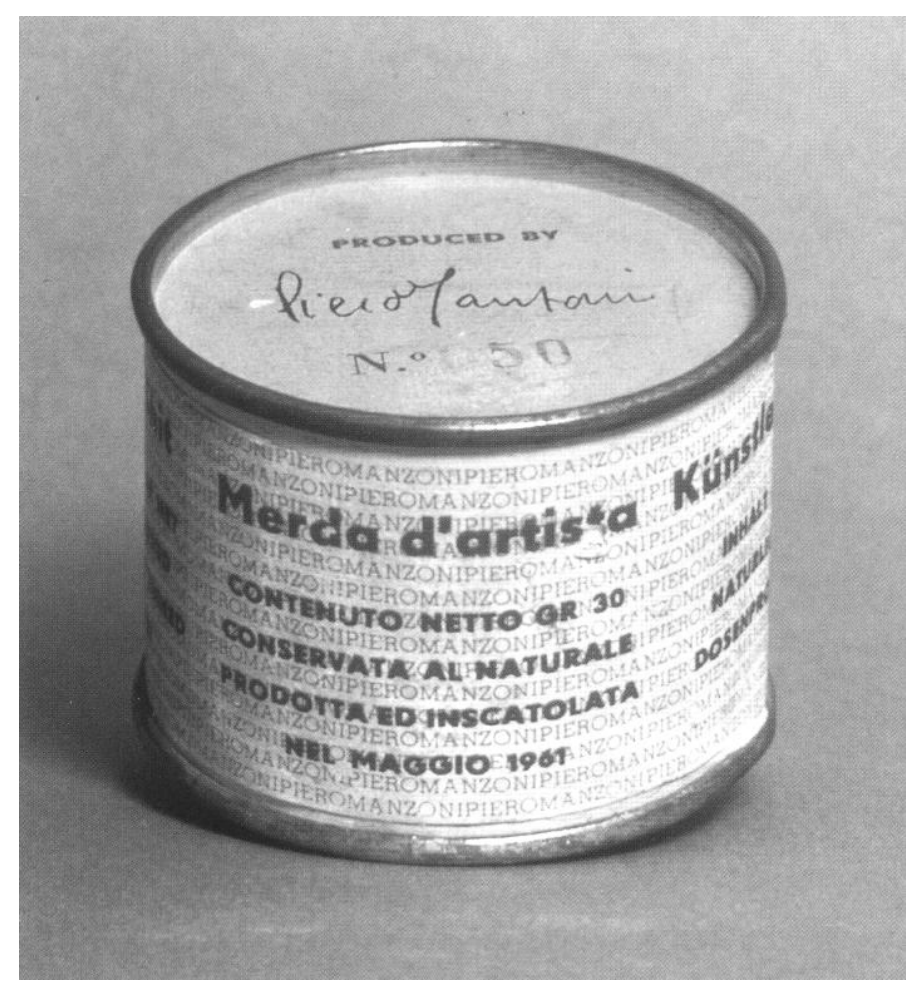

29. Piero Manzoni - Merda d'artista (1961)

\footnotetext{
${ }^{58}$ SCHIMMEL, Paul, "Leap into the void: Performance and the object", en el catálogo de la exposición Out of Actions..., op. cit., p. 47.
} 
Piero Manzoni trasladó esta dimensión performativa a otro tipo de producciones como fue su Base magica, que presentó por primera vez en la Galleria la Tartaruga de Roma en 1961. Estas bases constaban de un pedestal sobre el cual se habían fijado dos pisadas de fieltro que otorgaban temporalmente la condición de escultura a toda persona u objeto que se dispusiese sobre ellas. ${ }^{59}$ Este proceso le llevó a aceptar que cualquier huella física del ser humano - sobre todo del propio artista - podía tener valor artístico, fuesen las huellas dactilares, la sangre - que disponía en frascose incluso los restos de las funciones biológicas más elementales, Merda d'artista (1961), que conservaba en latas de treinta gramos y que, para cuestionar la mercantilización de la obra de arte, vendía por gramos a un precio basado en la cotización del oro. ${ }^{60}$

Sin embargo, aquella ansia de convertirse en una especie de rey Midas artístico, no le llevó a romper con ciertos convencionalismos perennes en la Historia del Arte: el mito de Pigmalión, aquella fantasía de que el hombre creó a la mujer. Del mismo modo que Yves Klein, vestido de esmoquin, dirigía el proceso de elaboración de las «antropometrías» con modelos desnudas, toda la documentación fotográfica que conocemos sobre las «esculturas vivas» de Manzoni queda conformada por la imagen del propio autor - convenientemente engalanado- junto a mujeres casi siempre desnudas y colocadas en estudiadas poses que toman como referente algunas representaciones artísticas tradicionales. ¿Qué personas fueron remuneradas para convertirse en Esculturas vivientes?, ¿cuáles fueron los honorarios de las mujeres que posaron desprovistas de su indumentaria?, pero ¿por qué no eligió para sus imágenes a modelos masculinos y también desnudos? Una vez más se nos presenta la objetualización del cuerpo femenino llevada al paroxismo, un claro ejemplo de la reiterada visión masculinista de los estereotipos de la mujer creados por el hombre.

\footnotetext{
${ }^{59}$ SCHIMMEL, Paul, op. cit., p. 49.

${ }^{60}$ SCHIMMEL, Paul, op. cit., pp. 46-49.
} 
Apenas puede abarcarse cuanto se ha escrito acerca de Joseph Beuys (Krefeld, 1921 - Düsseldorf, 1986), pocos artistas han ocupado tanto espacio en la opinión pública después de la Segunda Guerra Mundial. Su independencia, su investigación interdisciplinar y sus reflexiones le llevaron a terrenos desconocidos que impactaron en nuestra sociedad y sirvieron de revulsivo para que el arte fuera más allá de los planteamientos más radicales de las vanguardias artísticas del siglo XX. Tanto las experiencias de la infancia y de la guerra como el cristianismo, la mitología nórdica, los poetas románticos — Goethe, Schiller, Novalis, Rilke, entre otros - la antropología y las ciencias naturales - botánica y zoología-, constituyen el caldo de cultivo esencial de sus formas complejas de pensamiento. Beuys practicó la desacralización del objeto artístico, invitando a liberarse de las cadenas de lo bello, predicó el cambio de las condiciones sociales y trabajó incansablemente para ampliar los ambiguos límites del arte, redefiniéndolos respecto a los del ser humano. ${ }^{61}$

El autor germano desarrolló un trabajo de enorme complejidad altamente conceptual en el que performances, happenings e instalaciones se relacionaban generalmente con la toma de posiciones políticas. Para Beuys «Everybody is an artist», y por tanto, cada acción una obra de arte. ${ }^{62}$ Experimentó en muchas conferencias con el papel del artista como actor/maestro y chamán/profesor. ${ }^{63} \mathrm{Al}$ igual que muchas de las acciones de aquella época que llevaban implícita una alta carga ritual, Beuys, rayando en lo mesiánico, se autoproclamaba mensajero de un nuevo ser humano renovado en una legitimación de la actividad artística como algo excelso. ${ }^{64}$

${ }^{61}$ STACHELHAUS, Heiner, Joseph Beuys, Barcelona, Parsifal, 1990, pp. 7-17.

62 SCHELLMANN, Jörg y KLÜSER, Bernd, "Questions to Joseph Beuys", en SCHELlMANN, Jörg (ed.), Joseph Beuys. The Multiples, Munich - New York, Schellmann, 1977, p. 19.

${ }^{63}$ Para una aproximación a la faceta oradora de Joseph Beuys véase KLÜSER, Bernd (ed.), Joseph Beuys. Ensayos y entrevistas, Madrid, Síntesis, 2006.

${ }^{64} \mathrm{La}$ «escultura social» de Joseph Beuys va más allá del ready made de Marcel Duchamp ya que al artista germano no le interesa la relación museística, sino la relación antropológica. La creatividad es la ciencia de la libertad, por ello, cuando afirma que todo 
La extensa obra de Joseph Beuys recoge más de 70 acciones, 50 instalaciones y unas 130 exposiciones individuales, aunque consideramos que el núcleo de su trabajo lo ocupan las performances. Para el artista alemán las acciones son acontecimientos efímeros que trascienden a todos los géneros de las artes plásticas, a la vez que subvierten el tradicional concepto del objeto artístico. La fórmula de retrotraimiento hacia la interpretación icónica del objeto es una constante. Si juntamos todas sus representaciones de animales, vemos que lo que le interesaba esencialmente era expresar las energías psíquicas y espirituales de los mismos estableciendo analogías con el comportamiento de las criaturas y, por consiguiente, también con el comportamiento humano. De este modo, la liebre es el símbolo de la libertad, pero también representante de la naturaleza; la abeja deviene animal «sagrado, porque en realidad en toda su labor permite conocer cómo le va al propio ser humano»; la miel, en general, «se consideró en el contexto mitológico como una sustancia espiritual»; la grasa, el elemento curativo, energético y lubrificador; y la máquina —al igual que el hombre—, receptor y transmisor de energías. ${ }^{65}$

Para su primera exposición en público, celebrada en la Galería Schmela de Düsseldorf en 1965, Beuys presentó Cómo se le explican los cuadros a la liebre muerta. Para ello se encerró en el interior del local, de ahí que el público sólo pudiera ver la performance desde la puerta de entrada y la ventana que daba a la calle. El artista, sentado en una silla en un rincón de la galería, derramó miel sobre su cabeza y adhirió sobre ésta auténtico pan de oro por valor de 200 marcos. Entre sus brazos acunó una liebre muerta a la que susurraba constantemente. Más tarde, Beuys se levantó y llevó al animal hasta las pinturas colgadas en las paredes de la

individuo es un artista, no quiere decir que todas las personas sean pintores o escultores. Más bien, quiere decir que todos y todas poseemos facultades creativas que deben reconocerse y ser perfeccionadas. La creatividad es una característica humana. STACHELHAUS, Heiner, op. cit., p. 74.

${ }^{65}$ STACHELHAUS, Heiner, op. cit., pp. 64-67. 
galería y le habló de ellas poniendo las patas del animal sobre los cuadros mientras explicaba sus orígenes y conceptos. ${ }^{66}$

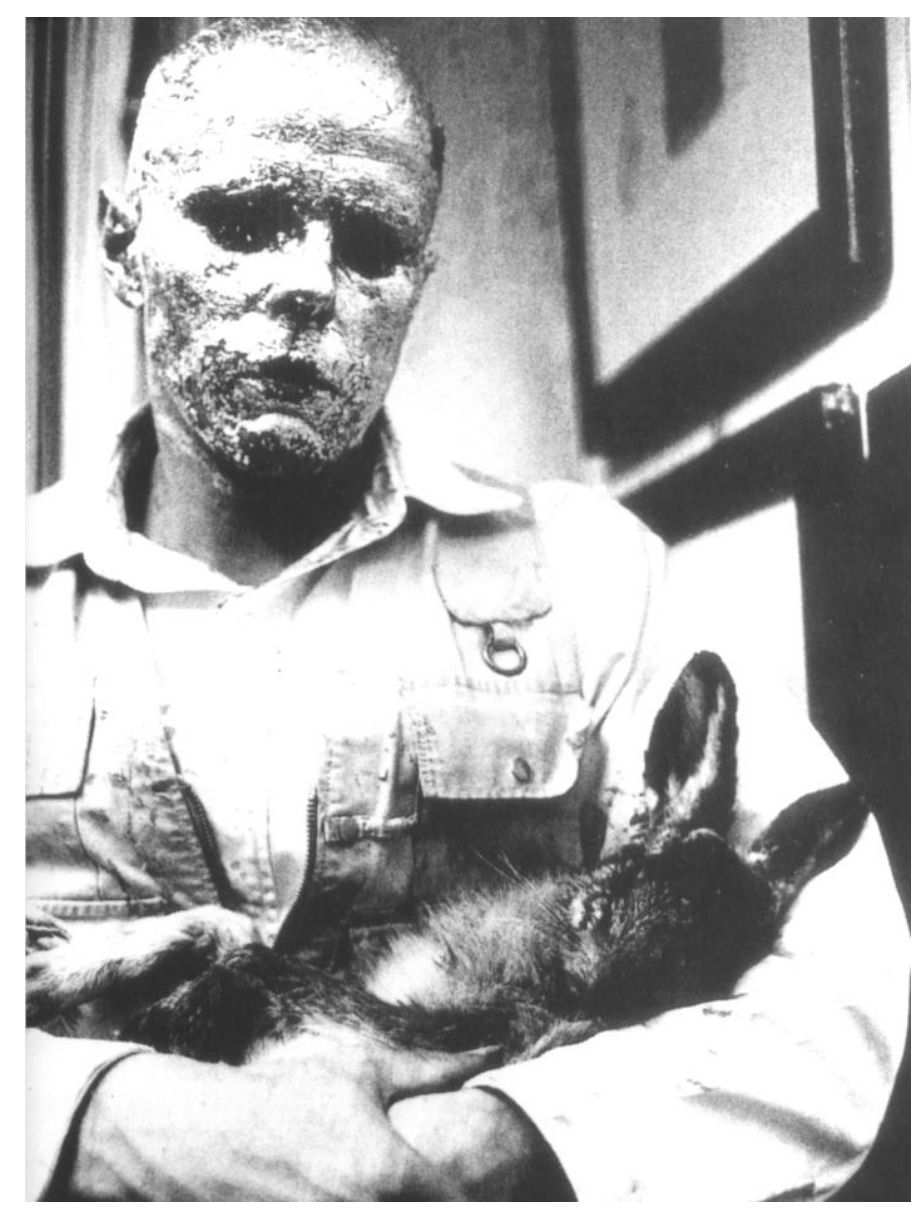

30. Joseph Beuys - How to Explain Pictures to a Dead Hare (1965)

Para la inauguración de la nueva René Block Gallery de Nueva York Beuys presentó del 21 al 25 de mayo de 1974 la acción I like America and America likes me conviviendo en el espacio expositivo con un coyote salvaje llamado Little Joe. A su llegada al aeropuerto JFK iba envuelto en una manta de fieltro, a continuación una ambulancia lo trasladó a la galería,

${ }^{66}$ STACHELHAUS, Heiner, op. cit., pp. 154-155. 
donde entró cubierto de heno y con un garrote. Los largos períodos de silencio, sueño y observación mutua se interrumpían cuando Beuys representaba el papel de mediador entre el salvaje oeste americano, simbolizado por el coyote, y su capitalismo contenido y continente, representado por el Wall Street Journal que apilaba día tras día en paquetes de 25 ejemplares en el espacio de la galería de Nueva York. Transcurridos los cinco días, el artista regresó al aeropuerto de la misma forma en la que había llegado. ${ }^{67}$

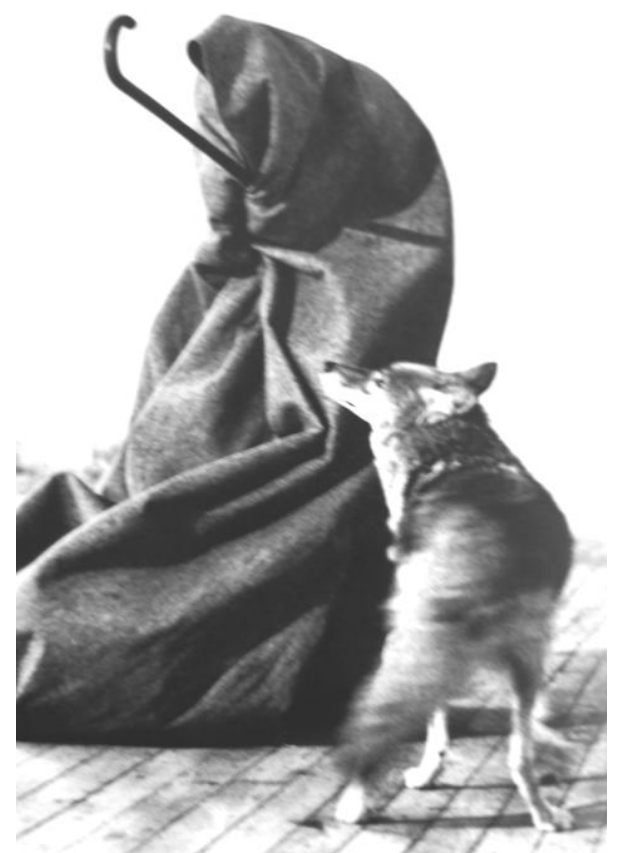

31. Joseph Beuys - I like America and America likes me (1974)

Joseph Beuys deviene emisor y su transformación del arte pasa en todo momento por la transformación de los parámetros del lenguaje y del pensamiento. Probablemente sea el autor que mayor influencia ha

\footnotetext{
${ }^{67}$ Sobre la obra performativa de Joseph Beuys véase ROSENTHAL, Mark, "Joseph Beuys: Staging Sculpture", en el catálogo de la exposición Joseph Beuys. Actions, Vitrines, Environments, Houston, The Menil Collection, 2004, pp. 10-125.
} 
ocasionado en los y las artistas de la siguiente generación en el sentido de la responsabilidad de definir la cultura en la que vivimos.

\subsubsection{El Accionismo vienés}

Viena, anclada en el corazón de Europa, aislada política y culturalmente de la Europa moderna y dominada por el pragmatismo de un estado burocrático que paralizaba la actividad artística, intentaba encontrar respuestas a las barbaridades del nacional-socialismo y sus inclinaciones culturales e intelectuales enraizadas en el siglo anterior. La presión ejercida por los pequeños burgueses, enclavados en un exacerbado catolicismo, impulsó una tensión artística que se manifestó, de forma agresiva y violenta, a través del cuerpo. El arte debía producir sentido, significado y comunicación a través del gesto o de la acción. Esta postura, encabezada por el Wiener Gruppe, el colectivo de poetas que consiguió abrir una brecha auténticamente moderna en el escenario del estancamiento vienés de posguerra, se acogió a la tradición de Wittgenstein, asumiendo posiciones estructurales y analíticas desde sus primeros trabajos. ${ }^{68}$

En Austria, a diferencia de Alemania, la reconstrucción post-bélica fue un tanto más complicada. Por una parte, pervivía una adhesión al nacional-socialismo, con lo que el país fue sometido a una gran represión después de la guerra, llegando su integración europea en 1955. Por otra parte, los valores tradicionales y burgueses estaban marcados por un enraizado catolicismo y una carencia de vanguardias durante las primeras décadas del siglo XX. ${ }^{69}$ En la ruptura y la disgregación de la hegemonía abstracta se perciben indicios de un cambio de arquetipo y de los conflictos que ello generaba. Si partimos de este contexto, es ineludible volver la mirada hacia la Viena de los años sesenta para comprender cómo se produjo

\footnotetext{
${ }^{68}$ PARCERISAS, Pilar, op. cit., p. 13.

${ }^{69}$ PARCERISAS, Pilar, op. cit., p. 9.
} 
aquella crisis de la representación mediante la ruptura que provocó la exposición de las relaciones de poder.

Por primera vez tuvo lugar en Austria una actitud verdaderamente vanguardista, sin embargo, a falta de ésta, se produjo un retorno a la modernidad escéptica, una mirada regresiva al mundo del inconsciente y a su emancipación a través de la liberación de los impulsos sexuales. Los desastres de la guerra marcaron cruelmente la infancia y la juventud de los accionistas vieneses, quienes emprendieron una actitud insurreccional con la pintura, en la cual vieron un acto de liberación psico-terapéutico. Sin embargo, pronto fueron las acciones - a modo de «extensión» de sus pinturas - las liberadoras de los instintos en sus ataques al sexo y a la religión. Unas acciones que fueron blasfemas por utilizar los arquetipos religiosos y sus símbolos en un sentido contrario a la norma católica; a la par que exhibicionistas — por mostrar en público la intimidad del cuerpo y sus funciones - e irreverentes - por la mezcla entre sexo y religión. ${ }^{70}$

Para comprender el alcance de este gesto colectivo de protesta contra la historia que realizaron en tan breve período de tiempo, conviene no olvidar que los accionistas vieneses son los hijos del horror nacionalsocialista y de la Segunda Guerra Mundial, una tragedia que acabó con millones de personas, con cientos de miles de desplazados y finiquitó, de modo radical, las esperanzas propuestas por las utópicas vanguardias europeas. $^{71}$ El Accionismo vienés y las respuestas artísticas paralelas y deudoras del mismo supusieron un caudal de experiencias corporales que estremecieron a los detentadores de la decencia en una sociedad mojigata y represiva. No obstante, la fama y el renombre de los accionistas, así como su leyenda transgresora, ha oscurecido las contradicciones existentes entre cuatro artistas que ni son homogéneos, ni comparten un pensamiento uniforme: Hermann Nitsch, Günter Brus, Otto Mühl y Rudolf

\footnotetext{
${ }^{70}$ PARCERISAS, Pilar, op. cit., p. 15.

${ }^{71}$ LEBRERO STALS, José, "Alto voltaje", en el catálogo de la exposición Accionismo vienés..., op. cit., p. 5.
} 
Schwarzkogler. En 1965 constituyeron el Wiener Aktionsgruppe, iniciado por Nitsch y Mühl y, sus objetivos, fueron formulados con claridad: reaccionar contra el Expresionismo abstracto norteamericano y sus derivaciones utilizando su propio cuerpo como soporte material de la obra de arte, un cuerpo que podía ser degradado, envilecido e incluso mancillado en un proceso de «política de la experiencia». ${ }^{72}$

Aquella reivindicación de la vida psíquica propia de los parámetros del happening en Europa, va íntimamente ligada a la magia y al ritual. La ampliación de la percepción se conjuga con la liberación del funcionamiento y la extensión de todas las actividades psíquicas. Es preciso insistir que ciertas manifestaciones europeas se interesaron por el happening como reconquista de la función mágica del arte y como transmisión de ciertas fuerzas psíquicas que son expresión de un pensamiento mítico que surge como reacción a la civilización tecnocrática y a la industria de la cultura. Muchas de estas experiencias manifiestan incluso semejanzas estructurales con el ritual. ${ }^{73}$

Los accionistas vieneses pusieron énfasis creativo en prácticas corporales expresionistas, provocativas, transgresoras $\mathrm{y}$, sobre todo, fetichistas que buscaban su justificación en las teorías psicoanalíticas de Freud, Jung y Reich; en el trabajo de artistas austriacos como Egon Schiele y Oskar Kokoschka; en los rituales paganos (episodios dionisiacos) y cristianos (escenas de la pasión de Cristo); en las fiestas populares y carnavalescas; así como en el teatro futurista y dadaísta. El grupo, como tal, tuvo una vida muy corta, ya que se disolvió tras Kunst und Revolution, una acción colectiva que también reunió a Peter Weibel, Oswald Wiener y al Direct Art Group. La obra se realizó en la Universidad de Viena en 1968 y de ella se derivaron diversos arrestos, condenas (Günter Brus fue condenado a seis meses de prisión por insultar a la República austriaca —en su acción

\footnotetext{
${ }^{72}$ SARMIENTO, José Antonio, "El Arte de la Acción", en el catálogo de la exposición El Arte de la Acción, Santa Cruz de Tenerife, Centro de Arte La Granja, 2000, pp. 11-12.

${ }^{73}$ MARCHÁN FIZ, Simón, op. cit., p. 201.
} 
se quitó la ropa, se cortó con una hoja de afeitar, se bebió su orina, se introdujo el dedo en la garganta para vomitar, defecó y se frotó su cuerpo con sus excrementos mientras cantaba el himno nacional-), e incluso exilios, como el de Nitsch. ${ }^{74}$

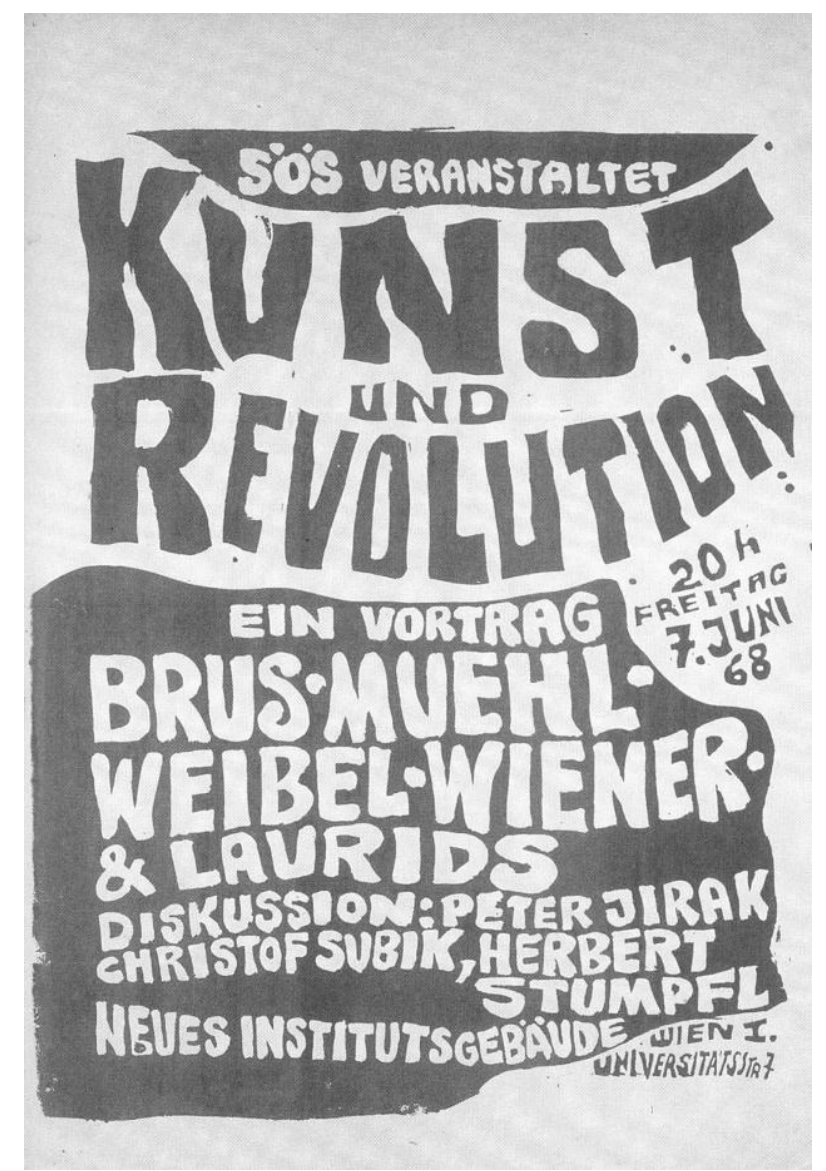

32. Cartel anunciador de la acción Kunst und Revolution (1968)

El grupo vienés actuaba mediante una inversión de los roles, identificándose ellos mismos como los agresores —un evidente mecanismo de defensa. Ante un peligro externo, asumían su función y sus símbolos por mecanismos miméticos. La víctima se convertía en verdugo y el torturado

${ }^{74}$ SARMIENTO, José Antonio, op. cit., p. 16. 
en torturador. El ofensor sufría la misma injuria que había infligido al ofendido. Todos los impulsos hacia la destrucción eran permitidos con total libertad. Se interpretaban verdaderos ritos de contaminación donde el poder de la violencia era utilizado para subvertir y descomponer la normalidad de la persona. Las analogías entre ceremonias obsesivas y prácticas de culto son evidentes. ${ }^{75}$

El interés en este tipo de performances dependía mayoritariamente de la capacidad de distinguir qué era real y qué irreal. Las acciones rozaban lo absurdo para todas aquellas personas cuyo sentido de la realidad fuera totalmente integral. Su espanto tenía que ser lo suficientemente fascinante y brutal para romper con lo que ellos mismos reprimían - en este caso las tensiones intolerables que existían en el yo y las que eran atribuidas a los demás. ¿Puede el ser humano reconocerse a sí mismo y asumir su propia identidad desde la maldad, tomando el mal como riesgo, como violencia sobre los demás o sobre la persona misma, como disipación? ¿Podemos reconocernos en la autoherida, en la automutilación o en el suicidio? Esta necesidad de librarse a sí mismo de ciertas cargas puede llevar a la forma más horrenda de sacrificio.

El análisis que aporta Lea Vergine en su esencial trabajo Body Art and Performance nos aproxima a una visión crítica muy interesante, aunque poco precisa, dado que no concreta sobre estas cuestiones. Para la autora italiana la mayoría de estas prácticas artísticas son inherentes a una feroz misoginia. Ello se evidencia especialmente en aquellas acciones escatológicas donde la ingestión de orina, heces y otros productos de eliminación adquieren cierta simbología atribuible a la envidia del útero, acciones que, a su vez, actúan como una especie de exorcismo ante el temor a los genitales femeninos. ${ }^{76}$ De lo que no cabe ninguna duda es de que en numerosas acciones se advierten claros signos de violencia de género donde

\footnotetext{
${ }^{75}$ VERGINE, Lea, Body Art and Performance. The Body as Language, Milano, Skira, 2000, pp. 19-20.

${ }^{76}$ VERGINE, Lea, op. cit., p. 20.
} 
el cuerpo femenino - a diferencia del masculino - adquiere un carácter exhibitorio descaradamente sexista, cayendo una vez más en la tradición arquetípica de la femme fatale.

En el trabajo de Hermann Nitsch (Viena, 1938), laten constantemente las relaciones e interferencias entre religión y sexualidad. $\mathrm{Su}$ obra pasó sin solución de continuidad de una pintura informal de gran formato e intensidad emotiva conectada con el Action Painting de Pollock, a una práctica de arte total inmersa en lo que se denominó Orgien Mysterien Theatre, una aproximación al concepto wagneriano de la Gesamtkunstwerk consistente en acciones rituales en las que las crucifixiones de corderos y cerdos destripados, la manipulación de sus entrañas, la recogida de su sangre en cubos y la exaltación de los órganos genitales se entendían como medios de catarsis y de regeneración. En su programa de la obra de arte total Nitsch ha descubierto las reservas semánticas éticas y estéticas del accionismo que, creado por el artista-filósofo, procede del mito y se manifiesta en la representación. El autor mezcla los misterios medievales, las procesiones católicas y la espontánea vitalidad y sensualidad de la tradición rural de la fiesta patronal con las formas demoníacas reinterpretadas de los antiquísimos rituales mediterráneos de salvación y fertilidad. $^{77}$

Dentro de la extensa trayectoria en el accionismo de Nitsch una performance sobresale por la contundencia de las imágenes fotográficas que se han exhibido a posteriori y por el contenido blasfemo: se trata de la acción $\mathrm{n}^{0}$ 32, también bautizada como La concepción de María. Es considerada la más significativa «obra de arte total» de Nitsch, mezcla de escritura, dibujo, collage, pintura abstracta, objetos encontrados y música. Para tal ocasión el artista se valió de actores meticulosamente preparados que presentó crucificados y embadurnados con sangre de animales

\footnotetext{
${ }^{77}$ HEGYI, Lóránd, "Hermann Nitsch: el intento de obra total del 'teatro de orgías y misterios' en el contexto del arte austriaco de postguerra", en el catálogo de la exposición Hermann Nitsch. El teatro de orgías y misterios, València, Centre Cultural La Beneficència, 1996, p. 35.
} 
destripados, llevando con ello hasta las últimas consecuencias el efecto de catarsis, de purificación ritual y de resurrección en una buscada relación con la teatralidad del barroco contrarreformista. En la acción adquiere un particular protagonismo una participante que viste sostén y pantis y que permanece inmovilizada con los pies atados. Nitsch, sumo sacerdote ataviado con un hábito blanco, ${ }^{78}$ le vierte las entrañas de un cordero - animal utilizado frecuentemente en sus acciones. La mujer, que simbólicamente actúa como alter ego de la Virgen María, parece estar dando a luz. La postura no es muy decorosa. Un signo delata las intenciones provocadoras del artista. La protagonista lleva las uñas pintadas dando así pistas de una falta de recato. En algunas fotos - apenas expuestas o reproducidas en catálogos - la falsa María introduce en la boca de Nitsch un consolador en forma de pene. El artista, embadurnado de sangre y pintura, parece disfrutar. Al respecto Nitsch, en los estatutos del Orgien Mysterien Theatre, afirmó que el ejercicio del arte conlleva el sacerdocio de una nueva concepción existencial.

Según afirma Pilar Parcerisas, Nitsch pretende hacer añicos la figura del padre, sus acciones son un ritual parricida que muestra mediante el éxtasis dionisíaco a la figura del progenitor como la gran perdedora de esa posguerra, como símbolo del poder, la familia y el Estado. ${ }^{79}$ Sin embargo, ¿es posible luchar contra la figura del padre utilizando reiteradamente la figura femenina como centro de atención en sus rituales?, ¿por qué las participantes nunca desempeñan un papel de la misma relevancia que los del sexo dominante?

\footnotetext{
${ }^{78} \mathrm{C}$. Welchman realiza un breve e interesantísimo recorrido histórico sobre el color blanco en la representación artística. En su texto destaca la importancia de este color en el Accionismo vienés, donde los autores lo utilizaban reiteradamente como soporte, primero en el lienzo y posteriormente en el vestido o en sus cuerpos. C. WELCHMAN, John, "Blanc trencat", en el catálogo de la exposición Günter Brus. Quietud nerviosa a l'horitzó, Barcelona, MACBA, 2005, pp. 16-26.

${ }^{79}$ PARCERISAS, Pilar, op. cit., p. 16.
} 
Si el arte no se ha cansado de representar el dolor, el martirio, lo sublime, la obra de Günter Brus (Ardning, 1938) consiste en transferir al cuerpo del artista el sufrimiento en una estrategia propia del teatro de la crueldad. ${ }^{80}$ Sus acciones difieren bastante respecto a las del resto del grupo de Viena, caracterizándose fundamentalmente por hacer de su propio cuerpo el campo privilegiado en el que se produce la violencia. La mayoría de actividades del artista se resumen en los Body Analyses, término acuñado por él mismo en 1969. En este tipo de prácticas el lenguaje se reduce a lo corporal y lo orgánico, desde defecar $u$ orinar hasta masturbarse, pero estas actividades obedecen a intentos de ruptura de las leyes sociales sobre la higiene, la decencia y la moral. «El meu cos és la intenció, el meu cos és el succés, el meu cos és el resultat». ${ }^{81}$

En su obra se asocian ciertos componentes pictóricos derivados del Expresionismo abstracto y, sobre todo, del Informalismo, con la aludida gestualidad corporal enraizada en los comportamientos sexuales censurados del ser humano. En la búsqueda de la acción total, al igual que hace Otto Mühl con el que se siente especialmente identificado y con el que en 1966 funda el Instituto para el Arte Directo, Brus radicaliza sus prácticas corporales sadomasoquistas, que suele acompañar de escritos y dibujos de una gran violencia expresiva en los que se reconocen las huellas de Egon Schiele, hasta el extremo de automutilar (Selbstverstümmelungen) su cuerpo o sexualizarlo a través del exhibicionismo anal, transgrediendo toda norma moral o estética y convirtiendo lo prohibido en arte. La transgresión brusiana entrelaza lo repulsivo con lo placentero.

Sin embargo, a menudo Brus se pone bragas o pantis con los que juega a transformar su pene en otra cosa. ¿Qué pretendía el autor con estas vagas pinceladas de travestismo? Estamos ante un tipo de planteamientos

\footnotetext{
${ }^{80}$ ASENSI, Manuel, "Günter Brus: art de la fisura", en el catálogo de la exposición Günter Brus..., op. cit., p. 30.

${ }^{81}$ Cit. en FABER, Monika, "Excés pictòric. De la pintura d'acció al body-art", en el catálogo de la exposición Günter Brus..., op. cit., p. 12.
} 
que evocan la dimensión lúdica que posteriormente será esgrimida en las performances de Vito Acconci.

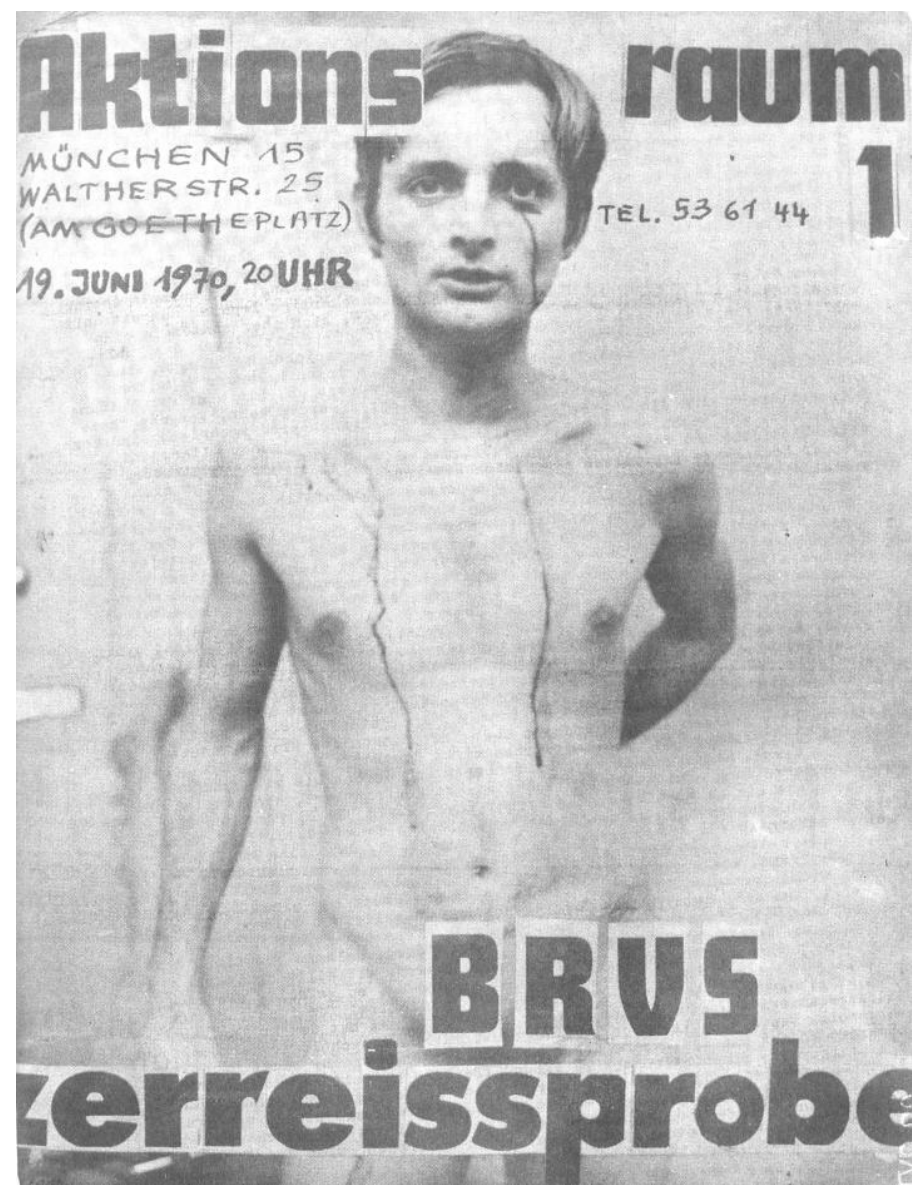

33. Günter Brus - Invitazion Zerreissprobe (1970)

En 1970, Brus llevó a cabo en Munich una de sus acciones más duras y provocativas: Zerreissprobe en la que la automutilación se justificaba en tanto que reflexión transindividual y transocial de una cultura represora de los instintos humanos. Estamos ante una acción extrema, repleta de signos y gestos convulsivos en la que el autor evita el toque grotesco, una acción que supuso su despedida del Accionismo. Tras practicarse una incisión en la cabeza y en el muslo, el artista se cosió la 
herida como escarificación real y simbólica de una fractura social que perduró abierta en Austria durante años, una fractura que escondía el silencio sobre la colaboración con el nazismo de muchos austriacos y que se traducía en comportamientos y políticas represivas, mediadas por las autoridades y consentidas por algunos sectores de la población. Un detalle nos invita a la reflexión ¿por qué el autor lleva puesto en todo momento un liguero?

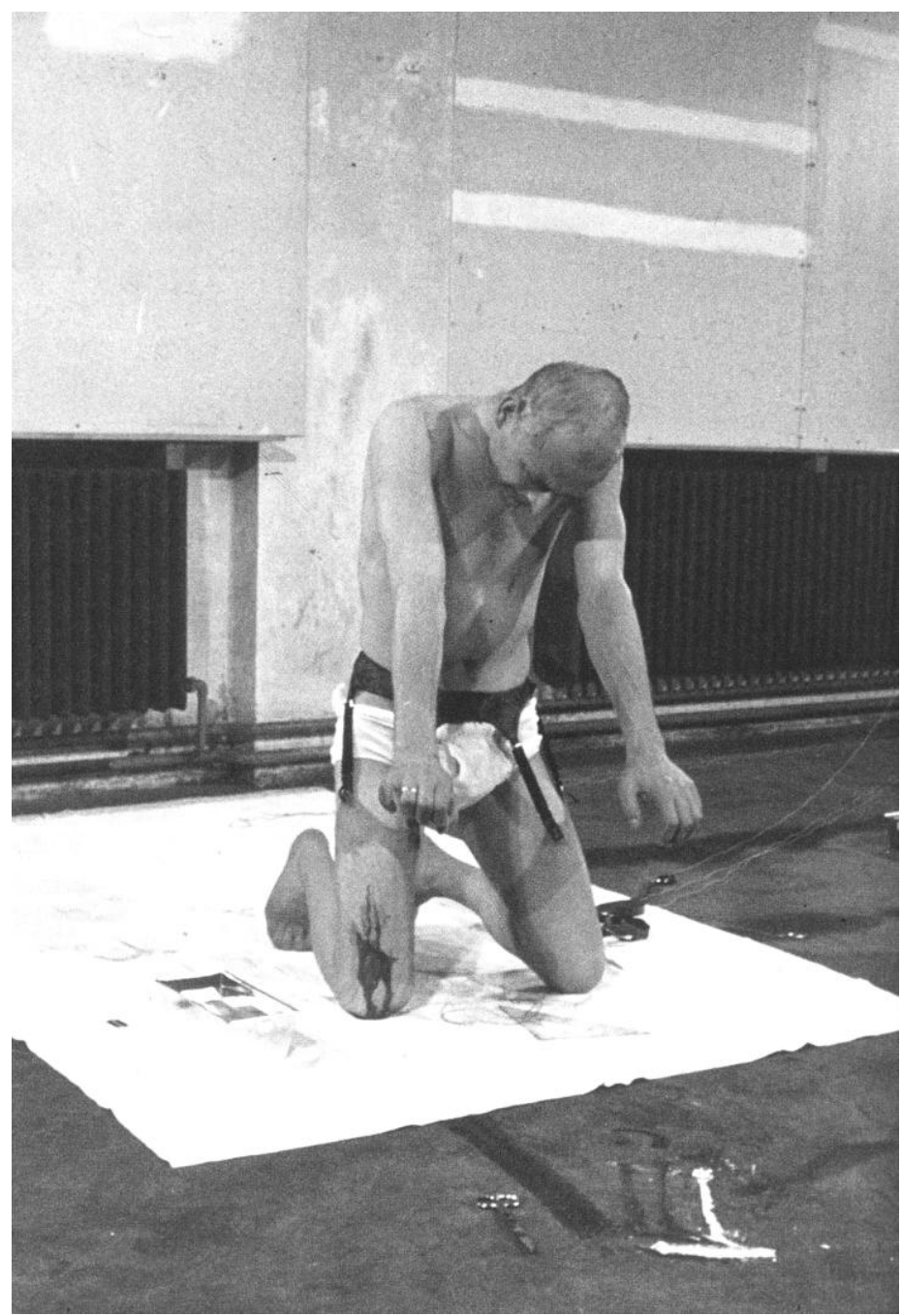

34. Günter Brus - Zerreissprobe (1970) 
Tal y como afirma Cortés, Brus se olvida del maquillaje de la pintura $\mathrm{y}$ pone en escena su cuerpo totalmente desnudo y sexualizado por el exhibicionismo anal o genital, el travestismo o la defecación. ${ }^{82}$ El autor intentaba analizar la experiencia del cuerpo como una fuente de poder y de conocimiento, iniciar un proceso de purificación con la finalidad de llegar a una nueva unidad de mente y cuerpo.

En sus acciones, cargadas de un importante contenido de crítica política e ideológica sobre el papel y la función del cuerpo, Brus se transforma al unísono en héroe y mártir, en un guerrero que busca la libertad mediante el sacrificio y la autoaniquilación. Pero, tal y como plantea Manuel Asensi, estas acciones son, al mismo tiempo, reales y no reales, implican la participación de un yo, el del «autor», también afectado por esta contradicción. ¿Qué grado de auto-bio-grafía -o auto-tanato-grafíaexiste en su obra? Si narra la historia de un cuerpo que se masturba, defeca, orina, sangra... ¿Es teatro? ¿Finge el autor esta secuencia de actos? ${ }^{83}$

Al igual que G. Brus, Otto Mühl (Grodnau, 1925), tras unas primeras acciones vinculadas al Action Painting, al Tachismo y a las prácticas Junk, ${ }^{84}$ a partir de 1964 define su territorio dentro del Accionismo vienés,

${ }^{82}$ G. CORTÉS, José Miguel, El cuerpo mutilado. La angustia de muerte en el arte, Valencia, Generalitat Valenciana, 1996, p. 94.

${ }^{83}$ ASENSI, Manuel, op. cit., p. 34.

${ }^{84}$ El término Junk fue acuñado por L. Alloway para designar al movimiento americano de los años cincuenta surgido como reacción al idealismo propio del Expresionismo abstracto. Introduce en sus obras materiales sin valor, desechos, basura y otros desperdicios urbanos mediante assemblages, detritus urbanos y objetos de consumo recuperados. Representa una rebelión contra la doctrina tradicional de materiales nobles y un deseo de mostrar que las obras de arte pueden crearse aprovechando objetos humildes y despreciables. El movimiento es desconocido ya que es asociado al Neo-dadaísmo. Su punto de partida de remonta a los Combine-Paintings de Rauschenberg y, hasta 1962 constituyó el medio en el que el assemblage evoluciona hacia los environments y los happenings, en los cuales se desarrolla el interés por el objeto cotidiano que lleva al Pop Art. El Junk Art de los Estados Unidos - también denominado Trash Art- transforma la chatarra y los desperdicios dejados por la guerra en objeto artístico. Entre los y la artistas Junk encontramos a Dine, Oldenburg, Kaprow, Grooms, Samaras, Di Suvero, Stankiewics o Chamberlain. Véase VERGINE, Lea, When Trash Becomes Art: TRASH Rubbish Mongo, Milano, Skira, 2007. 
interesándose primero por las relaciones con connotaciones sexuales entre los cuerpos humanos, generalmente femeninos, y los materiales más diversos, y luego en la «acción política» enraizada en la historia y tradiciones de su país. La obra de Mühl cuestiona el aspecto sacrificial, separador y castrador, del funcionamiento cultural. Para luchar contra la represión preconiza una experimentación del exceso en carne y hueso, pero ritualizada, y proyecta una sociedad que ya no estaría fundada en el sacrificio de las pulsiones y la división del sujeto. ${ }^{85}$

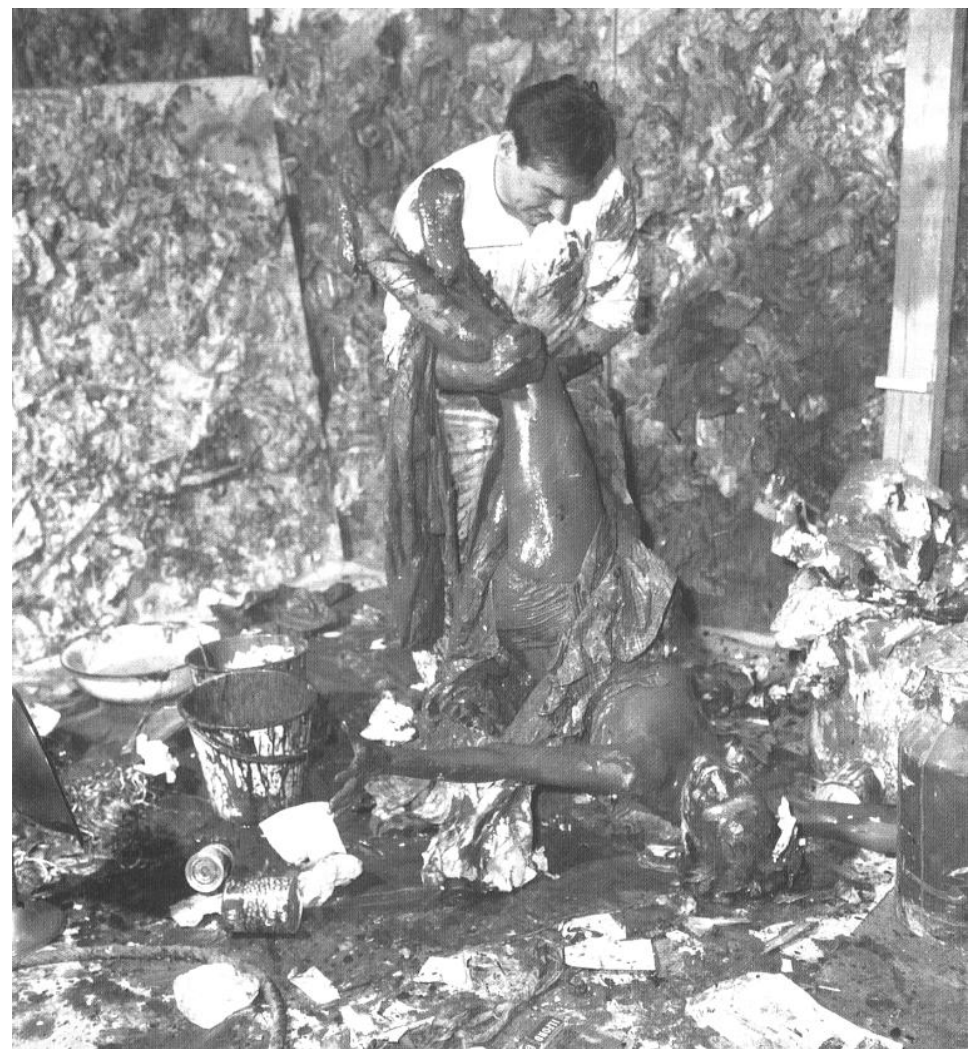

35. Otto Mühl - Material Action n 1 Degradation of a Venus (1963)

\footnotetext{
${ }^{85}$ Es sin duda el más controvertido del grupo debido a sus actividades extrartísticas. El autor permaneció encarcelado durante siete años acusado de abuso de menores y de uso de drogas en su comuna de La Gomera, tras haber fundado otra en Austria. Debemos evitar que los sucesos en la comuna determinen sobremanera la interpretación de las acciones artísticas.
} 
Una de las primeras obras precursoras del Accionismo fue El órgano de sangre. El aparato $M$, de junio de 1962. A través de este trabajo Mühl admite que su preocupación ética fundamental consiste en desarrollar y liberar abiertamente las pulsiones que él denomina creativas, a saber: el sadismo, la agresión, la perversidad, el deseo de reconocimiento, la avaricia, etcétera. Un año después, Mühl anunció que realizaría una acción denominada Degradación de una Venus. La intención era denigrar el símbolo de la belleza que encarna la mujer en la tradición y en la Historia del Arte. En otoño de ese mismo año llevó a cabo una versión de la misma. Las fotos conservadas muestran a Mühl de pie desvistiendo a una mujer pintarrajeada. Éste va a ser un proceder que se convertirá en marca de la casa Mühl: pintar, embadurnar, manchar, mancillar el cuerpo de los demás, sobre todo el de la mujer. ${ }^{86}$ La carga machista se percibe en la inactividad de la mujer, en su condición de superficie, que se convierte en leitmotiv reiterado hasta la saciedad en la obra del artista austriaco y de sus colegas.

En Invesmentfonds, oder: Erich Kommt, una acción de 1970, un hombre mayor en representación de la clase alta va vestido como un bedel. Ataviado con un sombrero de bombín - signo elocuente de categoría social y/o profesional - entra en un apartamento a la vez que empuja a una mujer desnuda en un carro de la compra. En otro momento la escena se repite salvo que es ella quien se abalanza lascivamente sobre el hombre. En otra escena, el mismo hombre lleva una máscara en forma de pene/consolador y penetra a la mujer que sonríe complaciente. Acto seguido es ella quien se coloca la máscara y en este caso simula penetrarle, ¿por qué no lo cumple? A continuación, Mühl y otro actor se ponen ropa interior femenina y hacen payasadas y gestos afeminados. ¿Acaso es la puesta de indumentaria íntima del sexo femenino lo que suscita ese comportamiento? La supuesta subversión de las reglas de género no llega demasiado lejos. La acción concluye con una suerte de escenificación de una violación salvaje. La

${ }^{86}$ ALIAGA, Juan Vicente, op. cit., p. 216. 
participante es colocada en una silla donde los hombres se masturban a su alrededor antes de penetrarla uno tras otro.

A través de la exhibición de un cuerpo que orina, defeca, se ensucia, huele, etcétera, Mühl trataba de alcanzar su objetivo: poner en tela de juicio el sistema de valores burgueses que pretende que el sujeto esté controlado y su cuerpo disciplinado. Mühl pretendía que las personas presentes en sus acciones pudieran saborear como voyeurs una dimensión de lo prohibido. Sin embargo, tal y como puntualiza Aliaga, nunca mostró ningún planteamiento crítico respecto al papel subordinado que socialmente oprimía a la mujer, realimentando su objetualización. ¿Acaso es coherente hablar en términos de «Totalrevolution» cuando se menosprecia e infravalora a un colectivo excluido? ${ }^{87}$

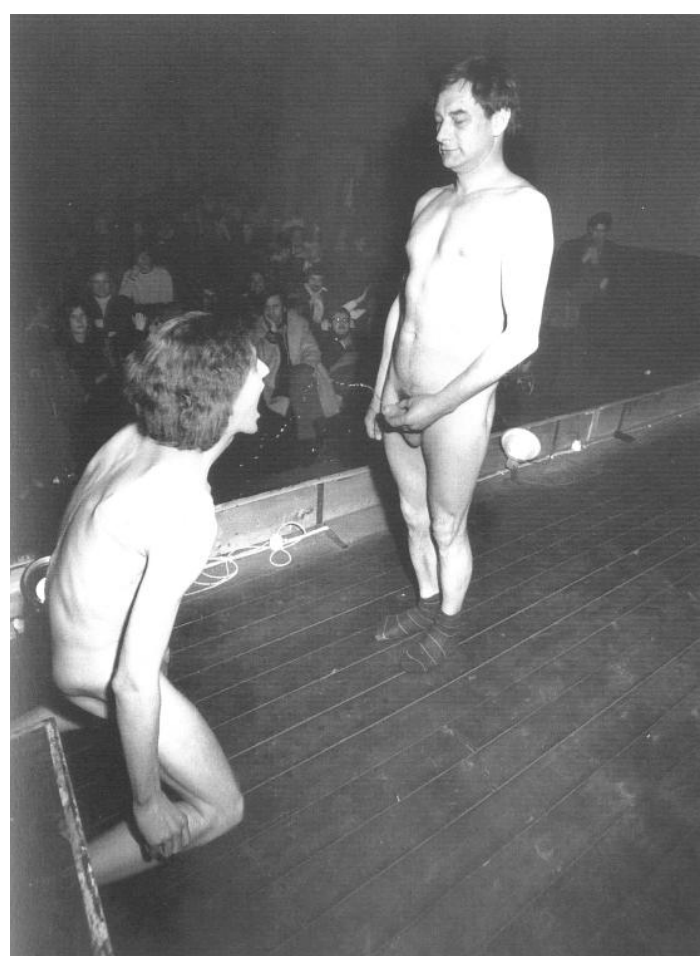

36. Otto Mühl - Pissaction (1969)

${ }^{87}$ ALIAGA, Juan Vicente, op. cit., p. 222. 
En esta línea destaca su papel fundamental en la acción Kunst und Revolution, en la que colaboró todo el grupo de accionistas vieneses, más Oswald Wiener con el que Mühl firmó en 1967 el manifiesto $Z O C K,{ }^{88}$ un «programa ideológico de reestructuración social». La acción deviene un verdadero hito del arte neovanguardista que ha dejado huella en la historia de la cultura visual. Llevada a cabo el 7 de junio de 1968, es decir, a rebufo de los hechos del Mayo francés, en el Neues Institutsgebäude de la Universidad de Viena y ante quinientas personas, Otto Mühl y los demás participantes hicieron virulenta mofa de los símbolos del Estado, lanzaron insultos contra el recién asesinado Robert Kennedy, tres hombres desnudos organizaron una sesión que consistía en ver quién meaba más lejos, y practicaron públicamente el onanismo y el masoquismo, activando con todo ello un gran escándalo nacional que, aparte de las consecuencias personales, conllevó la disolución del grupo, ya que el mismo fue acusado de difamar la institución del matrimonio y de la familia — de hecho, a Brus le cayó una sentencia de seis meses de cárcel.

El más joven de los accionistas vieneses, Rudolf Schwarzkogler (Viena, 1940-1969) realizó sus acciones corporales con una voluntad simbólica alejada del componente catártico presente en Nitsch y Brus. Contrariamente a lo que en ocasiones se ha escrito y se le ha censurado, Schwarzkogler, para quien el arte era «purgatory of senses and a detox

\footnotetext{
${ }^{88}$ El manifiesto de Mühl del festival ZOCK - término carente de sentido lógico- fue gestado en colaboración con el teórico Oswald Wiener en 1967. En el manifiesto se suceden críticas contra la religión, el matrimonio, la propiedad y la familia. Estas cuatro fuentes acarrean una crítica sociopolítica al sistema en el que se sustentaba Austria y cualquier otra nación capitalista del entorno. Austria fue un país en el que abundó la complicidad y el colaboracionismo con el Tercer Reich, tema espinoso que se tapó y no se depuró adecuadamente tras el final de la Segunda Guerra Mundial. La mujer, en tanto que guardiana de la familia y de la tradición, es el enemigo número uno de ZOCK. Cada mujer que ha tenido hijos será asesinada y comida por la juventud $Z O C K$ en los festejos enormes del día de la madre. En el día del padre, los padres podrán usar a sus hijos e hijas para su placer sexual. A través de estas acciones ZOCK logrará demoler la familia como el mayor elemento de mantenimiento del Estado.
} 
cure», ${ }^{89}$ nunca practicó herida alguna en su cuerpo, que tan sólo utilizaba como soporte de simulaciones de actos sexuales, agresiones físicas, procesos de autocastración y travestismo.

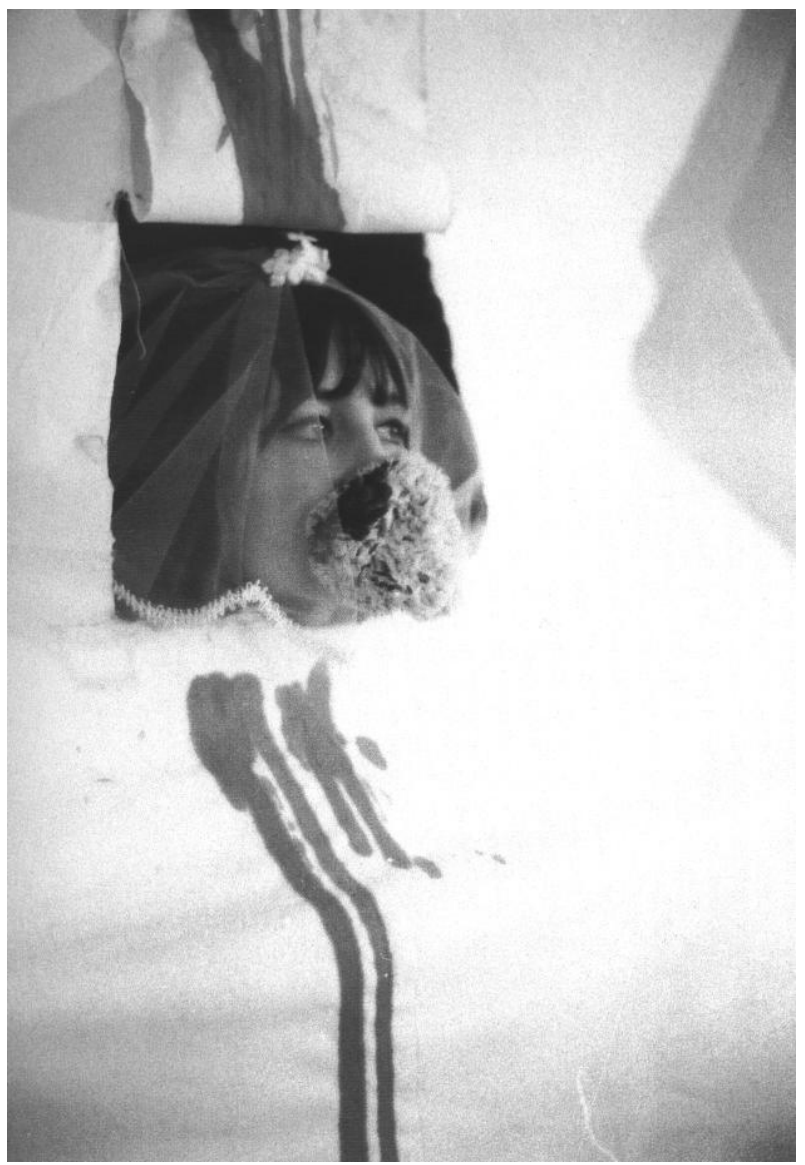

37. Rudolf Schwarzkogler - Action 1 Wedding (1965)

Pilar Parcerisas describe el trabajo del autor de manera irreprochable: una maquinaria esteticista de la crueldad bajo una atmósfera esterilizante de hospital y redimida por el artificio de la cosmética —abe indicar que la madre de Schwarzkogler era esteticista y su padre médico,

${ }^{89}$ ALFANO MigLIETTI, Francesca, Extreme Bodies. The Use and Abuse of the Body in Art, Milano, Skira, 2003, p. 22. 
éste se suicidó después de haber perdido las dos piernas en Stalingrado durante la guerra. ${ }^{90}$ Siempre llevó a cabo sus contadas y muy calculadas acciones públicas ante un número muy reducido de contempladores, conociéndose gracias a los documentos fotográficos y a los textos de gran fuerza poética, verdaderas conceptualizaciones verbales de sus actos, que solían acompañarlas. Como subraya Juan Antonio Ramírez, es difícil saber si la artisticidad radicaba en las acciones, meticulosamente escenificadas, o en las imágenes de las mismas captadas por la cámara. ${ }^{91}$

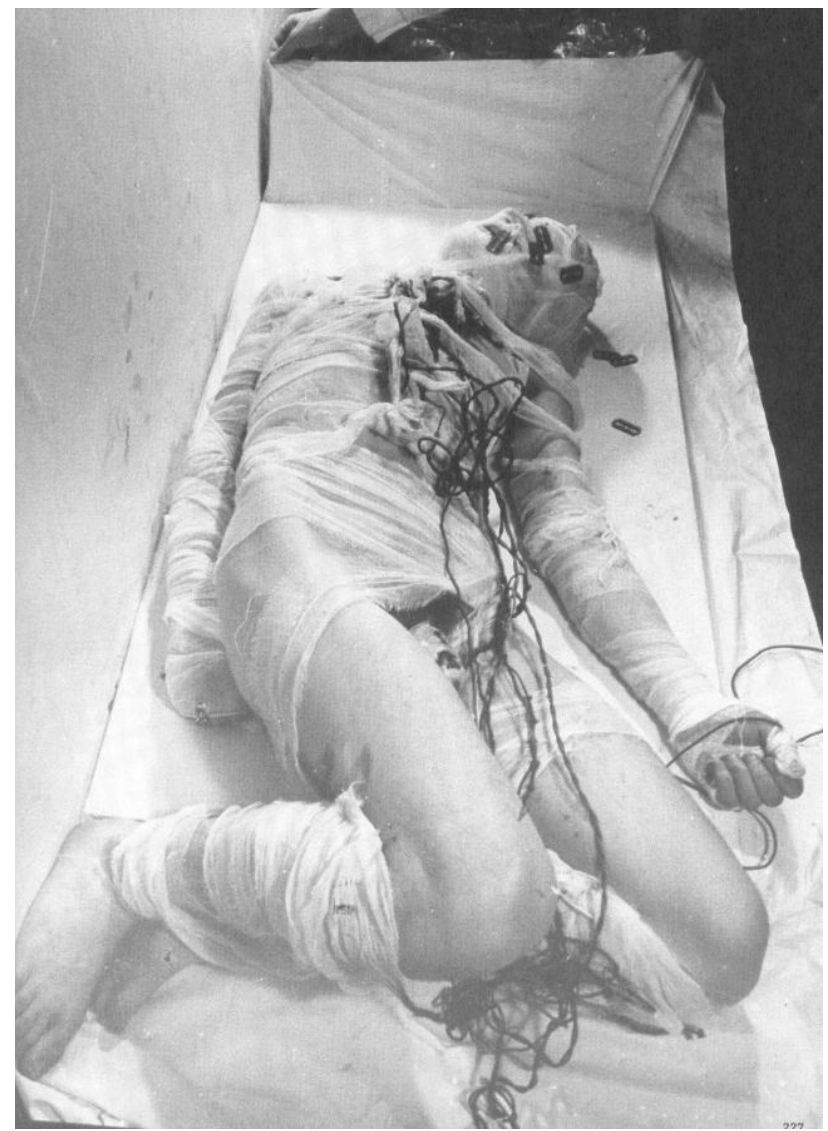

38. Rudolf Schwarzkogler - Aktion 4 (1965)

\footnotetext{
${ }^{90}$ PARCERISAS, Pilar, op. cit., p. 15.

91 RAMÍREZ, Juan Antonio, Corpus Solus. Para un mapa del cuerpo en el arte contemporáneo, Madrid, Siruela, 2003, pp. 76-77.
} 
A través de tales documentos, se vislumbra que Schwarzkogler desarrollaba sus acciones con una dramaturgia altamente efectista, con gestos medidos y equilibrada belleza, que en algunos aspectos fue $a$ posteriori retomada por Gina Pane. La leyenda envolvió su muerte, que algunos consideran su última acción, consecuencia de una autocastración real, si bien, su suicidio arrojándose desde una ventana no fue más que el fatal desenlace de una profunda depresión que se apoderó de Schwarzkogler en sus últimos meses de vida. ${ }^{92}$

El Accionismo vienés tuvo mucho que ver con la actividad del también austriaco Arnaulf Rainer (Baden, 1929). Sus primeras incursiones en el campo del arte, las realizó partiendo de su interés por la arquitectura y por los presupuestos revolucionarios del surrealismo, lo cual le llevó a formar en 1950 el Hundsgruppe. Tras pasar por diversas fases pictóricas que en los años cincuenta se decantan hacia el Expresionismo abstracto o a la negación de la propia pintura en su serie de obras recubiertas, a partir de 1960 empieza a utilizar el cuerpo como medio creativo para indagar en las capas más profundas de su yo, en una especie de introspección influida por el psicoanálisis de Freud y por el misticismo religioso.

Esa reflexión sobre el lenguaje de la imagen y el lenguaje del cuerpo le llevó a realizar una serie de fotografías de sí mismo, especialmente de su rostro, imitando los gestos y muecas anticulturales y primitivistas de los enfermos mentales, fotografías sobre las cuales, en una segunda fase, pinta gestualmente pretendiendo liberar su subconsciente mitopoético al margen

\footnotetext{
92 Sobre su muerte se han escrito demasiadas falsedades que han conducido a considerar a Schwarzkogler como un mártir del arte corporal. Todo tiene su origen en un artículo publicado por Robert Hughes en Time sobre la V Documenta de Kassel de 1972 en el que afirma lo siguiente: «Su mayor logro (y aunque pueda ser limitado, no se le puede negar; murió, mártir de su arte, en 1969, a los veintinueve años) fue convertirse en el Van Gogh del arte corporal. Como todo el mundo sabe Van Gogh se cortó una oreja y la mandó a una prostituta: Schwarzkogler parece haber deducido que lo importante no es la aplicación de la pintura, sino la eliminación de los apéndices necesarios. De modo que precedió, centímetro a centímetro, a amputarse el pene, mientras un fotógrafo tomaba constancia del acto como gran acontecimiento artístico». Cit. en SARMIENTO, José Antonio, op. cit., pp. 17-18.
} 
de todo apriorismo, imposición o censura, para reproducirse «cómo era, cómo soy, cómo seré, cómo podría ser». La voluntad de hacer del arte una investigación antropológica le lleva a realizar obras como Farce Faces (1969-1975) en las que, a través del estudio de su fisonomía torturada y flagelada, analiza las tensiones de su entorno, para descubrir las personalidades desconocidas que anidan en su subconsciente.

Teniendo en cuenta lo señalado hasta el momento en relación al Accionismo vienés, ¿qué conclusión podemos obtener del mismo? Juan Vicente Aliaga establece, grosso modo, dos vías interpretativas respecto a este breve período. La primera hace hincapié en una especie de concepción neoprimitivista según la cual los accionistas patentizan un deseo de regresar a un estado primigenio, un destino de origen mítico completamente ritualizado. Por otro lado, la segunda interpretación tiene en cuenta el contexto de la guerra y el peso del nazismo del cual quieren deshacerse. ${ }^{93}$

Las acciones, performances, ritos y ceremonias de los y las artistas de Europa, siguiendo la herencia dejada por los accionistas vieneses y, en especial por Hermann Nitsch, inciden mayoritariamente en los aspectos profundos de la vida individual y colectiva, en el sufrimiento físico y en las prácticas masoquistas o sadomasoquistas no exentas de cierto misticismo. A menudo hunden sus raíces en la doctrina cristiana de la redención humana a través del dolor y de la mortificación del cuerpo y en la plasmación artística de los cruentos suplicios, martirios y muertes de santos, así como en la pasión y crucifixión de Cristo. La reacción de un sector ultraconservador de la sociedad austriaca alcanzó cotas de suma violencia en su recepción de la agitación accionista, puesto que este sector se sentía atacado en sus creencias y en su sentido del pudor y el recato.

Toda una serie de acciones han presentado el libertinaje sexual como producto de la represión. Los autores opinaban que con la destrucción de las inhibiciones sexuales mediante imágenes directas se creaba la base para una

${ }^{93}$ ALIAGA, Juan Vicente, op. cit., p. 235. 
politización de otros campos y cuestiones vitales. En todos estos casos, la pornografía, los rituales mezclados con la política y las acciones más extrañas buscan ante todo un efecto directo y provocativo que se apoya en la misma perspectiva energética de la acción, en su des-estetización y en su carga antropológica. Pero, ¿por qué unos luchadores de la hipocresía moralista ultraconservadora cayeron - tal y como se manifiesta en su trabajo - en problemáticas sobre las jerarquías de género? 



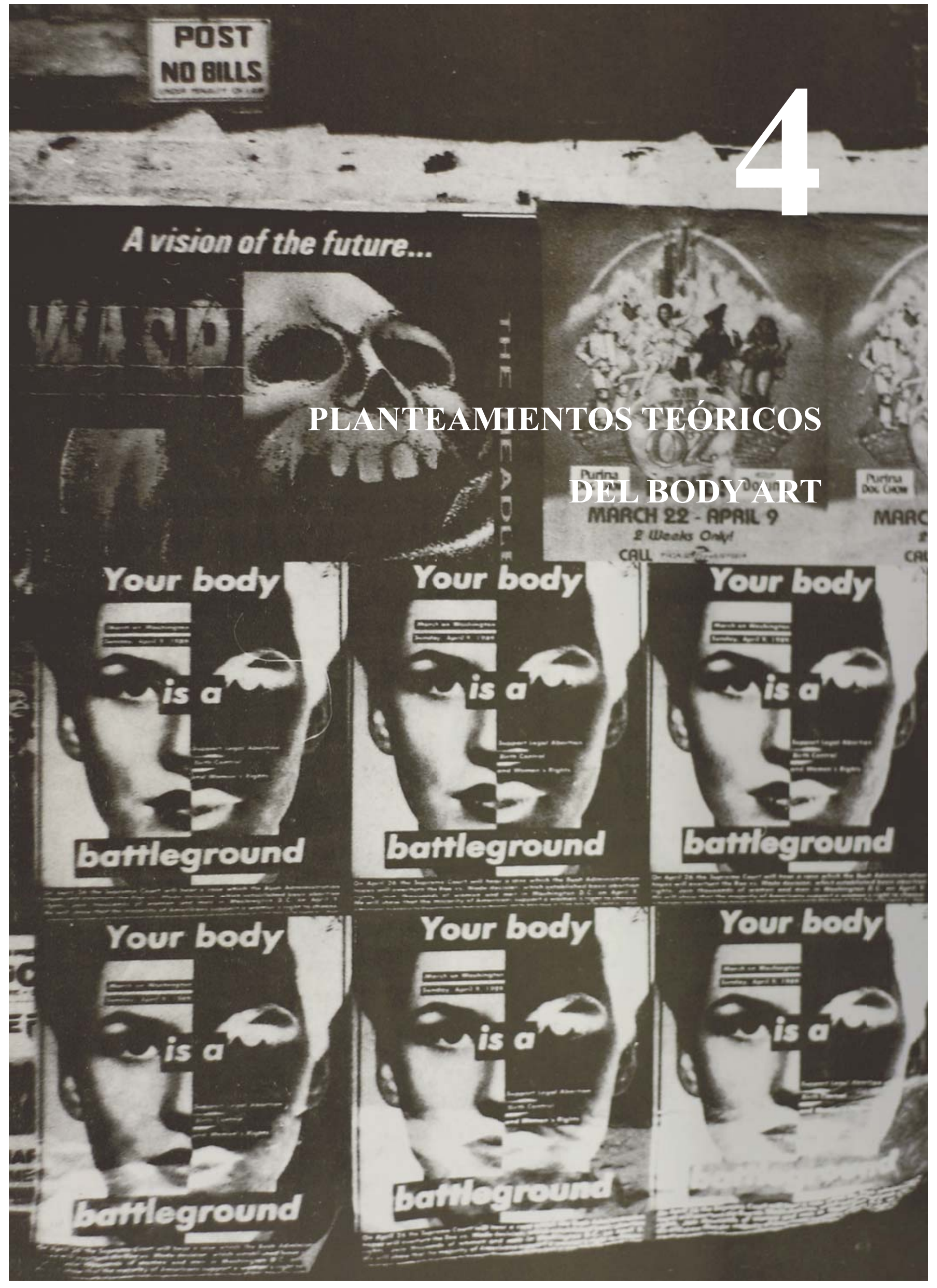



emos puesto de relieve la importancia del cuerpo a lo largo de la primera mitad del pasado siglo, cómo este deviene utensilio primordial de trabajo y creación cargado de un gran potencial. Tras un somero recorrido histórico en torno a la representación corporal característica de aquel período, consideramos oportuno ahora realizar un breve inciso y establecer las pautas teóricas y formales que conformaron la dimensión artística y social del Body Art, así como su nacimiento y consolidación.

Ya desde las vanguardias artísticas del siglo $\mathrm{XX}$, tal y como ha quedado reflejado a lo largo de los anteriores capítulos, el cuerpo deviene componente cardinal de la representación artística. Factores esenciales como aquella ruptura con un orden burgués que delimitaba el arte a las disciplinas tradicionales - pintura y escultura entre otras - , hicieron de la presencia humana un nuevo objeto-sujeto capaz de materializar las principales directrices de gran cantidad de autores y autoras. No obstante, el nacimiento del Body Art se produce tras los lánguidos años de posguerra, un complejo 
instante histórico en el que, tal y como hemos analizado, ciertos sectores de la sociedad comenzaron a manifestarse frente a una hegemonía tremendamente reaccionaria - consecuencia directa de la Segunda Guerra Mundial. En este contexto tampoco debemos olvidar que las batallas por el poder geoeconómico no se apaciguaron lo más mínimo tras el conflicto bélico.

Revisando el concepto de performance, podemos apuntar que ésta es la acción de un o una artista que no interpreta papel alguno sino a sí mismo. No debemos confundirla con el teatro, ya que en la performance no hay texto, sino una estructura presencial, es decir, una disposición de elementos visuales y objetos escénicos. Así pues, performance es una de las denominaciones con las que se caracterizan ciertos comportamientos artísticos surgidos a partir de la recuperación de los programas dadaístas que impulsaron, hacia finales de los años cincuenta, los y las artistas agrupados en Fluxus o próximos a este heterogéneo grupo. De las múltiples posibilidades que abren el uso del propio cuerpo y la consideración del tiempo como materia intrínseca de la obra de arte, dan testimonio las denominaciones que estas actividades han ido recibiendo según sus expresiones - happening, acción, event, etcétera.

No obstante la performance no inauguró su presencia artística hasta finales de los años sesenta. Los acontecimientos sociopolíticos de aquella época se fusionaron con el mundo del arte de un modo excepcional, se convocaron asambleas para decidir qué se debía hacer, qué acciones tomar. Galeristas y conservadores de museos ofrecieron sus espacios para un uso político: distribución de información, protestas, anuncios, mítines. Y, sobre todo, se buscaron nuevos modos de representación al margen del arte institucionalizado.

De esta manera, las primeras experiencias de arte corporal se dieron casi simultáneamente a ambos lados del Atlántico a finales de los años 1960. Mientras en París, en plena resaca de Mayo de 1968, el crítico 
François Pluchart propagaba desde las páginas de Combat el concepto de arte sociológico y defendía la integración del cuerpo en el proceso creativo, Michel Journiac presentaba acciones en el curso de las cuales oficiaba el sacramento de la comunión con su propia sangre (Messe pour un corps, 1969). Al mismo tiempo, en Estados Unidos, artistas como Vito Acconci, Chris Burden, Bruce Nauman o Dennis Oppenheim empezaban a considerar el cuerpo como lugar y medio de expresión artística. Aquellas declaraciones que se centraban en éste como material y referente creativo llegaron a conocerse, posteriormente y de manera muy genérica, con un nombre: Body Art. ${ }^{1}$

En aquel embrionario movimiento convivían - sin apenas colisiones - el discurso cultural europeo con el norteamericano, entendiendo como característica fundamental del primero una actitud persistentemente escéptica respecto a las percepciones, lo cual llevaba inevitablemente tanto a la aceptación de un «yo» consciente que se relacionaba con los objetos, como a la consideración del lenguaje como un vehículo que validaba tal contacto. Las representaciones artísticas europeas llevaban implícitas una considerable dosis de pesimismo y escepticismo. En Norteamérica, por el contrario, a menudo dominaba un empirismo con cierto grado de ingenuidad que se sometía solamente a la supuesta evidencia de los hechos y que cuando se encontraba en dificultades convertía los vehículos de relación con los objetos en entidades mismas o los identificaba con el sujeto, para salir del paso más o menos airosamente. ${ }^{2}$

En la consolidación del arte corporal desempeñaron un papel decisivo la creación de dos revistas que contaron con una gran difusión: por una parte, la neoyorquina Avalanche y, por otra, la francesa arTitudes. Una consolidación que no habría sido posible sin la presencia de artistas corporales en foros, reuniones y múltiples actividades de gran resonancia,

${ }^{1}$ GUASCH, Anna Maria, El arte último del siglo XX. Del posminimalismo a lo multicultural, Madrid, Alianza, 2000, p. 81.

${ }^{2}$ GUASCH, Anna Maria, op. cit., p. 81. 
manifestaciones todas ellas que no sólo contribuyeron a fijar los significados culturales de las nuevas prácticas, sino a perfilar, a través de textos y manifiestos programáticos, su ideología.

Tras aquella euforia continuada en el terreno artístico durante prácticamente toda la década de los setenta, en las décadas posteriores las representaciones artísticas en las que se vinculaba el cuerpo como elemento matérico e ideológico de la obra desapareció casi por completo, de la misma manera que sucedió tras la Segunda Guerra Mundial. ¿Cuál fue el motivo fundamental por el que la propia fisicidad del o de la artista o colaboradores y colaboradoras fue relegada a un segundo plano? La razón es evidente: el fracaso de los ideales de los años 1960-1970.

Así, por una parte, muchos y muchas jóvenes que mantuvieron un activismo de pancarta comenzaron a ostentar cargos de poder; por otra, el VIH vino como anillo al dedo a la derecha más conservadora para utilizarlo como cortafuegos de una liberación sexual que comenzaba a ser respaldada por los sectores más tolerantes de la sociedad. Curiosamente, ya entrados en el siglo XXI, la utilización del cuerpo en el arte ha regresado con renovada fuerza gracias a la revisión que algunos y algunas artistas más jóvenes han realizado de todas estas prácticas.

\subsection{La escena estadounidense: el Body Work de Avalanch}

Los intelectuales de la vieja Europa pusieron sus relojes en hora con América y abandonaron Francia, su vieja madre. Desde el nuevo continente se dictaron las directrices de todos los cambios: costumbres, arte, política, etcétera.

Al mismo tiempo, el país en el que se originan todos estos cambios atravesaba una profunda crisis económica y social. Sus contradicciones internas eran cada vez mayores, sus presidentes denunciados y expuestos a 
la vergüenza pública, como Nixon. Las minorías oprimidas —étnicas, culturales o sexuales - clamaban por sus derechos y abandonaban el pacifismo que las caracterizaba sustituyéndolo por acciones con cierto carácter violento.

La cultura que América exportaba era fiel reflejo de aquella crisis, de aquel intento de mantener los valores más tradicionales -cómics de superhéroes que mantenían a raya a los peligrosos villanos del comunismo, duros cowboys que eran capaces de poner orden en una temida ciudad $\sin$ ley gracias al resurgimiento del más clásico cine del oeste o, incluso, la mitificación de las grandes estrellas hollywoodienses son, entre otros, sólo algunos de los más relevantes ejemplos. Como reacción contra los valores tradicionales surgió el underground, que englobaba múltiples movimientos contestatarios semiclandestinos. La parte cultural $-\mathrm{O}$ subcultural, o contracultural - de este underground, se propaló en su propio país invadiendo los más modernos medios de expresión —cine, música, literatura, pintura, teatro, etcétera- con mensajes corrosivos que impregnaban a intelectuales de todo el mundo.

William Burroughs, Jerry Rubin, Allan Watts, pensadores que - salvando las enormes distancias que median entre todos y cada uno de ellos - criticaron de manera virulenta la sociedad norteamericana, se convirtieron - por obra y gracia de la democracia y, no nos engañemos, por la necesidad comercial de lanzar nuevos productos al mercado- en los máximos exponentes de aquella misma sociedad y cultura.

La sociedad americana, en los albores de la era del consumismo, perseguía un ridículo y poco satisfactorio confort, dejando a un lado el verdadero bienestar individual y colectivo. Al mismo tiempo, el país emprendía absurdas guerras coloniales — como la de Corea- con el pretexto de defender la «libertad» contra el comunismo. Torturas raciales y maltrato a vagabundos y homosexuales convivían con un uso de la religión 
convertida en convención social y sin ningún valor espiritual. En definitiva, Estados Unidos empezaba a ganarse fama como país de pesadilla.

En este contexto, en Nueva York, los hermanos Mekas inventaban el cine underground, un cine casero, realizado con cámaras de 16 y hasta 8 mm., y cuyos actores eran amigos de los realizadores. A pesar de la pobreza de medios, se llegó a contar con obras verdaderamente importantes y que hoy tienen su espacio en todas las filmotecas del mundo, ya que de ahí salieron directores como Andy Warhol o Kenneth Anger. ${ }^{3}$

En el entorno educativo, la influencia de la disciplina de las Bellas Artes como carrera universitaria fue un factor primordial en la popularización de un emergente Body Art. Recordemos que en Estados Unidos la formación artística no entró en el sistema universitario hasta los años 60. Antes de aquellas fechas quien tuviera intención de formarse en este ámbito tenía que hacerlo en academias o talleres. El cambio tuvo lugar en el momento en que un modelo excesivamente elogiado como educación liberal ofrecida a cualquier ciudadano fue remodelado con la intención de instrumentalizar y producir nuevas élites tecnologizadas $-\mathrm{y}$ por tanto ampliamente «extensibles»-, un reflejo evidente de lo que entendemos como vanguardias estudiantiles.

El desarrollo de la educación artística, alejándose de un marco elitista de búsqueda de apreciación o disponibilidad del arte hacia la normalización como disciplina universitaria, adquirió dos formas muy diferenciadas:

- Como dimensión recreativa de la educación de estudiantes en disciplinas útiles para los sectores empresariales y militares, como la ingeniería.

3 VIDAL ESTÉVEZ, Manuel, "New American Cinema: el Underground", en MONTERDE, José Enrique y RIAMBAU, Esteve (coords.), Historia general del cine, vol. XI, Madrid, Cátedra, 1995, pp. 261-278. 
- Como sumidero para el alumnado incapaz de afrontar con éxito esos sectores.

Los nuevos programas de máster en artes plásticas (MFA) contribuyeron a legitimar el arte frente a un público más amplio, diseminando nuevos discursos academizables y creando un sistema de itinerarios —ambas cosas para obtener empleo en la educación superior como profesionales del ámbito.

Es innegable, por tanto, que los cambios que tuvieron lugar en la práctica artística de los años 1960 y 1970 afectaron al contenido de la educación artística a causa del «experimentalismo» de la época. La interdisciplinaridad y el trabajo multimedia, la fotografía, el conceptualismo, la performance, el vídeo y audio experimental encontraron su lugar en algunos departamentos de las facultades de Bellas Artes en los que mantenerse alejado del mercado seguía siendo el ingrediente primordial de la disciplina. Los estudios y la teoría crítica - facetas propias de la institucionalización de cualquier educación superior - se incorporaron a los requisitos necesarios para titularse en los departamentos de arte de las universidades, emulados por las propias escuelas. Eruditos y críticos estuvieron muy al tanto de las nuevas disciplinas, como la cultura visual y los estudios culturales, que abarcaban nuevas prácticas, y cuyas publicaciones proporcionaban interpretación, diseminación y más legitimidad.

Todo ello favoreció un ambiente propicio para que artistas, profesores y profesoras, intelectuales y demás figuras vinculadas a la expresión artística se unieran con el principal objetivo de dotar al arte de su valor fundamental: libertad.

A finales de los años 1960 y principios de 1970 el decadente barrio del SoHo, al sur de Manhattan, se convirtió en uno de los centros primordiales más activos de las actividades artísticas radicales. El ambiente se caracterizaba por una actitud compartida de experimentación, inmediatez 
y urgencia, siendo la principal preocupación el proceso de la realización de las obras. Existía un verdadero deseo de ampliar la definición de lo que se consideraba arte y de alterar la estructura establecida del mundo artístico. Cada vez más autores, movidos por la necesidad, tomaban el control de su propio contexto, creando espacios alternativos, explorando nuevos territorios más allá del objeto y la galería. Tengamos en cuenta que el discurso oficial americano estaba dominado casi exclusivamente por el canon greenbergiano, A su vez, la convicción de los postminimalistas de que la pintura había llegado a su fin debe ser vista sobre el fondo de esta situación. $^{4}$

Se ha escrito mucho sobre aquel período pionero del SoHo. Antes de que los edificios derruidos y las fábricas abandonadas al sur de Houston Street se transformaran en lo que es hoy una zona histórica, el barrio era un verdadero paraíso para los y las artistas que buscaban un sitio amplio, un alquiler bajo y un vecindario a quienes apenas le importara el ruido que se hiciera. Los locales del barrio eran espléndidos y ahí es donde residía su mayor atractivo. Además de ser unos lugares ideales para celebrar fiestas, también eran el laboratorio perfecto donde indagar en el terreno artístico y donde desarrollar un arte conceptual y fuertemente político. ${ }^{5}$

En abril de 1969, Gain Ground abrió por primera vez sus puertas en West 80th Street como foro para el intercambio verbal y visual con una primera exposición que presentaba a artistas tales como Vito Acconci, Dan Graham, Robert Newman y John Perrault, entre otros. En el mismo año, en la calle 23, Billy Apple inició una alternativa independiente y experimental para la presentación de obra propia y de otros y otras artistas. Toda esta creciente actividad creó nuevas posibilidades para que más artistas realizaran obras y abrieran las puertas de sus espaciosos lofts para comenzar

${ }^{4}$ DISERENS, Corinne, "Los años de Greene Street", en el catálogo de la exposición Gordon Matta-Clark, Valencia, IVAM, 1992, p. 11.

${ }^{5}$ MORRIS, Catherine, "Food: el contexto", en el catálogo de la exposición Comer o no comer. O las relaciones del arte con la comida en el siglo XX, Salamanca, Centro de Arte de Salamanca, 2002, p. 128. 
a construir una red de apoyo mutuo entre ellos. Las amistades y relaciones que fueron tejiendo los y las artistas que se instalaron en la zona fueron la base de todas las actividades. Una atmósfera que rebosaba actividad social y en la que se combinaba lo personal, lo creativo y lo intelectual fomentó el surgimiento de nuevas ideas sobre cómo vivir, crear y mostrar arte. ${ }^{6}$

Animada por Gordon Matta-Clark —una de las personas que más contribuyó al ambiente de libertad que se respiraba en aquella época- la bailarina y fotógrafa Caroline Gooden invirtió toda su herencia y más de dos años en construir un restaurante totalmente regido por artistas en el epicentro artístico del SoHo. Su objetivo era crear un restaurante que cada noche sirviera una comida diferente ${ }^{7}$ y posibilitar un lugar de trabajo para artistas que no tuviera restricción alguna en lo que respecta a la cantidad de horas al día o de días a la semana que trabajara el o la artista, de modo que pudiera dejarlo según sus necesidades y volver en cuanto quisiera. Fue un éxito en todos los sentidos, se organizaban performances y se hacía «teatro de la comida». Food — constantemente anunciada en Avalanch, una importante revista dedicada al arte a la que dedicaremos un breve espaciosirvió de apoyo a, nada más y nada menos, unos trescientos artistas. Food fue un proyecto artístico, económico y político engendrado por artistas, una crítica radical de la cultura en su dimensión artística cuya evolución fue paralela a la revista Avalanch y al 112 Greene Street. Asimismo, fue la fórmula a una necesidad de transformar el mundo del arte: Food existía sólo donde ya no cabía hablar de fronteras entre las necesidades pragmáticas de los seres humanos y la creación de obras de arte. ${ }^{8}$

\footnotetext{
${ }^{6}$ DISERENS, Corinne, op. cit., p. 11.

${ }^{7}$ Una de las cenas más nombradas, que los domingos por la noche reunían en el restaurante Food a gentes del mundo del arte, fue preparada por Matta-Clark. Estaba compuesta por camarones vivos en salmuera servidos en huevos cocidos previamente vaciados. Según narra Carolina Gooden, aquella comida despertó reacciones maravillosas, algunos gritaban al ver el camarón moverse en el huevo que tenían delante, otros simplemente se levantaban y se iban. Cit. en MORRIS, Catherine, op. cit., p. 133.

${ }^{8}$ MORRIS, Catherine, op. cit., p. 128.
} 
Otra persona que no pudo resistirse al imán del buen ambiente artístico fue el artista Jeffrey Lew, amigo íntimo de Gordon Matta-Clark, un carismático personaje hiperactivo que sentía la necesidad de cambios radicales en el proceso artístico — creación y exhibición. En una entrevista en la revista Avalanch el artista proclamaba: «[...] it's time for action and clear thinking. There was once a time for being chaotic and letting yourself completely freak out. Now I just don't feel that way. I feel like getting it together $[\ldots]$ things which make you an artist can make you a revolutionary, can make you change your own environment». ${ }^{9}$

En 1970, un edificio de su propiedad situado en el número 112 de Greene Street se convirtió en el taller que acogió las aventuras artísticas más experimentales. El local pasó a ser la base de las primeras obras experimentales de creadores, bailarines, músicos y performers. «We didn't think of it as an alternative space at the time. We just wanted to get our work out and it was fantastic to have a place that wasn't pristine, that we could knock around in $[\ldots] \gg{ }^{10}$

La inagotable energía de Lew y su radicalismo a la hora de entender la creación y la forma de exponer arte eran de lo más interesantes. El hecho de que el espacio — bautizado como 112 Workshop — ${ }^{11}$ fuera de su propiedad brindó a un buen número de artistas la oportunidad de entregarse por completo a sus creaciones. Lew apenas puso restricciones para su utilización, en parte, decía, porque nadie le hacía caso. Lew brindaba el único sistema artístico socialista existente por entonces en Nueva York.

A pesar de la resistencia que mantuvo Jeffrey Lew, la creciente popularidad del barrio — boutiques, restaurantes caros, población de alto

\footnotetext{
${ }^{9}$ Cit. en BRENTANO, Robyn y SAVITT, Mark (eds.), 112 Workshop / 112 Greene Street, New York, New York University Press, 1981, p. 7.

${ }^{10}$ BRENTANO, Robyn y SAVITT, Mark (eds.), op. cit., p. 7.

${ }^{11}$ El nombre 112 Workshop fue creado cuando el espacio se incorporó oficialmente al mundo del arte. La cuestión de si era una galería o un taller importaba a quienes veían el sistema como una fuerza mortal en el proceso creativo. Véase BRENTANO, Robyn y SAVITT, Mark (eds.), op. cit., p. 9.
} 
nivel adquisitivo - unida a la presencia de los marchantes de arte en busca de nuevos y nuevas artistas, acabaron por romper la libertad de la que gozaron a principios de la década de los setenta. La mayoría de artistas ya no podían pagar las astronómicas rentas que los propietarios de los lofts cobraban a sus inquilinos.

No obstante, hacia el verano del año 1968 había ocurrido otro hecho fundamental. El artista Graham Stevens, durante la exposición Air Art organizada por Willoughby Sharp, solicitó a su amiga Liza Bear que recuperara uno de sus films para exhibirlo posteriormente en Londres. Unos días en Nueva York bastaron a Bear para que enviara aquella grabación por correo y vendiera su billete de vuelta. Existían razones de peso para quedarse. W. Sharp era una mina de información, poseía una monstruosa colección de libros, catálogos y revistas especializadas en el arte del siglo $\mathrm{XX} \mathrm{y}$, curiosamente, ordenadas de manera meticulosa por orden alfabético. $^{12}$

En un segundo encuentro, meses más tarde, Willoughby y Liza -que entonces contaba con 26 años y W. Sharp con seis más- decidieron crear una revista capaz de tratar las nuevas formas artísticas. Ambos poseían una considerable experiencia en edición. Sharp había estudiado historia del arte y trabajaba como free-lance organizando exposiciones y produciendo catálogos. Bear, de padres franceses — aunque su educación se desarrolló principalmente en Inglaterra - comenzó su carrera de periodista profesional en Fleet Street, centro de la prensa londinense. ${ }^{13}$ Pronto abandonó aquel ambiente convencional para unirse a la contracultura de las revistas alternativas que afloraron durante la década de los años 60 y que entonces gozaban de un momento álgido.

\footnotetext{
${ }^{12}$ BEAR, Liza y SHARP, Willoughby, "Le body art \& Avalanche: New York 1968 1972", en el catálogo de la exposición L'art au corps. Le corps exposé de Man Ray à nos jours, Marseille, Mac-galeries contemporaines des Musées de Marseille, 1996, p. 89.

${ }^{13}$ BEAR, Liza y SHARP, Willoughby, op. cit., pp. 89-90.
} 
Como hemos visto, en aquella época el mundo artístico neoyorquino - igual que la mayor parte del mundo cultural - estaba marcado por una exuberancia y una actividad francamente febril. La radical innovación en todos los principales dominios artísticos exigía una nueva aproximación por parte de los mass media. Un apartamento de muros blancos en la East 20th Street sirvió como base de operaciones para el lanzamiento de la revista Avalanch, además de servir como vivienda y lugar cotidiano de trabajo. Los estrechos lazos que mantenía W. Sharp con varios artistas gracias a sus múltiples viajes a Europa, aseguraron una importante circulación de información. En el mismo instante en el que emergió la noticia de la creación de una revista dedicada a la creación artística, se fundaron amplias expectativas aumentando considerablemente el interés. De hecho, los autores y autoras enviaron abundante documentación fotográfica sobre su trabajo. Entre las contribuciones más destacadas y, en cierto modo espontáneas, podríamos citar las de Vito Acconci y William Wegman, incluso las de Terry Fox, un artista de San Francisco. ${ }^{14}$

La primera entrevista, realizada en diciembre de 1968, contó con la figura de Carl André. Sin embargo, a pesar de todos lo esfuerzos de Sharp y Bear, no fue hasta octubre de 1970 el momento en el que Avalanch se aseguró los servicios de una gran distribuidora nacional. La revista apareció en los kioscos más importantes de Estados Unidos, encontrándose también disponible en las capitales europeas de más proyección artística. A pesar de la ausencia de promoción en su estreno, el $72 \%$ de los tres mil ejemplares editados fueron vendidos según el distribuidor. Pronto obtuvo un beneplácito publicitario incondicional suministrado por la mayor parte de galerías y personalidades del mundo artístico. La revista contenía entrevistas realizadas por los editores, una columna titulada Rumbles en la que se reseñaban los acontecimientos más relevantes del mundo del arte, noticias comentadas sobre performances, inauguraciones y publicaciones novedosas, y páginas personales de artistas. ${ }^{15}$ Rápidamente la revista se vio honrada con

\footnotetext{
${ }^{14}$ BEAR, Liza y SHARP, Willoughby, op. cit., p. 90.

${ }^{15}$ BEAR, Liza y SHARP, Willoughby, op. cit., p. 90.
} 
los rostros más importantes del arte conceptual de finales de la década de los sesenta y principios de la de los setenta, entre los que cabe destacar a Vito Acconci, Joseph Beuys, Barry Le Va, Bruce Nauman, Yvonne Rainer, Robert Smithson, William Wegman y Lawrence Weiner.

Avalanche I - un número dedicado al Earth Art - fue impreso sobre papel glacé de alta calidad y en un formato cuadrado (24 x $24 \mathrm{~cm})$. Los ocho primeros números de un total de trece, mantuvieron estas mismas dimensiones hasta que en 1974 el coste del papel aumentó considerablemente a causa de la inflación. La cubierta de ese primer número se apoyaba en una foto de Joseph Beuys. En el interior se presentaban los primeros trabajos de Land Art: de Richard Long a la obra-proceso de Robert Morris. En dos entrevistas diferentes, una a Carl André y otra a Jan Dibbets, ambos precisaban su postura en referencia a la fabricación de la obra y su entorno. Todo ello fue expuesto en una mesa redonda que contaba, entre otros, con Michael Heizer, Robert Smithson y Dennis Oppenheim, este último anticipó por aquellos años la unión entre Land Art y Body Art. ${ }^{16}$

El artículo titulado Body Works trató de actividades donde el artista se utilizaba a sí mismo como material escultórico. Avalanch I divulgó de este modo el tema de su próximo número y percibió la aparición de una tendencia novedosa totalmente libre. Proponía nuevas maneras de mirarse a sí mismo. Aquel estudio de cuatro páginas enumeraba algunas de aquellas primicias: «el cuerpo como útil» (Barry Le Va), «el cuerpo como lugar» (Vito Acconci, Dennis Oppenheim), «el cuerpo como telón de fondo» (Bruce Nauman, William Wegman), «el cuerpo como objeto» y «el cuerpo como presencia en su devenir cotidiano». ${ }^{17}$

Para Willoughby Sharp el Body Work representaba un paso más hacia la «extensión» de la escultura-objeto, cuya relación con el arte figurativo no podía ser más que irónica. En el trabajo corporal, las ideas

\footnotetext{
${ }^{16}$ BEAR, Liza y SHARP, Willoughby, op. cit., p. 92.

${ }^{17}$ GUASCH, Anna Maria, op. cit., p. 92.
} 
preconcebidas sobre las maneras de ser se ponían en cuestión y se exploraban, a menudo con un desenfadado sentido del humor. Las acciones realizadas directamente sobre el cuerpo no pretendían desfigurar al autor, tampoco embellecerlo. A diferencia de lo que podemos leer en la mayoría de textos que tratan de clasificar los movimientos más contemporáneos, las nuevas representaciones artísticas podían también ser consideradas como una reacción al arte conceptual que trataba de ignorar la dimensión de la experiencia a través de la escultura. ${ }^{18}$

Además del texto, la revista incluía un completo anexo de ocho páginas con entrevistas, textos escritos por los propios artistas y documentos sobre su trabajo — nada de interpretaciones escritas sobre éstos. Para muchos autores y autoras, aquella publicación en Avalanch fue su primera aparición pública, incluso llegó a ser un acto previo al que se recurría frecuentemente antes de participar en una exposición. La voz del o de la artista bien definida y auténtica se mostraba en la revista neoyorquina - marcada por cierta inocencia - a través de diálogos o conversaciones que iban al fondo de la práctica artística, sin caer en las habituales entrevistas de celebridades. Se abría, así, un género de investigación-reportaje cuya meta fue fijada en la comprensión más que en la exposición, ya que la voz que interroga está de acuerdo con la sensibilidad del artista, sin caer en la presuntuosidad o en la estupidez. ${ }^{19}$

El trabajo era tan novedoso que los métodos de presentación debían estar a la altura. En lugar de adoptar una estética estándar, los anexos dedicados a los y las diferentes artistas eran concebidos individualmente. Avalanch incluyó importantes dossiers de fotos y una aproximación cinematográfica con secuencias, planos y ángulos con la finalidad de mostrar el trabajo de elaboración más que el resultado final al cual solemos estar habituados. Esta aproximación de la imagen y del texto, centrada en el proceso de creación, fue dictada por las obras, las cuales se presentaban en

\footnotetext{
${ }^{18}$ Cit. en BEAR, Liza y SHARP, Willoughby, op. cit., p. 90.

${ }^{19}$ BEAR, Liza y SHARP, Willoughby, op. cit., p. 98.
} 
un principio y casi siempre en forma fotográfica. El hecho de que el lector o lectora tuviera en sus manos la representación de un objeto en tres dimensiones y que su progresión de una página a otra se inscribiera en el tiempo fue parte integrante del concepto base.

Avalanch 2, un número doble de 144 páginas, apareció en abril del año 1971 presentando el trabajo de Bruce McLean de Inglaterra, Klaus Rinke de Alemania, Terry Fox de San Francisco y William Wegman. Aparecía también una larga entrevista con Bruce Nauman y fotografías de su instalación en la State University de San José, tomadas por Gianfranco Gorgoni. Sharp entrevistó al artista por teléfono para Ars-magazine, sin embargo, el encuentro para Avalanch tuvo lugar en directo durante una emisión de televisión. En ella, Nauman hablaba de su implicación en la conciencia del cuerpo.

Los locales con los que fue agenciándose Avalanch estaban situados a cuatro calles del centro de operaciones del mundo del arte: Max's Kansas City, entre East 17th Street y Park Avenue South. Max's, un bar administrado por Mickey Ruskin, había sido montado gracias al apoyo de Forrest Myers — artista vinculado a los Site Specific Objects y a la tecnología - que se dio a conocer en aquel lugar por la presentación de un láser. The Factory acababa de instalarse prácticamente en frente de Max's, y todas las noches Andy Warhol y compañía hacían una provocativa y espectacular entrada. En aquella época, Warhol lanzaba su propia revista, Interview, que posteriormente colaboró en algunas ocasiones con Avalanch. En 1968, Max's era el único lugar donde entraban en contacto diferentes mundos culturales — artes plásticas, rock, teatro, literatura, etcétera. Artistas de todas las tendencias, escultores postminimalistas, conceptuales e, incluso, expresionistas desarrollaban interminables debates sobre arte en una gran mesa situada al fondo del local. ${ }^{20}$

${ }^{20}$ BEAR, Liza y SHARP, Willoughby, op. cit., pp. 89-105. 
Lamentablemente, aquellos supuestos círculos radicales de intelectuales continuaban - como reiteradamente sucede en la Historia del Arte - ignorando el trabajo de mujeres, como los que en aquella época realizaban artistas como Joan Jonas o Carolee Schneemann, autoras que trabajaban desde hacía tiempo en el contexto de la danza y el vídeo arte, prestando una considerable atención al cuerpo. Ciertamente existía un importante grupo de escultoras que realizaban construcciones a gran escala y obras conceptuales, como era el caso de Jackie Winsor, Jackie Ferrara, Sarah Charlesworth, Brenda Miller o Mary Miss, sin embargo, las anatomías expuestas en todo su detalle eran en general masculinas (y de raza blanca).

¿Acaso se piensa que en aquella época las artistas mujeres no tenían un interés particular de atraer su atención hacia el cuerpo, vestido o no, maquillado o sin maquillar? Si la humanidad, en tanto que individuos, no se centraba en el cuerpo de las mujeres, ya se encargaba de eso el ambiente cultural más popular, la sociedad de consumo - los cuerpos de las mujeres representaban los sex-symbols y eran utilizados para vender cualquier producto. Probablemente, las mujeres querían concentrar su atención sobre su cabeza y sus manos, y hacer de este modo que su trabajo fuera visto y comprado.

Afortunadamente, hacia el fin de la década, gracias a la explosión de la consciencia feminista, apareció un signo irrefutable indicando que el movimiento había aterrizado verdaderamente. En Max's llegó a sentirse la voz femenina: «El de Max’s era un ambiente artístico, repleto de conciencia artística y conciencia de la propia conciencia artística. El mero hecho de entrar en el Max's ya suponía quedar absorto en la conciencia colectiva de la propia conciencia artística, bien como objeto, bien como colaborador. Yo no quería verme absorbida como colaboradora, porque eso significaría que mi propia conciencia se habría visto apropiada y modificada por la de los demás; significaría permitir que mi conciencia pudiera verse influida por las percepciones que otras personas tienen del arte y poner en evidencia mis 
percepciones del arte ante la conciencia de dichas personas, y yo no quería que eso sucediera. Siempre he sido muy individualista. Mi solución consistió en privatizar al máximo mi propia conciencia y privarla de aportes sensoriales de dicho entorno; aislarla de cualquier estímulo táctil, auditivo y visual. Al hacerlo, me presenté en aquel espacio como un objeto pasivo, secreto y silencioso, aparentemente dispuesto a ser absorbido como objeto en sus conciencias. Sin embargo, me di cuenta de que el ensimismamiento completo era imposible, ya que mi pasividad voluntaria a modo de objeto implicaba una elección, una actividad agresiva, una presencia independiente cuya autonomía chocaba con aquel ambiente artísticamente concienciado. Mi condición de objeto se convirtió en mi condición de sujeto». ${ }^{21}$

\subsection{Europa y $L$ 'art corporel de François Pluchart}

Creador y redactor jefe de la revista arTitudes, François Pluchart es el ejemplo más evidente de crítico comprometido con la defensa del arte contemporáneo $\mathrm{y}$, especialmente, con la de quien inventa el soporte y los medios. Fue uno de los primeros teóricos que definió qué era el arte corporal, organizando las primeras exposiciones de este tipo de manifestaciones artísticas. De hecho, en 1971, siendo aún colaborador artístico de Combat, fundó la revista arTitudes que durante siete años se convirtió en lugar no sólo de encuentro de las diversas expresiones de arte corporal que se generaban tanto en Europa como en Estados Unidos, sino también en medio de reflexión global sobre las experiencias de los años 1960.

La publicación consiguió hacerse un considerable hueco en aquellos años como modelo de revista artística, aunque pronto cimentaría su propio espacio de influencia: el arte corporal. En sus páginas reflejaba la crisis de

\footnotetext{
${ }^{21}$ PIPER, Adrian, “Untitled Performance for Max's Kansas City”, en el catálogo de la exposición Adrian Piper. Desde 1965, Barcelona, MACBA, 2003, p. 33.
} 
las omnipresentes producciones pictóricas de la escuela de París. arTitudes sobrevivió ininterrumpidamente de 1971 a 1977. Desde 1972 su imagen fue rediseñada cambiando su título originario por el de arTitudes international y fue editada en Saint-Jeannet, cerca de Niza, alcanzando una tirada de 8000 ejemplares en un formato de $21 \times 29 \mathrm{~cm}$.

Fue durante estos incipientes años cuando apareció el término «art corporel sociologique-critique». El concepto art sociologique fue empleado de manera inicial en 1968 durante la primera exposición de Michel Journiac, mientras que el concepto art corporel lo hizo a comienzos de los años 1970. Los escritos de François Pluchart, al igual que su trabajo editorial, siguen hoy vigentes gracias a su anticipación, a su lucidez precoz en cuanto a la evolución de las prácticas contemporáneas y a la fiabilidad de las elecciones, puramente artísticas (Acconci, Dan Graham, Michel Journiac, Dennis Oppenheim...), literarias (Guyotat), cinematográficas o musicales (la escena underground como extensión de la escena artística).

\subsubsection{Manifeste de l'art corporel}

Fue el propio F. Pluchart quien en 1975, el mismo año en el que se presentó en Estados Unidos la primera exposición de trabajos en y sobre el cuerpo, reunió en la Galería Stadler de París el trabajo de veinte artistas, entre ellos Burden, Bruce, Duchamp, Gilbert \& Georges y Nitsch. En el catálogo se publicó un primer manifiesto - datado el 20 de diciembre de 1974 - sobre arte corporal en el cual se proponía distinguir lo que era arte corporal de lo que no era: «Ce qu'il est, ce qu'il n'est pas». ${ }^{22}$

En el breve texto se reconocía el papel del cuerpo como eje fundamental de toda creación - y aproximación - artística. Para Pluchart, el placer, el sufrimiento, la muerte y/o la enfermedad dejan huella en él

${ }^{22}$ GUASCH, Anna Maria, op. cit., p. 92. 
esbozando a un individuo socializado capaz de satisfacer todas las exigencias y apremios del poder en cada momento, de este modo, ninguna persona escapa de esta opresión. Después de haber cuestionado la pintura y renunciar a su componente estético - lo cual ya hicieron anteriormente dadaístas y constructivistas capitaneados por Duchamp y Malevich, tras la provocación intelectual que supusieron las acciones de Duchamp (su tonsura en forma de estrella, 1919) — sólo restaba abrir las vías de desarrollo del happening y del arte de comportamiento, trayectos en los que artistas como Manzoni y Klein liberaron, tal y como hemos visto, a la pintura de sus ancestrales servidumbres para transformarla en instrumento de acción social y en arma de combate.

Según el teórico francés, el arte corporal no era en ningún caso una nueva receta artística destinada a inscribirse en una historia del arte fracasada. El arte corporal era exclusivo, arrogante, intransigente y no mantenía relaciones con ninguna forma supuestamente artística si de entrada no se declaraba sociológica o crítica. Éste derribaba, rechazaba y negaba la totalidad de los arcaicos valores estéticos y morales inherentes a la práctica artística, ya que la fuerza del discurso debía reemplazar a cualquier otro presupuesto del arte. Así, por primera vez en la historia occidental, una actitud de pensamiento no deseaba ser una tendencia abierta, sino al contrario, quedar cerrada sobre sus imperativos como una comunidad cuya única razón de existencia residía en acoger a los nuevos creadores y creadoras que trataban de construir una sociedad libre y harmoniosa, libre de falsas morales, de dictadores, de ideologías represivas y de censuras. ${ }^{23}$

${ }^{23}$ PLUCHART, François, "Manifestes de l'art corporel", en el catálogo de la exposición L'art au corps..., op. cit., p. 474. 


\subsubsection{Deuxième manifeste}

En 1977, con motivo de una exposición de arte corporal (L'art corporel) celebrada en la galería Isy Brachot de Bruselas, François Pluchart publicó un segundo manifiesto - París, 31 de enero de 1977- que puso el acento en la construcción de un lenguaje artístico fruto de la reflexión y del pensamiento filosóficos. En él se establecían cuatro etapas, muy desiguales en su arco cronológico, que antecedían al arte corporal.

En la primera de ellas, Le dérèglement du beau, comprendida entre 1870 y 1960, se ponía el énfasis en aquellas figuras que como el conde de Lautréamont, Stéphane Mallarme, Antonin Artaud y Georges Bataille en el terreno literario, y Malevich y Duchamp, en el plástico, crearon un lenguaje individual y social al margen de los criterios artísticos y estéticos tradicionales. Para Pluchart, las viejas estructuras se hundían sistemáticamente en una estética ruinosa, una belleza encargada de acotar los límites impuestos y que se hallaba epistemológicamente muerta. Sobre los escombros de la palabra, el delito de la pintura, el desmoronamiento del relato y la centralización del poder político, observa cómo una serie de artistas trataron de instaurar un lenguaje capaz de fundar un nuevo discurso tanto individual como social. Entre todas estas afirmaciones, el arte corporal se configura como elemento constitutivo del lenguaje contemporáneo.

En una segunda y breve etapa, Dérives $d u$ happening, iniciada en 1965, Pluchart nos menciona cómo el grupo Fluxus fue capaz de incitar a una serie de artistas a abrir la brecha que permitiría reconducir el cuerpo y rebatir las carencias del happening, incapaz de liberar la energía del lenguaje. Asimismo, establece los puntos de anclaje del arte corporal: Marcel Duchamp restaura la primacía mental de la obra de arte utilizando su cuerpo como lugar de discurso -Eau de voilette, Tonsure-; Pierre Molinier reabsorbe el producto artístico bajo las vivencias de una globalidad hermafrodita; Yves Klein, perseguido por la obsesión de capturar la sensibilidad inmaterial, evoluciona del monocromo al pincel vivo; y Piero 
Manzoni pasa del ácromo a Merda d'artista en un intento biológico de ser liberado.

Este segundo epígrafe es concluido con cuatro artistas que conformaron el Accionismo vienés. Éstos supieron transgredir el estancado esquema del happening derivando su acción sobre el cuerpo más primario. Los tabúes que durante siglos habían bloqueado toda comunicación no lingüística fueron fuertemente arremetidos. Hermann Nitsch ritualizó lo sagrado; Günter Brus puso al descubierto ciertas constantes eróticosexuales; Otto Mühl reveló lo que políticamente destruía la coherencia espacial del individuo y Rudolf Schwarzkogler circunscribió las componentes de la morfogénesis individual. Aquellos rituales de sangre y muerte plantearon nuevos porqués, nuevos brotes de ambigüedad. Lo que en 1965 era la causa del trabajo de estos artistas vieneses, se reencuentra, en cierta manera, en la obra de autores y autoras como Carolee Schenemann. ${ }^{24}$

La tercera etapa, denominada L'action corporelle (1970), comprendía aquellos artistas, tanto norteamericanos - Oppenheim, Acconci y más tarde Burden - como europeos - Journiac y Pane, a los que les siguieron Lüthi, Ontani, Pisani o Castelli entre otros-, que utilizaban el cuerpo como material artístico. Se trataba de definir con propiedad el carácter del nuevo discurso que de ello derivaba, es decir, de aquellos para los que el cuerpo era lugar algebraico de las componentes biológicas, pero también tópico último y lugar de encuentro irreductible del discurso a la vez fundador y fundado en el cual se ubicaba el lenguaje que se involucraba en la vieja ontología y que, al mismo tiempo, pretendía establecer una nueva definición del ser humano. ${ }^{25}$

La cuarta de las secuencias temporales apuntadas en el manifiesto bruselense, Le langage (1975), alude al momento en que la expresividad corporal rechaza el exhibicionismo, la pornografía, el masoquismo y la

\footnotetext{
${ }^{24}$ PLUCHART, François, op. cit., p. 475.

${ }^{25}$ PLUCHART, François, op. cit., p. 475.
} 
imagen por placer - aunque es cierto que cualquiera de estas nociones pueda ser liberadora en determinadas situaciones - en aras de un nuevo lenguaje expresivo universal que pudiera funcionar/jugar en todos aquellos terrenos en los que el arte se mide, incluyendo el del cuerpo. Para Pluchart, el trabajo de los grandes representantes del arte corporal es, de hecho, una producción no lingüística que lucha contra la mecánica politizada y socializada siendo el cuerpo objeto de placer, sufrimiento, mutilación, destino biológico y receptáculo transformador de su universo. Los desórdenes poéticos de Acconci, las heridas abiertas en el cuerpo de Pane, las tentativas de «comunión con el otro» de Journiac, el travestismo de Lüthi y el de Klauke, el travestismo mítico-ontológico de Ontani y Pisani, la autoagresión y las vivencias personales de los destinos esenciales de la época (ejecuciones legales, accidentes y poder tecnológico de Burden, entre otras expresiones) formaban parte del ejercicio de definir el ser humano del futuro en tanto que éste se definía como lenguaje. ${ }^{26}$

\subsubsection{Troisième manifeste}

Desde 1977 hasta 1980, año en que François Pluchart fecha en Niza un 24 de diciembre el último manifiesto de arte corporal, se multiplican las exposiciones sobre el cuerpo, tanto como lo hacen los seminarios, coloquios y simposios que debaten la cuestión. En la nueva - y última - declaración programática, el crítico y teórico francés establece una reflexión sobre el papel desempeñado por el arte corporal en las vanguardias, afirmando que éste emergió en el seno de una serie azarosa de vanguardias falsificadas. El arte se había quedado anquilosado como actividad caduca, una práctica completamente elitista y mundana que marcaba la rivalidad entre las personas. De este modo, cohabitaban dos puntos de vista irreductibles: el decorativo (representación del mundo, imágenes de lo divino y lo sagrado,

${ }^{26}$ PLUCHART, François, op. cit., pp. 475-476. 
estratificación social) y el discursivo (desalienante y provocador). Es en este segundo grupo donde se situaba el arte corporal.

Prácticamente doce años después de las primeras acciones corporales - Hermann Nitsch y el grupo de Viena, Michel Journiac, Vito Acconci y, poco más tarde, Gina Pane y Chris Burden- las cuestiones plásticas que perduraban cayeron en la trampa de un sistema burocrático, la más sofisticada, la más insidiosa y la más actual forma de dominio. ${ }^{27}$ Queda claro que para Pluchart la única escapatoria reside en el cuerpo, inalienable a toda noción de vanguardia, destino esencial, lugar común donde se resuelve el sufrimiento, la muerte, el júbilo, lo sagrado. El cuerpo es simultáneamente carne socializada y nido de sarcasmo.

El arte corporal basaba su discurso en el cuerpo, reclamaba su derecho a existir en su totalidad. Denunciaba los determinismos, los desórdenes, la tortura y todas las formas de condena a muerte. Enunciaba el deseo y las consecuencias políticas y culturales del rechazo con Hermann Nitsch y los artistas vieneses interrogando los rituales; los mecanismos sociales con Michel Journiac; los determinismos colectivos con Gina Pane; el condicionamiento del cuerpo con Acconci; la multiplicidad con Urs Lüthi; la destrucción con Burden; la mutilación con Peter Stembera y los artistas de la antigua Checoslovaquia; el travestismo con Castelli, Ontani o Jurgen Klauke. El discurso del arte corporal era una propuesta existencial en lo más profundo del ser, ya que proclamaba la violencia del deseo y el furor de la vida, la dulzura y el sentimentalismo. ${ }^{28}$

A su vez, funcionaba en el interior del par sexo-lenguaje. El sistema se encargaba de canalizar, humillar, culturizar la sexualidad, procedente en su totalidad del cuerpo. De este modo, se engendraba frustración, rechazo, agresividad, tortura, guerra, etcétera. Paralelamente, el lenguaje, encargado de fundar el funcionamiento mecánico del cuerpo, actuaba como un código

\footnotetext{
${ }^{27}$ PLUCHART, François, op. cit., p. 477.
}

${ }^{28}$ PLUCHART, François, op. cit., p. 477. 
descalificado y saturado ontológicamente, con un sentido arbitrariamente preestablecido. Tras diez años de arte corporal, François Pluchart creía necesario afirmar su función crítica y sociológica. No tenía nada que ver con una sociología del arte e interrogaba el funcionamiento de la sociedad. El arte corporal no era un producto de la belleza, del sentido, del arte, sino del lenguaje: un lenguaje inédito y no codificado que, rechazando la historia y su mitología, el sentido y la razón, era capaz de hablar del cuerpo. ${ }^{29}$

Como hemos visto, el Body Art se desarrolló en una situación aparentemente paradójica: por una parte, vivió un fuerte impacto popular; por otra, sufrió una ocultación del mecanismo museográfico y mercantilista, siendo víctima del rechazo general por parte del arte y la política. Sin embargo, no todos los y las artistas que reivindicaron - tanto en Estados Unidos como en Europa - el cuerpo como nuevo material y soporte - ya fuera físico, psíquico o vital - lo hicieron de similar manera. Aunque no existan diferencias extremas entre artistas europeos y norteamericanos sí puede decirse que los primeros tendieron a utilizar el cuerpo objetualmente y a plasmar sus creaciones a través de las fotografías, notas y dibujos, es decir, mediante «documentos estáticos»; los norteamericanos, por el contrario, dieron prioridad a la acción o performance $\mathrm{y}$, por tanto, a cuestiones como la percepción y el comportamiento del público y la temporalidad de la obra. En este caso, los documentos que hacen referencia a tales acciones son principalmente «documentos dinámicos» como los filmes y los vídeos.

También habría que resaltar el hecho de que los y las artistas estadounidenses partieron por lo común de conceptos de creación artística próximos al Minimal y al Conceptual — de ahí que en ocasiones se les considere conceptual performers o minimal performers - y que los europeos y europeas, sin duda influidos e influidas por los accionistas vieneses, realizaron trabajos corporales en los que predominaban los

${ }^{29}$ PLUCHART, François, op. cit., p. 477. 
aspectos dramáticos, masoquistas y sadomasoquistas no ajenos, por otra parte, a las relecturas de Sigmund Freud.

De lo que no cabe la menor duda es que frente al cuerpo surge lo social, mecanismo encargado de rechazar su existencia y de reproducir seres idénticos, sacrificando el componente corporal en una normatividad y negando el placer en pro del orden establecido. Hoy en día, ningún tipo de sociedad es capaz de escapar a este constante insulto hacia el cuerpo. El arte corporal se presentó como el primer remedio para combatir la enfermedad social puesta en evidencia por los desórdenes políticos y culturales del Mayo francés, y como la más contundente y violenta reacción contra el establishment que, conscientemente o no, era el responsable de poner el mundo al revés, un mundo que en lugar de dar vida, esclaviza, mutila y castra al ser humano. 



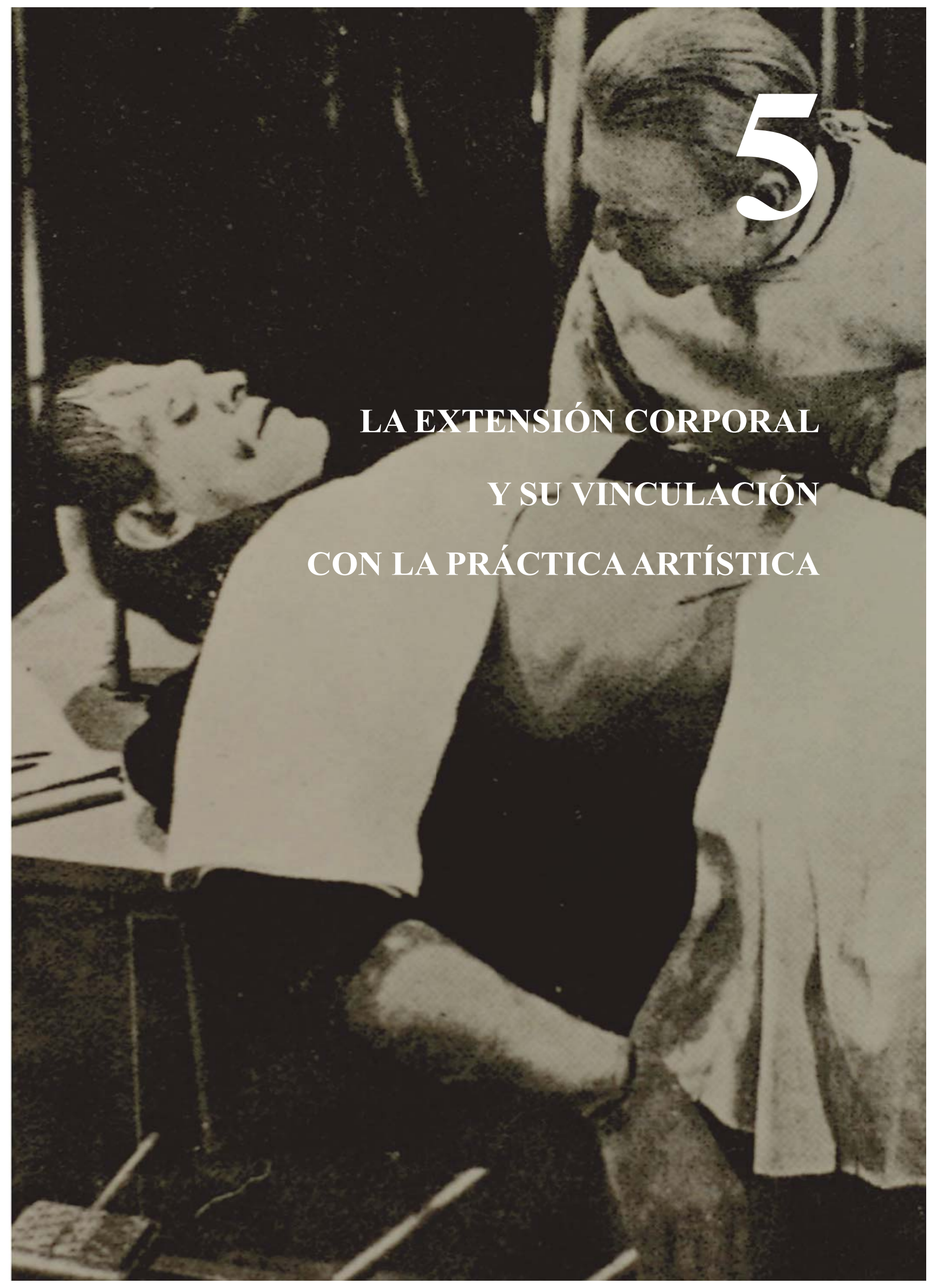



«Modelamos nuestras herramientas y luego éstas nos modelan a nosotros».

Marshall McLuhan

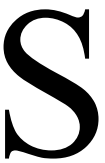

in profundizar en las cuatro diferenciaciones que François Pluchart estableció en su segundo manifiesto sobre el arte corporal y reconociendo - en su tercer manifiesto - éste como deudor directo de las vanguardias artísticas del siglo $\mathrm{XX}$, el Body Art, grosso modo, asimilaba la utilización del cuerpo como eje elemental de toda creación artística. Entendía el contexto social y cultural como una superficie sobre la que se forjaba a un individuo socializado y sometido a las exigencias de un poder capaz de engullirnos y del cual era imposible escapar. El Body Art fue, esencialmente, un modo de expresión que pretendía alejarse de toda corriente que no se declaraba crítica y, su principal objetivo, residía en construir una sociedad libre y armoniosa, excluida de toda ideología represiva.

Sin embargo, tras haber acotado y analizado los aspectos teóricos y el campo de acción que definieron el Body Art, conviene que abordemos dos cuestiones: ¿qué entendemos por «extensiones corporales» dentro de este contexto?, ¿qué artistas las utilizaron y con qué finalidades? 
Quizás el siglo XXI sea recordado como la época del cyborg, ${ }^{1}$ de la identidad como puro artificio $\mathrm{y}$, consecuentemente, la cuestión más inevitable de nuestra época sea la del reto de la representación de una subjetividad no esencialista. Desde que fuimos homínidos y desarrollamos locomoción bípeda, los miembros del cuerpo se convirtieron en manipuladores: comenzamos a fabricar herramientas, artificios, máquinas, ordenadores, etcétera.

La tecnología es inherente al desarrollo del ser humano, es la trayectoria que define nuestra humanidad. La indumentaria, los cada vez más extendidos cosméticos, los teléfonos móviles, los medios de transporte con los que nos desplazamos, hasta nuestras relaciones sexuales o los lugares de trabajo que ocupamos, están infestados de dispositivos a través de los cuales existimos tantas o más horas de las que dedicamos al descanso -incluso el sueño tiene relación directa con la tecnología, piénsese en esos nuevos colchones saludables, o en las almohadas terapéuticas. Podríamos hablar también de la domótica, ese conjunto de sistemas que automatizan una vivienda. Todos estos elementos nos convierten en seres que dependen de la tecnología mucho más de lo que estamos dispuestos a reconocer.

La vertiginosa y aplastante carrera tecnológica ha convertido a la cibernética en el modelo estético-vital dominante. «El cyborg se conforma

\footnotetext{
${ }^{1}$ El término cyborg —organismo cibernético - fue acuñado en los años 1960 para describir la fusión de la tecnología con el cuerpo humano. Los autores de la idea, Manfred Clynes y Nathan Kline, eran científicos de la NASA y tenían en perspectiva fortalecer el cuerpo humano para los largos y duros viajes espaciales. Con tal fin, ambos proponían que se utilizara una combinación de sustancias químicas y de cirugía tecnológica (implantes corporales basados en el funcionamiento de los ordenadores). La idea fue recogida parcialmente por el ejército de Estados Unidos, que la ha explorado por diversos ángulos con el fin de conseguir el guerrero cyborg, cuya visión, rango de actuación y otras facultades estarían potenciadas por sistemas electrónicos especializados acoplados al cuerpo. No obstante, estos híbridos del desarrollo tecnológico no prosperan tan sólo en el campo militar. Tal y como se defiende en The Cyborg Handbook - el libro de culto del pensamiento cyberpunk - la fusión ser humano-máquina ya convive con la humanidad: es el producto de la implantación de órganos y prótesis, de la reproducción asistida, etcétera. HABLES GRAY, Chris (ed.), The Cyborg Handbook, New York, Routledge, 1995.
} 
mediante un cuerpo con prótesis opto-electrónicas exteriores a él, o insertadas de manera permanente para que sean controladas directamente por el cerebro». ${ }^{2}$ Este presupuesto cientifista, introduciéndose en un exacerbado positivismo, insinúa que el cuerpo alcanzará su máximo potencial tanto físico como mentalmente a través de una parafernalia tecnológica.

Pero, a pesar de todo esto, no podemos negar el hecho de estar ligados a la naturaleza y, por tanto, a nuestro cuerpo. Ello nos obliga a trascender los límites que ésta impone. Una de las razones más trascendentales es nuestra existencia finita, ¿acaso el nacimiento de las religiones no está íntimamente vinculado a la búsqueda de explicaciones de hechos que nuestra razón es incapaz de comprender? El miedo a la muerte parece que nos conduce a todo tipo de actividades creativas. Numerosos campos como la ciencia, la tecnología, la magia o el arte mismo, también podrían ser considerados como estrategias creativas destinadas a aplazar la muerte. Éstas nos liberan — en cierta manera - del carácter arbitrario y de la precariedad de un orden natural. Otra razón que explicaría por qué somos incitados a trascender nuestra determinación resultaría del deseo de reconocimiento y legitimación que sentimos en tanto que sujetos conscientes de nosotros mismos.

Ello nos ha llevado, grosso modo, a crear una dependencia tecnológica que ha convertido profundamente en ambigua la diferencia entre lo natural y lo artificial, entre el cuerpo y la mente, entre el desarrollo personal y el planeado desde el exterior. Según afirma Haraway, nuestras invenciones están inquietantemente vivas mientras que nosotros y nosotras permanecemos aterradoramente inertes. ${ }^{3}$

\footnotetext{
${ }^{2}$ MARTÍNEZ COLLADO, Ana y NAVARRETE, Ana, "Cyberfeminismo: dos escenarios", en el catálogo de la exposición ZONA F, Castellón, EACC, 2000.

${ }^{3}$ HARAWAY, Donna, Ciencia, cyborgs y mujeres. La reinvención de la naturaleza, Madrid, Cátedra, 1995, p. 258.
} 
Pero ¿qué relación establece el cuerpo con la tecnología?, ¿en qué situación o momento histórico comienza a tener especial relevancia? Se podría decir que a partir del siglo XVII la humanidad se interesó progresivamente por el desarrollo de artilugios que imitaban, incluso superaban, las actividades propias de las personas, ya fuera con fines laborales y/o como mero divertimento. Las nuevas ideas sobre el cuerpo estaban vinculadas de manera directa con el nacimiento del capitalismo moderno y contribuyeron a la gran transformación social del individualismo. El individuo moderno es, por encima de todo, un ser humano móvil. Este proceso histórico es el que nos lleva a hablar directamente del «hombre-máquina», mito moderno por el cual se reduce al ser humano a su superficie, a la parte observable de su comportamiento físico, dado que la dimensión simbólica e inconsciente es ocultada. Al negar u olvidar el carácter simbólico del cuerpo la persona se ve reducida a un conjunto de mecanismos, de funciones sustituibles, de piezas intercambiables con el objetivo de una mejora en su funcionamientorendimiento.

Por otra parte, es evidente que si el cuerpo se convierte en una máquina escaparía éste de la precariedad de su existencia, la muerte ya no tendría lugar y sus piezas se irían sustituyendo, adaptando o modificando según las necesidades. Un ser nuevo —autómata, androide, cyborgconstruido con diferentes piezas: el mito de Frankenstein a la orden del día.

No es difícil observar que el cuerpo ha sobrepasado sus propias fronteras y se ha convertido en un laberinto, en un amasijo de agujeros y órganos mecánico-sexuales. La transgresión de los límites de la representación del cuerpo —esa invasión de miembros mutilados, sexos monstruosos, mecanismos corpóreos, formas imposibles - podría ser entendida como una proyección de las más diversas fantasías sadomasoquistas. Pero ¿cómo se originan y desarrollan las múltiples representaciones del cuerpo artificial?, ¿qué simboliza éste en la sociedad?, ¿cómo han evolucionado — $\mathrm{O}$ no- sus múltiples connotaciones en relación 
a su situación histórica?, ¿cuáles han sido los motivos por los que la máquina, el autómata, el robot, el cyborg han sido siempre altamente sexualizados?

\subsection{Frankenstein y la disfunción eréctil}

Aunque sería complicado delimitar una época en la que el ser humano se interesó por sus creaciones mecánicas, sí es cierto que una gran cantidad de autores y autoras han coincidido en que hay un antes y un después. ${ }^{4}$ Obviamente, desde el Paleolítico se han creado artilugios para facilitar el trabajo y se han elaborado objetos de una exquisita técnica que han ido evolucionando en el transcurso de los siglos, sin embargo la línea fronteriza en lo concerniente a la mecanización cabe situarla en la implantación de la máquina en todos los ámbitos de la vida social de las personas: la Revolución Industrial - la etapa decisiva de la transición del feudalismo al capitalismo.

El hombre de la arena de Hoffmann, Erewhon (Over de Range) de Samuel Butler, La Eva futura de Villiers de L'Isle-Adam o el mismísimo Frankenstein o el moderno Prometeo de Mary W. Shelley, no son más que algunos ejemplos de la literatura del siglo XIX en los cuales se muestra la clara existencia de un componente fantasmagórico inherente a aquellas máquinas precibernéticas, factor incuestionable que estructuraba la dialéctica entre materialismo e idealismo. A pesar de ello, las máquinas no eran capaces de moverse por sí solas, no decidían, no eran autónomas: no podían lograr el sueño humano, sólo imitarlo. No eran individuos, autores de sí mismos, sino caricaturas de una quimera reproductora rotundamente masculinista.

4 Sobre este tema es interesante revisar los trabajos de: GIEDION, Sigfried, La mecanización toma el mando, Barcelona, Gustavo Gili, 1978; FRANCASTEL, Pierre, Arte y técnica en los siglos XIX y XX, Madrid, Debate, 1990; y MUMFORD, Lewis, Técnica y civilización, Madrid, Alianza, 1998. 
Una sugestiva reflexión para comprender el papel que ha desempeñado el desarrollo tecnológico en la construcción de un imaginario en los siglos XIX y XX lo establece Michel Carrouges, quien a mediados del siglo pasado recopiló y analizó todo un inventario de máquinas que se alimentaban de una mezcla de sadismo y erotismo en un libro de culto titulado Les machines célibataires. El autor utilizó esta denominación duchampiana para catalogar con ella a una serie de máquinas fantásticas que encontró en la literatura y analizarlas en relación a la obra de Duchamp $L a$ mariée mis à nu par ses célibataires, même, más conocida como el Grand verre (1915-1923). Esta enigmática obra le sirvió de guía en la concepción de su teoría, Carrouges definió «máquina soltera» como un circuito cerrado por donde circula la energía, pero, debido a su condición, la reproducción resulta imposible. ${ }^{5}$

La revolución tecnológica decimonónica tuvo su culminación en el maquinismo, fenómeno que alcanza su apogeo a comienzos del siglo $\mathrm{XX}$, momento en el que se creó una enorme cantidad de nuevas máquinas que transformaron radicalmente el aspecto tanto de las ciudades como de toda la naturaleza. Así como en las edades mecánicas extendimos nuestro cuerpo en el espacio, a lo largo del siglo XX la tecnología ha extendido nuestro

\footnotetext{
${ }^{5}$ En ellas existe un espacio de disciplina — establecido por unos códigos y regulado jerárquicamente- situado encima de un espacio en el que hay elementos desobedientes que son castigados por ello. Para el autor, al revés de lo que sucede con las máquinas reales e incluso con la mayoría de las máquinas imaginarias, pero racionales y útiles; la máquina soltera se concibe primero como una máquina imposible, inútil, incomprensible, delirante. La máquina soltera puede estar formada por una sola máquina curiosa y desconocida o por un montaje aparentemente heteróclito que no tiene razón de ser en sí mismo, como máquina sometida a las leyes físicas de la mecánica y a las leyes sociales de la utilidad. Regida, ante todo, por las leyes mentales de la subjetividad, la máquina soltera se limita a adoptar ciertas figuras mecánicas para simular ciertos efectos también mecánicos. No posee, por tanto, razón de ser en sí misma como una máquina gobernada por las leyes sociales de la utilidad. De ahí que sea ésta es un simulacro administrado ante todo por las leyes mentales de la subjetividad. Véase CARROUGES, Michel, "Mode d'emploi", en el catálogo de la exposición JUNGGESELLENMASCHINENEN = Les machines célibataires, Bern, Kunsthalle, 1975, p. 21.
} 
sistema nervioso central hasta abarcar el mundo entero, llegándose a abolir el espacio y el tiempo.

Dado que las representaciones artísticas concuerdan con los principales accidentes simbólicos registrados por los sucesos históricos, es evidente que nuestra estrecha relación con la tecnología, tal y como hemos puesto de manifiesto en los capítulos precedentes de la presente investigación, no se ha materializado de la misma forma durante toda la pasada centuria. Si bien, un común denominador en el arte contemporáneo ha sido la integración del arte en la vida, ya que bajo este propósito, las vanguardias artísticas del siglo XX atacaron a la institución burguesa tratando de resquebrajar el discurso político de la alta cultura mediante la fusión ideológica y corporal con la creciente cultura del maquinismo que se desarrollaba a un ritmo vertiginoso desde el siglo XIX.

Aquel optimismo propio de la mayoría de movimientos de vanguardia se vio bruscamente truncado a causa de la tragedia de la Segunda Guerra Mundial. La poderosa máquina redentora que iba a impulsar al ser humano hacia territorios de posibilidades desconocidas, lo hizo pero en el sentido más negativo. Las críticas visiones dadaístas materializadas a través de los collages de Hannah Höch, Raoul Hausmann o John Heartfield, las grotescas caricaturas de George Grosz o la cadena de montaje fordista satirizada magistralmente por Charles Chaplin en Tiempos modernos (1936) se convirtieron en una realidad dantesca.

Pero ¿en qué se convirtió y cuál fue el proceso de transformación de aquel artificio mecánico aplicado al cuerpo propio de las vanguardias cuando fue traspolado a las representaciones más recientes del arte corporal? Parece evidente que el paso de la era mecánica a la era tecnológica estuvo estrechamente relacionado con los acontecimientos bélicos. Tras el final de la masacre, las principales prioridades de los gobiernos se centraron en la reconstrucción del tejido económico, las estructuras básicas y el proceso de cura de las heridas tanto físicas como psíquicas. Estas prelaciones 
desencadenaron muy pronto el conflicto indirecto entre la Unión Soviética y los Estados Unidos en la Guerra Fría. Los derechos sociales y civiles quedaron, con ello, relegados a un plano muy alejado de las principales decisiones políticas. Esta actitud se vio reforzada por un arraigado neoconservadurismo ideológico y religioso fuertemente instaurado al finalizar la guerra.

La necesidad de redefinir en aquellos años la relación del ser humano en su contextualización sociocultural llevó a la mayoría de autores y autoras a dejar de lado la tecnología, claro que, de manera inconsciente, ésta permanecía muy presente en la vida cotidiana. Mirando de soslayo la cultura popular, aquellas célebres pin-ups de Antonio Vargas son un claro ejemplo de cómo la tecnología fue capaz de crear un nuevo estereotipo de mujer que abarca desde los años 1920 con la Ziegfeld Girl, hasta la Bunny del Playboy de los años 1970. Piénsese en aquellos instrumentos de peluquería necesarios para erigir los ondulados cabellos a lo Marilyn o los seductores y brillantes labios rojos que permanecían intactos tras sorber ingentes cantidades de Coca-Cola. ${ }^{6}$

Aún así, ya desde la Primera Guerra Mundial, se inicia un vertiginoso ritmo de fabricaciones tecnológicas cuya cobaya era el propio cuerpo, una manera tremendamente sutil — ¿o quizás no tanto? - de construir nuestras subjetividades. Fijémonos en la siguiente enumeración: producción de placas de contrachapado playwood para producir tablillas de sujeción de los miembros mutilados en la guerra; puesta en marcha y sistematización de la utilización de moléculas hormonales; invención en 1946 de la primera píldora antibaby a base de estrógenos sintéticos — la molécula farmacéutica más mercantilizada en la historia de la humanidad-; comercialización de la molécula de metadona como analgésico — bien

\footnotetext{
${ }^{6}$ Las medidas de aquella mujer moderna americana continúan prácticamente vigentes en la actualidad: $1,70 \mathrm{~cm}$. de altura, $56 \mathrm{~kg}$. de peso, $94 \mathrm{~cm}$. de pecho, $60 \mathrm{~cm}$. de cintura y $92 \mathrm{~cm}$. de cadera. FALK, Gaby, Vargas. 20's - 50's, Berlín, Benedikt Taschen, 1990.
} 
conocemos su posterior utilidad-; lifting facial $^{7}$ y diversas intervenciones de cirugía estética que se convierten por vez primera en técnicas de consumo de masas en Estados Unidos y Europa; ${ }^{8}$ la «des-circuncisión» ${ }^{9}$ devenida una de las operaciones de cirugía estética más practicadas en Estados Unidos en los años posteriores a la Segunda Guerra Mundial; en 1953, el soldado americano George W. Jorgensen se transforma en Christine (primer transexual mediatizado); Hugh Hefner crea Playboy; en 1958 se lleva a cabo en Rusia la primera faloplastia; posteriormente, una rata es objeto de implantación de una prótesis osmótica en forma de rabo cibernético de laboratorio (utilización por primera vez del término cyborg); se crea arpanet (primera red de redes de ordenadores que dará lugar más tarde a Internet); realización del primer implante de pene a base de varillas de plástico de polietileno como tratamiento de la falta de erección. En 1988 se aprobó la utilización farmacológica de Viagra para tratar la disfunción eréctil y años más tarde ya era posible manipular -a través de una hormona- los mecanismos psicofisiológicos reguladores de la adicción para provocar la pérdida de peso. ${ }^{10}$ Hoy en día, a principios del nuevo milenio ya se han contabilizado más de cuarenta millones de consumidores de antidepresivos. Este bombardeo de aplicaciones no es más que un ínfimo retrato de nuestra absoluta dependencia tecnológica, de nuestro devenir cyborg, un interesante campo de estudio que tendría espacio en otra tesis.

Volviendo al terreno de la expresión artística, hacia los años 1950, la interdisciplinaridad se opuso al individualismo masculinista característico

\footnotetext{
${ }^{7}$ Recordemos que Andy Warhol se fotografía durante una operación de lifting facial, haciendo de su propio cuerpo uno de los objetos Pop de la sociedad de consumo. Posteriormente, Orlan retoma a través del carnal art nuevos significados mediante los tratamientos quirúrgicos en su propio cuerpo sin abandonar la objetualización de éste como producto de una sociedad pancapitalista.

${ }^{8}$ Las primeras destinatarias de los rudimentarios implantes son las trabajadoras sexuales japonesas del período inmediatamente posterior a la guerra, cuyos cuerpos sufrirán un proceso de estandarización según los criterios de consumo heterosexual del ejército americano.

${ }^{9}$ Reconstrucción artificial del prepucio del pene.

${ }^{10}$ PRECIADO, Beatriz, "Farmacopornografía", en El País, Madrid, 27 enero de 2008.
} 
del Expresionismo abstracto americano y del Informalismo europeo. Lo interdisciplinar se transformó en la palabra clave que satisfizo la razón de existir de las representaciones artísticas. Las innovadoras actuaciones de John Cage y Merce Cunningham fueron, probablemente, las influencias que llevaron a Allan Kaprow, Claes Oldenburg o Jim Dine a llevar su obra pictórica o escultórica — según el caso - a extensiones de la vida cotidiana. El happening, como ya hemos analizado, se convirtió en la más apropiada expresión artística capaz de abarcar varias disciplinas en una misma representación: danza, teatro, pintura o escultura entre otras. Las puertas que abrieron el éxito de grupos como el Judson Dance Group, auguraba una reificación y análisis del cuerpo y, sobre todo, una trascendental toma de conciencia social necesaria para colmar un vaso que se derramaría en Mayo del 68 .

El desarrollo de la performance a finales de los años 1950 fue análogo tanto en Europa como en Estados Unidos y aceptada por artistas como medio viable. Después de casi una década de una trascendental guerra, se dieron cuenta de que no podían aceptar el contenido apolítico del popular Expresionismo abstracto. De hecho, llegó a considerarse socialmente irresponsable pintar en estudios apartados cuando tantos problemas políticos reales estaban en disputa. Este estado de ánimo políticamente consciente alentó las manifestaciones y gestos al más puro estilo dadaísta como medio de atacar los valores establecidos.

Si el Body Art, según hemos ya analizado, nació como una noción determinada para denominar un tipo exclusivo de comportamiento artístico realizado entre finales de 1960 y principios de 1970 tanto en Estados Unidos como en Europa, el uso genérico del término - arte corporal - a modo de gran contenedor y de categoría inclusiva, puede permitirnos también elaborar una aproximación a la utilización de la tecnología aplicada al cuerpo. El Body Art tiene, por tanto, una vinculación cibernética. El mundo de la performance siempre ha sido el terreno, dentro del ámbito de la creación artística, en donde todas estas cuestiones de verosimilitud y 
codificación han tenido más eco. Sin duda, eso tiene que ver con el propio carácter escénico del fenómeno, pero también puede haber influido considerablemente en ello el hecho de que el Body Art haya asumido históricamente un fuerte valor crítico con respecto a las estructuras establecidas de representación y exhibición artísticas.

La reflexión acerca de un cuerpo modificado a través de extensiones y suplementos sería la evolución de aquellos estados anteriores que intentaron deconstruir los códigos modernos y las supuestas verdades esenciales. El cuestionamiento crítico del sujeto moderno se ha intentado resolver en un cuerpo modificado, corregido, ampliado o reconstruido. $\mathrm{Si}$, tal como demuestra Paul Virilio o Stelarc, el cuerpo humano - heredado y natural - ha devenido obsoleto, la tecnología exige una modificación corporal, un cuerpo ampliado: el ser humano ha de valerse de prótesis para afrontar el desafío social, pertenecer a su entorno más inmediato. El cuerpo vive una «extensión», en nuestro caso tecnobiomecánica, o mejor aún, «farmacopornográfica», pero al mismo tiempo una amputación. En nuestra era cibernética el individuo pierde la facultad de sentirse centro de energía y corre el peligro de tornarse inútil, completamente superfluo frente a la automatización de sus funciones productivas y perceptivas.

En este sentido, el Body Art afronta la provocación prostética desde dos puntos de vista a menudo enfrentados que podrían resumirse en: una posición negativa, crítica y estética $\mathrm{y}$, por otro lado, una postura afirmativa. Esta oposición debemos entenderla como una cómoda evolución de la conciencia social que tuvo lugar durante las vanguardias artísticas, en las que - como planteamos al inicio de este trabajo - movimientos tales como el Futurismo, el Constructivismo o la escuela de la Bauhaus ensalzaron la máquina hasta una categoría absolutamente deificada, mientras que el Expresionismo o el Dadaísmo presagiaron la catástrofe.

Rebeca Horn, Lygia Clark, Jana Sterbak y, posteriormente, Rosemarie Trockel o Mathew Barney utilizarán y diseñarán para el cuerpo 
una serie de prótesis y complementos inútiles, elementos que realmente, a diferencia de lo que pueda parecer, no ayudan al cuerpo, puesto que, siendo accesorios de quita y pon, responden - más que otra cosa - a un espíritu crítico hacia la sociedad pancapitalista. En paralelo a los y las artistas citados, es posible divisar una serie de autores tecnófilos que basan su trabajo en la aceptación de la tecnología y la proclamación de ésta como vía de escape al impasse de lo humano, tal y como se observa en las prótesis e implantes del australiano Stelarc, donde la ampliación y amplificación del cuerpo se nos presenta como modificación de éste en toda regla, quedando el mismo concebido como una entidad combinada.

\subsection{Con su permiso, Sr. McLuhan}

Teniendo en cuenta que, desde nuestro punto de vista, las representaciones artísticas son un profundo análisis, reflejo y reflexión de un instante social determinado, sería factible trazar un recorrido histórico en torno a las diferentes manifestaciones creativas que han tomado el cuerpo como un soporte susceptible de ser modificado por los avances técnicos. Este recorrido tendría su punto de partida en la era mecánica, evolucionaría a la tecnológica y desembocaría en una más actual era cibernética — quizás no sería incoherente augurar una posible era postcibernética pensando en el instante en el que nuestra línea de conducta ya no sea completamente regida ni por nuestro cerebro ni por nuestro sistema nervioso, sino por el feedback $\mathrm{y}$, por tanto, por la entropía, conceptos que rigen la automatización.

Numerosos autores y autoras nos han ofrecido trascendentales investigaciones y esfuerzos dirigidos a reflexionar acerca del impacto que esta evolución histórica ha tenido en el ser humano y su entorno. Partiendo de ellos y ellas hemos tratado de elaborar un término capaz de relacionar los vínculos existentes entre el cuerpo humano en las artes visuales y los componentes o suplementos capaces de redefinir nuestra relación con el 
entorno sociocultural. A dicho término lo hemos denominado «extensión corporal».

A sabiendas de que el término «extensión» fue acuñado y utilizado frecuentemente por Marshall McLuhan en sus reflexiones centradas mayoritariamente en torno a los efectos de los medios de comunicación en el pensamiento y la conducta social, encontramos el concepto mcluhaniano más que oportuno para reinterpretarlo e investigarlo desde un punto de vista disímil. A pesar de adaptar solamente algunos aspectos concretos de la teoría de McLuhan, esperamos no ser cómplices de ese canibalismo cultural del cual el autor norteamericano ha sido víctima.

Para McLuhan el término «extensión» define claramente el concepto «tecnología», caracterizado éste por actuar como suplemento prostético de una o varias funciones naturales. La prótesis - pensada como una sustitución artificial, como copia mecánica de un órgano vivo- ha transformado la estructura de la sensibilidad humana desembocando en lo que entendemos hoy en día, en el siglo XXI, como «posthumanismo».

Todos los medios, desde el primigenio alfabeto fonético hasta el más reciente ordenador, son prolongaciones de alguna facultad humana, psíquica o física. Por ello, son «extensiones» del propio individuo que, inevitablemente, desencadenan cambios profundos $\mathrm{y}$ duraderos transformando su entorno. ${ }^{11}$ Tales «extensiones» son una intensificación, una amplificación de algún órgano, sentido o función. De este modo, cualquier invento o tecnología es una «extensión»en sí misma pero, al mismo tiempo, una autoamputación del cuerpo físico y, como tal, requiere además de nuevas relaciones o equilibrios entre los demás órganos y «extensiones» del cuerpo. Pensemos por un momento cómo la Real Academia Española se ve en la obligación de adaptar sus normas a la fugacidad de nuestra sociedad contemporánea, o cómo son abordados los

${ }^{11}$ McLUHAN, Marshall y FIORE, Quentin, El medio es el masaje. Un inventario de efectos, Barcelona, Paidós, 1997. 
estudios más recientes sobre el conductismo adolescente y su atrofia caligráfica y gramatical a causa de las nuevas tecnologías - mensajes en móviles, Messenger o las más recientes redes sociales tales como Facebook o Twitter.

Según McLuhan, la condición autoamputativa es la respuesta de un sistema nervioso sobrecargado a una acción sociocultural, como la aceleración del ritmo y del volumen de datos (de origen tecnológico). Añade además, que cada autoamputación produce un entorpecimiento de la zona cerebral conectada con la nueva función traumáticamente amplificada mediante la tecnología. El sistema nervioso central parece establecer un bloqueo autoprotector del área afectada, aislándola y anestesiándola en relación a lo que le está sucediendo. ${ }^{12}$ El estudio de las «extensiones» podría explicarse, a priori, mediante el nunca explicado entumecimiento que cada una de éstas produce en el individuo. ${ }^{13}$

Para McLuhan, la exteriorización metafórica del sistema nervioso central - la «red eléctrica que coordina los diferentes medios de nuestros sentidos»— en forma de redes globales de telecomunicación y demás tecnologías cibernéticas, representa un mecanismo de supervivencia, desencadenado por la mecanización sucesiva de los diversos órganos físicos desde la invención de la imprenta, que ha producido una experiencia social demasiado violenta y estimulada para que la pueda soportar el sistema nervioso.

El autor nos traumatiza con lo que denomina la «narcosis de Narciso», un síndrome por el cual el ser humano permanece inconsciente ante los efectos psíquicos y sociales de una nueva tecnología. De este modo, se pone en funcionamiento una especie de circuito cerrado que inequívocamente nos remite al mito carrougesiano de las máquinas solteras,

12 McLUHAN, Marshall, "Entrevista de Playboy", en Escritos esenciales, Barcelona, Paidós, 1995, p. 284.

${ }^{13}$ McLUHAN, Marshall, Comprender los medios de comunicación. Las extensiones del ser humano, Barcelona, Paidós, 2009, p. 30. 
un circuito que la ninfa Eco fue incapaz de deshacer. ${ }^{14}$ Según McLuhan, la extensión de Narciso insensibilizó sus percepciones hasta convertirlas en un servomecanismo de su propia imagen extendida adaptado a la extensión de sí mismo. ${ }^{15}$ Cuando extendemos o ponemos en peligro el cuerpo debemos adormecer nuestro sistema nervioso o, de lo contrario, moriríamos.

A mediados del siglo XX McLuhan ya vislumbró en nuestra sociedad la fusión existente entre sexo y tecnología. Dándole la vuelta a la lógica publicitaria, encargada de dotar de atractivo sexual a los bienes de consumo, un alto porcentaje de anuncios — no sólo los que nos muestran productos de belleza modernos - resaltan su relación con la máquina, subyugada por la publicidad a las exigencias del mercado, una relación que constata cómo los individuos padecen una alienación dentro de su propio cuerpo. Sometido a las técnicas de producción industrial, especialmente el cuerpo femenino se separa en piezas independientes y sustituibles que devienen objetos extendidos, palancas de poder para manejar a la audiencia.

Años más tarde Jean Baudrillard continuó en El sistema de los objetos con esta relación existente entre el cuerpo artificial y el sexo. Para el citado autor, el mito de una funcionalidad milagrosa del mundo -el nacimiento de la tecnología - es correlativo al fantasma de una funcionalidad también milagrosa del cuerpo. De ahí que el esquema de ejecución técnica del mundo se encuentre estrechamente ligado al esquema de relación sexual del sujeto. Dicho de otra forma, el gadget, instrumento por excelencia, es fundamentalmente un sustituto del falo, médium operatorio de la función por excelencia. Por otra parte, cualquier objeto tiene siempre algo de chisme en la medida en que su instrumentalidad se desvanece, y puede ser investido de mera instrumentalidad libidinal. «Basta

\footnotetext{
${ }^{14}$ Para castigar a Narciso por la negación cruel de su amor a Eco, Némesis, la diosa de la venganza, hizo que se apasionara de su propia imagen reflejada en una fuente. En una contemplación absorta, incapaz de apartarse de su imagen, acabó arrojándose a las aguas. En el sitio donde su cuerpo había caído, creció una hermosa flor, que hizo honor al nombre y la memoria de Narciso.

${ }^{15}$ McLUHAN, Marshall, Comprender los medios..., op. cit., p. 67.
} 
con que la práctica concreta se pierda para que el objeto se transfiera a las prácticas mentales. Detrás de cada objeto real hay un objeto soñado». ${ }^{16}$

Baudrillard, con cierta relación a lo anteriormente expuesto por McLuhan, nos habla sobre el mito del robot. Éste nos resume todos los caminos del inconsciente en el dominio del objeto, es un microcosmos simbólico del ser humano y del mundo, es decir, sustituye, a la vez, a ambos, puesto que actúa como síntesis entre la funcionalidad y el antropomorfismo absoluto, una «extensión» de éste. Por esta razón —afirma Baudrillard - el robot, en el fondo, no es sino la culminación mitológica de una fase ingenua de lo imaginario: la de la proyección de una funcionalidad continua y visible. Si el robot es para el inconsciente el objeto ideal, no sólo se debe a que éste es un simulacro del ser humano en su eficiencia funcional, sino también a que no es lo bastante perfecto como para ser su doble, no dejando de ser nunca un objeto y, por tanto, un esclavo.

El robot - prosigue el autor - puede tener todas las cualidades, excepto una, que constituye la soberanía de la persona: el sexo. Es en ese límite donde la máquina ejerce su fascinación y su valor simbólico. Mediante su polifuncionalidad da testimonio del imperio fálico del hombre sobre el mundo, pero da testimonio al mismo tiempo — puesto que está controlado, dominado, regido, asexuado - de que este falo es esclavo, de que esta sexualidad está domesticada y carece de angustia: no queda más que una funcionalidad obediente, encarnada en un objeto que se le parece. Deviene por tanto abstracción narcisista. El robot es como el esclavo, muy bueno y muy pérfido a la vez, muy bueno como la fuerza encadenada, muy malo como la que se desencadena. El ser humano tiene buenas razones para temer la resurrección de esta fuerza a la que ha conjurado o encadenado a su imagen. Pues esta fuerza es su propia sexualidad, que se vuelve entonces contra él, y a la cual le tiene miedo. Liberada, desencadenada, rebelde, la sexualidad se convierte en el enemigo mortal del hombre; es lo que expresan las múltiples e imprevisibles variaciones de los robots, su mutación maléfica

${ }^{16}$ BAUDRILLARD, Jean, El sistema de los objetos, Madrid, Siglo XXI, 1979, p. 134. 
o simplemente la angustia de esta conversión brutal que es siempre posible. ${ }^{17}$

El ser humano, entonces, choca con las fuerzas más profundas de sí mismo y se ve enfrentado a su doble, dotado de su propia energía, cuya aparición como dice la leyenda, significa la muerte. Insurrección de las energías fálicas esclavizadas, tal es el sentido de la perfidia mecánica de los robots. En este momento aparecen en los relatos dos soluciones simplificadas y harto manidas: o bien el ser humano doma las fuerzas «malas» y todo vuelve a circunscribirse al orden «moral», o bien, las fuerzas encarnadas en el robot se destruyen a sí mismas, llevando el automatismo hasta el suicidio.

En 1984 Donna J. Haraway sorprendió a toda la sociedad intelectual con la publicación de un texto - de rabiosa actualidad - que revolucionaría la concepción sobre el cyborg: Manifiesto para cyborgs: ciencia, tecnología y feminismo socialista a finales del siglo $X X$. Aunque aparentemente brinquemos de la era tecnológica a la cibernética sin demasiados reparos, la relación existente con el concepto de «extensión» de McLuhan es evidente. Mientras este último nos describe la tecnología como una «extensión del ser humano», Haraway parte de una aseveración primordial, todos y todas somos sujetos híbridos formados por naturaleza y artificio, un organismo que se ha desarrollado tecnológicamente. Vamos, por tanto, a complementar el amplio concepto de «extensión» de McLuhan con una ligera incursión en el archiconocido texto de Haraway.

No cabe duda de que el cyborg es hijo ilegítimo del militarismo y del capitalismo patriarcal. A pesar de ello, Haraway arroja un irónico análisis - calificado por la propia autora como una blasfemia - en el que analiza la imagen de éste como una metáfora de liberación basada en la construcción de la conciencia, de la comprensión imaginativa de la opresión y, también,

\footnotetext{
${ }^{17}$ BAUDRILLARD, Jean, op. cit., p. 134.
} 
de lo posible. ${ }^{18}$ Así pues, el vocablo «liberación», desde este punto de vista, guarda una sugestiva afinidad con la materialización del cyborg: realidad social — dado que tal experiencia es un hecho político importante- y ficción — ¿hasta qué punto es posible escapar de las relaciones de poder?

Un organismo cibernético es un híbrido de organismo y máquina, por tanto, una criatura de realidad social, formada por nuestras relaciones sociales vividas, nuestra construcción política: un mundo actual cambiante y un mundo de ficción. ${ }^{19}$ La autora entiende el cyborg como una utopía que abarca nuestra realidad social y corporal, como un recurso imaginativo sugerente de acoplamientos $\mathrm{y}$, por tanto, - con el permiso de Rosalind Krauss - como «campo expandido».

Ya entrados en el siglo XXI — prosigue Haraway — no cabe duda de que somos quimeras, híbridos teorizados y fabricados, un entretejido de máquinas y organismos. El cyborg es la imagen apropiada capaz de condensar la imaginación y la realidad material. Es en esta fusión donde se estructura toda posibilidad de transformación histórica. Desde este punto de vista, el cyborg queda situado en la parcialidad, la ironía, la intimidad y, cómo no, la perversidad. ${ }^{20}$

El Manifiesto cyborg, además de una denuncia de la concepción occidental del mundo, es también una severa crítica a la actitud de un amplio sector del feminismo que rechaza la ciencia y la tecnología. Al respecto, es interesante retomar la aportación de Mark Dery en la que - debido al caos de nuestra época turbulenta - las feministas deberían aprovechar la ocasión que se les presenta para desestabilizar el poder patriarcal explotando las posibilidades que ofrece la desaparición de las distinciones entre el término privilegiado y su devaluado término opuesto, a

${ }^{18}$ HARAWAY, Donna, op. cit., pp. 251-253.

${ }^{19}$ HARAWAY, Donna, op. cit., p. 253.

${ }^{20}$ HARAWAY, Donna, op. cit., pp. 253-256. 
través de la ruptura de los dualismos jerárquicos que estructuran el yo occidental. $^{21}$

Para Haraway, atravesar las fronteras entre territorios hasta entonces inviolables - gracias a la ciencia y a la tecnología - es coherente con el pensamiento académico contemporáneo: el postestructuralismo. ${ }^{22}$ No obstante, cuando retomamos el discurso foucaultiano sobre la biopolítica, el autor francés parece omitir el conjunto de profundas transformaciones que en las tecnologías de producción de subjetividad se producen a partir de la Segunda Guerra Mundial. Al saber-poder disciplinario y moderno debemos añadir un régimen más de subjetivización que toma en consideración el impacto de las nuevas tecnologías del cuerpo en la construcción de éste y de su subjetividad.

Es aquí donde Haraway y McLuhan quedan fusionados. Para ambos, una prótesis no reemplaza únicamente a un órgano ausente, es también la modificación y el desarrollo de un órgano vivo con la ayuda de un suplemento tecnológico en su relación con el mundo. Ya no existe ni la naturaleza ni el cuerpo, ambos están contaminados de manera definitiva. Nos apoyamos pues en el perspicaz discurso de Haraway para comprender la importancia de la técnica aplicada al cuerpo con los consiguientes cambios sociales que ello conlleva.

\footnotetext{
${ }^{21}$ DERY, Mark, Velocidad de escape. La cibercultura en el final del siglo, Madrid, Siruela, 1998, pp. 268-269.

${ }^{22}$ El postestructuralismo es una rama contemporánea de la teoría de la crítica que afecta a áreas tan diversas como el psicoanálisis, la historia, la filosofía y la teoría literaria. Podría definirse como derivado del estructuralismo aunque también como su antítesis. El postestructuralismo trata de superar la tendencia de contemplar la realidad como la unión de dos opuestos y, al igual que el estructuralismo, rechaza la primacía del sujeto humano. Al sujeto se le considera como un producto, un punto focal de fuerzas, más que un agente creativo. La obra literaria es un tejido de otros textos cuyo significado viene determinado por sus lectores más que por la intención del autor o autora. Las implicaciones de semejante punto de vista en el psicoanálisis y la historiografía son inmensas. La historia postestructuralista analiza las estructuras institucionales, sociales y políticas en términos de la relación entre significado y poder, y su teoría pone en cuestión la verdadera naturaleza de las relaciones entre la realidad, el lenguaje, la historia y el sujeto.
} 
Ya en la actualidad y a caballo de los comentarios premonitorios de McLuhan y Haraway —entre muchos otros - sobre la imagen híbrida, ampliamente extendida, del sexo, la tecnología y la muerte, la técnica erotizada, el sexo asistido por máquinas, la copulación con lo tecnológico y los deseos carnales que acaban por conllevar orgías de destrucción de alta tecnología, Beatriz Preciado nos pone al día de todo ello en su último trabajo Testo yonqui. Para la autora, el contexto somatopolítico de producción tecnopolítica del cuerpo posterior a la Segunda Guerra Mundial, está dominado por un conjunto de nuevas tecnologías del cuerpo —biotecnologías, cirugía, endocrinología- y de representación - fotografía, cine, televisión, cibernética - que infiltran y penetran la vida cotidiana como nunca lo habían hecho antes. La autora engloba y define este vínculo bajo un término: «farmacopornografía». ${ }^{23}$

Preciado da una vuelta de tuerca y se sube a hombros de las teorías formuladas por Teresa de Lauretis y Donna Haraway aproximándose a los textos de Foucault, Deleuze y Guattari, pero desde una relectura tomada desde el lesbianismo radical o la crítica queer. La autora parte del fordismo como síntesis y definición de producción y de consumo, lo que conlleva a un conflictivo agenciamiento entre el cuerpo y la máquina. Asimismo, establece una pavorosa cronología de las transformaciones de la producción industrial del último siglo desde el punto de vista del — cada vez másnegocio del nuevo milenio: la gestión política y técnica del cuerpo y, por tanto, del sexo y la sexualidad.

Este bombardeo informativo sólo representa una ínfima parte de los índices de aparición de un régimen postindustrial, global y mediático que Beatriz Preciado califica convenientemente como «farmacopornográfico» tomando como referencia los procesos de gobierno biomolecular (fármaco-) y semiótico-técnico de la subjetividad sexual (-porno). ${ }^{24}$ No es de extrañar que el cuerpo sea uno de los centros de investigación artística teniendo en

${ }^{23}$ PRECIADO, Beatriz, Testo yonqui, Madrid, Espasa, 2008, p. 66.

${ }^{24}$ PRECIADO, Beatriz, op. cit., pp. 25-46. 
cuenta que más de un siglo avala un control «farmacopornográfico» del individuo.

A partir de esto, la indumentaria, el espacio que ocupamos, los objetos cotidianos, el maquillaje o las operaciones de cirugía, entre otros, devienen medios de comunicación, «extensiones», especialmente en el sentido de que configuran y reordenan los patrones de asociación y comunidad humanas.

Llegados a este punto, podemos definir las «extensiones corporales» como aquellos componentes - diseñados o apropiados y, por tanto, descontextualizados - utilizados por una serie de artistas que, añadidos o complementados al cuerpo, adquieren la función de analizar, transgredir y/o ampliar uno o varios miembros pertenecientes al cuerpo humano - ya sea física o metafóricamente. Estos artilugios son, generalmente, exteriores al cuerpo - exocorporales-, sin embargo, en ciertas ocasiones podremos encontrar «extensiones» endocorporales, aplicadas éstas en el interior del cuerpo del sujeto mediante diversos métodos - cirugía, incisiones y perforaciones entre otras técnicas.

Diferentes productores discursivos contemporáneos nos incitan a evitar dos tipos de trampas narrativas de corte metafísico y semióticofascista cuando tratamos de pensar en el futuro de la especie y/o del planeta. Primero, la tentación mesiánica: alguien va a venir a salvarnos, una fuerza única, religiosa o técnica, un saber único posee todas las respuestas para transformar la condición de la humanidad. Segundo, la tentación apocalíptica: no hay nada que hacer, la desaparición de la especie es inminente. Deberíamos aprender a dudar de nuestros miedos y certezas sobre los desastres, así como de nuestras quimeras de progreso. Deberíamos aprender a vivir sin los rígidos discursos de la historia de la salvación.

Entre estos dos puntos de vista aparentemente extremos, las tecnologías más cotidianas - como lo son el maquillaje o el vestido- dan perfecta cuenta del cuerpo como ente no-fijado. La mayor parte de nuestra 
imagen social presenta el cuerpo en su apariencia, en su vertiente de proyección social del yo. A través de determinadas «extensiones corporales» artistas como Urs Lüthi, Jürgen Klauke, Pierre Molinier, Michel Journiac o Cindy Sherman basan gran parte de su trabajo en el cuestionamiento de la identidad como algo estable y en la subversión y desmantelamiento del sentido unívoco del yo, entendiendo éste como un constructo lingüísticovisual consolidado por las jerarquías de poder.

Por otra parte, si los avances tecnológicos propician un cuerpo prostético, el desarrollo de la ciencia médica —en especial de la cirugía y la genética - va a dar paso a una nueva concepción de éste. El cuerpo es - más que nunca - física y psíquicamente modificable pero, ¿podríamos afirmar que la aplicación cotidiana de la cirugía estética y de las técnicas de reproducción asistida contribuyen a la expansión de una mayor conciencia de emancipación del cuerpo? El cuerpo activista se encargó de erosionar el cuerpo fijado. Tras aquella importante deconstrucción, muchos autores y autoras trataron de reconstruirlo. Posiblemente, la reivindicación del individuo como propietario de su fisicidad que tan radicalmente mostró el provocador discurso de Orlan, se ha banalizado. En cualquier publicación que precise de publicidad para difundir su información nos encontramos con un bombardeo a página completa de determinadas empresas de cirugía estética, y es que, queramos o no, vivimos en una falsa diversidad cuya función se reduce a camuflar una terrible homogeneidad.

De lo que no cabe duda es que cualquier «extensión» — sea de la piel, de la mano o del pie- afecta a todo el complejo psíquico y social. Probablemente, a día de hoy, sea el cuerpo individual el que haya pasado a funcionar como una extensión de las tecnologías globales de comunicación, tal vez seamos nosotros «extensiones tecnológicas».

Dicho esto, los capítulos que siguen a continuación establecen tres grandes grupos cuyo común denominador radica en la utilización de «extensiones corporales»: 
- El capítulo 6 se centra en aquellos y aquellas artistas que analizaron el campo semántico de lo masculino y cuestionaron las actitudes hegemónicas, sus «extensiones» son propias de un proceso de autorepresentación que adquirió la capacidad de construir nuestra subjetividad.

- El objeto será el protagonista del capítulo 7, una entidad material cargada de simbolismo y que será epicentro de análisis de las imposiciones sociales —opresión social, dominación de la mirada masculina, fanatismo radical, etcétera.

- Para terminar, en el capítulo 8 nos centraremos en aquellas representaciones artísticas cuya finalidad queda definida por la hibridación entre lo corpóreo y lo tecnológico, una reflexión explícita sobre los límites de nuestra propia fisicidad. 



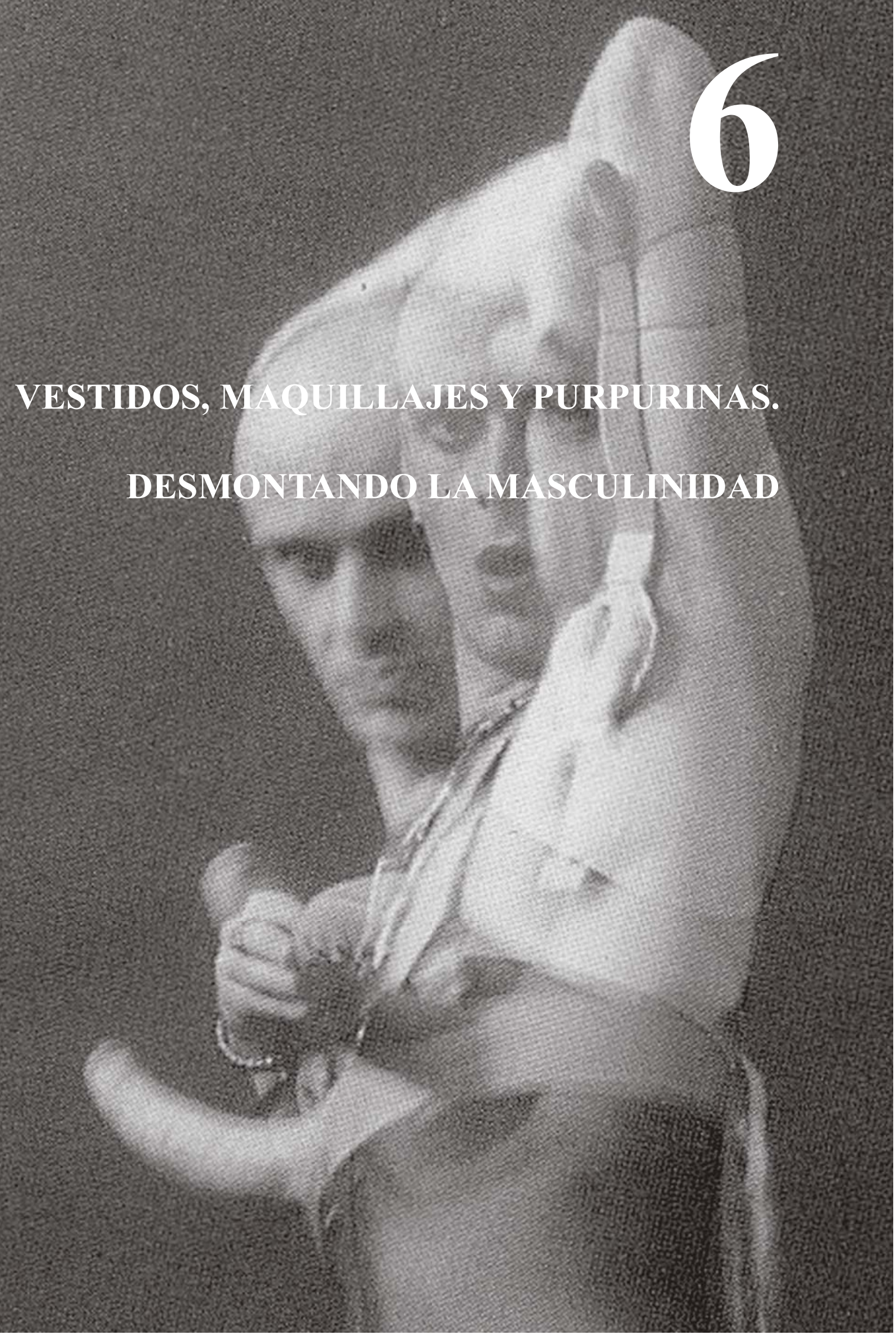



«It was no longer possible to take the history of things as stage-managed by the media and the educational system seriously. Everything we knew was wrong... Free at last or, if you like, at sea without paddle, we were giving permission to ourselves to reinvent culture the way we wanted it. With great big shoes».

David Bowie

\begin{abstract}
A lo largo del tercer capítulo, al analizar el contexto y los antecedentes del Body Art, hemos visto cómo los años posteriores 1 a la Segunda Guerra Mundial llevaron a un reforzamiento de los convencionalismos más reaccionarios. Esta situación se extendió gracias a dos motivos fundamentales: por una parte, las necesidades económicas - reconstrucción social- y, por otra, la reestructuración de un orden profundamente decoroso - el hogar como refugio moral. Sin embargo, este orden establecido entró en crisis a finales de la década de 1960, catalizándose durante los inmediatos años posteriores en un contundente rechazo del orden burgués propio de las vanguardias artísticas. Fue así como aquella nueva década devino símbolo de un replanteamiento del ego y, lo que es más, una recodificación del género. Se intentó unificar el marxismo y el psicoanálisis en el deseo de hacer evolucionar conjuntamente los aspectos sociales e ideológicos de una sociedad. No es de extrañar que las teorías de Deleuze y Guattari expuestas en su archiconocido Anti Edipo conformaran un aproximado reflejo de una época enormemente convulsa: para muchos
\end{abstract}


autores y autoras, la economía política y la economía de la libido estaban estrechamente interrelacionadas. ${ }^{1}$

Con ello se trató de modificar las pautas de comportamiento. Verbigracia, muchos jóvenes — tanto hombres como mujeres - se pusieron flores y decidieron vivir cerca de la naturaleza, apostaron por una sociedad no competitiva y dejaron crecer sus cabellos y que la ropa les confundiera. Hoy día los hippies representan, de alguna manera, la negativa masculina a ser héroes y como estrategia de protesta adoptaron una actitud que convencionalmente se entiende como femenina. ${ }^{2}$ No obstante, es preciso aclarar que el movimiento hippie, alejado de una ejemplar tolerancia, reaccionó ante la asociación que la imagen popular le atribuía: sus pelos largos e indumentaria ambigua eran relacionados con cierta imaginería gay, ello acrecentó ciertas actitudes homófobas y misóginas en su modo de pensar. En el film Velvet Goldmine, dirigido por Todd Haynes en 1998, se hace patente como, en multitud de ocasiones, los integrantes de estos grupos mantenían una mera actitud de rebeldía juvenil absolutamente incapaz de liberar sus propios prejuicios más viscerales y derruir los muros de la intolerancia. ${ }^{3}$

Aquellos años convulsos son un claro ejemplo de que el cuerpo humano es un material rico y complejo, un generador de mitos, un productor de símbolos mutables susceptibles de escapar de cualquier estructura rígida, verdad fundamental o significación dada. Sin embargo, padecemos un

${ }^{1}$ DELEUZE, Gilles y GUATTARI, Félix, El Anti Edipo. Capitalismo y esquizofrenia, Barcelona, Paidós, 1995.

2 DE DIEGO, Estrella, El andrógino sexuado. Eternos ideales, nuevas estrategias de género, Madrid, Visor, 1992, pp. 128-131.

${ }^{3}$ Velvet Goldmine narra la historia de Arthur Stuart —interpretado por Christian Bale-, un reportero que, diez años después, investiga el misterioso asesinato del cantante glam Brian Slade (Jonathan Rhys-Meyers) en uno de sus conciertos — del mismo modo que le sucedió a Ziggy Stardust. Aunque la historia es ficticia, es obvia la inspiración que Haynes encontró en David Bowie e Iggy Pop. En la película encontramos una escena en la que Brian Slade, ataviado con un característico vestido largo, actúa ante un público más preocupado por denigrarle que por escuchar su música. En el apartado 6.3 profundizaremos sobre la cuestión del transformismo en la música de los años 1970. 
constante deseo de controlar y codificar nuestro cuerpo para que de éste emane un conjunto de mensajes y, cómo no, de fantasías. Estamos sometidos y sometidas a un proceso de aprendizaje cultural en el cual se asimila el control y las limitaciones que el sistema social impone a la utilización del cuerpo como modo de expresión.

El recién nacido Body Art se convirtió en un oportuno modo de expresión desde el cual un considerable conjunto de artistas analizaron el campo semántico de lo masculino cuestionando, desde los más diferentes puntos de vista, las actitudes hegemónicas que entienden la potencia, la fuerza y el control como sinónimos de unos valores inherentes. Para ello, utilizaron su «destino anatómico» con el fin de interrogarlo y desestabilizar su estatus, consiguiendo así, acalambrar la imagen del varón e incidir en aspectos tan ignorados como ocultos.

Con ello, ciertas «extensiones corporales» tales como la indumentaria o el maquillaje conformaron una tecnología ineludible para el proceso de auto-representación $\mathrm{y}$, a su vez, adquirieron la capacidad de construir nuestra subjetividad. La función de los complementos no reside únicamente en la protección ante las condiciones meteorológicas, sino que afirma una identidad particular y encuentra la confirmación de ésta en la opinión de las personas que nos rodean - pertenencia al grupo, clase social o ideología. Desde este punto de vista, la indumentaria y el maquillaje constituyen una tecnología del yo: nos aportan cierta dosis de control sobre nosotros mismos y sobre el mundo público en el cual vivimos.

A través de ropa, máscaras y maquillajes, el cuerpo se «extiende» más allá del arraigado corsé de los géneros. Se oculta y muestra al mismo tiempo: mientras encubre una identidad visible, supone una similitud que pretende ser más deseada, más anhelada. ¿Qué es más real? En este sentido, ponerse una máscara puede ser, desde la cobertura que supone, un verdadero descubrimiento. Cubriendo el rostro se revela aquello que no se quiere mostrar. Se evidencia así un descontento hacia la apariencia existente y, al 
mismo tiempo, un anhelo por la imagen escogida. Tales «extensiones corporales», por tanto, niegan tanto como afirman. Nos permiten, asimismo, ocultarnos bajo una apariencia, desarrollar un rol.

En definitiva, el cuerpo es el primer comunicador de sexo, raza y clase social. Sin embargo, hablando en términos artísticos, éste se utiliza - especialmente en el Body Art — a modo de superficie de inscripción de un lenguaje visual de identificación, tanto del real como del proyectado a partir de los estereotipos. Las ideas del yo y la identidad se interpretan en público o se revelan a través del atrezo, las máscaras, los vestidos y los disfraces, auténticas «extensiones corporales» que utilizan numerosos y numerosas artistas para prolongar su identidad.

En el presente capítulo estudiaremos cómo — a través de diferentes manifestaciones artísticas - se cuestionaron los códigos sociales de género mediante la representación y adopción de una identidad caracterizada por el uso de signos y significados aceptados — como lo son la ropa, el maquillaje o los atributos físicos simulados.

La relación de trabajos que veremos a continuación muestra cómo el sexo deviene público y el cuerpo se transforma en un espacio de reapropiación y recitación de las tecnologías normalizadoras y naturalizantes. La imaginería de estas representaciones artísticas provocará extrañamiento, hará surgir la pregunta de qué es, cómo definimos o nombramos aquello que estamos viendo. Ante la incapacidad identificativa de estas propuestas, nos planteamos el desafío a la codificación y legibilidad social de la normalidad. Un desafío que pone en cuestión su función como escritura del cuerpo, es decir, como tecnología social que naturaliza al individuo, nombrándolo en términos excluyentes entre sí al establecer una equivalencia directa entre rasgos biológicos, características psicológicas, expectativas sociales y modos de vida. Los valores propios de la masculinidad quedarán, por ello, profundamente desestabilizados. 


\subsection{Umbrales de una «extensión corporal»}

La década de 1970 dio importantes frutos en lo concerniente a la ambigüedad y a la inversión de las reglas sobre los géneros. No sólo en el mundo del arte sino también en el de la música y el cine, un considerable número de artistas se apropiaron de gran parte del lenguaje físico de sectores sociales altamente estigmatizados con los que se sentían identificados de alguna manera - homosexuales, travestis y transexuales. El glam rock procedente de Gran Bretaña y Estados Unidos ensalzó figuras de hiperfeminidad cercanas al transformismo, al más puro estilo drag-queen. ${ }^{4}$ Para muchos de estos creadores — en su mayoría masculinos — las imágenes y/o las obras de Diane Arbus y Pierre Molinier se erigieron como emblema de una actitud que se oponía claramente a la restricción de una sexualidad dominante. Ambos se convirtieron en los pioneros de una nueva generación —la de los años 1960-1970 — que se mostraba abierta a la liberación gay, al unisexismo y a la cultura andrógina. Este hecho es el que determina que les dediquemos una especial atención dentro del presente capítulo.

\subsection{1. «Je suis lesbien». ${ }^{5}$ El caso de Pierre Molinier}

La importancia de Pierre Molinier (Burdeos, 1900-1976) radica en que tanto su vida como su obra fueron emblemas de una actitud opuesta y crítica a la restricción de una sexualidad dominante y a una forma de vida convencional. No es de extrañar que, por ello, se convirtiera en influencia obligada para una nueva generación que se mostraba especialmente abierta a diferentes tipos de comportamientos. A su vez, su obra permitió dar una

\footnotetext{
${ }^{4}$ ALIAGA, Juan Vicente, "Jambe, mollet, pied, anus... Je vous aime. Sobre Pierre Molinier y su arte inmoral", en el catálogo de la exposición Pierre Molinier, Valencia, IVAM, 1999, pp. 11-13.

Recordemos que la traducción al francés del vocablo «lesbiana» tiene la terminación propia del femenino lesbienne.
} 
vuelta de tuerca a las pautas que marcaron inicialmente el arte corporal, aparentemente muy radicales.

Molinier fue uno de los encargados en abrir una pequeña grieta en los gruesos muros de la norma. Mediante sus fotografías y collages buscó alcanzar dos grandes objetivos. Por una parte, desestructurar los más arraigados códigos de género y analizar la construcción social para, posteriormente, devolver su rabia transformada en inquietantes obras perversamente provocadoras y desconcertantes, que actuaban como una verdadera amenaza para la normalidad. Por otra parte, Molinier deseaba poner a prueba el orden simbólico mofándose del cuerpo reprimido y plantear la corporalidad como soporte receptor de sentidos.

El artista francés hizo uso de un conjunto de «extensiones corporales» como metáfora de un cuerpo cuyo potencial carece de límites. No es de extrañar que su obra escape de toda trayectoria y movimiento marcado por los recorridos unidireccionales de la más convencional Historia del Arte. Veinte años después de un suicidio perfectamente premeditado, ${ }^{6}$ Molinier despertó un insólito interés sobre las cuestiones relativas a la representación del cuerpo - especialmente la obra fotográfica realizada entre 1965 y 1976, verdaderas performances fotográficas. En ellas, aunque sea explícito un enérgico carácter exhibicionista, el autor realizó un pulcro y elaborado proceso creativo evitando todo contacto directo con el espectador o espectadora, un gesto de extremado perfil intimista. Tal y como afirma Cortés, el acto fotográfico supondrá la única posibilidad de acceder al otro y

\footnotetext{
${ }^{6}$ Molinier quiso ser dueño de su propio cuerpo. Tras haber dejado claro que donaba su despojo a la ciencia y hastiado de un cuerpo con el que ya no podía disfrutar — un adenoma de la próstata-, se suicidó metódicamente el 3 de marzo de 1976 a las siete y media de la tarde. "Je me tue. La clé est chez le concierge», esta fue la última nota que dejó el autor. No quería que se olvidaran de los pocos compañeros que tenía los últimos años de vida, sus gatos. Preparó el arma, escogió la postura y la vestimenta adecuada para la ocasión, exactamente con el mismo procedimiento meticuloso con el que realizaba sus trabajos. Molinier construyó su propia muerte y la disfrazó como si se tratara de una obra de arte más, su último acto narcisista.
} 
el fotomontaje le permitirá alcanzar ese cuerpo «imposible» que la sociedad inhibe. $^{7}$

Pierre Molinier fue ante todo un ser profundamente individualista. Hizo de su creación artística un constante cuestionamiento de la identidad, una permanente reivindicación del travestismo narcisista y un amplio muestrario del fetichismo sexual. La intención esencial del autor radicaba en la ruptura de la representación normativa y especulativa del cuerpo, así como en la creación de éste como una herramienta clave para transgredir y traspasar los límites entre lo imaginario y lo real. Se produce, de esta manera, un fenómeno de extensión-deconstrucción mediante el proceso de fracturar el cuerpo, deformarlo, fragmentarlo, cortarlo, distorsionarlo y vaciarlo de sus connotaciones - morales, psicológicas y sexuales. No pretendía con ello reconstruir una imagen plena del cuerpo y del sujeto, sino proyectarlo en la propia inestabilidad de su forma, más allá de todos sus significados.

La realidad a la que nos remite en sus reproducciones es la realidad de un imaginario en el cual la omnipresencia de la «extensión corporal» - godemichets, tacones de aguja, medias negras de seda, corsés, ligueros, máscaras, maquillajes - nos recuerda ansiosamente el entramado de sustituciones y deslizamientos que constituyen la realidad social del sujeto, su naturaleza intrínsecamente paradójica y escindida. Una realidad que significa, al mismo tiempo, pérdida y continua búsqueda en el juego de la representación. Por ello, sus imágenes son una verdadera biografía, la escritura de una vida que intenta desplegarse más allá del poder aniquilador de imágenes normativas y preestablecidas; más allá de convenciones, leyes, prohibiciones y censuras; pero sobre todo, más allá del simple binarismo que estructura nuestro imaginario y que pretende atar a los seres humanos a las supuestas esencias universales y normativas. Sus imágenes nos recuerdan constantemente que el género es una de las fuerzas más poderosas

\footnotetext{
${ }^{7}$ G. CORTÉS, José Miguel, "Je Suis Lesbien. (Pierre Molinier o el cuestionamiento de la
} virilidad)", en Acción Paralela, no 3, www.accpar.org/numero3/molinier.htm. 
capaces de moldear el imaginario social y controlar, de este modo, cuerpos y corporeidades.

Los personajes retratados en su obra - casi siempre objetualizados - quedan marcados sexualmente, expuestos a la mirada, exhibidos, entrelazados con otros cuerpos. Muestran y evidencian su sexo, su participación en prácticas que cuestionan las normas y los estereotipos adquiridos en nuestra sociedad. Los modelos masculinos presentan rasgos propios del cuerpo de la mujer y elementos que, en el imaginario patriarcal, han connotado tradicionalmente la feminidad: el maquillaje, el corsé, los ligueros, los guantes, las joyas, los pechos, las medias de rejilla, los tacones de aguja. Los cuerpos de Molinier devienen soportes en los que las «extensiones corporales» cumplen la función de cubrir, acompañar, rozar, ceñir, penetrar y configurar al mismo tiempo, subvirtiendo así las limitaciones tanto físicas como culturales. ${ }^{8}$

Cada una de las fotografías de Molinier era el resultado de largos y cuidadosos preparativos. Había que afeitarse y depilarse de manera escrupulosa, posteriormente, engalanarse adecuadamente para la ceremonia, componer las medias, la ropa interior y cada uno de los complementos pertinentes. Inmediatamente después venía el ritual del maquillaje a través del cual hombres y mujeres, muñecas de cera y máscaras de cartón, jóvenes $\mathrm{y}$ viejos, todos y todas, acababan pareciéndose fantasmagóricamente. A cada modelo le atribuía la apariencia ambigua propia de sus pinturas. Molinier era un brujo esteticista que poseía el poder de hacer desaparecer los rasgos más determinantes de las personas.

Autorretrato con velo (s.f.) y Autorretrato con velo, máscara, chistera y banqueta (s.f.) toman como protagonista fundamental la máscara y el maquillaje. A pesar de no mostrar con excesivo detalle cada uno de los objetos enumerados en el título de los fotomontajes, ¿por qué incide en estas

\footnotetext{
${ }^{8}$ COLAIZI, Giulia, "L'occhio che uccide", en el catálogo de la exposición Pierre Molinier, op. cit., pp. 66-67.
} 
descripciones? ¿Lo hace quizás con cierta ironía? En la segunda de las imágenes citadas, al lado derecho de la banqueta se intuye una persona yacente sobre una especie de lecho de la cual únicamente advertimos ambos pies calzados con zapatos de tacón, ¿es un maniquí, un cadáver, un o una amante? ${ }^{9}$ Las connotaciones propias de la chistera devienen una verdadera provocación teniendo en cuenta la relación que dicha prenda tiene con la burguesía.

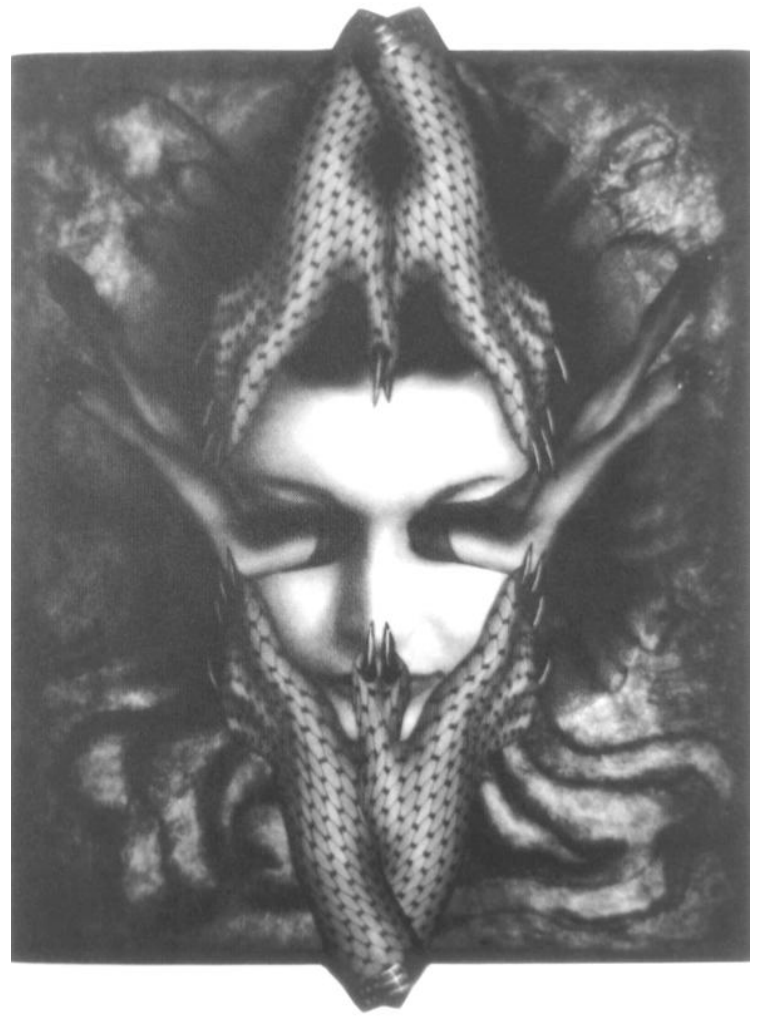

39. Pierre Molinier - L'enfant homme (1968-70)

\footnotetext{
9 En el libro de Pierre Petit Molinier. Une vie d'enfer, principal obra de referencia biográfica, el artista cuenta los detalles más oscuros de su vida, entre ellos, la experiencia sexual que tuvo el autor con su hermana al fallecer ésta. Posiblemente, su obra tenga cierta relación con aquel acontecimiento. Posteriormente se ha sabido que Molinier recreó parte de su vida en la construcción de un personaje próximo a Sade. Véase el catálogo de la exposición Transparencias fugadas: Siete pintores fotógrafos, Teruel, Museo de Teruel, 1995.
} 
La misteriosa L'enfant homme (1968-70) es un collage en blanco y negro cuyo elemento central queda ocupado por un rostro absolutamente cubierto por varias extremidades. ${ }^{10}$ La boca y la nariz quedan ocultadas por los pulgares de dos manos entrecruzadas que, saliendo de los límites de la composición, parecen sustentar el rostro de la modelo. Los ojos se extienden hacia los laterales de la imagen sustituidos esta vez por unas estilizadas piernas ataviadas con medias negras y calzadas con zapatos de tacón. En la parte superior, un par de manos — similares a las anteriormente citadas y colocadas en una meticulosa simetría - sujetan la cabeza en un gesto dulce pero firme. El fondo de la composición podría ser perfectamente el de cualquier pintura del propio Molinier, fondos abstractos que sugieren formas descaradamente orgánicas. En Ossipago, del libro Le chaman et ses créatures, ${ }^{11}$ un único tronco — el cuerpo de Molinier con máscara de mujer maquillada - aguanta seis piernas abiertas como flores.

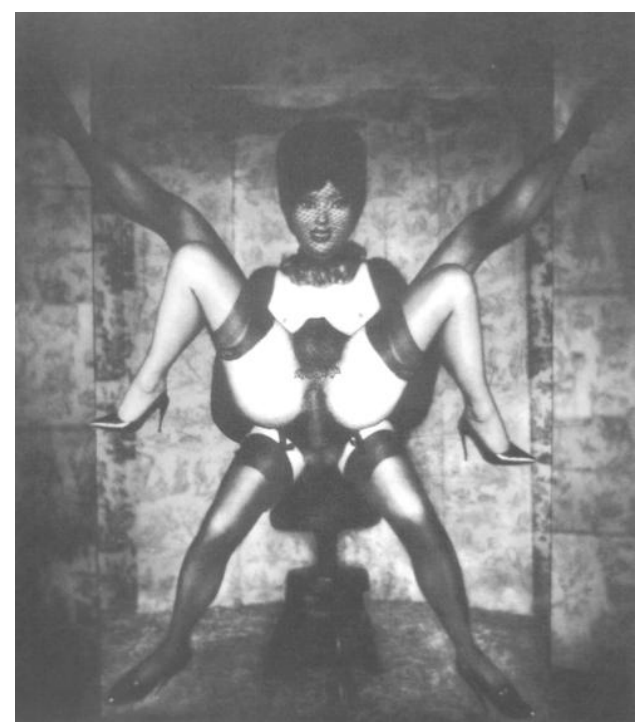

40. Pierre Molinier - Ossipago (1968-1970)

\footnotetext{
${ }^{10}$ El rostro corresponde a la joven alemana Hanel Koeck, su adorado doble y alma gemela, modelo que trabajó en el accionismo de Hermann Nitsch y compañera de Peter Gorsen, estudioso del arte y de la sexualidad que publicó en 1972 Pierre Molinier, par lui même.

${ }^{11}$ Molinier dio vida en un libro a sus más extraños seres. Le Chaman et ses Créatures, Paris, William Blake and Co., 1995.
} 
Además de los elementos citados —máscaras y maquillajesMolinier poseía cientos de prótesis de muy diversas partes del cuerpo con las cuales componía sus extrañas criaturas y creaba situaciones eróticas. No obstante, los objetos que construyó en mayor número y utilizó para darse placer fueron los godemichets. Engarzados estos en los tacones de sus zapatos le servían para gozar sexualmente consigo mismo, adquiriendo el mayor grado de ambivalencia hermafrodita, un elemento extremadamente ambiguo capaz de trascender los límites impuestos por la naturaleza. Molinier defendía la superioridad sexual de los objetos artificiales que elaboraba él mismo de manera enormemente meticulosa con cuero, seda o látex.

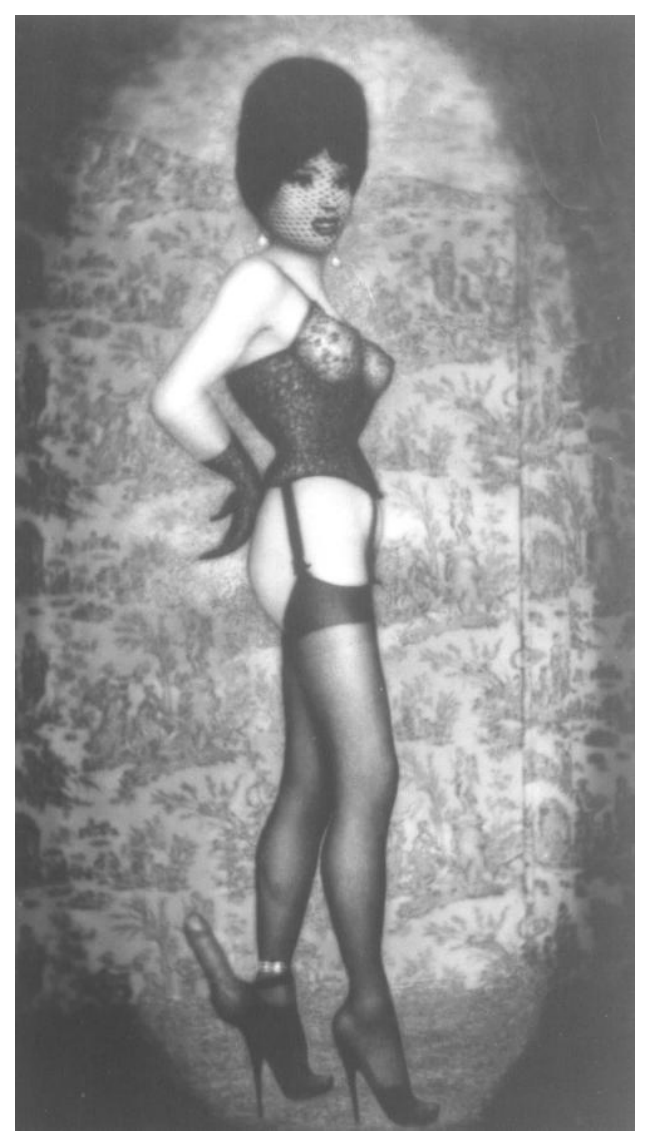

41. Pierre Molinier - L'Aiguillon de l'amour (1966-68) 
En L'Aiguillon de l'amour, una de las obras más representativas del artista, se recrea a sí mismo como la imagen de su propio deseo. Se transforma en hermafrodita, según él, un estado de «perfección sagrada», paralizado por el goce de sus propios ojos de voyeur. Transforma su cuerpo masculino en femenino al añadirle pechos, ocultar su pene y ponerse ropa interior de mujer. El falo se encuentra en uno de los tacones, lo que le permite utilizarlo en sí mismo. La representación del falo castrado, reconstruido y pegado a un objeto «femenino» fetichista - los zapatos de tacón de aguja - constituye una ruptura con el sistema de oposiciones binarias al que se asocia tradicionalmente la noción de género. «Preferiría ser sodomizado por un consolador. ¡Y por una mujer! O por un hermoso travestido [...] Pero creo que sería mejor una mujer, dado que socialmente se le considera malsaine [peligrosa, nociva, perniciosa]». ${ }^{12}$

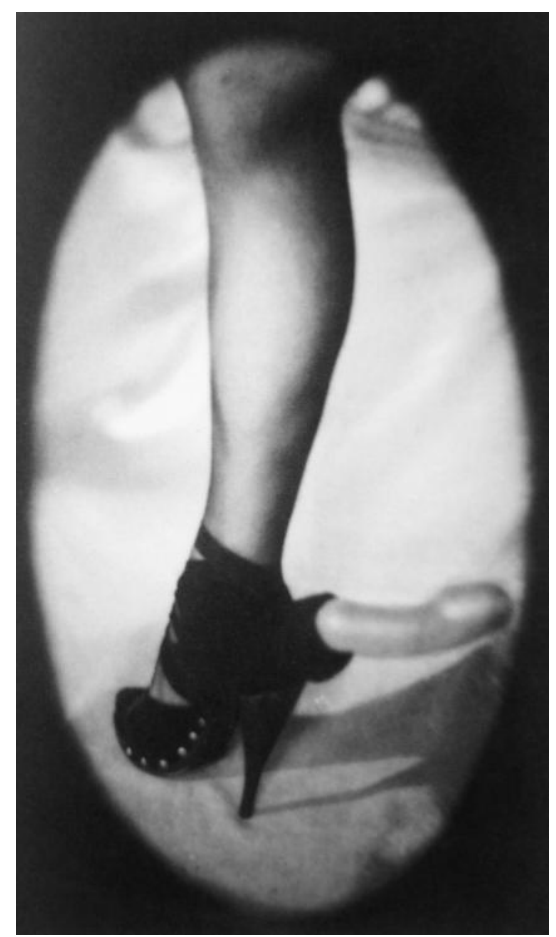

42. Pierre Molinier - Mon fétiche des jambes (1966)

${ }^{12}$ Cit. en WARR, Tracey (ed.), The Artist's Body, London, Phaidon, 2000, p. 135. 
En sus dos versiones de Mon fétiche des jambes (1966) Pierre Molinier muestra su artilugio más representativo. La fotografía de una pierna calzando sus peculiares tacones de aguja queda enmarcada por un óvalo de bordes difuminados. Mediante este efecto - harto recurrido por el autor- quien presencia la obra es transformado o transformada en voyeur simulando la imagen que se produce cuando miramos a través de un orificio.

El godemichet en la fotografía de Molinier toma significado de un elemento ambiguo cargado de connotaciones muy concretas. Para el autor no es un sustitutivo - un elemento al cual recurrir cuando no se dispone de otro-, sino una «extensión corporal», un complemento que, añadido al cuerpo, es capaz de subvertir nuestras limitaciones físicas - y por tanto culturales. Si la pantorrilla y la pierna eran para Molinier los miembros físicos más estimulantes, sus «extensiones corporales» se convertirán en prolongaciones de las mismas. Así, las inserciones anales con un consolador mientras se masturbaba, travestido, mirándose al espejo, serán uno de los motivos centrales de su obra fotográfica. ${ }^{13}$

La adición de extremidades a modo de prótesis con la finalidad de crear nuevos seres, se hace patente en sus fotomontajes - especialmente los que destina a su obra Le chaman et ses créatures. Molinier recortaba meticulosamente sus retratos, miembro por miembro, cabeza por cabeza, nalga por nalga. Los fragmentos se acumulaban en una caja donde seleccionaba, según sus deseos, las partes de su metamórfica criatura ideal. Posteriormente, difuminaba los contornos con lápices, hacía arreglos, ensombrecía, aplicaba grises y volvía a fotografiar varias veces si ello lo requería. Tras un despedazamiento absolutamente bellmeriano, la ortopedia de Molinier adquiere un carácter muy personal. ${ }^{14}$

\footnotetext{
${ }^{13}$ G. CORTÉS, José Miguel, "Pierre Molinier y el auto-fetichismo de los años setenta", en el catálogo de la exposición El rostro velado. Travestismo e identidad en el arte, Donostia, Koldo Mitxelena Kulturenea, 1997, p. 158.

${ }^{14}$ ALIAGA, Juan Vicente, op. cit., p. 55.
} 
En la serie L'oeuvre, le peintre et son fétiche, al igual que en Autoportraits couleur - ya en la última etapa de su vida - el autor parece revelar abiertamente todo lo que es y representa. Mientras que en trabajos anteriores dosificaba aspectos concretos de sus inquietudes más viscerales, su último legado son verdaderas radiografías de su credo. De ahí que Molinier evite entretenernos con desgarradores y provocativos detalles, dejando de recurrir a sus encuadres resaltados por marcos negros de bordes difuminados y al artificio de embellecer la exposición con estudiadas poses y/o composiciones.

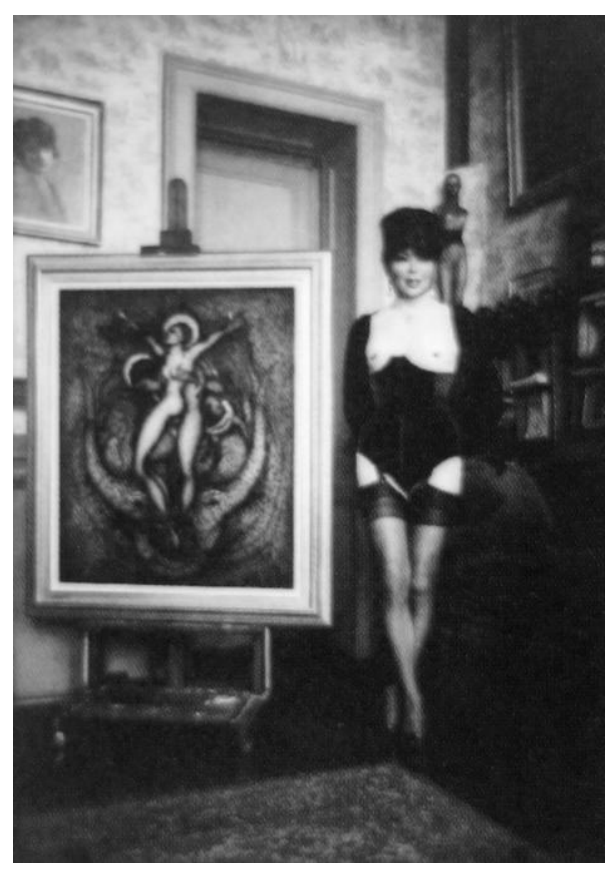

43. Pierre Molinier - L'auvre, le peintre et son fétiche (s.f.)

Haciendo uso de planos fotográficos generales, el autor se muestra ataviado con ropa interior femenina y situado siempre a la parte derecha de su propia obra pictórica o gráfica - Ceci qui est merveilleux. Esta vez se «desnuda» más que nunca mostrando todo lo que hay, todo lo que debemos saber sobre él. Son imágenes de carácter premonitorio, en las que parece tener la intención de revelarnos su futuro — suicidio - a través de estas 
últimas series fotográficas. Pero, no nos llevemos a engaño: Molinier no cae en ningún tipo de victimismo ni nos está pidiendo auxilio, todo lo contrario, su expresión - sonriente aunque no especialmente alegre- es la de agotamiento o imposibilidad. ¿O es que tal vez alcanzara su meta — «Je suis lesbien»— y tras ello no esperara nada más en la vida?

Teniendo en cuenta lo señalado, se podría hacer una lectura de su trabajo como un proceso mediante el cual se plantea la negación de la diferencia sexual y el deseo de conseguir en su propio cuerpo fetichizado la unidad de la dialéctica hombre-mujer. El cuerpo de Molinier se convierte, al unísono, en contenedor y contenido. De este modo, manifiesta un doble deseo de no identificarse con ningún sexo, a la par que intenta poseer lo que más anhela de cada uno de ellos, disfrutando de ambos. La valoración de una de las partes corporales más despreciadas por la sociedad cuestiona la noción de virilidad y amplía la concepción masculina a partes del cuerpo y prácticas prohibidas por los modelos convencionales. Esta actitud sexualmente desinhibida y rebelde, situada contra las normas sociales y alejada de cualquier mistificación o convencionalismo, le llevará a desarrollar libremente sus pulsiones sexuales y a evidenciar una identidad escindida que le hará aparecer como emblema del arte de los años setenta y como referencia obligada en décadas posteriores.

\subsubsection{La mirada de Diane Arbus}

Aunque sería una aberración situar la obra de Diane Arbus (Nueva York, 1923-1971) en una contextualización próxima al concepto de Body Work acotado por Willoughby Sharp y Liza Bear ${ }^{15} \mathrm{y}$, por otra parte, aunque su trabajo no tiene relación alguna con los retratos de Pierre Molinier, consideramos primordial realizar una breve aproximación a la obra fotográfica de Arbus por dos motivos: en primer lugar, porque es innegable

${ }^{15}$ Véase el apartado 4.1 del presente trabajo. 
la influencia de la fotógrafa en artistas adscritos al arte corporal y, en segundo lugar, debido a que propala imágenes de los sectores más afrentados de la sociedad, referencia obligada en determinados artistas adscritos al Body Art.

En 1972 tuvo lugar una exposición retrospectiva de la obra de Diane Arbus en el Museo de Arte Moderno de Nueva York. Ciento doce fotografías reflejaban seres extraños y dolidos, habitando espacios solitarios. Arbus, de profesión fotógrafa de moda, se rebeló contra la mentira cosmética encargada de enmascarar las ingratas desigualdades marcadas por nacimiento, clase y apariencia física, mostrando un verdadero catálogo de personas inmovilizadas en identidades y relaciones mecánicas. Fue su manera de protestar contra el imaginario social de la revista Vogue, contra la moda y contra lo convencionalmente estético. ${ }^{16}$

Sus obras, de rabiosa actualidad, guardan cierto carácter ambiguo al retratar a sujetos excluidos de la sociedad con la distancia necesaria para mostrar su soledad, aunque también con el interés suficiente capaz de imponer su presencia. Cada una de sus fotos es una evidencia y un enigma, donde no sabemos a ciencia cierta hasta dónde llega lo inaudito y dónde comienza la actitud contra lo admitido, lo normal y lo bello. Tal y como afirma Susan Sontag, la obra de Arbus expresa su rebelión contra lo que era público, convencional, seguro, tranquilizador $-\mathrm{y}$, por consiguiente, también tedioso - en pro de lo que era privado, oculto, feo, peligroso y fascinante. ${ }^{17}$

Fotografió numerosos ejemplos de personas que, escapando de las categorías más clásicas, se situaban en esos espacios dudosos entre la masculinidad y la feminidad - travestis, transexuales y hermafroditaspero siempre sin complacencias, sin lugar para la jovialidad ni el disfrute. Lejos de espiar a los personajes para sorprenderlos desprevenidos, la

${ }^{16}$ SONTAG, Susan, Sobre la fotografía, Barcelona, Edhasa, 1981, p. 42.

${ }^{17}$ SONTAG, Susan, op. cit., p. 55. 
fotógrafa entabla un diálogo con ellos persuadiéndoles a posar como cualquier noble victoriano. Arbus muestra a los sujetos de sus imágenes en el interior de sus domicilios, en las situaciones más cotidianas, en los momentos menos dulces. De este modo, se puede ver con total crudeza los diferentes rasgos que el maquillaje ya no oculta, como en A Young man in curlers on West 20th Street (1966); o los rostros después del espectáculo, cuando ni la ropa sucia y desastrada, ni el maquillaje desvanecido pueden hacernos soñar, caso de Hermaphrodite and Dog in a Carnival Trailer (1970).

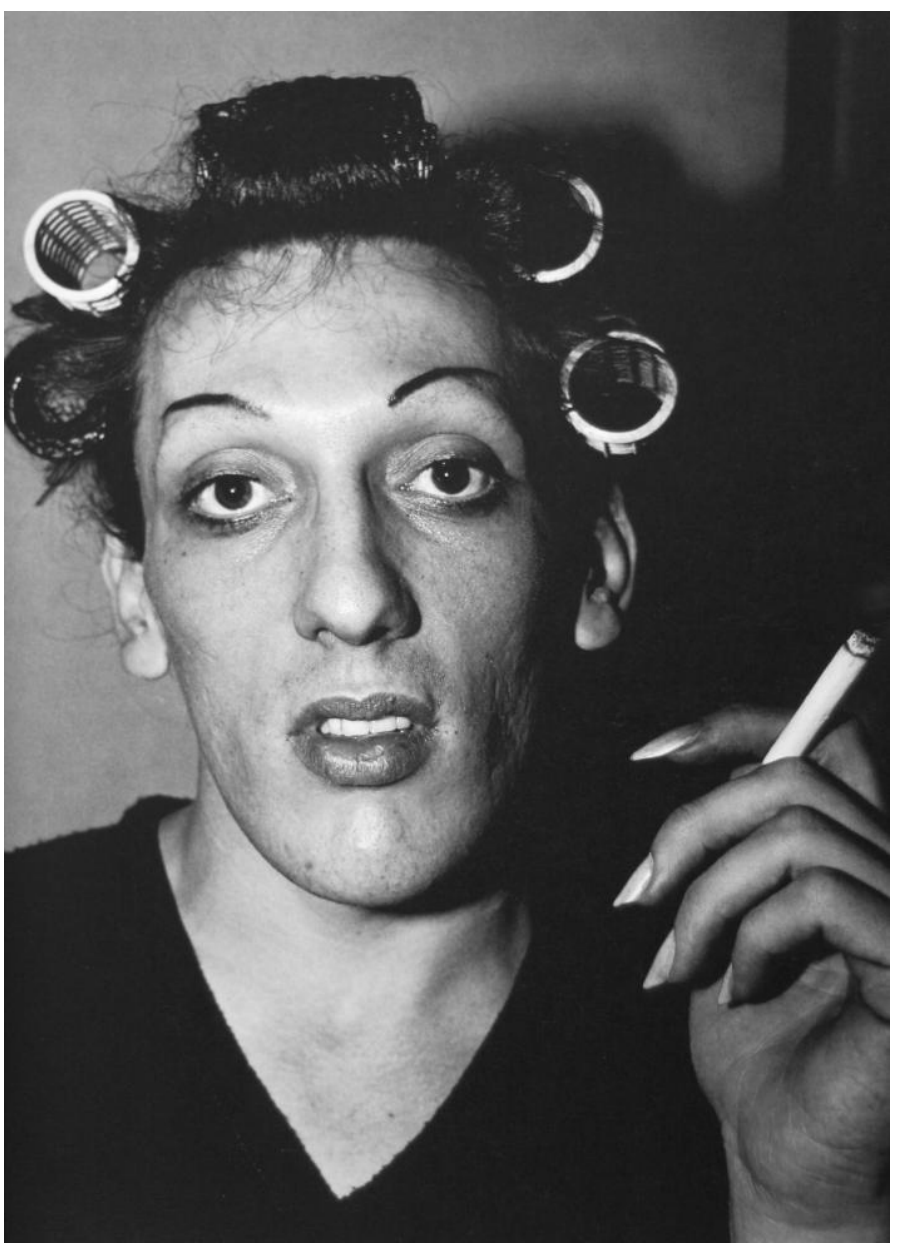

44. Diane Arbus - A Young man in curlers on West 20th Street (1966) 
En A naked man being woman (1968) observamos la pose teatral de un individuo que, despojado de su ropa y con el rostro maquillado, anhela ser una mujer disimulando su sexo afeitado entre los muslos. Una imagen cargada de cierto grado de patetismo e inmersa en un mundo que necesita mayor comprensión y amplitud de miras.

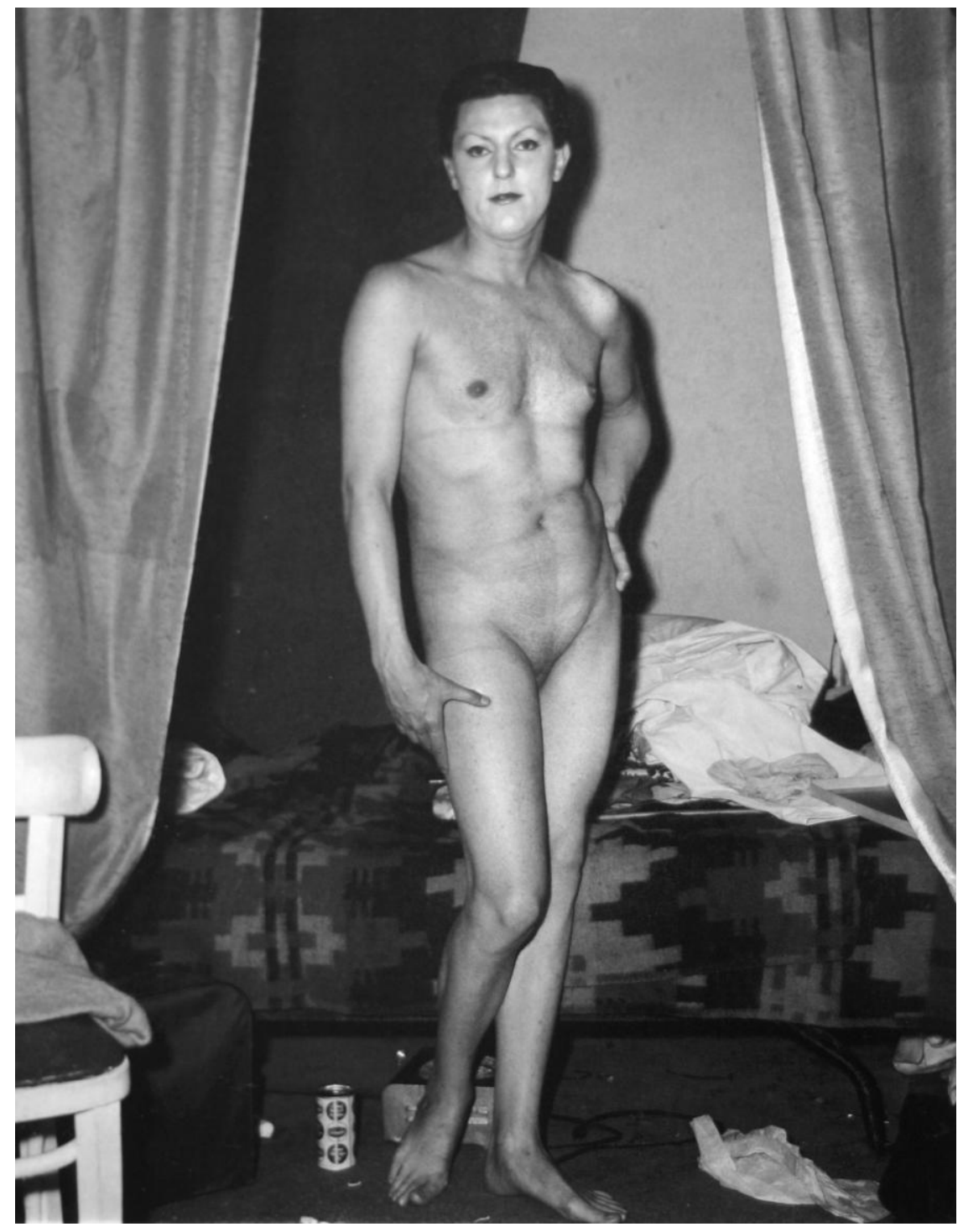

45. Diane Arbus - A naked man being woman (1968) 
Cabe señalar que Diane Arbus nunca fue protagonista de sus fotografías sino que captó la imagen de otros. Por otra parte, su visión del mundo de los travestis y transexuales es terriblemente melodramática. Son temas ahistóricos, patologías privadas, vidas secretas. Sin embargo, su gran popularidad e influencia en la fotografía contemporánea nos lleva a destacar su obra como parte esencial de los y las artistas que trataremos a continuación.

\subsection{Transformer. La serie fotográfica como proceso performativo}

Un considerable conjunto de artistas, siguiendo el más puro espíritu de Pierre Molinier e influenciados y influenciadas por los sórdidos ambientes de Diane Arbus, desarrollaron, a partir de 1968, un trabajo de fuerte carácter autobiográfico donde la representación de sí mismos fue el principal leitmotiv. Esta serie de autores y autoras ocuparon todo el espacio mental y físico de la obra estableciendo una relación absolutamente voyeurística de profundo carácter narcisista que vislumbraba el cabeceo dialéctico de las ambivalencias entre el ser y el parecer. Su cuerpo se transformó en el elemento esencial de construcción, en el soporte más idóneo capaz de generar - gracias a una serie de claras «extensiones corporales»- una nueva imagen y satisfacer así el objeto de nuestros fantasmas.

Estos y estas artistas desarrollaron generalmente un juego de roles y sexos en mutuo diálogo con la imagen representada. Ello dio lugar a una criatura -andrógina o travestida en algunos casos y completamente monstruosa en otros - que traspasaba las fronteras del individuo —reivindicado especialmente desde los acontecimientos de Mayo del 68y que actualizaba su identidad. Aquel resurgir del concepto de «cuerpo extendido» se convirtió en el tema esencial de artistas tales como Urs Lüthi y Jürgen Klauke. 
$\mathrm{Si}$ revisamos de manera somera el concepto de género - masculinidad, feminidad- llegamos a la conclusión de que éste permanece extremadamente codificado respecto a las estructuras de poder pertenecientes a una sociedad en una época determinada. No podemos negar que la biología proporciona una superficie básica para la inscripción social, pero no es una esencia fija ni estática, sino que interactúa con las relaciones psíquicas y sociales más significativas.

Retomando nuevamente las nociones tratadas en el primer capítulo acerca del binomio cuerpo y corporeidad, recordaremos que al primer término se le atribuía el significado de entidad material, mientras que el segundo implicaba aquello que denominábamos procesos de incorporación, es decir, los factores socioculturales que nos construyen como individuos. De este modo, el cuerpo deviene indicio de un sexo y corporeidad de un género, de ahí que nuestra percepción del cuerpo, nuestra visión de él, es posible sólo con una lectura y un entendimiento concurrente del género. El cuerpo humano se torna comprensible, en gran parte, mediante la inteligibilidad de su género.

No reconocemos a una persona sin su condición de masculina o femenina, la ambigüedad engendra ansiedad en unos casos y fantasía transgresora en otros. El andrógino deviene objeto de fascinación voyeurista, de investigación sobre la medida de su masculinidad en detrimento de su feminidad, de búsqueda de signos de similitud y/o diferencia, de confirmación de lo otro. El sexo es uno de los aspectos a través de los cuales el cuerpo es producido y, por tanto, el modo de representación de sí mismo.

El cuerpo no puede ser visto como un soporte virgen, pasivo, un terreno neutral de significado, sino que es un soporte activo y productivo. Las morfologías corporales son los resultados de un significado social. Si alguien no se adapta a la norma masculina, o a la femenina, su humanidad está completamente cuestionada. Tal y como afirma Judith Butler, el cuerpo 
funciona como una extensión sobre la cual se registra el género. Ello hace que tanto éste como el sexo sean construcciones ingeniadas que nada tienen que ver con una supuesta verdad natural. La autora norteamericana objeta la idea de una esencia prelingüística interna reivindicando, por tanto, que los actos de género no son performed — actuados, llevados a cabo- por el sujeto, sino que constituyen performativamente al sujeto - es un efecto o consecuencia del discurso más que su causa. No existe un original de género que se copie o imite, todo son copias. Recordemos la celebérrima sentencia de Simone de Beauvoir: «no se nace mujer sino, sino que se llega a serlo».

Gran número de obras transgredieron mediante diferentes «extensiones corporales» las identificaciones y los placeres sexuales que se consideraban normales, inundando el mundo del arte y de otras disciplinas de una imaginería autorrepresentacional de fuerte contenido narcisista. Tal y como observa Cortés, las prácticas del travestismo han formado parte del mundo mágico de rituales religiosos de numerosas culturas y civilizaciones, siendo socialmente bien aceptado en muchas de ellas. No obstante, el travestismo no se da de la misma manera en períodos y culturas diferentes. Si revisáramos históricamente los códigos sociales, nos daríamos cuenta de que estos han sido, fundamentalmente, reguladores de los géneros. La ropa es, probablemente, el mayor o más importante símbolo del género que permite a las otras personas identificar inmediatamente el rol del género individual. $^{18}$

El efecto cultural del travestismo desestabiliza todos los planteamientos binarios: no sólo hombre y mujer, sino también homosexual y heterosexual, sexo y género. La anatomía deja de marcar el destino de las personas, se plantea una clara disociación de los signos de las supuestas referencias naturales. Con ello se extiende el principio de incertidumbre, se abolen los límites y se vislumbra una pérdida de cualquier principio referencial.

\footnotetext{
${ }^{18}$ G. CORTÉS, José Miguel, "El travestismo: un desafío histórico a las diferencias", en el catálogo de la exposición El rostro velado..., op. cit., p. 25.
} 
En todas estas actividades las relaciones sexuales son vistas como una especie de teatro que tiene una cierta naturaleza de ritual y de juego, a la vez que manifiestan una potencia terapéutica y catártica; es decir, rompen el hechizo de un deseo negado y permiten enfrentarse a la propia represión del deseo, impidiendo que se conviertan en obsesiones. No se trata sólo de conseguir placer, existe una erotización ritualista de la libido, de la realización de fantasías prohibidas y de las diferencias de poder como significantes de deseo sexual. El travestismo supone un cambio transitorio y provisional de atuendo con fines eróticos, y quien lo practica, sea mujer o varón, no tiene por qué sentir la necesidad de tener vagina o pene.

Cuando un hombre o una mujer se trasviste, ${ }^{19}$ ocurre que se subvierten los códigos sociales que nos señalan qué apariencia debemos mostrar en nuestra reglamentada sociedad. A través del mismo se abren múltiples posibilidades de reconfiguración del imaginario cultural, se cuestiona el significado de cualquier identidad y se plantea una sensación de inestabilidad, anarquía y desafío que se convierte en una crítica a la posibilidad de representación de sí mismo.

Es en la época del Body Art, de las performances y de la estética del Transformer, cuando se pondrán en práctica formas mucho menos estéticas y más auténticas de representación. Así pues, el travestismo está en la base de una serie de artistas que subvirtieron los límites de unos estereotipos sociales profundamente arraigados. En 1974 se celebró en Lucerna (Suiza) la exposición Transformer: Aspekte der Travestie, organizada por JeanChristophe Ammann. La exposición tomó prestado el título del álbum homónimo de Lou Reed publicado en 1973 en el cual relataba la vida urbana de los ambientes drags. La muestra mezcló en el espacio museístico imágenes de Jürgen Klauke, Urs Lüthi, Katharina Sieverding o Andy Warhol, entre otros y otras artistas, junto a músicos cuya posición radical respecto a la identidad alcanzaba componentes performativos muy próximos

\footnotetext{
${ }^{19}$ El término travestismo fue acuñado por el sexólogo alemán Magnus Hirschfeld en 1910 y no fue claramente diferenciado del transexualismo como categoría clínica hasta 1960.
} 
al teatro de vanguardia y al Body Art (David Bowie, Brian Eno, Lou Reed o The New York Dolls). ${ }^{20}$

Como un medio de expresión fuertemente marginalizado en la jerarquía de la Historia del Arte, la fotografía fue abrazada durante la década de 1970 como el medio transgresivo por excelencia. «Stop painting!» fue una de las frases más aclamadas por los nuevos medios de expresión. La sentencia de McLuhan — «the medium is the message»— se convirtió en un icono de la escena cultural de la última década de los años 1960 y de la siguiente. Con ello, la fotografía avanzaba las posibilidades específicas para transmitir el espíritu de libertad, puesto que era el único medio que ofrecía la posibilidad de construir una imagen sobre la condición humana entre la vida y la muerte, entre la búsqueda científica y la ilustración creativa. ${ }^{21} \mathrm{Su}$ reproductibilidad mecánica, su denigrado estatus cultural y sus capacidades miméticas ofrecieron a los y las artistas un vehículo perfecto a través del cual podían transmitir sus inquietudes sin la necesidad de crear objetos estéticos. Muchos autores y autoras se apropiaron del estilo propio del fotoperiodismo para sus esfuerzos de análisis. La documentación fotográfica fue adoptada por aquellos y aquellas artistas que deseaban evitar ciertas convenciones estéticas, pero sobre todo, por quienes querían documentar episodios o performances en la privacidad del estudio.

De este modo, la acción fotográfica se convirtió en una interesante posibilidad de acceder al otro. Posibilidad a través de la cual el o la artista introduce el medio fotográfico como una documentación susceptible de ser alterada, como un espejismo de quien observa la obra en una imagen manipulada por el autor o autora en una explosiva estrategia basada en la reflexión sobre el mundo visible.

\footnotetext{
${ }^{20}$ BLESSING, Jennifer, Rrose is a Rrose is a Rrose. Gender Performance in Photography, New York, Solomon R. Guggenheim Museum, 1997, p. 70.

${ }^{21}$ POHLEN, Annelie, "Image, Space, Reality \& Perception, Living Space", en el catálogo de la exposición Sieverding, Bonn, Bonner Kunstverein, 1992, p. 32.
} 
Como veremos a continuación, muchos de los trabajos de aquella época recurrieron a la multiplicidad de la imagen. El recurso fotográfico como arte secuencial sembró un terreno de posibilidades para expresar y preservar la noción de tiempo. Por ello, la serie fotográfica se convirtió en uno de los modos de expresión más utilizados con la finalidad de registrar los procesos de reflexión sobre el género. Este juego de seriación sugiere el intento de fijar una identidad transitoria y fugaz, un intento por captar la imagen del espejo y por ser quien se quiera ser en cada momento (siendo «real», y asegurando, así, la existencia). ${ }^{22}$

Hoy en día, tal como afirma Juan Vicente Aliaga, la popularización en los medios de comunicación de masas, en particular de la televisión, el cine, la cultura de las discotecas y las revistas juveniles, de personajes que trataban de rompen los límites indumentarios — drag-queens, drag-kings o transformistas con mensaje político - conlleva, en la mayoría de ocasiones, una vulgarización que desactiva la carga irreverente de dichas manifestaciones. ${ }^{23}$

Por otra parte, cuando una mujer representa ciertos rasgos masculinos, ello no significa una pérdida de su estatus, ya que continúa siendo identificable como femenina e, incluso, adquiere ciertas connotaciones seductoras para el espectador masculino - recordemos las famosas escenas de Marlene Dietrich. Por el contrario, el hombre no puede aparecer con ninguna vestimenta de mujer sin sufrir el escarnio público. A pesar de que el vestido no tiene propiedad en sí mismo, está altamente cargado de significado y ha sido asignado socialmente a un género u otro. Por el contrario, mientras las representaciones de artistas hombres en torno al travestismo tuvieron licencia en el mundo cultural de los años 1970, cuando mujeres artistas hicieron lo propio fueron inexplicablemente

\footnotetext{
${ }^{22}$ SPECTOR, Nancy, "Performing the Body in the 1970s", en el catálogo de la exposición Rrose is a Rrose is a Rrose..., op. cit., p. 159.

${ }^{23}$ ALIAGA, Juan Vicente, op. cit., pp. 56-57.
} 
marginadas. Muy lejos estamos, todavía, de alcanzar la ruptura de los estereotipos establecidos, aunque en el terreno artístico no falten tentativas.

A partir de 1969 el travestismo se convirtió en la obra de Urs Lüthi (Lucerna, Suiza, 1947) en el modo de expresión esencial utilizado. Él mismo - sin recurrir a ningún intermediario - fue el material de trabajo y la significación: su rostro y su cuerpo se alzaron como modos de expresión donde la alteración y la mutación simbólica — provocada por el travestismo - tenía un componente físico, aunque también psíquico y, por tanto, social, significando una patente negación de su yo.

Los autorretratos de Lüthi tildan, al mismo tiempo, la realidad y la ficción del yo. Afirman con evidente igualdad la conciencia de sí y la alteridad. Esta transformación física, psíquica y social de la que da testimonio su trabajo — alteración provocada por la máscara, el maquillaje y el vestido - parece un intento de desposesión de uno mismo por medio de unas metamorfosis que trasladan desde una mutación simbólica hasta el odio y la negación del yo. Sin embargo, estas imposturas pueden ser comprendidas como un esfuerzo de recuperación de una consciencia inquieta e incierta: el yo como fuente de interpretación que va de la ironía a la melancolía, del deseo preciso a la obsesión y al fantasma.

Para Maurice Fréchuret la importancia de la indumentaria debe ser leída como un efectivo sustituto del propio autor y como la última frontera que éste deberá sobrepasar para llegar a la realidad que le interesaba. Los autorretratos producidos en aquellos años fueron el fruto de una reflexión sobre el estado ambivalente que gobernaba la realidad. Pintura y fotografía, artista y modelo, hombre y mujer, intimidad y exterioridad, son, entre otras, dualidades que el artista tomó en consideración para establecer a posteriori un método de aproximación a él mismo en relación con el mundo que le rodeaba. A diferencia de otros autores genéricamente adscritos al Body Art, no es Urs Lüthi quien se exhibe en público, él es —ante todo- un generador de imágenes que tratan una realidad que se muestra frágil, una 
enigmática consideración de una vida que ansía escapar de sus más arraigados dilemas estableciendo su propio mito de manera voluntaria y radical. $^{24}$

Así pues, sus autorretratos fotográficos —ambivalentes e irónicosconstituyen una reflexión de raigambre kitsch. El cuerpo sólo existe en tanto que objeto de un travestismo cargado de significados perturbadores a través de los cuales se despliega un irónico juego psicológico entre el yo y el otro, un juego cuyos significados son presentados estratégicamente en un continuo cambio de papeles. El travestismo y las metamorfosis se convierten en una forma de comunicar los roles, represiones y autoextensiones comunes a la psicología de ambos géneros. Sin embargo, estas ambiguas representaciones no manifiestan el infortunio de un sexo equivocado, sino que divulgan los estratos del ser y el parecer, los potenciales de la identidad y los efectos manipuladores de la imagen. ${ }^{25}$

Urs Lüthi posó ante la cámara para comprobar «hasta dónde podía llegar en la relación entre hombre y mujer». Motivado por una exploración de su dimensión psicológica y de cómo reaccionaría ésta si se estableciera un vínculo íntimo con el sexo opuesto, el autor esperaba que comunicando «todo lo íntimo y personal» incitaría al espectador o espectadora a reflexionar y a cuestionarse los aspectos personales y contradictorios de uno mismo. La manera de representar visualmente sus «rasgos femeninos» fue a través de su caracterización. Con la destrucción de los estereotipos relativos al género Lüthi señala que la conexión que siente con lo «femenino» se encuentra en un lugar muy profundo de la psique, alejado de la apariencia y el comportamiento sociales. ${ }^{26}$

${ }^{24}$ FRÉCHURET, Maurice, "Les années 70 : l'art en cause", en el catálogo de la exposición Les années 70 : l'art en cause, Bordeaux, capcMusée d'art contemporain, 2003, pp. $42-46$

${ }^{25}$ MASON, Michael, "L'œuvre multiplié", en el catálogo de la exposición Urs Lüthi. L'œuvre multiplié 1970-1991, Genève, Cabinet des Estampes, 1991, p. 144.

${ }^{26}$ JONES, Amelia, cit. en "Representación de la identidad", en El cuerpo del artista, Londres, Phaidon, 2006, p. 139. 
Estableciendo una cierta relación con la obra Le peintre de l'espace se jette dans le vide! u Obssesion de la lévitation, ilustrada en un periódico de un solo día - Dimanche - creado por el anteriormente citado Yves Klein, Lüthi presentó I'll be your Mirror (1972), título adoptado del nombre de una canción del grupo Velvet Underground del año 1966. La obra consistía en un offset sobre papel de prensa, aunque esta vez la misma sí que vio la luz en la edición del sábado 28 de diciembre del National-Zeitung. Aquellos lectores y lectoras que desearan poseer una prueba firmada por el artista reenviaban la página a la editorial. El mismo Lüthi se encargaba de firmarla antes de devolverla al propietario o propietaria por un precio de diez francos suizos. Dos años más tarde realizó la serie Tell me who Stole your Smile (1974), compuesta por ocho offsets en los que se retrataba con diferentes apariencias y expresiones, tanto burlonas como desafiantes.

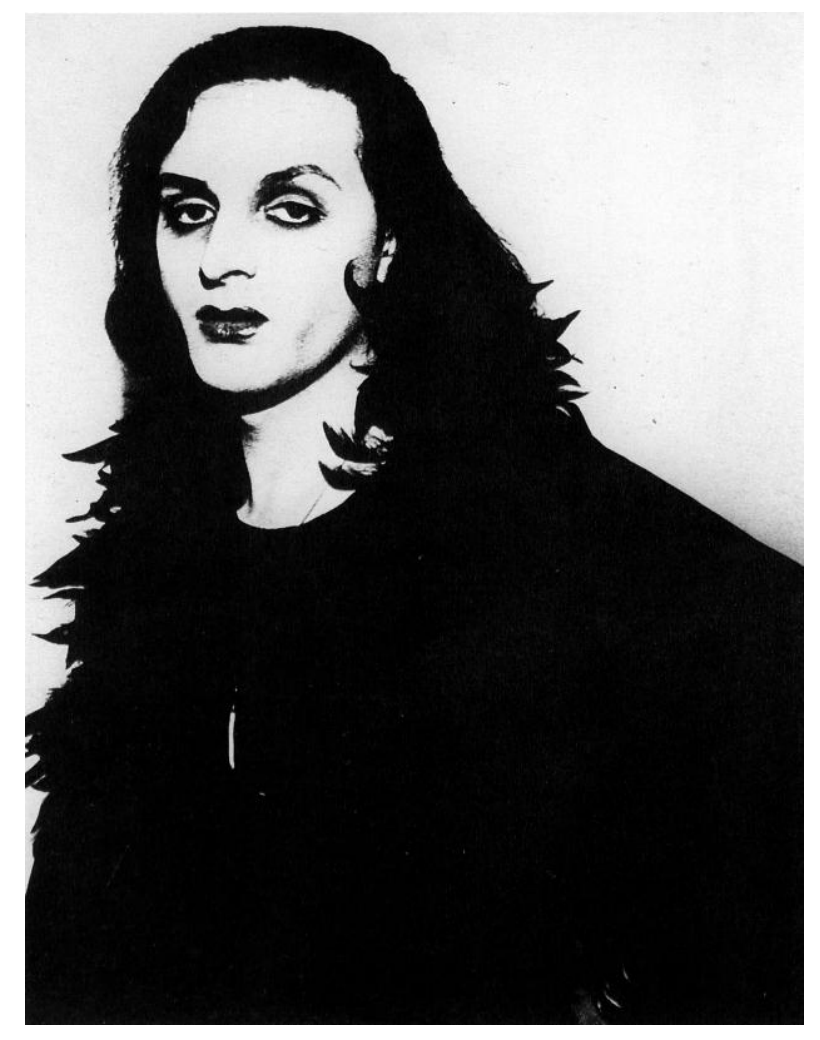

46. Urs Lüthi - Tell me who stole your smile $n^{o} 8$ (1974) 
En 1974 Urs Lüthi realizó una serie de fotografías junto a su compañera sentimental. Self-Portrait with Ecky los mostraba uno al lado del otro, mejilla contra mejilla, vestidos y maquillados de idéntica manera de modo que parecían la misma persona («pretendía identificarme al máximo con mi novia y, de alguna forma, meterme en su piel»). El mismo año realizó My Face behind Ecky's Face, en la cual un primer plano de Ecky apenas deja ver al autor cuya silueta se adivina cual extensión de la imagen femenina, articulando así un interesante juego entre el doble y el otro.

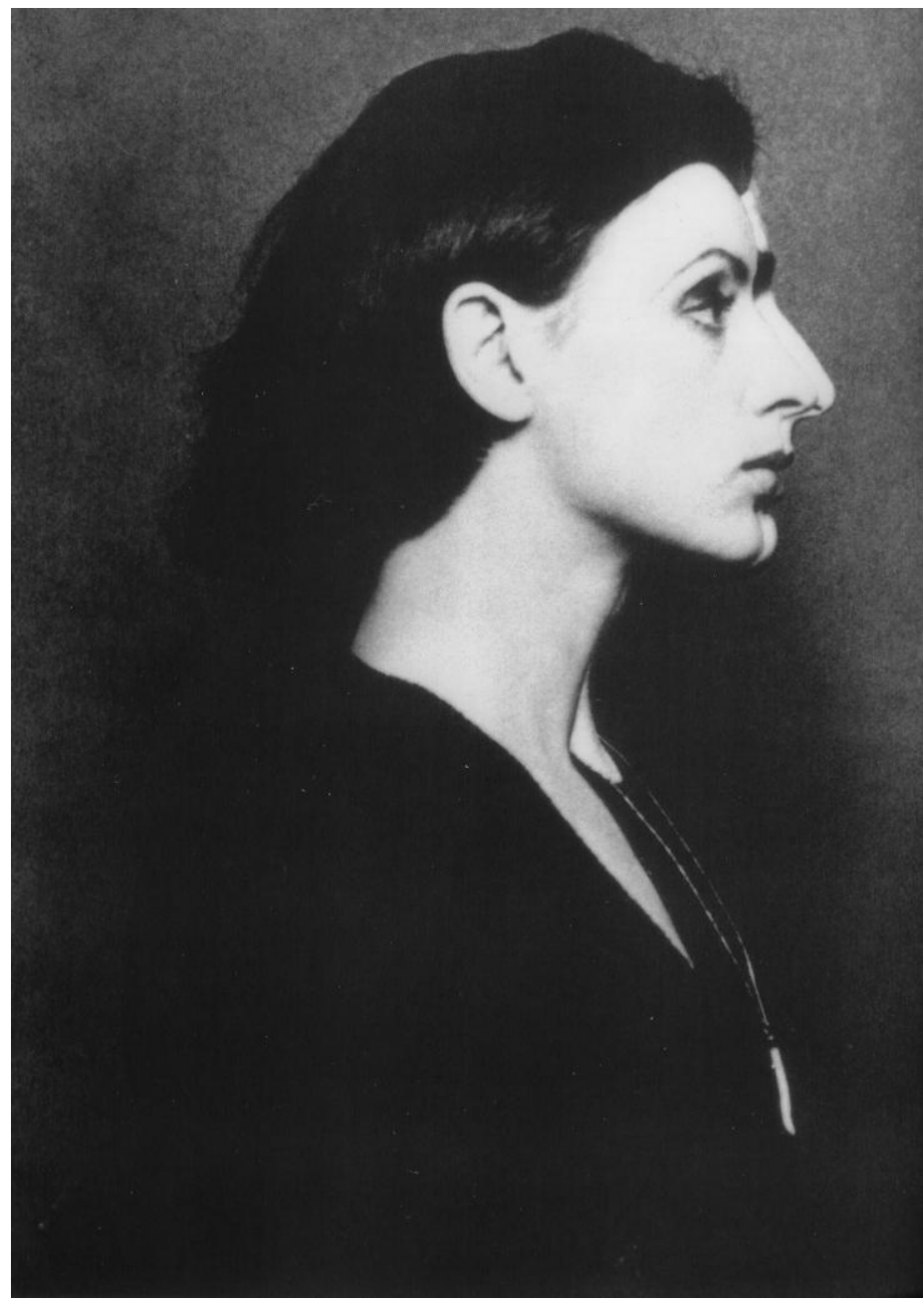

47. Urs Lüthi - Self-Portrait with Ecky (1974) 
Lüthi se desenvuelve como una especie de actor en movimiento continuo que —obsesivamente - parte de sí mismo, pero a diferencia de Narciso, se autocuestiona infatigablemente. Su cuerpo multiplicado constata, trivializa, comenta, sitúa y articula la existencia a través del autorretrato, así como mediante la diversidad y pluralidad de caras que van rotando en su posición delante de la cámara y creando nuevos rostros cada vez. $^{27}$ El autor pone en escena un juego simultáneo de ocultación y divulgación del destino individual y social del yo. Con sus fotografías intenta tanto captarse como perderse en un intento de querer reconocerse e identificarse, pero dicho acto deviene banal al comprobar su imposibilidad. De este modo, al observar su trabajo quedamos intimidados e intimidadas por una dramaturgia — casi subliminal - dirigida al juego narcisista, de alteraciones físicas, afectivas y sociales tendentes a la desposesión de sí y a la realización de simulacros que registran el esfuerzo de recuperación de una conciencia inquieta e incierta. ${ }^{28}$

La abertura de Lüthi hacia el mundo no se opera sólo por la naturaleza de los simulacros que encarna, sino también por las leyendas que a menudo acompañan y comentan su relación (¿su experiencia?) fotográfica. En este contexto, la obra de Urs Lüthi debe ser relacionada con la de Jürgen Klauke, Katharina Sieverding o Michel Journiac, quienes a principios de los años 1970 admitieron el travestismo como medio de expresión y como cuestionamiento de las dualidades propias de la cultura occidental.

Jürgen Klauke (Kidling, 1943) creó imágenes de sí mismo con una interesante carga de ambigüedad sexual en verdaderos rituales sadomasoquistas realizados con accesorios que imitaban los genitales tanto masculinos como femeninos. Klauke investigó representaciones de una sexualidad e identidad nada convencionales en series de autorretratos efectuados con sugerentes secuencias fotográficas de carácter performativo

\footnotetext{
${ }^{27}$ MASON, Michael, "Trois thèmes", en el catálogo de la exposición Urs Lüthi..., op. cit., p. 153.

${ }^{28}$ MASON, Michael, op. cit., p. 156.
} 
y/o mediante el uso de la fotografía única como medio para capturar la verdad de una identidad fija.

El autor, y en este aspecto difiere claramente de Urs Lüthi, centra sus imágenes en sus fantasías eróticas y en el desvelamiento, de un modo potentemente provocativo y perturbador, de la intimidad de unos deseos sexuales que van desde el maquillaje hasta el bondage. El autor se fotografió en forzadas poses y con variadas vestimentas representativas de toda una gama de marcadas etiquetas culturales con la finalidad de retratar una identidad en constante evolución. ${ }^{29}$
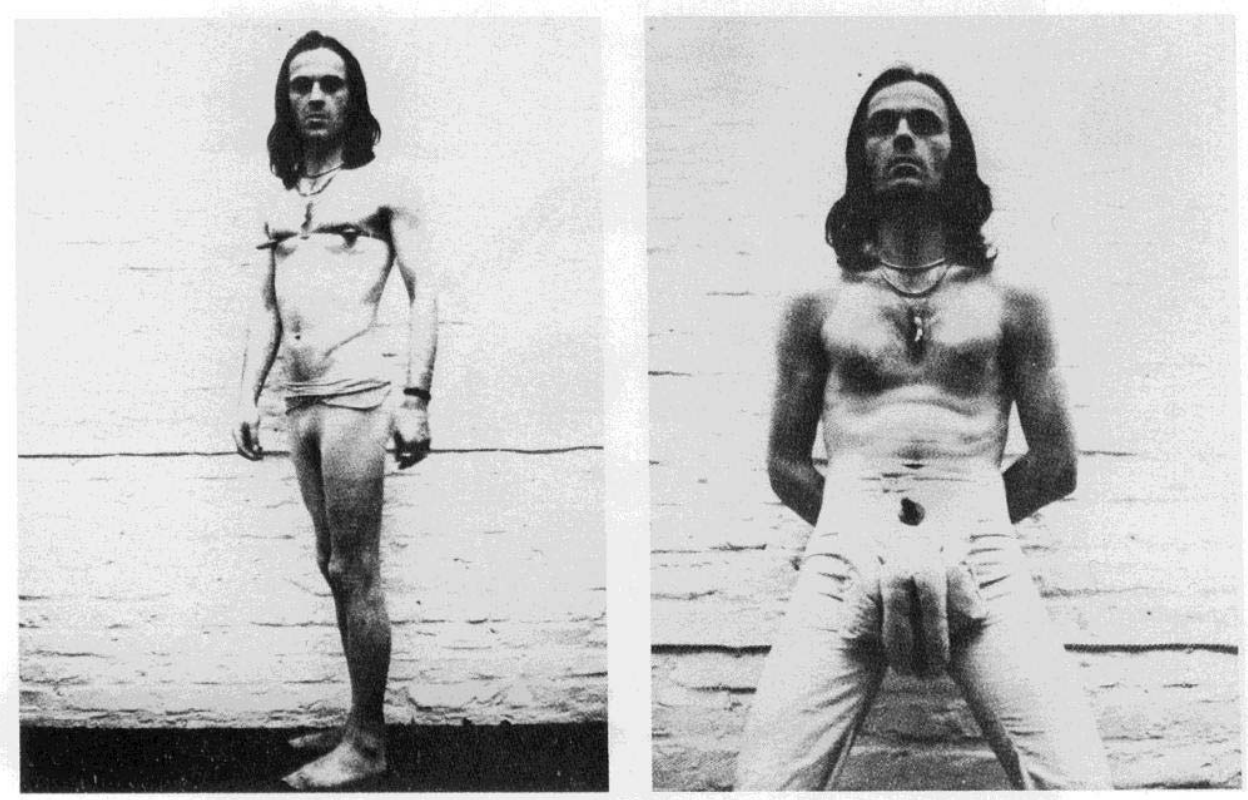

48. Jürgen Klauke - Self-Performance (1972-73)

$\mathrm{Su}$ primer trabajo fotográfico significativo fue Self-Performance (1972). La obra posee dos ediciones — una primera de doce partes ampliada

\footnotetext{
${ }^{29}$ STILES, Kristine, "Uncorerupted Joy: International Art Actions", en el catálogo de la exposición Out of Action: Between Performance and the Object 1949-1979, Los Angeles, The Museum of Contemporary Art, 1998, p. 263.
} 
posteriormente a trece- en la que el artista aparece con el cabello largo y ante un muro de ladrillo pintado de blanco. Klauke mira al espectador o espectadora con cierto aire provocativo y se presenta, en ocasiones, como un tipo viril con un órgano sexual inflado alejado de toda proporción real. En otras imágenes se muestra como una mujer cubierta por un vestido largo o, también, como un macho enfundado en cuero cuyos pechos se transforman en erectos cuernos en forma de penes.

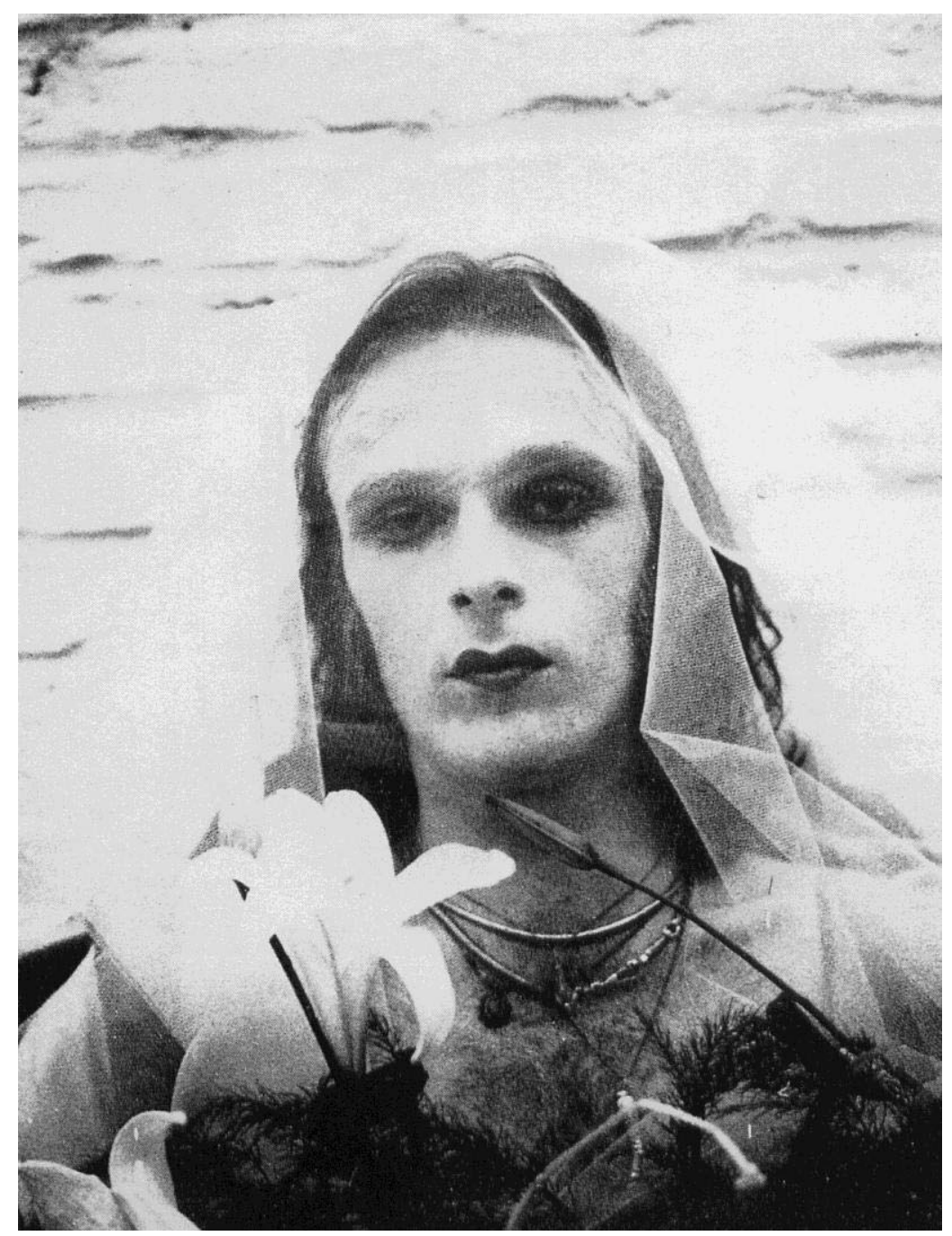

49. Jürgen Klauke - Self-Performance (1972-73) 
Dentro de esta serie se integra un retrato del artista vestido como una madona. Su cara está cuidadosamente maquillada con los ojos perfilados y la boca acentuada, además, lleva un pañuelo en la cabeza. La imagen se completa con algunos complementos: una vela y un ramo de crisantemos. Como contraste destacado, una fotografía muestra un peculiar detalle adjunto: una especie de cojín en la entrepierna sobre el cual Klauke pintó un sexo femenino. Según afirma Klaus Honnef la secuencia muestra una serie de confrontación y descubre ciertas asociaciones con la Historia del Arte, la madona y la prostituta — La catholicité blasphématoire. ${ }^{30}$

En numerosas ocasiones J. Klauke utilizó la parodia artística como recurso. No obstante, el transformismo deviene aspecto fundamental en su obra más que una mera oposición blasfema. El autor juega con el rol viril y, por su implicación, con el de la mujer. Sin embargo, va más allá de un simple cambio de roles, ya que concreta la imagen de una simbiosis entre hombre y mujer, un ser con sexo doble: el sueño de la concepción artística romántica. ${ }^{31}$ El motivo de esta doble sexualidad es retomado en diferentes series fotográficas: Verschleierungen (1973), Mif y Masculine-Féminin, ambas de 1974. Tanto estas secuencias fotográficas, como los dibujos que realizó en la misma época introducen implicaciones míticas y experiencias originales enterradas que, en el mejor de los casos, se manifiestan en el inconsciente humano como los presentimientos de épocas en las cuales el ser humano y la naturaleza devenían un solo fenómeno.

En trabajos como Physiognomien (1972-73) el artista se colocó unos lascivos velos transparentes, a modo de segunda piel, adquiriendo diferentes poses y roles con los que escaparse de su identidad masculina y apelar a su parte más femenina.

\footnotetext{
${ }^{30}$ HONNEF, Klaus, "Jürgen Klauke. Autoportrait comme portrait de la société", en el catálogo de la exposición Jürgen Klauke. Ich War Eine Dose, Düsseldorf, Galerie Udo Bugdahn, 1988, p. 16.

${ }^{31}$ Como obligada introducción y reflexión sobre el mito del andrógino véase: DE DIEGO, Estrella, op. cit.
} 
En Transformer (1973) posaba de un modo divertido como un objeto sexual con una ropa que exageraba y parodiaba el hermafroditismo. Klauke se retrataba como una caricatura de la personificación visual de su vehemente deseo de adoptar múltiples formas y un género andrógino. El artista pensaba que la interpretación del género de los demás permitía conectar con aquellos aspectos de otros que había en sí mismo y, por lo tanto, ensanchar sus límites internos y el autoconocimiento.

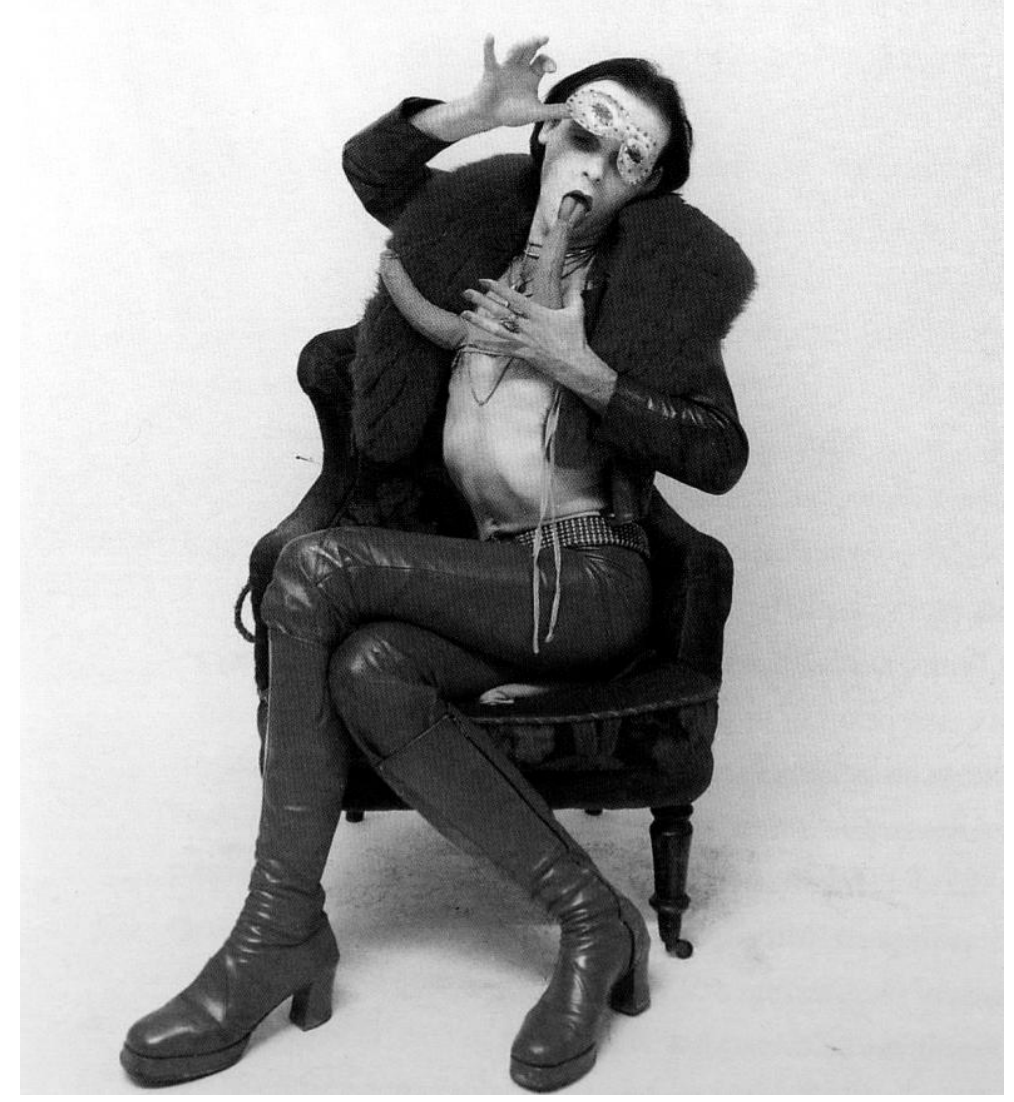

50. Jürgen Klauke - Transformer (1973) 
En serie fotográfica Viva España (1976-79) dos seres, uno masculino y otro femenino, se mezclan entre sí sin características individuales de identificación. Un proceso violento y tierno al mismo tiempo. La obra se caracteriza por un desarrollo altamente ceremonial donde destacan las referencias eróticas y sexuales.

Una de las series fotográficas más difíciles desde el punto de vista interpretativo quizás sea Dr. Mullert Sex-Shop oder So stell'ich mir die Liebe vor (1977). En ella el autor se mostraba travestido y jugando con diferentes objetos (un pájaro, una muñeca de plástico, un enorme pene...). Estos artículos le servían para crear una absurda fantasía de sólido contenido erótico con la que pretendía romper los límites convencionales del deseo y buscar la propia identidad en relación con los demás. Como el mismo artista decía: «[...] it's still possible to find your identity through that of others, a rising of consciousness, a reaching out for the limits, and with a little luck perhaps even beyond [...]. I do not assume other roles, I don't want to be a woman or any other person, and I am certainly not striving for unit and divine perfection [...] if anything, it's a "happy hybrid"». ${ }^{32}$

Para Honnef, estos trabajos fotográficos anuncian el aislamiento doloroso del individuo en un mundo tecnológico, el enquistamiento del propio yo. Los mismos determinan el clima de pérdida del individuo en un mundo alienado y sin calor emocional. Jürgen Klauke redibuja en sus emotivas imágenes los vanos esfuerzos para romper esta atmósfera deprimente. Descubriendo nuestra otredad se perfila una sombra en nosotros mismos. $^{33}$

Mientras que la mayoría de las mujeres artistas contemporáneas que trabajaban con imágenes de identidad estaban preocupadas por realzar su diferenciación respecto al género masculino, Katharina Sieverding (Praga, 1945) —al igual que Lüthi o Klauke - se empeñó en encontrar similitudes

\footnotetext{
${ }^{32}$ KLAUKE, Jürgen, "Interview with Peter Weibel", 1994, citado en WARR, Tracey (ed.), The Artist's Body, op. cit., p. 140.

${ }^{33}$ HONNEF, Klaus, op. cit., p. 17.
} 
entre ambos sexos. En sus primeras obras reflejó un compromiso creativo y político con las corrientes contraculturales de aquellos años. La autora creó series de montajes fotográficos con su compañero Klaus Metting en las cuales sus rostros, ayudados por maquillajes y peinados similares, devenían prácticamente indiscernibles.

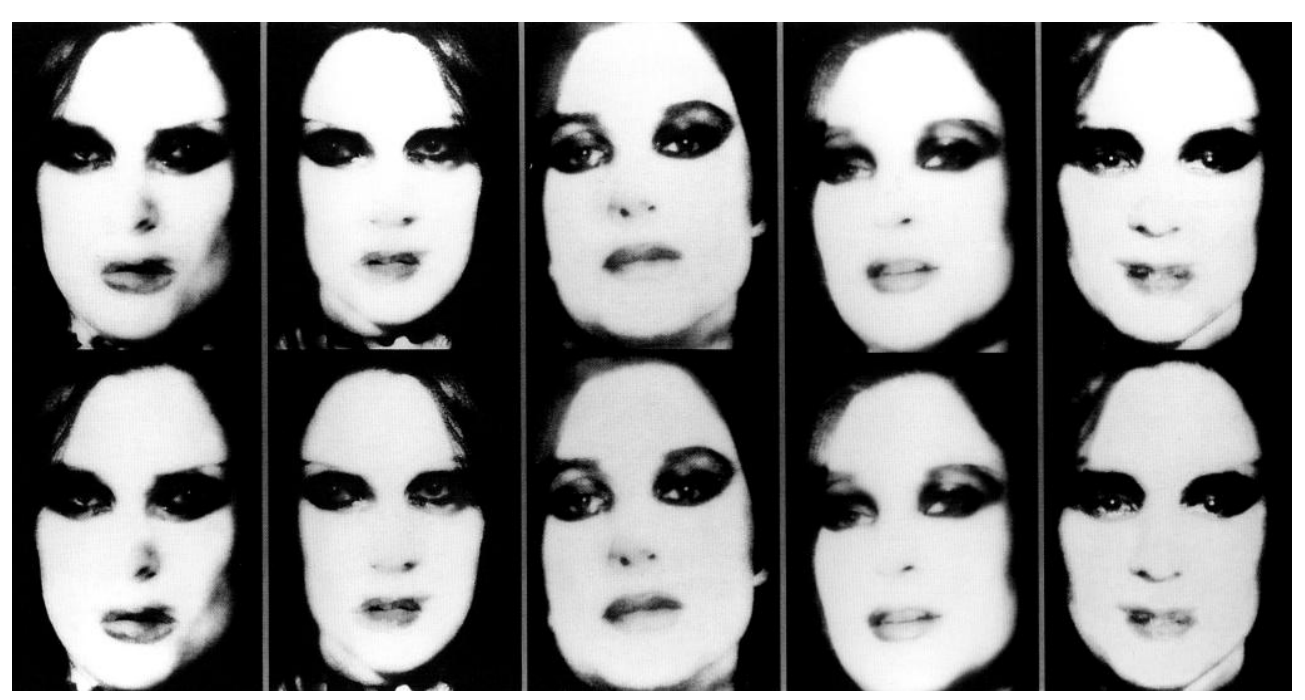

51. Katharina Sieverding - Trasnformer 1 A/B (1973-74)

Esta superposición del cambio de identidad se hizo evidente en la serie fotográfica Transformer 1 A/B (1973-74), donde la fusión subrayaba una dialéctica lingüística y sensual. ${ }^{34}$ Estas imágenes solarizadas de enorme tamaño funcionaban a modo de máscara: la mujer imita al hombre y el hombre a la mujer, por ello, los retratos resultantes presentan unos límites desdibujados y distinciones arbitrarias que enfatizan la falta de diferencia entre uno mismo y el otro. Sieverding explicó que, como mujer, necesitaba ponerse en el papel del hombre para comprender el punto de vista contrario, siendo esto el mejor modo de aprehensión. ${ }^{35}$ La autora, por tanto, se

\footnotetext{
${ }^{34}$ Podemos ver, con una excelente calidad de impresión, cada una de las imágenes que aparecían en la serie de la autora en un catálogo que se editó con motivo de la exposición. Katharina Sieverding. Transformer, Stadtische Galerie am Markt, Hällisch Fränkisches Museum Schwäbisch Hall, 1998.

${ }^{35}$ JONES, Amelia, op. cit., p. 141.
} 
aproximó al travestismo como un medio de comunicación capaz de desenmascarar roles, represiones y auto-extensiones: "The conquest of another gender takes place in oneself»». ${ }^{36}$

En paralelo a estas obras encontramos la aportación de Michel Journiac (París, 1938-1995). Para éste, el cuerpo, tomado como objeto social, se convierte en el tema central de su obra, un trabajo mediante el cual mezcla las señas de identidad personal travistiéndose y ritualizando diferentes prácticas sexuales. Después de efectuar estudios de Teología, paradójicamente relacionados con su homosexualidad, hizo su debut en el medio artístico con un artículo publicado en mayo de 1968, "De la révolte à l'interrogation", en la revista Combat. En él la rebelión era originaria y la vivió a través de su homosexualidad. ${ }^{37}$ En su obra de los años 1970 Journiac subraya lo absurdo de las definiciones convencionales cuya función es la de dotar a gran parte de los individuos de una tranquilidad. De esta forma, todos los lugares comunes y los determinismos son cuestionados en su trabajo.

Sin abandonar del todo las primeras obras de carácter ritual y de fuerte simbolismo religioso y vivencial - desde Contrat pour un corps (1972) a Action meurtre (1985) —, el travestismo fue el método por el cual Journiac intervino regularmente, efectuando una lectura del cuerpo y de su extensión semántica como cuerpo social. ${ }^{38}$

Entre nuestro cuerpo y el exterior se sitúa una frontera: la indumentaria. Journiac cuestionó las relaciones que se establecen entre esos diferentes elementos. Pero en los planteamientos del autor francés, la vestimenta es una trampa social, una barrera que condiciona e impide la comunicación. La ropa es lo que permite a cada persona construirse a sí misma, es lo que determina las actitudes personales, las situaciones sociales

${ }^{36}$ Cit. en SPECTOR, Nancy, op. cit., p. 170.

${ }^{37}$ DONGUY, Jacques, "Arte corporal", en el catálogo de la exposición Arte acción. 1958 1998, Valencia, IVAM, 2004, p. 162.

${ }^{38}$ FRÉCHURET, Maurice, op. cit., p. 42. 
$\mathrm{y}$, finalmente, las relaciones sexuales. Journiac pretende analizar el rol desempeñado por la vestimenta en una sociedad que tiende a negar el cuerpo y a estigmatizar su presencia. ${ }^{39}$

Piège pour un travesti (1972) fue una efímera exposición de Journiac en la Galería Stadler de París. En ella se mostraban cuatro inmensos paneles fotográficos en los que reflexionó en torno al papel de la indumentaria en la identidad sexual y en el transformismo entre ambos sexos. En cada uno de los paneles encontramos tres fotografías de tamaño natural de un sujeto masculino: en la primera imagen éste aparecía vestido, en la siguiente desnudo y en una tercera, travestido, basándose en la apariencia de un personaje popular (Rita Hayworth, Greta Garbo). Pero lo realmente inquietante de la obra es que al final de cada una de las series, al extremo derecho del conjunto fotográfico y en un tamaño exacto al de cada una de las fotografías, se situaba un gran espejo con la intención de reenviar al espectador o espectadora la imagen de su propio travestimiento, el mismo que adoptamos en relación con la sociedad y con nosotros y nosotras mismos. $^{40}$

Esta reflexión queda también constatada en 24 heures de la vie d'une femme ordinaire (1974), en la cual realiza toda una serie de fotografías donde el autor, vestido de mujer, desempeña un gran número de actividades, situaciones, anhelos y problemas de la vida cotidiana. La pieza es una mirada crítica y cáustica sobre la condición femenina, la cual deviene representación sociológica donde se desmenuza la mitología cotidiana de los clichés de la mujer francesa característica de la prensa popular - Elle o Marie-Claire. ${ }^{41}$ En veinticuatro imágenes de un realismo sobrio que roza la

\footnotetext{
${ }^{39}$ G. CORTÉS, José Miguel, "Pierre Molinier y el auto-fetichismo...”, op. cit., p. 162.

40 STADLER, Rodolphe y POLASTRI, Stefano, "Piège pour un travesti, galerie Stadler, 1972”, en el catálogo de la exposición Michel Journiac, Paris, Les Musées de Strasbourg, 2004, pp. 129-131.

${ }^{41}$ DONGUY, Jacques, "Entretiens \& textes", en el catálogo de la exposición L'art au corps. Le corps exposé de Man Ray à nos jours, Marseille, Mac-galeries contemporaines des Musées de Marseille, 1996, p. 225.
} 
banalidad, Journiac pasa revista a los fantasmas y quimeras más arraigados de la existencia de la mujer.
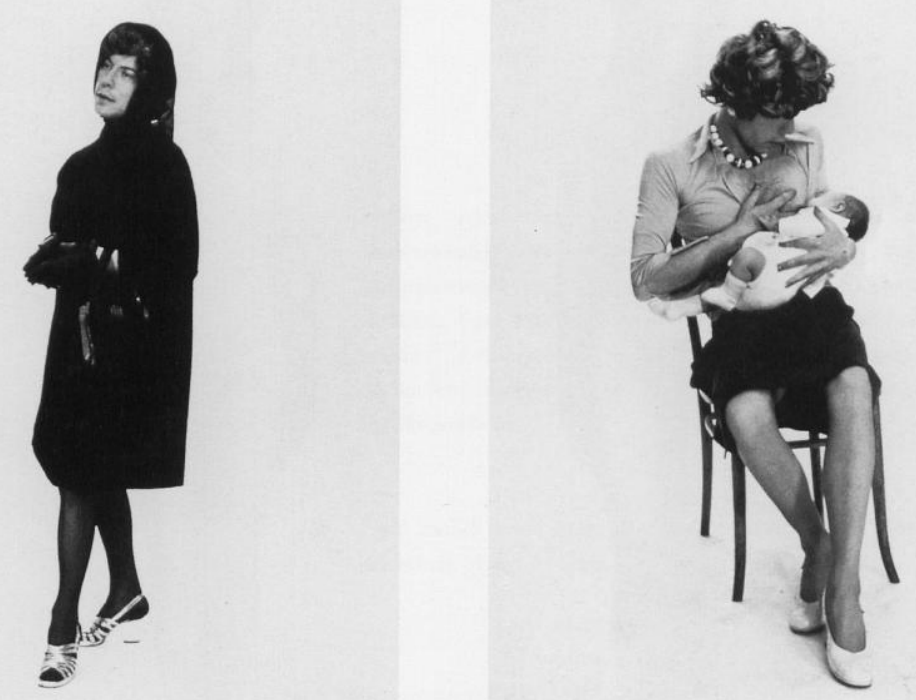

52. Michel Journiac - 24 heures de la vie d'une femme ordinaire (1974)

En la serie Hommage a Freud. Constat critique d'une mythologie travestie (1972) — uno de los trabajos más definitorios de su carrera- lleva la experiencia del travestismo a representar todos los papeles de su familia: padre, madre e hijo. De esta manera, señala cómo la identificación de los roles sociales pasa por los rostros y modos de vestir. Journiac denuncia la reconciliación edípica y psicoanalítica de la familia, según la cual el padre ocupa un lugar primordial. A su vez, plantea una denuncia no tanto contra Freud, sino contra sus más acérrimos seguidores, quienes convierten la racionalización del psicoanálisis en un listado absurdo y anticientífico de enfermedades mentales, las cuales no existen, ya que son los hechos sociales, políticos y económicos los que obligan a la gente a comportarse de un modo u otro. 

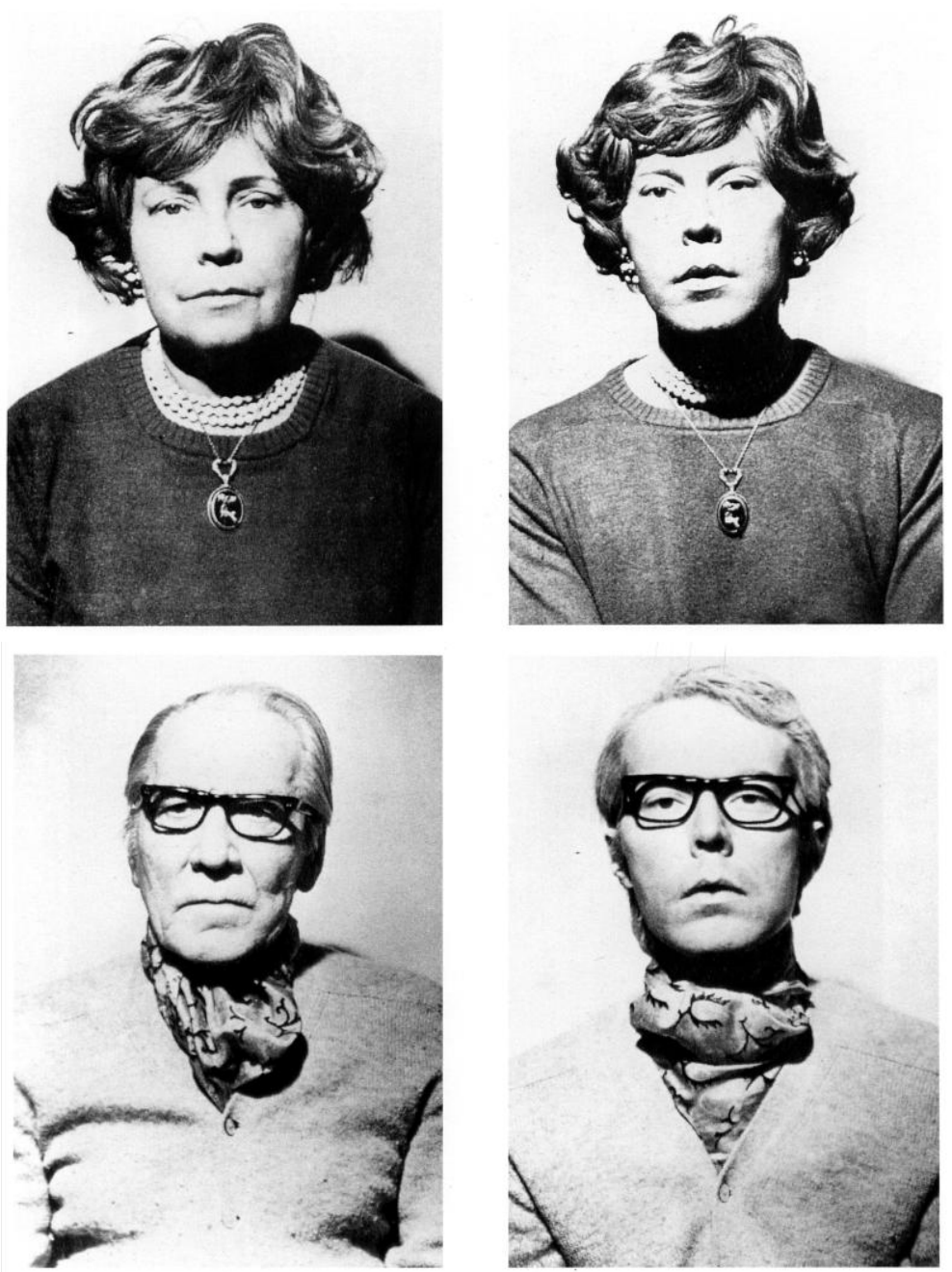

53. Michel Journiac - Hommage à Freud, constant critique d'une mythologie travestie (1972-84)

El documento visual de este homenaje, divulgado por envío postal, reinterpretaba los complejos de Edipo y Electra a través de cuatro fotografías dispuestas dos a dos bajo el título de la acción. En la parte superior - todas de medio cuerpo - utilizaba una fotografía de su padre, Robert Journiac, travestido de Robert, junto a una de su hijo Michel, travestido de Robert Journiac. La parte inferior, se componía con la imagen 
de su madre, Renée Journiac, travestida de ella misma, junto a una fotografía de su hijo travestido de Renée Journiac. Ni los padres ni el hijo se presentaban tal cual, sino travestidos de sí mismos o, en el caso de Michel Journiac, travestido de su padre y de su madre.
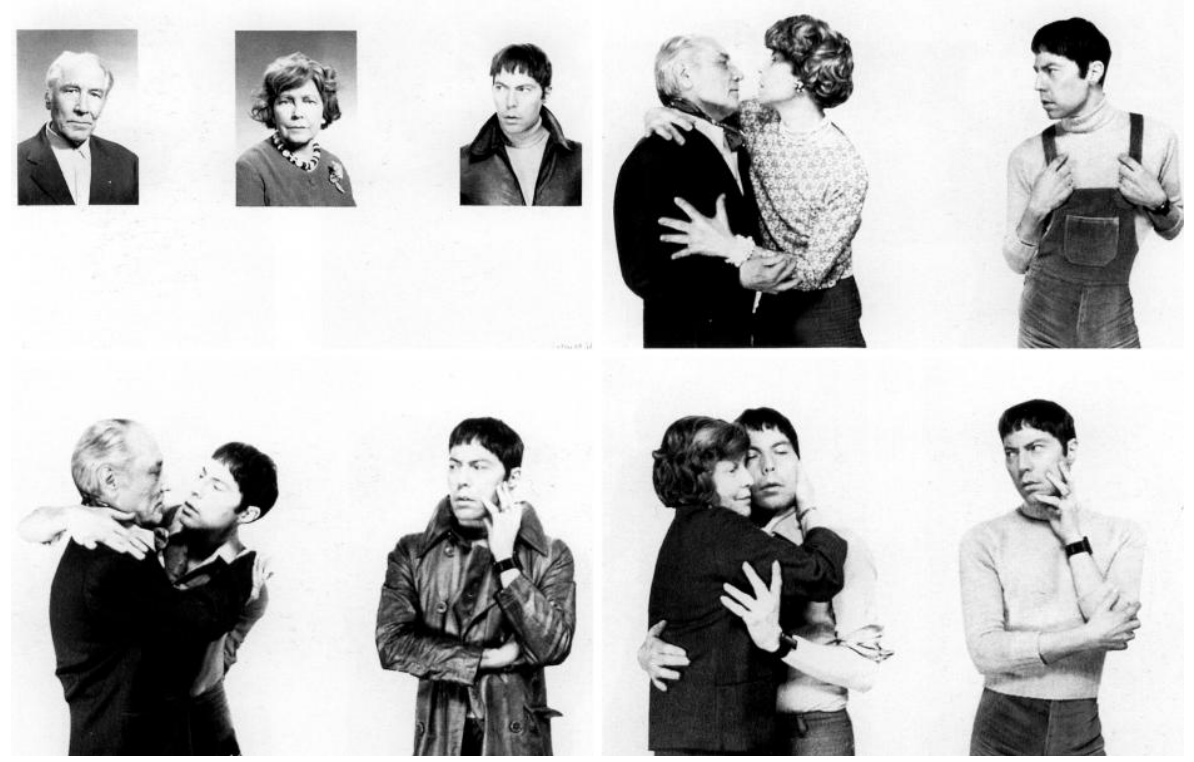

54. Michel Journiac - L'inceste (1975)

Su actitud polimórfica, paródica e irónica se va a ver ampliamente reflejada en su obra L'inceste (1975), un conjunto de fotografías que reúnen siempre tres personajes: el hijo mirón y dos más que van cambiando en cada imagen (hijo amante, hijo/padre amante, hijo/chico amante, madre amante, etcétera). Enfrentándose al sistema de identificación forzado, Journiac pretende la multiplicidad del individuo a la vez que identifica su aspecto exterior con un camuflaje, metáfora visual de la representación social. Tal y como afirma Susana Narotzky, la tradición judeo-cristiana ha instaurado la confusión entre los conceptos de sexualidad, procreación, paternidad social y matrimonio heterosexual. Debido a que el matrimonio legítimo no es 
válido sin sexualidad, ésta sólo es lícita si es procreadora y, a su vez, dentro del matrimonio. ${ }^{42}$

Las críticas a una sociedad ampliamente fundada en la apariencia son puestas en evidencia en tales demostraciones. Journiac desplaza la problemática de la identidad del terreno individual a la esfera pública y social reactivando, de esta manera, la noción de persona de la que la filosofía ha hecho uso tradicionalmente. Sin embargo, la sociedad se muestra - no inocentemente - deseosa de restablecer lo que considera una verdad pretendida de la persona y de las relaciones sociales impuestas.

Dentro de un ámbito cultural más próximo, y tras un viaje a Londres para ver actuar a David Bowie, la obra de Carlos Pazos (Barcelona, 1949) apostó por la ambigüedad, el desdoblamiento y la creación irónica e irreverente. El rock inglés marcó profundamente al autor, quien comenzó a trabajar con su cuerpo, la ropa, el pelo y el maquillaje. A medio camino entre el dandismo y la ambigüedad bowiniana, creó un personaje mutante y transformista presentándose de aquella manera en las reuniones sociales. Pazos se convirtió en uno de los primeros referentes artísticos en nuestro país en lo que respecta al cuestionamiento de la identidad física y psicológica. $^{43}$

El autor tomó su propio cuerpo como soporte de una obra en proceso en la que apostaba por una personalidad procaz y múltiple. Para ello utilizó tanto la influencia de la cultura popular y el glamour hollywoodiense como, según hemos comentado, la ambivalencia sexual de los músicos de la década de 1970 —David Bowie.

En 1975 Carlos Pazos realizó una obra mítica en su trayectoria: Voy a hacer de mí una estrella. La muestra se componía de un recorrido de

\footnotetext{
${ }^{42}$ NAROTZKY, Susana, "El marido, el hermano y la mujer de la madre: algunas figuras del padre", en TUBERT, Silvia (coord.), Figuras del padre, Cátedra, Madrid, 1997.

${ }^{43}$ QUERALT, Rosa, en el catálogo de la exposición Carlos Pazos, Barcelona, Sala d'exposicions de l'Obra Cultural de la Caixa de Pensions, 1982, pp. 9-10.
} 
veintiuna fotografías en blanco y negro en las que el autor se mostraba - a la vez que ironizaba - como un personaje del mundo del star system basándose en poses, trajes, maquillajes y demás «extensiones» propias de Rodolfo Valentino, Tarzán o Marlon Brando, entre otros. En la misma dirección realizó En la intimidad y Suelo fantasma, una crítica y un divertimento al mismo tiempo sobre el star system. ${ }^{44}$

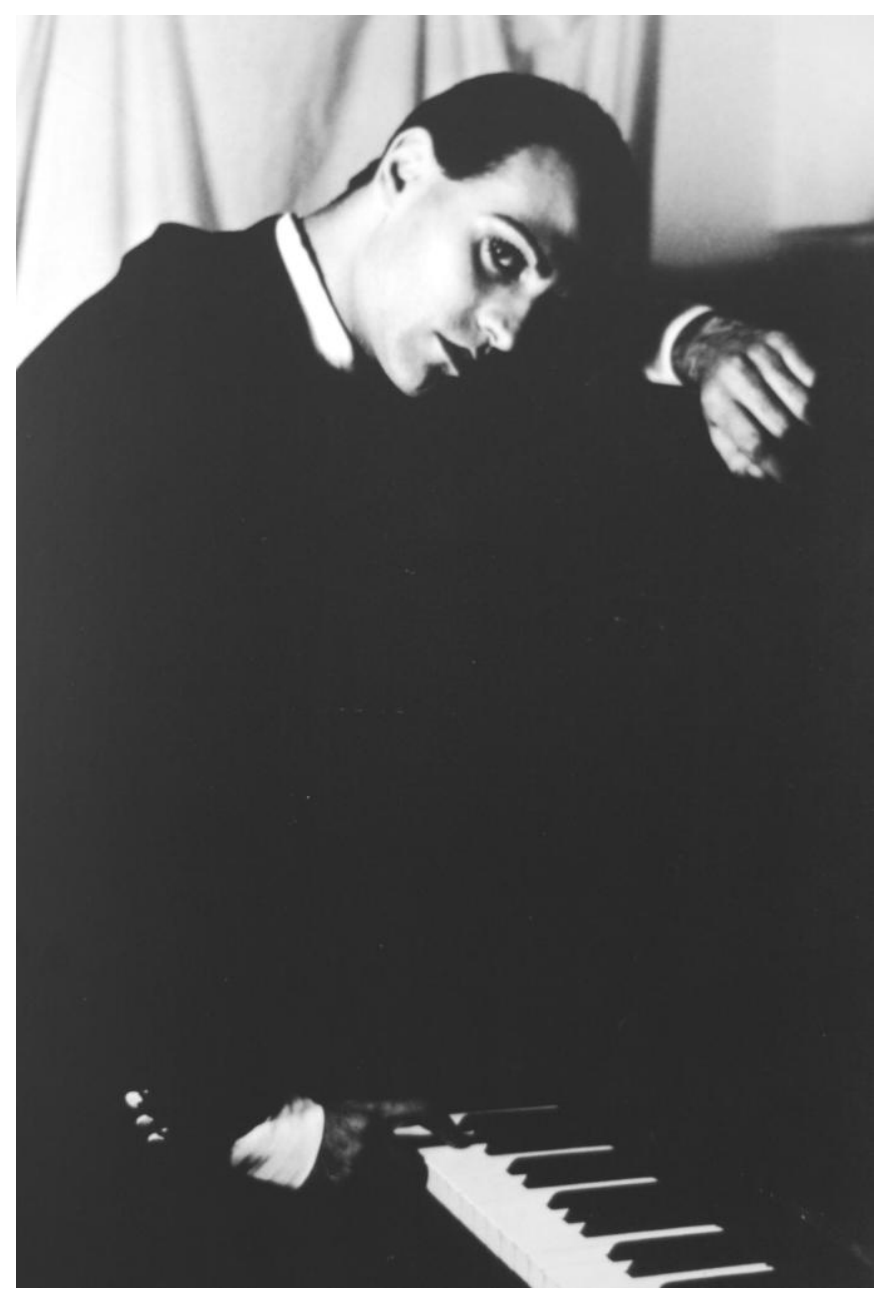

55. Carlos Pazos - Voy a hacer de mí una estrella (1975)

${ }^{44}$ GONZÁLEZ GARCÍA, Ángel, "El llançaflames", en el catálogo de la exposición Carlos Pazos. Un elefant als llimbs, Barcelona, Generalitat de Catalunya, 1993, pp. 13-14. 
A finales de los años setenta, Andy Warhol (Pennsylvania, 19281987) realizó una serie de autorretratos con una cámara Polaroid. El autor sentía una gran fascinación por los poderes metamorfoseantes del aparato fotográfico. Una foto era para él mucho más que un simple recuerdo: era un útil de transformación imaginario, la metáfora del consumismo fácil y la distancia voyeurista. Todas las fotografías de esta serie son muy parecidas: de frente o de perfil, Warhol posa con una peluca de pelo rubio un poco rizado y los labios pintados de un intenso rojo. La actitud en todas ellas es seria, un tanto distante. El fondo blanco, la pose hierática, el rostro anodino y el pequeño tamaño de las obras, nos trae a la memoria las fotografías que se realizan para los carnets de identidad o pasaportes.

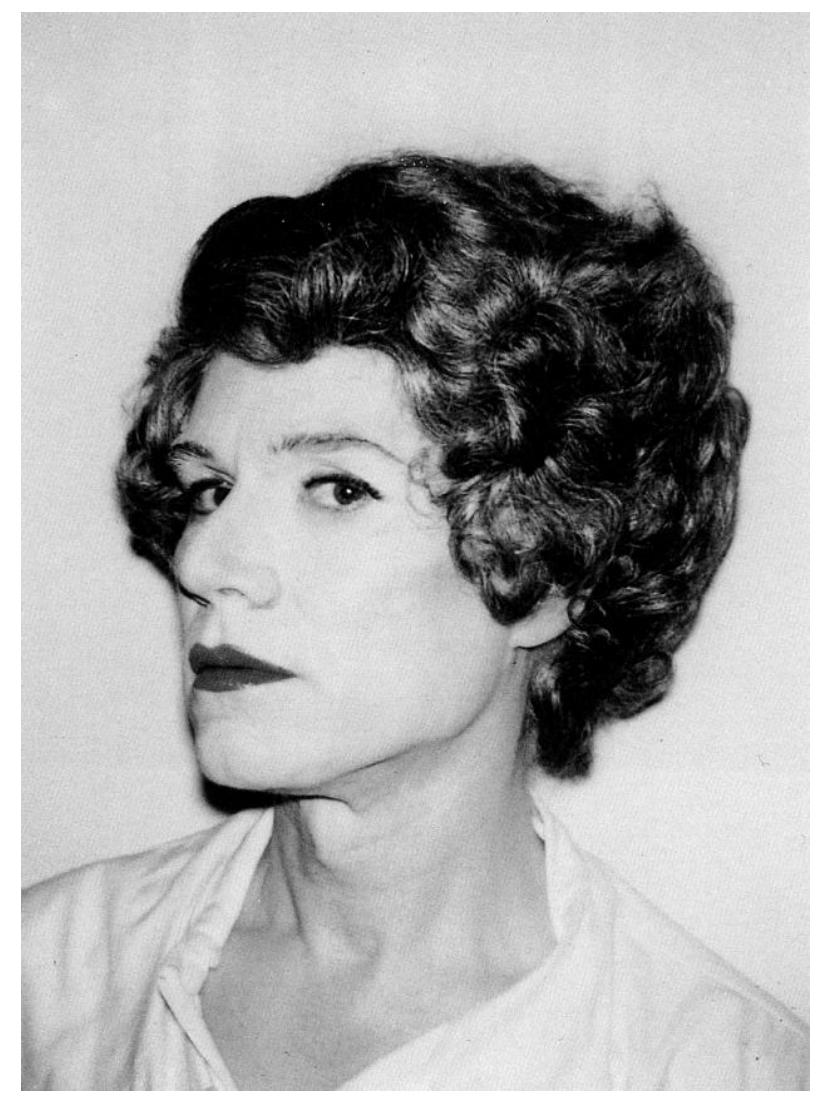

56. Andy Warhol - Self-Portrait in Drag (1979) 
Continuando con el juego de la cámara Polaroid, Lucas Samaras (Kastoria, Gracia, 1936) creó una extensa serie de autorretratos. Uno de sus primeros trabajos Auto Polaroid (1969-71) consistía en dieciocho imágenes dispuestas en un formato cuadriculado. El autor capturaba instantes de una vida teatralizada completamente inventada y las transponía como imágenes que podían ser leídas como escenas dramáticas y/o pseudodramas propios de una película de serie B. En una instantánea el propio artista se muestra maquillado y con una larga peluca rubia, en otra nos mira desafiante en una actitud chulesca y con un cigarrillo en la boca. Samaras juega con múltiples identidades en todas y cada una de las imágenes de la obra caracterizada por cierta clave de humor.
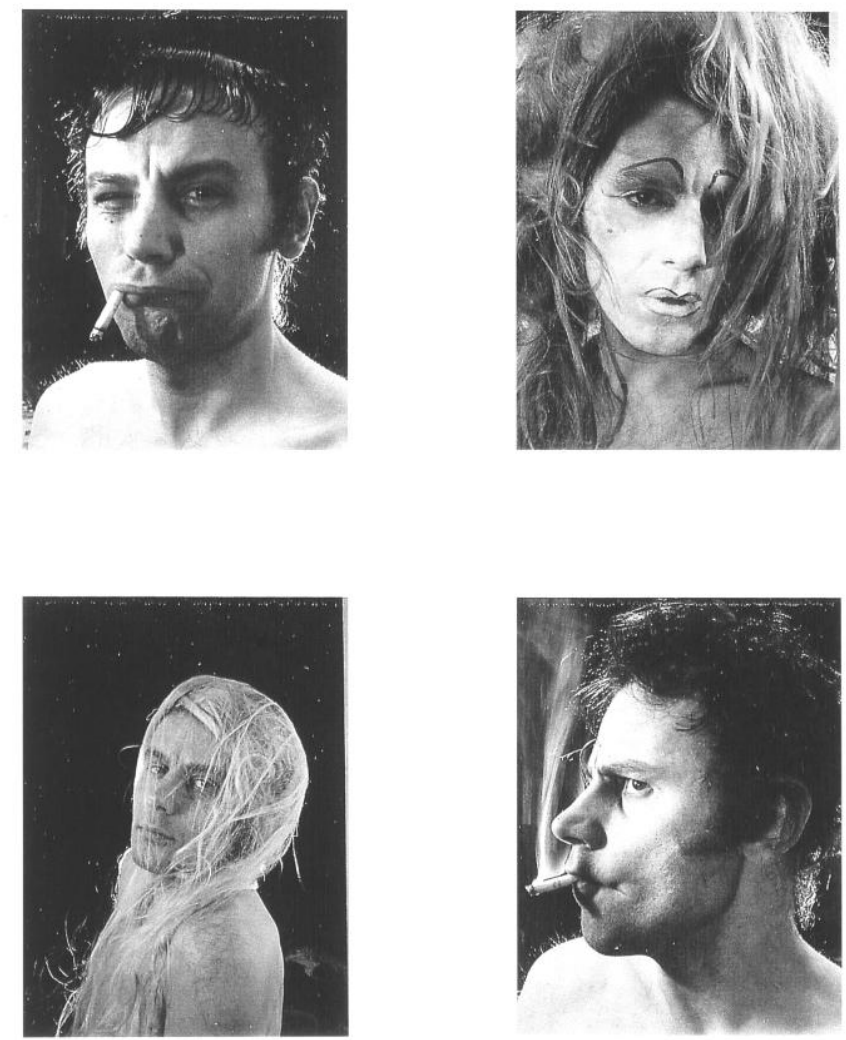

57. Lucas Samaras - Auto Polaroid (1969-71) 
Más tarde, en Photo-Transformations (1973-76), manipuló la emulsión húmeda de la Polaroid para desfigurar y embellecer el resultado final, de este modo creó una multitud de extraños personajes. La extrema teatralización de su obra fotográfica pone en duda nuestro concepto de realidad, ya que nos invita a reflexionar sobre el poder visceral con el que los mass media manipulan el imaginario colectivo. ${ }^{45}$

A lo largo del siglo XX una serie de fotógrafos como Brassaï, Weegee o, posteriormente, la citada Diane Arbus tomaron como sujetos de sus representaciones personas que se situaban en esos espacios dudosos entre la masculinidad y la feminidad. A principios de 1970, Nan Goldin (Washington D.C., 1953) empezó a retratar drag queens y transexuales preop que frecuentaban The Other Side, un bar situado en Boston. ${ }^{46}$ En estas series de fotografías, caracterizadas por un considerable voyeurismo, presenta a los modelos con su propia personalidad. A su vez, entra en un ámbito fotográfico que se deleita en la documentación de lo que la normalidad entiende como inusual, afirmando la realidad de lo nunca visto hasta ahora y/o de lo inimaginable, y permitiendo a quien presencia sus imágenes mirar fijamente y reflexionar sin vergüenza ni lástima sobre la realidad de la persona retratada. «I wanted to pay homage, to show them how beautiful they were. I never saw them as men dressing as women, but as something entirely different —a third gender that made more sense than either of the other two. I accepted them as they saw themselves; I have no desire to unmask them with my camera». ${ }^{47}$

Pero lo que distingue las fotografías de Goldin es su relación con los sujetos, así como su propia representación. Son fotografías públicas, pero también íntimas. El trabajo de Goldin sugiere una especie de álbum de

\footnotetext{
${ }^{45}$ BLESSING, Jennifer, op. cit., p. 73.

${ }^{46}$ En 1993 publicó un libro donde se recopilaba una importante serie de fotografías que desde 1972 había realizado a sus amigos y amigas del mencionado bar: «This is a book about beauty. And about my love for my friends». GOLDIN, Nan, The Other Side, New York, Scalo Publisher, 1993.

${ }^{47}$ GOLDIN, Nan, op. cit., p. 5.
} 
familia, una comunidad, pero sobre todo, una batalla. ${ }^{48}$ Los sujetos documentados, incluida ella misma, son diseñados para humanizarlos, para rechazar la visión tradicional que considera su sexualidad y su género como una patología. «Most people get scared when they can’t categorize others -by race, by age, and, most of all, by gender [...]. The people in this book are not of people suffering gender dysphoria but rather expressing gender euphoria. This book is about new possibilities and transcendence». ${ }^{49}$

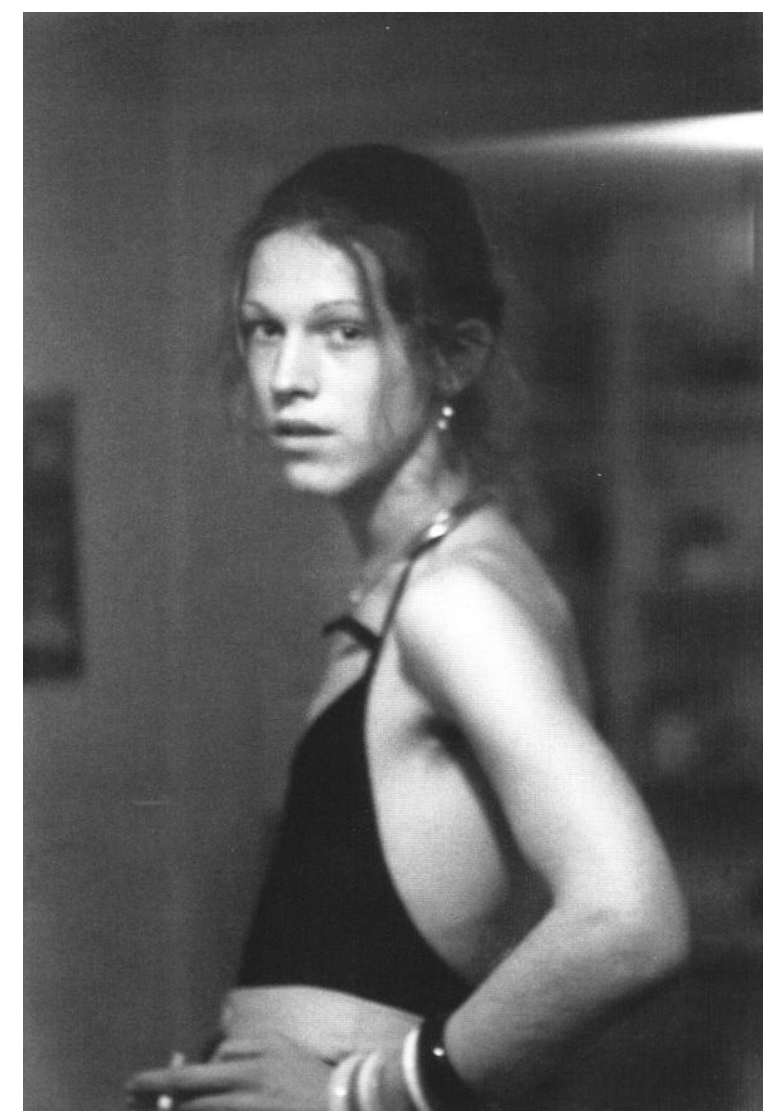

58. Nan Goldin - David at Grove Street, Boston (1972)

\footnotetext{
${ }^{48}$ La hermana de Nan Goldin, Barbara, se suicidó a los 19 años, hecho crucial en la obra de la autora. Los desencuentros con sus padres provocaron el abandono del hogar familiar en su adolescencia. Goldin atribuye a la fotografía y a las drogas la razón por no acabar como Barbara. Véase GOLDIN, Nan, Sœurs, Saintes et Sibylles, Paris, Regard, 2005.

${ }^{49}$ Cit. en BLESSING, Jennifer, op. cit., p. 81.
} 
Paradójicamente y en la más trágica tradición en lo que respecta a las más diversas manifestaciones, mientras los artistas masculinos tuvieron la libertad de realizar sus propias auto-representaciones alterando a su voluntad los roles de género, las mujeres que experimentaron similares estrategias fueron fuertemente criticadas, cuando no rechazadas por autoindulgencia o comportamiento narcisista.

\subsection{Empieza el espectáculo. Cross-Dressing en la cultura popular}

Tal y como mostró la citada exposición Transformer: Aspekte der Travestie, las relaciones entre el arte y otras disciplinas posibilitaron una actitud profundamente crítica respecto a los estereotipos sociales y culturales impuestos en Occidente. En ese camino en el que los cuerpos se extienden hasta diluir las fronteras del género, tanto la música como el cine tuvieron durante los años 1970 un papel muy relevante a la hora de transformar un comportamiento — que hasta dicho momento había sido marginal - en un aspecto de importancia capital. Aquello que en los años 1930 se trataba con angustia, en la década de 1960 iba a ser abordado con absoluto descaro o simple complacencia. A medida que los habitantes de submundos perversos eran marginalizados y expulsados de sus restringidos territorios —vetados por ser desagradables, públicamente molestos y obscenos - los mismos se infiltraban más en la conciencia como temática artística, adquiriendo cierta legitimidad difusa y cierta proximidad metafórica.

La subcultura sexual de los últimos años de la década de 1960 y principios de 1970 estuvo repleta de drag queens, butch dykes y transexuales en el imaginario de la cultura popular a través de las corrientes musicales y fílmicas. La utilización de actitudes sexualmente ambiguas y de ropas femeninas fue una manifestación estrechamente vinculada a la música rock, inaugurando una estética de provocación y ultraje que cuestionó lo más sagrado de la moral occidental: la afirmación de la virilidad. 
El comportamiento de las estrellas del rock de aquellos años se caracterizó por un fuerte exhibicionismo y un profundo narcisismo en el que la utilización del travestismo debía ser considerado como la búsqueda de una imagen ideal: la de la fusión perfecta. La masculinidad atravesó un importante proceso de feminización y androginización, en un principio desde la contracultura de la década de 1960 y, posteriormente, por la glam attitud, si bien, es cierto que en diferentes formas y fines. La imagen masculina pasiva, introspectiva y amable atribuida a la subcultura hippie fue una imagen feminizada surgida como oposición a la masculinidad agresiva responsable de haber desencadenado la Guerra de Vietnam, sin embargo, todavía se presumía de una natural heterosexualidad. Por contrapartida, la masculinidad glam, insinuaba la posibilidad de homosexualidad o bisexualidad, mostraba una androginia desde un punto de vista en el que cada individuo tenía deseos tanto masculinos como femeninos, una aseveración entendida como natural, pero sobre todo, como reacción contra la cultura dominante eternamente preocupada por suprimir esa androginia innata en favor de una supuesta identidad masculina o femenina estables. ${ }^{50}$

El uso del maquillaje en el glam rock ilustraba claramente su identidad sexual como una construcción. Sin embargo, esta moda unisex contracultural, esta combinación de códigos masculinos y femeninos, no difuminaba en absoluto la distinción entre hombres y mujeres: los glam rockers fueron claramente hombres que adoptaron «extensiones» femeninas. ${ }^{51}$ No existía nada de gratuito en aquellas botas de tacón alto. La ropa y las manifestaciones bisexuales - falsas en ocasiones - eran signos externos de un cambio profundo en la forma de ver el mundo y las

\footnotetext{
50 AUSLANDER, Philip, Performing Glam Rock. Gender \& Theatricality in Popular Music, Michigan, University of Michigan, 2006, pp. 60-61.

${ }^{51}$ Tanto en el documental sobre el concierto realizado por David Bowie, Ziggy Stardust and the Spiders from Mars: The Motion Picture (1973), como en la aparición de New York Dolls en el programa de televisión Don Kirschner's Rock Concert en 1974, ambos comenzaban en el camerino maquillándose. Este énfasis en el proceso de transformación de una imagen masculina a una andrógina desmitificaba en cierta manera la imagen mediática del glam al cuestionar la masculinidad como una construcción social.
} 
relaciones entre sexos y entre personas, signos externos que hacían pensar - quizás de una forma un tanto ilusoria y optimista - que aquel cambio radical de costumbres y de forma de vida que empezó a producirse en Estados Unidos e Inglaterra a mediados de la década de 1960 no había sido una vana agitación superficial.

Tal y como afirma Eduardo Haro en su pionero trabajo Gay Rock, texto que va a servirnos de referencia básica en estas páginas, en aquellos años la música se convirtió en algo paralelo a lo que fue el Pop Art en pintura, adoleciendo incluso de los mismos defectos: falta de profundidad visual — en este caso sonora-, distanciamiento de la realidad — sustituida por la imagen y el cliché-, manierismo y procedismo, y estéril agotamiento del signo, que acaba por no expresar nada más que el signo mismo. ${ }^{52}$

Musicalmente hablando, el movimiento hippie - más centrado en complejas e interminables interpretaciones cargadas de cierto virtuosismoquedaba relegado por el rock, una música urbana que desarrollaba cierto grado de violencia, una actitud insolente de desafío, un travestismo irreverente y un profundo inmoralismo. Es por definición una palmaria actitud - Rock and Roll attitud - que se inscribe contra la opresión, la educación y la autoridad patriarcal.

Artistas como Marc Bolan - líder de T-Rex - comenzaron a buscar la espontaneidad y frescura que podíamos encontrar en el viejo rock'n'roll. Para ello, añadieron decibelios y los combinaron con el pop surgido en la década de 1960, no sin adornar el producto con letras que poseían claras referencias sexuales, reforzando por ello su lado más salvaje.

Sin embargo, eso no fue todo, la estética formaba parte de la música. Ante aquella imagen hipermasculina propia del rock emergió la ambigüedad sexual y una actitud tan descarada como provocativa. Diferentes textos muestran contradicciones respecto a quién fue el pionero en la utilización

${ }^{52}$ HARO IBARS, Eduardo, Gay Rock, Madrid, Júcar, 1975, p. 14. 
del travestismo en la música. De lo que no hay duda es de que el inventor del glamour rock, Marc Bolan, fue - junto a su formación T-Rex- el primero en lucir con descaro trajes de leopardo, chisteras y boas, convirtiéndose en una figura del underground.

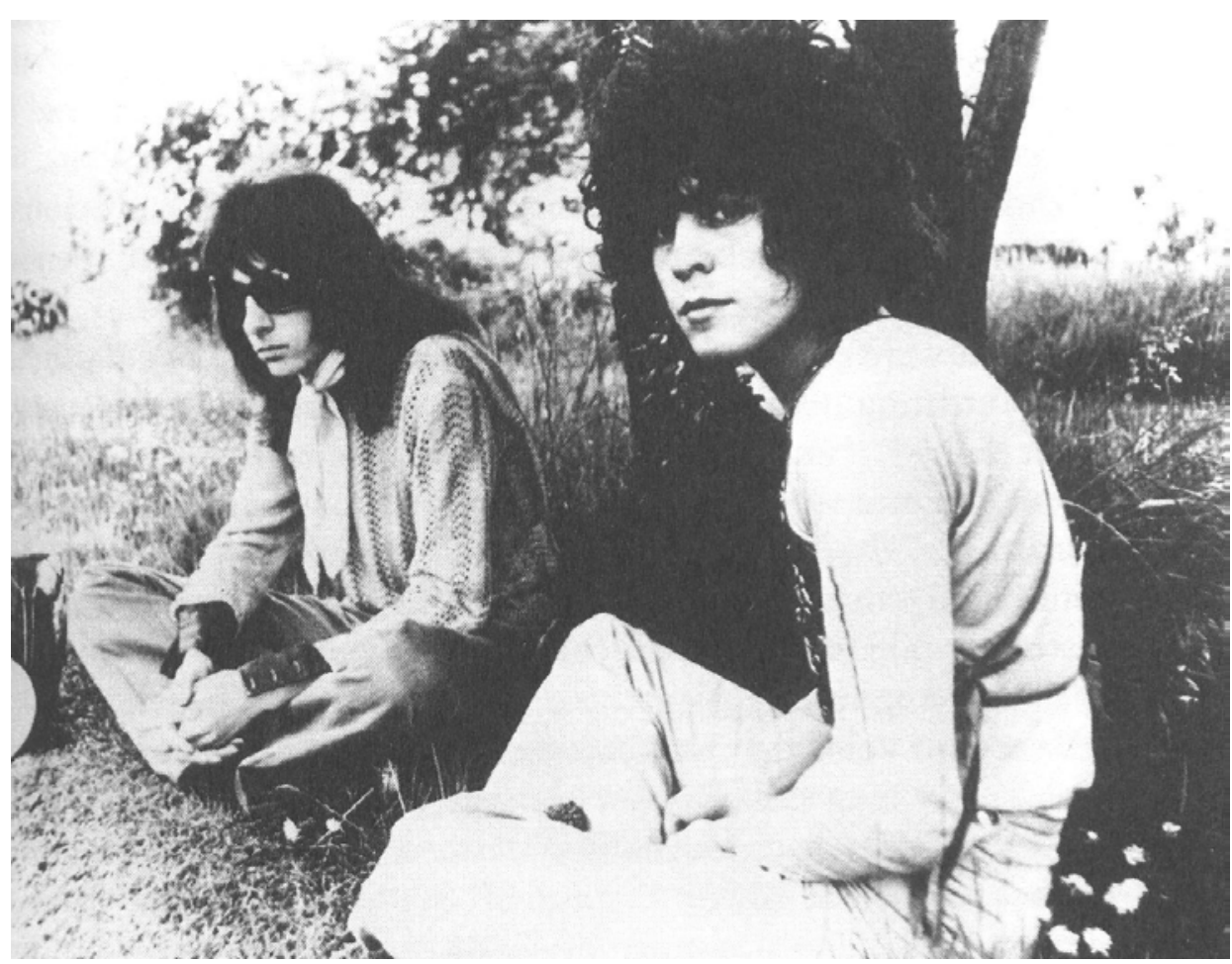

59. Tyrannosaurus Rex (1968)

Con su pegadizo Boogie Rock puso las bases del estilo reuniendo bajo un nombre todas las corrientes que caracterizaban al género: potentes riffs amplificados de una Flying $V$, letras hedonistas y una forma de cantar premeditadamente sexy. Bolan utilizó su atractivo físico en la descarada comercialización como "objeto sexual", reservada hasta entonces a las mujeres. Asimismo, abandonó su antigua vestimenta de príncipe de cuento ${ }^{53}$

\footnotetext{
${ }^{53}$ Hasta aquel momento Bolan estaba inmerso en una literatura relacionada con la trilogía de J. R. R. Tolkien El señor de los anillos y en una música de raíces folk descaradamente influenciada por Bob Dylan.
} 
y empezó a usar ceñidísimos pantalones, camisas chillonas, zapatos de dos colores con plataforma y un maquillaje nada perverso que resaltaba su apariencia de adolescente que se niega a dejar de serlo. A pesar de lucir ropa ambigua y estar cubierto de maquillaje, su imagen era bastante tosca y no dejaba de ser un rockero disfrazado de mujer en lugar de un travesti con glamour. La intención de Marc Bolan estaba más próxima a atraer a las teeny bopers ${ }^{54}$ que a subvertir los convencionalismos sociales.

Conforme el género se fue extendiendo, se popularizaron los trajes brillantes futuristas, las botas con plataforma, los peinados virtuosos y las ingentes cantidades de maquillaje y purpurina. Aunque el glam fue en sus inicios invento británico, David Robert Jones, quien pronto cambiaría su nombre por David Bowie (Londres, 1947), fascinado por las formaciones americanas como los Stooges y la Velvet Underground, realizó varios viajes a Estados Unidos donde se encontró con Lou Reed y con los demás miembros de la Warhol Factory. De ellos aprendió lo importante que podía resultar cierto amaneramiento decadente. ${ }^{55}$ Rápidamente, al igual que muchas fórmulas de la música rock, el glam se convirtió en un verdadero cruce de caminos entre Norteamérica y Gran Bretaña. ${ }^{56}$

Bowie se convirtió en la mayor estrella del movimiento cuando mutó en Ziggy Stardust, un personaje de propia invención cuyas vicisitudes cuenta en The Rise and Fall of Ziggy Stardust and the Spiders from Mars, disco que inyectó al glam grandes dosis de dramatismo, convirtiéndose en el

\footnotetext{
${ }^{54}$ Adolescentes cuyas edades oscilan entre los trece y los dieciséis años, lolitas que ya saben - al menos en teoría - lo que es el sexo, y que desean un pin-up boy para colgarlo en las paredes de sus habitaciones.

${ }^{55}$ Véase el contenido de la letra "Andy Warhol": «Like to take a cement fix/ be a standing cinema/ Dress my friends up just for show/ see them as they really are/ put a peephole in my brain/ two New Pence to have a go/ like to be a gallery/ put you all inside my show./ Andy Warhol looks a scream/ hang him on my wall/ Andy Warhol, Silver Scream/ can't tell them apart all./ Andy walking. Andy tired/ Andy take a little snooze/ tie him up when he's fast asleep/ send him on a pleasant cruise/ when he wakes up on the sea/ sure to think of my and you/ He'll think about paint and he'll think about glue/ what a jolly boring thing to do». (David Bowie)

${ }^{56}$ AUSLANDER, Philip, op. cit., p. 45.
} 
LP clave del género y en uno de los mejores trabajos de la historia del rock: una desmitificación de la imagen del rock star que mantenía con él, al mismo tiempo, una cierta complacencia. Bowie no hizo más que explotar los descubrimientos del glam rock de Bolan y darle un matiz de bisexualidad que éste, en principio, no tenía. ${ }^{57}$

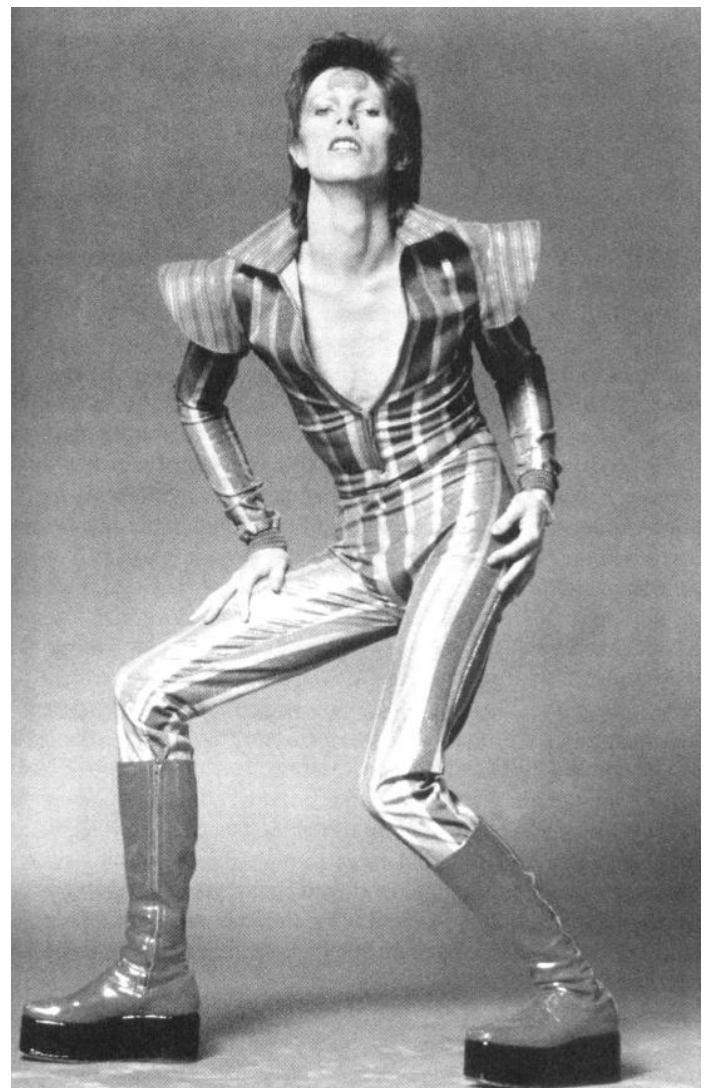

60. David Bowie como Ziggy Stardust (1973)

\footnotetext{
${ }^{57}$ Nadie sabe con certeza los verdaderos gustos sexuales de Bowie. Está casado, tiene un hijo y no se le conoce ningún amorío masculino. Proclamarse gay en la década de 1970 parece una estrategia inteligente: la creciente liberación del sentimiento de culpabilidad por parte de los homosexuales hizo que se le tomara como paladín. Se convirtió en un símbolo viviente de una nueva moral sexual, adquiriendo una nueva importancia más sociológica que musical. Por otra parte, las letras de sus canciones no contenían ninguna mención de contenido ideológico similar al del Gay Liberation Front. Parece ser que todo fue una cuestión de vestuario, oropeles y máscaras.
} 
Con todo, ambos abrieron camino a una serie de conjuntos menores -The Sweet, Gary Glitter, etcétera - que aprovecharon toda aquella guardarropía para alcanzar el anhelado éxito.

En paralelo, al otro lado del océano, surgieron formaciones que comenzaban a apartarse de la corriente psicodélica de los años 1960: en California, el grupo de Frank Zappa \& The Mothers of Invetion y, en Nueva York, The Velvet Underground de Warhol y Lou Reed. Ambos contribuyeron a crear una ideología terrorista cultural.

Lou Reed sucumbió ante las lentejuelas y el rímel en aquellos días. Dos años después de que The Velvet Underground se disolviera y de que Reed se formara como poeta y probara todas las drogas cuyos efectos había cantado, viajó a Inglaterra y aceptó un contrato de la RCA para grabar un nuevo disco, seguramente influido en su decisión por el éxito de David Bowie. Tras un verdadero fiasco firmó uno de los mejores discos de su carrera: Transformer (1972), producido por el mismísimo David Bowie. El corte Walk in the Wild Side - su mayor éxito comercial- es un poema dedicado a todos los chulitos y travestis que formaban la corte neoyorquina de la Factory de Andy Warhol, aquellos que le rodeaban y aparecían en sus películas. ${ }^{58}$ En su segundo trabajo, Berlin (1973), recoge la vena más dramática y sórdida del glam en un álbum conceptual al más puro estilo Bowie y en el que narraba la historia de una prostituta alemana y un soldado americano en el Berlín Occidental, una historia depresiva cuya única perspectiva es la aniquilación y el suicidio. ${ }^{59}$ Desde los comienzos de su

\footnotetext{
${ }^{58}$ A pesar de su éxito, Transformer fue un disco muy criticado. Se acusaba a Lou Reed de oportunismo, de haber encontrado una fórmula para el éxito, y de que aquella fórmula era nada menos que su "decadencia" y la del ambiente que le rodeaba. Otros, por el contrario, se apresuraron a aclamarle como el Dylan de los años 1970. HARO IBARS, Eduardo, op. cit., p. 89.

${ }^{59}$ Como ejemplo, véase el contenido de la letra de "How do You Think it Feels": «How do you think it feels/ when you're speeding and lonely./ Come here baby/ how do you think it feels/ when all you can say is if only./ If only I had a little/ If only I had some change/ If only, if only, if only/ How do you think it feels/ and when do you think it stops?/ How do you think it feels/ when you've been up for five days/ Come down here Mama/ Hunting
} 
carrera hasta la actualidad, Lou Reed ha tratado en sus canciones los problemas de aquellos que sufren la persecución social a causa de sus tendencias sexuales. ${ }^{60}$

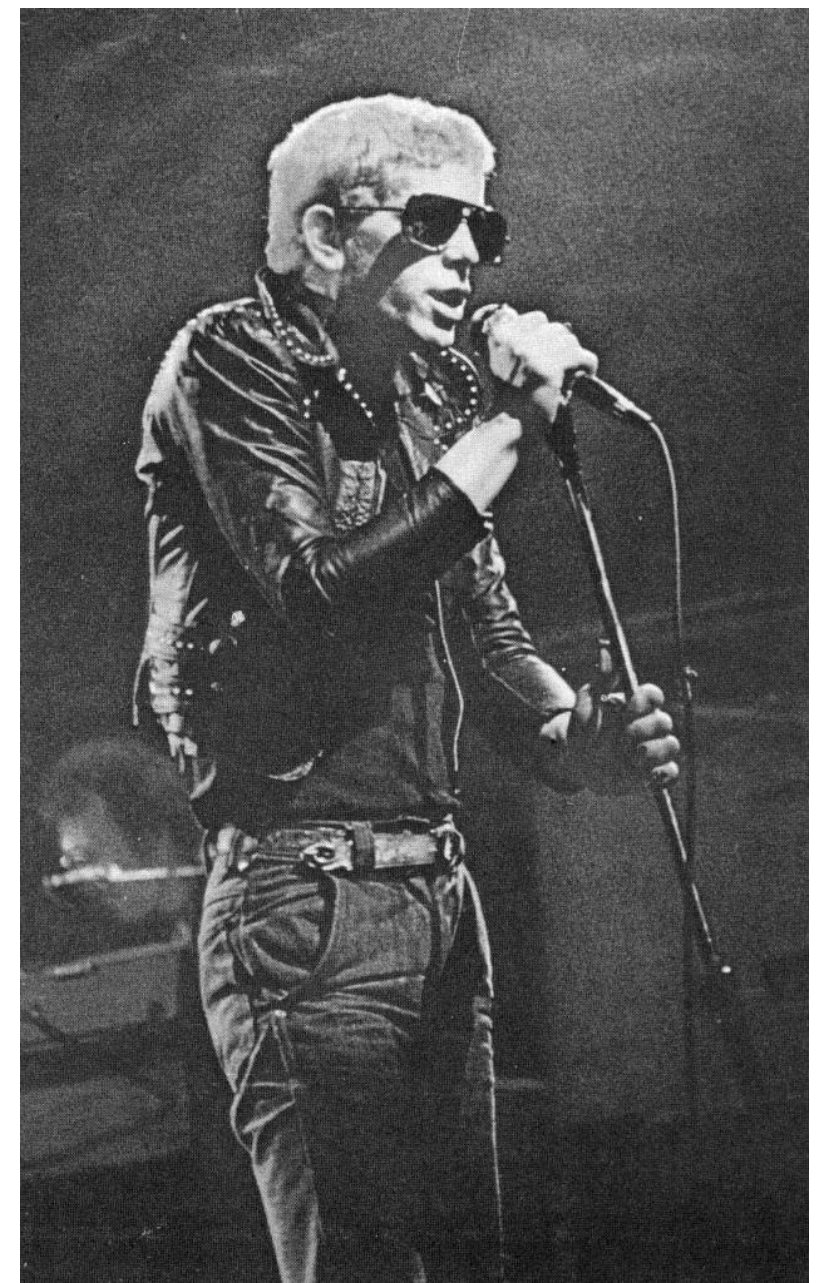

61. Lou Reed en el Olympia de París (1974)

around always - ooh/ 'cause you're afraid of sleeping./ How do you think it feels/ to feel like a wolf and foxy/ How do you think it feels/ to always make love by proxy?/ How do you think it feels/ and when do you think it stops?/ When so you think it stops?». (Lou Reed, 1973).

${ }^{60}$ HARO IBARS, Eduardo, op. cit., p. 95. 
En el momento que la Velvet Underground hacía en Nueva York su música al margen de todas las convenciones del momento, en la West Coast, Frank Zappa \& The Mothers of Invention se ocupaban de subvertir — desde dentro de la imagen hippie - las convenciones de la sociedad americana incluyendo en ella a sus mismos residuos contestatarios. Zappa fue el primer músico de rock que se travistió: en 1966 apareció en la portada de Melody Maker vestido de señora, lo que suscitó una verdadera ola de protestas. Más tarde, en su álbum We're Only in It for the Money - parodia del Sgt. Pepper de los Beatles - todos los miembros del grupo aparecieron travestidos. Zappa se convirtió en el verdadero inventor de un rock-espectáculo cargado de fuerte matiz erótico. ${ }^{61}$

Años más tarde nació en Estados Unidos una combinación entre hard rock y glam. Entre sus pioneros encontramos a Alice Cooper y, posteriormente, KISS, formación que vendió millones de discos a finales de la década de 1970. Del glam tomaban su teatralidad para convertirla en algo mucho más espectacular, introduciendo la hiperteatralización de un terror lúdico como parte del show. Alice Cooper fue probablemente la primera formación dentro del rock que construyó su imagen en torno al travestismo, enfrentándose intencionadamente al público mediante «extensiones corporales» e incidiendo así en sus inseguridades. Los componentes del grupo se autodefinían como trashy transvestites, de hecho la portada de su primer trabajo consolidado mostraba a Vincent Furnier - el cantante que, posteriormente, tomó el nombre del grupo - junto a los demás miembros vestidos en un característico estilo que combinaba ajustados pantalones de cuero, mayas doradas, medias de encaje y lencería —al poco tiempo vino el estilizado maquillaje con el que Furnier nos tiene familiarizados y actualmente utiliza en sus actuaciones. ${ }^{62}$

${ }^{61}$ En sus conciertos simulaba el coito con muñecas de trapo de tamaño natural, o bien hinchaba inmensos globos de formas fálicas. HARO IBARS, Eduardo, op. cit., p. 99.

${ }^{62}$ AUSLANDER, Philip, op. cit., p. 30. 
En referencia a su nombre femenino explica el propio Cooper: «Todos somos, biológicamente hablando, macho y hembra. El americano medio, grande, fuerte y... tonto, piensa que es macho cien por cien. Pero se equivoca, es evidente». Alice Cooper había oído decir en una ocasión a un hipnotizador que el ser humano estaba dividido en tres elementos: macho, hembra y niño. Parece ser que esta teoría le entusiasmó y decidió llevarla a la práctica en su música. Parte del proyecto de Alice Cooper implicaba cuestionar la heterosexualidad normativa. «One of the things I'd like to do would be to play for Women's Liberation and Gay Liberation since so many people are trying to liberate themselves from the roles our society has imposed on them». ${ }^{63}$

Cooper aparecía en escena vestido de mujer, con ropa interior y llevando un peculiar maquillaje que resaltaba su apariencia grotesca y ambigua. El escenario se construía con cubos de basura, miembros humanos y artilugios de tortura. A su vez, los miembros de la formación jugaban a destripar muñecas, a lanzarse brazos y piernas de maniquíes, fingiendo degollar gallinas y rociando al público con su sangre.

Cuando Alice Cooper acuchilla muñecas, finge ahorcarse $\mathrm{o}$ electrocutarse responde: «Queremos mostrar a la gente en qué se ha convertido su pequeño mundo honesto». ${ }^{64}$ Según las declaraciones de Cooper, se pretende pues, un espectáculo catártico, liberador, donde el público se horrorice con lo que ve para acabar descubriendo que es su propia imagen, sus sueños más secretos, sus deseos prohibidos. ${ }^{65}$ No

\footnotetext{
${ }^{63}$ AUSLANDER, Philip, op. cit., p. 32.

${ }^{64}$ HARO IBARS, Eduardo, op. cit., pp. 100-101.

${ }^{65}$ Véase como ejemplo el tema "Sick Things": "Sick things in cars rotate "round my stars./ Sick things, my things, my pets, my things/ I love you./ Things, I see as much as you love me, you things are/ heavenly when you come worship me./ You things are chilled with fright for I am out tonight./ You tell me where to bite, you whet my appetite./ I eat my things, / what love it brings, / come here, my things,/ don't fear my little things./ Things, I see as much as you love me, you things are/ heavenly when you come worship me./ You things are chilled with fright for I am out tonight./ You tell me where to bite, you whet my
} 
obstante, para Eduardo Haro los espectáculos del grupo de Phoenix son un intento de recuperación comercial de las técnicas de teatro de vanguardia al que se le privó de su aguijón y veneno crítico.

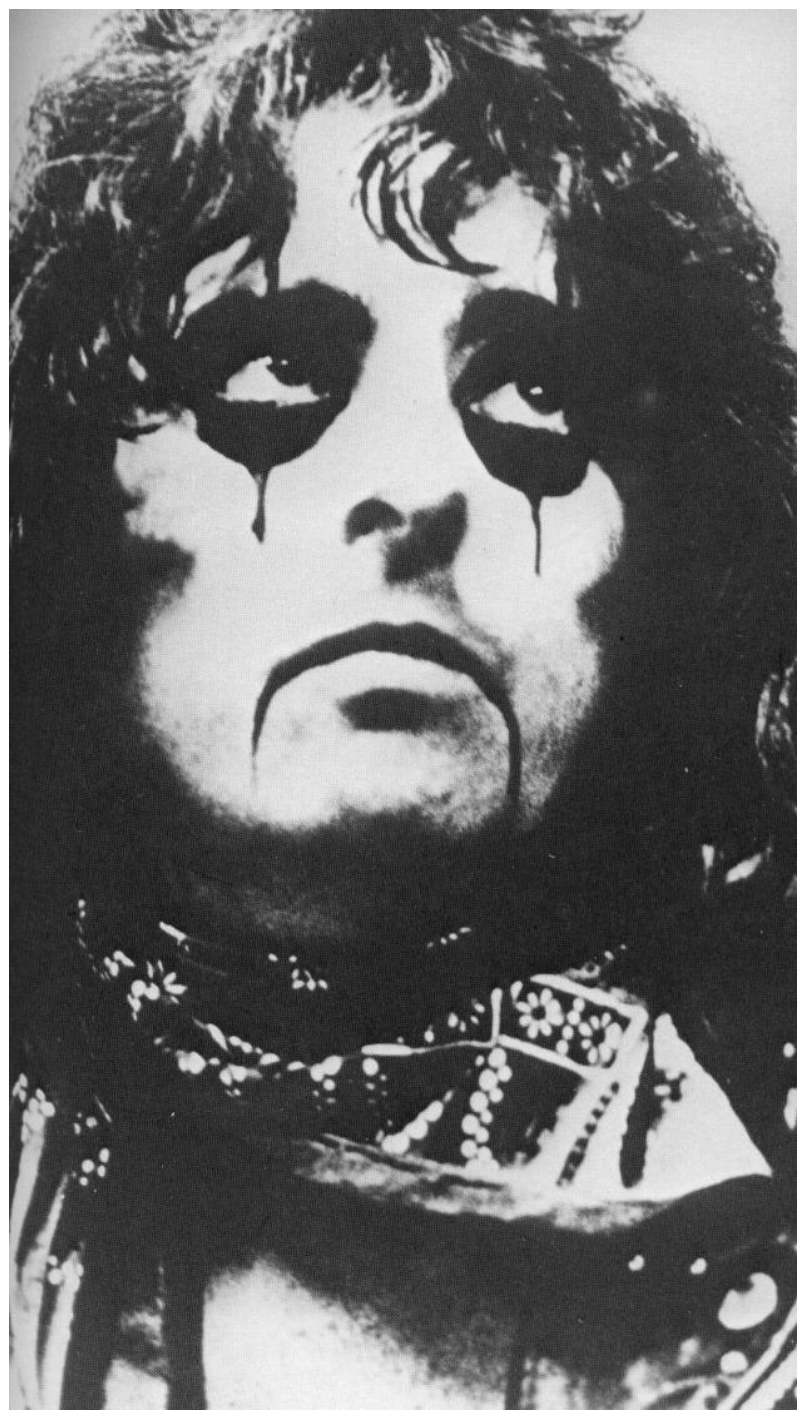

62. Alice Cooper (1979)

appetite./ Sick things in cartridge tapes my stars./ Sick things, play things, pretty things, my things». (B. Erzin, A. Cooper, M. Bruce, 1973). 
Con independencia de Alice Cooper, e inspirados en los inicios del glam británico, los pioneros del desmadre neoyorquino de bisexualismo y hard rock fueron los New York Dolls, quienes supieron llevarse al bolsillo al público que añoraba a The Velvet Underground. ${ }^{66}$ Sus fotos aparecieron en Interview - la revista de Warhol- y actuaron en centros de extravagancia millonaria. Su desenvoltura y su descaro, su bisexualidad descocada y proclamada a los cuatro vientos, les proporcionaron un éxito rotundo entre la elegante vanguardia neoyorquina. En el verano de 1972 se habían convertido en el grupo vedette de los locales del Greewich Village. Sus fotos - provocativo maquillaje y vestimenta exagerada - aparecieron en todas las revistas.

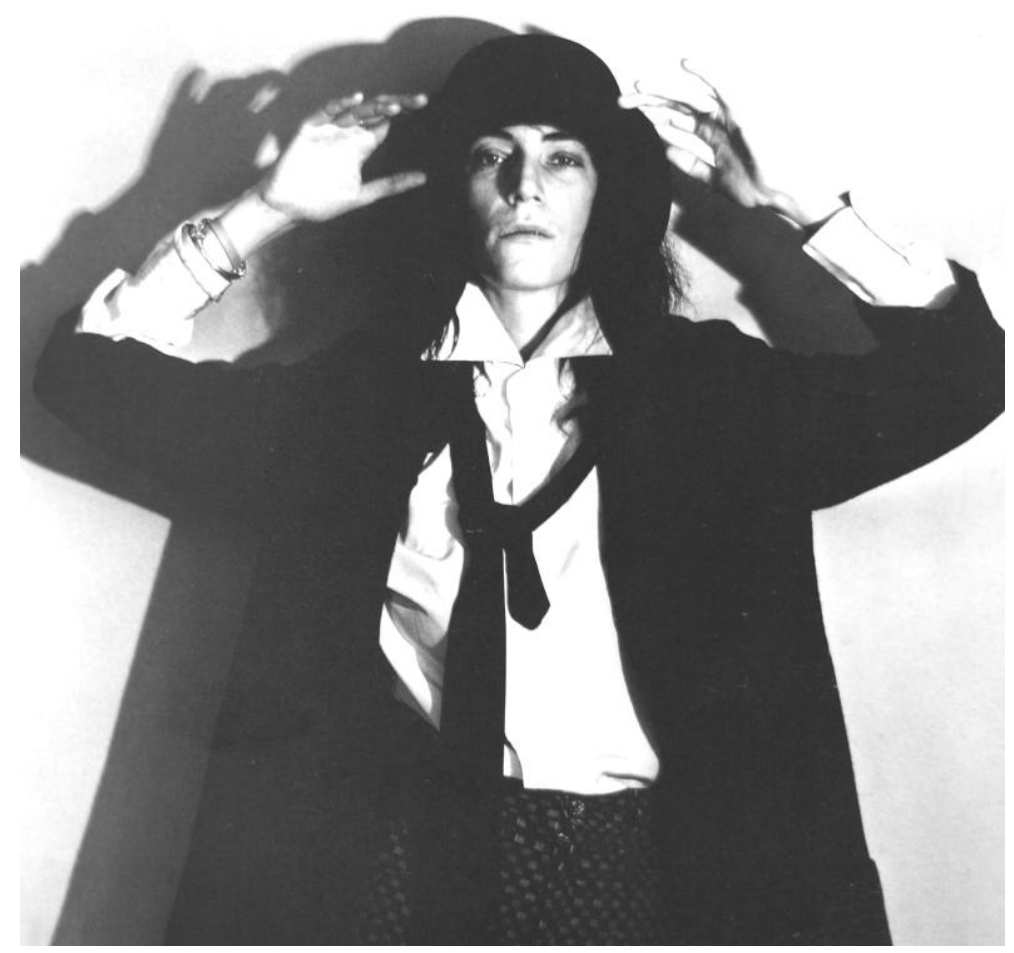

63. Robert Mappelthorpe - Patti Smith (1975)

\footnotetext{
${ }^{66}$ Salvando las distancias, Nancys Rubias tratan de rememorar en la actualidad una fórmula muy similar al grupo neoyorquino.
} 
A pesar de la popularidad del andrógino en la cultura del rock, es extraño encontrar la versión female-to-male en las corrientes de la música de aquellos años. Uno de los ejemplos que, de alguna manera, podríamos citar es el de Patti Smith, quien fue fotografiada vestida de hombre por Robert Mapplethorpe para la portada del álbum Horses (1975). Una camisa blanca arrugada, una corbata negra desajustada, el pelo despeinado y una pálida imagen denunciaban el marketing de la estrella de rock femenina como sex symbol. Mientras la feminización del hombre fue fácilmente aceptada por el público, la mujer masculina no lo será en los códigos sociales que determinan la cultura de la visibilidad.

Después de este apresurado recorrido podemos concluir destacando la existencia de dos tipos de actitudes dentro del rock de aquellos años:

- Por un lado, los y las artistas más satíricos y revulsivos. Ellos conformaban el símbolo vivo de la transgresión y de lo prohibido, ya que ridiculizaban la imagen tradicional del estatus masculino y adoptaban unos maquillajes y unas vestimentas provocativos. Eran los representantes de una poesía que sublimaba la violencia de la calle, las drogas, la homosexualidad o el fetichismo. Frank Zappa fue, dentro del ámbito estadounidense, el primero en travestirse en 1966. The Rolling Stones en un single también del año 1966 van travestidos de azafatas con cierto aire perverso. The New York Dolls aparecen en la carátula de un disco como prostitutas de Broadway. Alice Cooper usaba maquillajes grotescos, absurdos y destructivos. Y Lou Reed se convirtió en un poeta apocalíptico vinculado al movimiento gay americano.

- Por otro parte, la cultura del rock utilizó unos modos sofisticados y con más glamour que se manifiestan — con un carácter más estético que formal - en artistas como: Little Richard, Marc Bolan, Gary Glitter y, sobre todo, 
David Bowie quien, después de su gira en 1970 por Estados Unidos, adquirió un comportamiento afectado y un amaneramiento decadente proclamando así el gay rock. No obstante, nada de esto tenía ningún contenido ideológico próximo al Gay Liberation Front, dado que todo se mostraba como una cuestión de vestuario, oropeles y disfraz.

Lo cierto, sin embargo, fue que el cross-dressing de Alice Cooper y New York Dolls resultó más radical que el de los artistas británicos, precisamente porque esta práctica era menos familiar en Estados Unidos. Verdaderamente estas attitudes creaban una especie de ansiedad cuyo efecto distaba enormemente al provocado en el Reino Unido. De lo que estamos seguros es que ya fuera con oropeles y maquillajes, o a través de actitudes ideológicamente comprometidas, todos ayudaron a crear un clima de libertad sexual desconocido hasta la época. Clima que suponía un componente ideológico basado en la crítica amarga, no sólo al sistema establecido en su aspecto político, sino también, a las condiciones mismas de la existencia, mediante una crítica sarcástica y desesperanzada.

Con todo, no querríamos finalizar este capítulo sin efectuar una alusión al ámbito parateatral y al filmográfico. A medio camino entre el arte de acción y la música underground encontramos uno de los proyectos más singulares: COUM Transmissions. Fue fundado en 1969 por parte de Cosey Fanni Tutti ${ }^{67}$ y Genesis P-Orridge, uniéndose posteriormente el fotógrafo Peter Sleazy Christopherson. Sus participaciones en la esfera pública mantuvieron en tensa alerta tanto a galerías como a promotores. El grupo realizó más de ciento cincuenta acciones en calles, galerías y festivales, pero casi siempre en un contexto alejado, incluso, de los espacios alternativos donde se realizaban performances. En los inicios, sus acciones constituían horrorosos rituales corporales caracterizados por un fuerte componente de

\footnotetext{
${ }^{67}$ Esta artista adoptó su nombre de Così fan tutte, la famosa ópera de Mozart cuya temática principal gira en torno a la supuesta frivolidad femenina.
} 
autolesión propio de la naciente estética punk que buscaba - y lo conseguía - el shock del espectador o espectadora. ${ }^{68}$

En 1976 tuvo lugar la exposición Prostitution celebrada en el Institute of Contemporary Art de Londres donde se mostraba una explícita documentación de las actividades de Cosey como modelo para una revista pornográfica. ${ }^{69}$ La ofensa llegó hasta el Parlamento Británico en un día en que los autores fueron señalados como los «destructores de la civilización»». ${ }^{70}$ A pesar de la advertencia en la invitación en la que indicaba que no se admitiría a los menores de dieciocho años, la prensa se sintió ultrajada y acusó al Arts Council —patrocinador del Institute of Contemporary Arts - de despilfarrar el dinero público. El objetivo principal de COUM Transmissions se centró en reprochar los modos con los que las leyes británicas clasificaban la prostitución. Cosey entendía su trabajo de modelo y actriz pornográfica como una infiltración en las conciencias de las masas, un verdadero análisis sobre la comercialización y mercantilización del sexo. ${ }^{71}$ Posteriormente a este escándalo, COUM Transmission fue vetado en todos los espacios oficiales del Reino Unido.

Como consecuencia de aquella prohibición P-Orridge y Christopherson formaron el grupo Throbbing Gristel —que más adelante cambiaría su nombre por el de Psychic TV_, así como el sello discográfico

\footnotetext{
${ }^{68}$ MACRÌ, Teresa, Il corpo postorganico. I turbamenti dell'arte, Milano, Costlan, 2006, p. 43.

${ }^{69}$ En 1976 Cosey había trabajado durante dos años posando como modelo pornográfica para unas cuarenta revistas dedicadas al género, una deliberada estrategia performativa en la que las fotografías fueron utilizadas para la "sexhibición" Prostitution.

${ }^{70}$ ESTABIEL, César, "En busca del tercer sexo", en El País, 28 de noviembre de 2008.

${ }^{71}$ «My projects are presented unaltered in a very clinical way, as any other COUM Project would be. The only difference is that my projects involve the very emotional ritual of making love. To make an action I must feel that the action is me and no one else, no influences, just purely me. This is where the photos and films coum in. I am lying myself open, fully to myself, and through my action to other people also... Here you will see COUM only as you want to see us. The world dictates what it deems to be rality, thereby annihilating reality and we, COUM, cease to exist». Cit. en STILES, Kristine, "Uncorrupted Joy: International Art Actions", en el catálogo de la exposición Out of Actions..., op. cit., p. 269.
} 
Industrial Records, inventores de la música industrial, un emergente estilo que trataba de representar el ambiente urbano y las señales sonoras de lo cotidiano produciendo una especie de distrofia perceptiva gracias al eclecticismo estilístico. La música industrial, más que un género musical, fue una especie de movimiento artístico constituido por artistas post-punk cuya radicalidad se orientaba hacia la autonomía organizativa esquivando todos los canales comerciales tradicionales para promover el uso de sintetizadores y de elementos extra-musicales —como la utilización del vídeo y otros dispositivos. ${ }^{72}$

Genesis P-Orridge continuó su carrera desarrollando un trabajo que se desplazaba constantemente entre el cabaret y el glam. A día de hoy es una leyenda viva del underground, representa la contracultura surgida a principios de los cincuenta y amparada en el LSD y la liberación sexual. Su personaje se popularizó cuando — junto a su compañera Lady Jaye — tomó la decisión de someter su cuerpo a operaciones quirúrgicas para llegar, como meta final, a un físico absolutamente fusionado. Este proyecto de diseño corporal implicaba desdibujar las líneas entre los sexos hasta convertirlos en un nuevo género, al cual llamaron pandroginia.

En el terreno filmográfico, el cine underground retomó y recreó modelos olvidados del cine de posguerra, donde los cuerpos se extendían más allá de sus limitaciones físicas. Siguiendo los planteamientos propios de los años sesenta - donde amplios sectores de la sociedad se plantearon abiertamente las relaciones de género- travestis $y$ transexuales protagonizaron un considerable número de proyecciones, a menudo en clave de humor, pero con la intención última de desenmascarar las contradicciones de la sociedad desde aquella nueva protesta de roles.

El polémico, original y extravagante Kenneth Anger es un director de cine, militante gay y discípulo del mago inglés Aleisteir Crowley. Su obra ha sido clara influencia para cineastas tan dispares como John Waters,

${ }^{72}$ MACRİ, Teresa, op. cit., pp. 44-45. 
Vincent Gallo o Martin Scorsese. Películas como Fireworks o Flaming Creatures, esta última del norteamericano Jack Smith, muestran escenas de gran violencia homo y heterosexual, sus personajes son gamberros neoyorquinos de ajustados vaqueros y chupas de cuero y de rostros maquillados que, en cierto modo, prefiguran la imagen física y la temática sadomasoquista de la primera época de Lou Reed.

El film The Rocky Horror Picture Show — creado por Jim Sharman en 1975 basándose en la ópera rock homónima de Richard O'Briancontagió al espectador creando un clímax de rebelión contra el orden social y liberando comportamientos y actitudes que antes permanecían ocultos. La historia narra las peripecias de una pareja (representante del más puro conservadurismo americano) que, tras una avería en su coche, se ven obligados a pasar la noche en la mansión del Doctor Frank n' Furter donde se celebra la convención de transilvanos con motivo de la creación de su criatura - Rocky Horror-, un hombre perfecto cuyo «medio» cerebro pertenece a un delincuente juvenil. Tim Curry interpreta al Dr. Fank n' Furter, un extraterrestre travestido sediento de sexo y procedente de Transexual-Transilvania. En el film — de género musical- se glorifica el placer y el deseo en todas sus formas. Acaba dando un consejo: «Don't dream it, be it». ${ }^{73}$

Asimismo, el director John Waters se burla de todas las convenciones sociales subvirtiendo las normas sexuales para deformar la visión de la realidad e irritar a una sociedad mojigata y puritana. Cada una de sus películas parte de una situación que, siendo una extensión de la normalidad, se desliza hacia la locura. Su actor principal es Divine, un travesti de grotesco glamour con peso y volumen considerables y con una sexualidad absolutamente depredadora. El actor interpreta mujeres

${ }^{73}$ Una amplia imaginería propia del cine de terror centró cierto interés en la actitud característica del glam rock: la transformación del hombre lobo, el Dr. Jekyll y Mr. Hyde, pero especialmente Frankenstein. Alice Cooper la incluía en The Ballad of Dwight Fry, New York Dolls en Frankenstein y Edgar Winter en el corte instrumental también titulado Frankenstein. 
dominantes y sádicas tan convincentes que tenemos que recordar que ella no es una mujer. Pink Flamingo (1972), Female Trouble (1974) o Polyester (1981) son, posiblemente, las películas más interesantes, donde Waters y Divine realizan una áspera crítica a los aspectos más delirantes del sueño americano, dando una esperpéntica visión de sus valores familiares.

El cine de Warhol/Morrisey no sólo parte también de la figura del travesti en personajes como el sheriff de Lonesome Cowboys (1968), sino también de los cambios de roles en Chelsea Girls (1966). Para Estrella de Diego, la misión última de estos personajes es vapulear el universo de la «gente como nosotros», conducir la mirada hacia un mundo que no desea ver y que al mismo tiempo le fascina, como todo lo prohibido, de la misma manera que le sucede a la pareja protagonista del film The Rocky Horror Picture Show. A través de un replanteamiento de género y de hábitos sexuales, arrastran a la mirada dominante hasta lugares de lo antiestablecido. $^{74}$

En Un año con trece lunas (1978), ${ }^{75}$ una de las películas más intimistas y personales de Rainer Werner Fassbinder, se narran los últimos cinco días de la vida del transexual Elvira Wishaupt - interpretado por Volker Spengler. El film supone un recorrido letal donde Erwin, casado y con una hija, decide ir a Casablanca y operarse para - por amor a su compañero - transformarse en Elvira. Cuando su amante le rechaza, la protagonista comienza un peregrinaje por su pasado, intentando acercarse a las personas que están a su alrededor y buscando una razón para seguir viviendo. Su vida permanece atrapada en un purgatorio social y sexual del que no puede escapar. Relegada al límite de la sociedad, amargamente aislada y sola, Elvira no encuentra más salida que quitarse la vida.

\footnotetext{
${ }^{74}$ DE DIEGO, Estrella, op. cit., p. 187.

${ }^{75}$ Se dice que cada siete años sucede el "Año de la Luna", en el cual, las personas más sensibles sufren fuertes depresiones. Si el "Año de la Luna" resulta ser, a la vez, un año con trece lunas nuevas, la depresión puede desencadenar en grandes catástrofes personales.
} 
En el cine español de estos mismos años, es necesario señalar diversas películas. Leo es pardo $(1976)^{76}$ de Iván Zulueta es un cortometraje de apenas diez minutos de duración que narra el proceso de travestización y transfiguración sufrido por el protagonista en un ritmo vertiginoso $\mathrm{y}$ neurótico cargado de cierta dosis psicodélica. Ocaña, retrat intermitent (1978) de Ventura Pons, un documental sobre el pintor Ocaña - una persona popular de la Ramblas en la década de 1970-, superpone dos perspectivas: el drama de la marginación a lo diferente y la lucha diaria para enfrentarse a su entorno. Pons fusiona la protesta contra el machismo con la reivindicación del travestismo y la provocación política. Un hombre llamado Flor de Otoño (1978), dirigida por Pedro Olea, narra la doble vida de un abogado que por las noches se traviste en un cabaret de Barcelona de los años 1920. Asimismo, es necesario mencionar la película Les intringues de Sylvia Couski (1974), dirigida en París por Adolfo Arrieta y donde se explican las peripecias de los travestis parisinos en torno a los años 1970 en el Barrio Latino.

\footnotetext{
${ }^{76}$ Este cortometraje se puede visualizar íntegramente en la siguiente dirección web: www.youtube.com/watch? $\mathrm{v}=\mathrm{GBeXxWYFLqc.}$
} 



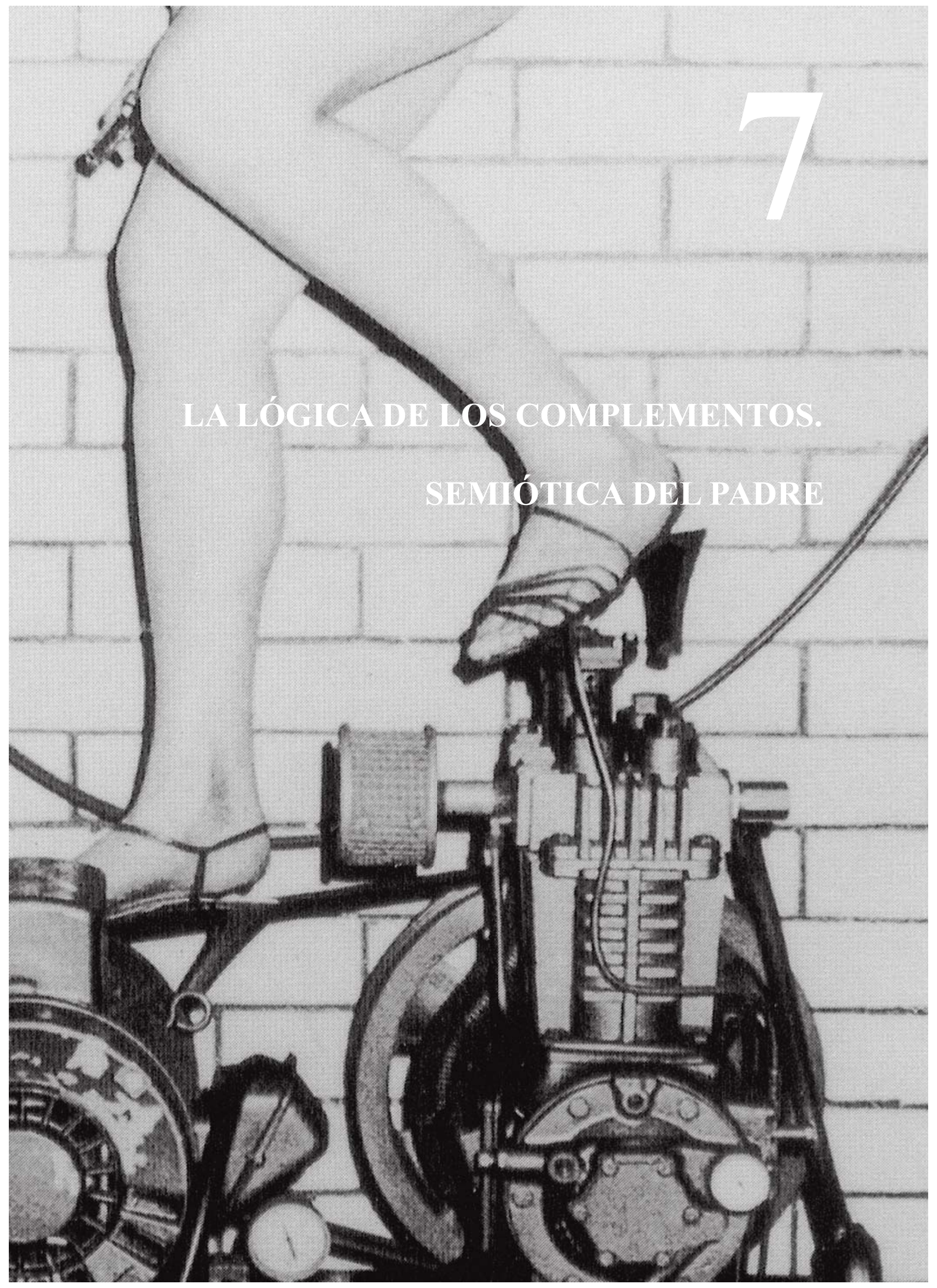



«Una persona se libera a sí misma de sí misma por el propio acto mediante el cual se hace a sí misma un objeto para sí misma».

Jean-Paul Sartre

o social se impone a lo corporal al establecerse como mecanismo encargado de encorsetar la existencia del cuerpo. El objetivo de este mecanismo es la reproducción de seres homogéneos en los que se oculta el placer en pro de un orden establecido y productivo. Hoy en día, ningún tipo de sociedad es capaz de escapar de este constante escarnio hacia el cuerpo. Siguiendo lo apuntado por François Pluchart en sus Manifestes de l'art corporel, el Body Art se presenta como medicina para la enfermedad social y como la más contundente y violenta reacción contra el establishment, el principal responsable de poner el mundo al revés, un mundo que en lugar de dar vida, esclaviza, mutila y castra al ser humano. ${ }^{1}$

A mediados de los años 1970 un re-emergente movimiento feminista cuestionó la construcción social de la feminidad. Lucy Lippard, fuertemente vinculada al movimiento minimalista, publicó un artículo en el cual recopilaba numerosos ejemplos de trabajos en los que la mujer examinaba la

${ }^{1}$ PLUCHART, François, "Manifestes de l'art corporel”, en el catálogo de la exposición L'art au corps. Le corps exposé de Man Ray à nos jours, Marseille, galeries contemporaines des Musées de Marseille, 1996, pp. 475-476. 
determinación de los roles con los que fueron marcadas como sujetos femeninos y experimentaron con posibilidades alternativas. Este artículo le sirvió para publicar un año después From the Center. Essays on Women's Art, un trabajo que abogó por la centralidad del discurso feminista en la teoría del arte. ${ }^{2}$

Asuntos como la opresión social, la dominación de la mirada masculina - perpetuadora de su ideal femenino_-, el fanatismo radical, la autoría de la obra de arte o el valor económico y la contribución del trabajo artístico, se materializaron en diferentes «extensiones corporales», en complementos que se adhirieron al cuerpo, dando lugar a potentes y demoledoras obras de inquietante y provocadora forma, así como de desconcertante y conmovedor fondo. Un arte que fue $-\mathrm{y}$ de alguna manera es aún visto así- como una verdadera amenaza por gran parte de la sociedad. ${ }^{3}$ La sujeción a una cultura visual de la apariencia, de la belleza y del cuidado del cuerpo interesó en la década de los setenta a un conjunto de artistas inmersos e inmersas directamente en el feminismo y en el estudio del orden patriarcal.

Desde un punto de vista foucaultiano, estas reflexiones acerca del cuerpo fueron dirigidas principalmente a revelar la tortura y la deformación infligida sobre éste por una acción política, por una gestión biotecnológica - según unas determinadas imágenes normativas, unos códigos económicos y el uso del castigo, el trabajo y la educación-, pero sobre todo, por un concreto orden simbólico materializado en objetos y complementos

\footnotetext{
${ }^{2}$ Véase GUASCH, Anna Maria, La crítica dialogada. Entrevistas sobre arte y pensamiento actual (2000-2006), Murcia, Cendeac, 2006, pp. 87-97.

${ }^{3}$ No es difícil dar un paseo por la red y encontrar una infinidad de trabajos que han sido mutilados por las mentes biempensantes que conforman la más estricta moralidad. En 1994 Antoni Muntadas inició un proyecto de arte en la red: The File Room. La obra es un enorme archivo de casos acerca de la censura en el arte y la cultura. El proyecto cuenta, por un lado, con una videoinstalación - la que se exhibe en los espacios expositivos- $-\mathrm{y}$, por otro lado, con una importante fuente de archivos en la red. La búsqueda es posible hacerla mediante diferentes clasificaciones: por fechas, por localización, por el tipo de arte o soporte artístico y por el motivo de la censura (sexual, religioso, político, racial, etcétera).
} 
destinados a desempeñar una clara función metalingüística una vez que estos se acoplan al cuerpo.

Sin embargo, retomaremos el trabajo de Beatriz Preciado Testo yonqui para recordar el papel prioritario que desempeña el sistema «farmacopornográfico» - ese conjunto de nuevas tecnologías que abarcan lo corporal (biotecnologías, cirugía, endocrinología, etcétera) y su representación (fotografía, cine, televisión, cibernética, etcétera). A través del predominio de este sistema se nos muestra cómo las relaciones económicas y sociales establecen las formas de un cuerpo que está profundamente sumergido en un terreno tecno-biopolítico. Las relaciones establecidas por la «farmacopornografía» operan sobre él de manera inmediata: lo envisten, lo marcan, lo conducen, lo torturan y lo reducen, exigiendo del cuerpo signos específicos para así, conformar sus significados específicos. De esta manera, esta investidura de lo corporal queda ligada, según dependencias extremadamente complejas y recíprocas, a una utilización meramente económica y productiva: el cuerpo está fuertemente vinculado a relaciones de poder y dominación, un saber - un dominioque se ejerce sobre él y constituye lo que denominamos la tecnología biopolítica del cuerpo. ${ }^{4}$

Dentro de la exploración acerca de la opresión social, el nacimiento del Body-Art es inherente al análisis del campo semántico del padre, así como a sus modos de producción, funcionamiento y recepción de un sistema de signos producidos por su causa. Diversas autoras - y también autorescuestionaron, desde diferentes puntos de vista, las actitudes hegemónicas que entienden la potencia, la fuerza y el control como sinónimos de los valores patriarcales. Para ello, utilizaron el soporte más próximo a cada cual, la superficie donde emanan las cicatrices de la deformidad infligida: su propio destino anatómico. Lo analizaron y desestabilizaron su estatus, consiguiendo así, acalambrar la imagen del padre e incidir en aspectos profundamente ignorados y ocultos.

${ }^{4}$ PRECIADO, Beatriz, Testo yonqui, Madrid, Espasa, 2008, p. 66. 
En la abyecta puesta a prueba de este orden simbólico se desarrolló un considerable conjunto de «extensiones corporales». Por una parte, los autores y autoras que tantearon el cuerpo reprimido por la ley paterna fueron mayoritariamente mujeres - es el ejemplo, entre otras, de Louise Bourgeois, Cindy Sherman, Hannah Wilke o Martha Rosler-, mientras que los artistas que adhirieron al cuerpo posturas infantiloides para burlarse del padre fueron hombres - es el caso de Mike Kelley y, especialmente, Paul McCarthy. Al igual que en el Surrealismo y en el Dadaísmo, también aquí la risa aparece con frecuencia, sin embargo, no es mera diversión: la risa puede ser un acto disruptivo que expresa en el rostro lo ridículo del sujeto, ya que la misma se carga de implicaciones críticas.

Dentro del arte contemporáneo esta mímesis regresiva es pronunciada, siendo muy interesante establecer la relación directa que este sistema de signos establece con la vanguardia dadaísta y surrealista, dominada por personajes infantiloides: recordemos el niño anárquico de Hugo Ball y Claes Oldenbourg, por ejemplo, o el sujeto autista en el Ernst de Dadamax..$^{5}$ Pero, ¿es casualidad que estos aspectos respondan, paradójicamente, a leyes impuestas por el género?

\subsection{Trazando el sujeto. Ficciones del yo}

En aquellos años convulsos en los que se contextualiza el Body Art se demostró que el cuerpo humano era un soporte complejo, un generador de ficciones, un productor de símbolos en constante transformación, pero también un modelo susceptible de mímesis. Padecemos una terrible necesidad de controlar y codificar nuestra fisicidad para exteriorizar un conjunto de mensajes y fantasías. Estamos sometidos y sometidas a un proceso de aprendizaje cultural mediante el cual asimilamos

\footnotetext{
${ }^{5}$ FOSTER, Hal, El retorno de lo real. La vanguardia a finales de siglo, Madrid, Akal, 2001, pp. 163-164.
} 
involuntariamente el control y las limitaciones que el sistema social nos impone a la utilización del cuerpo como modo de expresión.

Nuestra subjetividad implica una autopercepción en tanto que identidades definidas apropiadas a nuestras propias vidas, a la par que exige la adaptación de complementos adicionales, lo que nos lleva a la diferenciación de los demás y a la creación de nuestra supuesta identidad. Esta exigencia implica, por una parte, una capacidad de formular las intenciones que no son inmediatamente determinadas por un impulso natural $\mathrm{y}$, por otra, la compleja necesidad de entender que una identidad — la elaboración de una versión del tipo de persona que somos- exige obligatoriamente que la representemos a los demás. La necesidad de reconocimiento implica, pues, una capacidad de autocreación: conocerse a sí mismo entraña la necesidad de crearnos para los demás.

La idea de subjetividad como producto de la voluntad implica la capacidad de aislamiento de nuestro propio terreno cultural, de reconfigurarlo en tanto que campo simbólico del cual se extraen las ideas, los valores, las metáforas y todo lo que se necesita para construirse y representarse. Aun así, nunca alcanzaremos una abstracción total del orden simbólico cultural, siempre permanecemos implicados y condicionados de mil y una maneras.

Debido a todo ello, se puede señalar que el disfraz físico se transforma en el paso previo al camuflaje mental. Mediante esta «extensión corporal» el sujeto penetra, hasta integrarse permanentemente en él, en un mundo ajeno. Una premisa bastante manida que no deja de mostrarse eficaz.

La obra fotográfica de Cindy Sherman (New Jersey, 1954) se empeña en demostrar que el yo conforma una serie discontinua e interminable de reproducciones, imitaciones y falsedades. Aunque la autora utilice el medio fotográfico en sus representaciones artísticas, no debemos pasar por alto que Sherman es, ante todo, una performer que se aprovecha de las posibilidades de la imagen fotográfica para desleírse en sus nuevos 
egos, recrear caracteres con los que distanciarse de su yo condicionado, experimentar la otredad y acercarse al personaje retratado.

Sherman se crea a sí misma incesantemente, sin embargo, no trata de revelar el verdadero yo artístico, sino evidenciar cómo la identidad es una construcción imaginaria y ambigua que se convierte en actriz y creadora de la propia narración que se nos muestra. Las fotografías que Sherman comenzó a realizar desde 1977 nos enseñan la agonía del estereotipo, la deconstrucción de la identidad y su plasmación en el caos, planteando, al mismo tiempo, las consecuencias de la mujer simplificada culturalmente como una dualidad: sujeto/objeto. Una mannequin sans visage que es, al mismo tiempo, objeto de sus propios oscuros deseos y sujeto que los goza y los padece. ${ }^{6}$

Con la multiplicación de su imagen, Cindy Sherman renuncia a tener la suya propia. Sus imágenes no pueden ser consideradas como autorretratos dado que ninguna de ellas la refleja, aunque esté presente en todas. Las mujeres que aparecen en sus fotografías no existen, no son retratos de nadie, pero, paradójicamente, representan de manera fehaciente la imagen estereotipada de la mujer en la sociedad occidental contemporánea. Sus múltiples rostros devienen deconstrucción de la imagen femenina, un producto de la representación caracterizado - desde un punto de vista falocéntrico - por la inestabilidad, la pérdida de identidad, la ausencia y la mascarada. En la sociedad occidental la mujer se ha convertido en el objeto pasivo de la mirada del hombre, el cual proyecta sobre ella sus fantasías y sus deseos más o menos inconscientes, haciéndola vulnerable y frágil, poniéndola bajo su control. $^{7}$

\footnotetext{
${ }^{6}$ BLESSING, Jennifer, "Rrose is a Rrose is a Rrose. Gender Performance in Photography", en el catálogo de la exposición Rrose is a Rrose is a Rrose. Gender Performance in Photography, New York, Solomon R. Guggenheim Museum, 1997, p. 81.

${ }^{7}$ G. CORTÉS, José Miguel, El rostro velado. Travestismo e identidad en el arte, Donostia, Koldo Mitxelena Kulturenea, 1997, p. 222.
} 
El origen del trabajo de Cindy Sherman se remonta al momento en el que empezó a vestirse con distintos tipos de ropa cuando acudía a inauguraciones y eventos que se celebraban en las galerías de su ciudad natal, Buffalo, en el estado de Nueva York. «Since I was small I have been interested in the perverse side of disguise. I didn't want to be the ballet dancer or the princess, I was looking for the monster which may lurk behind each image». ${ }^{8}$

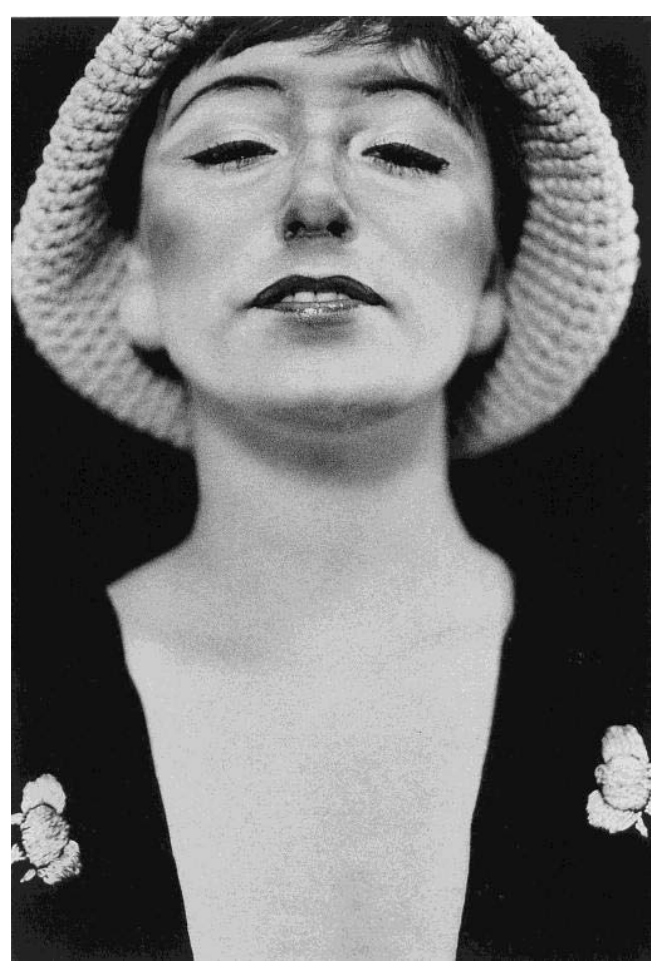

64. Cindy Sherman - Untitled (1975)

El traslado a la gran urbe transformó sus acciones en una serie de fotografías que documentaban la interpretación de sus roles: Film Stills. Inmersa en el anonimato de la metrópolis posaba ante la cámara mimetizando la esencia de distintas protagonistas cinematográficas que,

${ }^{8}$ Cit. en OLIVARES, Rosa, "Bad Girl”, en el catálogo de la exposición Cindy Sherman, Madrid, Museo Nacional Centro de Arte Reina Sofía, 1996, p. 11. 
aunque no eran concretamente identificables, sí que resultaban inmensamente familiares. Sherman se diluye en la interpretación de un personaje y utiliza las fotografías como una forma más de narración, resumiendo palmariamente el instante imposible que traduce cada uno de los aspectos psicológicos sobre el personaje en una imagen visible $\mathrm{y}$, por si fuera poco, totalmente decodificable por parte de quien observa la obra. El cine posee tal importancia en nuestra conciencia cultural que es lógico que este proceso decodificador pueda ser llevado a cabo y que el mismo haya tenido tanta influencia en la autora como la Historia del Arte.

Sherman se responsabiliza por completo de todo el atrezo y de la ambientación de sus imágenes. En gestos aparentemente espontáneos de un modo en el que a veces se pierde la nitidez, cuenta también, como los fotógrafos clásicos de la foto fija, con un instante poético, que produce el efecto casual. Es una especie de solo performance de la detención y/o paralización lo que Cindy Sherman documenta: una mezcla de teatro, fotografía y travestismo, en la que la artista se apropia de las grandes poses del cliché. Una performance que sólo ella controla y que sólo tiene lugar ante la cámara. ${ }^{9}$

Los Film Stills devienen esbozos seriados de variaciones, siempre nuevas, de una identidad femenina que se alimenta de las ofertas estereotipadas de la cultura popular. Entre sus personajes destacan una mujer en ropa interior y un vaso de Martini en la mano, una bibliotecaria de aspecto dulce propia de una película de serie $\mathrm{B}$, una joven secretaria de una ciudad, una provocativa mujer extraída de una película neorrealista italiana, una fugitiva inocente, una víctima de una película de cine negro, una mujer intranquila en camisón o mujeres en confortables pisos. Seductora, absorta en sus pensamientos, mirándose en el espejo o tendida en la cama, todas ellas reflejan actividades que, convencionalmente, suelen considerarse femeninas.

\footnotetext{
${ }^{9}$ LUEKEN, Verena, "Cindy Sherman y sus 'Film Stills'-Performances sin movimiento", en el catálogo de la exposición Cindy Sherman, op. cit., p. 22.
} 


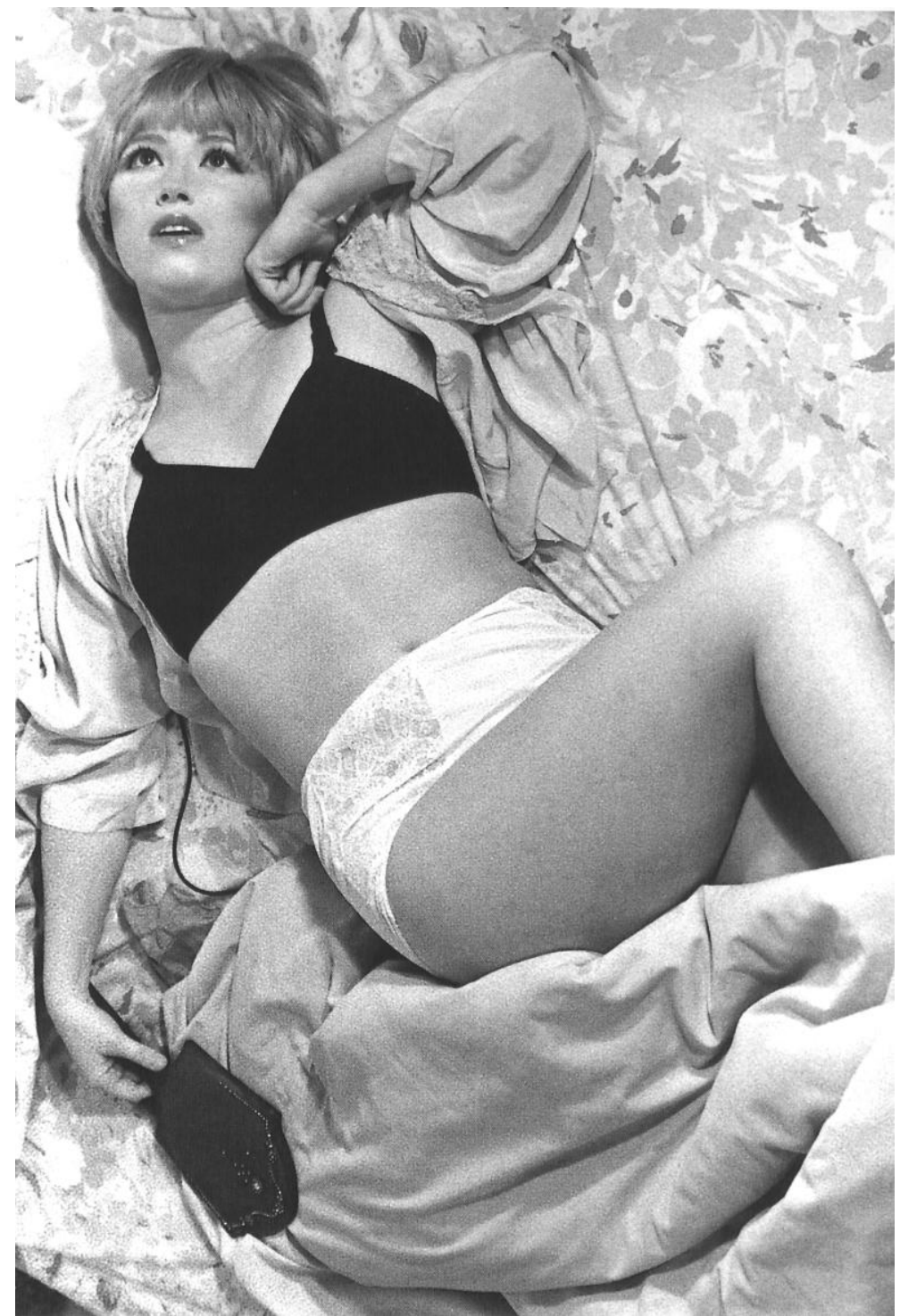

65. Cindy Sherman - Untitled Film Still 6 (1977)

La definición de este recuerdo es parte del material de Cindy Sherman. Los Film Stills no tienen título y con frecuencia se prestan a explicaciones cada vez más variadas, sin por ello permitir que una sola interpretación establezca un orden seguro. Son escenarios de fantasía en los 
que la autora trabaja ese mundo de imágenes ofrecido por los mass media, que desde hace tiempo se han convertido en parte de la realidad sin haber sido nunca su reflejo. Sobre estas imágenes la autora manifestó en una entrevista: «[...] to pick a character like that was about my own ambivalence about sexuality - growing up with the women role-models that I had, and a lot of them in films, that were like that character, and yet you were supposed to be a good girl». 10

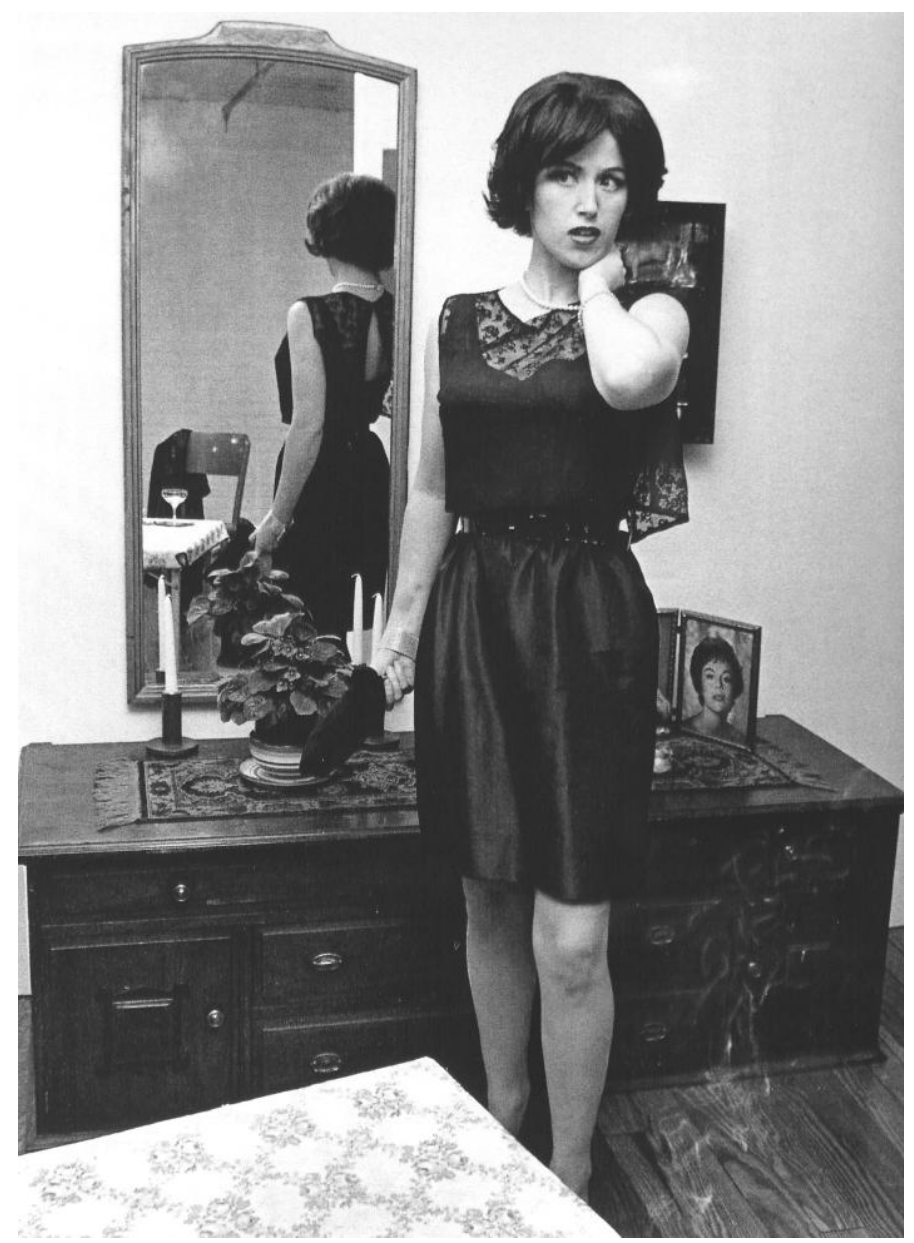

66. Cindy Sherman - Untitled Film Still 14 (1978)

${ }^{10}$ HOWELL, Georges, "Anatomy of an Artist", en Art Papers, no 4, julio - agosto 1995, p. 7. 
A la serie Film Stills le siguieron otras en las que, en vez de imitar los rasgos formales del cine de la década de los años 1940, se reproducían las formas de la televisión y de la fotografía de revistas especializadas en moda y pornografía. En todas ellas, la problemática que Sherman parecía tener la intención de abordar era la de la identidad de la mujer y/o la de la elaboración de su imagen según clichés y convenciones sociales.

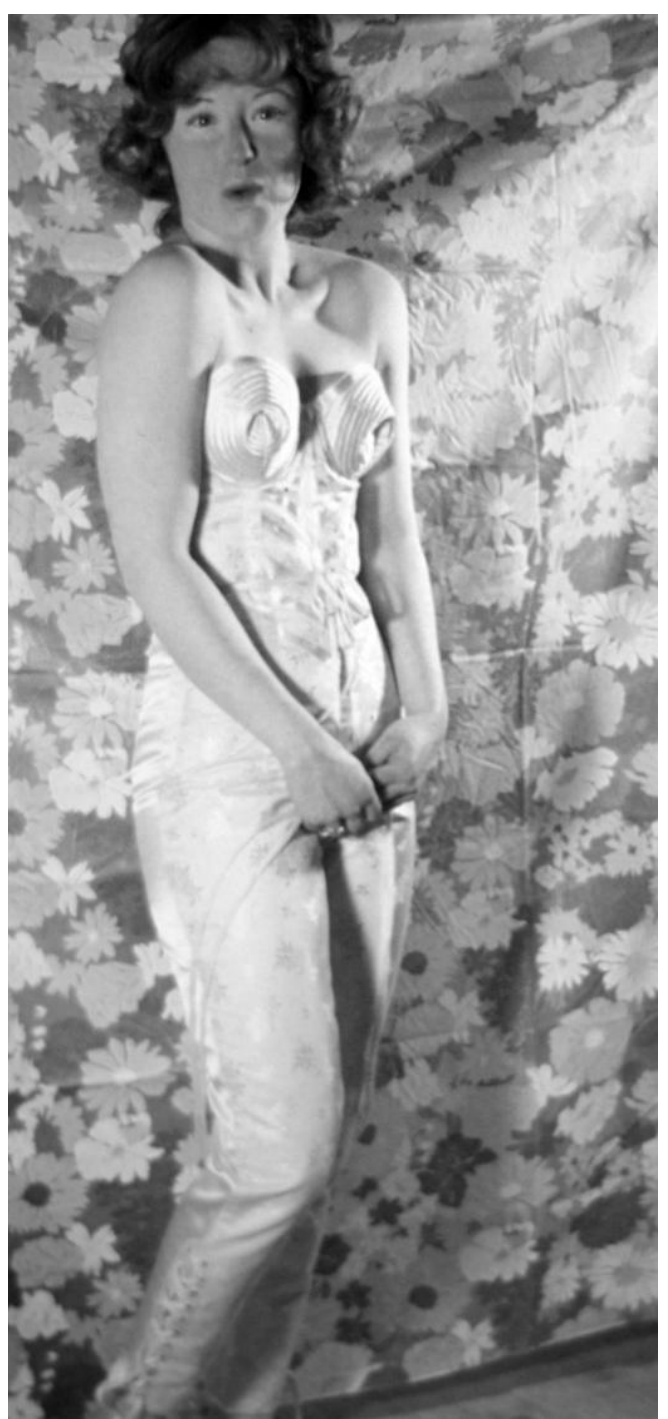

67. Cindy Sherman - Untitled \#131 (1983) 
En esta misma línea, Sherman realizó un encargo para Diane Benson, propietaria de una tienda, que consistía en una serie de fotografías de moda para la revista Interview. Para ello le proporcionaron ropa de diseñadores como Jean-Paul Gaultier y Comme des Garçons. El resultado supuso una subversión del glamour de la alta costura, ya que se representó como un baile de disfraces de estereotipos femeninos caricaturizados en prendas exageradas y poses excesivamente amaneradas. Sin embargo, en una segunda serie de fotografías realizada para una campaña publicitaria de la revista Vogue, el trabajo adquirió un carácter siniestro: Sherman aparecía enfadada, atemorizada, depresiva, posiblemente víctima de malos tratos o de un intento de violación. ${ }^{11}$ Lamentablemente, aunque la intención de estas imágenes estaba destinada a mermar las identidades ficticias que la industria de la moda vende a las mujeres, su teatralidad permitió a este sector aprovechar la cara oculta de la identidad femenina para hacer publicidad de sus prendas, una imagen harto frecuente en la actualidad. ${ }^{12}$

Sherman ha ido encarnando todos sus personajes y se ha mutado en las más diversas formas, modos de expresión y estados mentales. A través de ello ha buscado ratificar que hemos perdido la capacidad de reconocernos, que somos una multitud de caras diferentes y que nuestra imagen es tan ambigua que hace imposible una visión concluyente sobre la identidad. Tanto en sus Untitled Film Still, como en su obra posterior, Sherman refleja la paradoja de cómo ciertos complementos añadidos al

\footnotetext{
${ }^{11}$ WARR, Tracey y JONES, Amelia, "Performing Identity", en WARR, Tracey (ed.), The Artist's Body, London, Phaidon, 2000, p. 151.

${ }^{12}$ Hace tres años fue retirado un controvertido anuncio publicitario de Dolce \& Gabbana en cuya imagen aparecía un hombre con el torso desnudo inmovilizando a una mujer postrada en el suelo mientras otros cuatro individuos contemplaban la escena. Cuando, aisladamente, centramos nuestra atención en campañas de tal calibre, nos llevamos las manos a la cabeza. Sin embargo, es harto frecuente el bombardeo cotidiano de publicidad ofensiva sin ser conscientes de la repercusión social que posee ni hacer nada al respecto. Véase: http://www.elpais.com/?d_date=20070307.
} 
cuerpo devienen un progresivo e intenso sentimiento de pérdida, degeneración, descomposición, troceamiento y desaparición de éste. ${ }^{13}$

La autora se rebela contra la estandarización y la homogeneización, contra la reducción de la existencia humana a un solo y único punto de vista. Es su particular manera de subrayar con mayor fuerza la negación del ego y cuestionar las ilusiones de una identidad fija o los deseos de coherencia personal. Sus fotografías no pertenecen ni a un tiempo determinado ni a un lugar definido. Tampoco poseen un inamovible rol. Cruzan los límites de lo representable y muestran lo efímero de las poses, lo artificial de las imágenes. Tal y como afirma Estrella de Diego, Sherman es la perfecta heroína postmoderna que se disfraza de todas y que, a partir de la imagen de los medios, acaba poniendo en evidencia sus estrategias de falso espejo que promociona identificaciones alienantes. ${ }^{14}$

Para Anatxu Zabalbeascoa, Sherman rechaza de manera consistente cualquier interpretación teórica sobre su trabajo. Sus fotografías son disfraces que ocultan revelando. Se ha comentado que los personajes de Sherman devienen una búsqueda íntima que revela el miedo a la muerte de la persona disfrazada tras el personaje. Ninguna de las mujeres, o todas ellas, podrían ser Cindy Sherman. A través de sus autorretratos en los cuales Sherman aparece físicamente, la autora parece preguntarse: ¿existo o soy la mera repetición de una imagen? ${ }^{15}$

A pesar del carácter equívoco de estas imágenes, la obra de la artista estadounidense se ha prestado fácilmente a un discurso feminista. Juan Antonio Ramírez ha reflexionado sobre este aspecto en un capítulo de su trabajo Corpus Solus, un texto que — sin compartir plenamente su posturallama la atención por su tono crítico hacia la iconología «preponderante» de

\footnotetext{
${ }^{13}$ G. CORTÉS, José Miguel, op. cit., p. 223.

${ }^{14}$ DE DIEGO, Estrella, El andrógino sexuado. Eternos ideales, nuevas estrategias de género, Madrid, Visor, 1992, p. 178.

15 ZABALBEASCOA, Anatxu, "Màscara i mirall", en el catálogo de la exposición Màscara i mirall, Fons d'Art Contemporani de Barcelona, Barcelona, 1997, p. 16.
} 
la obra de Sherman. ${ }^{16}$ El autor niega que los Film Stills traten de una exploración sistemática de los papeles femeninos en la sociedad contemporánea, puesto que la fotógrafa siempre se muestra como una chica atractiva - o por lo menos interesante. ¿Qué puede haber aquí de discurso específicamente feminista? ¿Acaso no preocupa a los hombres la naturaleza problemática y arbitraria de su propia identidad? Ramírez nos advierte del sentido invertido de ciertas interpretaciones y califica el trabajo de ciertos «fotógrafos alegóricos» —en los que incluye a Cindy Sherman- como un «arte para la castidad y la anorexia». ${ }^{17}$

Fiel a la performance Joan Jonas (New York, 1936) también investigó sobre la construcción de identidades. El modus operandi de su proceso creativo desencadena un texto, un poema, una historia. Centrándonos en los aspectos que más nos interesan de la obra plástica de la autora, cabe destacar que en los inicios de su trabajo la temática remitía a sí misma, particularmente a sus avatares, transformaciones, deformaciones y reconstrucciones a través de un alter ego, una serie de abstracciones sobre lo femenino y sobre la composición de roles sexuados. ${ }^{18}$

La performance permitió a Jonas explorar una definición de la escultura en la que se podía entender el gesto como un objeto más de reflexión y combinar su interés por diferentes culturas. En Mirror Piece I (1969) y Mirror Piece II (1970) el espejo se transformó en una «extensión corporal» capaz de dirigir las obras hacia la experiencia, la penetración y la fragmentación de un espacio que deviene, al mismo tiempo, real e ilusorio. Estos trabajos fueron representados en grandes ámbitos, tales como

\footnotetext{
${ }^{16}$ Esta actitud se echa de menos en el resto del libro de Ramírez, una actitud que - comulgando o no con sus juicios - invita a cuestionar las interpretaciones mayoritarias. Véase RAMÍREZ, Juan Antonio, Corpus Solus. Para un mapa del cuerpo en el arte contemporáneo, Madrid, Siruela, 2003.

${ }^{17}$ Véase RAMÍREZ, Juan Antonio, op. cit., pp. 234-242.

${ }^{18}$ MARÍ, Bertomeu, "Otros tiempos y otros lugares. El arte de Joan Jonas", en el catálogo de la exposición Joan Jonas. Timelines: transparencias en una habitación oscura, Barcelona, MACBA, 2007, p. 9.
} 
gimnasios, auditóriums y lofts, consiguiendo alterar completamente la percepción de las personas asistentes a la obra.

En Mirror Check (1970), a una distancia de seis metros del público, Jonas inspeccionaba todas las partes de su cuerpo desnudo con un pequeño espejo circular realizando un pausado movimiento circular y señalando en voz alta: «This is my right side», «this is my left side». ${ }^{19}$ Quienes presenciaban la acción no podían ver la imagen reflejada, tal vez intuir e imaginar cada detalle inspeccionado por Jonas. La fragmentariedad visual a la que es expuesto el espectador o espectadora permite elaborar una linealidad imaginaria, una realidad falsa generada a partir de nuestro constructo sociocultural.

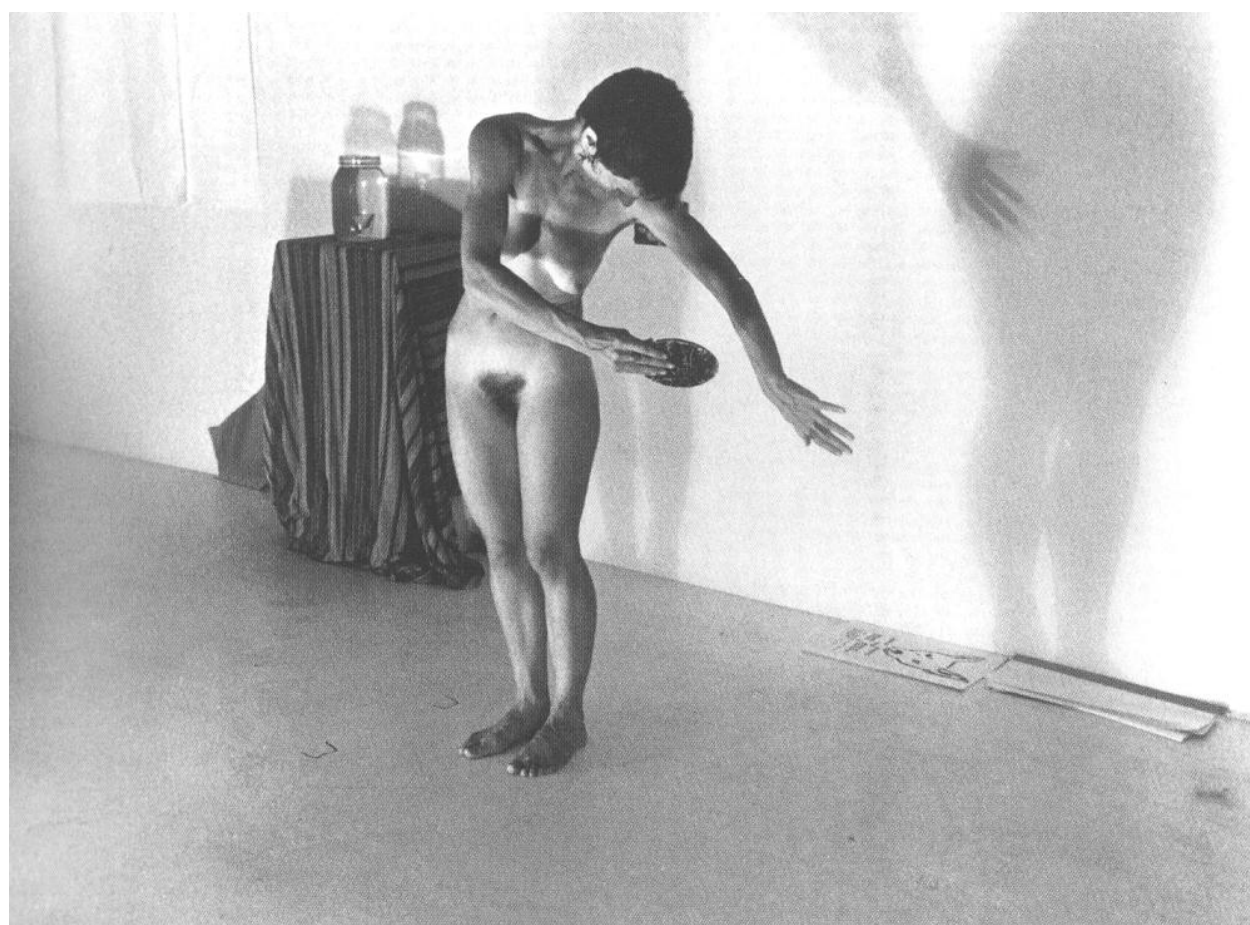

68. Joan Jonas - Mirror Check (1970)

${ }^{19}$ HEILMANN, Mary, "Mirror Pieces 1968-1971/1994. Outdoor Pieces 1970-1990/1994", en el catálogo de la exposición Joan Jonas. Works 1968 - 1994, Amsterdam, Stedelijk Museum, 1994, p. 28. 
Organic Honey's Visual Telepathy (1972) fue la acción que logró cautivar a los críticos. Ese mismo año preparó una versión ampliada de ésta -Organic Honey's Vertical Roll_ - además de una pieza de vídeo de veinte minutos: Vertical Roll.

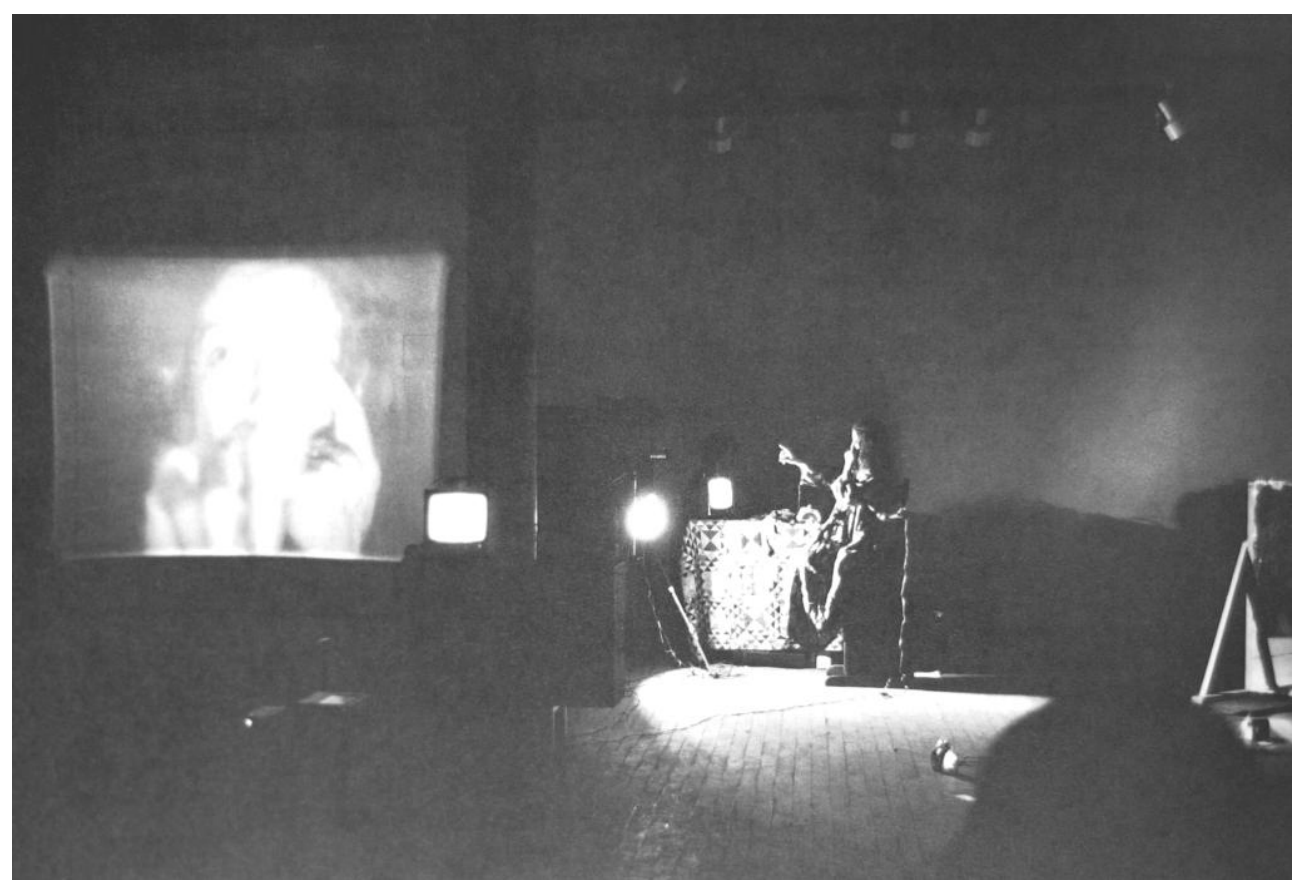

69. Joan Jonas - Organic Honey's Visual Telepathy (1972)

Utilizando una multitud de espejos de varios tamaños, aparatos de grabación de vídeo, proyecciones simultáneas y circuitos cerrados de vídeo, creó, multiplicó y fragmentó a su hechicera eléctrica, un deslumbrante personaje conocido con el nombre que daba título a la obra: Organic Honey. Jonas, mientras danzaba, cantaba y dibujaba al ritmo de la música, se sometía a un proceso de creación ante los ojos de los espectadores y espectadoras: primero aparecía vestida con un kimono, después se ataviaba con un sofisticado tocado hecho con plumas de pavo real, en otro momento se ocultaba tras una máscara semitranslúcida con cara de muñeca. Todo ello ayuda a poner en evidencia su deuda con el teatro oriental: el uso de la máscara y el ruido de piezas de madera, el alter ego y sus posturas en el 
escenario, una construcción dramática ajena a la cultura occidental. Arrodillada en el suelo y tras haberse colocado la máscara en lo alto de la cabeza, Jonas utilizó una cuchara para hacer añicos rítmicamente un espejo situado delante de ella. Las imágenes en vídeo de su cara y su cuerpo eran transferidas y simultáneamente fragmentadas en la pantalla de un monitor, en el que aparecían reproducidas como imágenes móviles, distorsionadas e interrumpidas por barras negras.

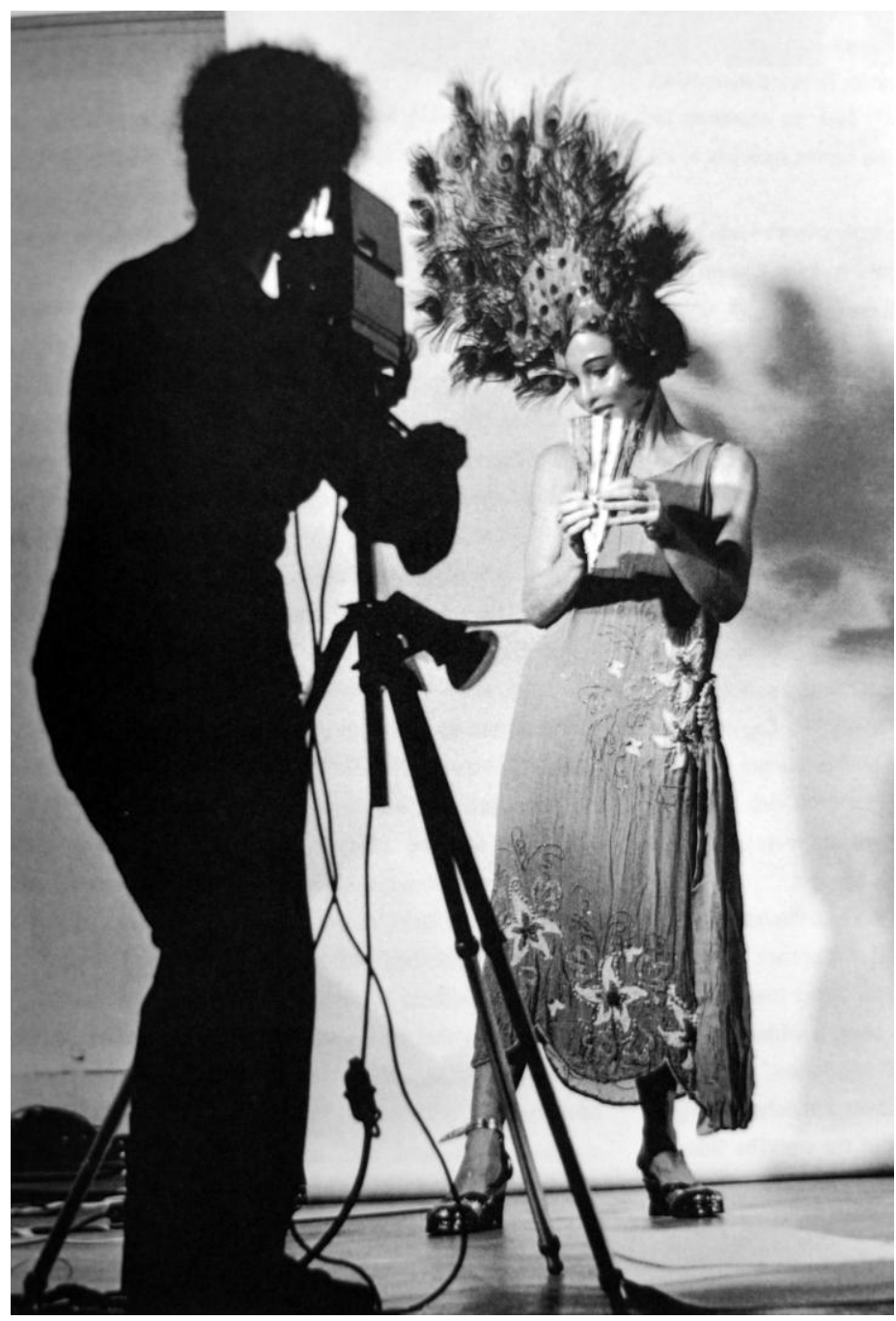

70. Joan Jonas - Organic Honey's Vertical Roll (1972) 
La autora utilizó su imagen física junto a la capacidad técnica del vídeo para transformarse en una superficie proyectiva de lo que se considera el yo. El efecto del vídeo en circuito cerrado —en el que la cámara se filma a sí misma filmando en una especie de retroalimentación orgiástica- crea una infinita secuencia de imágenes exponiendo, a su vez, la exposición de la imagen misma. ${ }^{20}$ En palabras de Joan Jonas: «Organic Honey's Visual Telepathy evolved as I found myself continually investigating my own image in the monitor of my video machine. I then bought a mask of a doll's face, which transformed me into an erotic seductress. I named this TV persona Organic Honey. I became increasingly obsessed with following the process of my own theatricality, as my images fluctuated between the narcissistic and a more abstract representation. The risk was to become too submerged in solipsistic gestures. In exploring the possibilities of female imagery, thinking always of a magic show, I attempted to fashion a dialogue between my different disguises and the fantasies they suggested. I always kept my eye on the small monitor in the performance area in order to control the image making». ${ }^{21}$

Como deducimos de la pieza, el cuerpo de Jonas actúa como epicentro de un trabajo en el que el mismo queda atrapado entre diferentes aparatos y actos de grabación, reproducción y percepción. El efecto del vídeo se transforma en un eco que transforma el cuerpo de la protagonista en un medio por el que pasa la información. La presencia paralela del cuerpo y del medio videográfico — como aparato de grabación y reproducción - pasa a ser algo más que un simple transmisor de datos. A la autora le interesaban enormemente las discrepancias entre la actividad realizada y la duplicación, el cambio y la alteración constantes de la información. Una acción marcada por un impulso tremendamente narcisista.

${ }^{20}$ CLAUSEN, Barbara, "Danza en la encrucijada", en Juan Jonas. Timelines..., op. cit., Barcelona, MACBA, 2007, pp. 21-23.

${ }^{21}$ JONAS, Joan, en el catálogo de la exposición Joan Jonas. Works 1968 - 1994, op. cit., p. 42. 
Una importante cuestión subyacente - afirma Joan Jonas - fue la de encontrar la imagen femenina para explorar los papeles desempeñados por las mujeres. La representación del modo como la iteración de la mirada construye la presencia de lo femenino, evoca lo que Teresa de Lauretis describiría -años después- como un proceso sin fin de autorrepresentación. Con ello Jonas cortaba con la tradición física basada en la imposición mediática de la representación, la identidad y el sexo femeninos en la cultura, la historia y la sociedad. ${ }^{22}$

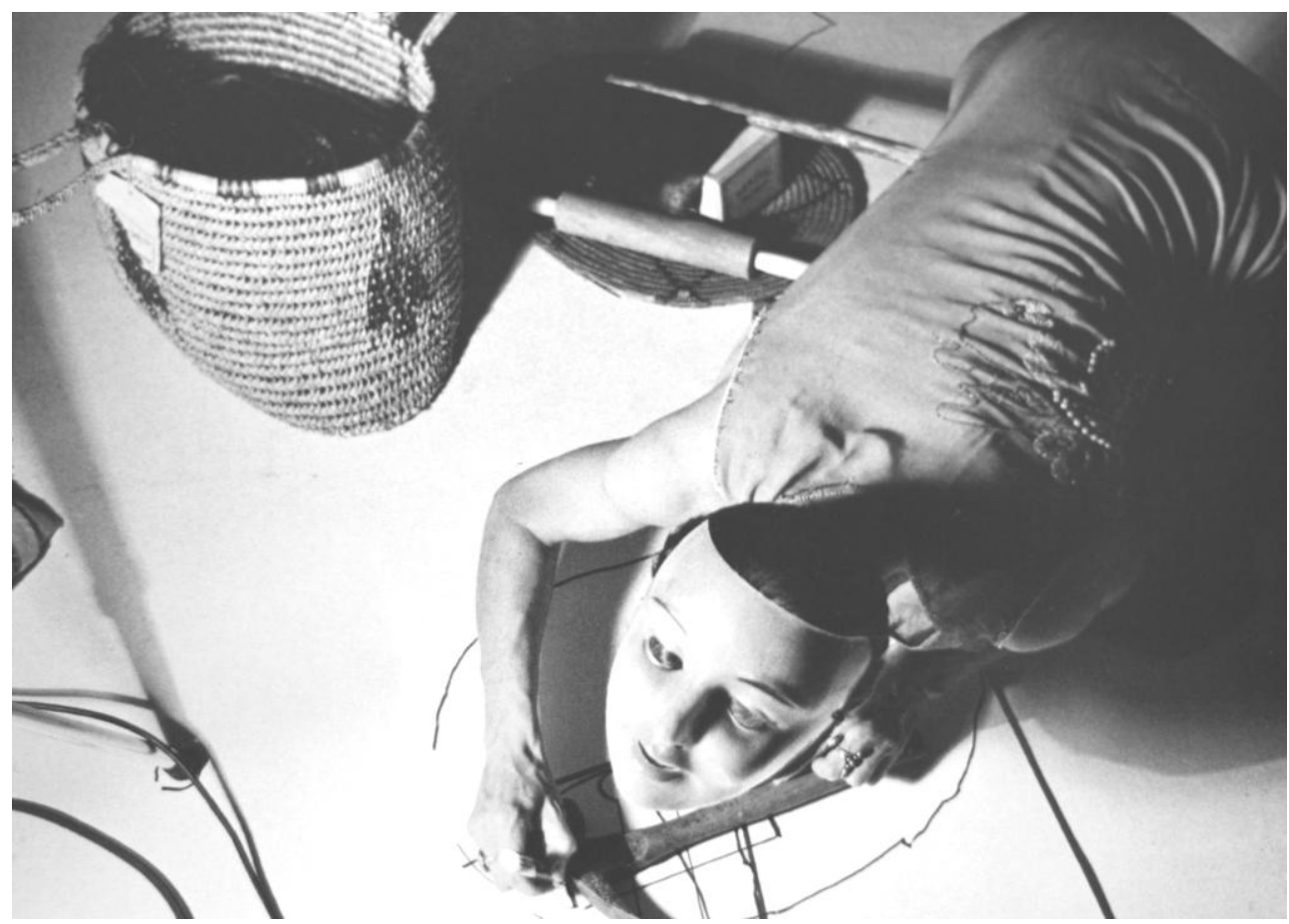

71. Joan Jonas - Organic Honey's Vertical Roll (1972)

Jonas trabajó en numerosas ocasiones con el efecto del circuito cerrado, proceso en el que la cámara se filma a sí misma filmando. Creaba así, una infinita secuencia de imágenes, con lo que exponía la producción de la imagen misma. Ese acto de la transcripción dentro del medio de

22 JONAS, Joan, Joan Jonas. Timelines..., op. cit., p. 56. 
comunicación en el que se aborda directamente la indexicalidad de los gestos de la autora, es específico de las performances de aquella época, como por ejemplo, la ya mencionada serie Organic Honey o Glass Puzzle (1974). Este proceso establece una relación psicológica en la que una esfera de acción está marcada por un impulso narcisista. El efecto del vídeo en circuito cerrado es un eco que transforma el cuerpo de la protagonista de la performance en un medio por el cual pasa la información.

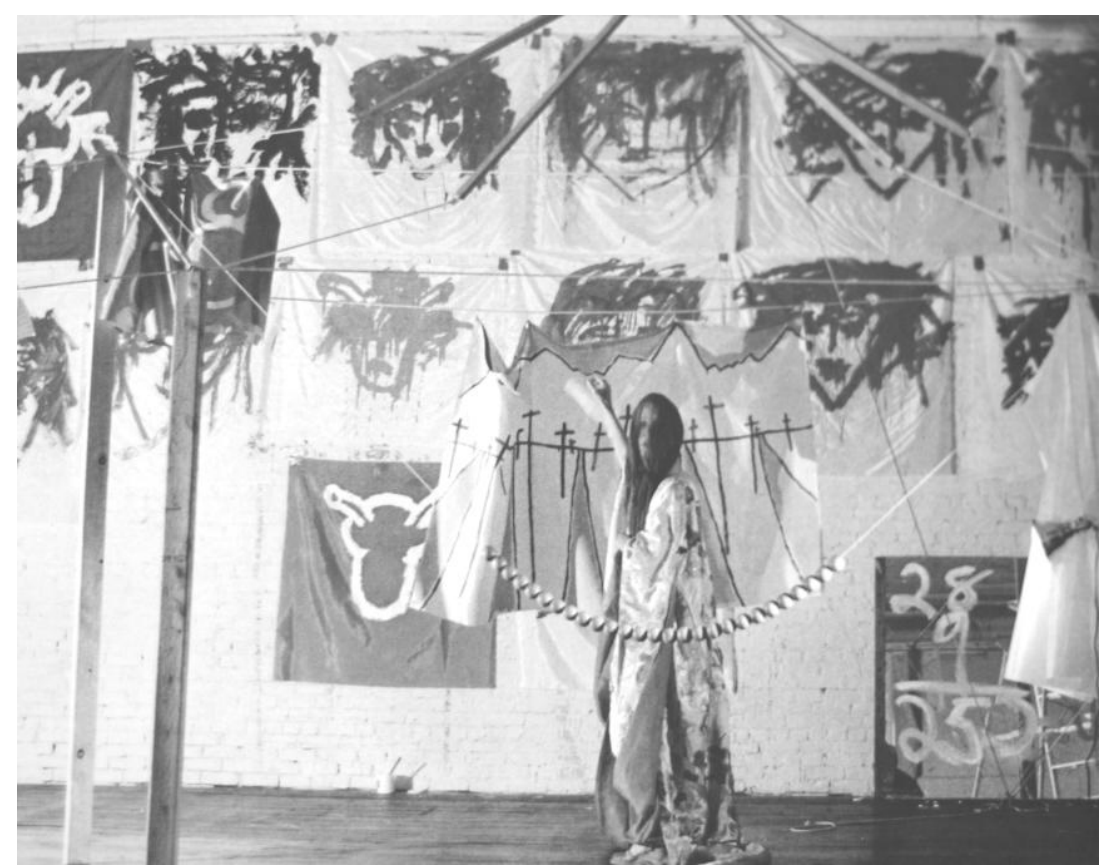

72. Joan Jonas - Juniper Tree (1978)

En 1976 realizó Juniper Tree, basada en un fragmento del cuento infantil de los hermanos Grimm. ${ }^{23}$ Jonas presentó toda una amalgama de

\footnotetext{
${ }^{23}$ El cuento de los hermanos Grimm relata la truculenta historia de celos de una madrastra por su hijastro, a quien acaba decapitando, troceando y cocinando con sus fragmentos un suculento estofado. La hermanastra, creyendo que había tenido alguna relación con su muerte, se encargó de recoger los huesos, envolverlos en un precioso pañuelo de seda y enterrarlos en un bello y aromático enebro en el cual yacía su verdadera madre. Tras esto, el árbol se agitó como si se tratase de un ser humano y salió de éste un pajarillo que entonaba
} 
escenas e imágenes que representaban un particular universo deconstructivo de la historia. Éste se encontraba repleto de imágenes infantiles, de referencias al doble y al espejo, a las máscaras y a las sombras. A su vez, todo ello se encontraba inmerso dentro de una banda sonora editada por la propia artista expresamente para esta performance a partir de canciones de Simone Forti.

En I Want to Live in the Country (and Other Romances) (1976-77) Joan Jonas utiliza el ambiente de un estudio de televisión como marco para sus imágenes. En las secciones de la cinta tomadas en interiores, la pantalla aparece ribeteada en rojo mostrando la nuca de Jonas en el lateral inferior izquierdo mirando, supuestamente, lo que ocurre en el centro de la pantalla. Las escenas al aire libre, tomadas en Nueva Escocia, muestran imágenes muy estáticas en las que se ha eliminado el marco rojo. En una de las secuencias, una mujer lleva a cabo actividades sencillas como sentarse en un taburete y levantarse de él, correr por la habitación o toquetear su vestido blanco.

A partir de la obra de Joan Jonas, Douglas Crimp introduce el concepto de-synchronization - una conjunción entre fragmentación y repetición - como estrategia. La falta de estabilidad y el esfuerzo por imaginar la imagen completa nos sitúa directamente ante una especie de voyeurismo. Crimp parte de la imagen videográfica de Jonas para referirse a la desincronización entre el monitor y el transmisor de frecuencias produciendo el hipnótico movimiento de una franja negra que se desplaza verticalmente a través de la pantalla. ${ }^{24}$

una canción en la que narraba lo sucedido. GRIMM, Jacob y GRIMM, Guillermo, El enebro y otros cuentos de Grimm, Barcelona, Lumen, 1989.

${ }^{24}$ CRIMP, Douglas, "De-synchronization in Joan Jonas's Performances", en el catálogo de la exposición Joan Jonas. Scripts and Descriptions 1968 - 1982, Berkeley, University Art Museum, 1983, pp. 8-10. 


\subsection{EI poder de los objetos. EI signo como extensión}

«[...] no soy ni sujeto ni objeto, sino más bien un sujeto que se siente devenir objeto: [...] me convierto verdaderamente en espectro».

Roland Barthes

Tal y como define Moles, el objeto es un elemento del mundo exterior fabricado por el ser humano y que puede ser tomado o manipulado. Por ello, es uno de los componentes esenciales de nuestro entorno, constituyendo uno de los datos primarios de contacto del individuo con el mundo. De ahí que la noción misma de objeto esté unida a una semiótica puesto que el objeto es manipulado conceptualmente a partir del nombre que sirve para designarlo. ${ }^{25}$

Van Lier pone en entredicho esta definición de carácter simplista remitiéndonos a las relaciones entre conceptos como natural y artificial, que hemos tratado en el apartado 1.2 del presente estudio. Decir que el objeto es lo que se manipula, o bien lo que afecta a los sentidos, no resulta inteligible más que para la sociedad occidental. ${ }^{26}$

Especialmente desde la Revolución Industrial, nuestro universo cultural se ha caracterizado por la fabricación de elementos que han cambiado fugazmente el paisaje del mundo en el que vivimos, creando un

25 MOLES, Abraham, “Objeto y comunicación”, en MOLES, Abraham, Los objetos, Buenos Aires, Tiempo Contemporáneo, 1974, p. 9.

${ }^{26}$ VAN LIER, Henri, “Objeto y estética”, en MOLES, Abraham, op. cit., p. 129. 
entorno artificial al que hemos atribuido una palabra: cultura. De esta manera hemos poblado nuestro orden simbólico con signos, situaciones y objetos.

El marco de nuestra vida cotidiana ha sido invadido poco a poco por los objetos. No es descabellado pensar que exista una verdadera sociología del objeto que aplica los métodos y el marco de pensamiento de los seres en grupo al universo de aquellos. No podemos aislar el papel que desempeña el objeto en nuestro contacto con el entorno social, de ahí que en una cultura de los objetos, la noción de cultura no puede ser restringida únicamente a las imágenes, los sonidos o los textos. Los objetos cotidianos de nuestro entorno - comprados, usados y desechados- cumplen las mismas funciones de comunicación que los periódicos, los conciertos o las reproducciones de obras de arte. Su circulación en la sociedad sigue las mismas leyes y cumple las mismas acciones. En términos marxistas, el individuo está atado al objeto por su propio deseo, luego por su propio placer y finalmente por su propio pesar.

Desde el punto de vista de Baudrillard, es indudable que los objetos son portadores de un índice de significaciones sociales, es decir, portadores de una jerarquía cultural y social que constituyen un código. Pero, precisamente por esto, puede pensarse que los individuos y los grupos, lejos de seguir sin rodeos las prescripciones de ese código, actúan con el repertorio distintivo e imperativo de los objetos como cualquier otro código moral o institucional. ${ }^{27}$

«Cache-toi objet!» fue uno de los graffiti más espectaculares aparecidos en la Sorbona durante los acontecimientos de Mayo del 68. ¿Estaba dirigido al primer objeto que saliera al paso o, más eficazmente, al primer consumidor-de-masa? Tampoco dejaba de evocar — por la ironía del destino que lo colocaba en ese lugar de la alta cultura - algunos fragmentos

${ }^{27}$ BAUDRILLARD, Jean, "La moral de los objetos. Función-signo y lógica de clase”, en MOLES, Abraham, op. cit., p. 46. 
de frases: «Objetos inanimados, ¿tenéis alma?», «Mujeres, mujeres, objetos queridos y funestos [...]». El transeúnte veía aplastarse contra esa pared su condición de poseedor incondicional. Su alienación, que empezaba a reconocer verbalmente como temible pero técnicamente confortable, lo acorralaba de improviso. ${ }^{28}$

Los objetos en interacción con la sociedad han adquirido un (des) orden simbólico que no queda exento de unas connotaciones muy determinadas. Jean Baudrillard establece en El sistema de los objetos una relación muy interesante entre el objeto y el sexo. Para el autor, el mito de una funcionalidad milagrosa del mundo - nacimiento de la tecnología- es correlativo al fantasma de una funcionalidad milagrosa del cuerpo, por tanto, el esquema de ejecución técnica del mundo está estrechamente ligado al esquema de relación sexual del sujeto. Desde otro punto de vista, la «extensión corporal» es fundamentalmente un sustituto del falo, médium operatorio de la función por excelencia. Además, cualquier objeto tiene algo de chisme en la medida en que su instrumentalidad se borra, pudiendo ser investido de mera instrumentalidad libidinal. «Basta con que la práctica concreta se pierda para que el objeto se transfiera a las prácticas mentales. Detrás de cada objeto real hay un objeto soñado». ${ }^{29}$

Como bien sabemos, en todo tipo de mensaje existen dos aspectos generales distintos: mensaje semántico y mensaje estético, distinción retomada en forma muy amplia por la lingüística a través de la oposición binaria entre estructuras denotativas y connotativas, $\mathrm{o}$ bien entre significación y evocación. Desde el propio lenguaje se ha atribuido una cultura en torno al género otorgando características y cualidades convencionalmente aceptadas como masculinas o femeninas, perpetuando así las desigualdades entre las personas.

\footnotetext{
${ }^{28}$ MORIN, Violette, "El objeto biográfico", en MOLES, Abraham, op. cit., p. 187.

${ }^{29}$ BAUDRILLARD, Jean, El sistema de los objetos, Madrid, Siglo XXI, 1979, p. 134.
} 
Dentro de las coordenadas del feminismo de los años 1970 - consciente de que para rebatir las normas de género predominantes por las cuales la feminidad era percibida como débil y degradada, era necesario cuestionar la opresión corporal, la colonización masculina del cuerpo transmitida mediante la tradición y todo tipo de discursos y soportes-, cabe situar el trabajo de Hannah Wilke (Nueva York, 1940-1993). La autora exploró su cuerpo a través de signos especialmente relacionados con particularidades atribuidas a la feminidad para poner al descubierto la alienación a la que tradicionalmente se ha visto sometida la mujer en una sociedad patriarcal. ${ }^{30}$
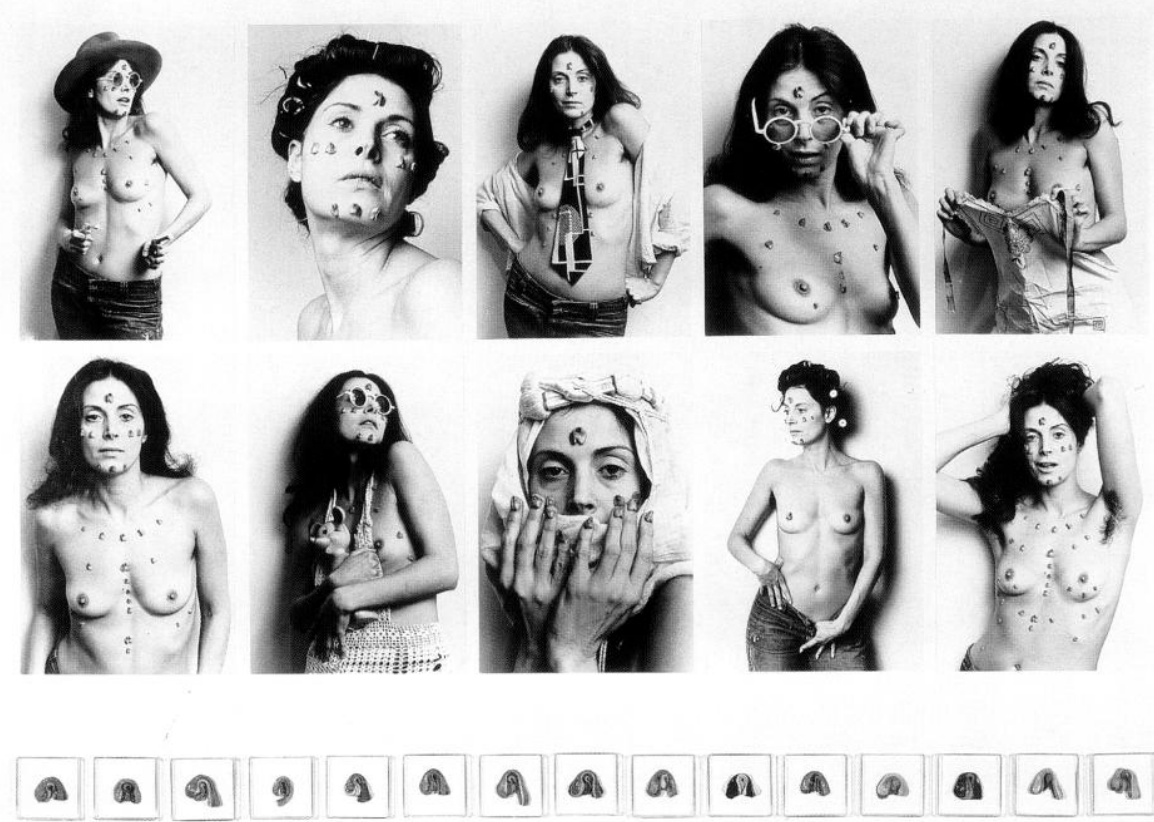

73. Hannah Wilke - S.O.S. Starification Object Series (1975)

\footnotetext{
${ }^{30}$ COTTINGHAM, Laura, "Are you experienced? Le feminism, l'art, et le corps politique", en el catálogo de la exposición L'art au corps. Le corps exposé de Man Ray à nos jours, Marseille, Mac-galeries contemporaines des Musées de Marseille, 1996, p. 337.
} 
Objeto y autobiografía se entremezclan con una gran dosis de inteligente sentido del humor, con una aguda ironía y con una ambigua utilización del sistema de signos. Wilke fue la primera artista en utilizar formas vaginales en su escultura, incluso antes de que Judy Chicago y Miriam Schapiro teorizaran sobre esta iconografía para convertirla en el marchamo de la lucha feminista de un grupo de artistas del momento. ${ }^{31}$ Wilke fue una de las autoras más representativas de aquel grupo que configuró la primera generación de mujeres que tuvieron que militar en distinto frente por primera vez en la historia — el arte dominado por la acción y la visión de los varones, las políticas conservadoras, los prejuicios sociales, las discriminaciones sexistas, etcétera - y que finalmente crearon las condiciones para la aparición, no sólo de unas circunstancias igualitarias entre los hombres y las mujeres, sino además, un modo inédito de hacer y entender el arte, por surgir de las manos, de los cuerpos y de las mentes de mujeres. Todo ello condujo a Hannah Wilke a una identificación total entre su arte y su vida. ${ }^{32}$

A partir de $1974 \mathrm{y}$, paralelamente al desarrollo de su obra escultórica, la autora se convirtió en el objeto de su arte. En S.O.S. Starification Object Series (1975) se autoproclamó como una víctima de las etiquetas y prejuicios de la gente, de hecho, fue constantemente incriminada de narcisista y pornográfica. ${ }^{33}$ Wilke se muestra como una modelo publicitaria en diferentes poses, a veces sofisticada, sexy o frívola, y otras más ingenua, pensativa o ausente. A través de estas poses, la artista consigue - de modo irónico - representar un auténtico muestrario de las típicas actitudes femeninas que la sociedad espera de una mujer, siempre

\footnotetext{
${ }^{31}$ FERNÁNDEZ ORGAZ, Laura, "Hannah Wilke. Exchange Values", en el catálogo de la exposición Hannah Wilke. Exchange Values, Vitoria-Gasteiz, Centro Museo Vasco de Arte Contemporáneo, 2007, p. 15.

${ }^{32}$ GONZÁLEZ DE DURANDA, Javier, "La ofrenda del cuerpo", en el catálogo de la exposición Hannah Wilke..., op. cit., p. 6.

${ }^{33}$ JONES, Leslie C., "Transgresive Feminity: Art and Gender in the Sixties and Seventies", en el catálogo de la exposición Abject Art. Repulsion and Desire in American Art, New York, Whitney Mueseum of American Art, 1993, pp. 50-51.
} 
representada así en los medios de comunicación. Los rulos, el delantal y otros accesorios, como un sugerente vestido o unas gafas de sol, ayudan a remarcar los estereotipos. En todas estas fotografías el cuerpo de la autora se ha complementado con unas pequeñas protuberancias que emergen del cuerpo de la autora a modo de estigmas que convierten a la modelo en una especie de víctima. Si nos fijamos detenidamente, estos extraños objetos son esculturas vaginales modeladas con chicle.

El juego de palabras que se da en starification - que podría traducirse como hacer de alguien una estrella- en relación con el vocablo scarification, revela el mensaje. Ser mujer y bella puede elevar a la categoría de star pero, eso sí, pagando un precio muy alto: ser marcada y reducida a lo mismo que la entronizó — una vagina y todo lo que ello conlleva. S.O.S. no es sólo una reflexión para ironizar sobre los roles femeninos y la mirada masculina en torno a la mujer, sino también una crítica al estereotipo sobre la belleza, vista como algo carente de expresividad y de inteligencia $\mathrm{y}$, desde luego, como algo muy mal considerado entre las feministas del momento.

Hannah Wilke realizó en el espacio P.S. 1 de Nueva York una serie de «autorretratos interpretativos» recogidos bajo el título So Help Me Hannah: Snatch-shots with Ray Guns (1978-1984), posando con un revólver, desnuda y con tacones altos en diversos espacios caracterizados por una ambientación un tanto decadente. Wilke utilizó los roles convencionales de la seducción femenina para penetrar en territorio masculino y, una vez en él, erosionar y destruir el poder del macho subvirtiendo la cartesiana separación entre cuerpo y mente que sostiene el mito de la trascendencia masculina. En las fotografías se superponían citas de filósofos, artistas, críticos e historiadores de arte masculinos que hablaban de la relación entre los individuos, el arte y la sociedad. La 
instalación se completaba con una colección de formas de pistola fundidas con una serie de fotografías tomadas alrededor del edificio. ${ }^{34}$

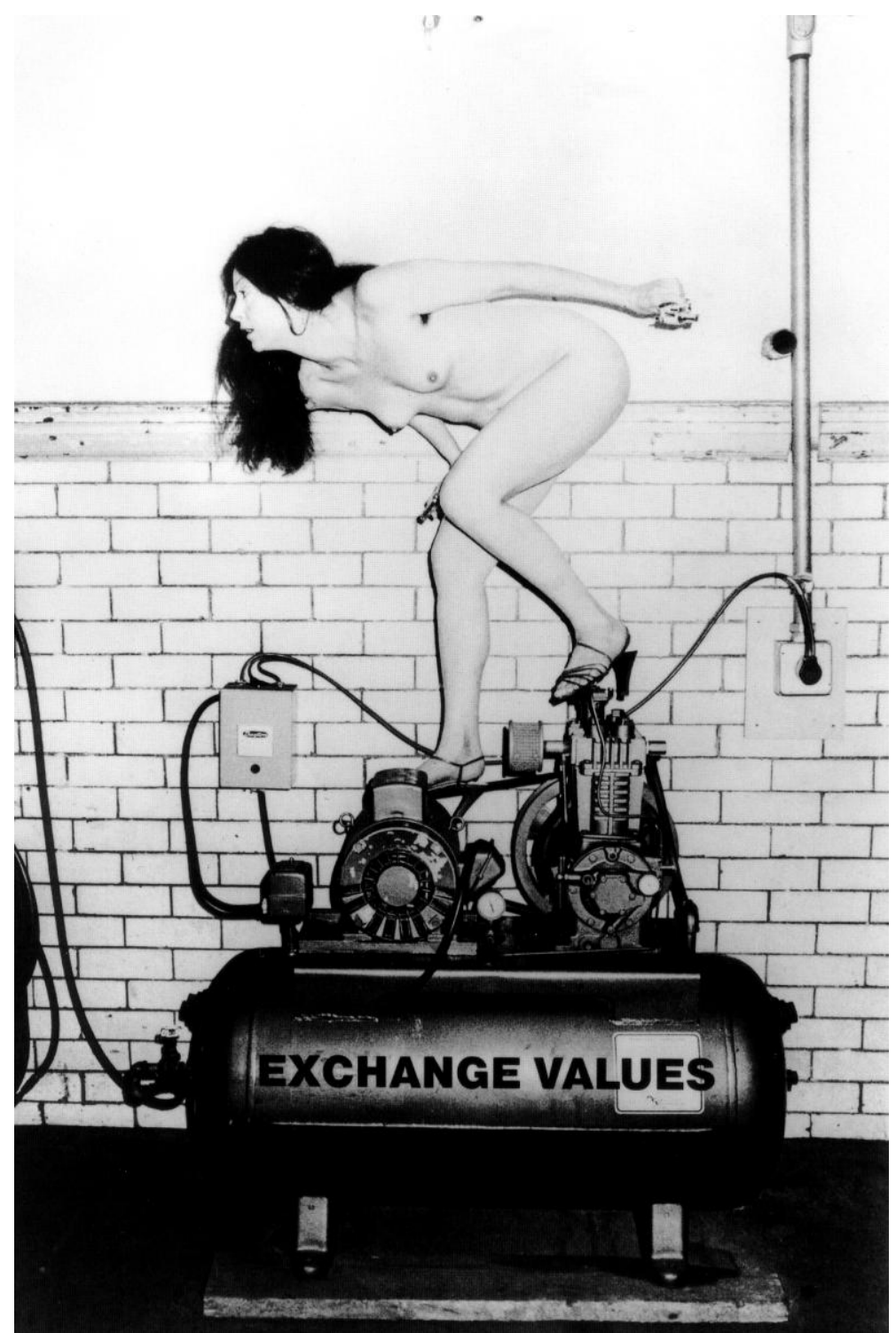

74. Hannah Wilke - Exchange Values (1979) ${ }^{34}$ FERNÁNDEZ ORGAZ, Laura, "Hannah Wilke. Exchange Values”, en el catálogo de la
exposición Hannah Wilke..., op. cit., p. 11. 
Un año más tarde la pieza evolucionó a una serie de performances grabadas en vídeo en las que Wilke se movía lentamente por el espacio y se detenía de vez en cuando para posar. La acción se acompañaba de una banda sonora en la que la autora leía fragmentos manipulados de las citas, como ésta de Marx, extraída de El capital: «Si las mercancías pudieran hablar dirían: nuestro valor de uso tal vez interese a los hombres. Pero a nosotras, en cuanto objetos, nos tiene sin cuidado. Lo que nos interesa objetivamente es nuestro valor. Nuestra propia circulación como cosas-mercancías así lo demuestra. Sólo nos referimos unas a otras como valores de cambio».

De esta cita la autora mantuvo las últimas palabras -exchange values - añadidas a una elocuente y potente fotografía: su propio autorretrato desnuda, con tan sólo unos zapatos de tacón, una pistola en cada mano y subida a un compresor de aire. Estas dos palabras extrapoladas de la cita completa admiten dos posibilidades: o bien como sustantivo + sustantivo, «valores de cambio», o bien como verbo imperativo + sustantivo, «cambia valores». Por un lado, parece que la artista se quiere presentar como un deseado cuerpo de mujer, un mero objeto de uso, un valor de cambio imprescindible para la sociedad patriarcal representada simbólicamente por el compresor — la «extensión corporal» de la máquina como metáfora de engranaje social. Sin embargo, la ambigüedad de la imagen y del mensaje exchange values, se transforma al descubrir que Wilke va armada con una pistola. La expresión de su rostro y su pose cobran un sentido diferente: la actitud enérgica y arrebatadora parece estar exhortando al mundo a la rebelión, a conquistar la máquina y apropiarse de las palabras de Marx, pero esta vez en sentido imperativo. Para que se levante y cambie el sistema.

La obra fusiona explícitamente el cuerpo-objeto femenino - su calidad objeto se ve acentuada por los zapatos de tacón y por la pose, que presenta el cuerpo como un objeto expuesto - y la mente o el «yo» de la producción cultural, como reflejan los textos y la reapropiación y la yuxtaposición que la artista realiza con ellos y su propia imagen. La forma 
en que Wilke se apropia de la posición subjetiva tradicionalmente ostentada por el hombre resulta aún más paródica debido al revólver, un símbolo fálico de potencia y destrucción que contrasta con la exposición de su vulnerable cuerpo desnudo para forzar al espectador o espectadora a cuestionarse sus prejuicios acerca de la forma de ver el cuerpo femenino.

Tanto al principio como al final de su trayectoria la autora utilizó de manera radical su propio cuerpo: primero, desde la belleza de la juventud, en la que exhibe su desnudez desde una orgullosa y total carencia de complejos; después, desde la enfermedad, analizando aquello que nos resistimos con frecuencia a ver y reconocer. Son excepcionales también, las reflexiones escritas que nos legó y en las que volcaba sus ideas, dudas y críticas acerca del feminismo, el arte de su tiempo y su propio trabajo. Wilke tuvo muy claras las convicciones acerca de lo que tenía que hacer y aplicó su inteligencia con acierto a los objetivos que se propuso.

El análisis semiológico de los objetos también ha sido una constante en la extensa obra de Martha Rosler (Nueva York, 1943). Performances, vídeos, obras textuales, fotografías e instalaciones se enfrentan al público con temas políticos, analizando el papel de los medios, la vida cotidiana, doméstica y urbana desde un punto de vista feminista no desprovisto de humor. La autora estadounidense fue uno de los más claros ejemplos de la involucración de la juventud en la Nueva Izquierda luchando por los derechos civiles y participando en protestas contra la Guerra de Vietnam.

La obra de Rosler llamó por primera vez la atención en la década de los setenta a través de una presentación particularmente contundente - tanto a través de vídeos como de performances - de los temas feministas de la época: servidumbre doméstica, anorexia, y las especiales exigencias y/o limitaciones impuestas a las mujeres a través de la dinámica del fetichismo de las objetos.

A lo largo de sus investigaciones sobre temas específicos analiza el hecho de cómo el sistema de una cultura masculina, heterosexual, blanca y 
dominada por el capitalismo impregna la vida cotidiana. Rosler ha seguido un principio como estrategia artística: ubicarse en la raíz del problema. Desde el principio de su trayectoria estaba preocupada por la diversidad de la represión, por el modo en que una crítica de la vida cotidiana, así como del fetichismo que domina todos los registros de la existencia en la formación social capitalista, puede ser vista como parte de un continuo que abarca el espectro más amplio de la represión de necesidades, anhelos y deseos.

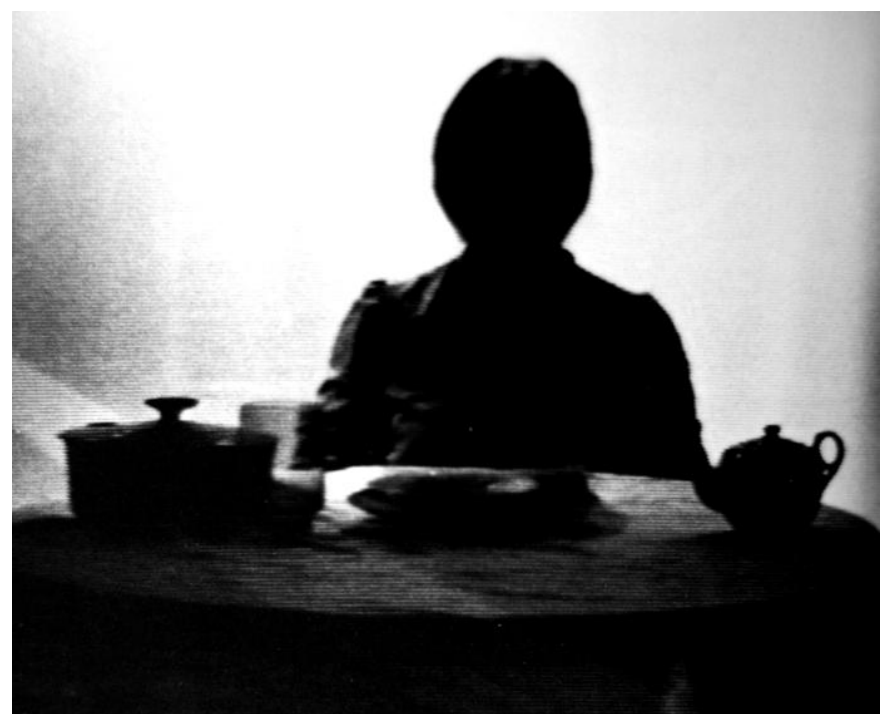

75. Martha Rosler - A Budding Gourmet (1974)

A Budding Gourmet (1974) forma parte de una trilogía - Service: A Trilogy on Colonization - que investigaba los usos sociales de la comida y de las cosas corrientes de la vida. La obra —en su versión videográfica, a diferencia de McTowers Maid y Tijuana Maid presentadas como proyecto de mail art_ ${ }^{35}$ es el monólogo despiadadamente ingenioso y burgués de un ama de casa sobre la «autosuperación» y la movilidad social ascendente a

${ }^{35}$ ALIAGA, Juan Vicente, "Lo público y lo privado: entrecruzamientos productivos. Unas notas acerca de la obra de Martha Rosler", en el catálogo de la exposición Martha Rosler. La casa, la calle, la cocina / the house, the street, the kitchen, Granada, Centro José Guerrero, 2009, pp. 42-43. 
través del consumo de «las mejores cosas de la vida»: la cocina extranjera y exótica. La noción de chef - atribuida, incluso hoy en día, a hombresacentúa la sensación de una distinción que permite la mejora de clase, y de la cocina como glotonería, puesto que la burguesa se percibe a sí misma como poseedora de una auténtica cultura internacional y como ciudadana del mundo. La obra actúa, por ello, como un discurso sobre la bulimia cultural presentada como una «política de creatividad», que celebra el modo en que en Estados Unidos puede tomar lo mejor de todas las épocas y lugares.

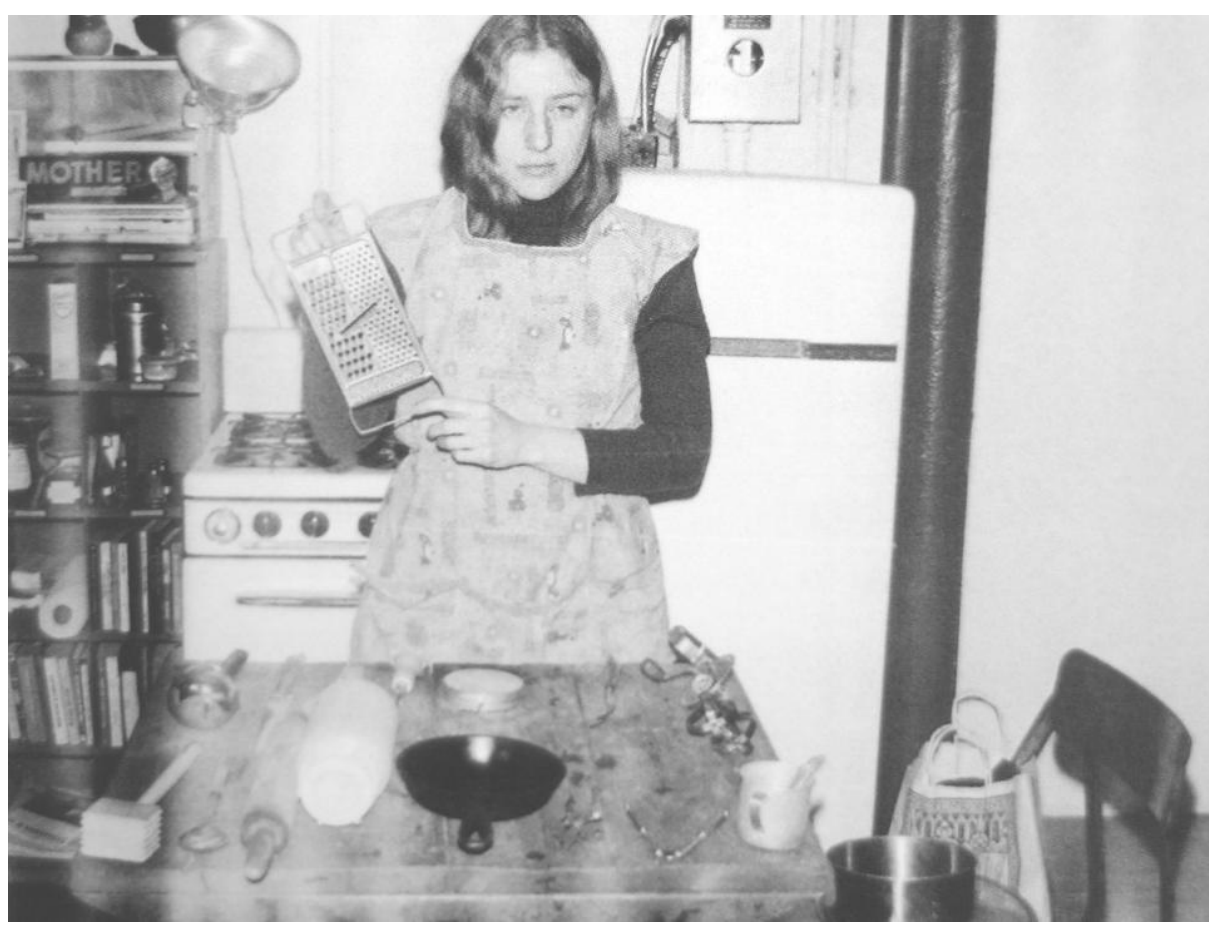

16. Martha Rosler - Semiotics of the Kitchen (1975)

En Semiotics of the kitchen (1975), Martha Rosler nos presenta en un vídeo de poco más de seis minutos de duración una serie de objetos cotidianos utilizados en la cocina. Tal y como afirma Juan Vicente Aliaga en el reciente catálogo publicado con motivo de la exposición de la artista en Granada, los espacios privados y la semiótica de la domesticidad no son 
simples habitáculos, dado que están cargados de un entramado de relaciones sociales, de poder, de roles de género, de jerarquías y de contratos, de manera similar a como sucede con los objetos que conforman nuestra cotidianidad. ${ }^{36} \mathrm{Su}$ demostración transcurre en riguroso orden alfabético - de apron a tenderizer - al estilo de un programa de televisión culinario o de televenta. En su presentación de los utensilios, con cierto matiz cómico, trata a cada objeto - a causa de la agresividad gestual- como un instrumento de ataque.

Tal y como afirma Silvia Eiblmayr al demostrar la posición instrumentalizada de la mujer, Rosler — siguiendo la lógica de su orden alfabético- se convierte en un utensilio más: con el cuerpo escribe las letras $\mathrm{U}, \mathrm{V}, \mathrm{W}, \mathrm{X}, \mathrm{Y}, \mathrm{Z}$, lo que a su vez significa que su cuerpo queda escrito por ellas. La autora muestra claramente que no se trata únicamente de un papel al que sus personajes están sujetos, un rol social atribuido que es posible - y debería - cambiarse. También muestra que las estructuras de poder, dominación y sumisión, así como sus ramificaciones ideológicas, tienen que ser detectadas y analizadas no sólo desde las perspectivas políticas, sociales y económicas, sino también desde dentro del propio sistema lingüístico y de signos que constituye el orden de lo simbólico. ${ }^{37}$

El vídeo Vital Statistics of a Citizen Simply Obtained (1977) examina la conversión de las mujeres en meros objetos de una sociedad tecnológica. La obra se centra en la representación de la técnica de medir aplicada al cuerpo de la mujer en cada una de sus partes, incluso las articulaciones de los dedos de las manos y los pies. Describe la invasión tecnocrática del cuerpo de la mujer a través de una alegoría en la que dos médicos exploran, miden y registran sistemáticamente, centímetro a centímetro, el cuerpo desnudo de la artista. La cinta muestra un largo plano continuo que revela el examen y la evaluación que de una mujer efectúa un

\footnotetext{
${ }^{36}$ ALIAGA, Juan Vicente, op. cit., p. 22.

${ }^{37}$ EIBLMAYR, Silvia, "Los personajes de Martha Rosler", en el catálogo de la exposición Martha Rosler: Posiciones en el mundo real, Barcelona, MACBA/Actar, 1999, p. 153.
} 
examinador blanco y un coro de tres ayudantes femeninas. En este caso la tecnología aparece representada claramente como mecanismo de opresión y de control social, pero no porque se entienda el cuerpo femenino como «templo profanado», sino subrayando más bien cómo dicho cuerpo es precisamente un constructo de esa tecnología médica patriarcal que aquí se escenifica. ¿Cómo hemos llegado a ser considerados como objetos?

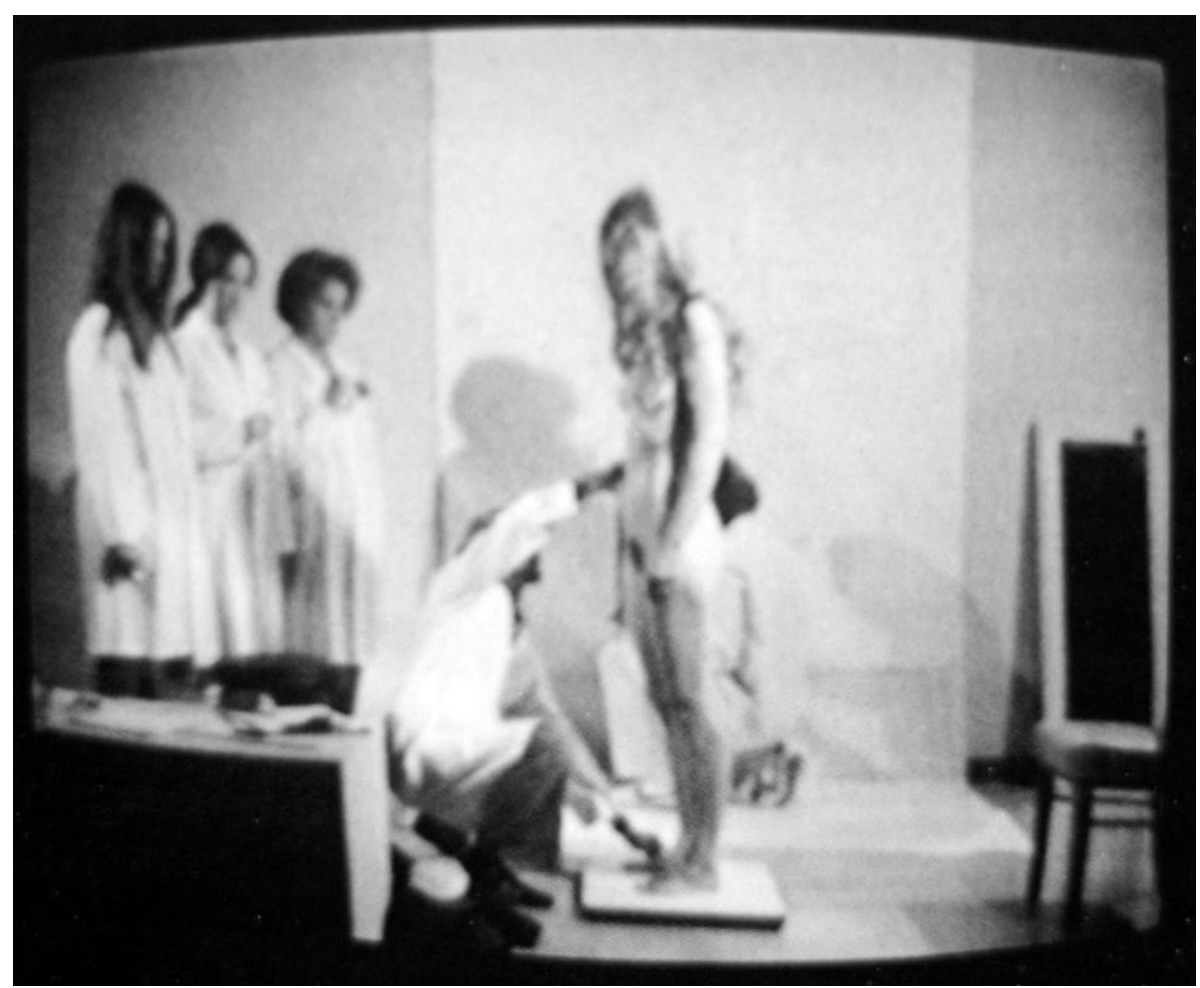

77. Martha Rosler - Vital Statistics of a Citizen Simply Obtained (1977)

Tal y como afirma Annette Michelson, en Vital Statistics encontramos el desarrollo de las premisas y principios rectores del análisis de Rosler: la noción de la medida como fuente de información de la verdad sobre el yo, la imposición de la medida como técnica de normalización y sometimiento, la internalización por parte del sujeto de las normas impuestas. Los contextos, implicaciones y resultados concretos de estas premisas implican el cuestionamiento de los procedimientos de pruebas y la 
formación de los individuos para ajustarse a los lugares y posiciones decretados como apropiados. Asimismo, también supone el cuestionamiento de la socialización y la integración de las poblaciones trabajadoras dentro del marco decretado por el cientificismo del diseño y la planificación. ${ }^{38}$

El mismo año en el que se realizó este vídeo, Rosler contrató a dos actores para interpretar a un supuesto matrimonio que recuerda las vivencias de su hija fallecida a causa de anorexia. Losing: ... A Conversation with the Parents refleja un entorno de lo más convencional, mientras la pareja hojea un álbum de fotos de la hija. Ambos comentan los aspectos «normales» de la adolescente: gustos, costumbres, detalles. La influencia de los medios de comunicación y la cultura patriarcal en su interés por objetualizar a la mujer se desgranan del discurso de Martha Rosler. ${ }^{39}$

Hoy en día, la artista neoyorquina mantiene firme su capacidad crítica ante las realidades cambiantes y conflictivas del mundo. A través de su obra reivindica las conquistas y avances sociales respecto a la igualdad y el espíritu más revolucionario de la década de 1970.

En 1974 Lynda Benglis (Louisiana, 1941) estaba preparada para responder con distancia crítica, ironía, humor y parodia al potencial misógino inherente a las prácticas artísticas, así como a todo lo que ello conllevaba. Durante más de cuarenta años ha utilizado látex, poliuretano, metal fundido y otros materiales tóxicos para crear trabajos que reflejaran sus intereses formales creando esculturas-objetos biomórficos, orgánicos y decorativos. En una crítica al proceso gestual pollockiano realizó series de performances en las que combinaba action painting con esculturas minimalistas que centraban su formalismo en el concepto de gravedad:

\footnotetext{
${ }^{38}$ MICHELSON, Annette, "La solución del rompecabezas", en el catálogo de la exposición Martha Rosler: Posiciones en..., op. cit., p. 187.

${ }^{39}$ ALIAGA, Juan Vicente, op. cit., p. 44.
} 
Fallen Painting (1968), Odalisque (Hey, hey, Frankenthaler) (1969) o For Carl Andre (1970). ${ }^{40}$

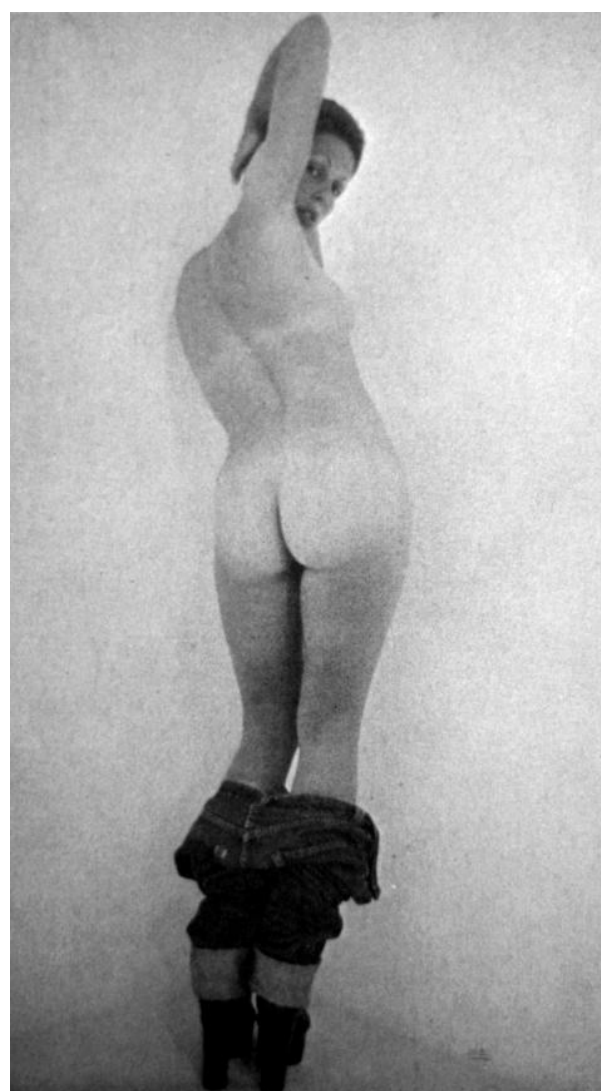

78. Invitation for Lynda Benglis Exhibition at Paula Cooper Gallery (1974)

Pero vamos a centrarnos en los aspectos - a nuestro juicio- más interesantes de la trayectoria de Lynda Benglis. La relación con el feminismo queda patente en su trabajo videográfico y fotográfico. Para las invitaciones a sus exposiciones Benglis acostumbraba a utilizar fotografías de sí misma en las que interpretaba distintos roles estereotipados centrando las imágenes en un universo repleto de objetos muy concretos y, como es de

40 AA.VV., "Artist Biographies", en el catálogo de la exposición Wack! Art and the Feminist Revolution, Los Angeles, The Museum of Contemporary Art, 2007, p. 217. 
esperar, cargados de enormes connotaciones simbólicas. Esta serie de intervenciones en la que se retrataba a sí misma permanecen indudablemente como su más prominente y controvertido compromiso con el discurso feminista en el mundo del arte.

En abril de 1974 se publica un anuncio en la revista especializada Artforum en la que Benglis posaba, en una llamativa pose «macharina» ${ }^{41}$, como un hombre apoyado en su Porsche. En mayo del mismo año, se mostró desnuda para una exposición en la galería Paula Cooper, siendo fotografiada por la espalda en una estereotipada pose a lo pin-up con los pantalones bajados y unos zapatos de tacón de considerable altura.

Uno de los trabajos que más eco dieron a su obra fue la respuesta lúdica a una imagen de su íntimo amigo Robert Morris. ${ }^{42}$ Envió a la revista Artforum un anuncio en el que aparecía desnuda, en una peculiar pose cargada de evidentes connotaciones de dominación, ataviada con unas gafas de sol blancas y sujetando con su mano derecha — a la altura del pubis - un consolador de tamaño colosal. Esta imagen se concibió inicialmente como póster central de la publicación, no obstante, su director impidió que se publicara como tal. De este modo, Benglis terminó pagando por un espacio publicitario contratado a nombre de la galería, alegando que colocar el nombre de la misma en la obra reforzaba su posición. En paralelo, buscaba

\footnotetext{
41 «Macharina» era el calificativo con el que Lynda Benglis calificaba a las poses sobreactuadas masculinas. Véase KRANE, Susan, en el catálogo de la exposición Lynda Benglis: Dual Natures, Atlanta, High Museum of Art, 1991, p. 40.

42 El escultor y bailarín Robert Morris creó en 1974 un autorretrato en tamaño póster para su exposición en la Castelli-Sonnabend Gallery de Nueva York. Evocando el sometimiento del masoquismo a través de los pesados grilletes que le aprisionan el cuello y las muñecas, así como la dominación del fascismo simbolizada por las gafas oscuras y el casco alemán, la imagen de Morris parodia y reafirma los códigos dominantes de la masculinidad heterosexual, a la vez que evoca asociaciones con la homosexualidad. Su fornido y musculoso cuerpo y su actitud agresiva parecen confirmar un retrato de hipermasculinidad, reforzada por la vestimenta militar. En aquella época, Morris trabajaba con Lynda Benglis los estereotipos del hombre y la mujer, así como el juego de la dominación y la sumisión. Esta imagen presenta una «extensión corporal» claramente masculina que al mismo tiempo reafirma y cuestiona su potencia sexual.
} 
mofarse del aspecto comercial del anuncio, del star system del arte y del modo en que los artistas se utilizan a sí mismos y a sus imágenes para vender sus obras.

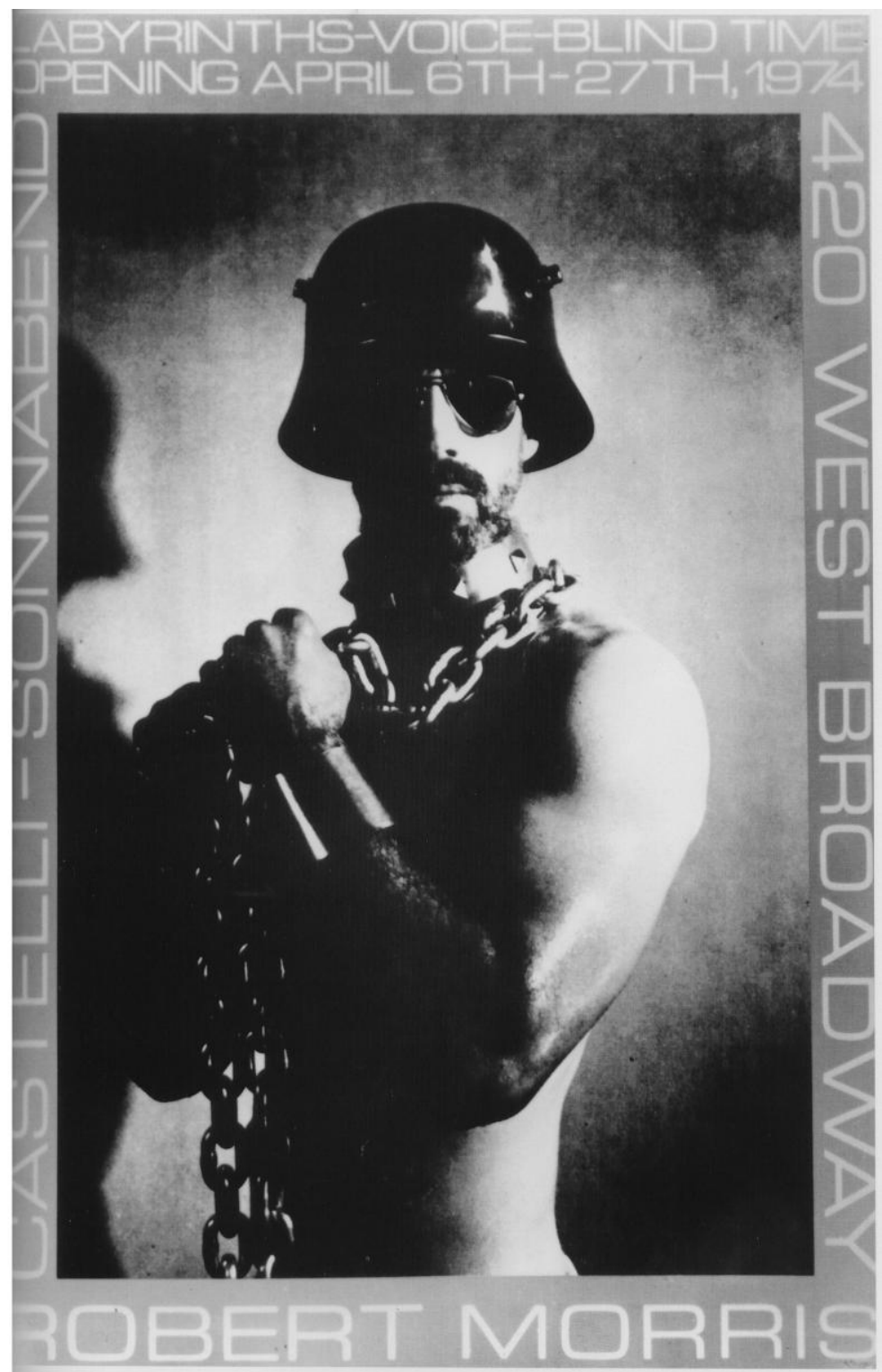

79. Robert Morris - Untitled (1974) 
La obra de Benglis pretendía ser una burla de la sexualidad, del masoquismo y, en parte, de ciertos sectores feministas. El contexto de la publicación del anuncio en una revista de arte era impactante. Más adelante la autora explicó que su intención había sido ridiculizar la idea de la necesidad de definirse sexualmente - ser un hombre artista o una mujer artista-, así como cuestionar las campañas orquestadas por los medios de comunicación. «My intention was to mock the idea of having to take sexual sides — to be either a male artist or a female... Also, I was mocking the media. It was a very Nixonian time; the media was very much in question. Since all advertisement was about "hype", I wanted to do the ultimate "hype". I was involved with how I could mock both sexes». ${ }^{43}$

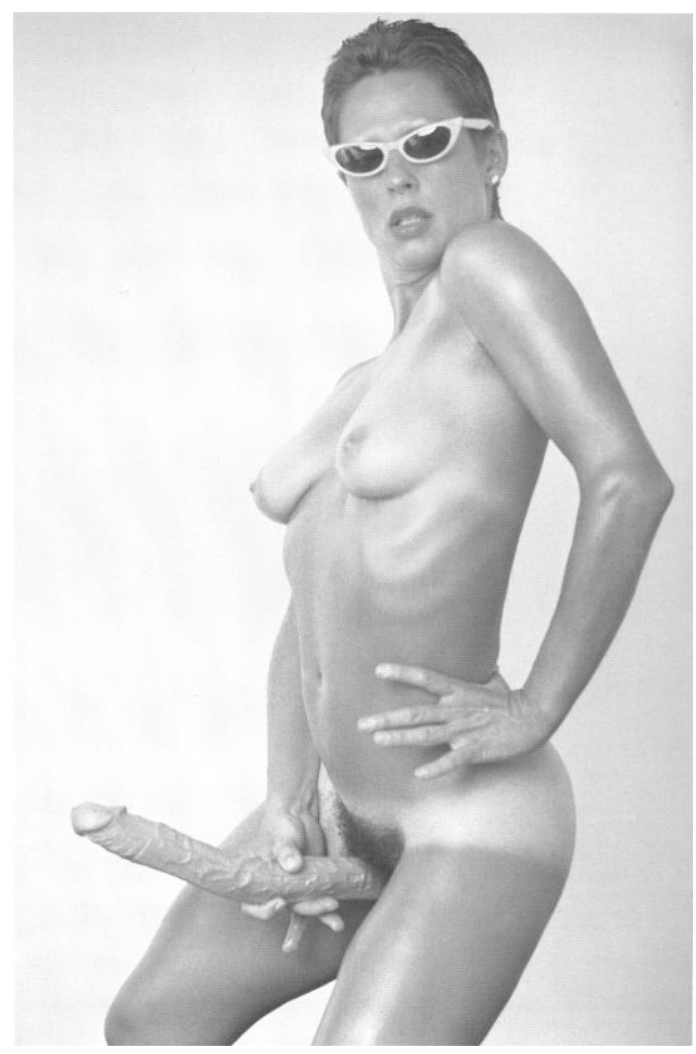

80. Lynda Benglis - Untitled (1974)

${ }^{43}$ KRANE, Susan, op. cit., p. 29. 
Con el fin de combatir la subordinación femenina al pensamiento cultural machista, así como al sistema de los mass media que imponen a la mujer un estereotipo marcado por la sensualidad, la autora no dudó en mostrar su cuerpo en el papel de controlador. De este modo, tal y como afirma Estrella de Diego, la mujer de Benglis no parece masculina por su extensión díldica, lo verdaderamente masculino de ella responde al gesto desafiante y a las gafas que esconden la mirada. ${ }^{44}$

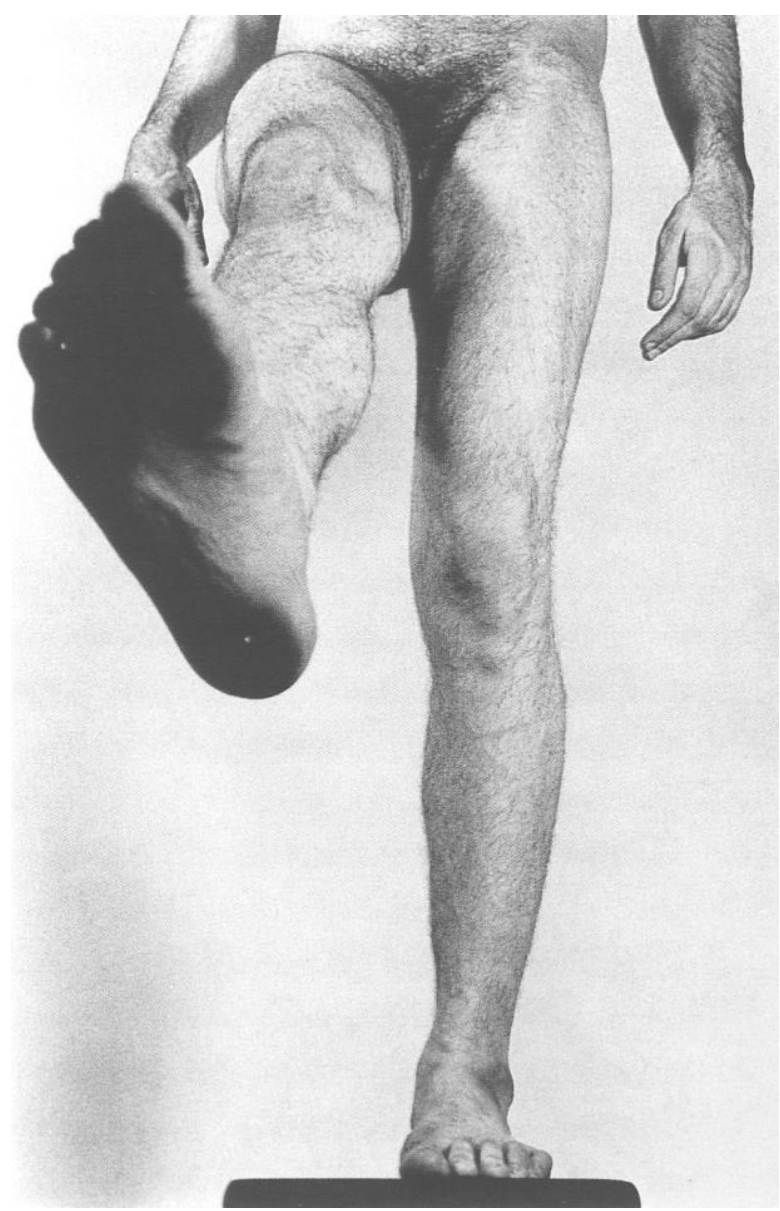

81. Vito Acconci - Conversions

(Part II Insistence, Adaptation, Groundwork, Display) (1971)

${ }^{44}$ DE DIEGO, Estrella, op. cit., p. 20. 
Desde la óptica artística, Benglis denigra los estereotipos masculinos acudiendo a la estética del manifiesto y a la de los mass media. En cierto sentido podemos considerar su obra como una verdadera burla a la pieza de Vito Acconci. ${ }^{45}$ Esta actitud es un verdadero desafío, pero al mismo tiempo un giro en el enfrentamiento al machismo. Benglis propala una mujer que se basta a sí misma mostrando una imagen agresiva de la sensualidad y la personalidad femeninas asumidas hasta aquel momento al supermacho. ${ }^{46}$ Como podemos observar, los elementos masculinos asociados al poder tienen implicaciones inconscientes muy fuertes que no se limitan únicamente a elementos de referencia sexual, sino que se imbrican en lenguajes puramente gestuales.

\subsection{Lo personal es político. Cuerpo-objeto en el espacio público}

¿A qué llamamos y cómo se define el espacio público? Se puede señalar que el mismo es el lugar donde cohabitan los seres humanos estableciendo una intrincada red de relaciones de poder, intereses $\mathrm{y}$ diferencias. Estrechamente ligadas a modos de actuación propios del happening, numerosas prácticas implicadas en el Body Art aprovecharon las

45 En 1971 Vito Acconci realizó una performance dividida en tres partes titulada Conversions. El autor estadounidense trató de ocultar su masculinidad quemándose el vello corporal, tirando de sus pezones - en un intento de producir pechos - y escondiendo el pene entre las piernas. Mediante esta manera de alterar los límites sexuales del cuerpo, Acconci abordó la noción de la metamorfosis personal. Sin embargo, podemos observar ciertos elementos de comedia y patetismo provocados por la conversión del cuerpo masculino del artista en uno más femenino, quizás mermado por la violencia sacrílega que supone quemarse el vello del cuerpo. ¿Por qué Acconci accede a lo femenino con muecas y poses próximas a la burla? ¿Acaso nos está diciendo que acceder a lo femenino puede resultar ridículo y doloroso? Véase MOURE, Gloria, Vito Acconci. Escritos, obras, proyectos, Barcelona, Polígrafa, 2001, pp. 114-121.

${ }^{46}$ Este tipo de acciones fue visto desde perspectivas afines al feminismo de los años setenta como una evidente respuesta a la práctica eyaculatoria del action painting de Jackson Pollock. ROSE, Barbara, "Jackson Pollock and the Death of Painting" en ROSE, Barbara, Autocritique. Essays on Art and Anti-Art. 1963-1987, New York, Weidenfeld \& Nicolson, 1988, pp. 143-148. 
posibilidades de su lenguaje expresivo y los del propio espacio público para involucrar a espectadores y espectadoras casi siempre ajenos a las disciplinas artísticas más contemporáneas.

El mismo cuerpo, transformado en un mero objeto, actuaba como un valor de intercambio comunicativo e ideológico que buscaba la interacción social y que invitaba a la reflexión —a menudo involuntaria- del transeúnte que se cruzaba en su camino. El o la artista se exponía ante la contemplación pública asumiendo todas y cada una de las consecuencias. Este tipo de trabajos se convertían en una reflexión sobre el papel que desempeña el cuerpo y sobre cómo éste interactúa en el espacio que le rodea. Lo corporal, tal y como venimos reiterando, se convierte en vehículo de códigos socioculturales. Debido a ello, para los autores y autoras que se citan a continuación, tanto la vida cotidiana como las estructuras ideológicas, tanto lo público como lo privado, están íntimamente relacionados. Y en dicha relación cobra un destacado papel esta lógica de los complementos que venimos analizando en el presente capítulo.

Fascinada por la libertad y las posibilidades de las formas expresivas artísticas recién ensayadas, Adrian Piper (Nueva York, 1948) se entregó al trabajo conceptual. A partir de 1971, la autora decidió trasladar sus actividades artísticas de las galerías y los museos a los espacios públicos. Sus performances tenían lugar en la calle, el metro, los museos, las librerías y otros espacios públicos. La autora trataba de mostrar el deseo de cuestionar y trastornar la actitud colectiva general en relación con la diferencia y su interpretación a través de la apariencia de los gestos de una persona.

El punto de inflexión del trabajo de una joven Piper con una amplia trayectoria influenciada fuertemente por el conceptualismo se produjo con la pieza Meat into Meat (1968), originariamente titulada Five Unrelated Time Pieces. La autora quería documentar el proceso de transformación de una hamburguesa: el proceso de envasado, su preparación y su ingestión por 
parte del entonces compañero de la artista, David Rosner. Algunos factores sociales y políticos tuvieron unas consecuencias tan intensas en la performance real de la obra que ésta acabó teniendo un carácter totalmente diferente a los planteamientos previos. En esta obra Piper se permitió por primera vez establecer una relación entre lo personal, lo político y lo estéticamente concreto. $^{47}$

En la serie Hypothesis (1968-1970) Piper empezó a incluir el propio cuerpo en sus exploraciones conceptuales, ya que lo consideraba también como un objeto físico concreto que remitía a sí mismo y a otros objetos cotidianos con los que encontraba similitudes y diferencias. La autora se investigaba a sí misma como un objeto que se mueve a través del espacio y del tiempo con la particularidad de poder registrar, a diferencia de un mero objeto tridimensional, las acciones realizadas a modo simbólico y abstracto para, posteriormente, comunicarlas. En dos ejes que representaban el tiempo y el espacio, Piper examinaba y documentaba con la cámara a la altura de sus ojos, ocupaciones y percepciones rutinarias y personales como, por ejemplo, leer el periódico, pasear por la calle donde vivía, o ir a comprar. Aquellas fotos son representaciones simbólicas del contenido de su conciencia en un lugar y un momento concreto. En aquel tiempo empezó a percibirse a sí misma como paradigma de esta sociedad. ${ }^{48}$

La invasión de Camboya, el movimiento de liberación de la mujer, o los disparos que la Guardia Nacional realizó contra estudiantes que se manifestaban contra la Guerra de Vietnam llevaron inmediatamente a Piper a politizarse, lo cual reflejó tanto en su actividad artística como en su forma de pensar, y también en el análisis de su posición como artista, como mujer y como negra en la sociedad. El arte conceptual dejó de parecerle un medio válido para expresar su posición estética. Los contextos artísticos como las galerías, los museos o las performances le resultaban cada vez más

${ }^{47}$ PIPER, Adrian, "Meat into Meat", en el catálogo de la exposición Adrian Piper. Desde 1965, Barcelona, MACBA, 2003, pp. 17-18.

${ }^{48}$ PIPER, Adrian, "Hypothesis", en el catálogo de la exposición Adrian Piper..., op. cit., pp. 19-21. 
inaceptables. La actividad artística como agente catalizador que desencadena un cambio en el espectador o espectadora debía potenciar el efecto de las obras de arte mediante el efecto de la confrontación humana. Pero, sobre todo, lo que más le interesaba a Piper era mostrar su arte de forma imperceptible en situaciones no artísticas. ${ }^{49}$

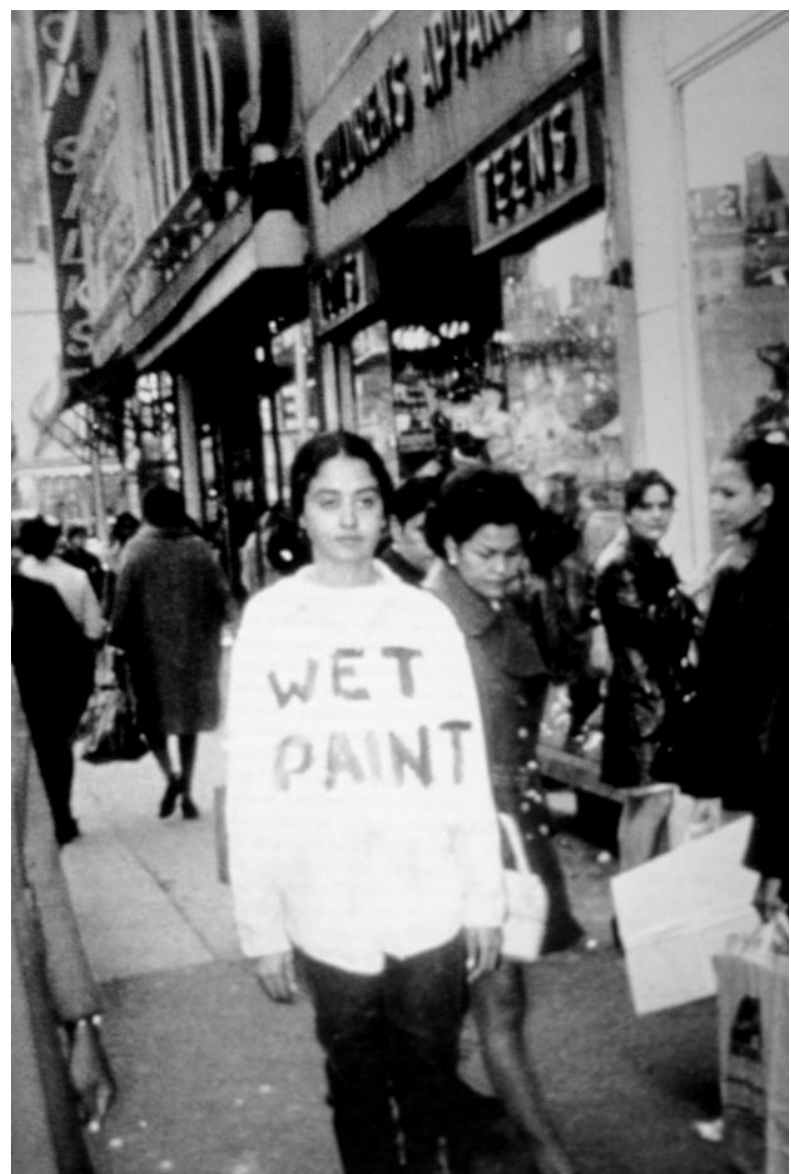

82. Adrian Piper - Catalysis III (1971)

En la serie Catalysis (1970-71) su presencia —unida a actividades personales estrafalarias - era totalmente subversiva. Cuanto más fuerte

${ }^{49}$ BREITWIESER, Sabine, "Introducción", en el catálogo de la exposición Adrian Piper..., op. cit., p. 9. 
fuera la obra, mayor sería su impacto y la reacción del público: la trascendencia y experiencia queda definida por las reacciones e interpretaciones de los espectadores y espectadoras. De este modo, la obra existe tan sólo como agente catalizador entre Piper y el público inconsciente de su propia condición.

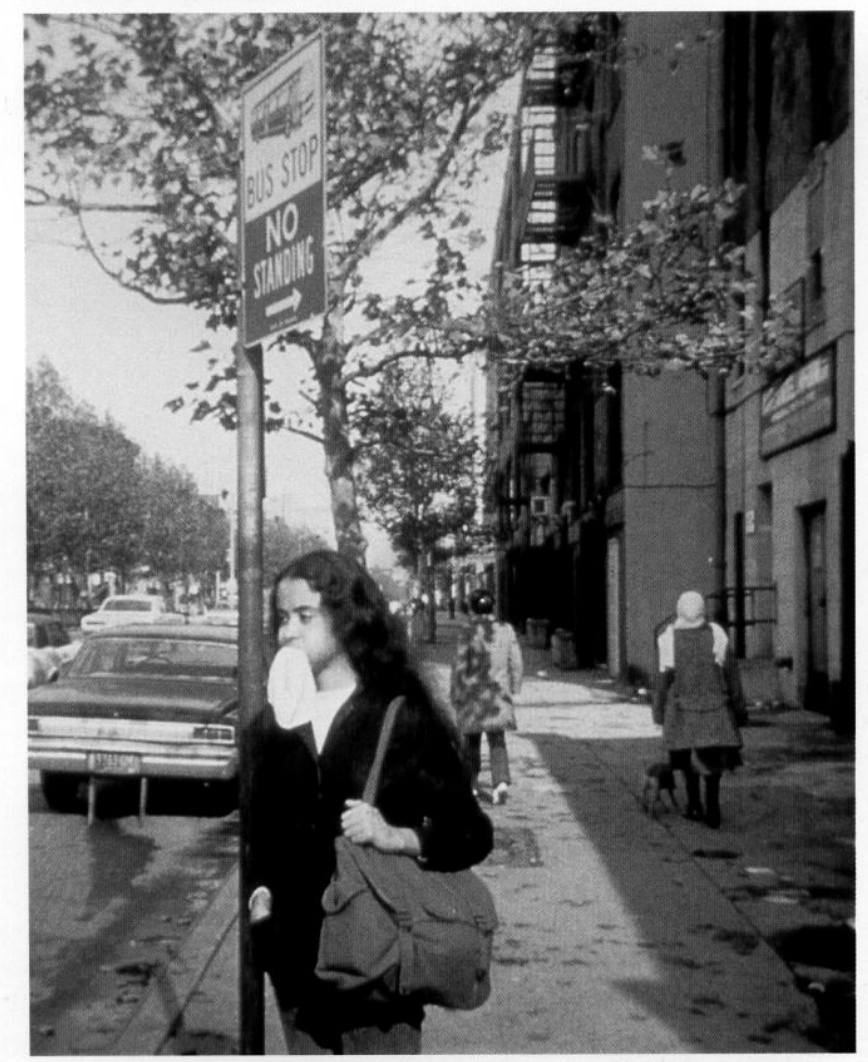

83. Adrian Piper - Catalysis IV (1971)

Por ejemplo, en Catalysis I viajó en metro en hora punta vestida con ropa rociada con un caldo hecho a base de vinagre, leche, aceite de hígado de bacalao y huevo. En Catalysis VI atravesó Central Park y el vestíbulo del Plaza Hotel con varios globos de Mickey Mouse llenos de helio atados a las orejas, la nariz, el pelo y los incisivos. En Catalysis III iba de compras a 
unos grandes almacenes elegantes vestida con ropa en la que se leían las palabras «WET PAINT» escritas con una pintura de aspecto viscoso, o bien se presentaba en una biblioteca con una cinta oculta en la que se oía eructar ruidosamente. Para Catalysis IV Piper tomó un autobús obligando a los viajeros a afrontar su anormalidad, se vistió de modo muy formal, pero introdujo en la boca un pañuelo blanco hasta que sus mejillas se hincharon de manera considerable dejando un trozo de tela sobresaliendo de la boca. ${ }^{50}$

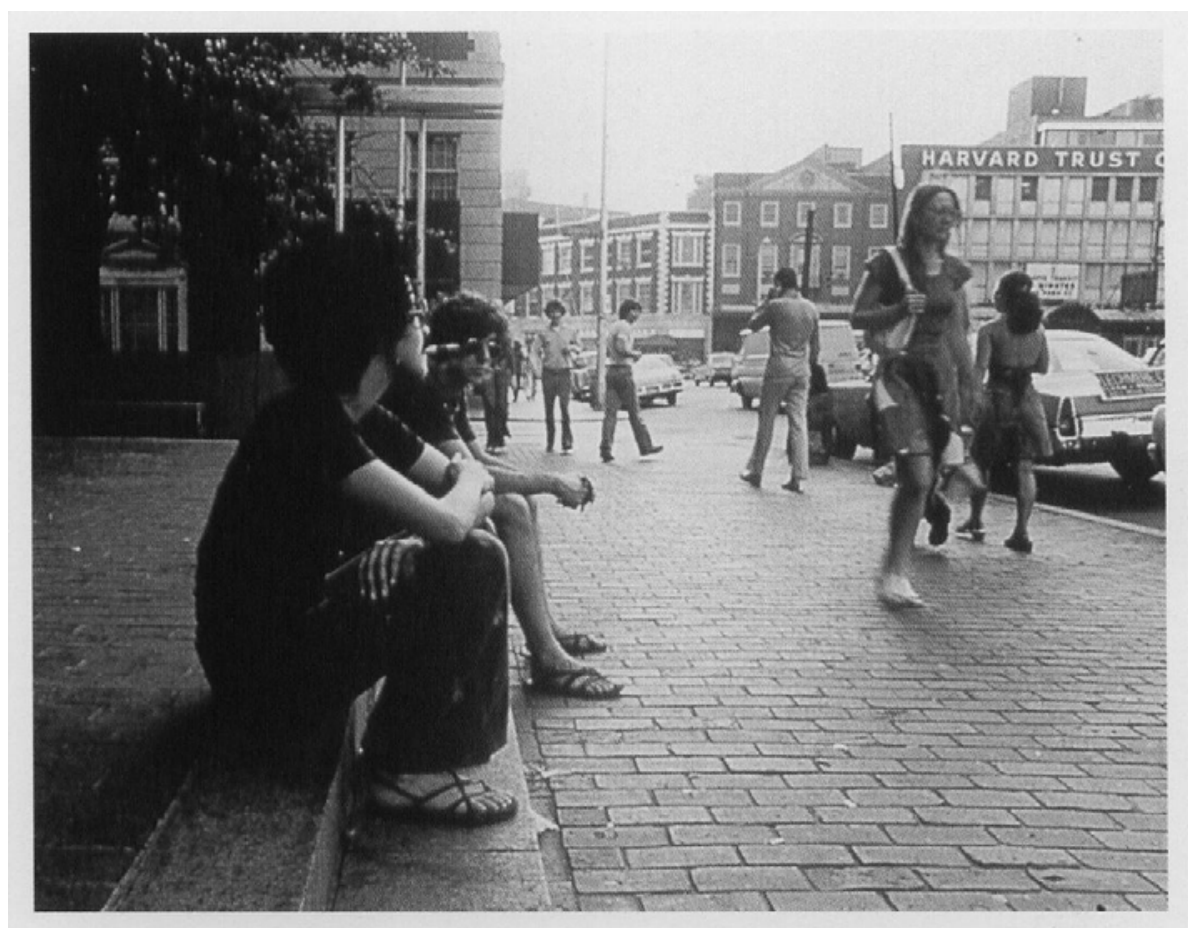

84. Adrian Piper - The Mythic Being (1975)

En la serie Mythic Being (1975), la autora adoptó un disfraz andrógino de joven de raza indeterminada vestido con una camiseta negra, vaqueros anchos, grandes gafas de sol, una peluca afro y un bigote a lo Zapata. Asimismo cambió su comportamiento, caminaba con paso firme y

\footnotetext{
${ }^{50}$ PIPER, Adrian, "El arte como catálisis", en el catálogo de la exposición Adrian Piper..., op. cit., pp. 50-51.
} 
arrogante, bajaba sus cejas, alzaba los hombros y se sentaba con las piernas bien separadas para colocar cómodamente sus prominentes genitales. La autora experimentaba, mediante el contacto con los demás y el recuerdo de su pasado personal, una versión masculina de ella misma.

A diferencia de la mayoría de las performances que están ancladas en el contexto artístico tradicional, las acciones de Piper se definen en gran medida por las reacciones concretas de su público. Para la autora estos contextos están infiltrados por retazos de otras estructuras de desintegración: políticas, sociales, psicológicas, económicas. De esta forma forzaba un enfrentamiento directo con el público que, según ella, le provocaba «ciertos cambios de personalidad realmente acusados». Para la autora el arte poseía un rol importante en las transformaciones sociales y ella quería ser un instrumento de ese cambio, un medio de comunicación entre los individuos.

Ejemplo claro de la influencia del Accionismo vienés son las performances más directamente politizadas de la también austriaca Valie Export (Linz, 1940) quien, iniciada en el campo de las artes como actriz de teatro, se sirvió del poder comunicativo de lo textual, así como de lo fílmico y lo videográfico. Esta perspectiva multidisciplinar muestra bien la presencia de los posicionamientos de género que son de carácter estructural en una artista que conoció de primera mano el Institut für Direkte Kunst y presenció otras actividades de los accionistas.

En sus performances - entre las primeras acciones feministas- y films se establecen tensas, radicales y agresivas relaciones de dominio entre los dos sexos, teniendo como tema nuclear la resistencia femenina a la dominación del hombre sobre la mujer. Su obra constituye una oposición crítica surgida, en parte, en oposición al agresivo clima de machismo autoritario y obstinado del Accionismo. La autora ataca en su trabajo y en su comportamiento algunos de los cimientos masculinistas y patriarcales generadores de violencia y discriminación. 
Su primera intervención pública data de 1967, cuando adoptó el nombre VALIE EXPORT como su concepto artístico y como logo inspirado, en parte, en el package de unos cigarrillos cubierto de eslóganes que le interesaba asimilar: "Made in Austria», «Always and everywheresemper et ubique», y «Smart». Como acto de autorreflexión este gesto fue crucial, ya que supuso una alteración de su identidad femenina, abandonando el nombre del padre y utilizando significados artísticos para crear un nuevo nombre acorde con su radical autodeterminación. Este proceso fue bastante significativo como reacción a la predominante crítica de la producción artística y social en la Austria de la postguerra.

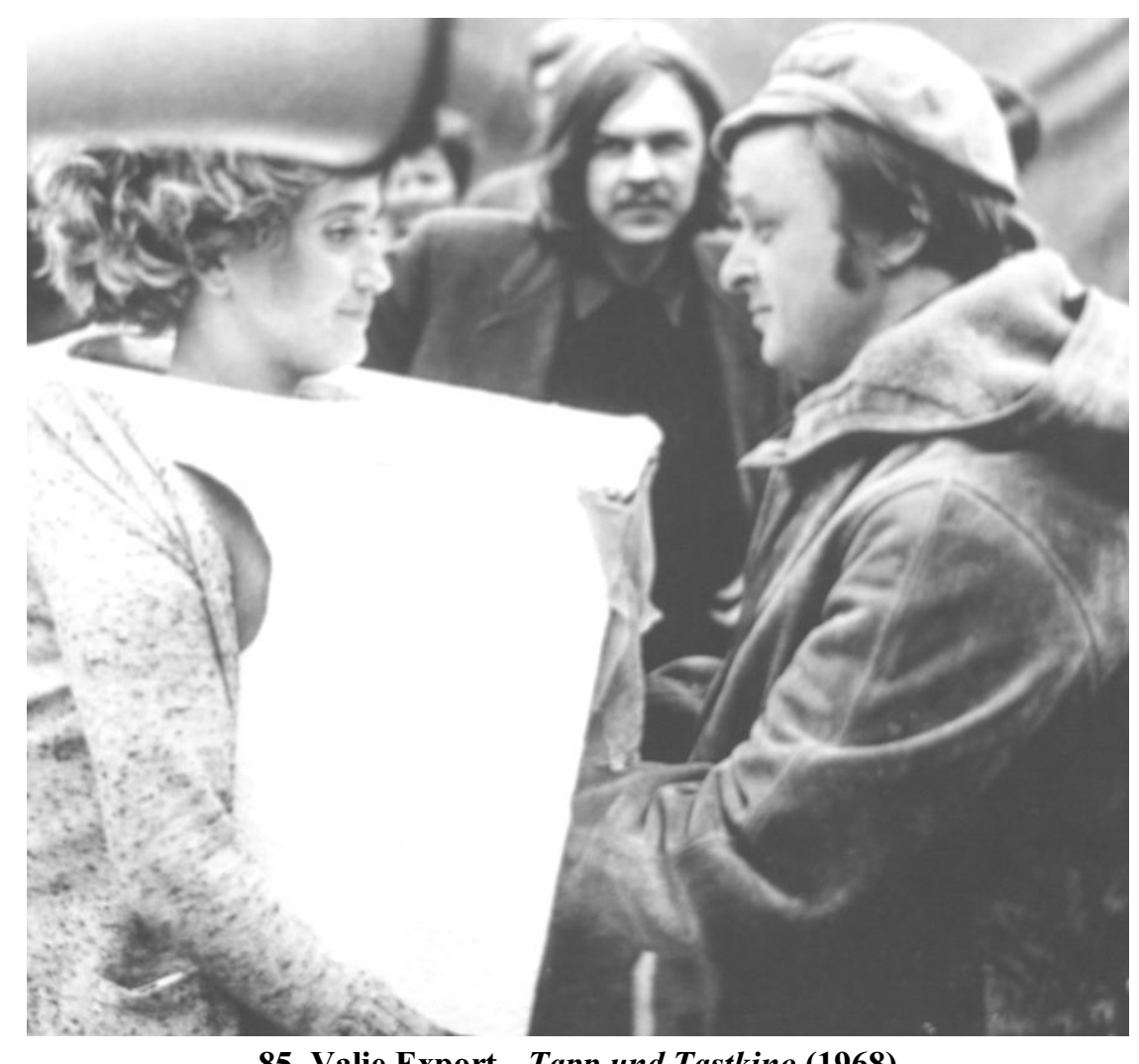

85. Valie Export - Tapp und Tastkino (1968)

En Tapp und Taskino (1968), una acción corporal llevada en Munich, Colonia y Viena, Valie Export transportaba sobre su pecho una 
especie de caja-escenario con su correspondiente telón mientras Peter Weibel, a golpe de altavoz, invitaba a los transeúntes más curiosos, a tocar los senos de la artista. Sobre esta performance comenta la autora: "In that I, in the language of film, allowed my "body-screen", my chest, to be touched, I broke through the confines of socially legitimate social communication. My chest was withdrawn from "the society of spectacle", which had drawn the woman into "objectification" with it. Moreover, the breast is no longer the property of one single man; rather, the woman attempts through the free availability of her body to determine her identity independently: the first step from object to subject». 51

Sometiéndose a la mirada pública, Tapp und Tastkino ofrecía una reflexión sobre la objetualización del cuerpo de la mujer. Mostrando el cuerpo como vehículo de códigos socializados, la autora superaba los límites de estas construcciones a través de la acción directa en la vía pública, superficie donde nuestras interacciones sociales son proyectadas y donde decretamos nuestros deseos.

Aktionhose/Genital Panik (1969) fue una osada acción en la cual la artista se hizo pasar por una especie de terrorista. Ataviada con unos pantalones con la entrepierna recortada, una camisa negra, el pelo cardado y armada con una metralleta mostró su sexo al público en un teatro en Munich en plena proyección de un film pornográfico. La autora, dirigiéndose a la audiencia que había asistido para deleitarse con genitales proyectados en la pantalla, ofreció su bajo vientre real para que pudieran hacer lo que desearan. La finalidad - tal y como considera Aliaga — era la de atemorizar al público para que se enfrentara a sus propias fobias y miedos. Como anécdota, cabe decir que los espectadores huyeron despavoridos. ${ }^{52}$ En palabras de la propia autora: «I moved down each row slowly, facing

${ }^{51}$ Cit. en STILES, Kristine, "Uncorrupted Joy: International Art Actions", en el catálogo de la exposición Out of Actions. Between Performance and the Object 1949-1979, Los Angeles, The Museum of Contemporary Art, 1998, p. 266.

52 ALIAGA, Juan Vicente, Orden fálico. Androcentrismo y violencia de género en las prácticas artísticas del siglo XX, Madrid, Akal, 2007, p. 238. 
people. I did not move in an erotic way. I walked down each row, the gun I carried pointed at the heads of the people in the row behind. I was afraid and had no idea what the people would do. As I moved from row to row, each row of people silently got up and left the theater. Out of film context, it was totally different way for them to connect with the particular erotic symbol». ${ }^{53}$

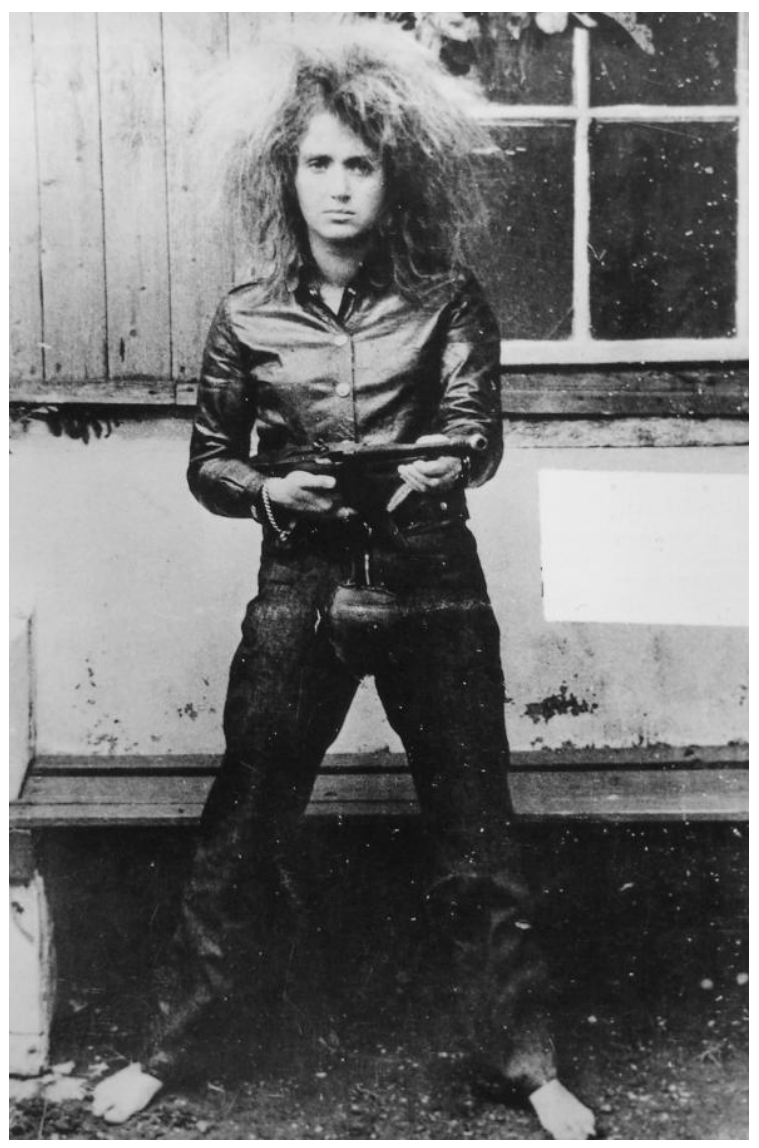

86. Valie Export - Aktionhose/Genital Panik (1969)

En 1970 realizó la acción Body Sign Action, de la que se conservan algunos textos explicativos y una serie de fotografías. Export mostraba el

${ }^{53}$ Cit. en STILES, Kristine, op. cit., p. 266. 
tatuaje de un liguero inscrito en su muslo para grabar en su propia carne un símbolo asociado tradicionalmente a lo femenino y al que se le atribuye socialmente cierta disponibilidad sexual. ${ }^{54}$ La obra se convirtió en una semiótica de la esclavitud de género. La marca corporal de Export devenía significado corporal de una sexualidad reprimida perteneciente a una clase social que exigía una conducta condicional. La acción mantenía vivo lo que la autora describía como el problema de la autodeterminación y/o la otra determinación de la feminidad. ${ }^{55}$ Sin embargo, más allá de que la imagen del tatuaje fuera convincente, es fundamental comprender que la imagen establecía el diálogo entre la esfera pública y la autora.

A través de la autocreación y de la adopción de roles muy determinados las acciones corporales de Valie Export van a devenir espacio intermediario entre arte y vida. Su trabajo constituirá una afirmación tajante de la autonomía femenina y será utilizado para cuestionar asuntos sobre la interacción social, con una clara oposición al clima de machismo autoritario propio de los accionistas.

\subsection{El control de los atuendos}

La cultura patriarcal ha aplicado la tecnología de manera recurrente al cuerpo femenino para satisfacer las fantasías masculinas: el corsé produjo los pechos realzados de las novelas románticas a costa de bloquear la respiración, entorpecer el movimiento y desplazar los órganos internos, y el polisón levantaba y acentuaba el culo, produciendo una postura de claras connotaciones sexuales.

\footnotetext{
${ }^{54}$ G. CORTÉS, José Miguel, “Comentarios sobre las obras de la exposición”, en el catálogo de la exposición Micropolíticas. Arte y cotidianidad 2001 - 1968, Castellón, EACC, 2003, p. 451.

${ }^{55}$ Cit. en STILES, Kristine, op. cit., p. 256.
} 
Sin embargo, la desaparición del corsé y del polisón no acabó con la remodelación del cuerpo femenino en función de los cánones masculinos. La sociedad de consumo y la modernidad industrial no hicieron más que evidenciar los fundamentos económicos de estas prácticas. La publicidad enseñaba a las mujeres a considerarse como objetos que debían crearse para competir con otras mujeres. Esta fantasía perniciosa ha sido sinónimo de regímenes inhumanos, desequilibrios alimenticios, operaciones de cirugía estética y toda una serie de ritos iniciáticos de enorme carácter masoquista.

La obra creativa de Jana Sterbak (Praga, 1955) refleja el aspecto de la complejidad de nuestra relación con la cultura. La autora queda desatada de las tradiciones culturales en las cuales ha estado acunada para servirse mejor intelectual y estéticamente. La obra de Sterbak construye una exploración inicial de la compleja lógica que gobiernan los complementos del cuerpo gracias a los materiales utilizados y a los objetos que redirecciona hacia el proceso de representación corporal en el mundo público, así como a la lógica opuesta de los complementos que derivan. La autora se introduce en una especie de exploración de la subjetividad situada en la interfaz entre nuestro cuerpo y nuestras «extensiones», es decir, todo un recorrido en torno a la unificación del cuerpo.

La compleja importancia que Jana Sterbak atribuye a lo somático es revelada en dos obras realizadas al principio de su carrera: Mètre-rubans en cône (1979) y Golem: Les objets comme sensations (1979-82). La primera pieza consiste en una serie de metros — propios de costura- enrollados en forma de conos en una serie de extensiones de sus extremidades. Imágenes lúdicas y desafiantes al mismo tiempo, midiendo y siendo medidas. Una fotografía ofrece la imagen de un brazo desnudo ligeramente flexionado hacia lo alto. La mano queda prácticamente ocultada por una prótesis inesperada: un cono anaranjado construido a partir de una cinta métrica de costura estrechamente enrollada. Asimismo, el cono también está ligeramente curvado, prolongando la línea del brazo en un arco abierto que gira hacia lo alto. Se considera una imagen extraña debido a la 
yuxtaposición, más bien curiosa, de la desnudez del brazo y de la forma del cono, que constriñe y a la vez amenaza. La belleza natural del brazo desaparece en la regularidad del punto de fuga que constituye el interior del cono. Esta simple imagen está llena de contradicciones: elegante y extraña, divertida y amenazadora. La oposición que evoca entre el cuerpo y sus ornamentos, entre la naturaleza física y el artificio humano, entre el hecho de conferir un poder y la restricción que entraña una puesta en forma, son los temas centrales de la obra de Jana Sterbak. ${ }^{56}$

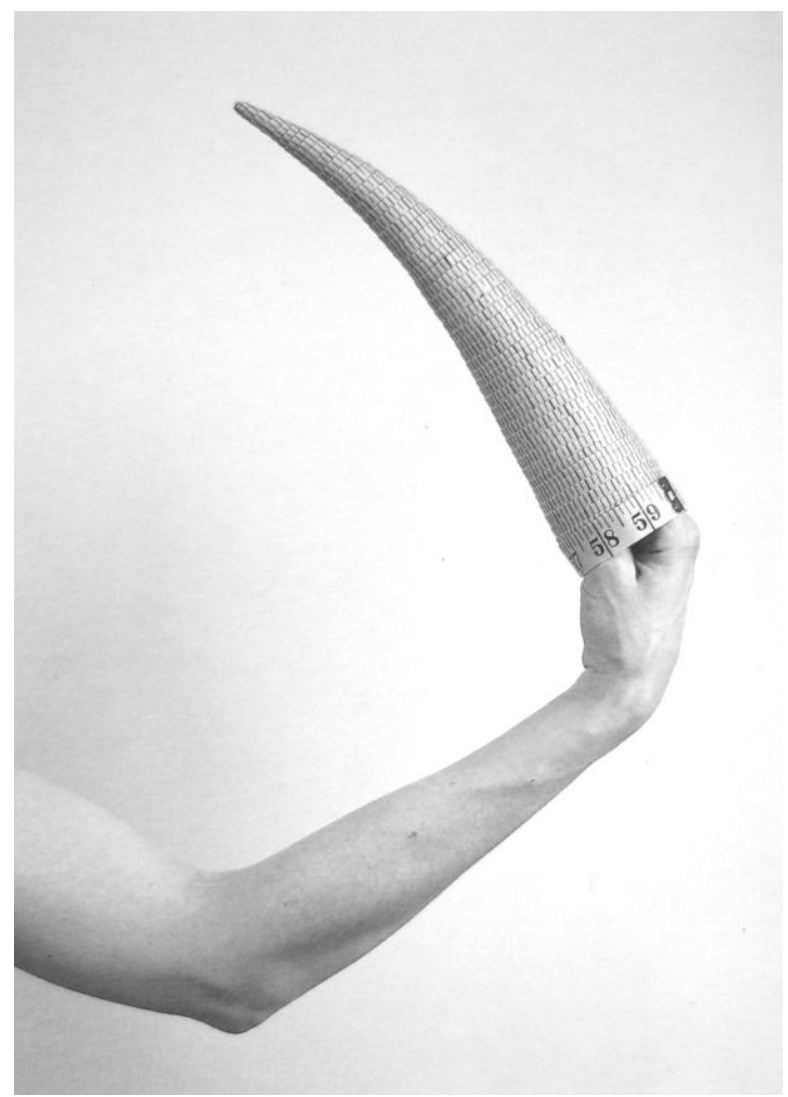

87. Jana Sterbak - Mètre-rubans en cône (1979)

\footnotetext{
${ }^{56}$ NOBLE, Richard, "Jana Sterbak: dialectique de la création et de sa mise en forme”, en el catálogo de la exposición Velleitas. Jana Sterbak, Saint-Étiènne, Musée d'Art Moderne Saint-Étienne, 1995, p. 55.
} 
Las medidas constituyen una condición previa al vestido del cuerpo en tanto que proyección de una concepción específica de sí en el espacio público. Las cintas métricas completan el cuerpo y lo someten a un sistema convencional de medida, al que corresponde abrir las posibilidades ilimitadas de artificios y representaciones. Se tratan al mismo tiempo un acto de creación y de contención.

El sujeto extrae su poder de las tecnologías de la medida y de la capacidad de representarse en términos más y más complejos y sofisticados, pero al mismo tiempo, es sometido a una serie de medidas normativas y a las exigencias de conformidades que se derivan implícitamente. $\mathrm{La}$ tecnología permite crearse y recrearse hasta el infinito. Sin embargo, ella reduce al sujeto en objeto al que se aplican las normas sobre los cuales este mismo sujeto no tiene ningún control. Los conos esculpidos que Sterbak hace con las cintas contribuyen a señalar todavía más el carácter contradictorio de tal complementariedad. Por una parte, pueden ser llevados en tanto que decoración divertida y ligeramente grotesca, prolongando los dedos o el brazo; por otra parte, ponen en forma y limitan el carácter artificial de su construcción. Ello supone una ironía sutilmente subversiva: la artista desarma la autoridad reguladora de las cintas al transformarlas en decoraciones un tanto absurdas.

Este trabajo marcó el inicio de toda una serie de obras que la autora dedica a la ropa y al vestido como estadio de aculturación, en éstos, la identidad viene manifestada y explicada por el actual sistema de signos. ${ }^{57} \mathrm{~A}$ pesar del anacronismo en el que podamos incurrir, es conveniente realizar una mirada de soslayo a la labor que Sterbak desarrolló posteriormente bajo estas premisas.

El deseo cobra enorme fuerza en Je veux que tu éprouve ce que je ressens... (La robe) (1984-1985). Partiendo del sentimiento extremo de la historia de Medea, Jana Sterbak realiza un extraño vestido en el cual el

${ }^{57}$ MACRÌ, Teresa, Il corpo postorganico, Milano, Costlan, 2006, p. 159. 
cuerpo deviene inmaterial, un continente invisible, un cuerpo que ofrece únicamente su propio sentir. El vestido está realizado en hilo eléctrico, conectado a una toma de corriente situada en el muro. Cuando el espectador o espectadora se aproxima, un sensor activa la pieza calentando el hilo y transformando el vestido en un simulacro corpóreo, un artificio sensitivo, un objeto sinestésico. Al mismo tiempo, para Sterbak, esta aspiración está siempre minada por la realidad privada del cuerpo. ${ }^{58}$

Es posible que en Vanitas: Robe de chair pour albinos anorexique (1987) la tensión entre el cuerpo y sus representaciones sea la más manifiesta. La obra estaba confeccionada por treinta kilos de bistecs de ternera crudos cosidos entre ellos a modo de patchwork para constituir un vestido mutante de carne, grasa y músculo que la artista llevó sobre su propio cuerpo desnudo en el espacio artístico de la galería. ${ }^{59}$ Esta pieza se sitúa en la tradición de las vanitas representadas en el Settecento en pintura y en escultura, donde el cuerpo fue igualmente la fuente de nuestra vanidad $\mathrm{y}$ de nuestra concupiscencia $\mathrm{y}$, por tanto, de nuestra alienación con respecto a Dios. $^{60}$

El vestido de carne se apoya sobre esta tradición para señalar lo absurdo de los esfuerzos que nos empujan a superar los límites del cuerpo, sin embargo, este vestido incide también sobre la presencia constante de la tragedia en toda vida humana. A medida que pasa el tiempo, el vestido se deshace, se transforma en una cáscara dura, parecida al efecto del envejecimiento de la piel humana. La evolución de la obra, su desecamiento, simboliza el camino que tiene el ser humano hacia la mortalidad, nos recuerda nuestro destino y se burla igualmente de nuestras obsesiones. Toda nuestra cultura de curas corporales, cremas, regímenes y ejercicio físico se revela fútil de cara al carácter ineluctable de nuestra muerte. Como en otros

\footnotetext{
${ }^{58}$ NOBLE, Richard, op. cit., p. 60.

${ }^{59}$ RAMÍREZ, Juan Antonio, op. cit., pp. 152-153.

${ }^{60}$ Sobre la relación entre la obra de Jana Sterbak y el Barroco véase MOSER, Walter, "Difracciones barrocas en la obra de Jana Sterbak", en el catálogo de la exposición Jana Sterbak: de la performance al vídeo, Vitoria-Gasteiz, Artium, 2006, pp. 28-37.
} 
trabajos de Jana Sterbak, el material emite signos de alteración y de una conflictividad perceptiva que oscila entre la repulsión y la atracción.

Corona laurea (noli me tangere) (1983-1984) es una máquina diabólica, una amenazante corona de laurel fabricada con una resistencia eléctrica. Podría parecer la moderna versión de la engañosa diadema ofrecida por Medea a su rival. La corona de laurel representa el símbolo de la victoria, pero dicho atuendo se desliza en un inquietante retorno al casco eléctrico, al mecanismo lobotomizante utilizado en psiquiatría como terapia para los enfermos mentales. En este visionario trabajo, locura e inspiración se yuxtaponen. Se genera, así, una zona de represión donde se encuentran el poder normalizante y el comportamiento desviado, hecho que supone una potente inspiración para dirigir su discurso hacia el cuerpo reprimido.

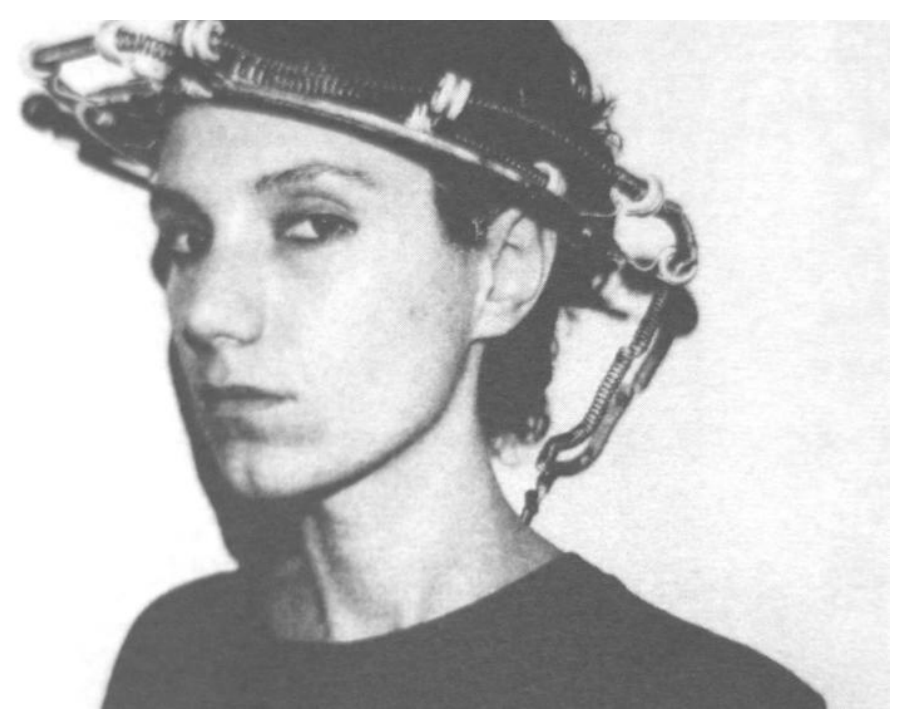

88. Jana Sterbak - Corona laurea (noli me tangere) (1983-84)

Ya posteriormente, en Télécommande II (1989) —entendemos este trabajo como finalización de una etapa en la extensa obra de Sterbak - la carne cede su territorio a la máquina. Un vestido de estructura gigante en forma de jaula está montado sobre unas ruedas motorizadas. En su interior una mujer se encuentra suspendida por una especie de arnés hecho de tela. 
El control se desplaza según el mando a distancia cambie de mano y pase de la mujer suspendida a un operador exterior. De este modo lo privado y lo público luchan por el control. En un momento, la mujer está completamente a cargo de su destino, liberada del suelo, manipulando el espacio, retrayéndose y dilatándose por un gesto del dedo. Al minuto siguiente, ella se encuentra indefensa, suspendida en el aire mientras cualquier otro manipula el espacio, su espacio. Su abrigo móvil no es ni protector ni liberador, sino paralizante y aterrador.

La tensión presente entre el cuerpo y nuestra representación evoca una cierta tensión en todo artificio humano. Podemos ver en el vestirse una clase de técnica, un medio por el cual el yo está presente en el mundo. Partiendo de ello, el interés de Sterbak por el vestido acompaña su interés por la técnica y la ciencia. Tanto una como otra están íntimamente ligadas a nuestra aspiración de liberarnos de las obligaciones de la naturaleza física y ambas dejan entender que el poder — sobre nosotros y nosotras mismos, sobre las y los otros y sobre la naturaleza - es un medio necesario para alcanzar dicha libertad. De este modo, las tecnologías que creamos para liberarnos de la naturaleza tienden a la vez a conferirnos un poder, pero también sirven para contenernos y controlarnos. ${ }^{61}$

Para la autora lo corporal constituye el punto de partida. Los materiales que emplea y los objetos que fabrica sugieren íntimas relaciones con nuestro cuerpo. Su carácter puramente físico efectúa una irrupción brutal en nuestras conciencias, atravesando las capas intermediarias de la historia, la cultura y la teoría con la fuerza de una sensación visceral. No nos podemos desvincular del cuerpo. Los vestidos hechos de carne o de cables de luz, las diversas jaulas y otros mecanismos de aprisionamiento, toman sentido en referencia al cuerpo y a sus limitaciones, así como al carácter efímero de nuestra existencia física. Las obras de Jana Sterbak reflejan un claro interés por el complejo papel que desempeña el cuerpo en nuestra construcción como sujetos. En tanto que base física de nuestra existencia,

${ }^{61}$ NOBLE, Richard, op. cit., p. 55. 
éste nos relega a la naturaleza, ese orden material que se caracteriza por las relaciones de causa-efecto independientes de los propósitos y las aspiraciones humanas. Nuestros deseos, nuestras limitaciones físicas y, más que todo eso, nuestra mortalidad, implican para Jana Sterbak la inconfortable verdad según la cual la base física de nuestro ser es independiente de nuestra voluntad y va al encuentro de nuestras aspiraciones más profundas.

Sin embargo, la autora sitúa, al mismo tiempo, al cuerpo en el origen de la motivación que nos estimula a trascender nuestra determinación por la naturaleza física. Jana Sterbak está fascinada por el proceso de autocreación, ya que para la autora el cuerpo está en la base de nuestro deseo de crearnos en tanto que sujetos independientes y con identidades específicas.

El juicio que lleva sobre la actividad de autocreación está lleno de ambivalencia en cuanto a la posibilidad de no alcanzarla nunca. Ella considera esta actividad como un proceso a la vez necesario y potencialmente liberador, pero adopta al mismo tiempo una perspectiva siempre irónica, alcanzando así tanto sus ambigüedades como sus promesas. Esta ambivalencia nace de lo que Sterbak concibe como una dialéctica entre la creación y la contención inherentes a nuestras tentativas de construirnos como sujetos. Para Sterbak, esta oposición está siempre presente y nunca resuelta, tanto en nuestra autorrepresentación como en nuestras tentativas más ambiciosas de liberar la humanidad de los diversos males que la afligen.

Para Jana Sterbak el atuendo está en función de un cuerpo que se siente amenazado y, como segunda piel, representa una mediación social entre la naturaleza y la tecnología. El hábito queda, pues, concebido como extensión y como sistema de supervivencia. Es un remedio que permite a los individuos reacomodarse según la necesidad a través de conexiones o artificios polifuncionales. 
Sus vestidos son una evidente reflexión sobre los estereotipos femeninos que el sistema impone, una acusación a los cánones inducidos por el capitalismo. Para Sterbak el proyecto en torno al cuerpo asume siempre, más que una apariencia social, una estructura formal derivada de la extensión vectorial y orgánica del cuerpo y de su expansión por capas o membranas. ${ }^{62}$

Según afirma la propia Louise Bourgeois (París, 1911) el arte es la experimentación o, mejor, la reexperimentación del trauma. Toda su obra está enraizada en las memorias de los espacios que ha habitado a lo largo de su vida, pero especialmente, los de su infancia. Espacios y memorias son los elementos centrales de sus historias, vivencias domésticas vinculadas con importantes traumas de su niñez y adolescencia. La autora utiliza el arte como catarsis, a modo de terapia.

Al igual que en su conocida instalación escultórica The Destruction of the Father (1974), Louise Bourgeois refleja en Costume for "A Banquet» (1978) el deseo personal de alcanzar —a través de una extensión muy particular - una feminidad maternal fuerte para combatir y superar el abuso patriarcal. En su obra son harto recurrentes las formas que evocan los pechos, tomando aspectos variados, a veces fálicos y a veces en forma de ovoide. Esta imagen de la maternidad castradora del padre evoca las estatuas de la diosa Artemisa propias de la antigua Grecia, en cuyos rituales se castraban toros y se sacrificaban hombres. Su iconografía quedaba representada mediante grupos muy similares de protuberancias redondeadas, que podrían hacer referencia tanto a los testículos castrados como a formas de senos femeninos. ${ }^{63}$ En 1978 Bourgeios se atavió con esta especie de

${ }^{62}$ NOBLE, Richard, "Jana Sterbak: Dialéctica de la creación y la contención", en el catálogo de la exposición Velleitas. Jana Sterbak, Saint-Étienne, Musée d'Art Moderne Saint-Étienne, 1995, pp. 51-70.

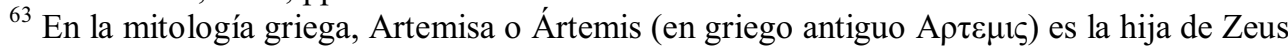
y Leto y la hermana melliza de Apolo. Solía ser representada como una diosa virgen de la caza, llevando un arco y flechas. Más tarde pasó a estar asociada con la luna, como su hermano Apolo lo estaba con el sol. Fue una de las deidades más ampliamente veneradas y una de las más antiguas. En Éfeso Artemisa era adorada principalmente como una diosa 
vestido para la acción The Banquet/A Fashion Show of Body Parts y para su instalación Confrontation, una evolución posterior de la fiesta caníbal de Destruction of the Father.

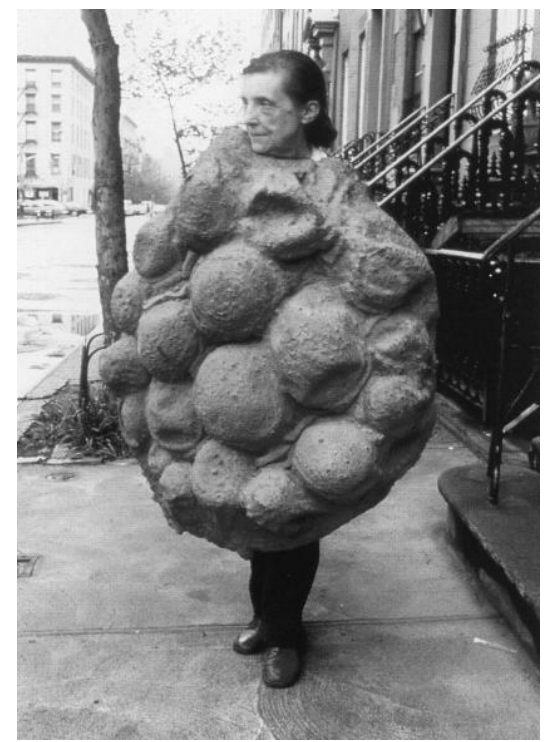

89. Louise Bourgeois - Costume for a Banquet (1978)

En el conjunto de obras hechas con protuberancias, contornos y redondeces, la autora se apodera del símbolo del poder masculino y lo muestra de diferentes maneras: bajo el brazo, colgado, en movimiento. Consigue quitarle, de este modo, su presencia poderosa para convertirlo en un apéndice colgante, mucho más inofensivo y vulnerable de lo que la normativa del hombre nos ha hecho creer.

La imagen nos recuerda enormemente a la serie de dibujos Femme Maison (1945-47). La casa para Louise Bourgeois es el símbolo a través del cual expresa su protesta contra el machismo y, en particular, contra la

madre, semejante a Cibeles. Su culto se llevaba a cabo en un antiguo santuario donde su imagen de culto representaba a la «Señora de Éfeso» adornada con múltiples protuberancias similares a pechos, que fueron tradicionalmente interpretadas como múltiples senos accesorios o testículos de toros sacrificados. 
despreciada figura paterna. La autora destruye lo privado al exponerlo en público, mostrando su fragilidad y exhibiendo sus heridas y su vulnerabilidad. De este modo, supera la línea que separa lo público de lo privado.

\subsection{Père-versiones}

¿Qué es lo que conduce el concepto de familia a la desesperación? ¿Influencias externas, agravios internos? ¿Habituales conflictos intergeneracionales o complicadas dependencias emocionales? ¿Normas o conductas impuestas desde fuera? ¿Qué sucede con los medios de comunicación, la publicidad, la industria cinematográfica, capaces de definir el bien y el mal? ¿En qué sentido afectan a la vida familiar las diversas facetas de los esfuerzos individuales para vivir en sociedad? Personajes famosos, cuentos de hadas y paraísos soñados aportan esperanza a muchas personas y se convierten en figuras con las que identificarse. Pero, en realidad, ¿desciframos aquello que comunican? ¿Hasta qué punto influyen en la educación y desarrollo de las personas e imprimen su firma?

Paul McCarthy (Salt Lake City, 1945) empezó su carrera performativa experimentando con la gravedad como componente metafórico. Sin embargo, a partir de 1974, su representación artística dio un radical giro con provocativas acciones que hacían referencia directa a la sexualidad y a la agresividad. McCarthy representa las relaciones sociales de poder en un teatro abyecto que remite al orden patriarcal como lugar de profundas perturbaciones. A pesar de que su obra ha sido relacionada con el accionismo vienés de Otto Mühl, al autor estadounidense no le interesa la autenticidad de los sentimientos reprimidos. ${ }^{64}$ Los mitos hegemónicos de la

${ }^{64}$ «People make references to Viennese art without really questioning the fact that there is a big difference between ketchup and blood. I never thought of my work as shamanistic. My work is more about being a clown than a shaman». Cit. en AF PETERSEN, Magnus, "Paul McCarthy's 40 years of hard work - an attempt at a summary", en el catálogo de la 
sociedad biempensante son sustituidos por referencias a mitos modernos producidos por Disney y Hollywood.

McCarthy analiza lo que la cultura de masas se niega a reconocer, su proyecto podría ser entendido como una «extensión» de las ideas situacionistas definidas por Guy Debord en su manifiesto de 1957. Somos prisioneros de infinidad de sujetos y objetos que conforman nuestro orden, McCarthy arremete contra el ocio popular construyendo situaciones que desgarran la identificación psicológica del espectador con el héroe.

Los simulacros de McCarthy son verdaderas materializaciones del placer sensorial y oral sustituto de un deseo primario erótico y escatológico. Amelia Jones analiza las performances de McCarthy como un asalto a la figura autoritaria masculina, una figura que pierde los pantalones y se convierte en un buffon patriarch. ${ }^{65}$

Prácticamente en toda su obra McCarthy se interesa por la infancia o, más exactamente, por la fetichización infantil y adolescente. Indudablemente, la razón reside en que en este preciso período de la vida es en el que se forjan los determinismos. Su interés por la pedagogía y la educación le han servido para analizar en su trabajo un vocabulario de la cultura popular contemporánea: la televisión, la publicidad y los fenómenos de Hollywood y Disney. El contraste se apropia de mitos modernos dotándolos de un nuevo contenido crítico. Le interesa una cultura atrapada en la interacción estandarizada de la familia, la educación y los medios de

exposición Paul McCarthy Head Shop/Shop Head. Works 1966-2006, Stockholm, Moderna Museet, 2006, p. 20.

${ }^{65}$ JONES, Amelia, "Paul McCarthy's Inside Out Body and the Desublimation of Masculinity", en el catálogo de la exposición Paul McCarthy, Los Angeles, MOCA, 2000, p. 131. 
comunicación, una cultura absolutamente controlada por —en la ya citada terminología de Preciado- el «farmacopornografismo». ${ }^{66}$

$\mathrm{Su}$ lenguaje visual es inmediato, despiadado y no teme a las metáforas o analogías más comunes. Da la vuelta a los valores generalmente aceptados. Los deseos físicos se expresan superficialmente con erotismo, sexo y violencia. La higiene civilizada se transforma en mugre y suciedad. La superioridad mental que supuestamente caracteriza al ser humano se contrarresta con el descontrol, el desorden y el caos. McCarthy ataca el concepto de limpieza impoluta que se ha cultivado deliberadamente para suprimir el subconsciente y el mundo de los sueños a fin de que la sociedad pueda funcionar con total eficacia. El tosco vocabulario que utiliza en sus representaciones de instintos humanos puede parecer tan provocador como sus exageraciones y exacerbaciones formales.

La naturaleza efímera de sus acciones, vídeos y dibujos que creó en la década de 1970 es la causa de que su obra fuese conocida por un reducido grupo de artistas y especialistas. Sus performances desmitifican la masculinidad hurgando en los aspectos más vulnerables y patéticos de su propio cuerpo. La virilidad pasa de ser comprendida como algo trascendente a algo absolutamente histérico, convulsivo y contingente. Muñecos, esculturas mutantes y todo un decadente imaginario infantil se mezclan con grotescas imágenes sexuales a modo de catarsis alegórica de un mundo reprimido por una cultura patriarcal. Tal y como afirma Cortés, McCarthy nos muestra el cuerpo de un hombre vulnerable que ha perdido toda autoridad y coherencia, un hombre herido, lleno de agujeros, que estructura su subjetividad mediante un terrible miedo a la castración. El falo, entendido socialmente como el símbolo por antonomasia del poder masculino, se ha convertido en un pene flácido, patético, manipulable e intercambiable. Se ha pervertido toda norma que asegura las fronteras de la masculinidad abriendo

\footnotetext{
${ }^{66}$ MEYER-HERMANN, Eva, "Lo intangible contenido", en el catálogo de la exposición Paul McCarthy. Brain Box Dream Box, Málaga, Centro de Arte Contemporáneo de Málaga, 2005, p. 10.
} 
un amplio precipicio de inseguridad y ansiedad que cuestiona los mecanismos de la cultura patriarcal. ${ }^{67}$

Hacia 1974 el artista alcanzó cierto reconocimiento local por una serie de performances. En sus acciones McCarthy ingería carne cruda, mayonesa, ketchup, mostaza y otros alimentos que le servían para crear falsos fluidos corporales. El autor llevaba al límite los rituales propios del accionismo vienés a través de una especie de grotesco film de terror al que Paul Schimmel calificaba como American Popular Culture.

Ma Bell (1971) fue el inicio en el que McCarthy asumía un determinado carácter en su obra. ${ }^{68}$ La cámara enfoca una guía telefónica que el mismo artista está hojeando. Al instante vierte aceite de motor sobre las páginas esparciendo el viscoso líquido con un algodón, mientras murmulla y balbucea como un bebé, cada vez más intensamente hasta llegar al borde de la histeria. ${ }^{69}$

Meat Cake recoge una serie de performances realizadas en 1974. Uno de los principales elementos utilizados fue un pequeño tocador con un espejo de dos caras con el que se sirvió para actuar de protagonista y asumir otra personalidad. Sentado frente a su propio reflejo, al que constantemente convierte en dos personajes distintos, se vendó cara y genitales, y se cubrió el cuerpo con pelucas y prendas femeninas. ${ }^{70}$

67 G. CORTÉS, José Miguel, "Masculinidad y representación”, en HERNÁNDEZ SÁNCHEZ, Domingo (ed.), Arte, cuerpo y tecnología, Salamanca, Universidad de Salamanca, 2003, p. 238.

${ }^{68}$ En los textos que analizan la obra de McCarthy — ninguno traducido al españolencontramos el término persona, un término que define un carácter, un rol.

${ }^{69}$ AF PETERSEN, Magnus, op. cit., p. 17.

${ }^{70}$ La imagen reflejada en el espejo ha sido objeto de la atención de McCarthy en numerosas obras. La utilizó en sus investigaciones sobre lo que es una imagen, cómo se produce y cómo se percibe. Al igual que en Alicia en el País de las Maravillas o Los Viajes de Gulliver, los espectadores y espectadoras se ven transportados a un plano supuestamente infantil, surreal, a fin de percibir mejor el mundo. MEYER-HERMANN, Eva, "Yellow Table", en Paul McCarthy. Brain Box..., op. cit., p. 56. 


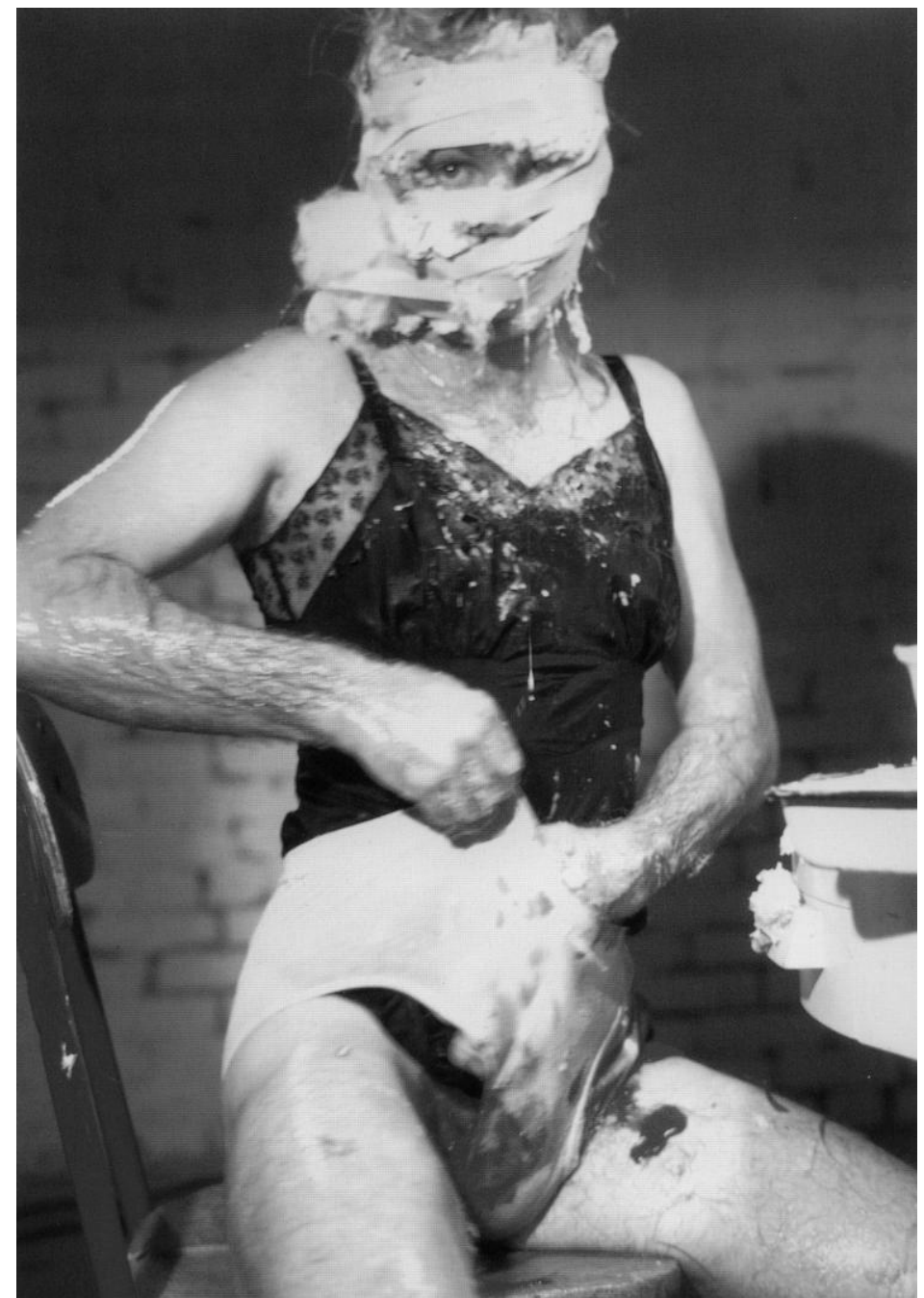

90. Paul McCarthy - Meat Cake (1974)

En Sailor's Delight/Sailor's Meat (1975) incluía referencias a marineros, mitos transexuales, transgresión de límites morales y una manifiesta violencia. El artista adoptó la personalidad de un marinero envilecido, un viajero cuyos actos carnales se rodean de un conglomerado de atributos femeninos: una peluca rubia, maquillaje y la parte inferior de un biquini negro. En la cama de la habitación de un hotel muestra un bulto de carne cruda que en unas ocasiones acaricia y en otras intenta penetrar. La 
obra muestra una alteración simbólica del lenguaje de la cultura popular que evoca, más concretamente, imágenes de fotogramas de películas eróticas. ${ }^{71}$

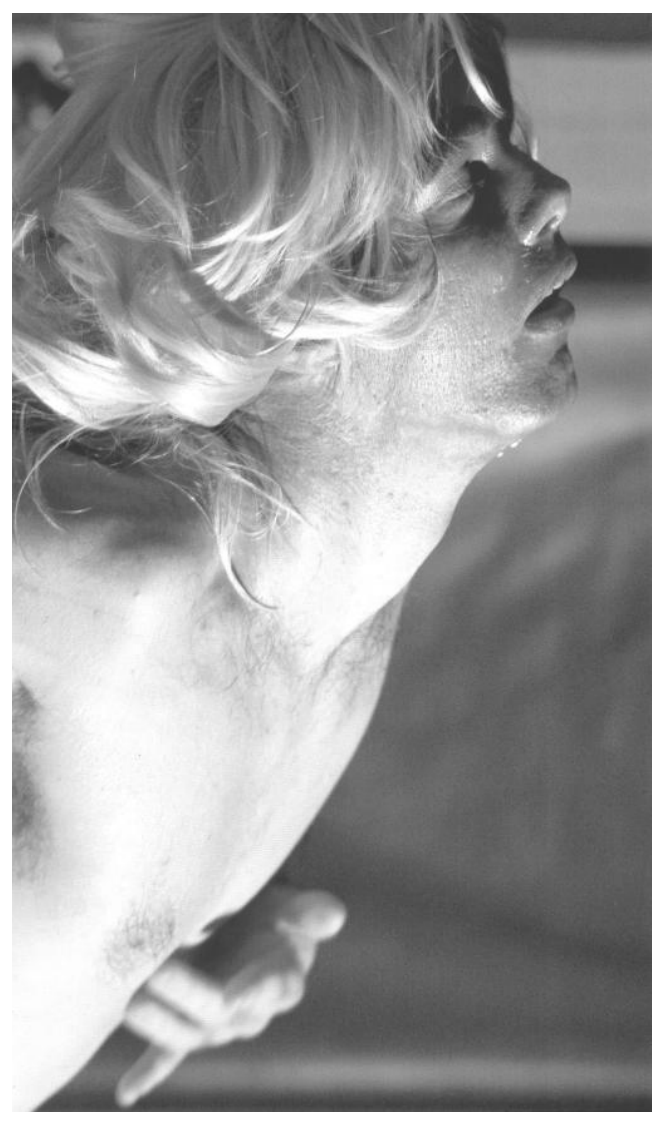

91. Paul McCarthy - Sailor's Meat (1975)

En palabras del propio McCarthy: «I'm dressed with eye makeup and a wig, but you are very aware that it is a man. It's the image of an androgynous figure. The illusion goes back and forth between watching a male and watching a female, and I think the power of the piece is that you

\footnotetext{
${ }^{71}$ Paul McCarthy se apropió de la postura de la protagonista de un fotograma publicitario de Europe in the Raw (1963), un film pornográfico de Russ Meyer.
} 
get lost. It's this idea of seducing through an androgynous figure, exploring those sides of myself». ${ }^{72}$

Dentro del contexto de violencia simbólica y condicionamientos sociales provenientes de la estructura familiar patriarcal y de la alienación ideológica y cultural de los medios de comunicación, el trabajo de Paul McCarthy debe ser entendido como metáfora de los sistemas de poder y de las convenciones culturales que definen nuestro entorno. Con un imaginario violento, macabro y amargamente cómico, el autor trata de desentrañar los lados más oscuros de los mitos y los estereotipos que conforman la plácida vida de la clase media norteamericana.

Con este objetivo, en sus performances y vídeos no ha dudado en disfrazarse de algunos de los personajes más arquetípicos de ese mundo, tales como Heidi, Pinocho o Popeye, para insistir en la naturaleza perversa del autoritarismo jerárquico y la violencia paterna. Estas caracterizaciones le sirven para llevar a cabo unas acciones que se conforman como alegorías no sólo de los traumas de la sociedad de consumo, sino también con aspectos básicos como la identidad, la sexualidad o la confusión de las fronteras corporales. En el cuerpo que McCarthy nos muestra, las fronteras que lo delimitan han estallado y las partes internas se abocan al exterior, como si se tratara de una bolsa de carne que acaba de reventar, dando pie a un paisaje de intestinos y líquidos que disuelven los límites. Así, las eyaculaciones de mayonesa, las hemorragias de ketchup, las diarreas de mostaza o los vómitos de carne picada se suceden obsesivamente ocupando el lugar de los fluidos corporales, como sustitutos del esperma, la sangre o los excrementos.

Kristine Stiles define magistralmente el trabajo de Paul McCarthy en una frase: «[...] you create another language, a language of abuse used to discredit the language which has been abused». ${ }^{73}$

${ }^{72}$ Cit. en WARR, Tracey (ed.), op. cit., p. 146. 
A finales de la década de 1970, McCarthy escribió un poema en el cual reflexionaba y definía su obra:

VENTED $(1977-78)^{74}$

The vent.

The house vent.

Furnace vent.

You may understand my actions as vented culture.

You may understand my actions as vented fear.

You may understand my actions as a dream.

Dream as venting.

Different point of view.

I can't see into all of the spaces in the vent.

Uninhabited space.

Contemporary fear

The man had a bald head.

His penis could be snapped off and snapped on.

Snap off, snap on tools.

Cultured.

The idea has been in the back of my head. The snake's head had been cut off.

I was sitting on the couch. A woman came in the room, bent down and ate the severed snake's head.

National fear.

${ }^{73}$ STILES, Kristine, "Interview. Kristine Stiles in conversation with Paul McCarthy", en RUGOFF, Ralph; STILES, Kristine y DI PIETRANTONIO, Giacinto, Paul McCarthy, London, Phaidon, 1996, p. 20.

${ }^{74}$ En RUGOFF, Ralph; STILES, Kristine, DI PIETRANTONIO, Giacinto, op. cit., p. 116. 
They live together, twenty of them in the same room. A woman tried to explain to me the beliefs of the group. As she did, a nude man lying on a bed would spread his legs at me. He had an erection. The woman would smile.

She asked the man to come inside. He was reluctant.

She walked down the stairs. He walked up the stairs.

She put out her hand. He put out his hand.

The child lying on the bed had a penis longer than his body and thin like a noodle.

To protect his mother, the young boy killed the snake with a spade. Chopping repeatedly, he chopped the snake into small pieces. He was congratulated.

I had shoved a broom handle in my front pocket and pushed down. I looked down.

I had pushed the handle through my stomach and down into my penis. The skin of the penis fit the handle of the broom like a glove.

I had pushed the contents of the penis out through the hole of the penis.

I often play the role of the captain. We refer to our sex organs as an oar. You must understand this is an experiment. An experiment for ourselves. Let me explain something. The term 'cast off' refers to castration.

When I say the oar floats on the surface of the ocean, I am saying the oar is drifting.

Es difícil desvincular el trabajo de McCarthy del de Mike Kelley (Detroit, 1954), cuyas colaboraciones entre ambos han sido frecuentes entrados en la década de 1990, una relación que quedó marcada bajo una indiscreta condición: «I'm the father, you're the son». ${ }^{75}$

\footnotetext{
${ }^{75}$ Bossy Burger (1991) fue el primer trabajo cuya grabación fue concebida como una escultura-instalación. En el vídeo McCarthy lleva una máscara de Alfred E. Newman, zapatos de payaso y una indumentaria propia de un cocinero. Posteriormente trabajaron
} 
Desde la década de 1970 Kelley ha venido indagando en la construcción sociopolítica de la vida cotidiana. No falto de sarcasmo y una inteligente naturalidad, ha extrapolado la mirada sobre los objetos de uso diario acentuando los aspectos que presentan relación directa con el orden moral y familiar de la cultura occidental, en particular, la norteamericana. Tanto en su obra personal y, muy especialmente, en sus más recientes acciones - centradas en muñecos de peluche y juguetes infantiles - Kelley ha ideado un abyecto universo mezclado con unas pinceladas de ironía pop capaz de cuestionar la realidad más privada y, por tanto, tabú. Hasta la crítica más contundente se convierte en un ejercicio divertido y gratificante.

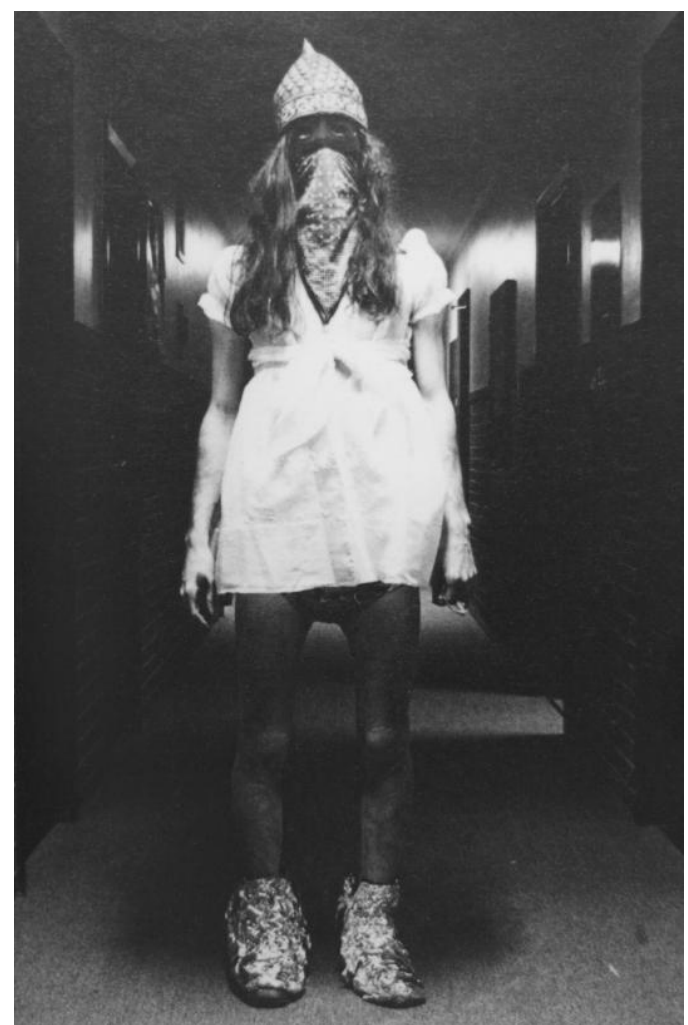

92. Mike Kelley - Vestido para el Futurist Ballet (1973)

juntos en diferentes proyectos caracterizados por la yuxtaposición entre la cultura corrupta y la naturaleza inocente como es el caso de Heidi: Midlife Crisis Trauma Center and Negative Media-Engram Abreaction Release Zone (1992). 
En 1973 presentó, sin permiso alguno, un happening de guerrilla dentro de una sala de conferencias de la University of Michigan el Futurist Ballet. Tras empapelar la ciudad universitaria de carteles anunciando eventos de naturaleza «intelectual» o «estética», el público se encontró con una performance de verdadero carácter neodadá. Un hombre recitaba fragmentos seleccionados de su colección pornográfica; una representación en vivo de una entrevista a Pat «Hippy Strippy» Oleszko (reina del Hash Bash), y otros actos de naturaleza similar que iban acompañados de grandes ruidos generados por músicos sin talento, aspiradores y grabaciones en loop..$^{76}$

Desde sus dibujos de los años setenta hasta su obra más reciente, Mike Kelley lleva al extremo las polaridades binarias que la civilización occidental ha establecido para mantener el orden. Naturaleza/cultura, kitsch/modernidad, campo/ciudad o sano/enfermo actúan como polaridades que evidencian hasta qué punto las normas sociales aceptadas mayoritariamente nos enseñan que nuestro destino biológico está sujeto a una disciplina. Ante ello Kelley intenta construir una estética híbrida que sirva de oposición a la tradición fálica y monumental de la cultura mayoritaria. $^{77}$

Si Mike Kelley utiliza el vocabulario formal de la infancia y la adolescencia — muñecas, animales de peluche, juguetes, etcétera - no es por complacencia pueril, sino por exigencia genealógica. Su obra la utiliza para seguir todo lo que funciona vergonzosamente, los valores considerados juveniles de la civilización occidental y americana. Si estos objetos están generalmente desprovistos de su carga sexual y escatológica, hasta el punto de ser metáforas higiénicas de la conciencia correcta adulta, el planteamiento de Kelley consiste en re-invertir su territorio corporal de

${ }^{76}$ KELLEY, Mike, "The Futurist Ballet (1973)", en C. WELCHMAN, John (ed.), Mike Kelley: Minor Histories, Statements, Conversations, Proposals, Cambridge, The MIT Press, 2004, pp. 176-179.

${ }^{77}$ G. CORTES, José Miguel, "Comentarios sobre las obras de la exposición”, en el catálogo de la exposición Micropolíticas..., op. cit., p. 459. 
origen. La obra de Mike Kelley hace referencia explícita a un fundamento de la civilización que no se atreve a decir su nombre, a fuerza de haber sido superado-sublimado-relevado en el orden adulto de la genitalidad. ${ }^{78}$

78 MARCADÉ, Bernard, "Le devenir-femme de l'art", en el catálogo de la exposición Fémininmasculin. Le sexe de l'art, Paris, Centre Georges Pompidou, 1996, p. 29. 


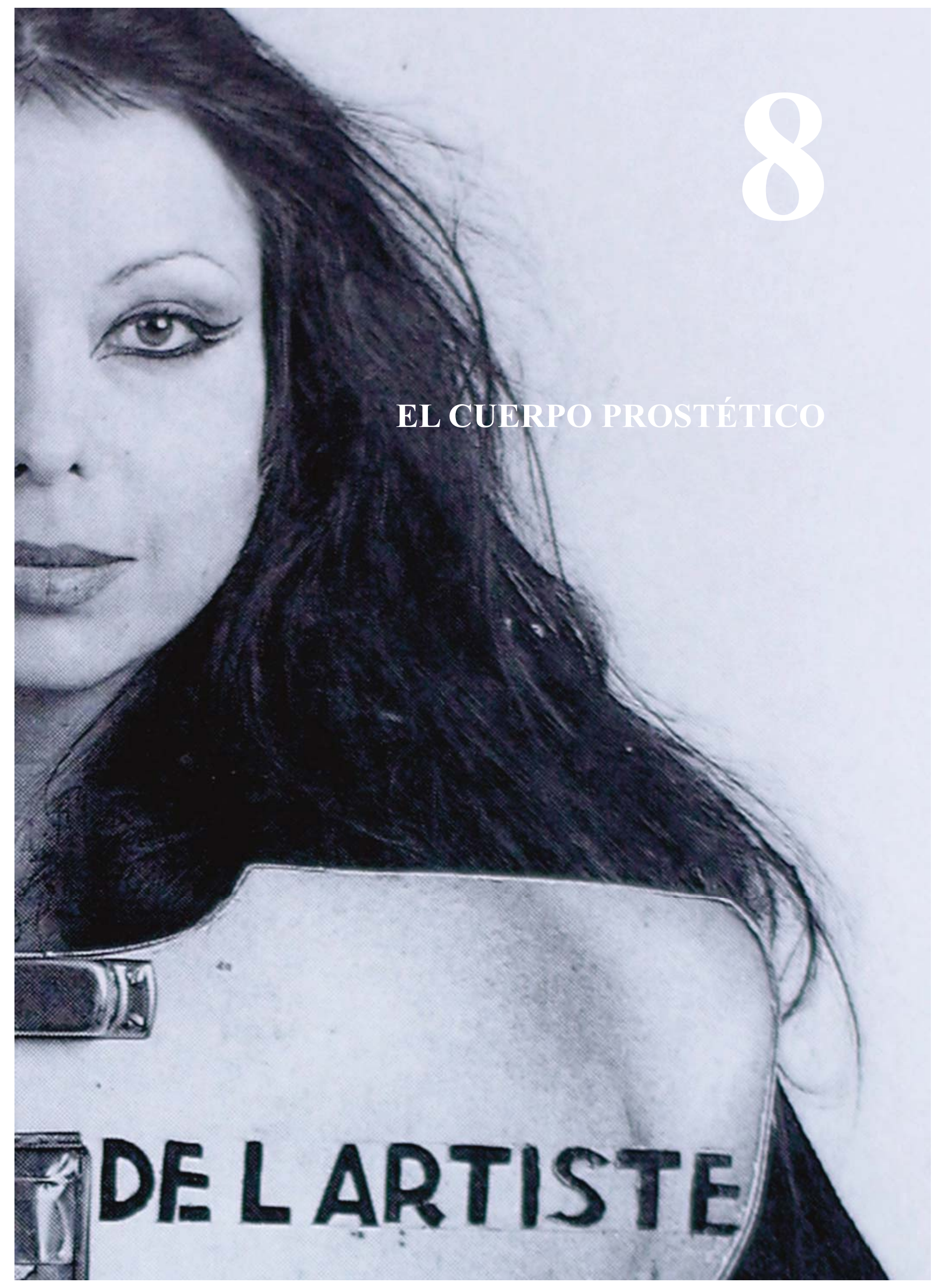



«El medio, o el proceso, de nuestro tiempo — la tecnología eléctrica- está remodelando y reestructurando los patrones de la interdependencia social y cada uno de los aspectos de nuestra vida privada. Nos está forzando a reconsiderar y revaluar prácticamente cada pensamiento, cada acción y cada institución que hasta hoy se daban por establecidos».

Marshall McLuhan

$\prod$

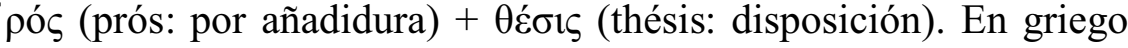
$\pi \rho o ́ \theta \varepsilon \sigma 1 \varsigma$ (prótesis) significa 'exposición', mientras que $\pi \rho o ́ \sigma \theta \varepsilon \sigma 1 \varsigma$ (próstesis) es 'adición', 'cosa añadida'. Por tanto, la palabra procede de próstesis y en español debería ser próstesis, de hecho, en sentido quirúrgico está atestiguado prosthesis (inglés) en 1706, mientras que prothesis lo está más tarde, en 1848.

Como hemos visto a lo largo de los capítulos precedentes, a partir de la década de los setenta la mayoría de autores y autoras - concienciados y comprometidos con los problemas sociales que atravesaba la sociedadtrataron de abrir nuevos espacios de identidad. Sin embargo, comenzaban a emerger una serie de creadores y creadoras obstinados en rebasar las fronteras existentes entre exterior e interior del cuerpo a través de la experimentación de éste con añadidos, más o menos tecnológicos, a modo de aproximación reflexiva más allá de lo meramente individual. 
Bajo estos parámetros, experimentaron con ellos y ellas mismos la hibridación entre lo corpóreo y lo tecnológico, reafirmando no sólo la existencia de una identidad variable e inédita, sino también una nueva estética política absolutamente anticonformista e ilimitada respecto a las acepciones categóricas más convencionales, todo ello creado por voluntad propia y con buenas dosis de dolor y masoquismo. Natural y artificial - nature y nurture - se ensamblaron para emprender una batalla crucial, propia de algún personaje cyberpunk, y hostilizaron la cultura artística con imágenes liberadas de la arraigada constricción fisiológica.

Muy próximos a la mentalidad de principios de siglo XXI, los artistas del Body Art reflexionaron —en este caso- sobre la tecnología desde dos puntos de vista claramente diferenciados. Por una parte, encontramos a quienes advirtieron sobre la anulación del individuo, siendo conscientes de la necesidad contemporánea de la tecnología e inventando «extensiones corporales» capaces de devolvernos la sensibilidad que nos había sido privada. Por otra parte, los más acérrimos defensores y defensoras de la obsolescencia del cuerpo, centraban sus esfuerzos en la búsqueda de una nueva identidad o, mejor aún, la destrucción del concepto convencional del término, entendido como cualidad por excelencia del individuo.

Ciertamente, las prótesis mentales y las estrategias denominadas «farmacopornográficas» - si entendemos éstas como las construcciones sociales a las que estamos sometidos y sometidas desde nuestra infanciavan más allá de las prótesis reales. Quizás no esté tan lejos el día en que lo natural sea desvalorizado por ser muy poco natural.

\subsection{Extensiones sensoriales. De la antropofagia a Rebecca Horn}

El fugaz avance tecnológico ha conseguido aletargar a una sociedad que ha cambiado su libertad identitaria por un falso hedonismo, una 
búsqueda de un bienestar inalcanzable ofrecido, especialmente, por los mass media. Como bien auguró Andy Warhol, la repetición acaba por anular la sensibilidad, nuestra individualidad queda absolutamente distorsionada y, de esta manera, es imposible estructurar una conciencia social. Una sociedad desestructurada es fácil de dominar y dirigir.

En el momento en que comienza a emerger el Body Art, algunas de las mentes más inconformistas trataron de atajar el problema desde su raíz, planteando el cuerpo como un receptor de sentidos que necesita ser estimulado constantemente bajo una premisa primordial: evitar la anulación del individuo. La concepción reaccionaria que caracterizó la sociedad global de los años de posguerra llevó a amplios sectores intelectuales a tomar conciencia del cuerpo y de su relación con el mundo, así como a luchar por la reconstrucción de la experiencia humana en su compleja totalidad.

Al otro lado del Atlántico, la artista brasileña Lygia Clark (Belo Horizonte, 1920 - Rio de Janeiro, 1988) perteneció a una generación extraordinaria de artistas e intelectuales brasileños - Hélio Oiticica y Glauber Rocha son dos ejemplos claros - que reformularon las categorías artísticas tradicionales e incluso los fundamentos antropológicos de la cultura moderna occidental replanteando e invirtiendo la relación entre centro y periferia, y cuestionando la noción de límite. ${ }^{1}$ Atrás dejó definitivamente el formalismo geométrico y se orientó hacia la consciencia de nuestros sentidos y la totalidad de nuestros cuerpos bloqueando el sentido visual, o volviéndolo hacia dentro y sumergiéndolo en lo sensorial como un todo.

En un giro característico de la cultura brasileña y directamente relacionado con el concepto de antropofagia cultural de Oswald de

\footnotetext{
${ }^{1}$ En aquellos años Brasil atravesaba una fase de desarrollo acelerado. El principal objetivo del país se centraba en la modernización y la apertura a una contemporaneidad materializada en la nueva capital federal, Brasilia. Véase BORJA-VILLEL, Manuel J., "Introducción", en el catálogo de la exposición Lygia Clark, Barcelona, Fundació Antoni Tàpies, 1997, p. 13.
} 
Andrade, ${ }^{2}$ Clark concibió el cuerpo como una especie de arquitectura, como un lugar de experiencia singular, no normativa y abierta. La autora fue capaz de transformar las corrientes constructivistas en «extensiones corporales» que convertían al ser humano en un mutante encargado de liberar al sujeto de sus anulaciones sensoriales. Sus experimentos adquirieron así una marcada dimensión social y política.

La propia artista contó cómo el azar había intervenido en ese salto que se produjo hacia 1966: «Había llenado de aire una pequeña bolsa de plástico, cerrándola con una goma. Puse una pequeña piedra encima y empecé a palparla, sin preocuparme por descubrir nada. Con la presión, la piedra subía y bajaba por encima de la bolsa. Entonces, de pronto, me di cuenta de que aquello era algo vivo. Parecía el cuerpo. Era el cuerpo». ${ }^{3}$

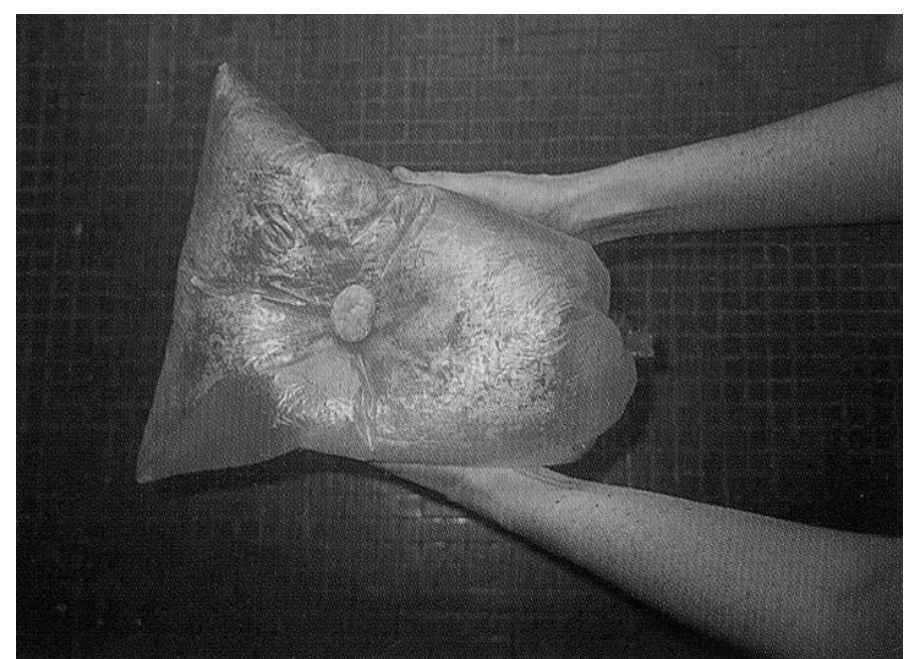

93. Lygia Clark - Ar e Pedra (1966)

\footnotetext{
${ }^{2} \mathrm{La}$ antropofagia, producto del primer florecimiento de la vanguardia brasileña en los años veinte, deviene la metáfora más poderosa de la cultura intelectual brasileña del siglo XX. Se trata de un referente esencial en el proceso brasileño de engullir diversas culturas mundiales para crear la suya, no de una forma depredadora, sino con un espíritu de rebelión anticolonialista. Véase SCHWARTZ, Jorge, "Tupí or not tupí. El grito de guerra en la literatura del Brasil moderno", en el catálogo de la exposición Brasil 1920-1950. De la antropofagia a Brasilia, Valencia, IVAM, 2000, pp. 141-156.

${ }^{3}$ Cit. en Brasil 1920-1950..., op. cit., p. 205.
} 
Ése fue el origen de otros trabajos caracterizados por la incorporación de la dimensión sensorial, particularmente táctil, y cargados de cierto carácter aleatorio. En Livro sensorial, Desenho com o dedo o Água e conchas (todas obras de 1966), Clark se sirvió del plástico como material blanco que tenía que ser manipulado por el espectador o espectadora. Sin embargo, es a partir de Diálogo de mãos —única obra que creó conjuntamente con Hélio Oiticica- donde una «extensión corporal» fue destinada a incrementar las cualidades sensitivas y las posibilidades comunicativas de los usuarios y usuarias. La pieza consistía en una pequeña cinta de Möbius ${ }^{4}$ con la cual se ataban las muñecas de dos participantes que dialogaban entre sí mediante los movimientos de sus manos. Un recorrido sin principio ni fin que abogaba por el entendimiento entre las personas.

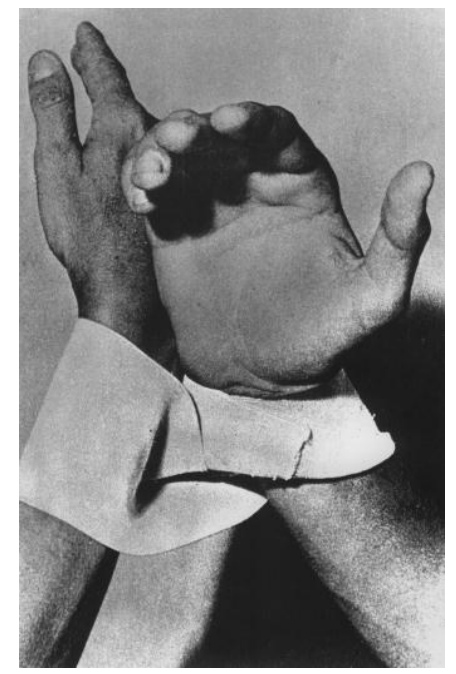

94. Lygia Clark - Diálogo de mãos (1966)

\footnotetext{
${ }^{4}$ La cinta o banda de Möbius fue co-descubierta por los matemáticos alemanes August Ferdinand Möbius y Johann Benedict Listing en 1858. Es una superficie que se puede formar con una cinta o tira de papel larga y rectangular al rotar uno de los extremos $180^{\circ}$ con respecto al otro y juntarlos formando un lazo. Es, por tanto, una superficie bidimensional que tiene una sola cara, tal y como puede ser comprobado dibujando una línea a lo largo de la banda: la línea vuelve a pasar por el punto inicial dos veces más —una por el lado opuesto del papel, y la segunda al completar la línea. Otra propiedad de la cinta de Möbius es que si se corta la banda a lo largo de la línea dibujada en el centro del lazo, se convierte en un lazo único con dos caras, en vez de quedar dividido en dos lazos.
} 
Al año siguiente la autora hizo - a nuestro modo de ver - algunas de sus piezas más relevantes. Las Máscaras sensoriais (1967) son una especie de capuchas holgadas, sueltas y confeccionadas con telas de distintos colores. Próximas a la nariz del usuario o de la usuaria, Clark cosió unas bolsitas de tela con semillas y hierbas creando diferentes sensaciones olfativas. La percepción visual tampoco quedaba indemne al flujo de estímulos, pues la artista dispuso varios tipos de tapaderas o añadidos en los agujeros de los ojos; también colocó, a la altura de las orejas, un cuenco de poliestireno por el que rodaba una bola provocando un sonido particular. ${ }^{5}$ Aquellas máscaras ofrecían un universo inconfundible de sensaciones, unas herramientas destinadas a incrementar el ámbito de la experiencia de quienes se decidían a utilizarlas.

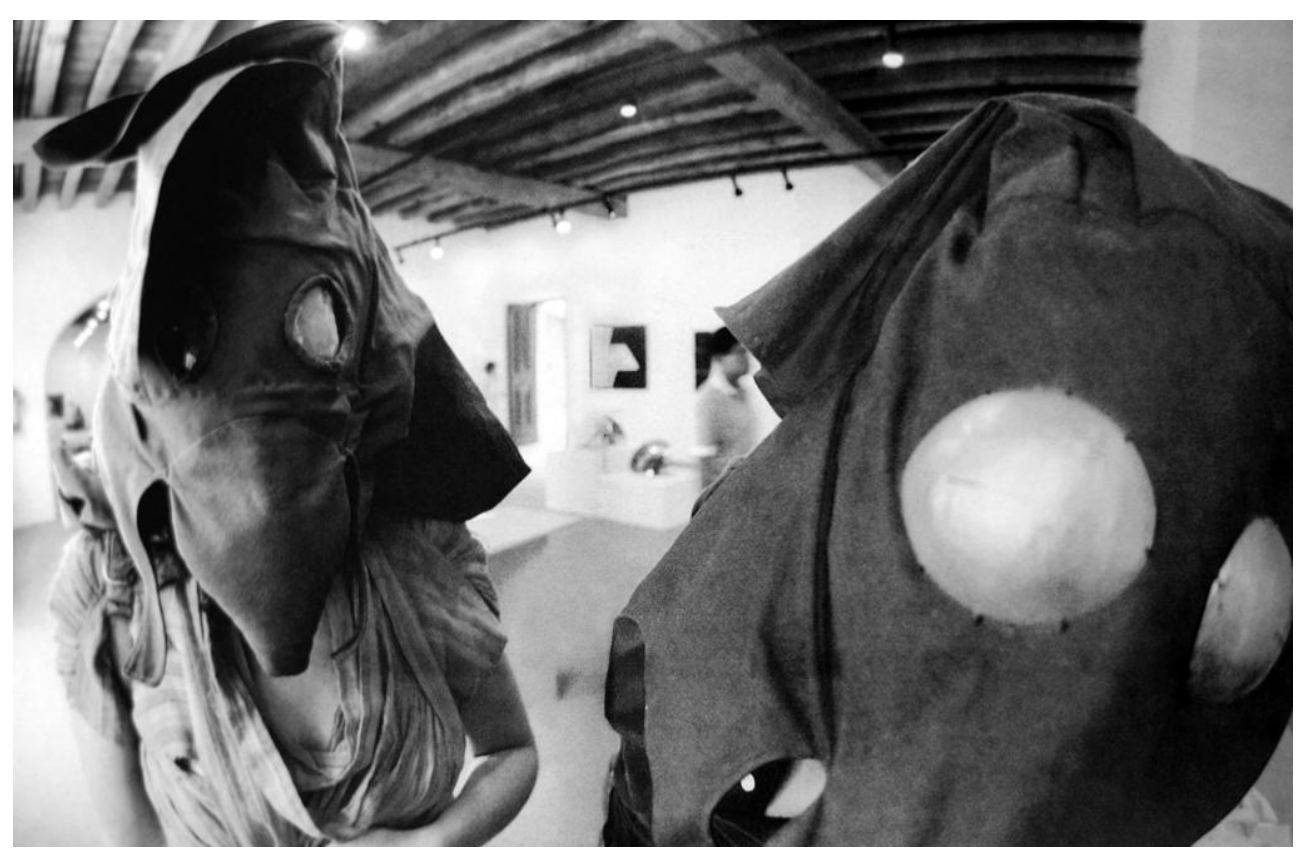

95. Lygia Clark - Máscaras sensoriais (1967)

\footnotetext{
${ }^{5}$ BRETT, Guy, "Lygia Clark: seis células", en el catálogo de la exposición Lygia Clark, op. cit., pp. 20-21.
} 
Pero ¿por qué este cúmulo de sensaciones, aparentemente agradables, envuelve una imagen exterior cargada de connotaciones tan particulares? Tal y como observa Juan Antonio Ramírez, las Máscaras sensoriais nos recuerdan a las caretas antigás utilizadas en la Primera Guerra Mundial e, incluso, a las capuchas de los penitentes de ciertas procesiones religiosas. ${ }^{6}$ Cuando observamos la forma externa de muchas de sus «extensiones corporales» recordamos todo un abanico de artilugios utilizados para la tortura y la resignación del ser humano: desde los instrumentos para castigar a los esclavos y esclavas, hasta los mecanismos de represión sexual como los cinturones de castidad, pasando no sólo por los violentos recursos que han sido utilizados para tratar las enfermedades mentales, sino también por toda una serie de fantasías de abusos para obtener placer erótico en la parafernalia fetichista y sadomasoquista.

¿Acaso Lygia Clark trata de concienciarnos acerca del ensimismamiento sensorial que padecemos en la sociedad contemporánea? El juego de la autora es aterrador, nos convierte en víctimas y verdugos al mismo tiempo. Evidentemente el dolor nos recuerda que estamos vivos. Sus obras pretenden despertar nuestros sentidos y nos invita a utilizarlos frente al aislamiento que conlleva la integración en la sociedad contemporánea, una sociedad que nos anula mediante el embotamiento y la contaminación mediática.

Máscaras abismo (1968) también compartía el paradójico mecanismo de encarcelamiento/liberación. La obra consistía en una especie de sacos de arpillera de nylon en cuyo fondo alojaba unas piedras y unas bolsas de plástico llenas de aire. Resultaba interesante el contraste entre el embudo aéreo creado ante el rostro y la naturaleza inerte e irregular del peso inferior, pero lo más llamativo era que la pulsión gravitatoria de la piedra obligaba al espectador o espectadora a esforzarse por elevar la cabeza, evitando «sumergirse en el abismo» mediante una actividad muscular

${ }^{6}$ RAMíREZ, Juan Antonio, Corpus Solus. Para un mapa del cuerpo en el arte contemporáneo, Madrid, Siruela, 2003, p. 166. 
transformada en consciente. ¿Por qué abismo? Como observa Paulo Herkenhoff, las Máscaras abismo actúan como un extraño espejo que permite al sujeto mirar hacia su interior, una especie de introspección analítica. El gran territorio de ese abismo se construye como si la cabeza mirase hacia dentro y se viese sintiendo su propio peso. Así pues, la máscara es el lugar de la fantasmagoría, donde el sujeto vive experiencias existenciales. ${ }^{7}$ Las Máscaras abismo nos hacen pensar en unos retales imaginarios cuyas capturas no tienen nada que ver con peces o cangrejos, sino con inertes piedras que obligan al hipotético pescador-portador de las mismas a considerar la existencia de un «abajo» oscuramente gravitatorio.

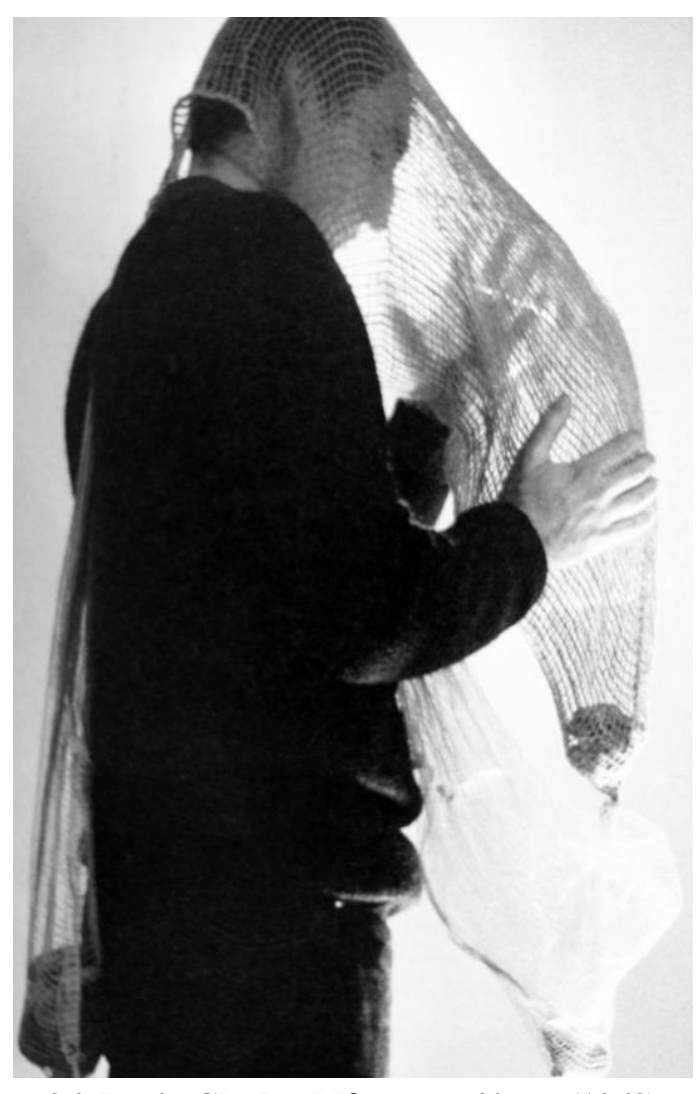

96. Lygia Clark - Máscaras abismo (1968) ${ }^{7}$ HERKENHOFF, Paulo, "Lygia Clark", en el catálogo de la exposición Lygia Clark, op.
cit., p. 48. 
O eu e o tu (1967), de la serie Roupa-corpo-roupa, se compone de dos monos de plástico que cubren, de pies a cabeza, los cuerpos de un hombre y una mujer. Dichos monos llevan un forro interior confeccionado con diversos materiales (entre otros, una bolsa de plástico llena de agua, espuma vegetal o caucho) que proporciona al hombre una sensación femenina, mientras que para la mujer dicha sensación es masculina. ${ }^{8} \mathrm{Si}$ observamos detenidamente la imagen, percibimos que los círculos oculares están también tapados, sólo quedan al descubierto las manos y una apertura en la parte inferior de la cara para favorecer la respiración y la emisión ocasional de la voz, ya que el silencio no es estrictamente obligatorio en el juego de Lygia Clark.

Los sujetos que experimentan la acción quedan así absolutamente aislados, sin embargo, ambos trajes rompen su hermetismo al estar conectados por un tubo de goma, como si se tratase de un cordón umbilical. Asimismo, los trajes mostraban seis cremalleras repartidas por la superficie del tejido. Las dos personas ataviadas con estas «extensiones corporales» se palpaban a ciegas el uno a la otra, abrían sus bolsillos y tocaban diferentes materiales que se traducían en partes del cuerpo del otro, como si se tratara de metáforas táctiles de la realidad orgánica, extremadamente sugerentes.

Pero ¿por qué en todos los documentos que tenemos de la obra la autora reitera la diferencia entre los cuerpos masculinos y los femeninos? Tal vez deseara una experiencia particular, una toma de conciencia del otro cuerpo que la mojigatería y la gazmoñería tratan constantemente de colocar en una oposición binara. Aún así, nos parece un tanto inocente tal diferenciación. Creemos que el trabajo habría resultado mucho más interesante si hubiera considerado todas las opciones posibles o, al menos, no las más convencionales. A pesar de la seriedad de la pieza, no podemos evitar el esbozo de una sonrisa al observar el semblante de los sujetos de la

\footnotetext{
${ }^{8}$ CLARK, Lygia, "La casa es el cuerpo", en el catálogo de la exposición Lygia Clark, op. cit., p. 214.
} 
acción, más próximos a unos Teletubbies que a unos trabajadores uniformados.

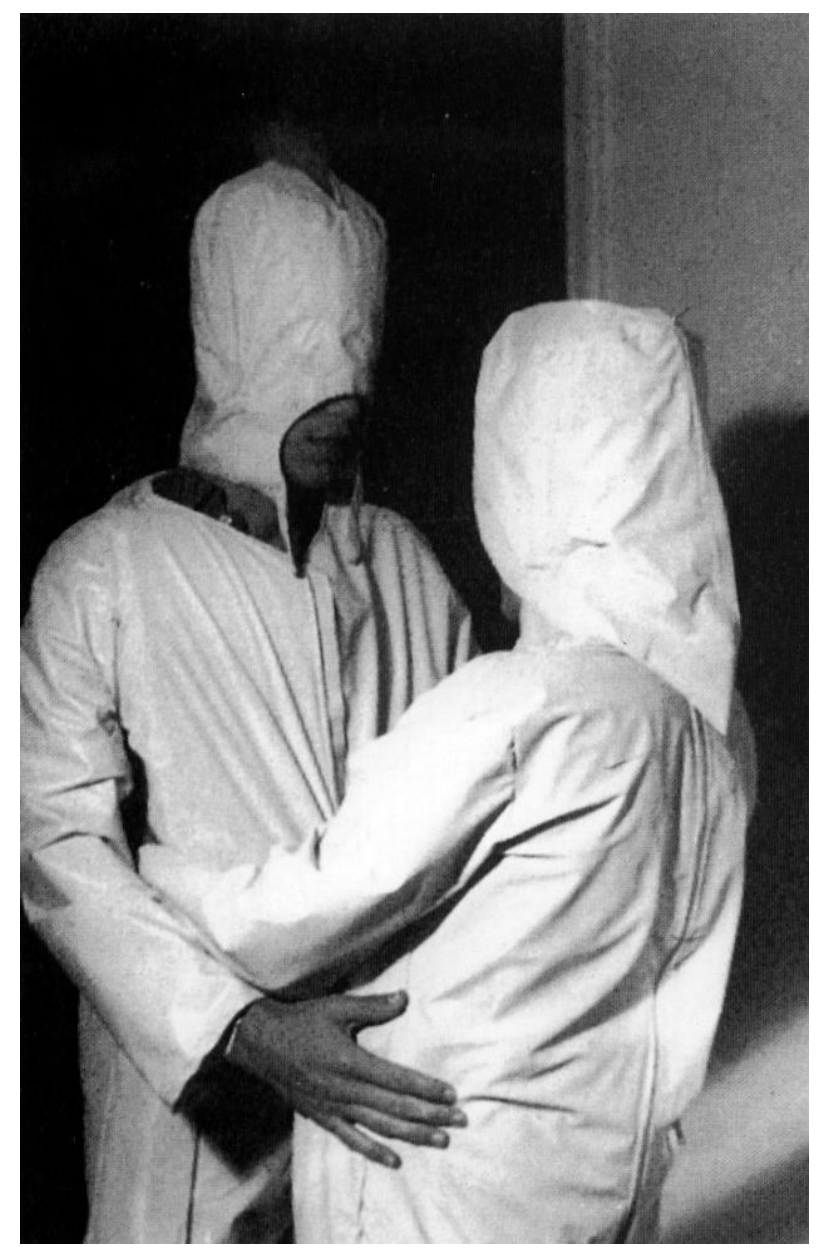

97. Lygia Clark - O eи e o tu (1967)

Como podemos deducir de lo apuntado hasta el momento, el común denominador de la obra más significativa de Lygia Clark reside en la participación de varias personas y el empleo o generación de «extensiones corporales» de diversa naturaleza. Canibalismo (1973) es otro buen ejemplo de lo señalado. Una persona con los ojos vendados, tumbada en el suelo boca arriba y vestida con un mono forrado de tela en cuyo abdomen se 
situaba una cremallera horizontal, ocultaba un depósito de fruta natural. Los otros participantes, también cegados con vendas, se sentaban junto a ella, abrían la cremallera y se comían los alimentos. Un acto simbólico — tal y como interpreta Juan Antonio Ramírez - dirigido a devorar al otro, hecho significativo en los procesos amorosos. ${ }^{9}$

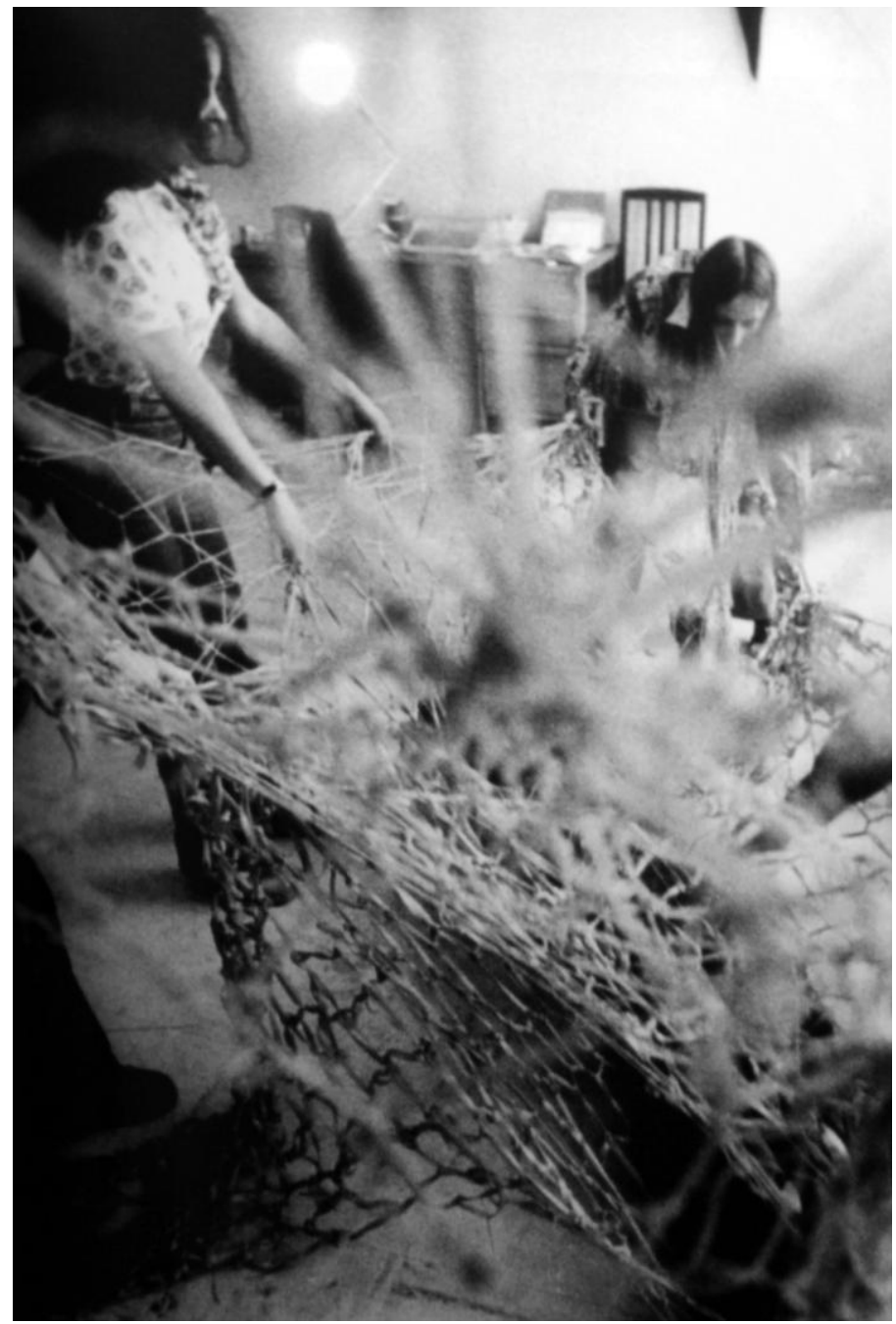

98. Lygia Clark - Rede de elástico (1973)

\footnotetext{
${ }^{9}$ RAMÍREZ, Juan Antonio, op. cit., p. 167.
} 
Del mismo modo, Rede de elástico consistía en la elaboración manual de una red confeccionada con aros de goma con la que se envolvían luego los y las participantes a fin de formar un cuerpo colectivo. ${ }^{10}$ Los movimientos imprevisibles y descoordinados de cada colaborador $\mathrm{o}$ colaboradora acababan provocando complicados anudamientos, enlazando a todos ellos y ellas en una maraña imposible de deshacer. La idea de la «tela de araña» emerge en este trabajo, una red que atrapa a una totalidad, ¿acaso pretendía la autora hacer alguna referencia al enmarañamiento formalista que caracterizaba los drippings de Jackson Pollock?

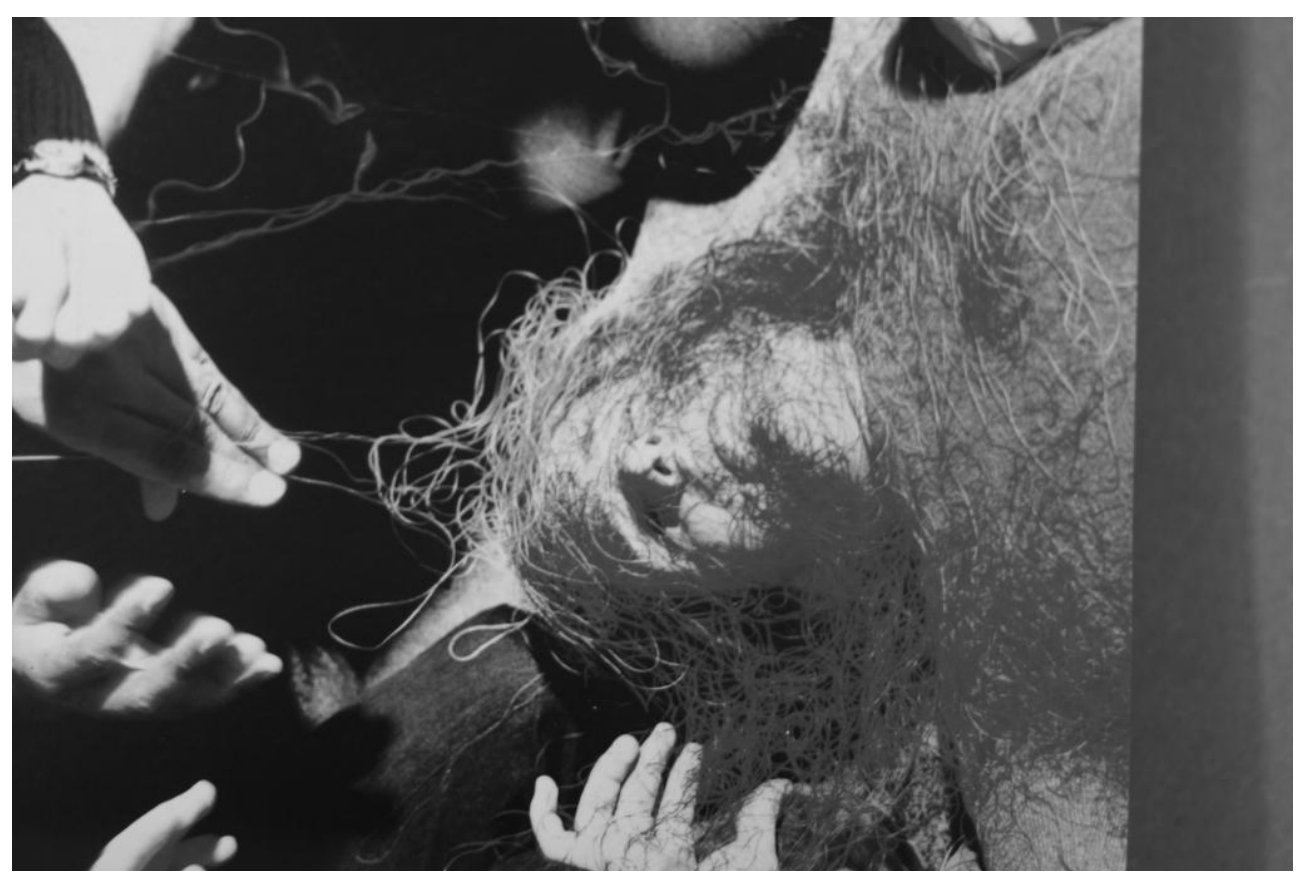

99. Lygia Clark - Baba antropofágica (1973)

Baba antropofágica (1973) nace como una síntesis de los últimos dos trabajos mencionados anteriormente. Varios y varias participantes rodeaban a una persona tumbada boca arriba, de la misma manera que en

\footnotetext{
${ }^{10}$ Para Lygia Clark, el Corpo colectivo se compone de un grupo cuyos integrantes viven propuestas juntos y se intercambian contenidos psíquicos. Cit. en CLARK, Lygia, "La casa es el cuerpo", en el catálogo de la exposición Lygia Clark, op. cit., p. 306.
} 
Canibalismo, aunque esta vez ninguno tenía los ojos vendados ni estaba vestido o vestida con ningún traje especial. Cada uno y cada una de los participantes portaba en el interior de su boca un carrete de hilo, de cuyo extremo tiraba con las manos para sacarlo afuera, impregnado de saliva.

Los hilos - de todos los colores y sabores - se mezclaban sobre el o la participante tumbado y acababan envolviéndolo, haciendo que su cuerpo se convirtiera en un vínculo físico, visual y gustativo de todo el grupo. La unión de las salivas era algo real, y su solidificación materializada en hilos evocaba claramente la producción de tejido que realizan algunas mariposas y arañas. Siguiendo a Ramírez, podemos señalar que el o la yacente se presentaba como una especie de víctima a devorar, atrapado o atrapada por la tela informe tejida por el resto de participantes, aunque también podía sentirse como una crisálida envuelta en el capullo multicolor tejido con las babas sólidas de sus madres-hermanos, lista para una resurrección apoteósica (mariposa simbólica), elevada ya a un estado de conciencia superior tras esa ceremonia regeneradora.

Tal y como asevera el citado historiador del arte, nada expresa tan bien como esta obra la gran riqueza de implicaciones del trabajo sensorial de Lygia Clark. Este ámbito de actividad le llevó desde una preocupación por la toma de conciencia de las potencialidades de cada persona hasta la integración del cuerpo individual en una entidad colectiva. No se trató de una actividad solipsista, pues ella fue plenamente consciente de la dimensión revolucionaria de su actividad. ${ }^{11}$

Son muchas las lecturas que podemos hacer de las obras de aquellos años, pero parece ineludible sugerir, en cualquier caso, la voluntad de poner en marcha diversos procesos interactivos. Según asevera Suely Rolnik, a través de la obra de la artista brasileña nos enfrentamos a un dispositivo en perpetuo movimiento de atracción y repulsión capaz de producir múltiples

${ }^{11}$ RAMÍREZ, Juan Antonio, op. cit., p. 168. 
sensaciones desconocidas y, al mismo tiempo, imposibles. ${ }^{12}$ Lygia Clark nos invita no sólo a buscar el cuerpo ajeno, sino a sentirlo. Sus «extensiones» devienen máquinas hiperbólicas para la apropiación física del otro, y el aspecto vagamente mecánico o industrial de sus construcciones parece acentuar tal dimensión. Dicho de otra manera, las «extensiones corporales» hacen factible —en el ámbito metafórico del arte — lo que no parece posible en el de la estricta realidad carnal. Con ello nos referimos a la creación de lo que Lygia Clark llamó «el cuerpo colectivo», algo estrechamente conectado con unas prácticas analíticas de invención propia, desarrolladas en un territorio híbrido que se nutre de los experimentos pedagógicos libertarios de la terapia de grupo y del más clásico psicoanálisis. Se trataba siempre de performances artísticas de difícil clasificación cuyo interés se ha ido acrecentando a medida que han pasado los años.

Los trabajos de Lygia Clark entroncan de manera asombrosa con los experimentos, también de carácter sensorial, de la artista alemana Rebecca Horn (Michelstadt, 1944). Revisando su formación artística de manera somera nos damos cuenta de que la autora pertenece a una generación que no tuvo ni el informalismo ni la abstracción normativa como ejes de referencia. Quizás fue por ello por lo que arrancó con una trayectoria compleja que le ha llevado a elaborar ambiciosas instalaciones y a que su obra se halle en la actualidad en pleno desarrollo. ${ }^{13}$

Rebecca Horn, como si se tratase de una mujer del renacimiento - escultora, performer, cineasta y poetisa - ha mantenido, como poética constante en su trabajo, una especial predilección por los autómatas. Poco después de finalizar sus estudios emprendió un sugestivo recorrido entre

\footnotetext{
${ }^{12}$ ROLNIK, Suely, "Lygia Clark et la production d'un état d'art", en el catálogo de la exposición L'art au corps. Le corps exposé de Man Ray à nos jours, Marseille, Macgaleries contemporaines des Musées de Marseille, 1996, p. 278.

${ }^{13}$ Rebecca Horn recibió su formación artística en la Escuela Superior de Artes Figurativas de Hamburgo y en la Escuela de Arte St. Martin de Londres. Entre 1972 y 1981 residió en Estados Unidos, donde desarrolló, además de su trabajo creativo, algunas actividades docentes.
} 
performances que se caracterizaban por temáticas relativas al propio cuerpo y su sistema sensorial. Estas primeras obras - y en última instancia las que le siguieron - se caracterizaron por el estrecho vínculo que establecía la autora entre el ser humano, el movimiento y el objeto. Su trabajo conforma verdaderos estudios sobre un cuerpo visto como fragmento, prótesis $\mathrm{y} / \mathrm{o}$ prolongación. En definitiva, como anuncio de una presencia de la máquina en tanto que «extensión corporal» a través de añadidos apropiados para una especie de ritual que nos permite tomar conciencia de nuestro propio yo. ${ }^{14}$

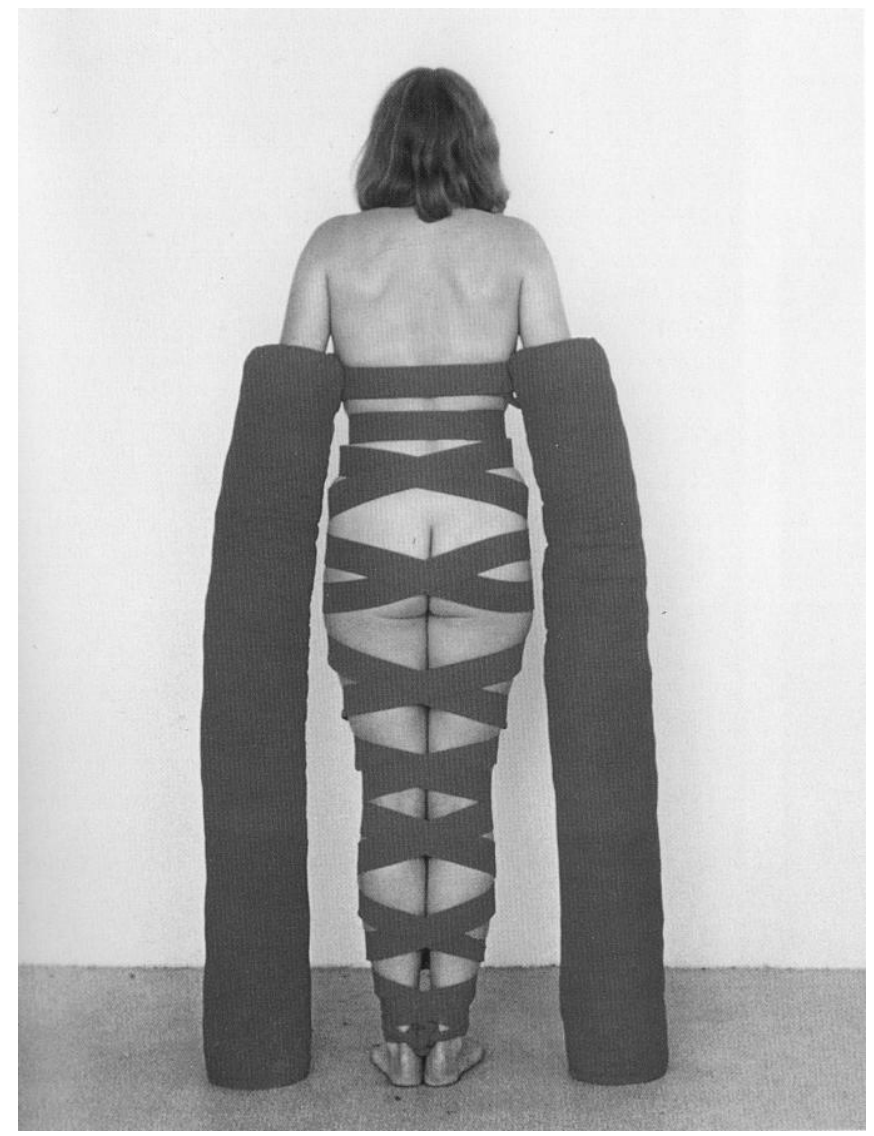

100. Rebecca Horn - Arm-Extensionen (1970)

14 FERNÁNDEZ-CID, Miguel, "Rebecca Horn en el CGAC", en el catálogo de la exposición Rebecca Horn, Santiago de Compostela, Centro Galego de Arte Contemporánea, 2000, p. 9. 
Entre sus primeros trabajos significativos figura Arm-Extensionen y Rüssel, ambos de 1968. El primero de ellos transforma las extremidades del cuerpo humano: los brazos devienen piernas, mientras que las piernas, atadas, desaparecen como tales. Horn describe el trabajo de la siguiente manera: «From her chest to her feet she is wrapped in criss-crossing bandages like a mummy. All movement becomes impossible. Both arms are imbedded in thickly wadded stumps, which serve as balancing props for her body. After being tied up for a while, the subject gains the impression that, in spite of her erect posture, her arms are gradually touching the ground, as if they were actually growing into the floor and turning into 'isolating columns' fixed to her own body». ${ }^{15}$

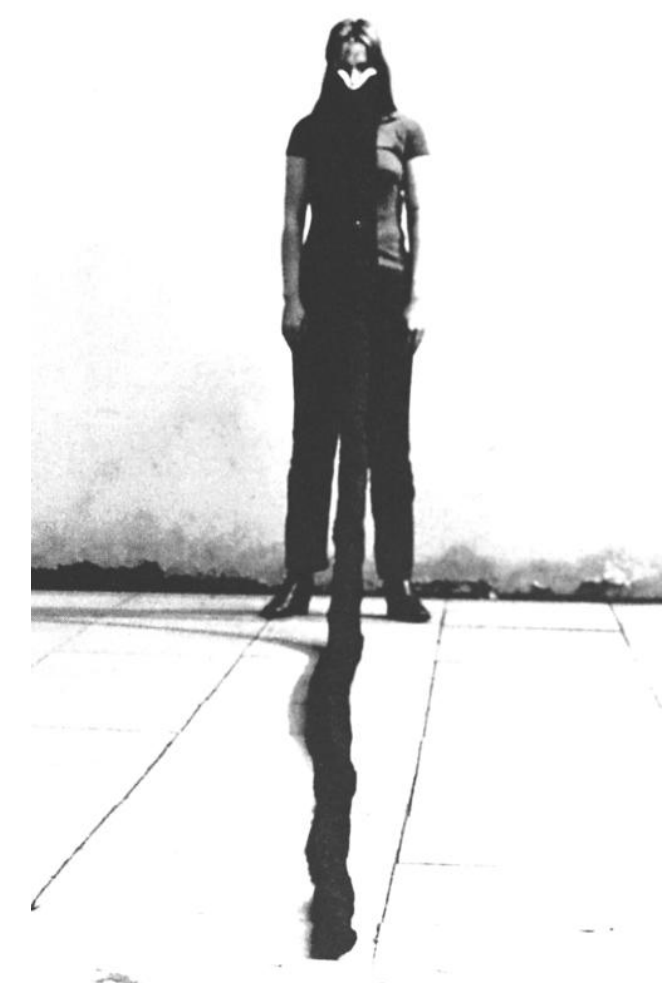

101. Rebecca Horn - Rüsel (1968)

${ }^{15}$ HORN, Rebecca, "Arm Extensions", en el catálogo de la exposición Rebecca Horn: The Inferno-Paradiso Switch, New York, Solomon R. Guggenheim Foundation, 1993, p. 69. 
Rüssel consistía en una especie de saco largo y estrecho de tela que se adosaba a la parte inferior del rostro, como si se tratase de una máscara, lo que hacía que la obra recordara - en cierta manera - a Máscaras abismo de Lygia Clark. Estos primeros estudios estaban, de algún modo, subordinados al tema de la anatomía femenina pero, lejos de presentar nociones armoniosas de un ideal de belleza, mostraban un cuerpo frágil e incluso maltratado. ${ }^{16}$

Poco después de materializar estas piezas pioneras, Horn fue hospitalizada a causa de una infección pulmonar grave. No es aventurado conjeturar que su internamiento clínico contribuyó a reforzar el interés por el arte corporal y a conformar algunas de sus obras. En este sentido, sus extensiones revelan una clara necesidad de autoprotección: «Pendant ces longs mois, je me sentais très isolée, et je me suis mise à écrire, beaucoup pour survivre. Et, simplement pour établir des contacts avec les autres, avec le monde, j'ai commencé à réaliser des objets très personnels, des sculptures corporelles, pour des gens que je connaissais»». ${ }^{17}$

De esta manera Horn diseñó toda una colección de artilugios capaces de ampliar las actividades orgánicas propias de las personas. Aunque imposibilitada aún para asistir a las clases debido a la continuación de los tratamientos médicos, desarrolló sus primeras esculturas corporales con la ayuda de compañeros y compañeras. En 1970 Horn transformó los artilugios médicos biomecánicos que habían esclavizado su vida en una serie de esculturas pseudo-médicas diseñadas para el conocimiento físico $\mathrm{y}$ sensorial. En aquella época trabajaba siempre con un objetivo, con una persona fija que ella elegía y que constituía el centro de cada acción. Los participantes se desvestían y se ponían las nuevas «extensiones corporales»

\footnotetext{
${ }^{16}$ ZWEITE, Armin, "Bodylandscapes de Rebecca Horn. Dez apontamentos sobre a corrida dos sentimentos e o desenho na era pós-mecânica”, en el catálogo de la exposición Rebecca Horn: Bodylandscapes. Desenhos, esculturas, instalações 1964-2004, Lisboa, Fundação Centro Cultural de Belém, 2005, p. 14.

${ }^{17}$ DURAND, Régis, "Rebecca Horn. Danger imminent", en Art Press, no 181, Paris, junio 1993, p. 12.
} 
que Horn había concebido. De este modo se establecía un diálogo muy próximo y directo entre un individuo y la propia autora. Las piezas estaban destinadas a comunicar una energía muy específica que funcionaba en el marco de una relación muy concreta, en un contexto específico. Tal y como afirma la autora, era como un rito de iniciación. Este ejemplo se materializa en Der Überstromer y Cornucopia, Séance für zwei Brüste. ${ }^{18}$

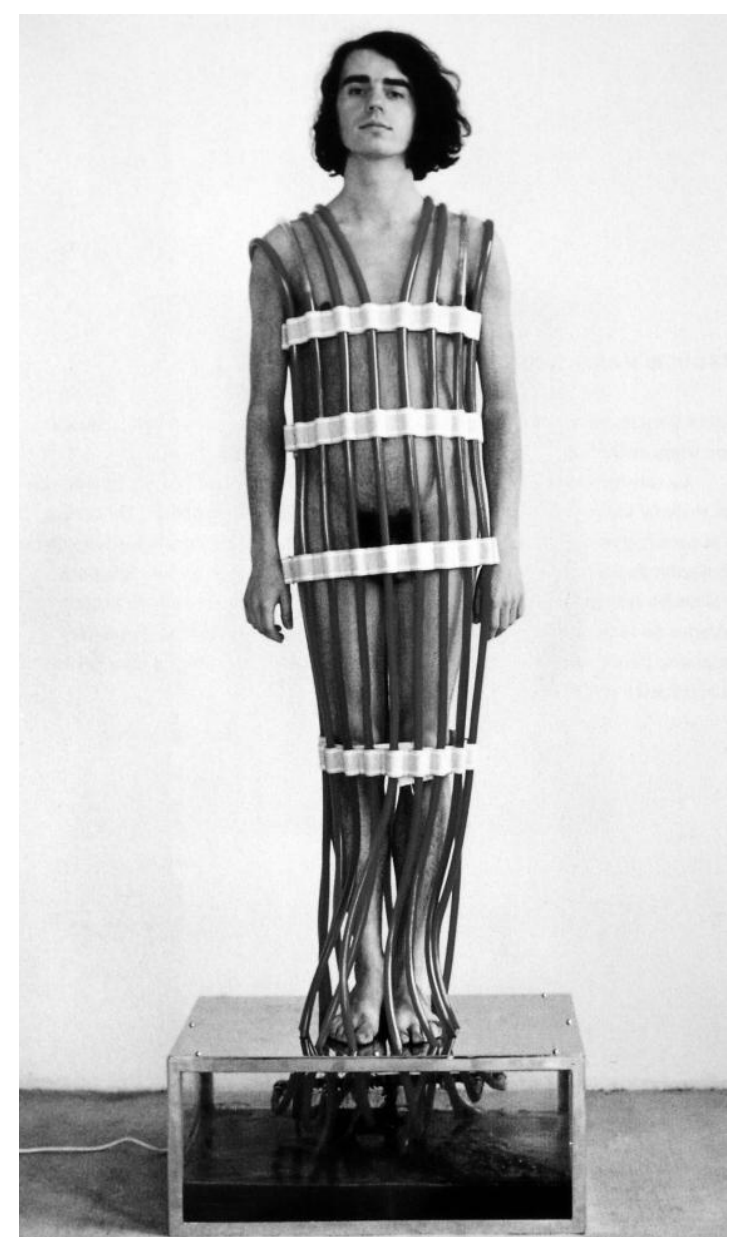

12. Rebecca Horn - Der Überstromer (1970)

18 EDELSZTEIN, Sergio, "Envoltorio de plumas - camisa de fuerza desgarrada. Representaciones de papeles para cuerpos animados e inanimados", en el catálogo de la exposición Rebecca Horn, op. cit., pp. 69-70. 
En el primero de estos trabajos, cuatro correas abrazaban ocho tubos unidos a una base de cristal en la que permanecía una persona. Una bomba situada en la base impulsaba sangre rítmicamente a través del sistema vascular exterior. Las ideas acerca de lo público y lo privado quedan diluidas y el concepto de interioridad pierde su absoluta intimidad. El líquido rojo es impulsado y depurado por un nuevo corazón mecánico que nutre a través de toda una serie de influjos la fragilidad de un cuerpo desnudo.

Cornucopia, Séance für zwei Brüste acentuaba mucho su similitud con los trabajos de Lygia Clark, pues consistía en un tubo de tela que unía la boca con los pechos desnudos de una portadora femenina. Horn tenía gran interés en reforzar con estas imágenes lo que podríamos denominar autoconciencia del cuerpo. Según recogía la autora, sus «extensiones corporales» generan una sensación de diálogo, «el espacio interior directo que comunica la boca y el pecho crea el deseo de hablarles y de percibir individualmente ambos pechos, aislados de su entorno y separados el uno del otro: la propia facultad perceptiva se amplía para convertirse en triángulo y proporciona individualidad a cada pecho, cual si fuesen dos seres separados entre sí»». ${ }^{19}$

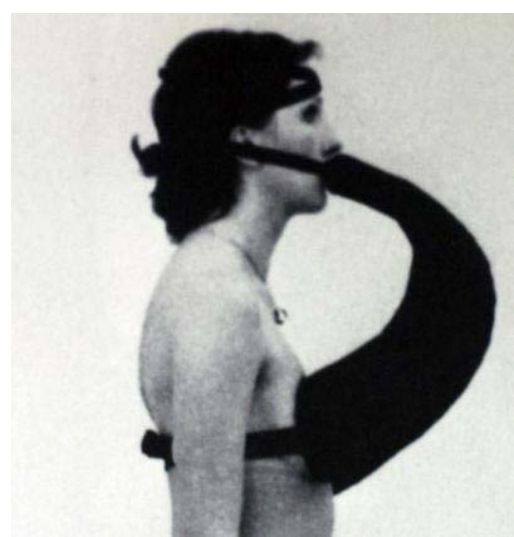

103. Rebecca Horn - Cornucopia, Séance für zwei Brüste (1970)

${ }^{19}$ HORN, Rebecca, "Sesión para dos pechos", en el catálogo de la exposición Rebecca Horn, op. cit., p. 46. 
En otra serie de trabajos se nos muestra el cuerpo transformándose enigmáticamente: al ser humano le brotan cuernos, plumas y alas, transformándose en una variedad de criaturas que poseen cierta relación mitológica. Así, Einhorn (1970) hace alusión inmediata al unicornio. ${ }^{20}$ Una modelo semidesnuda lucía sobre el cráneo una especie de cucurucho blanco portado en posición vertical. Unas cintas de idéntico color al del particular sombrero ocultaban ciertas zonas de su cuerpo. La documentación visual de aquella pieza nos muestra a la joven caminando por el campo, entre unos trigales, evidenciando así las referencias míticas del ente evocado en el título, y reforzando su asociación secular a la pureza virginal y a la fertilidad.

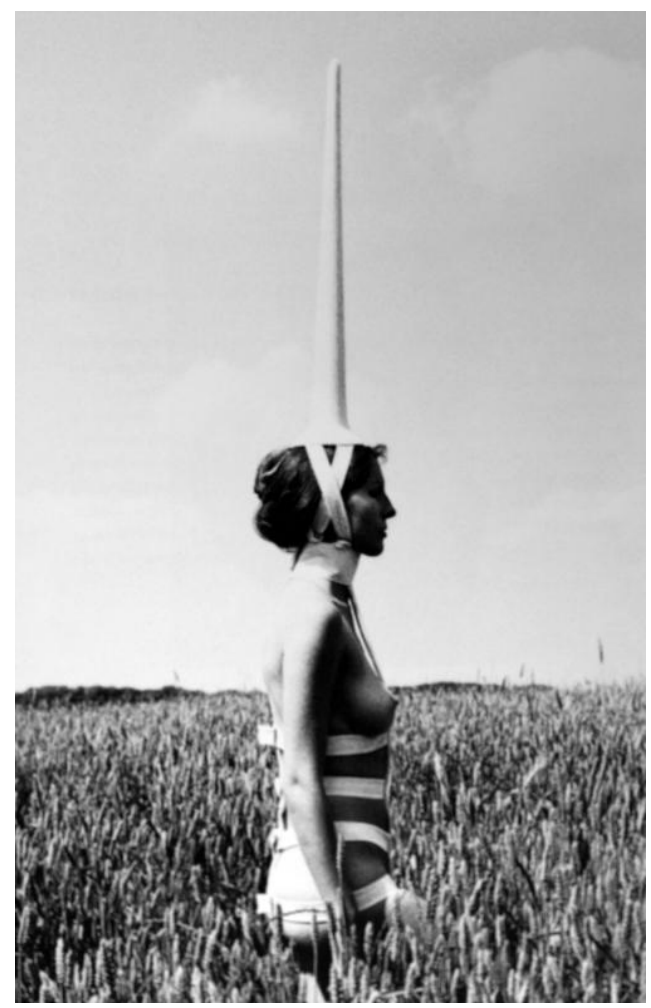

104. Rebecca Horn - Einhorn (1970)

\footnotetext{
${ }^{20}$ El unicornio es un animal mitológico totalmente blanco, con cabeza y patas de caballo y un largo cuerno recto situado en medio de su frente. Simboliza la santidad y la castidad.
} 
En 1972 Harald Szeeman pidió a la artista que presentara sus performances en Kassel. Se celebraba la Documenta $V$, para la que se había propuesto el tema «mitologías privadas». Rebecca Horn creó una estructura similar a un enorme cucurucho negro de unos cuatro metros de altura, realizada con varas revestidas de tela que fijó sobre la cabeza de un hombre de modo que impedía la visión de éste. El modelo estaba ataviado con ropas oscuras y situado en el centro de un grupo de colaboradores. Como ocurre constantemente en los trabajos de la autora, la idea de Kopf-Extension no es negar la vista sino, a través de su ocultación, ser consciente de ella, intensificarla. ${ }^{21}$

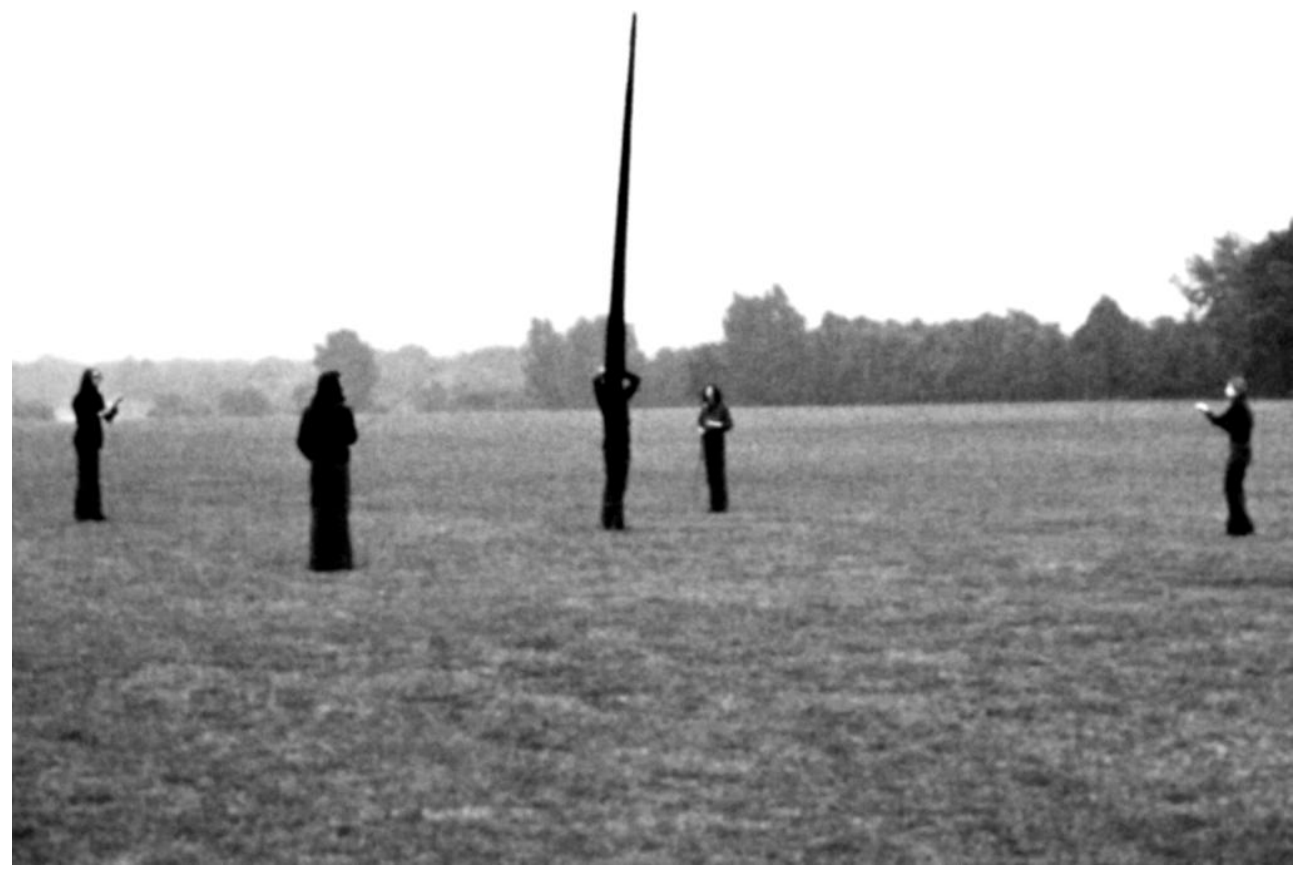

105. Rebecca Horn - Kopf-Extension (1972)

Las obras que acabamos de mencionar suministran algunas pautas comunes a todo el trabajo comprendido entre esos años. Se trataba siempre

${ }^{21}$ HAENLEIN, Carl, "Time Goes By (El tiempo pasa)", en el catálogo de la exposición Rebecca Horn, op. cit., p. 13. 
de prótesis o «extensiones» que se colocaban de forma temporal los y las participantes -entre los que podía figurar o no la propia autora. Al respecto, manifiesta Horn: «Para todas las acciones realizadas entre los años 1968 y 1972 se estableció un número fijo de participantes, por cuanto sólo un círculo reducido hace posible la percepción interpersonal; es decir, no debe alzarse una barrera entre el actor o actriz y el público pasivo, sólo hay participantes. Cada acción cuenta con una figura central, punto de referencia de todos los actos. Esta persona lleva el instrumento, que permite a los otros participantes comunicarse con ella. El "estar-situado-en-el-centro", con la atención de los demás puesta en el propio cuerpo, transmite la sensación de un ritual de iniciación. A la acción le precede un proceso que cuenta con la participación de la persona elegida. A partir de esta confrontación de deseos, proyecciones y representaciones surge un esquema sobre cómo y con qué se representa y se enfrenta la persona. El instrumento se construye y se adapta al portador o portadora. El hecho de probarlo, de adaptarlo y de llevarlo varias veces genera un mecanismo de identificación esencial para la acción. La persona permanece aislada durante la acción, apartada de su entorno cotidiano, permitiendo así una percepción ampliada de sí misma»». ${ }^{22}$

El deseo de jugar con los instrumentos de tortura y con la iconografía convencional del sadomasoquismo pareció inspirar la ejecución de Bleistiftmaske (1972), que era una especie de capucha elaborada con cintas negras verticales y horizontales de la que emergían hacia fuera amenazadores pinchos que no eran, en realidad, más que afilados lápices. Con ellos, moviendo la cabeza, podían hacerse dibujos semiautomáticos sobre un papel o lienzo dispuesto al efecto, una acción corporal que sintetiza el pensamiento conceptual con el procedimiento emocional. Este trabajo, nada ajeno a una estética punk, empieza a manifestarse por entonces como una dura alternativa corporal al candor floral y hedonista de los hippies. Lo cierto es que Rebecca Horn proporcionaba una curiosa negación de la impresión sádica inicial — los pinchos no hieren sino que dibujan — y eso es

${ }^{22}$ HORN, Rebecca, "Sesión para dos pechos", en el catálogo de la exposición Rebecca Horn, op. cit., p. 46. 
algo que contó también mucho en el significado de otros trabajos posteriores, como Hahnenmaske y Kakadu-Maske (ambas de 1973). En dichas obras el rostro de las portadoras estaba cubierto de plumas - negras y blancas respectivamente - y con ellas se podía acariciar a los y las demás; también era posible que otro u otra participante abriera esas máscaras con sus manos para ver la cara oculta tras las plumas. ${ }^{23}$

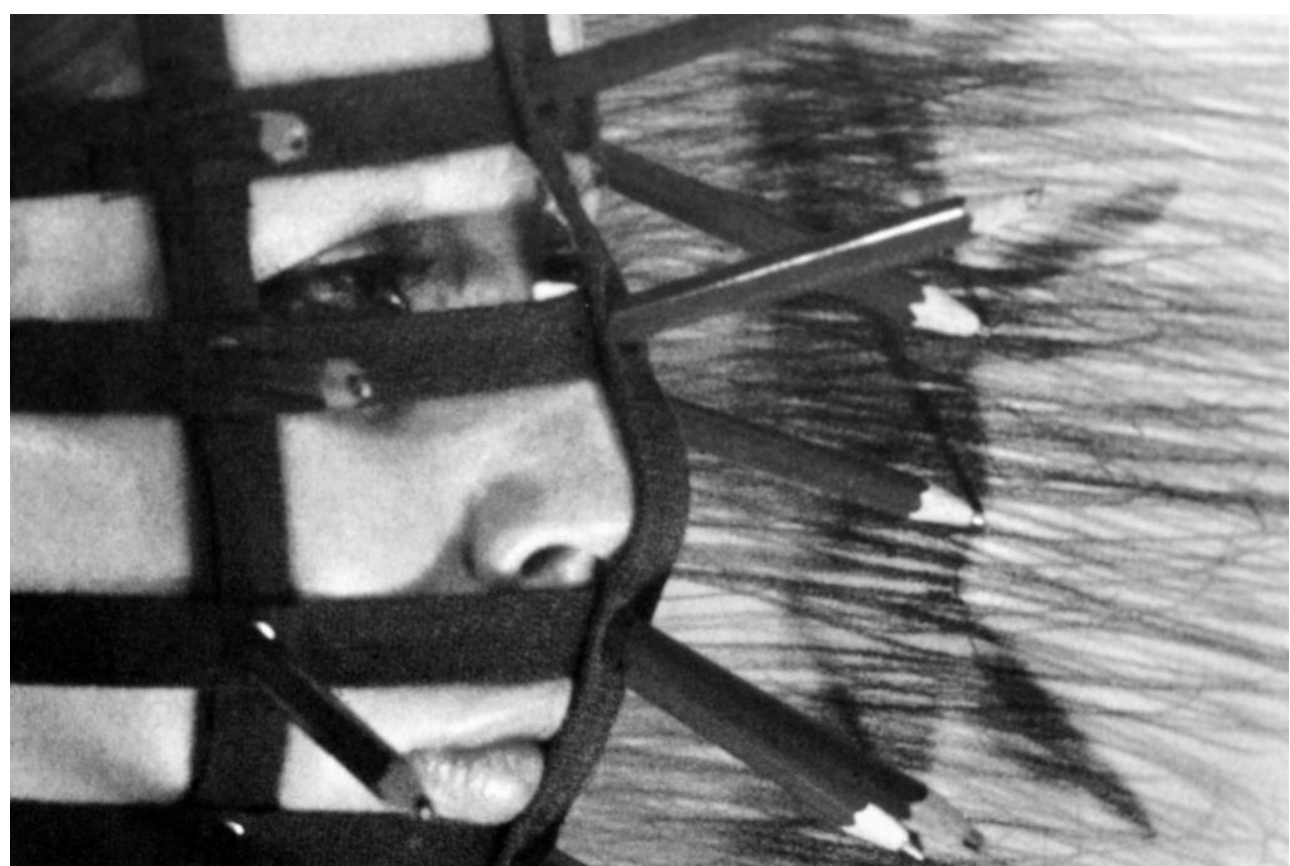

106. Rebecca Horn - Bleistiftmaske (1972)

Existía en ello una obvia metáfora del descubrimiento psicológico y también sexual. Algo que se evidencia mucho más en otros trabajos en los que todo el cuerpo está afectado por el envoltorio o la prótesis creados por la artista: Hahnengefieder (1971), Weisser Körperfächer (1972) o Der Eintänzer (1978). La referencia a un sexo femenino gigantesco, que se abre a quien observa, es lo que parece haberse evocado en todos estos casos, ya

${ }^{23}$ HORN, Rebecca, "Rebecca Horn. Sculptures, Installations, Films, Texts", en el catálogo de la exposición Rebecca Horn. Diving through Buster's Bedroom, Los Angeles, The Museum of Contemporary Art, 1990. 
sea confeccionándolo con plumas en las obras de 1971 y de 1978, o con una liviana tela blanca en la de 1972. En cualquier caso, nos hallamos siempre ante maravillosas esculturas móviles que parecen convertir los cuerpos de sus portadores en «obras de arte».

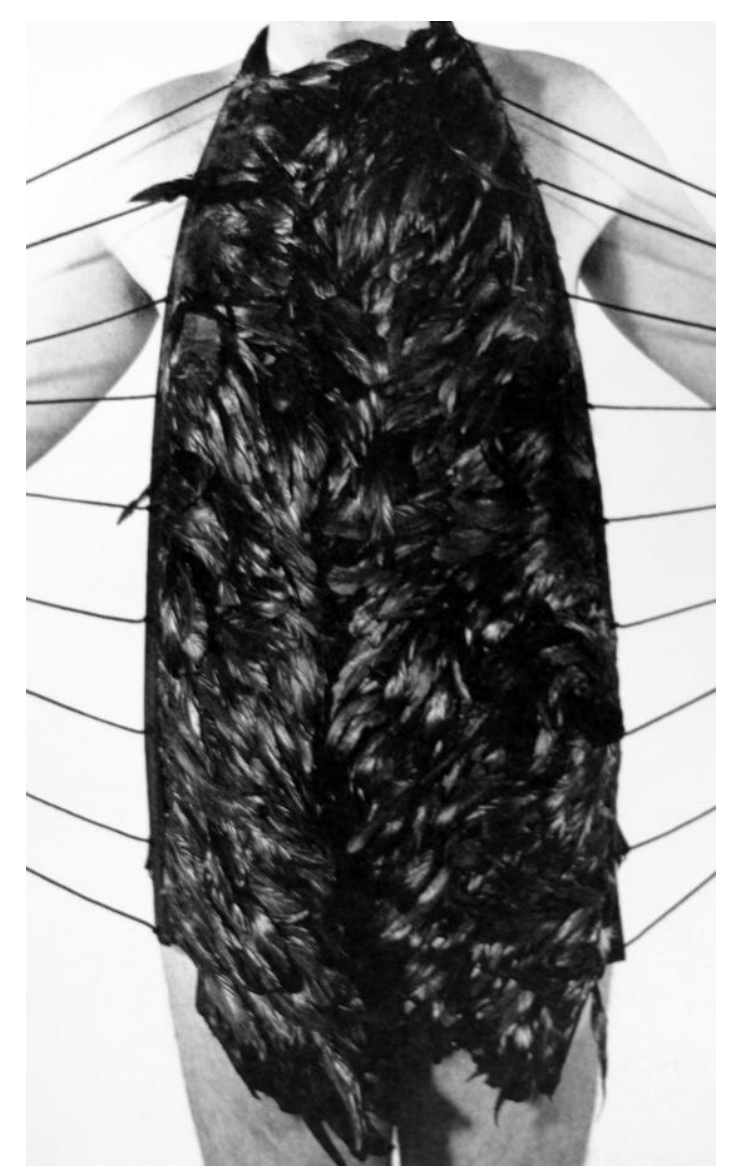

107. Rebecca Horn - Hahnengefieder (1971)

La finalidad de Rebecca Horn, sin embargo, era algo diferente: se trataba de transgredir el mero esteticismo formalista para contribuir a incrementar el ámbito de la experiencia sensorial y psicológica del ser humano. Imposible olvidar, en este sentido, las prolongaciones prostéticas para los dedos de ambas manos que concibió en 1972 y que tituló Fingerhandschuhe. En esta pieza el acto de tocar se convertía en algo 
insólito, gracias a una percepción táctil extendida. No se trataba de anular el tacto sino de llevarlo al límite, eliminando la percepción del detalle - la anécdota - para asumir y ser conscientes de dicho acto desde el mismísimo interior. Ello le permitió documentar, en 1974-75, la acción Gleichzeitig die Wände berühren. La artista, situada en el centro de una habitación de dimensiones medianas, tocaba ambos muros laterales gracias a una desmesurada extensión artificial de sus dedos. Pero esa especie de guantes daban a sus brazos extendidos una apariencia de alas, más o menos esqueletizadas, como si fuera posible para ella iniciar ese vuelo liberador al que han aspirado, con mucha frecuencia, diferentes cultivadores del arte corporal. Se puede apuntar, por ello, que prótesis, ropas y artificios parecen sólo meras extensiones auxiliares para lograr la felicidad. ${ }^{24}$

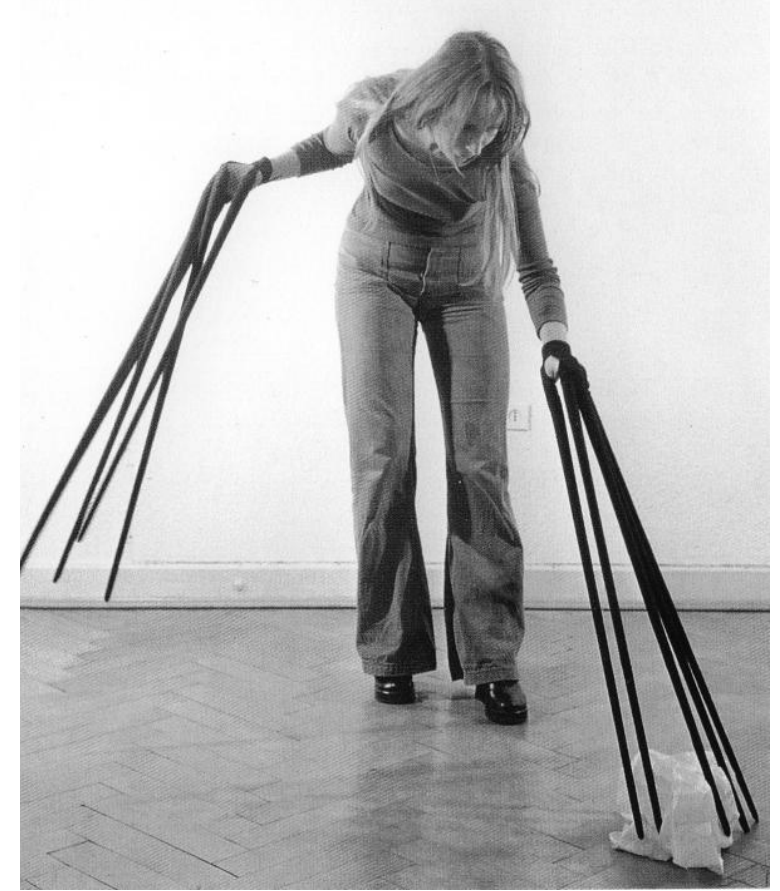

108. Rebecca Horn - Fingerhandschuhe (1972)

${ }^{24}$ RAMÍREZ, Juan Antonio, op. cit., pp. 173-174. 
A través de su obra, Rebecca Horn hurga en aquellas experiencias límite de la propia existencia y, exteriorizadas en acciones, las hace extensibles al espectador o espectadora bajo poéticos elementos que, autónomos y descontextualizados, adquieren el halo de objetos bellos, sin desprenderse, sin embargo, de la fuerza y del desasosiego inherente al momento en que fueron utilizados. Todos sus trabajos son cuestiones de historias personales y de interacciones con el espacio habitado en el momento de su creación.

La autora se vale de diversas «extensiones corporales» para — ayudada de su carga simbólica - explotar un potencial que le permita introducirse en ámbitos que escapan a las limitadas visiones de la realidad y que, por otra parte, están fuertemente adheridas a sus limitaciones a través de vendajes y ataduras. Horn se une a sus esculturas, manipulando y proyectando sensaciones corporales y sentimientos. Tal y como afirma José Luis Clemente, Rebecca Horn penetra territorios donde indefensión y autosuficiencia, coacción y rebeldía, se baten en un conflicto anímico en el que vence el complejo entendimiento entre arma y contendiente, entre objeto y sujeto. $^{25}$

\subsection{El cuerpo obsoleto. La «ciberestética» y el teatro de operaciones}

El avance tecnológico de la sociedad occidental solicita un cambio radical en el ser humano. La eterna lucha de éste contra el sufrimiento, la imperfección y la muerte se lleva cabo gracias a tecnologías como la

\footnotetext{
${ }^{25}$ CLEMENTE, José Luis, "El vuelo de Rebecca Horn y la armonía entre la naturaleza y la máquina: The Inferno Paradiso Switch", en Kalias. Revista de arte, n 11, Valencia, IVAM, 1994, p. 165.
} 
biónica, ${ }^{26}$ la biotecnología ${ }^{27}$ o la eugenesia, ${ }^{28}$ las cuales están cambiando la concepción de la vida y la relación con el cuerpo.

Especular sobre las posibilidades del cuerpo es una clara invitación a imaginar que el poder humano ha sobrepasado potencialmente al de la naturaleza. Ello se percibe como una nueva utopía, pero además plantea una idea ancestral: alcanzar el verdadero control sobre la vida humana. En la tradición fantástica - desde Frankenstein a Blade Runner - el diseño de un nuevo orden humano post-natural ha intentado alcanzar esta combinación. Prótesis, siliconas, colágeno, cirugía estética, marcapasos, cirugía de cambio de sexo, terapia genética, implantes artificiales de órganos, etcétera, impiden distinguir nature de nurture, lo natural de lo producido. ${ }^{29}$

Al socaire de una sociedad rehén de la industria tecnológica, aparecen nuevos acercamientos al cuerpo que consideran a éste como un soporte de lo falso, de lo artificial y lo simulado más allá del ilusionismo vinculado al discurso clásico de la representación. Partiendo de las teorías postestructuralistas, las cuales entienden la construcción del yo de una manera conceptual más que natural y de que el organismo humano —al margen de la evolución darwiniana - puede construirse con la ayuda de diferentes medios, algunas prácticas corporales apuntaron, a inicios de la década de 1970, hacia un nuevo modelo de individuo. Nos adentraremos pues en un patrón definido que ya nada tiene que ver con los discursos de carácter freudiano y que ensambla al individuo psicológico con su pasado y con su código genético.

El ser humano lleva mucho tiempo delegando y mejorando sus funciones físicas y mentales a través de herramientas y protocolos:

\footnotetext{
${ }^{26}$ Ciencia puente entre la biología y la tecnología aplicada a las máquinas a través de la que se intenta copiar lo natural para hacer equivalentes artificiales.

${ }^{27}$ Aplicación de conocimientos y avances biológicos a procesos tecnológicos o de interés industrial.

${ }^{28}$ Ciencia de la manipulación genética que se ocupa de la aplicación de las leyes biológicas de la herencia al perfeccionamiento del proceso evolutivo de la especie humana.

${ }^{29}$ Véase apartado 1.2 de la presente Tesis.
} 
verbigracia, un hecho tan asimilado como la invención de la escritura deviene un artificio que ha servido para que nuestra memoria perdure. Somos continuos generadores y generadoras de una actividad limitada por nuestra propia constitución, no obstante, estas limitaciones inherentes son el origen de la experiencia y la clave para mejorarla. Probablemente no esté el cuerpo hoy en día más obsoleto que hace mil años.

Sin embargo — especialmente a partir de la Revolución Industrial—, el desarrollo tecnológico nos ha llevado a límites insospechados. La invasión y complementación de artilugios vinculados al cuerpo se ha transformado en un recurrido tema de investigación y experimentación a lo largo de todo el siglo XX. Debido a ello, hemos comenzado el XXI convertidos en verdaderos cyborgs, organismos cibernéticos, es decir, sujetos de naturaleza prostética, provistos de una infinidad de añadidos destinados a ampliar, corregir y/o subvertir una corporalidad limitada por nuestra propia fisicidad. Este presupuesto de raigambre extremadamente positivista sugiere que el cuerpo alcanzará su máximo potencial, tanto físico como psíquico, a través de toda una compleja «extensión» tecnológica.

Tal y como hemos ido viendo a lo largo de nuestro estudio, Marshall McLuhan muestra en su trabajo Comprender los medios de comunicación que nuestra realidad está conformada por una infinidad de «extensiones corporales», comenzando por los medios de comunicación y terminando por la más prosaica cotidianidad. Somos verdaderos cyborgs gracias al ordenador, al coche, a la vestimenta y cómo no, al influjo del tecnobiopoder que hace del sexo la más pura expresión —en palabras de Beatriz Preciado - de la «farmacopornografía». Hoy día —y cada vez más - el cuerpo es susceptible de cambio y modificación por la dictadura del diseño.

La reflexión relativa a un cuerpo re-formado por extensiones, anexos, accesorios y suplementos es la consecuencia de la evolución de estados anteriores que intentaban deconstruir los códigos establecidos y las supuestas verdades esenciales. Aquel cuestionamiento crítico del sujeto 
moderno se va a resolver en un cuerpo modificado, corregido, ampliado y/o reconstruido. Es innegable, por tanto, que el ser humano ha de valerse de «extensiones corporales» para afrontar el reto social. El cuerpo vive una «extensión», en este caso tecno-biomecánica y, al mismo tiempo, una amputación. En nuestra era tecnológica el individuo pierde la facultad de sentirse el centro de energía y se torna infructífero, completamente superfluo frente a una automatización de sus funciones productivas y perceptivas.

A continuación, trataremos de analizar el trabajo de dos artistas que han alcanzado una interesante notoriedad adoptando deliberadamente riesgos espectaculares: Orlan y Stelarc. Ambos han promovido - y lo hacen en la actualidad - el escándalo entendido como una trampa para la moralidad capaz de causar perplejidad y confusión ética. El escándalo, en este sentido, pone a prueba el terreno de la moral y la sitúa en una posición de riesgo. En la época postmodernista, donde el escándalo queda altamente publicitado, esto provoca diferentes respuestas desde diferentes estratos de la sociedad, pero quizás la más interesante sea la generación de ansiedad por parecer que se amenaza la armonía del orden establecido.

La imaginería tradicional sobre el cuerpo del futuro está gobernada por ideas predeterminadas. El cuerpo humano es un proyecto de diseño situado entre la ingeniería y las disciplinas estéticas y, por ello, interpretado de acuerdo con un marco de convenciones. ${ }^{30}$ En las últimas cuatro décadas Orlan y Stelarc han estado cuestionando tales cuestiones y, cada uno a su manera, han trabajado con el cuerpo como principal medio artístico. Sus experiencias parten de vías tradicionales y populares inmersas en la cultura occidental, y repercuten directamente sobre la corporeidad. A su vez, todo ello se desarrolla dentro de en un clima de intensa especulación sobre el

${ }^{30}$ GOODALL, Jane, "An Order of Pure Decision: Un-natural Selection in the Work of Stelarc and Orlan", en FEATHERSTONE, Mike (ed.), Body Modification, London, SAGE, 2000 , p. 149. 
futuro de nuestro propio cuerpo, de ahí que sus ideas logren entrar en importantes provocaciones.

Orlan y Stelarc han explorado la corporeidad a través de las normas en las que se recrean las formulaciones de la ansiedad cultural. Paralelamente, buscan desvelar cuestiones fundamentales sobre la naturaleza y los significados del cuerpo humano, cuestiones que son fácilmente excluidas por el imaginario colectivo. A partir de los años 1970, la lucha entre la libre voluntad frente al determinismo generó una nueva crisis que ya no puede encontrar su cobijo, en el tradicional sistema de valores, apelando a la última autoridad - Dios, Naturaleza o Destino. En la actualidad, la ética — si es que la puede pervivir - se configura como único procedimiento mediante el cual podemos elegir el curso de nuestro devenir. $^{31}$

Orlan y Stelarc nunca han trabajado ni colaborado conjuntamente, sin embargo sus trabajos ofrecen significados paralelos. Ambos tienen más aspectos en común que la mera creencia en el hecho de que el cuerpo está obsoleto. Su edad está próxima, los dos comenzaron a producir trabajos significativos a principios de 1970 , y se sitúan entre los pocos autores que han superado las modas confeccionando su desafío a través de las décadas posteriores. $^{32}$

Lamentablemente, esta serie de experiencias que caracterizaron los inicios del trabajo de estos artistas han permanecido completamente desconocidas en el ámbito plástico y han desestimado su clasificación en el panorama histórico-artístico de aquellos años. ¿Cuáles fueron los motivos por los que los especialistas del arte de los años 1970 omitieron este tipo de acciones?

${ }^{31}$ GOODALL, Jane, op.cit., p. 150.
${ }^{32}$ GOODALL, Jane, op. cit., p. 151. 
Llegados a este punto de la historia, el arte sólo tiene un código posible que evita el cortocircuito: el de la mutación. Muy próximos al fin de siglo XX el arte ha superado la idea de lo humano, el cerebro ha devenido una especie de brainware acelerado, que ha modificado la capacidad del ser humano y el proceso de re-combinación celular navegando en la dirección de una identidad completamente transgenética. La tecnología extiende y amplifica las funciones sensomotrices, psicológicas y cognitivas. ${ }^{33}$

Orlan (Saint-Étienne, 1947) sostiene junto con Stelarc la opinión de que el cuerpo humano está obsoleto y de que no ha tenido tiempo de adaptarse a la velocidad de los cambios de su entorno presente. El cuerpo es para ambos una estructura ineficiente, no resistente, sujeto a la enfermedad, débil y de muerte segura. ${ }^{34}$ Sin embargo, hay notables diferencias.

Orlan ha sido plenamente consciente de cómo el hombre se ha obsesionado por la creación del ideal femenino y, probablemente sea este el aspecto que consideramos más interesante de la autora. El cuerpo artificial, creado por la fantasía, ha servido durante siglos $-\mathrm{y}$ lo hace en la actualidad - como sustituto o sucedáneo y como espejo en el cual se proyecta un ideal. Para los artistas varones - en su mayor parte- la producción de ese ser ideal permitía generar un ente femenino más auténtico y verdadero que las mujeres reales. De este modo, se extinguía la otredad de la mujer real, de la que sólo el exterior servía como modelo para construir el ideal. ${ }^{35}$

El objetivo de tal proyección era un ser en el cual el hombre situaba su propio deseo. La destrucción de la muñeca - casi siempre acompañada por la muerte de aquél que pierde la cabeza por su hechizo - aparece en múltiples ocasiones en la literatura como castigo, pues esta mujer artificial,

\footnotetext{
${ }^{33}$ MACRÌ, Teresa, Il corpo postorganico, Milano, Costlan, 2006, p. 125.

${ }^{34}$ LANDI, Oscar, "Mutantes de fin de siglo". Véase www.afbuenosaires.com/expos99/orlanzona.htm.

${ }^{35}$ PEDRAZA, Pilar, Máquinas de amar. Secretos del cuerpo artificial, Madrid, Valdemar, 1998, pp. 19-28.
} 
al mismo tiempo encarnación de la pureza y expresión de las obsesiones sexuales, representa una amenaza para el orden social que únicamente puede conseguirse ocultando y marginando aquello que es diferente. ${ }^{36} \mathrm{El}$ trabajo de Orlan, por tanto, podría ser concentrado en una excéntrica investigación sobre la construcción del ideal femenino a lo largo de la historia y la reivindicación de una identidad propia.

Durante la década de los años 1960 utilizó su propio cuerpo en una serie de denuncias feministas y sociales cuyo objetivo consistía en inquietar a una cultura francesa un tanto chauvinista. Los primeros trabajos de Orlan consisten en instalaciones y esculturas, verdaderos ejercicios de travestismo y striptease o performances como Étude documentaire: la tête de Méduse, trabajo en el que mostraba su sexo con la mitad del vello púbico pintado de azul a través de un vidrio de aumento en pleno período menstrual. Unos monitores de vídeo mostraban los rostros de quienes llegaban, así como las perplejas expresiones de quienes miraban y de quienes se iban. A la salida repartía un texto de Freud sobre la cabeza de Medusa que decía lo siguiente: "At the sight of the vulva, the devil himself flees». ${ }^{37}$

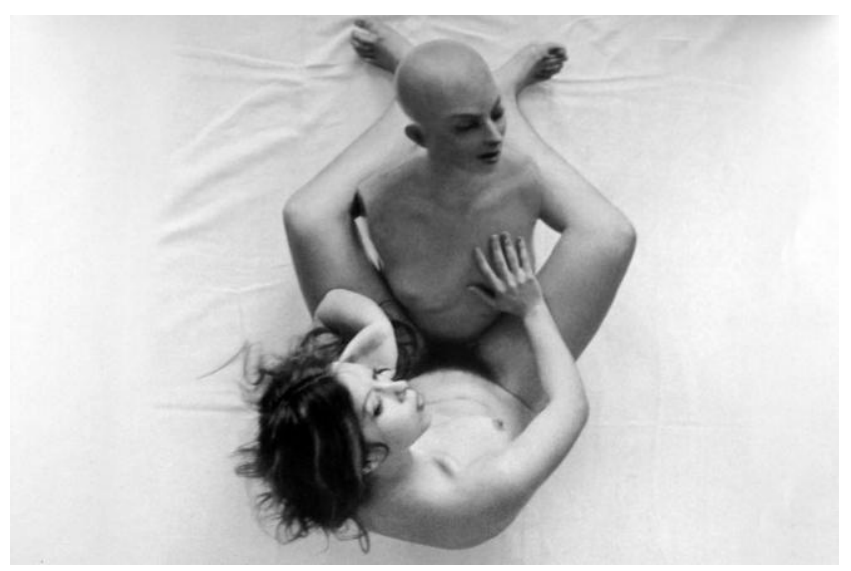

109. Orlan - Orlan accouche d'elle m'aime (1964)

\footnotetext{
${ }^{36}$ Para un análisis sobre el imaginario de la mujer artificial en la literatura véase: ALBIAC, Gabriel, Caja de muñecas, Barcelona, Destino, 1995.

${ }^{37}$ Cit. en CLARKE, Julie, "The Sacrificial Body of Orlan", en FEATHERSTONE, Mike (ed.), op.cit., p. 191.
} 
En 1964 realizó Orlan accouche d'elle-m'aime, una fotografía en la que muestra el deseo de darse a luz a ella misma, de convertirse en su propia madre y su propio producto. Cuatro años después inició su primera serie de performances recogidas bajo el título Les draps du trousseau (Les tableaux vivants: situations-citations) en la que remontándose a la tradición, posó según obras pictóricas célebres como La grande Odalisque de Ingres, La maja desnuda de Goya o El nacimiento de Venus de Botticelli, esta última utilizada frecuentemente como decoración de sus posteriores escenariosquirófanos. $^{38}$

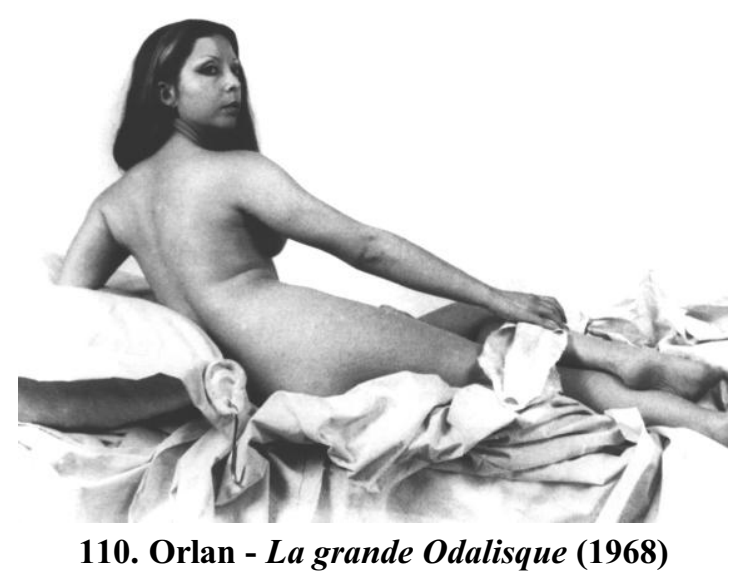

38 DONGUY, Jacques, "Entretiens \& textes", en el catálogo de la exposición L'art au corps..., op. cit., p. 206. 
En 1971 creó un autorretrato fotográfico de ella misma — Sainte Orlan. A través del mismo conformaba un gesto reverente y blasfemo al mismo tiempo: reverente en el sentido de su reconocimiento de la potencialidad de la iconografía judeo-cristiana, blasfemo en su détournement de la imagen sagrada. En su trabajo, las imágenes diseñadas para producir una mezcla de intoxicación espiritual y disciplina física son transformadas en fuentes de intoxicación física y provistas de bases para una disciplina estética que es profundamente material. Aunque existe una especie de reverencia en la adhesión a las imágenes, no hay vinculación a la estructura con la que éstas han servido para crear. Existe una profunda blasfemia en la paródica apropiación de lo religioso junto con el rechazo de una identidad social. Juan Antonio Ramírez subraya la implicación erótica, la representación típicamente barroca $^{39}$ de mostrar el arrebato místico mediante expresiones reconociblemente carnales con gestos y detalles significativos. ${ }^{40}$ De este modo, Orlan reconoce y explota el estado crucial del cuerpo como lo que delimita el propio yo y otorga el significado por el cual el sobrealcance debe ser humilde.

En 1977 realizó para la Feria Internacional de Arte Contemporáneo la acción Le baiser de l'artiste. Junto a Orlan se erigía una peana sobre la que se había colocado una silueta de plástico en la que figuraba un torso femenino desnudo atravesado por un canalillo transparente. En la parte superior se podía insertar una moneda de cinco francos que desembocaba en un contenedor triangular situado en la zona púbica de la figura. El espectador o espectadora que pagaba recibía un intenso beso de la artista ambientado por unos compases de la Toccata en si menor de Bach, el ósculo era interrumpido por el sonido de una estridente sirena eléctrica.

\footnotetext{
${ }^{39}$ Para una reflexión sobre las implicaciones barrocas en la obra de Orlan véase ENRICI, Michel y NOËL BRET, Jean, "El triunfo del barroco. Entrevista con Christine BuciGlucksmann", en el catálogo de la exposición Orlan. 1964 - 2001, Álava, ARTIUM Universidad de Salamanca, 2002, pp. 42-65.

${ }^{40}$ RAMÍREZ, Juan Antonio, "Frankenstein, Jekyll, panóptico: omnipresencia de Orlan”, en el catálogo de la exposición Orlan. 1964 -2001, op. cit., p. 68.
} 
Al lado de la peana se situaba un modelo de cartón-piedra que representaba a Sainte Orlan. En este caso, el público podía insertar una moneda en la imagen religiosa y, en lugar de un beso, se ofrecía la posibilidad de encender una vela a la Madonna. La oposición entre estas dos imágenes femeninas - la santa y la prostituta - representa dos extremos incompatibles, de modo que quien presencia la obra se enfrenta a dos roles conflictivos en los que la figura femenina se disloca a causa de un imaginario masculino profundamente estereotipado. La actitud experimental de Orlan sobre la corporeidad pertenece a un proyecto que se enfrenta directamente contra el poder del conservadurismo asociado directamente al sistema de creencias judeo-cristianas que domina nuestra herencia cultural. ${ }^{41}$

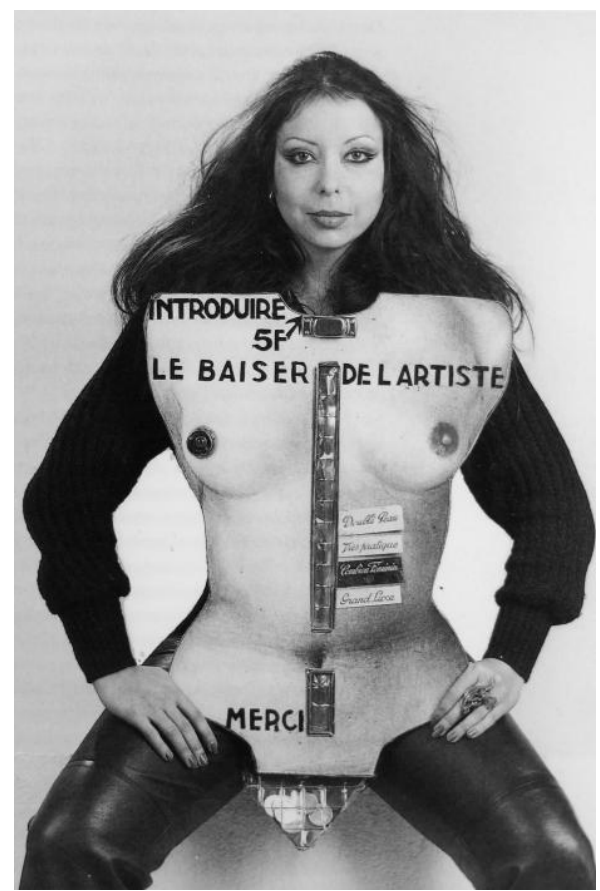

111. Orlan - Baiser de l'artiste (1976-77)

\footnotetext{
${ }^{41}$ Un mes más tarde de la FIAC, Le baiser de l'artiste fue llevada a cabo en Lyon. A los ocho días Orlan recibió un telegrama procedente de la dirección del Atelier des trois soleils comunicándole que sus actividades externas eran incompatibles con su función docente. GUINOT, Olga, "El arte se hizo carne... y se llamó Orlan”, en el catálogo de la exposición Orlan. 1964 - 2001, Álava, ARTIUM - Universidad de Salamanca, 2002, p. 39.
} 
Sin embargo, Orlan ha alcanzado una tremenda popularidad por someterse a operaciones quirúrgicas en nombre del arte. Su primera experiencia con la cirugía se remonta a 1965, una época de performances de calle y compromiso intelectual con su obra en la que tuvo que ser operada de urgencia. Este hecho fue el punto de inflexión por el cual decidió dar un vuelco a su situación considerándola como un «fenómeno estéticamente recuperable». Partiendo de esta premisa, grabó un vídeo y fotografió la intervención. El resultado fue expuesto como si se tratase de una performance perfectamente planeada. Recordemos que Andy Warhol ya se fotografió durante una operación de lifting facial haciendo de su propio cuerpo uno de los objetos pop de la sociedad de consumo.

Es necesario, pues, conocer aquella experiencia accidental y - tal y como confiesa la autora - las lecturas de la obra de la psicoanalista lacaniana Eugénie Lemoine-Luccioni para entender cómo a finales de los años 1970 comenzó a utilizar la cirugía estética para crear con su propio cuerpo una nueva fisonomía, metamorfosis que continúa utilizando en la actualidad. La piel era tomada como una expresión de la dictadura irracional de la naturaleza y, por ello, un nuevo medio plástico susceptible de nuevos diseños y a entera disposición del artista.

La finalidad primordial de Orlan consiste en llegar a convertirse en una obra maestra absoluta. Las manos de los cirujanos son guiadas por un canon compuesto por detalles digitalizados de cuadros famosos. Su imagen está quirúrgicamente confeccionada por la frente de la Gioconda, los ojos de la Psique de Gérôme, la nariz de una Diana de la escuela de Fontainebleau, los labios de la Europa de Boucher y la barbilla de la Venus de Botticelli, y todavía queda mucho para completar su metamorfosis. Desde entonces, ha decidido convertirse en una criatura de síntesis, ofreciendo su propio cuerpo a los deseos estereotipados del bisturí. Orlan está siempre en constante construcción, su estética se introduce en el concepto de mutación corporal convertida en tema de provocación y de debate público, más allá de la esfera 
privada y del secreto. La autora ha llegado a señalar que se implantará una nariz tan grande como su anatomía le permita. ${ }^{42}$

Mientras el bisturí deviene el instrumento por el cual la artista remodela las líneas de su cara en permanente transformación, Orlan — anestesiada bajo la epidural- lee textos filosóficos, psicoanalíticos o literarios sobre los que construye cada una de sus performances. Ella agradece su inspiración a pasajes como el de la anteriormente citada Lemoine Luccioni: «Skin is deceiving [...] in life, one has only one's skin [...] there is a bad exchange in human relations because one never is what one has [... I I have the skin of an angel but I am a jackal [...] the skin of a crocodile but I am a poodle, the skin of a black person but I am white, the skin of a woman but I am a man; I never have the skin of what I am. There is no exception to the rule because I am never what I have».. ${ }^{43}$

Fijémonos que el hecho de cambiar la fisionomía de nuestra cara equivale, en nuestra cultura, a cambiar nuestra identidad y el modo de comunicarnos con la sociedad. El rostro de Orlan trata de ser el reflejo de un cuadro viviente cargado de nuevas significaciones tanto políticas como antropológicas respecto a las acepciones categóricas tradicionales, más allá de la estética y de la idea de belleza. Para Lorena Amorós, además de ridiculizar, desacreditar y subvertir la hegemonía de la imaginación masculina que condena a las mujeres a callar y limitarlas según un estereotipado repertorio de imágenes, Orlan diluye, mediante su trabajo, la diferencia entre el nacer y el ser hecha. ${ }^{44}$

Dentro de este contexto no podemos omitir la importancia de los restos corporales - grasa, sangre, vestigios de tejidos orgánicos- del cuerpo de Orlan extraídos en sus acciones quirúrgicas y destinados a la

${ }^{42}$ ZABALBEASCOA, Anatxu, "Màscara i mirall", en el catálogo de la exposición Màscara i mirall, Barcelona, MACBA, 1997, p. 22.

${ }^{43}$ Cit. en GOODALL, Jane, op. cit., p. 157.

${ }^{44}$ AMORÓS BLASCO, Lorena, Abismos de la mirada. La experiencia límite en el autorretrato último, Murcia, Cendeac, 2005, p. 215. 
creación de unos singulares relicarios. Estos dotan de significado a lo que contienen: la materia-cuerpo de la autora extraída de sus operaciones constituye una prueba más de su identidad. La forma de tales relicarios varía en función de la intervención quirúrgica: por ejemplo, los llevados a cabo en la quinta operación - en la que fabricó el mayor número de ellos- son placas de vidrio en los que - como ella misma define - hay un recipiente circular que guarda una decena de gramos de su carne conservados en un líquido especial y/o insertos en resina, todo ello encuadrado dentro de un marco metálico soldado que otorga la impresión de cierta inmunidad. ${ }^{45}$ Debemos recordar que Orlan no es la primera autora que ha exhibido relicarios, el ya citado Hermann Nitsch los utilizaba como recuerdos de sus performances y también como piezas de exposición.

Todas las operaciones efectuadas por Orlan han sido planeadas como una serie de diez performances, aunque hasta el momento nueve acciones quirúrgicas han tenido lugar en su investigación en torno al diálogo, a través del propio cuerpo, entre estética y cirugía. Cuando acaben todas las operaciones el objetivo final será legalizar su cambio total de identidad.

Esta apropiación quirúrgica de los ojos, de la frente, de la nariz, del mentón o de la boca está realmente lejos de tener como fin la mejora o el rejuvenecimiento - función primordial que cumple la cirugía estética. Afirma la propia autora: «My body expresses the possibility of showing that beauty can take on appearances that are not generally considered to be beauty. Every civilization has fabricated its own bodies: showing that the body is completely alienated by religion, labour, sports, and even by our sexuality, which is the fruit of previously established models». ${ }^{46}$ Orlan se plantea la reconquista de una nueva mirada femenina que sirva al tiempo como demostración de la falsa idea de que la mujer ideal es igual a la suma

\footnotetext{
${ }^{45}$ AMORÓS BLASCO, Lorena, op. cit., p. 330.

${ }^{46}$ ALFANO MIGLIETTI, Francesca, Extreme Bodies. The Use and Abuse of the Body in Art, Milano, Skira, 2003, p. 169.
} 
de las partes. ¿Acaso no se encuentra Orlan muy alejada de la tradición de la añorada Galatea de Pigmalión ${ }^{47}$

En su «teatro de operaciones» libera toda carga sagrada y cultural del cuerpo, mostrándolo tan manipulable como cualquier otro elemento a nuestro alcance. Probablemente sea ésta su mayor transgresión conceptual. Frente a los preceptos de la religión o la filosofía que nos hablan del cuerpo propio como un orden natural que no debe ser modificado por la decisión de la persona que lo posee, la artista francesa levanta el derecho a la infinita mutación voluntaria de la carne. Y, paradójicamente, la tesis que dirige la sutura de este cuerpo torturado y vilipendiado es la propia del canon occidental del visitante del Museo del Louvre o la Galeria degli Uffizi, algo tan romántico como diluirse en los paisajes de la "belleza universal" anhelados por los y las turistas que frecuentan los museos.

Esta estética de la mutación gira alrededor de un presupuesto paradigmático: la frontera entre ser humano y máquina, entre lo orgánico y lo inorgánico, puede y debe ser abolida. Orlan propone cuerpos que, al perder sus propios límites de contención, se abran mostrándonos aquello que no queremos mirar: lo abyecto, sus vísceras y, también, sus instrumentos. Su labor artística se sitúa en la convergencia de la biotecnología, la cirugía estética y la computadora, pero bajo una maleabilidad corporal cargada de absoluta intención militante.

La autora ha resquebrajado el concepto de arte como representación y ha disuelto oposiciones binarias tales como cultura-naturaleza. Se ha apropiado de los arquetipos para, a posteriori, erigirse a sí misma en una realidad en la que toman cuerpo las convenciones. Mientras numerosas artistas femeninas reivindicaron el momento en que la mujer fuera dueña de reinventarse a sí misma, Orlan también lo hizo, pero a su manera. Fue más allá del plano de la representación simbólica, entró en el terreno de la realidad tangible, sin desligarse de los modelos creados por la mirada

${ }^{47}$ AMORÓS BLASCO, Lorena, op. cit., p. 212. 
masculina, convirtiéndose en síntesis de todos ellos. No se trata simplemente de invertir el signo actual del auge de la cirugía estética al servicio de ciertos modelos de belleza. Para Orlan, la mutación permanente del cuerpo nos habla en el fondo de la posibilidad de crear identidades nómadas, fluctuantes, inestables, reversibles. Su metamorfosis voluntaria es una metáfora que cuestiona la clasificación binaria de las personas, una clasificación por la cual nos definimos como hombres o mujeres, como bellos o feos, como normales o anormales. El cyborg está entre nosotros a través de la fusión y la hibridación: máquina/cuerpo, yo/otro, mente/materia, cultura/natura, realidad/apariencia, activo/pasivo, total/parcial.

De este modo, l'art charnel ${ }^{48}$ de Orlan se opone a la naturaleza y a la condición humana desde las nuevas tecnologías y los usos mediáticos. Para Olga Guinot, l'art charnel es, ante todo, una declaración de independencia frente a los diferentes grupos de artistas que comenzaban a invadir la esfera corporal. ${ }^{49}$ La utilización de la cirugía deviene medio $-\mathrm{y}$ por tanto «extensión»- para batallar contra los estándares de belleza dictados por la ideología dominante que, cada vez más, se marcan en las carnes femeninas - aunque también comienzan a tener una gran acogida en el ámbito masculino- y no sólo en los casos más extremos, como el archiconocido caso de Lolo Ferrari, quien se sometió a dieciocho operaciones para satisfacer a su marido. ${ }^{50}$

Durante sus performances Orlan deconstruye asimismo la idea de espacio, la originaria e impoluta imagen del quirófano. Ya no hay distancia entre lo público y lo privado. En este caso, el acto quirúrgico se desacraliza y se convierte en un acto transparente, teatralizado y puesto al alcance de la sociedad gracias a las evidentes analogías que la caja tonta nos muestra en

\footnotetext{
${ }^{48}$ A partir de 1993 Orlan habla d'art charnel para definir su trabajo como un autorretrato sobre el cual se inscribe directamente en la carne con la ayuda del escalpelo. El término fue citado por primera vez por Barbara Rose en el artículo que escribió sobre la artista para Art in America, en febrero de 1993. DONGUY, Jacques, op. cit., p. 206.

${ }^{49}$ GUINOT, Olga, op. cit., p. 13.

${ }^{50}$ AMORÓS BLASCO, Lorena, op. cit., pp. 213-214.
} 
sus platós. De ahí que lo ornamental sea relevante para Orlan, quien como artista plástica ha querido intervenir en la idea estética quirúrgica, fría y estereotipada e intercambiarla para confrontarla con otras que añaden paradójicamente connotaciones de glamour, a modo de actriz espectacular.

Otro de los conceptos que surgen a colación en el análisis del trabajo de la autora francesa corresponde a la herida. Ésta podemos entenderla como una forma de liberación, de transgresión de unos límites instaurados por la sociedad en pro de aquellos fijados por uno mismo, donde lo íntimo y lo privado de la cotidianidad se exterioriza. La intención de Orlan, obviamente aún en fase de proyecto, es la de modificar su cuerpo después de su fallecimiento y exponerlo en un museo con el fin de convertirse en la más importante de la reliquias.

El trabajo de Orlan está siempre explorando la falta de relación entre dos conceptos: identidad e imagen. La idea está tomada desde un yo que rechaza la identidad como forma corporal. La idea de que la identidad es enteramente alcanzada a través del acto de hacer o re-hacer el propio cuerpo según la propia voluntad proviene de una tradición cultural y su poder se expresa en uno de los textos favoritos de la autora: el último poema de Antonin Artaud Pour en finir avec le jugement de Dieu (1947). En este texto se nos propone que para restablecer en el ser humano su propia y libre condición es necesario poner el cuerpo sobre una mesa de autopsia para una reconstrucción anatómica completa. «Car liez-moi si vous voulez, mais il n'y a rien de plus inutile qu'un organe./ Lorsque vous lui aurez fait un corps sans organes, alors vous l'aurez délivré de tous ses automatismes et rendu à sa véritable liberté./ Alors vous lui réapprendrez à danser à l'envers comme dans le délire des bals musette et cet envers sera son véritable endroit». ${ }^{51}$

En su fascinación por un estricto proceso psicológico de alcanzar un cuerpo sin órganos, Orlan se aproxima a las reinterpretaciones artaudianas

\footnotetext{
${ }^{51}$ ARTAUD, Antonin, Pour en finir avec le jugement de Dieu, suivi de "Le Théâtre de la Cruauté", Paris, Gallimard, 2003, p. 27.
} 
de Deleuze y Guattari tomando su significado prácticamente desde la literalidad. La performance postorgánica representa el desposeimiento del cuerpo en su proceso de maquinización, es la «extensión» de las máquinas deseantes, es la elipsis irreversible de la pulsión inconsciente, es la declarada infidelidad a la irreversibilidad de la materia, es una especie de transmutación alquímica caótica, una escisión de lo orgánico, una corrosión de la partícula. ${ }^{52}$

Para Julie Clarke las performances quirúrgicas de Orlan podrían ser vistas como un ejemplo extremo de inscripción corporal en el cual la autora utiliza la superficie de su piel como indicador de una cultura desintegrada en sus imágenes. Sin embargo, Orlan no revela la superficie de su rostro y cuerpo creando más imágenes susceptibles de ser consumidas, ella muestra lo abyecto, las sangrientas capas subcutáneas más allá de la piel que significan lo orgánico y la inminencia de la muerte. ${ }^{53}$

Según afirma Teresa Macrì, la performance de Orlan se pone en relación con la biopolítica del cuerpo postmoderno, con la reconstrucción del yo, con la complejidad de la diferencia, con el cyberfeminismo, con la refiguración del cuerpo humano, con la esquizofrenia del poder mediático y con la estrategia biotecnológica de la reconstrucción corpórea. ${ }^{54}$ Su trabajo entra así en un doble desafío: contra la naturaleza y contra la afirmación de lo artificial. Se trata de un trabajo que rebasa todos los límites de los intereses de la biotecnología y todos los debates sobre las patologías del cuerpo al reflexionar sobre el estándar genético. Orlan resume su trabajo de la siguiente manera: «My work is a struggle against: the innate, the inexorable, the programmed, Nature, DNA (which is our direct rival as... artists of representation), and God! My work is blasphemous». ${ }^{55}$

\footnotetext{
${ }^{52}$ MACRİ, Teresa, op. cit., p. 136.

${ }^{53}$ CLARKE, Julie, "The Sacrificial Body of Orlan", en FEATHERSTONE, Mike (ed.), op. cit., p. 188.

${ }_{55}^{54}$ MACRİ, Teresa, op. cit., p. 116.

${ }^{55}$ Cit. en GOODALL, Jane, op. cit., p. 152.
} 
Cuando Orlan proclama lo señalado nos está diciendo que la suya es una lucha contra la religión y la ciencia, los dos mayores paradigmas que han mediado y definido el cuerpo humano - especialmente el femenino-, entidades invisibles y al margen de nuestra esfera de la experiencia. Negar el ADN significa negar que los cuerpos pueden ser reducidos a un código, una estrategia para escapar de nuestro destino biológico y demostrar que la vida puede ser «extendida». Consecuentemente, el rostro reconfigurado de Orlan es una pantalla sobre la cual se proyectan nuestros temores más ocultos de desfiguración, enfermedad y anormalidad. ${ }^{56}$

El escándalo de la obra de Orlan pasa por la indignación de que su cuerpo postorgánico pueda ser arte y por las ofensas de malversación de la ciencia médica y de la cirugía. No obstante, no debemos pecar de ingenuos, en las representaciones-operaciones de Orlan, tanto el paciente, como el cirujano y las enfermeras llevan trajes de alta costura - diseñados, entre otros, por Paco Rabanne, Franck Sorbier, Issey Miyake o Lan Vu-y la sala de operaciones está adornada con un crucifijo, frutas de plástico y enormes carteles con el nombre de los patrocinadores de la operación, al más puro estilo kitsch propio de las carteleras de cine de los años cincuenta. Tal y como se cuestiona Mark Dery, cabría descubrir si las performances quirúrgicas de Orlan están más cerca del arte carnal que del carnaval, tal vez su definición del sometimiento al bisturí, plena de reminiscencias catárticas, no nos sorprendería en absoluto, a día de hoy, en boca de una adicta a la cirugía estética. $^{57}$

A ello cabe añadir la turbia cuestión de su autopromoción. Orlan es una experta frecuentadora de los medios y conoce al dedillo los eslóganes de éxito asegurado: «He dominado mi cuerpo», «El cuerpo no es más que un disfraz», «Soy la artista que ha ido más allá». La autora difumina, como si se tratase de una reencarnación puramente warholiana, los límites entre arte

\footnotetext{
${ }^{56}$ CLARKE, Julie, op. cit., p. 195.

${ }^{57}$ DERY, Mark, Velocidad de escape. La cibercultura en el final del siglo, Madrid, Siruela, 1998, p. 265.
} 
y publicidad, entre producto e imagen pública. Su narcisismo es la expresión de la patología de una cultura esbozada en imágenes y obsesionada con las apariencias.

El artista Stelarc (Chipre, 1946) se inclina por la transición del individuo biológico hacia el cibersistema a través de un nuevo proyecto de cuerpo. En su caso, la microtecnología como «extensión corporal» será la que permita romper las fronteras biológicas.

Al grito de «iEl cuerpo está obsoleto!» ${ }^{58}$ ha llevado a un extremo las tendencias más radicales del Body Art. Stelarc —un macluhaniano convencido - trata su cuerpo como si fuese un objeto de puro diseño, a modo de materia prima susceptible de ser modificada por la máquina para acceder a un cuerpo extendido y transhumano, una premisa manifestada por la disposición de su cuerpo desnudo. En un furor contiguo al $B D S M$, recibe intermitentes descargas eléctricas o sincroniza los movimientos de sus órganos — corazón, pulmones - y extremidades. Tal y como afirma Félix Duque, Stelarc habría hecho palidecer de envidia al mismísimo Marinetti. ${ }^{59}$

Originariamente Stelios Arcadiou, hace más de treinta años que adoptó legalmente este solitario nombre, el único que aparece en su pasaporte. Nacido en Chipre, educado en el mundo y residente en Australia, es un artista fascinado por la estética alternativa en relación con las nuevas tecnologías. No ha dudado en utilizar sistemas virtuales, sensoriales y médicos para explorar, potenciar y extender las capacidades de actuación del cuerpo.

\footnotetext{
${ }^{58}$ «The problem with us is that we're genetically immersed in the past. So can the trajectory of the body be replotted to minimize its dependence on memory, to enhance the choice and operational complexity of the present and to generate more diverse strategies for any future moment collapse? If one tries to function in that way I think one perhaps is closer to a posthuman situation». Cit. en FARNELL, Ross, "In Dialogue with 'Posthuman' Bodies: Interview with Stelarc", en FEATHERSTONE, Mike (ed.), op. cit., p. 136.

${ }_{59}$ DUQUE, Félix, "De cyborgs, superhombres y otras exageraciones", en HERNÁNDEZ SÁNCHEZ, Domingo (ed.), Arte, cuerpo y tecnología, Salamanca, Universidad de Salamanca, 2003, p. 175.
} 
Desde su época de estudiante estuvo interesado en cómo la tecnología podía conectarse al cuerpo y alterar su percepción. Los primeros trabajos que realizó en la escuela de arte consistieron en objetos bautizados como Compartimentos sensoriales. Se trataban de gafas y cascos capaces de alterar la visión binocular. El artista ha descrito estos instrumentos como el resultado de una toma de conciencia sobre la estructura fisiológica del cuerpo. Ésta es lo que determina su inteligencia y sus sensaciones, de ahí que en el momento en que modificamos esa estructura, obtenemos una percepción absolutamente alterada de la realidad. Afirma el propio autor: «Any extension whether of skin, hand, or foot, affects the whole psychic and social complex». ${ }^{60}$

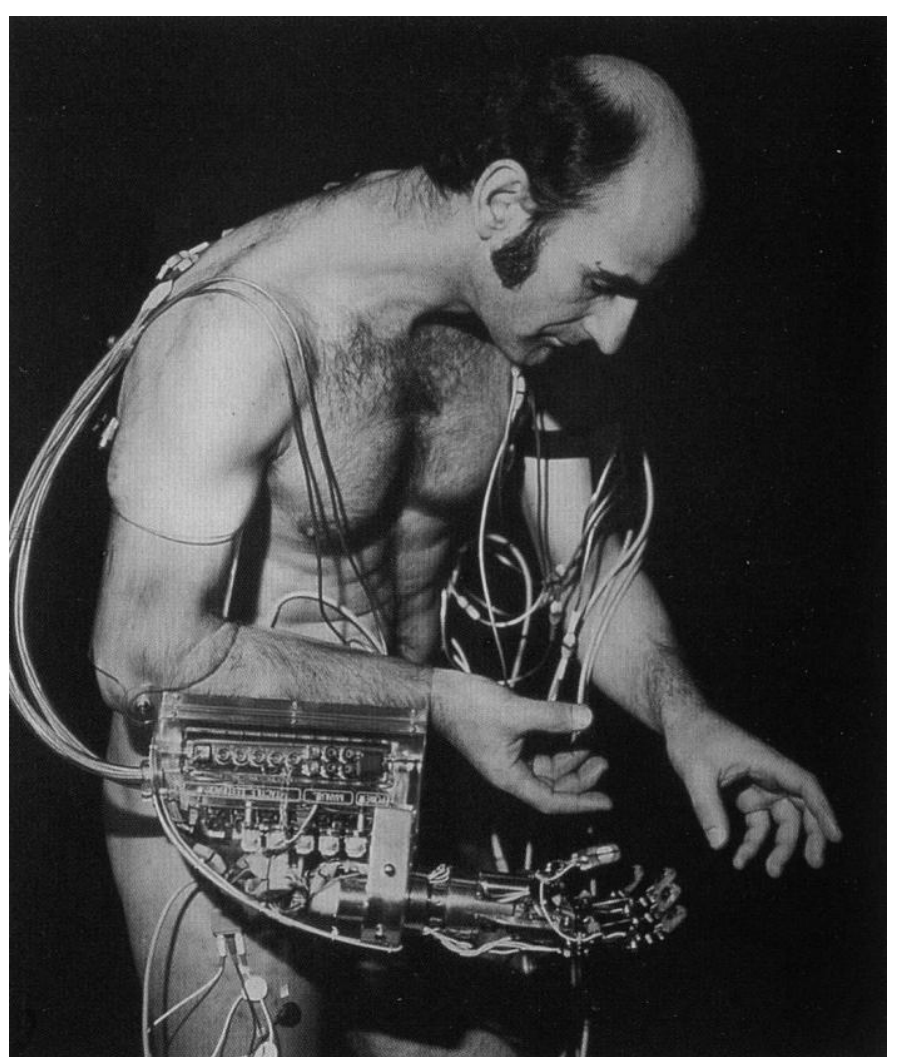

112. Stelarc - The Third Hand (1976-80)

${ }^{60}$ GOODALL, Jane, op. cit., pp. 161-162. 
Ya en los años 1970, Stelarc se convirtió en el pionero de la experimentación «ciberestética» mediante la concepción y creación de una mano electrónica que utilizó en una performance, una mano artificial fijada al brazo derecho como elemento adjunto, no como sustitución prostética. $\mathrm{La}$ pieza fue controlada directamente por su cerebro a través de electrodos ajustados sobre la cabeza. De esta manera escribió «evo-lut-ion», tres sílabas con cada una de las tres manos. ${ }^{61}$

En 1972 realizó —a través de endoscopias - películas en $16 \mathrm{~mm}$. y en color del interior de su estómago (14 minutos), intestinos (16 minutos) y pulmones (15 minutos). Para realizar estos «internal landscapes» ingería una cápsula telemétrica que contenía una cámara. Cabe indicar que, en aquellos años, las dimensiones de aquel armatoste no eran tan minúsculas como las existentes hoy en día. El procedimiento requería una inyección para prevenir el rechazo de un objeto externo, así como la aplicación de anestesia local para adormecer su garganta ante el doloroso proceso. ${ }^{62} \mathrm{Su}$ intención tenía como fundamento experimentar con las posibilidades acústicas y visuales de su cuerpo a través de viajes interiores - contracciones musculares, latidos del corazón, etcétera.

Esta trayectoria inicial parece esbozar la globalidad de su búsqueda: sondar el cuerpo en su totalidad, acotarlo y sobrepasar sus límites biológicos. Stelarc parece esbozar una especie de viaje a la inmaterialidad corpórea, un éxodo a esa zona límite que no es otra que el inquietante interior del propio cuerpo: l'horreur intérieure. El artista australiano, a modo goethiano, va a la búsqueda de la belleza, pero - a diferencia de Orlan - la misma es en este caso interna, una belleza hecha de vísceras y de órganos, músculos, humores y tejidos celulares, una idealización que renuncia al concepto estético de la apariencia concentrándolo en la búsqueda

${ }^{61}$ RIVERA, Daniel, "Ciber-cuerpo, ciber-arte, ciber-etcétera”, en http://serpiente.dagsca.unam.mx/jornada/1997/oct97/971025/ciberc.html.

${ }^{62}$ ALFANO MIGLIETTI, Francesca, op. cit., pp. 195-198. 
en un interior capaz de poner en movimiento, de hacer vibrar y de excitar lo externo. ${ }^{63}$

El objetivo de todo ello es representar lo irrepresentable, mostrar lo imperceptible y diluir los límites entre lo visible y lo invisible en la tensión extrema de un cuerpo totalizado. En lugar del cuerpo sin órganos de Artaud, los órganos sin cuerpo. Su búsqueda pretende también sentir una nueva carne: desconocida, anatómicamente indefinida y subversiva en su dimensión potencial. Lo interno deviene entrada al inconsciente $y$ reactivación de un pensamiento integral del cuerpo al que se vincula la idea de sujeto global. En esta nueva dimensión perceptiva corpórea Stelarc asume con empeño la transgresión de la sensibilidad carnal como momento radical de intensificación perceptiva. ${ }^{64}$

La primera obra del artista que alcanzó repercusión internacional tuvo lugar en Tokio en el año 1976. Stelarc, combatiendo la ley de la gravedad, era sustentado en el espacio por varios cables cuyos extremos acababan en unos ganchos de acero que perforaban su propia piel. Tales utensilios son los mismos que se utilizan generalmente en carnicerías y pescaderías para colgar los productos. Veintisiete Body Suspensions fueron llevadas a cabo entre galerías y espacios urbanos de las cuales únicamente cinco de ellas se realizaron ante público.

En Event for Skin in Suspension $n^{\circ} 4$ (1977) dieciocho ganchos colocados estratégicamente en la piel de la espalda y el abdomen se encargaban de sustentar el cuerpo de Stelarc en posición vertical respecto al pavimento de la sala de la Art Accademy de Mónaco. Para Stelarc fue la primera experiencia verdadera de privación sensorial asociada a una situación de estrés físico vivido y realizado como un verdadero proceso autocognoscitivo. Suspenderse de ganchos no sólo era un desafío al sufrimiento físico, una práctica de dolor, era sobre todo un intento de

${ }^{63}$ MACRÌ, Teresa, op. cit., pp. 139-141.

${ }^{64}$ MACRİ, Teresa, op. cit., p. 141. 
analizar y subvertir las leyes físicas. En palabras del propio Stelarc: «C’était une sorte d'exploration générale des limites physiques et psychologiques du corps tout en développant des stratégies pour élargir les capacités du corps». ${ }^{65}$

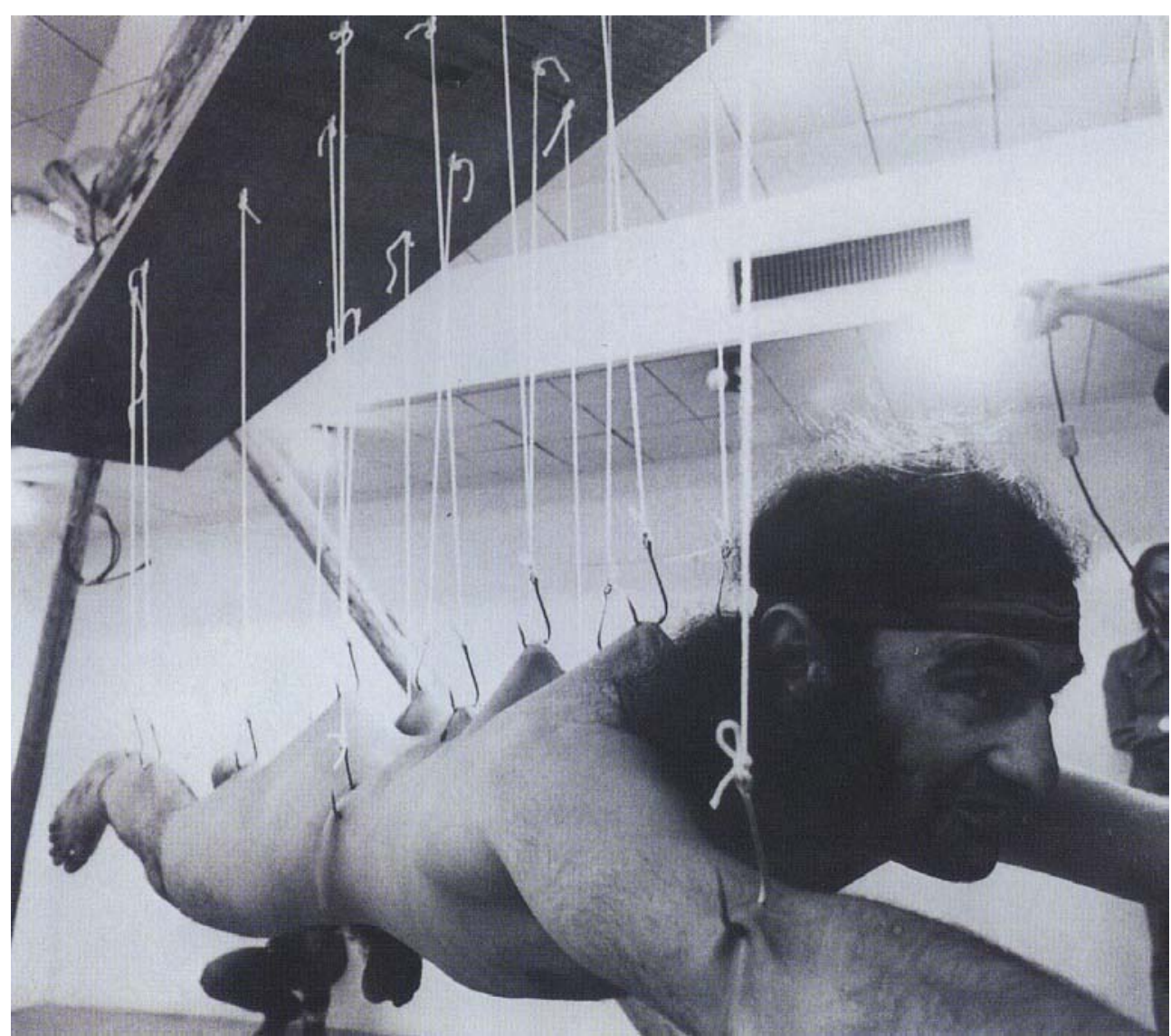

113. Stelarc - Event for Stretched Skin (1976)

A pesar de las evidentes relaciones que se pueden establecer entre las Body Suspensions y los ritos primitivos y/o chamánicos, Stelarc niega rotundamente esta vinculación: «Les actions de se suspendre ne sont pas des manifestations de chamanisme, de conditionnement par le yoga ou de mise

${ }^{65}$ DONGUY, Jacques, op. cit., p. 215. 
en harmonie du corps pour une sorte de quête transcendantale ou spirituelle. Ces performances ne portent pas sur une recherche pseudo-médicale. Ces performances sont simplement des actions artistiques, et il n'y a aucune préparation spéciale, aucune méditation, aucune médication [...] Ma pensée est la même avant la performance, durant la performance et après la performance. Le concept de la performance n'a rien à voir avec ces sortes de pratiques traditionnelles, ou avec ces expériences pseudo-scientifiques». ${ }^{66}$

Para Stelarc, la piel - como superficie - fue uno de los comienzos del mundo y simultáneamente el límite del mismo. Sin embargo, hoy en día, estirada, perforada y penetrada por la tecnología, la piel no es más que la suave y sensitiva superficie de un espacio. La piel ha dejado de significar envoltorio, la ruptura de la superficie, puesto que significa borrar el interior y el exterior. ${ }^{67}$

En Event for Support Structure (1977) Stelarc pasó tres días en la Galería Tamura de Tokio atrapado entre dos tablas colgadas de un haz de dos estacas con la boca y los párpados cosidos con hilo quirúrgico. Por la noche dormía en el suelo de la galería. Como relata cómicamente el autor, lo verdaderamente insoportable y doloroso de la acción fue el hecho de no poder bostezar, un detalle que no había previsto.

Estas experiencias rudimentarias representan claramente los primeros pasos que marcaron su objetivo: diseñar un cuerpo humano postbiológico e incentivar sus investigaciones sobre inteligencia artificial y robótica. Identificando la compleja estructura muscular, circulatoria y ósea de la anatomía humana como incompatible con el medio tecnológico creado por el ser humano, Stelarc reitera incesantemente la obsolescencia del cuerpo. Cuando se le acusa de masoquista, el autor niega rotundamente tales acusaciones, sus acciones — según afirma— están dentro de los parámetros

${ }^{66}$ DONGUY, Jacques, op. cit., p. 215.

67 STELARC, "Parasite Visions: Alternate, Intimate and Involuntary Experiences", en FEATHERSTONE, Mike (ed.), op. cit., p. 119. 
normales propios de una sociedad donde el dolor juega un papel fundamental. ${ }^{68}$

En el extenso período de las Body Suspensions, Stelarc ya había proyectado el trabajo con la tercera mano, de cualquier modo todas estas investigaciones fueron simultáneas. $\mathrm{Si}$ sus performances suspensivas conformaban una especie de superación del anestesiante proceso existencial, la tecnología, en su expresión más directa, tiene sobre el cuerpo el mismo poder desensibilizador. Conectado a una interfaz tecnológica enganchada a flor de piel, el cuerpo se sumerge en el mismo efecto asensorial. La hibridación entre humano y artificio carga al organismo de una hiperexcitación endémica que, paradójicamente, provoca una especie de desensibilización. Lo que realmente importa a Stelarc es que el cuerpo humano se caracteriza por unos constantes estímulos sensibles, se trata de un cuerpo que recibe información y que, por ello, es susceptible de recodificación sensorial. ${ }^{69}$

Hacia finales de los años 1980, las acciones coreográficas llevaron a Stelarc a concebir una estructura electrónica que le permitió trabajar sobre la amplificación como proceso extensivo corpóreo: Amplified Body, Laser Eyes and Third Hand (1981-1994). En sus performances los procesos del cuerpo capaces de amplificar incluyen las ondas cerebrales (con electroencefalogramas), los movimientos musculares (con electromiogramas), las pulsaciones (con pletismogramas), el ritmo cardíaco

\footnotetext{
${ }^{68}$ STILES, Kristine, "Uncorrupted Joy: International Art Actions", en el catálogo de la exposición Out of Actions: Between Performance and the Object 1949-1979, Los Angeles, The Museum of Contemporary Art, 1998, p. 326.

${ }^{69}$ Sobre el concepto «sensorial» en la obra de Stelarc véase STELARC, "Da strategie psicologiche a cyberstrtegie: prostetica, robotica ed esistenza remota", en CAPUCCI, Pier Luigi (a cura di), Il corpo tecnologico. L'influenza delle tecnologie sul corpo e sulle sue facoltà, Bologna, Baskerville, 1994, pp. 61-76.
} 
(con electrocardiogramas) y la circulación sanguínea (a través del efecto Doppler de emisión continua). ${ }^{70}$

A través de su estrecha relación con la tecnología, Stelarc trata de abrir las fronteras de la conciencia. En sus más recientes actuaciones tenía insertadas micromáquinas en el estómago, las cuales respondían con una serie de estímulos - luminosos, sonoros y motores - a las manipulaciones remotas de quienes interactuaban con el autor. Stelarc considera que las redes telemáticas son capaces de abrir la posibilidad de redefinir las funciones del cuerpo, incluso hasta el punto de que llegue el día en que podamos prescindir de éste.

Para este autor, las actuaciones artísticas no son sólo expresiones con imágenes y representaciones simbólicas, sino que conectan expresiones con experiencia. Según Stelarc, actualmente lo que tiene sentido ya no es la libertad de ideas, sino la libertad de formas: la libertad de modificar y cambiar el cuerpo. La pregunta ya no especula sobre si la sociedad permitirá la libertad de expresión al ser humano, sino si la ética autorizará a los individuos a la realización de codificaciones genéticas humanas alternativas. «The artist can become an evolutionary guide, extrapolating new trajectories; a genetic sculptor, restructuring and hypersensitizing the human body; an architect of internal body space; a primal surgeon, implanting dreams, transplanting desires; an evolutionary alchemist, triggering mutations, transforming the human landscape»». ${ }^{71}$

La estructura biológica está en un espacio reducido, pero un cuerpo puede proyectar la presencia humana y efectuar acciones físicas en lugares remotos. Stelarc encarna con anticipación el híbrido hombre-máquina en el que nos estamos convirtiendo todos metafóricamente.

\footnotetext{
${ }^{70}$ El efecto Doppler responde a la variación aparente de la frecuencia de cualquier onda emitida cuando la fuente de ésta se acerca o se aleja del observador, por ejemplo como sucede con la luz o el sonido. El efecto toma su nombre del físico austriaco Christian Doppler, quien formuló por primera vez este principio físico en 1842 .

${ }^{71}$ Cit. en GOODALL, Jane, op. cit., p. 166.
} 
La redefinición corpórea implica la redefinición del mundo. En otros términos se plantea el problema fundamental de modelar una fisiología humana «panplanetaria», es decir, el problema de cómo modelar un cuerpo humano que pueda existir en diversas condiciones de atmósfera, de gravedad y de campos electromagnéticos. Según el propio artista, desea diseñar un cuerpo modular con un metabolismo más resistente, que sea más longevo. Stelarc se refiere a una «extensión» radical de la duración de la vida en el ámbito de una mutación que pueda cambiar radicalmente los conceptos de nacimiento y muerte — procesos ya aplicados a la cotidianidad como, por ejemplo, la fecundación artificial. ${ }^{72}$

Sus más recientes performances son un desafío hacia los conceptos dominantes de individualismo, identidad, organismo y autonomía. Así crea situaciones en las cuales el cuerpo interactúa con la simulación desde una multiplicidad de fuentes externas. Sus acciones interactivas son un intento de modificar y extender la conciencia más allá de los parámetros familiares de la cultura convencional y la intención individual. ¿Somos, pues, destinos biológicos a los cuales se nos han añadido «extensiones corporales» o nuestra fisicidad se ha convertido realmente en «extensiones mecánicas», es decir, complementos que se añaden a las máquinas para transgredir y/o ampliar uno o varios miembros pertenecientes a éstas?

Posiblemente se trate de mera ciencia ficción, de una especie de visión postmoderna sobre lo que será el individuo del futuro. Las fantasías de Stelarc rozan lo patológico, pertenecen al orden de las fantasías de destrucción del mundo, al narcisismo del aislamiento. Estamos demasiado condicionados por la idea cartesiana de que somos mente y de que el cuerpo es cosa, unas coordenadas muy similares a las de una máquina. Tal objetivación del cuerpo tiene algo de odio propio, de extrañamiento ante nosotros y nosotras mismos.

${ }^{72}$ MACRÌ, Teresa, op. cit., p. 146. 
Para Stelarc, la tecnología establece una especie de bypass ideológico ante las pautas marcadas por el modernismo y el postmodernismo, sobre todo en lo que se refiere a la apropiación, sin aportar estrategias discursivas de arquetipos culturales. Cuando trabaja sobre el cuerpo postorgánico y nos habla de rediseñar nuestra fisiología, el autor no tiene una visión apocalíptica, ni desea crear una raza superior, ni reestructurar la cultura o la sociedad, lo que nos está diciendo es que podemos decidir si queremos tener un implante ya sea por razones médicas, estéticas o meramente altruistas. ${ }^{73}$

Pero el arte y el pensamiento de Stelarc no se sitúan, como él cree, en el vacío de una cultura sin valores. Su sueño futurista de un cuerpo que logra escapar de su destino como receptáculo de lo social es atacado por todas partes: por la crítica feminista sobre el cuerpo, por el debate sobre bioética y por las críticas ecologistas en contra de las consecuencias capitalistas del progreso tecnológico y su crecimiento desenfrenado. Concretamente, la crítica feminista ha visto sus maniobras con recelo, interpretándolas como un rechazo de la corporeidad y extendiendo estas interpretaciones a un abuso del cuerpo provocado por ansiedades sobre su papel determinante. Stelarc ha sido comparado despectivamente con aquellos artistas cuyo trabajo se limita a representar los valores formales y técnicos de obras que muestran un cuerpo idílico. ${ }^{74}$

Problablemente la retórica de Stelarc invita a opiniones merecedoras de tales comentarios, aunque es más que evidente que las pretensiones del autor son otras. Ante estas críticas, a Stelarc le irrita el aparente deseo de evaluar el status quo de la sociedad según la cultura popular - especialmente el cine. La relación que se le ha atribuido con esa especie de anquilosamiento macho-militar al más puro estilo de Terminator o Robocop, lo considera una vulgar simplificación de su trabajo. ${ }^{75}$ En palabras

${ }^{73}$ FARNELL, Ross, op. cit., p. 145.

${ }^{74}$ GOODALL, Jane, op. cit., p. 162.

${ }^{75}$ FARNELL, Ross, op. cit., pp. 137-138. 
de Stelarc: "I think that is very simplistic, and the validity and the meaningfulness of feminist critique is undermined if [it] wants to continue with those sorts of simplistic assertions; that technology is simply a construct that perpetuates male power, or that this is all about toys for boys. Certainly the use of technology for me has never been grounded either in that type of technology, nor in that sort of discourse. I think what's more pertinent is to examine the way I've used medical technologies, which is also another happy hunting ground for feminist critique, in that they see medical technologies as another means by which male society has controlled women's bodies»». ${ }^{76}$

Sin embargo, Stelarc no parece darse cuenta de que su discurso se encuentra atrapado entre un fuego cruzado de culturas. Cobijado por una licencia poética, trata de eximirse del requisito científico de unidad y coherencia de una teoría. Rechaza toda interpretación simbólica por depender de un contexto — psicológico y social— del que pretenden escapar las teorías postevolutivas. Pero el propio concepto de un discurso mental fuera de una ideología, es decir, de un espacio social en el que la colisión de cuerpos y máquinas ocurra fuera de la política del poder, recibe el nombre de ciencia ficción. La verdad es un concepto que se construye desde un punto de vista social, las metodologías neutras también son víctimas de los prejuicios sociales. $^{77}$

\footnotetext{
${ }^{76}$ FARNELL, Ross, op. cit., p. 142.

${ }^{77}$ DERY, Mark, op. cit., pp. 189-190.
} 


\section{CONCLUSIONES}

La idea inicial de este enorme laberinto fue suscitada por un especial interés en temáticas circundantes a la corporeidad — desde un punto de vista muy próximo a las teorías de género - dentro de un contexto social en el que la tecnología $\mathrm{y}$, posteriormente, la cibernética se han fusionado a nuestra cotidianidad de tal manera que nos hemos transformado en verdaderos cyborgs, seres humanos que dependemos íntegramente de la tecnología para nuestra subsistencia. De este modo, decidimos tomar como punto de partida las vanguardias artísticas del siglo XX, herederas del imaginario y las consecuencias de la Revolución Industrial, así como pioneras en la utilización del cuerpo en su relación con la máquina, un verdadero lenguaje revolucionario que constituyó el elemento configurador de la dinámica urbana.

Siguiendo los senderos que la simbiosis cuerpo-tecnología nos ha ido trazando, encontramos la base fundamental de Extensiones corporales en el contexto del Body Art. Revolución del deseo: la utilización de diversos complementos que, en conjunción con el cuerpo, cumplieron la función de analizar, reflexionar y poner en tela de juicio todo un conjunto de normas y estereotipos impuestos en la sociedad occidental. La complejidad de este proyecto nos ha llevado a acotar nuestro estudio a una década iniciada en torno a 1968, fecha mediática que pone en solfa a una sociedad aletargada y 
que actúa como un instante simbólico en el que los y las artistas retoman el espíritu más revolucionario que caracterizó a las vanguardias artísticas.

Son numerosas las cuestiones que nos han surgido tras este largo viaje y es, por tanto, tarea ardua poner punto y final sin atorarnos en un trabajo que ha ocupado un período tan extenso e intenso de nuestra vida académica. Sin embargo, ha llegado el momento de detenernos y reflexionar sobre los argumentos más destacados a los que nos ha llevado nuestro trabajo, así constatamos que:

I. El Body Art se ha convertido en toda una institución. A día de hoy, pocos se atreverían a cuestionar que su influencia — desde el punto de vista de la sensibilidad y la política cultural - ha caracterizado el desarrollo de nuestro conocimiento visual. Investigar las fronteras entre lo público y lo privado ha sido uno de sus mayores logros lo que ha supuesto trazar una ruptura con tradiciones sociales y culturales. El arte corporal, heredero directo de las vanguardias artísticas del siglo XX, ha vuelto a ofrecernos la posibilidad de reflexionar sobre esa mirada higiénica que el establishment trata de vender y cómo dicha reflexión ha transformado nuestro imaginario en un complejo espacio escenográfico, un entorno que interactúa con la superficie corporal sacando a relucir aquello que no somos capaces de reconocer: todo lo que puede desequilibrar el orden establecido.

II. El Body Art rompió con las formas estables y restringidas de representación-exhibición de los y las artistas. Salió a la palestra con una finalidad: desnudar la complicidad de la mirada ajena. Propició la desaparición de las fronteras entre arte, espectáculo y vida, y abolió la pasividad del espectador o espectadora interactuando con su presencia. Su efecto provocador era tanto mayor cuanto más íntimo era lo que se representaba, lo que se exponía. 
III. El Body Art fue un lenguaje emparentado con la resistencia y con la denuncia política, que pretendió construir un proyecto social alternativo y sacudir nuestros prejuicios para volver a mostrar lo que ya conocíamos, pero eso sí, desde puntos de vista a menudo extremos. Sin embargo, debemos plantearnos si verdaderamente alcanzó sus objetivos. Cabe recordar que es sorprendente la habilidad de nuestro mecanismo social para, por una parte, generar actividades al margen $\mathrm{y}$, por la otra, absorberlas rápidamente. Acciones que en la década de 1970 fueron un escándalo absoluto -revisemos cualquier performance de las citadas en la presente tesis- figuran como hitos en los museos de arte contemporáneo más importantes. Parece ser que hoy en día ya no se puede ser subversivo, ni políticamente incorrecto $\mathrm{y}$, mucho menos, a través de los mass media, donde absolutamente todo, incluso lo más grotesco, tiene cabida.

IV. Aquella contracultura que definió los principios fundamentales del Body Art —con sus analogías y diferencias respecto a las vanguardias artísticas del siglo $\mathrm{XX}$ - comenzó rápidamente a confundirse con una incipiente cultura digital. Como ejemplo, cabe destacar que un considerable número de artistas se acogieron a nuevas bases para realizar sus actividades y en ello ejerció un notable influjo la invención y comercialización de los medios de grabación y reproducción videográficos. Así pues, nos atrevemos a afirmar que en el postmodernismo artístico contribuyó de manera determinante la expansión del uso del vídeo entre los autores y autoras de una generación que no dudó en aplicar la atención creativa a la tecnología emergente de aquel momento. La toma de conciencia de la ruptura del espacio y del tiempo se convirtió en categoría fundamental de la percepción marcando un antes y un después en el desarrollo de las artes visuales. No podemos omitir que el artista de aquella época fue heredero directo de las invenciones del cine experimental de principios del siglo $\mathrm{XX}$, 
evidentemente, de la lógica del collage $-\mathrm{y}$ su correlato fotográfico: el fotomontaje. De aquí nos surge una cuestión a considerar ¿por qué coincide ese desarrollo tecnológico con la pérdida de interés en la denuncia de los derechos sociales y se torna al individualismo introspectivo que caracterizó el Expresionismo abstracto?

V. La aparición de la pandemia del SIDA, junto al uso político que se le dio, fue uno de los motivos más trascendentales para que aquella actitud reivindicativa del cuerpo se viera mermada. Hoy día, vemos cómo los sectores más reaccionarios critican que las revueltas de Mayo del 68 y la esperanza de libertad de la década de 1970, hayan desembocado en el abandono de la voluntad, de la disciplina, de la fe en la familia y en el ejército, de los valores morales y de la justicia de la autoridad. No deberíamos bajar la guardia, esta mojigatería hipócrita, aliada con los máximos representantes de la fe católica, ha emprendido una verdadera cruzada para encauzar una sociedad hacia su verdad, que es tomada por ellos como suprema.

VI. El Body Art ha centrado la mayor parte de sus investigaciones en propalar la objetualización de la mujer como imagen de un fallido deseo mecánico, y la máquina, como instrumento despiezable y recomponible del juego narcisista del deseo. Esta visión del sexo, que reduce la experiencia sexual a un problema de mecánica e higiene, se asume y expresa por doquier desde mucho antes de la Revolución Industrial.

VII. La prosperidad y la productividad de los cuerpos se ha convertido en el núcleo del poder. El cuerpo social se ha transformado en el motor para producir y acumular, fuerza que es ejercida sobre, a través y por el sujeto. Las tecnologías mecánicas y cibernéticas no son meros instrumentos neutros surgidos en un paraíso científico, que podrían, en un segundo momento, ser aplicados con fines políticos o médicos más o menos saludables. Todas estas tecnologías son desde un 
principio sistemas políticos que vienen a asegurar la reproducción de estructuras socio-económicas muy precisas.

VIII. Nuestro cuerpo se ha «extendido» hasta límites insospechados. El avance tecnológico de la sociedad occidental exige continuos cambios radicales en el ser humano para los que, a menudo, no está preparado. La eterna lucha de éste contra el sufrimiento, la imperfección y la muerte se ha llevado a cabo por tecnologías esenciales como la medicina; sin embargo, ante un innegable destino biológico, se nos seduce maquiavélicamente con otro tipo de estrategias extremadamente perversas como la eterna juventud.

IX. Cuando la historia se reduce a una serie de poses congeladas y de vulgares clichés, el viaje por el tiempo es instantáneo y las décadas se pueden mezclar y adaptar. Nuestra concepción de la vida y la relación con el cuerpo ha llevado implícito re-cartografiar al sujeto provocando una grave desnaturalización del ser humano. Se ha reconstruido un poder coercitivo que tiende a la sumisión del individuo a través de prácticas castradoras del deseo, como la canonización de los modelos femeninos adquiridos y los tabúes atávicos y culturales.

X. La obsesión por la mímesis, producto directo de las aceleradas tecnologías infográficas, ha alentado $-\mathrm{y}$ lo sigue haciendo ferozmente- a que la perfección sea concebida como algo más real que la propia realidad. La aparición de un territorio virgen posibilita una inmediata apropiación simbólica a través de la cual las tecnologías de poder, apresuradamente, excluyen a quienes utilizan el mismo para escapar de la norma y el estereotipo. ¿Acaso es imposible aprovechar aquellos pequeños recovecos de libertad que la novedad - por el mero hecho de serlo- ofrece para devolver al individuo la posibilidad de crear su espacio y una nueva identidad, afrontar el discurso sobre una subjetividad nómada, re-escribir 
nuestro yo y aceptar el cyborg - nuestra ontología- como reconfiguración posthumana?

XI. La aparición de una nueva tecnología es inherente a un efecto embotador o narcótico: adormece la atención cuando esta nueva forma cierra de golpe las puertas del juicio y de la percepción. Los nuevos medios y tecnologías con los que nos amplificamos y extendemos constituyen una inmensa operación quirúrgica practicada en el cuerpo social con absoluto desprecio de los antisépticos. Si dicha operación es necesaria, debe considerarse la inevitabilidad de infectar todo el organismo en su transcurso. Al operar una sociedad con una tecnología nueva, no es el área de la incisión la más afectada. La zona de impacto es insensible, es el organismo entero el que ha cambiado. Cada nuevo impacto modifica las proporciones entre los sentidos.

Tras estas observaciones, no podemos concluir este trabajo sin aportar, a modo de reflexión y/o epílogo, unas palabras finales. A pesar del embotamiento intelectual que en los últimos años hemos padecido a causa de la exclusividad del estudio del cuerpo humano, consideramos necesario Extensiones corporales en el contexto del Body Art. Revolución del deseo, un trabajo que - acotado en un marco histórico específico- muestra que siguen sin ser apaciguados los arraigados patrones que sustentan nuestro imaginario sociocultural. ¿Supone ello un fracaso del Body Art?

En la actualidad, la cultura de los mass media se encarga de reproducir y repetir hasta la saciedad los esquemas más simplistas. Numerosas editoriales nos ofrecen un abanico de consejos sobre cómo alcanzar la imagen requerida a través de disciplinas dietéticas, ejercicios y compras. La publicidad, el cine o la televisión juegan incesantemente con barbies y maniquíes, coquetean con máquinas y actúan sobre el propio cuerpo de la misma manera que Pigmalión lo hizo sobre su estatua de 
Galatea. ¿Dónde han quedado las quimeras de Piper, Rosler, Horn, Clark o Wilke? ¿Qué repercusión ha tenido en la sociedad el trabajo de McCarthy, Lüthi, Klauke, Sieverding, Orlan o Stelarc? ¿Por qué la música o el cine, lenguajes populares por excelencia, no se atrevieron a desvincularse completamente de los esquemas moralizantes? ¿Acaso se ha convertido nuestro devenir en una «extensión corporal» disfuncional propia de la siempre ausente plenitud fálica masculina?

La utopía del discurso postfeminista en su lucha contra el determinismo biológico no ha llegado a entenderse y su efecto transgresor — verdaderamente escandaloso, incluso hoy día (¡qué paradoja!) — ha quedado terriblemente anulado. ¿Acaso el carnal art orlaniano puede llegar a ser tan grotesco como el último grito estadounidense en moda quirúrgica en el que, a través de una labioplastia, otorgan a la vagina de la paciente el aspecto del bajo vientre de una niña de doce años bajo la quimérica promesa de mejorar el placer sexual? Tal y como afirma Toni Morrison - Nobel de literatura en 1993-, la cirugía plástica es el burka moderno. Aquella proclama «este cuerpo es mío» se ha malinterpretado. Parece ser que cada vez somos menos dueños y dueñas de nuestro destino biológico, aceptarse a uno mismo o una misma en la sociedad contemporánea es aceptar el propio cuerpo y el propio rostro. Así rezan los mass media.

Lo que realmente debe preocuparnos es la tendencia televisiva actual a aplanar y machacar los logros en la mentalidad social sobre la igualdad de los hombres y las mujeres. Estamos asistiendo a una feminización reaccionaria de la mujer en los medios audiovisuales, a un aumento del sexismo, a un constante e insidioso hurgar en cuanta grieta se puede detectar en la armonía entre los géneros, acentuando las diferencias pueriles y no las coincidencias. La televisión, especialmente, se ha convertido en un basurero al que arrojar la imagen de la mujer y el cuerpo popular. Eso es tan grave y erróneo como cualquier otro tipo de contaminación, y a medio plazo pagaremos por ello. 
Confiamos en que este trabajo nos abra las puertas hacia una tercera fase de reivindicación del cuerpo, un período que - corrigiendo sus errores - vuelva a reivindicar el somacentrismo propio de las vanguardias artísticas y del posterior Body Art. 


\section{RESUMEN DE LA TESIS}

Desde su aparición biológica el ser humano se ha visto obligado a crear objetos que facilitaran su subsistencia. En este proceso la Revolución Industrial va a marcar un momento histórico determinante, ya que la máquina asumirá muchas de las funciones que, hasta la fecha, eran competencia del individuo. Debido a ello, éste quedará adherido, más que nunca, a un proceso tecnológico, un destino biológico «extendido» $\mathrm{y}$ «expandido» por mecanismos que alterarán profundamente su relación con el mundo.

Tomando el arte como reflejo social, la industria, la máquina y la nueva era fueron adoptadas como epicentro de las representaciones artísticas del siglo XX y, con ello, se subvirtió el lenguaje tradicional. Los sectores más críticos trataron de despedazar el discurso de la alta cultura a través de la fusión con lo popular, creando, de esta manera, una ecuación fundamental: arte = vida. Espacios públicos, teatros, pero especialmente bares y cafés fueron escenario de peculiares representaciones en las que lo corporal fue el principal protagonista, una manera particular de reflexionar sobre las repercusiones que la técnica infligía en el cuerpo y su verdadero papel en la sociedad contemporánea.

Libertad y entusiasmo fueron los conceptos que definieron a las vanguardias artísticas del pasado siglo, una euforia que se desvaneció a causa de la Segunda Guerra Mundial. El cuerpo y su representación quedaron ocultos. Tras la tragedia, la sociedad fue víctima de una reestructuración profundamente conservadora.

Bastó una década para que ciertos sectores intelectuales sintieran que no podían seguir aceptando un contenido cultural y artístico desideologizado. Aquel estado de ánimo políticamente consciente alentó las manifestaciones y gestos reivindicativos recuperando el más puro estilo dadaísta como vehículo para atacar el establishment. A finales de la década de 1950, tanto en Estados Unidos como en Europa, se reemprendió la acción corporal en la representación artística como un lenguaje necesario para atacar la ideología burguesa.

Con ello, llegamos al año 1968, fecha clave en la que se despertó la conciencia social contra el totalitarismo y en la que el cuerpo recuperó su 
categoría. La performance - término que no se inauguró como tal hasta los años 1970 - se transformó en el lenguaje más apropiado para representar los nuevos valores estéticos, así como para poner en práctica las teorías más reivindicativas. Poco a poco se consolidaba un concepto de arte sociológico que defendía la integración del cuerpo en el proceso creativo, unas demostraciones que se acuñaron como Body Art.

En la década de 1970 podemos volver a hablar de somacentrismo. Sin embargo - y es aquí donde Extensiones corporales en el contexto del Body Art. Revolución del deseo cobra su sentido-, algunos y algunas artistas, insatisfechos con una exploración del cuerpo de raigambre materialista, adoptaron elementos configuradores de la corporeidad tales como vestidos, complementos y objetos de diversa naturaleza. Aquel interés que los y las artistas de vanguardia mostraron por la tecnología se había transformado en otra de naturaleza muy distinta que, pese a sus diferencias, cumplía las mismas funciones que la máquina adquirió a principios de siglo $\mathrm{XX}$ : la de «extensión corporal».

Esta vez no fue necesaria una guerra para paliar la ideología radical de la década de 1970, la aparición del SIDA, una aguda crisis económica y, como consecuencia, una actitud cargada de resignación y desengaño llevaron a marcar, diez años después, el final de este período. La popularización de la era digital se ha encargado de mostrar una realidad que retrocede a los valores más reaccionarios. 


\section{RESUM DE LA TESI}

Des de la seua aparició biològica l'ésser humà s'ha vist obligat a crear objectes que facilitaren la seua subsistència. En aquest procés la Revolució Industrial va a marcar un moment històric determinant, donat que la màquina assumirà moltes de les funcions que, fins aleshores, eren competència de l'individu. Per eixa raó, aquest quedarà adherit, més que mai, a un procés tecnològic, una destinació biològica «extensa» $\mathrm{i}$ «expandida» per mecanismes que alteraran profundament la relació amb el món.

Prenent l'art com a reflex social, la indústria, la màquina i la nova era, van ser adoptades com a epicentre de les representacions artístiques del segle XX i, amb això, es va subvertir el llenguatge tradicional. Els sectors més crítics tractaren d'espedaçar el discurs de l'alta cultura a través de la fusió amb tot allò popular, la qual cosa creà, d'aquesta manera, una equació fonamental: art $=$ vida. Espais públics, teatres, però especialment bars i cafès foren escenari de peculiars representacions en les quals, tot allò corporal fou el principal protagonista, una manera particular de reflexionar al voltant de les repercussions que la tècnica infligia en el cos i el seu veritable paper en la societat contemporània.

Llibertat i entusiasme van ser els conceptes que definiren a les avantguardes artístiques del segle passat, una eufòria que es va esvair a causa de la Segona Guerra Mundial. El cos i la seua representació quedaren ocults. Després de la tragèdia, la societat va ser víctima d'una reestructuració profundament conservadora.

Va bastar una dècada perquè certs sectors intel-lectuals sentiren que no podien seguir acceptant un contingut cultural i artístic desideologitzat. Aquell estat d'ànim políticament conscient va encoratjar les manifestacions i gestos reivindicatius recuperant el més pur estil dadaista com a vehicle per a atacar l'establishment. A finals de la dècada de 1950, tant als Estats Units com a Europa, es va reprendre l'acció corporal en la representació artística com a un llenguatge necessari per atacar la ideologia burgesa. 
Amb això, arribem a l'any 1968, data clau en què es va despertar la consciència social contra el totalitarisme $\mathrm{i}$ on el cos va recuperar la seua categoria. La performance - terme que no es va inaugurar com a tal fins als anys 1970 - es va transformar en el llenguatge més adient per a representar els nous valors estètics, així com per a posar en pràctica les teories més reivindicatives. Poc a poc es consolidava un concepte d'art sociològic que defenia la integració del cos en el procés creatiu, unes demostracions que es van encunyar com a Body Art.

En la dècada de 1970 podem tornar a parlar de somacentrisme. No obstant això - i és ací on Extensions corporals en el context del Body Art. Revolució del desig cobra el seu sentit-, alguns i algunes artistes, insatisfets amb una exploració del cos d'arrelament materialista, adoptaren elements configuradors de la corporeïtat com ara vestits, complements i objectes de diversa natura. Aquell interès que els i les artistes d'avantguarda mostraren per la tecnologia s'hi havia transformat en altra, de natura molt distinta que, a pesar de les seues diferències, complia les mateixes funcions que la màquina va adquirir a principis de segle XX: la d'«extensió corporal».

Esta vegada no fou necessària una guerra per pal·liar la ideologia radical de la dècada de 1970, l'aparició de la SIDA, una aguda crisi econòmica $i$, com a conseqüència, una actitud carregada de resignació $i$ desengany, provocaria, deu anys després, el final d'aquest període. La popularització de l'era digital s'ha encarregat de mostrar una realitat que retrocedeix als valors més reaccionaris. 


\section{THESIS ABSTRACT}

Since his biological appearance the human being has been forced to create objects which facilitate his subsistence. In this process the Industrial Revolution is going to mark a moment of crucial importance in history, because the machine will assume many of the functions that, up-to-date, were a human occupation. Because of this, the individual will remain adhered, more than ever, to a technological process, a biological destination widespread and expanded by mechanisms that will alter deeply his relationship with the world.

Taking art as a reflection of society, the industry, the machine and the new age were adopted as the epicentre of the $20^{\text {th }}$ century artistic representations and, with that, the traditional language was subverted. The most critical sectors tried to tear into pieces the high culture speech through the merger with the popular, creating, this way, a fundamental equation: art $=$ life. Public places, theatres, but specially bars and cafés were the scene of peculiar representations in which the body was the main starring, a particular way of thinking about the repercussions that skill inflicted into the body and his real role in the contemporary society.

Freedom and enthusiasm were the concepts that defined the last century artistic avant-garde, an euphoria that vanished because of the Second World War. The body and his representation remained hidden. After the tragedy, the society was victim of a deeply conservative restructuring order.

A decade was enough for certain intellectual sectors to feel they could not continue accepting a cultural and artistic desideologized content. That politically conscious state of mind encouraged demonstrations and protests recovering the purest Dadaist style as a way to attack the establishment. At the end of 1950s, both in The United States and in Europe, the action body was restored in the artistic representation as a necessary language to attack the bourgeois ideology. 
This leads us to 1968 , a key date when the social conscience wake up against the totalitarianism and when the body recovers his category. Performance - a term that was not used as such until 1970 - turned into the most appropriate language to represent the new aesthetic values, as well as to put into practice the most protest theories. A sociological art concept was consolidated little by little. It defended the body integration into the creative process, proofs that were coined as Body Art.

In the 1970s we can speak again about somacentrism. Nevertheless -at this moment Body extensions in the context of the Body Art. Revolution of the wish makes sense-, some artists, unsatisfied with a materialistic body exploration, adopted elements of the embodiment such as dresses, accessories and objects of different nature. That interest that avant-guard artists showed for technology was transformed into a different one that, in spite of its differences, fulfilled the same functions that the machine acquired at the beginning of 20th century: the «corporal extension».

This time it was not necessary a war to relieve the 1970s radical ideology, the appearance of AIDS, a sharp economic crisis and, as a result, an attitude of resignation and disillusion, ten years later, the end of this period. The digital age popularization has taken charge of showing a reality that moves back to the most reactionary values. 


\section{ÍNDICE FOTOGRÁFICO}

1. Russolo y su asistente Piatti en el Laboratorio degli intonarumori en Milán (1913)

2. Giacomo Balla - Proyecto de coreografía Tipografia (1914)

3. Fortunato Depero - Balli Plastici (1918)

4. Enrico Prampolini y Franco Casavola - Il mercanti di cuori (1927)

5. Enrico Prampolini - Actuación de la bailarina Zdenka Podhaska (1928)

6. Vsevolod Meyerhold - Biomekhanica (1913)

7. Liubov Popova - Maqueta para la escenografía de El cornudo magnifico (1921-22)

8. Varvara Stepanova - Tercer acto de La muerte de Tarelkin (1922)

9. Componentes de la Bauhaus

10. Oskar Schlemmer - Das Triadische Ballett (1924)

11. Oskar Schlemmer - Boceto para la producción del escenario de Gabinete de figuras I (1922-23)

12. Oskar Schlemmer - Escena de Treppenwitz (1926-27)

13. Oskar Schlemmer - Danza de tablillas (1927)

14. Jackson Pollock pintando en su estudio (1950)

15. Bruce Nauman - Self Portrait as a Fountain (1966-67/1970)

16. Allan Kaprow - 18 Happenings in 6 parts (1959)

17. Carolee Schneemann - Meat Joy (1964)

18. Wolf Vostell - Im Ulm, um Ulm und Um Ulm Herum (1964)

19. Cartel anunciador del III Festival de la libre expression (1966)

20. Jean-Jaques Lebel - Cent vingt minutes au Divin Marquis (1966)

21. Emmet Williams - Counting Songs (1963)

22. Shigeko Kubota - Vagina Painting (1965)

23. Yves Klein - Dimanche, le journal d'un seul jour (1960)

24. Yves Klein - Anthropometry of the Blue Epoch (1960)

25. Yves Klein - Anthropometry of the Blue Epoch (1960)

26. Yves Klein - Anthropometry of the Blue Epoch (1960)

27. Piero Manzoni - Escultura viviente (1961)

28. Piero Manzoni - Fiato d'artista (1960)

29. Piero Manzoni - Merda d'artista (1961) 
30. Joseph Beuys - How to Explain Pictures to a Dead Hare (1965)

31. Joseph Beuys - I like America and America likes me (1974)

32. Cartel anunciador de la acción Kunst und Revolution (1968)

33. Günter Brus - Invitazion Zerreissprobe (1970)

34. Günter Brus - Zerreissprobe (1970)

35. Otto Mühl - Material Action $n^{\circ} 1$ Degradation of a Venus (1963)

36. Otto Mühl - Pissaction (1969)

37. Rudolf Schwarzkogler - Action 1 Wedding (1965)

38. Rudolf Schwarzkogler - Aktion 4 (1965)

39. Pierre Molinier - L'enfant homme (1968-70)

40. Pierre Molinier - Ossipago (1968-1970)

41. Pierre Molinier - L'Aiguillon de l'amour (1966-68)

42. Pierre Molinier - Mon fétiche des jambes (1966)

43. Pierre Molinier - L'auvre, le peintre et son fétiche (s.f.)

44. Diane Arbus - A Young man in curlers on West 20th Street (1966)

45. Diane Arbus - A naked man being woman (1968)

46. Urs Lüthi - Tell me who stole your smile $n^{o} 8$ (1974)

47. Urs Lüthi - Self-Portrait with Ecky (1974)

48. Jürgen Klauke - Self-Performance (1972-73)

49. Jürgen Klauke - Self-Performance (1972-73)

50. Jürgen Klauke - Transformer (1973)

51. Katharina Sieverding - Trasnformer 1 A/B (1973-74)

52. Michel Journiac - 24 heures de la vie d'une femme ordinaire (1974)

53. Michel Journiac - Hommage à Freud, constant critique d'une mythologie travestie (1972-84)

54. Michel Journiac - L'inceste (1975)

55. Carlos Pazos - Voy a hacer de mí una estrella (1975)

56. Andy Warhol - Self-Portrait in Drag (1979)

57. Lucas Samaras - Auto Polaroid (1969-71)

58. Nan Goldin - David at Grove Street, Boston (1972)

59. Tyrannosaurus Rex (1968)

60. David Bowie como Ziggy Stardust (1973)

61. Lou Reed en el Olympia de París (1974) 
62. Alice Cooper (1979)

63. Robert Mappelthorpe - Patti Smith (1975)

64. Cindy Sherman - Untitled (1975)

65. Cindy Sherman - Untitled Film Still 6 (1977)

66. Cindy Sherman - Untitled Film Still 14 (1978)

67. Cindy Sherman - Untitled \#131 (1983)

68. Joan Jonas - Mirror Check (1970)

69. Joan Jonas - Organic Honey's Visual Telepathy (1972)

70. Joan Jonas - Organic Honey's Vertical Roll (1972)

71. Joan Jonas - Organic Honey's Vertical Roll (1972)

72. Joan Jonas - Juniper Tree (1978)

73. Hannah Wilke - S.O.S. Starification Object Series (1975)

74. Hannah Wilke - Exchange Values (1979)

75. Martha Rosler - A Budding Gourmet (1974)

76. Martha Rosler - Semiotics of the Kitchen (1975)

77. Martha Rosler - Vital Statistics of a Citizen Simply Obtained (1977)

78. Invitation for Lynda Benglis Exhibition at Paula Cooper Gallery (1974)

79. Robert Morris - Untitled (1974)

80. Lynda Benglis - Untitled (1974)

81. Vito Acconci - Conversions (Part II Insistence, Adaptation, Groundwork, Display) (1971)

82. Adrian Piper - Catalysis III (1971)

83. Adrian Piper - Catalysis IV (1971)

84. Adrian Piper - The Mythic Being (1975)

85. Valie Export - Tapp und Tastkino (1968)

86. Valie Export - Aktionhose/Genital Panik (1969)

87. Jana Sterbak - Mètre-rubans en cône (1979)

88. Jana Sterbak - Corona laurea (noli me tangere) (1983-84)

89. Louise Bourgeois - Costume for a Banquet (1978)

90. Paul McCarthy - Meat Cake (1974)

91. Paul McCarthy - Sailor's Meat (1975)

92. Mike Kelley - Vestido para el Futurist Ballet (1973) 
93. Lygia Clark - Ar e Pedra (1966)

94. Lygia Clark - Diálogo de mãos (1966)

95. Lygia Clark - Máscaras sensoriais (1967)

96. Lygia Clark - Máscaras abismo (1968)

97. Lygia Clark - O eu e o tu (1967)

98. Lygia Clark - Rede de elástico (1973)

99. Lygia Clark - Baba antropofágica (1973)

100. Rebecca Horn - Arm-Extensionen (1970)

101. Rebecca Horn - Rüsel (1968)

102. Rebecca Horn - Der Überstromer (1970)

103. Rebecca Horn - Cornucopia, Séance für zwei Brüste (1970)

104. Rebecca Horn - Einhorn (1970)

105. Rebecca Horn - Kopf-Extension (1972)

106. Rebecca Horn - Bleistiftmaske (1972)

107. Rebecca Horn - Hahnengefieder (1971)

108. Rebecca Horn - Fingerhandschuhe (1972)

109. Orlan - Orlan accouche d'elle m'aime (1964)

110. Orlan - La grande Odalisque (1968)

111. Orlan - Baiser de l'artiste (1976-77)

112. Stelarc - The Third Hand (1976-80)

113. Stelarc - Event for Stretched Skin (1976) 


\section{BIBLIOGRAFÍA}

- $\quad$ A. JONES, Caroline y GALISON, Peter (eds.), Picturing Science Producing Art, New York, Routledge, 1998.

- $\quad$ AA. VV., Cindy Sherman. Retrospective, London, Thames \& Hudson, 1997.

- $\quad$ AA. VV., Mike Kelley, London, Phaidon, 1999.

- $\quad$ AA. VV., The Bauhaus, Massachusetts, The Mit Press, 1986.

- AA. VV., The Power of Feminist Art. The American Movement of the 1970's, History and Impact, New York, Harry N. Abrams, 1994.

- AGÚNDEZ GARCÍA, José Antonio, 10 happenings de Vostell, Mérida, Editora General de Extremadura, 1999.

- ALBELDA, José y SABORIT, José, La construcción de la naturaleza, Valencia, Generalitat Valenciana, 1997.

- AlfaNO MiGLIETTI, Francesca, Extreme Bodies. The Use and Abuse of the Body in Art, Milano, Skira, 2003.

- $\quad$ AliAgA, Juan Vicente y G. CORTÉS, José Miguel, De amor y rabia. Acerca del arte y el sida, Valencia, Universidad Politécnica de Valencia, 1993.

- AliAgA, Juan Vicente, Bajo vientre. Representaciones de la sexualidad en la cultura y el arte contemporáneos, Valencia, Generalitat Valenciana, 1997.

- $\quad$ AliAgA, Juan Vicente, Arte y cuestiones de género. Una travesía del siglo XX, San Sebastián, Nerea, 2004.

- $\quad$ AliAgA, Juan Vicente, Orden fálico. Androcentrismo y violencia de género en las prácticas artísticas del siglo XX, Madrid, Akal, 2007.

- AMORÓS BLASCO, Lorena, Abismos de la mirada. La experiencia límite en el autorretrato último, Murcia, Cendeac, 2005.

- ANDERS, Günther, Nosotros, los hijos de Eichmann. Carta abierta a Klaus Eichmann, Barcelona, Paidós, 2001.

- $\quad$ ARBUS, Diane, Diane Arbus, New York, Millertone, 1972.

- ARCHER, Michael; BRETT, Guy y DE ZEGHER, Catherine, Mona Hatoum, London, Phaidon, 1998.

- $\quad$ ARNALDO, Javier, Yves Klein, Madrid, Nerea, 2000.

- ARTAUD, Antonin, Pour en finir avec le jugement de Dieu, suivi de "Le Théâtre de la Cruauté”, Paris, Gallimard, 2003.

- AUSLANDER, Philip, Performing Glam Rock. Gender and Theatricality in popular music, Michigan, University of Michigan Press, 2006.

- BARTHES, Roland, La cámara lúcida. Nota sobre la fotografía, Barcelona, Paidós, 1997.

- BAUDRILLARD, Jean, De la seducción, Madrid, Cátedra, 1994.

- $\quad$ BAUDRILlARD, Jean, El sistema de los objetos, Madrid, Siglo XXI, 1979.

- BLOCKER, Jane, Desire, History, and Performance, Minneapolis, University of Minnesota, 2004.

- $\quad$ BOSWORTH, Patricia, Diane Arbus, Barcelona, Circe, 1999.

- BOURDIEU, Pierre, La dominación masculina, Barcelona, Anagrama, 2000.

- $\quad$ BOZAL, Valeriano, El tiempo del estupor, Madrid, Siruela, 2004.

- $\quad$ BRENTANO, Robyn \& SAVITT, Mark (eds.), 112 Workshop / 112 Greene Street, New York, New York University Press, 1981.

- BUTLER, Judith, El género en disputa: el feminismo y la subversión de la identidad, Barcelona, Paidós, 2001. 
- BUTLER, Judith, Mecanismos psíquicos del poder: Teorías sobre la sujeción, Madrid, Cátedra, 2001.

- BUTLER, Judith, Cuerpos que importan: sobre los límites materiales y discursivos del sexo, Barcelona, Paidós, 2003.

- C. WELCHMAN, John (ed.), Mike Kelley: Minor Histories, Statements, Conversations, Proposals, Cambridge, The MIT Press, 2004.

- CAPUCCI, Pier Luigi (a cura di), Il corpo tecnologico. L'influenza delle tecnologie sul corpo e sulle sue facoltà, Bologna, Baskerville, 1994.

- $\quad$ CONIO, Gérard, Le constructivisme russe, Laussane, L'Age d'Homme, 1987.

- CREGO, Charo, Perversa y utópica. La muñeca, el maniquí y el robot en el arte del siglo XX, Madrid, Abada Editores, 2007.

- CRIMP, Douglas, Posiciones críticas. Ensayos sobre las políticas de arte y la identidad, Madrid, Akal, 2005.

- $\quad$ CROMMELYNCH, Fernand, Le cocu magnifique, Paris, Labor, 2006.

- CRUZ SÁNCHEZ, Pedro A. y HERNÁNDEZ-NAVARRO, Miguel Á., Cartografías del cuerpo. La dimensión corporal en el arte contemporáneo, Murcia, Cendeac, 2004.

- DE DIEGO, Estrella, El andrógino sexuado. Eternos ideales, nuevas estrategias de género, Madrid, Visor, 1992.

- DE DOMIZIO DURINI, Lucrezia, Beuys, el barret de feltre. Història d'una vida, Girona, Llibres del segle, 1993.

- $\quad$ DE VICENTE, Alfonso, El arte en la postmodernidad. Todo vale, Barcelona, Del Drac, 1989.

- $\quad$ DEBORD, Guy, La sociedad del espectáculo, Valencia, Pre-Textos, 2005.

- DEEPWELL, Katy (ed.), Nueva crítica feminista de arte. Estrategias críticas, Madrid, Cátedra, 1998.

- DeleuzE, Gilles y GUATTARI, Félix, El Anti Edipo. Capitalismo y esquizofrenia, Barcelona, Paidós, 1995.

- DERY, Mark, Velocidad de escape. La cibercultura en el final de siglo, Madrid, Siruela, 1998.

- $\quad$ DORFLES, Gillo, Naturaleza y artificio, Barcelona, Lumen, 1972.

- $\quad$ ECKER, Gisela (ed.), Estética feminista, Barcelona, Icaria, 1986.

- $\quad$ FALK, Gaby, Vargas. 20's - 50's, Berlin, Benedikt Taschen, 1990.

- $\quad$ FER, Briony, Realismo, racionalismo, surrealismo. El arte de entreguerras (19141945), Madrid, Akal, 1999.

- $\quad$ FEATHERSTONE, Mike (ed.), Body Modification, London, SAGE, 2000.

- FERNÁNDEZ CUENCA, Carlos, La obra de S. M. Einsenstein, Madrid, Filmoteca Nacional de España, 1965.

- FERNÁNDEZ POLANCO, Aurora (ed.), Cuerpo y mirada, huellas del siglo XX, Madrid, Museo Nacional Centro de Arte Reina Sofía, 2007.

- FOSTER, Hal, El retorno de lo real. La vanguardia a finales de siglo, Madrid, Akal, 2001.

- $\quad$ FOSTER, Hal, Belleza compulsiva, Buenos Aires, Adriana Hidalgo, 2008.

- FOUCAULT, Michel, Las palabras y las cosas. Una arqueología de las ciencias humanas, Madrid, Siglo XXI, 1997. 
- FRANCASTEL, Pierre, Arte y técnica en los siglos XIX y XX, Madrid, Debate, 1990.

- $\quad$ FREUD, Sigmund, Obras completas, Vol. III, Madrid, Biblioteca Nueva, 1968.

- $\quad$ FREUD, Sigmund, Tres ensayos sobre la teoría sexual, Madrid, El País, 2002.

- $\quad$ FRUDE, Neil, The Intimate Machine, London, Century Publishing, 1983

- $\quad$ FRUEH, Joanna, Erotic Faculties, Berkeley, University of California Press, 1996.

- G. CORTÉS, José Miguel, El cuerpo mutilado. La angustia de muerte en el arte, Valencia, Generalitat Valenciana, 1996.

- G. CORTÉS, José Miguel, Hombres de mármol. Códigos de representación y estrategias de poder de la masculinidad, Barcelona-Madrid, Egales, 2004.

- GIEDION, Sigfried, La mecanización toma el mando, Barcelona, Gustavo Gili, 1978.

- $\quad$ GOLDBERG, Roselee, Performance Art, Barcelona, Destino, 1996.

- $\quad$ GOLDIN, Nan, Scurs, Saintes et Sibylles, Paris, Regard, 2005.

- $\quad$ GOLDIN, Nan, The Other Side, New York, Scalo Publisher, 1993.

- GRIMM, Jacob y GRIMM, Guillermo, El enebro y otros cuentos de Grimm, Barcelona, Lumen, 1989.

- GUASCH, Anna Maria, El arte último del siglo XX. Del posminimalismo a lo multicultural, Madrid, Alianza, 2002.

- GUASCH, Anna Maria, La crítica dialogada. Entrevistas sobre arte y pensamiento actual (2000-2006), Murcia, Cendeac, 2006.

- $\quad$ GUATTARI, Félix, Las tres ecologías, Valencia, Pre-Textos, 1996.

- GUILBAUT, Serge, De cómo Nueva York robó la idea de arte moderno, Valencia, Tirant lo Blanc, 2007.

- HABLES GRAY, Chris (ed.), The Cyborg Handbook, New York, Routledge, 1995.

- HARAWAY, Donna J., Ciencia, cyborgs y mujeres. La reivindicación de la naturaleza, Madrid, Cátedra, 1995.

- $\quad$ HARO IBARS, E., Gay Rock, Madrid, Júcar, 1975.

- HERNÁNDEZ SÁNCHEZ, Domingo (ed.), Arte, cuerpo, tecnología, Salamanca, Universidad Salamanca, 2003.

- HOCHMAN, Helaine S., La Bauhaus. Crisol de la modernidad, Barcelona, Paidós, 2002.

- $\quad$ KAFKA, Franz, La metamorfosis y otros relatos, Madrid, Cátedra, 1997.

- KELLEY, M., The Uncanny, Arnhem, Sonsbeek, 1993.

- $\quad$ KIRBY, Michael, Happenings, New York, P. Dutton, 1966.

- KLEIN, Yves, Le dépassement de la problématique de l'art et autres écrits, Paris, École Nationale Supérieure des Beaux-Arts, 2003.

- $\quad$ KLEIST, Heinrich von, Sobre el teatro de marionetas y otros ensayos de arte y filosofía, Madrid, Hiperión, 1989.

- KLÜSER, Bernd (ed.), Joseph Beuys. Ensayos y entrevistas, Madrid, Síntesis, 2006.

- KRAUSS, Rosalind E., La originalidad de las vanguardias y otros mitos modernos, Madrid, Alianza, 2002.

- $\quad$ KRAUSS, Rosalind E., Pasajes de la escultura moderna, Madrid, Akal, 2002. 
- KRAUSS, Rosalind y BRYSON, Norman, Cindy Sherman. 1975 - 1993, München, Schirmer/Mosel, 1993.

- $\quad$ LA METTRIE, Julien Offray de, El hombre máquina. El arte de gozar, Madrid, Valdemar, 2000.

- LAMBIASE, Sergio y NAZZARO, Battista (comps.), Marinetti entre los futuristas, México D. F., Fondo de Cultura Económica, 1986.

- $\quad$ LE BOT, Marc, Pintura y maquinismo, Madrid, Cátedra, 1979.

- $\quad$ LÉGER, Fernand, Funciones de la pintura, Barcelona, Paidós, 1990.

- LEMOINE-LUCCIONI, Eugènie, El vestido. Ensayo psicoanalítico, Valencia, Engloba, 2003.

- LIFSON, Ben, The Photographs of Lucas Samaras, New York, Aperture Foundation Inc., 1987.

- $\quad$ LIPPARD, Lucy R., The Pains and Pleasures of Rebirth. European and American Women's Body Art, New York, Dutton, 1976.

- LLAMAS, Ricardo (comp.), Construyendo sidentidades. Estudios desde el corazón de un pandemia, Madrid, Siglo XXI, 1995.

- $\quad$ LODDER, Christina, El constructivismo ruso, Madrid, Alianza, 1988.

- $\quad$ MACRÌ, Teresa, Il corpo postorganico, Milano, Costlan, 2006.

- MARCHÁN FIZ, Simón, Del arte objetual al arte de concepto, Madrid, Akal, 1994.

- MARTÍNEZ OLIVA, Jesús, El desaliento del guerrero. Representaciones de la masculinidad en el arte de las décadas de los 80 y 90, Murcia, Cendeac, 2005.

- $\quad$ MEYERHOLD, Textos teóricos, Madrid, Alberto Corazón, 1972.

- McLUHAN, Eric y ZINGRONE, Frank, McLuhan. Escritos esenciales, Barcelona, Paidós, 1995.

- $\quad$ McLUHAN, Marshall y FIORE, Quentin, El medio es el masaje. Un inventario de efectos, Barcelona, Paidós, 1997.

- McLUHAN, Marshall, Comprender los medios de comunicación. Las extensiones del ser humano, Barcelona, Paidós, 2009.

- $\quad$ MILlET, Kate, Política sexual, Madrid, Cátedra, 1995.

- MOLES, Abraham, Los objetos, Buenos Aires, Tiempo contemporáneo, 1974.

- MONTERDE, José Enrique y RIAMBAU, Esteve (coords.), Historia general del cine, vol. XI, Madrid, Cátedra, 1995.

- MOSTERÍN, Jesús, Ciencia viva. Reflexiones sobre la aventura intelectual de nuestro tiempo, Madrid, Espasa-Calpe, 2001.

- MOURE, Gloria, Behind the Facts. Interfunktionen 1968-1975, Barcelona, Polígrafa, 2004.

- MOURE, Gloria, Vito Acconci. Escritos, obras, proyectos, Barcelona, Polígrafa, 2001.

- MULVEY, Laura, Fetishism and Curiosity, Indiana, University Press/BFI Bloomington, 1996.

- $\quad$ MUMFORD, Lewis, Técnica y civilización, Madrid, Alianza, 1998

- NASH, J.M., El cubismo, el futurismo y el constructivismo, Barcelona, Labor, 1983. 
- NEAD, Lynda, El desnudo femenino. Arte, obscenidad y sexualidad, Madrid, Tecnos, 1998.

- O'DELL, Kathy, Contract with the Skin: Masochism, Performance Art, and the 1970s, Minneapolis/Londres, University of Minnesota Press, 1998.

- $\quad$ ORTEGA Y GASSET, José, Meditación de la técnica, Madrid, Alianza, 2002.

- $\quad$ PARCERISAS, Pilar, Art \& Co. La màquina de l'art, València, Afers, 2003.

- PEDRAZA, Pilar, Máquinas de amar. Secretos del cuerpo artificial, Madrid, Valdemar, 1998.

- PÉREZ, David (ed.), La certeza vulnerable. Cuerpo y fotografía en el siglo XXI, Barcelona, Gustavo Gili, 2004.

- PÉREZ GAULÍ, Juan Carlos, El cuerpo en venta. Relación entre arte y publicidad, Madrid, Cátedra, 2000.

- $\quad$ PICABIA, Francis, Escritos en prosa 1907-1953, Valencia, IVAM, 2003.

- $\quad$ PICAZO, Glòria (coord.), Estudios sobre performance, Sevilla, Centro Andaluz de Teatro, 1993.

- $\quad$ PICÓ, Josep (comp.), Modernidad y postmodernidad, Madrid, Alianza, 2002.

- $\quad$ PLUCHART, François, L'art corporel, Paris, Limage 2, 1983.

- PRECIADO, Beatriz, Manifiesto contra-sexual. Prácticas subversivas de identidad sexual, Madrid, Opera Prima, 2002.

- $\quad$ PRECIADO, Beatriz, Testo yonqui, Madrid, Espasa, 2008.

- RAMÍREZ, Juan Antonio, Corpus Solus. Para un mapa del cuerpo en el arte contemporáneo, Madrid, Siruela, 2003.

- RESTANY, Pierre, Yves Klein. Fire at the Heart of the Void, North Haven, Journal of Contemporary Art, 1992.

- $\quad$ RIECHMANN, Jorge, Un mundo vulnerable. Ensayos sobre ecología, ética y tecnociencia, Madrid, Catarata, 2000.

- $\quad$ ROSE, Barbara, Autocritique. Essays on Art and Anti-Art. 1963-1987, New York, Weidenfeld \& Nicolson, 1988.

- RUGOFF, Ralph; STILES, Kristine y DI PIETRANTONIO, Giacinto, Paul Mc Carthy, London, Phaidon, 1996.

- SAN MARTÍN, Francisco Javier, La mirada nerviosa. Manifiestos futuristas, Donostia, Arteleku, 1992.

- $\quad$ SAN MARTÍN, Francisco Javier, Piero Manzoni, Madrid, Nerea, 1998.

- $\quad$ SAVATER, Fernando, Diccionario filosófico, Barcelona, Planeta, 1995.

- SCHELlMANN, Jörg (ed.), Joseph Beuys. The Multiples, Munich - New York, Schellmann, 1977.

- SCHUBERT, Gianni, Piero Manzoni, Milano, Associazione Amici di Piero Manzoni, 1990.

- SHELlEY, Mary W., Frankenstein o el moderno Prometeo, Madrid, Siruela, 2000.

- SOBER, Elliot, El comportamiento altruista: evolución y psicología, Madrid, Siglo XXI, 2000.

- $\quad$ SONTAG, Susan, Sobre la fotografía, Barcelona, Edhasa, 1981.

- $\quad$ SONTAG, Susan, El sida y sus metáforas, Barcelona, Muchnik Editores, 1989.

- $\quad$ STACHELHAUS, Heiner, Joseph Beuys, Barcelona, Parsifal, 1990. 
- StOICHITA, V., Simulacros. El efecto Pigmalión: de Ovidio a Hitchcock, Madrid, Siruela, 2006.

- $\quad$ STANGOS, Nikos, Conceptos de arte moderno, Madrid, Alianza, 1994.

- $\quad$ SUBIRATS, Eduardo, La crisis de las vanguardias y la cultura moderna, Madrid, Ediciones Libertarias, 1985.

- TALON-HUGON, C., Goût et dégoût. L'Art peut-il tout montrer?, Nîmes, Jacqueline Chambon, 2003.

- $\quad$ TURBET, Silvia (coord.), Figuras del padre, Madrid, Cátedra, 1997.

- VERGINE, Lea, Il corpo come linguaggio, Milano, Giampaolo Praero, 1974.

- VERGINE, Lea, Body Art and Performance. The Body as Language, Milano, Skira, 2000.

- VERGINE, Lea, When Trash Becomes Art: TRASH Rubbish Mongo, Milano, Skira, 2007.

- $\quad$ WARR, Tracey (ed.), The Artist's Body, London, Phaidon, 2000.

- WHITFORD, Frank, La Bauhaus, Barcelona, Destino, 1991.

- $\quad$ WICK, Rainer, Pedagogía de la Bauhaus, Madrid, Alianza, 1986.

- WORTMANN, Sigfried, Women's Work. Textile Art from the Bauhaus, San Francisco, Chronicle Books, 1993.

\section{Catálogos}

- $\quad$ Absolute Windstille. Jürgen Klauke - Das Fotografische Werk, Bonn, Kunst- und Ausstellungshalle der Bundesrepublik Deutschland, 23 marzo - 8 julio de 2001.

- $\quad$ Abject Art. Repulsion and Desire in American Art, New York, Whitney Museum of American Art, 23 junio - 29 agosto de 1993.

- Accionismo vienés. Günter Brus, Otto Muehl, Hermann Nitsch, Rudolf Schwarzkogler, Sevilla, Centro Andaluz de Arte Contemporáneo, 2008.

- Adrian Piper. Desde 1965, Barcelona, MACBA, 17 octubre de 2003 - 11 enero de 2004.

- $\quad$ Ana Mendieta, Barcelona, Fundació Antoni Tàpies, 21 enero - 30 marzo de 1997.

- Annette Messager. Comédie tragédie 1971 - 1989, Musée de Grenoble, 16 diciembre - 12 febrero de 1990.

- Annette Messager. Les Messagers, Paris, Centre George Pompidou, Xavier Barral, 6 junio - 17 septiembre de 2007.

- $\quad$ Art Into Life. Russian Constructivism 1914-1932, Washington, Henry Art Gallery, 4 julio - 30 diciembre de 1990.

- $\quad$ Arte acción. 1958 - 1998, Valencia, Instituto Valenciano de Arte Moderno, 27 28 febrero de 2004.

- $\quad$ Artificial. Figuracions contemporànies, Barcelona, MACBA, 1998.

- Bodyworks, Chicago, Museum of Contemporary Art of Chicago, 8 marzo - 27 abril de 1975.

- Brasil 1920-1950. De la antropofagia a Brasilia, Valencia, IVAM Centre Julio González, 26 octubre de 2000 - 14 enero de 2001.

- Campos de fuerzas. Un ensayo sobre lo cinético, Barcelona, MACBA, 19 abril 18 junio de 2000 . 
- Carlos Pazos, Barcelona, Sala d'exposicions de l'Obra Cultural de la Caixa de Pensions, 1 - 19 diciembre de 1982.

- Carlos Pazos. Un elefant als llimbs, Barcelona, Generalitat de Catalunya, 4 febrero - 15 marzo de 1993.

- $\quad$ Cindy Sherman, Madrid, Museo Nacional Centro de Arte Reina Sofía, 8 julio - 22 septiembre de 1996

- Cindy Sherman: Working Girl. Decade Series 2005, St. Louis, Contemporary Art Museum St. Louis, 16 septiembre - 31 diciembre de 2005.

- Comer o no comer. O las relaciones del arte con la comida en el siglo XX, Salamanca, CASA. Centro de Arte de Salamanca, 23 noviembre 2002 - 19 enero de 2003.

- Diane Arbus, Madrid, Fundación Caja de Pensiones, 19 septiembre - 9 noviembre de 1986.

- Diane Arbus Revelations, San Francisco, San Francisco Museum of Modern Art, o marzo - 30 mayo de 2005.

- $\quad$ El Arte de la Acción, Santa Cruz de Tenerife, Centro de Arte La Granja, 8 octubre - 3 noviembre de 1999.

- El rostro velado. Travestismo e identidad en el arte, Donostia, Koldo Mitxelena Kulturenea, 12 junio - 6 septiembre de 1997.

- En l'esperit de Fluxus, Barcelona, Fundació Antoni Tàpies - Walker Art Center, 25 noviembre de 1994 - 29 enero de 1995.

- Face à l'histoire 1933-1996, Centre Georges Pompidou, Paris, 19 diciembre de 1996 - 17 abril de 1997.

- Fémininmasculin. Le sexe de l'art, Paris, Centre Georges Pompidou, 24 octubre 12 febrero de 1996.

- $\quad$ Fluxus, Basel, Kunsthalle Basel, 21 agosto - 31 octubre de 1994.

- Formas del abismo. El cuerpo y su representación extrema en Francia. 19301960, Donostia, Koldo Mitxelena Kulturenea, 21 octubre de 1994 - 15 enero de 1995.

- Fugas subversivas. Reflexiones híbridas sobre las identidades, València, Universtitat de València, 26 abril - 18 septiembre de 2005.

- $\quad$ Futurismo \& Futurismi, Venezia, Palazzo Grassi, 1986.

- Gordon Matta-Clark, Valencia, IVAM Centre Julio González, 3 diciembre 1992 31 enero de 1993.

- Günter Brus. Quietud nerviosa a l'horitzó, Barcelona, MACBA, 12 octubre 2005 15 enero de 2006.

- Hannah Wilke. Exchange Values, Vitoria-Gasteiz, Centro Museo Vasco de Arte Contemporáneo, 5 octubre de 2006 - 14 enero de 2007.

- Hermann Nitsch. El teatro de orgías y misterios, València, Centre Cultural La Beneficència, 18 octubre - 1 diciembre de 1996.

- Jana Sterbak, Chicago, Museum of Contemporary Art, 10 octubre de 1998 - 3 enero de 1999.

- Jana Sterbak. De la performance al vídeo, Vitoria-Gasteiz, Artium, 18 mayo - 3 septiembre de 2006. 
- Jean-Jaques Lebel. Bilder, Skulpturen, Installationen, Wien, Museum Moderner Kunst Stiftung Ludwig Wien, 31 enero - 15 marzo de 1998.

- Joseph Beuys. Actions, Vitrines, Environments, Houston, The Menil Collection, 8 octubre de 2004 - 2 enero de 2005

- Joseph Beuys, Palma, Casal Solleric, septiembre - octubre de 1997.

- Joseph Beuys. Múltiples, Valencia, Institut Valencià d'Art Modern, 28 febrero 25 mayo de 2008.

- Joan Jonas. Scripts and Descriptions 1968 - 1982, Berkeley, University Art Museum, 1983.

- Joan Jonas. Timelines: transparencias en una habitación oscura, Barcelona, MACBA, 20 septiembre de 2007 - 7 enero de 2008.

- Joan Jonas. Works 1968 - 1994, Amsterdam, Stedelijk Museum Amsterdam, 31 mayo - 19 junio de 1994.

- JUNGGESELLENMASCHINENEN = Les machines célibataires, Bern, Kunsthalle, mayo - julio de 1975.

- Jürgen Klauke. Ich War Eine Dose, Düsseldorf, Galerie Udo Bugdahn, 21 septiembre - 29 octubre de 1988.

- Katharina Sieverding, Düsseldorf, Kunstsammlung Nordrhein-Westfalen, 20 diciembre de 1997 - 1 marzo de 1998.

- Katharina Sieverding. Transformer, Stadtische Galerie am Markt. Hällisch Fränkisches Museum Schwäbisch Hall, 25 julio - 13 septiembre de 1998.

- $\quad$ L'Âme au corps. Arts et sciencies 1793-1993, Paris, Galeries Nationales du Grand Palais, 19 octubre de 1993 - 24 enero de 1994.

- L'art au corps. Le corps exposé de Man Ray à nos jours, Marseille, Mac-galeries contemporaines des Musées de Marseille, 6 julio - 15 octubre 1996.

- $\quad$ L'art corporel, Bruxelles, Galerie Isy Brachot, 12 - 30 marzo de 1977.

- La Bauhaus de festa. 1919-1933, Barcelona, Fundación "la Caixa”, 29 junio - 4 septiembre de 2005.

- László Moholy-Nagy. Fotogramas 1922-1943, Barcelona, Fundació Antoni Tàpies, 9 julio - 28 septiembre de 1997.

- Lawrence Weiner. In the Stream, Valencia, IVAM-Centre Julio González, 13 de julio - 17 de septiembre de 1995.

- Les années 70 : l'art en cause, Bordeaux, capcMusée d'art contemporain de Bordeaux, 17 octubre de $2002-19$ enero de 2003.

- Luces, cámara, acción (...) ¡Corten! El cuerpo y sus fronteras, Valencia, IVAM Centre Julio González, 8 - 30 mayo de 1997.

- Lygia Clark, Barcelona, Fundació Antoni Tàpies, 21 octubre - 21 diciembre de 1997.

- Lynda Benglis: Dual Natures, Atlanta, High Museum of Art, 29 enero - 31 marzo de 1991.

- Máquinas, Las Palmas de Gran Canarias, Centro Atlántico de Arte Moderno, 19 septiembre - 19 noviembre de 2000.

- Martha Rosler: passionate signals, Hannover, Sprengel Museum Hannover, 30 enero - 16 mayo de 2005. 
- Martha Rosler: Posiciones en el mundo real, Barcelona, Museu d'Art Contemporani de Barcelona - Actar, 20 octubre de 1999 - 10 enero de 2000.

- Martha Rosler. La casa, la calle, la cocina / the house, the street, the kitchen, Granada, Centro José Guerrero, 29 enero - 12 abril de 2009.

- Màscara i Mirall, Museu d'Art Contemporani de Barcelona, 23 abril - 31 agosto de 1997.

- $\quad$ Michel Journiac, Paris, Les Musées de Strasbourg, 19 febrero - 9 mayo de 2004.

- Micropolíticas. Arte y cotidianidad 2001 - 1968, Castelló, EACC, 31 enero - 21 septiembre de 2003.

- Mona Hatoum, Salamanca, Centro de Arte de Salamanca, 10 julio - 1 septiembre de 2002.

- Orlan. 1964 - 2001, Vitoria-Gasteiz, ARTIUM - Universidad de Salamanca, 27 junio - 1 septiembre de 2002.

- Oskar Schlemmer. Der Folkwangzyklus Malerei Um 1930, Stuttgart, Staatsgalerie, 11 septiembre - 14 noviembre de 1993.

- Oskar Schlemmer. Tanz, Theater, Bühne, Hannover, Sprengel Museum, 19 febrero - 21 mayo de 1995.

- Oskar Schlemmer, Barcelona, Fundació "la Caixa”, 1996.

- Out of Actions: Between Performance and the Object 1949-1979, Los Angeles, The Museum of Contemporary Art, 8 febrero - 10 mayo de 1998.

- Paul McCarthy, Los Angeles, MOCA, 12 noviembre de 2000 - 21 enero de 2001.

- Paul McCarthy. Brain Box Dream Box, Málaga, Centro de Arte Contemporáneo de Málaga, 19 noviembre - 20 febrero de 2005.

- Paul McCarthy Head Shop/Shop Head. Works 1966-2006, Stokholm, Moderna Museet, 17 junio - 3 septiembre de 2006.

- Piero Manzoni, Madrid, Fundación "la Caixa”, 9 octubre - 15 diciembre de 1991.

- $\quad$ Piero Manzoni, London, Serpentine Gallery - Charta, 1998.

- Pierre Moliner, Valencia, IVAM Centre Julio González, 15 abril - 21 junio de 1999.

- Post Human, Pully/Lausanne, FAE Musée d'Art Contemporain, 14 junio - 13 septiembre de 1992.

- Rebecca Horn, Santiago de Compostela, Centro Galego de Arte Contemporánea, 9 junio - 10 septiembre de 2000.

- Rebecca Horn: The Inferno-Paradiso Switch, New York, Solomon R. Guggenheim Foundation, 25 junio - 1 octubre de 1993.

- Rebecca Horn: Bodylandscapes. Desenhos, esculturas, instalações 1964-2004, Lisboa, Fundação Centro Cultural de Belém, 4 febrero - 17 abril de 2005.

- Rebecca Horn. Diving through Buster's Bedroom, Los Angeles, The Museum of Contemporary Art, 30 septiembre de 1990 - 6 enero de 1991.

- Reconsidering the Object of Art: 1965-1975, Los Angeles, MOCA, 15 octubre de 1995 - 4 febrero de 1996.

- Robert Morris. From Mnemosyne to Clio: The Mirror to the Labyrinth (19981999-2000), Lyon, Musée d'Art Contemporain de Lyon, 2000.

- Robert Morris. Recent Felt Pieces and Drawins, Sigean, Association L.A.C. Lieu d'Art Contemporain, 29 junio - 29 septiembre de 1996. 
- Rrose is a Rrose is a Rrose. Gender Performance in Photography, New York, Solomon R. Guggenheim Museum, 17 enero - 27 abril de 1997.

- $\quad$ Sieverding, Bonn, Bonner Kunstverein, 16 junio - 9 agosto de 1992.

- Splendeurs et misères du corps, Musée d'Art Moderne de la Ville de Paris, 25 octubre - 31 diciembre de 1988.

- $\quad$ The Art of Participation. 1950 to Now, San Francisco, Museum of Modern Art Thames \& Hudson, 8 noviembre - 8 febrero 2009.

- The Desert is Across the Street. A Work by Urs Lüthi, Elke Kilga, David Weiss, Zurich, Galerie Stähli, 1975.

- $\quad$ The End of the World?, Prague, The National Gallery in Prague, Kinsky Palace, 26 mayo - 19 noviembre de 2000.

- Transformer. Aspekte der Travestie, Kunstmuseum Luzern, 17 marzo - 15 abril de 1974.

- Transgeneric@s. Representaciones y experiencias sobre la sociedad, la sexualidad y los géneros en el arte español contemporáneo, Donostia, Koldo Mitxelena Kulturunea, diciembre de 1998 - febrero de 1999.

- Transparencias fugadas: Siete pintores fotógrafos, Teruel, Museo de Teruel, 7 noviembre - 10 diciembre de 1995.

- Un teatro sin teatro, Barcelona, MACBA, 25 mayo - 11 septiembre de 2007.

- Urs Lüthi. L'œuvre multiplié 1970-1991, Genève, Cabinet des Estampes, 1991.

- Velleitas. Jana Sterbak, Saint-Étiènne, Musée d'Art Moderne Saint-Étienne, 23 junio - 17 septiembre 1995.

- Wack! Art and the Feminist Revolution, Los Angeles, The Museum of Contemporary Art, 4 marzo - 16 julio de 2007.

- What's Fluxus? What's Not! Why, Brasília - Rio de Janeiro, Centro Cultural Banco do Brasil, 2002.

- Wolf Vostell, Nîmes, Carré d'Art - Musée d'Art Contemporain de Nîmes, 13 febrero - 12 mayo de 2008.

- $\quad$ Yves Klein, Madrid, Museo Nacional Centro de Arte Reina Sofía, 24 mayo - 25 agosto de 1995.

- Yves Klein. Corps, couleur, immatériel, Paris, Centre National d'Art et de Culture Georges Pompidou, 5 octubre de 2006 - 5 febrero de 2007.

- Yves Klein. La Vie, la vie elle-même qui est l'art absolu, Nice, Musée d'Art Moderne et D'Art Contemporain, 28 abril - 4 septiembre de 2000.

- Zona F, Castellón, Espai d'Art Contemporani de Castelló, febrero - marzo de 2000.

\section{Revistas y enlaces}

- Babelia. Mayo 68. Los restos de la revolución global en su 40 aniversario, $\mathrm{n}^{\circ} 856$, El País, sábado 19 de abril de 2008.

- $\quad$ Brumaria. Prácticas artísticas, estéticas y políticas. nº 3. “Arte, máquinas, trabajo inmaterial", diciembre 2006. 
- CLEMENTE, José Luis, "El vuelo de Rebecca Horn y la armonía entre la naturaleza y la máquina: The Inferno Paradiso Switch", en Kalías. Revista de arte, n 11, Valencia, IVAM-Centre Julio González, 1994.

- Debats. Del Post al ciberfeminismo, $\mathrm{n}^{\mathrm{0}}$ 76, Institució Alfons el Magnànim, primavera 2002.

- DURAND, Régis, "Rebecca Horn. Danger imminent", en Art Press, n 181, junio 1993.

- Escala: Las formas del vestir. Las formas del arte, nº 2, Escalarte, 1997.

- ESTABIEL, César, "En busca del tercer sexo", en El País, 28 de noviembre de 2008.

- $\quad$ G. CORTÉS, José Miguel, “Je Suis Lesbien (Pierre Molinier o el cuestionamiento de la virilidad)", en Acción Paralela, www.accpar.org/numero3/molinier.htm

- HOWELL, Georges, "Anatomy of an Artist", en Art Papers, no 4, julio - agosto 1995.

- KRAUSS, Rosalind, "Corpus delicti”, en Debats, n 79, Institució Alfons el Magnànim, Invierno 2002/03.

- LANDI, Oscar, "Mutantes de fin de siglo", en www.afbuenosaires.com/expos99/orlanzona.htm.

- Leo es pardo (1976) - Iván Zulueta, www.youtube.com/watch?v=GBeXxWYFLqc

- PÉREZ OLIVA, Milagros, “Adiós al hombre biónico”, en El País, 25 de agosto de 2008.

- $\quad$ PRECIADO, Beatriz, "Farmacopornografía", en El País, 27 enero de 2008.

- RIVERA, Daniel, "Ciber-cuerpo, ciber-arte, ciber-etcétera", en http://serpiente.dagsca.unam.mx/jornada/1997/oct97/971025/ciberc.html. 